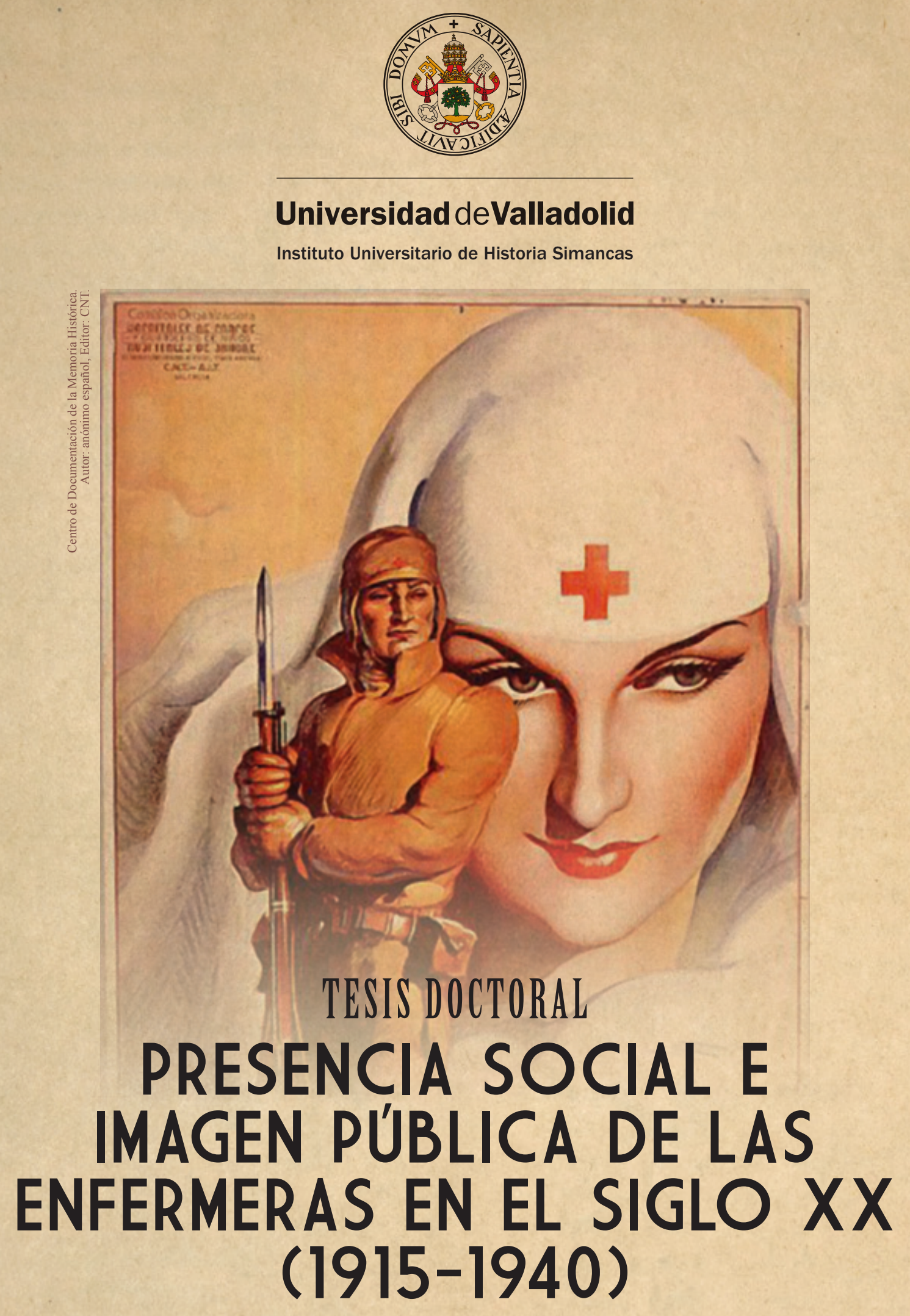

Presentada por

Dña. María López Vallecillo

para optar al grado de doctora por la Universidad de Valladolid

Dirigida por:

Dra. Magdalena Santo Tomás Pérez

Dr. José-Vidal Pelaz López 


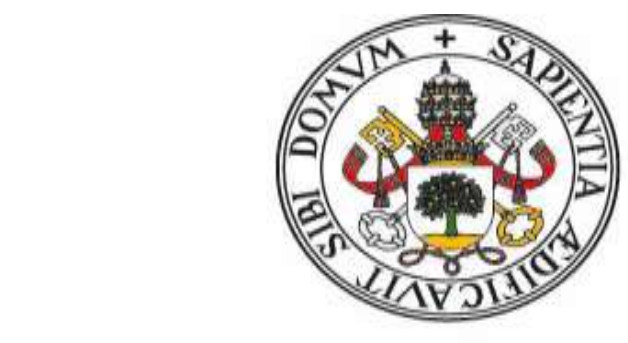

\section{Universidad deValladolid}

Instituto Universitario de Historia Simancas

TESIS DOCTORAL:

\section{PRESENCIA SOCIAL E IMAGEN PÚBLICA DE LAS ENFERMERAS EN EL SIGLO XX (1915-1940)}

Presentada por Dña. María López Vallecillo para optar al grado de doctora por la Universidad de Valladolid

Dirigida por:

Dra. Magdalena Santo Tomás Pérez

Dr. José-Vidal Pelaz López 

A mi familia 



\section{Agradecimientos}

Cuando me embarqué en la elaboración de mi tesis doctoral sabía que no iba a estar sola, que contaba con grandes apoyos para ayudarme a hacer más liviana esta ardua tarea.

Es indispensable empezar dando las gracias a mis directores de tesis, a los que considero mis maestros, la Doctora Magdalena Santo Tomás Pérez y el Doctor José-Vidal Pelaz López, a los que admiro profesionalmente, han sido y son un referente para mí. Gracias a su ayuda y su apoyo ha sido posible la elaboración de esta tesis doctoral.

También ha sido indispensable la información que me ha proporcionado el personal responsable de los distintos archivos, hemerotecas y bibliotecas que he consultado. Especialmente, no me puedo olvidar de María del Carmen Flórez Pérez, documentalista del Centro de Documentación de Cruz Roja Española en la Avenida Reina Victoria de Madrid, cuya ayuda ha sido inestimable.

En el campo académico, mis compañeras y compañeros de la Facultad de Enfermería de Valladolid han conseguido motivarme y animarme en los momentos difíciles, haciendo posible que avanzara hacia la consecución de mi objetivo.

En el día a día de mi trabajo asistencial en el Hospital Clínico Universitario de Valladolid he contado con el apoyo de mis compañeras, especialmente de la unidad de hospitalización de Medicina Interna 11 sur, sin cuyos ánimos no hubiera superado el reto de realizar una tesis doctoral. Quiero agradecer a Elena Barríos e Isabel Peña, enfermeras del programa de gestión de cuidados Gacela, amigas y compañeras a las que admiro y respeto, su estímulo a lo largo de este camino.

A la hora de diseñar el formato final de la tesis he contado con la ayuda inestimable de Gustavo Jiménez y Carmen Burguillo, que me han dado todo tipo de facilidades a la hora de estudiar las diferentes maquetaciones. 
Las risas, el ambiente distendido y los ratos de ocio han sido imprescindibles para superar los momentos de estrés y agobio, esto ha sido posible gracias a mis amigas, a las que quiero y a las que agradezco el haberme brindado tan buenos momentos a lo largo de estos tres años.

Tengo muy buen recuerdo de mi estancia en Madrid, donde tuve que permanecer una temporada para poder obtener la información que me ha llevado a elaborar este trabajo. Gracias a Alberto Camarero y a David Villamedia que me brindaron su apoyo y supieron entender la ilusión con la que abordé esta etapa de mi investigación. Especialmente a ti David por ser mi compañero incondicional a lo largo de esta interesante experiencia.

El cariño de mi familia, especialmente de mis padres y mi hermana ha sido indispensable, gracias por no dejar que me rindiera, por estar a mi lado en los peores momentos, por preocuparos cuando me veías cansada o desanimada, os quiero. 


\section{ÍNDICE GENERAL}

Índice de tablas

Abreviaturas

Introducción

Capítulo I. La Enfermería en el primer tercio del siglo XX: nacimiento de una profesión

1. Situación de la mujer española a principios del siglo XX: comienza el camino hacia la emancipación

2. Enfermería, una profesión de principios del siglo XX 35

\begin{tabular}{ll}
2.1 . Orígenes & 35 \\
\hline
\end{tabular}

2.2. Inicio del camino hacia la profesionalización enfermera en España 37

3. Cruz Roja Española y su papel en la formación de enfermeras 41

3.1. Sección de Señoras $\quad 42$

3.2. Damas y Enfermeras de Cruz Roja Española 46

3.2.1. Damas Enfermeras 46

3.2.2. Enfermeras profesionales de Cruz Roja $\quad 52$

3.2.3. Enfermeras visitadoras de Cruz Roja 56

3.3. Las enfermeras a través de los manuales y reglamentos de Cruz Roja Española: perfilando una imagen

3.4. Diferencias y similitudes entre damas enfermeras y enfermeras profesionales

4. La Campaña de Marruecos (1921-1927): labor de Cruz Roja Española

4.1. Papel de Cruz Roja Española en Marruecos a través de las memorias de las Juntas de Señoras

4.2. Hospitales de la Cruz Roja durante la Campaña de Marruecos 79

5. Mujer en guerra: las enfermeras en la campaña de Marruecos 85

$\begin{array}{ll}\text { 5.1. La Duquesa de la Victoria } & 85\end{array}$

5.2. Damas, Enfermeras y Hermanas de la Caridad durante la Campaña de Marruecos

\section{Capítulo II. Consolidación de las enfermeras profesionales durante la Segunda República}

1. Las mujeres en la Segunda República: un breve apunte

1.1. Asociaciones de mujeres

1.2. El trabajo femenino: nuevas expectativas

1.3. Educación: otras alternativas formativas para la mujer

2. Cruz Roja durante la Segunda República: adaptación a la nueva situación política

2.1. Damas Auxiliares Voluntarias

2.2. Enfermeras profesionales

2.3. Escuela de Enfermeras del Hospital Central de Cruz Roja: nuevos reglamentos 
3. Las enfermeras en la Segunda República: situación profesional

3.1. Las enfermeras a través de los manuales: consolidación de una imagen

3.2. Una apuesta por las enfermeras laica

3.3. Enfermeras Visitadoras: importancia socio-política para la higiene y la Salud Pública

3.4. Las enfermeras: una amenaza para practicantes y matronas 168

3.4.1. Los practicantes y su enfrentamiento laboral 168

3.4.2. Matronas: colegiación y conflictos profesionales 172

\section{Capítulo III. Movilización femenina y papel asistencial de las enfermeras en la zona republicana}

1. Mujeres republicanas y su implicación en la guerra

1.1. La mujer en el frente: el coyuntural auge de las milicianas

1.2. Movilización femenina: el trabajo de la mujer en la retaguardia

2. Sanidad Republicana: estructura hospitalaria y red asistencial 215

2.1. Recursos materiales

2.2 Tipos de hospitales, traslado y evacuación de heridos

3. Las enfermeras republicanas y su participación en el conflicto: labor asistencial

3.1. Nuevas enseñanzas: auge de los cursillos de capacitación

3.2. Las enfermeras extranjeras y su implicación en la Guerra Civil

3.3. Formación e imagen de las enfermeras republicanas a través de los manuales

3.4. Vida y trabajo de las enfermeras durante el conflicto

\section{Capítulo IV. Movilización femenina y situación sanitaria en la zona nacional}

1. La mujer en la nueva España: participación en el conflicto

1.1. La mujer nacional a través de Sección Femenina y su movilización durante la Guerra Civil

1.2. La mujer a través de la revista "Y"

1.3. Auxilio Social y su papel en la movilización femenina

1.4. Frentes y Hospitales: las Margaritas

2. La Sanidad en la zona nacional: instalación de una nueva red asistencial

2.2. Tipos de servicios sanitarios y hospitales militares

3. Nuevo modelo de enfermera: hacia una imagen de mujer ideal 315

3.1. Formación: nuevas necesidades sanitarias 317

3.2. Los manuales y su enfermera modelo 329 


\section{Capítulo V. Las enfermeras en la zona nacional: conflictos,} vivencias y trabajo desempeñado

1. Papel de las enfermeras nacionales durante el conflicto: un modelo de mujer

1.1. Requisitos exigidos para trabajar en los hospitales militares

1.2. Mercedes Milá y Nolla: su labor como Inspectora de Servicios Femeninos del Cuartel General de Sanidad Militar

1.3. Deberes y sanciones

1.4. Trabajo desempeñado: nuevas inquietudes profesionales 367

1.5. Conflictos laborales y políticos 377

1.6. Las enfermeras y los peligros de la guerra 383

1.7. Religión, propaganda y adoctrinamiento 389

2. Situación de las enfermeras al terminar la guerra: hacia el modelo ideal de profesionales

2.1. Recompensas y reconocimiento laboral

2.2. Situación laboral y económica: vencedoras y vencidas 404

2.3. Formación de enfermeras para la paz 408

$\begin{array}{ll}\text { Anexos V } & 415\end{array}$

$\begin{array}{ll}\text { Conclusiones } & \mathbf{4 2 7}\end{array}$

Fuentes y Bibliografía $\quad 445$ 



\section{Índice de tablas}

Págs.

Tabla 1. Promesas que debían cumplir las damas enfermeras de Cruz Roja. $\quad 48$

Tabla 2. Principales lecciones teóricas.

$\begin{array}{ll}\text { Tabla 3. Cualidades físicas exigidas a damas y enfermeras. } & \mathbf{7 0}\end{array}$

Tabla 4. Cualidades morales exigidas a damas y enfermeras.

Tabla 5. Lecciones teóricas Enfermería Segunda República. $\quad \mathbf{1 5 0}$

Tabla 6. Contenidos teóricos formación de enfermeras.

$\begin{array}{ll}\text { Tabla 7. Requisitos que debían cumplir las visitadoras sanitarias. } & \mathbf{1 6 7}\end{array}$

Tabla 8. Asociaciones de mujeres republicanas durante la Guerra Civil. $\quad 204$

Tabla 9. Contenidos formativos de los manuales de enfermeras republicanas. $\quad 240$

Tabla 10. Cualidades físicas y morales de las enfermeras nacionales de Falange. $\quad 331$

Tabla 11. Guión de conducta de la enfermera de Acción Católica. 333 


\section{Abreviaturas utilizadas}

\section{Asociaciones de mujeres}

JAE: Junta para Ampliación de Estudios

ANME: Asociación Nacional de Mujeres Españolas

ACM: Acción Católica de la Mujer

AMA: Agrupación de Mujeres Antifascistas

UDC: Unió de Dones de Catalunya

UM: Unión de Muchachas

ANDJ: Alianza Nacional de la Dona Joven

SFPOUM: Secretariado Femenino del Partido Marxista Disidente

AFAP: Asociación Femenina de Acción Popular

SF: Sección Femenina de Falange

AS: Auxilio Social

\section{Fuentes}

AMI: Ayuda Médica Internacional

BNE: Biblioteca Nacional Española

AGMAV: Archivo General Militar de Ávila

AGMM: Archivo General Militar de Madrid

AGA: Archivo General de la Administración

ACCRE: Archivo Central de Cruz Roja Española

BOE: Boletín Oficial del Estado 
INTRODUCCIÓN 

Entre las premisas fundamentales que han motivado este estudio, se encuentra el interés personal en dar visibilidad a la Enfermería y a sus profesionales, y analizar la influencia de los acontecimientos económicos, políticos, bélicos y sociales de las primeras décadas del siglo XX que inevitablemente han perfilado la imagen de lo que hoy se entiende por enfermera. Alberto González señala que, a pesar de que las mujeres han estado presentes en el ámbito sanitario, el discurso científico las ha mantenido en el olvido, ya que la historiografía tradicional se ha centrado en el estudio de las profesiones sanitarias masculinas ${ }^{1}$. Por eso, a través de la presente Tesis doctoral se pretende rescatar el papel que jugaron las enfermeras desde el nacimiento de la profesión en 1915 hasta el final de la Guerra Civil, a través del estudio de la imagen de las profesionales y su presencia social.

Según Ingrid Zamorano, podría decirse que hay una distorsión de la imagen de la enfermera, fomentada por los medios de comunicación, siendo necesario que sean los profesionales de la disciplina los que se impliquen de una forma directa en la construcción de la identidad de la misma ${ }^{2}$. Cabe preguntarse cómo pueden contribuir las enfermeras a cambiar el estereotipo de su profesión. Según Amparo Nogales, la Enfermería se compone de dos mundos, uno exterior ligado a los cuidados técnicos y especializados, y otro interior relacionado con los sentimientos, motivación, sensaciones y experiencias, que coexisten y se comunican ${ }^{3}$. Ambos están relacionados e imprimen carácter a la profesión, de forma que dibujan una imagen concreta de ella. En este sentido, creo que conocer su historia dentro de cada contexto socio-político puede ayudar a reflejar mejor su realidad.

${ }^{1}$ GonZÁlez GARCíA, Alberto: La epidemia de gripe de 1918-1919 en la provincia de Cuenca. Tesis doctoral, Programa de Doctorado en Investigación Sociosanitaria, Universidad de Castilla la Mancha, Cuenca, 2012, p. 269.

2 ZAMORANO PABÓN, Ingrid Carolina: Identidad profesional en Enfermería: un reto personal y profesional. Invest Educ Enferm. 2008; 26(suppl):168-171.

${ }^{3}$ NogAles ESPERT, Amparo: El asociacionismo en el arte de la enfermería. Hacia una estética del optimismo: la ilusión. En VV.AA: El asociacionismo en la Enfermería y su influencia en el desarrollo de la profesión: 150 años de historia del colegio de enfermeras de Madrid (1862-2012). Colegio Oficial de Enfermería de Madrid, Madrid, 2012, p. 282. 
En esta línea, Ana Choperena plantea que la Historia de la Enfermería es una herramienta al servicio del conocimiento que servirá para fortalecer la identidad profesional $^{4}$. Resulta imprescindible partir de un análisis crítico desde el inicio de la profesión para poder hacer una reflexión y seguir avanzando como disciplina indiscutible del cuidado hasta la actualidad. Para ello son necesarias líneas de investigación que profundicen en las condiciones laborales de las enfermeras, en su participación en los conflictos de su tiempo (singularmente los bélicos) y en sus vivencias personales. También es indispensable analizar el papel de las enfermeras como profesionales y como mujeres y valorar su labor en los distintos momentos históricos.

Existe una relación directa entre la profesión y los acontecimientos del pasado, podría decirse que en dos líneas: lo que la sociedad espera de las enfermeras y el papel que ellas creen que deben desempeñar. Virginia Henderson lo expresaba perfectamente cuando rememoraba su periodo como alumna en el hospital militar destinado a los heridos de la Primera Guerra Mundial donde aprendió a "servir a los demás en una atmósfera donde la enfermera, como representante de la sociedad, se sentía en deuda con el paciente" ${ }^{, 5}$. Parece por tanto necesario estudiar si la Enfermería se ha adaptado a los cambios socio-políticos, si la han afectado de una forma directa y si la influencia del rol mayoritariamente femenino de la profesión ha repercutido en la misma.

Según Cristina Heierle existen distintos estereotipos sobre la imagen que tiene la sociedad de las enfermeras, que resultan contradictorios en algunas ocasiones: desde ángel y dama, hasta libertinas y pecadoras. La visión que tienen las enfermeras de su profesión también está condicionada por el modelo ideal impuesto a través de la literatura y los medios de comunicación. La prensa escrita presenta una imagen no identificada que se pierde dentro del grupo de personal sanitario, mostrándola sin identidad propia dentro del mismo, mientras que el cine describe a

4 Choperena ARMendáRIZ, Ana: Memorias de enfermeras en la Guerra Civil Americana: de la dimensión doméstica a la profesional. Tesis doctoral, Universidad de Navarra, Facultad de Filosofía y Letras, Pamplona, 2014, p. 10.

${ }^{5}$ HeNDERSON, Virginia: La naturaleza de la Enfermería: reflexiones de 25 años después. InteramericanaMcGraw-Hill, Madrid, 1994, p. 11. 
una mujer subordinada al varón, en este caso del médico, que únicamente ejecuta órdenes durante el desempeño de su trabajo. Los medios han contribuido a distorsionar la realidad y a perpetuar los estereotipos negativos ${ }^{6}$.

Como señala Magdalena Santo Tomás, la Enfermería debe tener presente dos variables del pasado: mujer y poder, y ser capaz de relacionar ambos conceptos y su evolución histórica para poder entender su situación actual. Por eso, analizar la condición femenina se convierte en un "elemento central del papel de la mujer como cuidadora" dentro de la trayectoria profesional enfermera ${ }^{7}$.

Las mujeres han sido y son, espectadoras y actrices de los distintos periodos históricos. Su participación activa y pasiva en los acontecimientos socio-políticos, en los conflictos bélicos y en las transformaciones culturales, hace necesario identificar el papel que jugaron en los mismos. Hombres y mujeres forman parte de la humanidad y por eso es importante conocer y analizar ambos enfoques históricos, relacionados entre sí y no abordados como hechos aislados y separados. Como señala Françoise Thébaud, "la historia de las mujeres no es el final de la historia, no es el punto de vista de los puntos de vista que aspira a la visión total", pero sí es necesario estudiarla para enriquecer los modelos históricos y explicar la complejidad de los procesos sociales ${ }^{8}$.

María Isabel del Val Valdivieso, destaca la participación femenina en la construcción de la sociedad en la historiografía actual, ya que han sido en su mayoría, los testimonios de los hombres los que han contribuido a la misma. También aboga por incluir en el contexto histórico a la "otra mitad tan frecuentemente ocultada, las mujeres" y cambiar el enfoque con que se examina el pasado, incluyendo los testimonios masculinos y femeninos ${ }^{9}$.

Para Ángeles Egido y Ana Fernández, el siglo XX podría considerarse “el siglo de las mujeres" debido a la consolidación del sufragio femenino, los avances

\footnotetext{
${ }^{6}$ HeIERle VALERO, Cristina: Imagen social de las enfermeras a través de los medios. Tesis doctoral del Departamento de Didáctica de la expresión musical, plástica y corporal. Universidad de Granada, 2011.

7 SANTO TOMÁS PÉREZ, Magdalena: Líneas de investigación para avanzar en la historia de la Enfermería, p. 395, en GONZÁlEZ CANALEJO, Carmen, MARTínEZ LóPEZ, Fernando: La transformación de la Enfermería. Nuevas miradas para la historia. Editorial Comares, Granda, 2010.

${ }^{8}$ THÉBAUD, Françoise: Historia de las mujeres en occidente. 5, el siglo XX. Taurus, Madrid, 2000, p. 37.

${ }^{9}$ VAL VALdIVIESO, María Isabel del: Protagonista del pasado. Las mujeres desde la prehistoria al siglo $X X$. Castilla D. L. Valladolid, 2009, pp. 9-16.
} 
jurídicos y legales que las afectaron y la apertura al mundo laboral ${ }^{10}$. Según Mary Nash, en España, en la primera mitad de esta etapa histórica, hubo cambios significativos en la representación cultural de la mujer, tanto a nivel social, como económico y demográfico, sobre todo en los modelos culturales de género y discursos ideológicos femeninos. La imagen y su representación cambió, aparecía un nuevo modelo de mujer moderna, instruida y profesional, pero sin desligarse de la maternidad "como base esencial de la identidad cultural". El cometido social de la mujer y su estatus iba a ser diferente al del hombre, ya que era la responsable de la perpetuación de la especie, función prioritaria de su rol social. También debía contribuir al cuidado y educación de sus hijos, atendiendo a las demandas surgidas por los nuevos planteamientos higienistas. La maternidad como eje central de la función social femenina atisbó un cambio durante la Segunda República, cuando mujeres como Lucía Sánchez Saornil defendieron que el potencial humano femenino iba "más allá de su capacidad reproductiva". Esa posibilidad de cambio de mentalidad se vio frenada con el franquismo que retomó la "maternidad prolífica como exclusiva misión sagrada de la mujer" ${ }^{\prime 1}$.

Puede decirse que es necesario analizar la historia de las enfermeras para contribuir a perfilar la de las mujeres. Según Ana choperena, la Enfermería es una de las disciplinas que ha favorecido de una forma importante al desarrollo de la historia de las mujeres ${ }^{12}$. Se ha escrito mucho sobre la Campaña de Marruecos, la Segunda República y la Guerra Civil Española, pero siempre desde una perspectiva mayoritariamente masculina. En los años ochenta empezó a haber un cambio en las líneas de investigación, iniciado principalmente por historiadoras concienciadas con la necesidad de identificar cuál fue el papel que jugaron las mujeres en los mismos, luchando así contra la "invisibilidad del sujeto femenino"13. En este sentido sucede

10 EgIDO, Ángeles y FERnÁNDEZ ASPERILla, Ana: Ciudadanas, militantes y feministas. Mujer y compromiso polítco en el siglo XX. Eneida, Madrid, 2001, p. 9.

${ }^{11}$ THÉBAUD, F: ob. cit., ver NASH, Mary: Maternidad, maternología y reforma eugénica en España, 1900-1939, pp. 687-708.

${ }^{12}$ CHOPERENA ARMENDÁriz, A: op. cit., p. 15.

${ }^{13}$ NúÑEZ PÉREZ, María Gloria: El Trabajo extradoméstico de las mujeres en España (1931-1936). Tesis doctoral. Departamento de Historia Contemporánea. Facultad de Geografía e Historia, Universidad Complutense de Madrid, 1987, p. 1. 
lo mismo con las enfermeras que se vieron inmersas en los distintos acontecimientos socio-políticos y participaron en ellos. Se han iniciado trabajos enfocados a estudiar su implicación laboral en los conflictos bélicos y lo que sucedió con ellas cuando estos terminaron. En muchas ocasiones son demasiado locales y no identifican el contexto sanitario y social, pero aun así, son aportaciones encaminadas a arrojar luz sobre la profesión.

Parecía necesario plantearse un análisis global de la Enfermería de principios del siglo XX hasta el final de la Guerra Civil, a través sus protagonistas, las enfermeras. Describir dónde y qué estudiaban, cómo eran los hospitales en los que trabajaron, cómo desempeñaban su profesión, cómo se vieron afectadas por los cambios políticos, sociales y económicos que sacudieron a España, cuál fue su participación en los dos grandes conflictos bélicos del periodo y cómo las veía la sociedad, principalmente a través de la prensa. Además, en torno a la mujer enfermera han surgido una serie de imágenes, mitos y estereotipos preconcebidos que han perdurado en el tiempo, que están arraigados en la sociedad e impiden ver la realidad de la profesión. Se hacía ineludible identificar su origen, comprobar la influencia que han tenido en el desarrollo de la Enfermería y contrastarlos con la realidad, para así poder desmontarlos.

Profundizar en la historia de la Enfermería, entendida como una de las pocas profesiones femeninas socialmente aceptadas que se ha adaptado a los distintos contextos, nos ayudará a comprender mejor la historia de las mujeres. Nuestro objetivo principal ha sido analizar la evolución de la imagen de la enfermera y su consideración social durante las primeras décadas del siglo XX, en relación con la imagen de la mujer y su consideración social en general, en el mismo periodo.

Para ello el trabajo parte del estudio del contexto histórico y del conocimiento de la situación de la mujer en él para relacionarlo con la que vivieron las enfermeras. Se verá la influencia que han tenido los cambios políticos, sociales y económicos para la mujer enfermera en la monarquía de Alfonso XIII, la Segunda República y la Guerra Civil. Se describirá también la formación académica que recibieron a lo largo de las distintas etapas analizadas, reconociendo los cambios legislativos y de planes de estudios que influyeron en la evolución de la profesión. 
Se identificarán los diferentes perfiles que surgen en torno a la Enfermería, principalmente a través de las enfermeras profesionales, las damas enfermeras de Cruz Roja y las auxiliares voluntarias de Sanidad Militar, sin perder de vista el papel sanitario que han ejercido las religiosas, principalmente las Hermanas de la Caridad. Se detallará el tipo de trabajo que llevaron a cabo las profesionales, su jornada laboral, para describir dónde, cómo y con quién lo desempeñaron. El análisis de la imagen de "enfermera ideal" presentada en los manuales formativos es imprescindible, al igual que la de la enfermera como "mujer ideal" mostrada en la prensa. Se examinará el papel que han desempeñado las enfermeras en las dos guerras del siglo XX en España: la Campaña de Marruecos y la Guerra Civil, principalmente y con particular interés en este último conflicto, por la importante labor que realizaron millares de mujeres que sirvieron al esfuerzo bélico de los dos bandos tanto en el frente como en la retaguardia.

Dado que el objeto de la investigación son las mujeres enfermeras en las primeras décadas del siglo XX, se ha utilizado un enfoque histórico y de género, que permitirá analizar qué hacen, cómo lo hacen, su rol en la sociedad, en la familia, etc. Pero que también ayudará a establecer el papel de la sociedad en la imagen y función de las enfermeras. María José Cao explica que la transmisión de un juicio androcéntrico a través de la historia, en el que la mujer permanece en una condición de inferioridad, de subordinación, justificada por la ciencia, ha favorecido la ausencia de datos sobre el conocimiento de la vida de las mujeres ${ }^{14}$. Por eso es necesario trabajar con el método de género que permite hacerse preguntas sobre los motivos que impulsaron a las mujeres a ser enfermeras, qué supuso esa decisión para ellas dentro del contexto social y cuáles fueron las consecuencias de la misma.

Se han revisado las fuentes historiográficas relacionadas con la Enfermería en la primera mitad del siglo XX, cuyo número cada vez es mayor gracias al interés creciente en el tema como se ha podido constatar en el XIV Congreso de Nacional y IX Internacional de Historia de la Enfermería celebrado este año con motivo del

\footnotetext{
${ }^{14}$ CAO TORIJA, María José: Estudio de alimentación, nutrición y actividad fisica en población femenina adulta urbana de Valladolid (AMUVA). Tesis doctoral, Facultad de Medicina, Universidad de Valladolid, Valladolid, 2013, p. 40.
} 
centenario de la profesión. Únicamente se citarán en este apartado aquellos trabajos de mayor relevancia para la investigación, como los desarrollados por Carmen González Canalejo sobre la Enfermería contemporánea, los practicantes y las matronas, que han contribuido de una forma especial a contextualizar la situación profesional de las enfermeras. También se ha consultado la obra de Carmen Domínguez Alcón y Carmen Sellán Soto, sobre la profesión y el trabajo desarrollado por las enfermeras. Al hablar de la Guerra Civil se hace indispensable abordar los trabajos realizados por Anna Ramió, Roser Valls y Carme Torres, entre otras historiadoras de la Enfermería, sobre las enfermeras catalanas y su labor durante el conflicto. La obra de Angela Jackson, que recopila los testimonios orales de las enfermeras británicas que trabajaron en los equipos quirúrgicos republicanos, también ha sido de gran ayuda a la hora de reconstruir los hechos.

Cada vez son más numerosas las Tesis doctorales que abordan la Historia de la Enfermería, pero únicamente se destacarán aquellas centradas en conocer la participación y el papel de las enfermeras en las guerras, debido a la relación directa que tiene con el análisis que se va a realizar de la Campaña de Marruecos y la Guerra Civil. Siguiendo esta línea de investigación, Ana Choperena analiza las memorias de enfermeras durante la Guerra Civil Americana, mientras que Isabel Antón centra su investigación en las enfermeras en la Guerra Civil Española.

Para contextualizar la situación de la mujer se han revisado, entre otras, la obra de Rosa María Capel sobre el voto femenino y la Segunda República, o la de Mary Nash sobre las mujeres tanto en el periodo republicano como en la guerra. Gloria Núñez y la documentación sobre el trabajo femenino en la Segunda República, Kathleen Richmond y su análisis de la Sección Femenina y Mónica Orduña con su trabajo sobre la obra de Auxilio Social, también han sido referencias necesarias para encuadrar el contexto socio-laboral de las enfermeras.

Para identificar la imagen "oficial" de las enfermeras se han utilizado los manuales formativos de cada etapa histórica y los reglamentos sobre la profesión encontrados en los archivos. Para poder examinar la imagen "subjetiva" de las profesionales se han manejado libros de memorias de enfermeras y la correspondencia oficial sobre peticiones, nombramientos y destituciones. Para 
desarrollar la imagen "social" de las enfermeras ha sido imprescindible estudiar la prensa generalista, a través del $A B C$ y $L a$ Vanguardia, y la específica, que sería aquella relacionada con la profesión, tanto a nivel sanitario, como la oficial de los colegios y asociaciones profesionales.

Cabe señalar la dificultad inicial para encontrar documentación pertinente relacionada con el tema de estudio. Si es complejo describir la huella que han dejado las mujeres, más difícil ha sido localizar la información relativa a las enfermeras. Fue imprescindible revisar la documentación sobre el tema localizada en Madrid, en sus archivos y bibliotecas, en Salamanca y en Ávila. Una vez recopilados los datos, la diversidad de fuentes primarias analizadas ha hecho ciertamente complejo dar coherencia a toda esa información.

Los principales archivos, hemerotecas y bibliotecas utilizados han sido los siguientes:

Biblioteca Nacional Española (BNE), donde se han consultado principalmente manuales formativos para enfermeras y prensa especializada de la Segunda República y la Guerra Civil. En los primeros se plasman los conocimientos teórico-prácticos que estudiaron y las cualidades morales y físicas que debían reunir las enfermeras, incluidos sus deberes no tanto profesionales, sino en sus relaciones con los enfermos, los médicos, la institución para la que trabajaban y con sus compañeras. También se ha tenido acceso a revistas especializadas como los Boletines oficiales de los colegios de practicantes, en los que se puede observar la animadversión que tenían hacia a las enfermeras y los conflictos profesionales que surgieron. La revista de la Asociación de Enfermeras Visitadoras, órgano oficial de la misma, en la que se describían sus funciones y el trabajo realizado por las visitadoras. La BNE cuenta con prensa específica sanitaria editada durante la guerra en la zona republicana, en la que se ha podido identificar la divulgación de conocimientos básicos sobre primeros auxilios y condiciones de salubridad. A nivel médico se hicieron publicaciones de interés que sirvieron para perfeccionar las 
técnicas quirúrgicas y tratamientos. Sus artículos también se dirigían a los camilleros, chóferes y sanitarios en general, cuya labor fue fundamental.

Biblioteca Pública de Castilla y León, en ella se han examinado libros sobre el contexto histórico de la mujer, principalmente memorias y relatos de milicianas, de hospitales en los que se atendieron a los heridos durante la Guerra Civil y en los que trabajó el personal sanitario femenino, memorias de soldados y dos libros escritos por enfermeras, Así empezamos, memorias de una enfermera de María Rosa Urraca Pastor, y Misericordia en Madrid de Mary Bingham de Urquidi. También se analizaron tres números de 1938 de Y: revista de la mujer nacional sindicalista.

Biblioteca de la Universidad de Valladolid, se ha accedido principalmente a libros sobre el contexto histórico localizados en la Facultad de Filosofía y Letras, y del ámbito sanitario en la Facultad de Ciencias de la Salud, que han servido para encuadrar la formación y el trabajo que desempeñaron las enfermeras en cada etapa analizada y relacionarlos con la situación de las mujeres. En la hemeroteca de la Facultad se han encontrado las siguientes revistas sanitarias: Revista Española de Medicina y Cirugía de Guerra, y Revista Española de Medicina y Cirugía, que iniciaron su tirada en la Guerra Civil en el bando nacional y han servido para identificar cuál fue la situación sanitaria en la zona y la cobertura asistencial que se dio a través de los hospitales y equipos médicos.

Centro Documental de la Memoria Histórica, principalmente se ha tenido acceso a revistas sanitarias republicanas, en las que se describe el trabajo que llevaron a cabo los diferentes equipos quirúrgicos, tanto en los hospitales de vanguardia como de retaguardia. También aparecen artículos sobre la ayuda médica internacional y las enfermeras extranjeras que participaron en la guerra. Además se han podido consultar los carteles de guerra a través de la página web de la institución, entre los que se han encontrado aquellos que hacen referencia a la Sanidad a través de la imagen de las enfermeras. 
Centro de Documentación de Cruz Roja Española dispone de una amplia red de información sobre damas enfermeras y enfermeras de la institución. Se ha podido estudiar los manuales formativos desde el año 1917 hasta 1940, además de memorias de hospitales y juntas de señoras desde 1920 hasta 1926.

Se ha hecho una amplia labor de archivo, revisando todas las carpetas sobre enfermeras desde 1918 hasta 1940, en las que hay documentación sobre la Duquesa de la Victoria, la labor desarrollada por Cruz Roja y su personal sanitario durante la Campaña de Marruecos. También hay cajas sobre el periodo republicano, siendo escasos los documentos sobre la Guerra Civil y el papel de la institución durante la misma. No se ha encontrado constancia del trabajo que desempeñaron las enfermeras y damas de la institución en la zona republicana durante el conflicto.

Se ha consultado la revista de la institución desde el año 1918 hasta 1936, que contiene información relevante sobre los distintos periodos históricos y su personal sanitario, reglamentos, cursos formativos, entrega de recompensas y medallas. Fue el principal órgano de difusión de la labor de Cruz Roja y las funciones y trabajo desempeñado por las juntas de señoras y sus enfermeras.

Archivo de Palacio Real, la intención era encontrar correspondencia personal entre la Duquesa de la Victoria y la reina Victoria Eugenia establecida durante la Campaña de Marruecos de 1921 a 1925, si bien únicamente hay constancia del nombramiento de la duquesa como dama de la reina en 1911.

Archivo General de la Administración, se identificaron todas las cajas relacionadas con el tema de estudio, encontrando información sobre la Campaña de Marruecos y la situación sanitaria en la zona. Se halló documentación sobre la prensa gráfica republicana durante la Guerra Civil, principalmente fotografías de Sanidad Militar en las que aparecen enfermeras en los hospitales del frente, con los heridos y en las fiestas benéficas destinadas a la recaudación de fondos. También se han encontrado imágenes de mujeres en la retaguardia en los talleres de confección y fotografías de milicianas. 
Archivo General Militar de Madrid, principalmente se ha localizado documentación sobre la situación sanitaria en la Campaña de Marruecos, siendo menor la relacionada con la Guerra Civil.

Archivo Histórico de Defensa Judicial, en el mismo se ha accedido al sumario del juicio de dos enfermeras republicanas acusadas de auxilio a la rebelión.

Archivo General Militar de Ávila, se han revisado diferentes carpetas, principalmente aquellas que contienen la correspondencia de Mercedes Milá, inspectora de los Servicios Femeninos de Sanidad Militar. Ha sido información relevante y de gran interés para la investigación, ya que refleja el trabajo que desempeñaron las enfermeras nacionales, los requisitos que debían reunir para ir al frente con los equipos quirúrgicos, los nombramientos, ceses y destituciones, y los motivos de ellos. También se aprecian los conflictos que surgieron, los riesgos que corrieron y el control que ejerció Mercedes Milá sobre todo el personal sanitario femenino.

Hemeroteca Municipal de Madrid, se ha accedido tanto a prensa especializada como general, principalmente revistas para mujeres. Se ha indagado en los boletines oficiales de los colegios de practicantes y de matronas, ambos del periodo republicano. En los primeros aparecen artículos mordaces que son un ataque directo hacia las enfermeras y sus funciones asistenciales, en los que los practicantes dejaban claro que el único auxiliar del médico eran ellos. El Boletín del colegio de matronas fue el órgano de difusión del Seguro Obligatorio de Maternidad y los beneficios que supuso para el colectivo. También incluye algún artículo sobre las enfermeras, pero en menor medida. Dentro del periodo republicano se han estudiado revistas de mujeres con el objetivo de analizar la situación socio-laboral de las mismas. De la etapa bélica se ha accedido a la prensa sanitaria, publicaciones que describieron el trabajo sanitario en los frentes, la red hospitalaria republicana y se centraron en educar y enseñar a los soldados las medidas de salubridad necesarias para la prevención de enfermedades infecto-contagiosas. También se han leído las publicaciones de las revistas de las diferentes asociaciones femeninas republicanas. Respecto a las revistas nacionales, se ha podido analizar el contenido del Boletín de Auxilio Social, órgano de difusión de la asociación en el que puede verse el trabajo 
que llevó a cabo y el papel de las mujeres dentro de la organización, principalmente a través del Servicio Social. Finalmente se accedió a todo el contenido de Y: revista de la mujer nacional sindicalista, que describía el trabajo de Sección Femenina y el papel de la mujer en la "nueva" España.

Hemeroteca digital del $A B C$ y $L a$ Vanguardia, el objetivo de consultar ambos periódicos ha sido analizar los artículos sobre enfermeras, damas enfermeras, Cruz Roja, Sanidad y mujeres, desde 1915 hasta 1939. Se eligió el $A B C$, para poder tener dos visiones de la Guerra Civil, la de la cabecera de Sevilla y la de Madrid. Se incluyó la información de La Vanguardia, para ampliar la visión social de la Enfermería y sus profesionales.

Filmoteca Nacional Española contiene documentación gráfica sobre la Guerra Civil en ambos bandos, sobre los bombardeos y el trabajo de las mujeres republicanas. No se han encontrado films sobre enfermeras o su trabajo durante el conflicto.

Instituto Nacional de Estadística se ha buscado información relacionada con el número de enfermeras matriculadas en las Facultades, encontrando datos de la etapa republicana.

Boletín Oficial del Estado, ha aportado toda la documentación relacionada con la normativa que afecta los estudios de Enfermería y a sus profesionales en todo el periodo analizado, principalmente a través de la Gaceta de Madrid.

El manejo de estas fuentes documentales permite identificar la evolución formativa y laboral de las enfermeras españolas y relacionarla con la situación sociopolítica de la primera mitad del siglo XX y la que vivieron las mujeres. Para ello se abordan distintos enfoques, por un lado el papel que jugó Cruz Roja en el desarrollo de la profesión, tanto como institución sanitaria que participó en los conflictos bélicos de este periodo, como por la creación del cuerpo de damas enfermeras y enfermeras profesionales, lo que permite identificar las diferencias y similitudes entre ambas titulaciones, a la vez que facilitan estudiar las repercusiones que tuvo la Segunda Republica para la Enfermería, tanto a nivel profesional, como social. A 
través de los manuales formativos se han podido identificar las características físicas y morales exigidas a las enfermeras. Las fuentes facilitan el análisis de la participación de las enfermeras en la Campaña de Marruecos y en la Guerra Civil. De forma transversal y englobando toda la investigación se analizará el papel que jugó la prensa escrita en la configuración de la imagen social de la Enfermería y de sus profesionales.

La tesis se compone de cinco capítulos. El primero se centra en la monarquía de Alfonso XIII. Se inicia la investigación en 1915, año en el que nace la Enfermería española como profesión. Hasta ese momento únicamente se habían legitimado las profesiones de matrona y practicante gracias a la Ley Moyano de 1857, teniendo que esperar la Enfermería cincuenta y ocho años para iniciar oficialmente su camino. Una vez identificados los motivos y las consecuencias que tuvo la Real Orden para la Enfermería, se abordará el trabajo que desarrollaron las enfermeras españolas profesionales en la Campaña de Marruecos de 1921-1925, primer conflicto bélico en el que participaron.

El segundo capítulo aborda el periodo republicano, y cómo los cambios socio-políticos afectaron a las enfermeras, tanto como mujeres, como a nivel laboral. La Enfermería se consolida en esta etapa y aumenta el número de profesionales fomentado por la posibilidad de poder examinarse en otras Facultades de Medicina que no fuera la Central de Madrid. Empezaron a adquirir mayor peso las lecciones técnicas pero no desaparecieron las relacionadas con las características físicas y morales que debían reunir las enfermeras.

Posteriormente en el capítulo tercero se desarrollará la situación que vivieron las enfermeras durante la Guerra Civil en la zona republicana. Primero se identificará cual fue la participación femenina, tanto en el frente como en la retaguardia. A continuación se detallará la situación sanitaria y la red asistencial en la que trabajaron las enfermeras, para terminar describiendo la labor que realizaron, los peligros a los que enfrentaron y las condiciones adversas que superaron sin dejar de atender a los heridos. 
El hecho de contar con mayor documentación sobre las enfermeras en la zona llamada nacional hace que haya sido necesario dividir en dos capítulos la información. El cuarto centrado en la movilización y participación de las mujeres en la guerra, principalmente a través de las organizaciones femeninas. También se identificarán el tipo de hospitales y la situación socio-sanitaria en la que se vieron inmersas, para cerrar el mismo con la formación que se impartió a las enfermeras durante el conflicto.

El quinto y último capítulo aborda en profundidad los requisitos exigidos a las enfermeras para poder trabajar en los hospitales militares, los motivos de los nombramientos, ceses y destituciones. Se analizará el trabajo que desempeñó Mercedes Milá como inspectora general de los servicios femeninos de Sanidad Militar, la labor que llevaron a cabo las enfermeras, el papel que jugó en la misma la propaganda y la religión, y los peligros que corrieron. Finalmente se expondrán de forma breve las consecuencias que tuvo la guerra para las enfermeras en los primeros meses del franquismo, sin ahondar en este periodo tan amplio y complejo.

A lo largo de los diferentes bloques cronológicos se intenta mantener la misma estructura temática. Primero se hace un breve apunte de la situación sociopolítica de la mujer que ayudará a comprender mejor la realidad de las enfermeras. Posteriormente se desarrollarán las circunstancias de las enfermeras en ese contexto histórico, para después describir su formación, el trabajo realizado y la imagen proyectada a través de los manuales y la prensa, tanto especializada como general, que se integra en los distintos puntos para completar la información obtenida de otras fuentes documentales. Al final de cada capítulo se incluirán los anexos que apoyan el tema desarrollado. 
CAPÍTULO I

MUJER Y ENFERMERÍA EN EL PRIMER TERCIO DEL SIGLO XX: NACIMIENTO DE UNA PROFESIÓN 

Capítulo I. Mujer y Enfermería en el primer tercio del siglo XX: nacimiento de una profesión

\section{SITUACIÓN DE LA MUJER ESPAÑOLA A PRINCIPIOS DEL}

\section{SIGLO XX: COMIENZA EL CAMINO HACIA LA EMANCIPACIÓN}

La lucha por la igualdad femenina en España comenzó a finales del siglo XIX de la mano de Emilia Pardo Bazán ${ }^{1}$ y Concepción Arenal $^{2}$, que sentaron las bases del feminismo español como claras defensoras de la emancipación femenina ya que lucharon por romper con la imagen estereotipada de la mujer como ángel del hogar y por conseguir el libre acceso femenino a la educación reglada.

Todo cambio social afecta indistintamente a los diferentes estratos de la población, y en lo que compete a las mujeres, la industrialización provocó una mayor incorporación de mano de obra femenina, potenciándose de esta forma el trabajo fuera del hogar. Como señala Rosa María Capel, la mujer pasó a ser coproductora de riqueza, con la salvedad de que su incorporación laboral se hizo en términos de desigualdad, sobre todo económica. Fue contratada principalmente para sustituir o completar la mano de obra masculina, empleándola en puestos inferiores o secundarios, eventuales en muchos $\operatorname{casos}^{3}$.

Dentro de este contexto social, las mujeres comenzaron a asociarse, surgiendo así los primeros movimientos feministas. La historia de la mujer en España adquiere una serie de matices que difieren del planteamiento europeo, ya que el comienzo del feminismo fue más paulatino. Margarita Nelken ${ }^{4}$ lo explicaba en su obra La condición social de la mujer en España en la que resaltaba que en la España de principios del siglo XX, el feminismo era escaso y reciente, unido a la causa

\footnotetext{
${ }^{1}$ Ver Faus Sevilla, Pilar: Emilia Pardo Bazán: su época, su vida, su obra. Fundación Pedro Barrié de la Maza. Coruña, 2003.

${ }^{2}$ Ver MARTín, Elvira: Concepción Arenal. Confederación Española de Gremios y Asociaciones de libreros. Madrid, 1994.

${ }^{3}$ V.V.A.A: Mujer y Sociedad en España (1700-1975). Ministerio de Cultura, Estudios sobre la Mujer. Dirección General de Juventud y Promoción Socio-Cultural, Madrid, 1982, pp. 210-238.

${ }^{4}$ Ver GARCíA RodRíGUEZ, Fernando: Margarita Nelken: el arte y la palabra. Fragua Editorial. Madrid, 2010.
} 
económica y carente de lucha ideal ${ }^{5}$. También exponía que dentro del ambiente socio-cultural impuesto durante siglos, las aptitudes de las mujeres españolas estaban oprimidas por la educación recibida. Este incipiente feminismo se vio frenado por la proyección socio-política de una imagen de mujer delicada, abnegada y bondadosa, en cuyo interior anidaba el "germen" de la corrupción social y moral ${ }^{6}$.

Durante el reinado de Alfonso XIII, la mujer española comenzó a luchar por conseguir su emancipación, rompiendo para ello con la marginación impuesta por la sociedad patriarcal que la impedía participar en los asuntos de orden público, quedando relegada únicamente a la esfera privada, como "ángel del hogar". Será en este periodo cuando empiecen a aparecer los grupos femeninos que abogaban por la plena integración de la mujer en la vida política y social. Las mujeres precursoras de los mismos fueron las que poseían un nivel cultural superior a la media femenina o bien obreras que se agruparon en sindicatos o asociaciones de clase ${ }^{7}$.

Esta reivindicación social propició que en 1910 se reconociera de forma oficial el acceso y derecho de la mujer a la educación superior. Poco después, en 1915, a instancia de la Junta para Ampliación de Estudios (JAE), se fundó la Residencia de Señoritas de España, de la que fue directora María de Maeztu ${ }^{8}$, maestra y pedagoga. Cabría resaltar que la primera alumna matriculada en dicha residencia fue Victoria Kent ${ }^{9}$. La integración femenina en la sociedad, facilitar su acceso a la educación e impulsar un modelo de mujer preparada y activa a nivel profesional, capaz de participar en las inquietudes intelectuales y culturales del momento, fueron los objetivos que marcó María de Maeztu en la Residencia para Señoritas ${ }^{10}$.

\footnotetext{
${ }^{5}$ NeLKen MAUSBerger, Margarita: La condición social de la mujer en España. CVS ediciones, Madrid, 1975 , p. 35.

${ }^{6}$ NÚÑ̃z PUENTE, Sonia: Una historia propia. Historia de las mujeres en la España del siglo XX. Pliegos, Madrid, 2009.

${ }^{7}$ V.V.A.A. Mujer y Sociedad en España (1700-1975)...op.cit., pp. 243-260.

${ }^{8}$ Ver Pérez VillanueVa Tovar, Isabel: María de Maetzu: Una mujer en el reformismo educativo español. Universidad Nacional de Educación a Distancia. Madrid, 1989.

${ }^{9}$ Ver GutiérRez Vega, Zenaida: Victoria Kent: una vida al servicio del humanismo liberal. Servicio de Publicaciones Universidad de Málaga, Málaga, 2001.

${ }^{10}$ V.V.A.A. Mujeres en la historia de España. Enciclopedia biográfica. Plantea, Barcelona, 2000, p. 577.
} 
Entre las asociaciones de mujeres que empezaron a ver la luz en el primer tercio del siglo XX hay que tener en cuenta: Asociación Nacional de Mujeres Españolas (ANME), Acción Católica de la Mujer (ACM) y el Lyceum Club.

La Asociación Nacional de Mujeres Españolas (ANME), fundada en Madrid en 1918, estuvo integrada principalmente por escritoras, maestras, universitarias y aquellas mujeres interesadas en la concesión del voto femenino. Estableció un programa de acción específico que buscaba la reforma del código civil, de forma que se garantizara la igualdad femenina, además de luchar contra la discriminación social y legal que sufrían las mujeres ${ }^{11}$.

En 1919, se fundó Acción Católica de la Mujer (ACM), como un medio para contrarrestar la movilización femenina laica y propiciar el asociacionismo católico femenino. Su principal objetivo fue la defensa de los derechos de la mujer desde una perspectiva católica, donde primaban la abnegación y la piedad femeninas. ACM luchó por la educación y el trabajo extradoméstico de la mujer siempre dentro de los postulados marcados por la religión católica, y para ello se centró en las cualidades femeninas relacionadas con su superior moralidad y religiosidad ${ }^{12}$.

El Lyceum Club Femenino fue otra de las asociaciones que permitió a las mujeres salir a la esfera pública. En él se desarrollaron actividades de interés cultural, en torno a las cuales se reunía la élite femenina, preparada académicamente e interesada en defender los intereses morales y materiales de las mujeres. La ruptura con el rol tradicional femenino suscitó críticas y burlas por parte de los círculos católicos conservadores que veían como una amenaza a las mujeres del Lyceum ${ }^{13}$.

\footnotetext{
${ }^{11}$ En el capítulo dedicado a la Segunda República se abordará nuevamente el papel de la ANME por su participación activa en la lucha por el sufragio femenino.

${ }^{12}$ V.V.A.A. Historia de las mujeres en España y América latina. Del siglo XX a los umbrales del XXI. Cátedra, Madrid, 2006, Blasco, I. Feminismo católico. pp.55- 71.

${ }^{13}$ V.V.A.A. Mujeres en la historia de España... op.cit., p. 578.
} 
Dentro de este contexto socio-cultural y político, la Enfermería nacía como una profesión de mujeres que les permitiría su emancipación gracias al desempeño de un trabajo remunerado. Antes de abordar cuál fue la situación laboral de las enfermeras y su rol durante la monarquía de Alfonso XIII, es necesario establecer cuáles fueron los orígenes de la profesión y el papel de Cruz Roja como institución que la potenció. 


\section{ENFERMERÍA, UNA PROFESIÓN DE PRINCIPIOS DEL SIGLO} XX

\subsection{Orígenes}

A nivel internacional, el nacimiento de la Enfermería profesional aparece en la segunda mitad del siglo XIX, siendo Florence Nightingale ${ }^{14}$ su figura principal, como pionera en la formación de enfermeras. El trabajo sanitario realizado por Nightingale durante la guerra de Crimea, le sirvió para conseguir los apoyos necesarios para fundar la primera escuela de enfermeras en Londres en 1860, en el Hospital de Santo Tomás, en una sociedad victoriana reticente al trabajo femenino de las mujeres pertenecientes a clases sociales acomodadas ${ }^{15}$. Como señala Carmen Sellán Soto, el éxito de Florence Nightingale se centró principalmente en la secularización de la Enfermería femenina ${ }^{16}$.

Nuevas líneas de investigación, como la seguida por Juana María Hernández Conesa, atribuyen a la Enfermería moderna un origen anterior a Florence Nightingale. En su libro, Un estudio de los paradigmas educativos enfermeros durante el siglo XIX, Conesa describe un manual de enfermeras escrito por Ernesto Rusca veintiséis años antes que Notas de Enfermería: qué es y que no es ${ }^{17}$. Además de existir una gran similitud entre los conocimientos aportados en ambas obras, 1o relevante es que a diferencia de Nightingale, Rusca, lo escribió dirigiéndose directamente a las enfermeras y no a las mujeres ${ }^{18}$. Aun así, no se puede negar que Florence Nightingale cambió el rol de la Enfermería, convirtiendo a las enfermeras en profesionales del cuidado ${ }^{19}$.

Por lo que respecta a España, la Enfermería profesional no apareció hasta principios del siglo XX, gracias a la Real Orden de 7 mayo de 1915. Esto no quiere

\footnotetext{
${ }^{14}$ Ver SchaEFER, Lola, M: Florence Nightingale. Capstone, Minesota, 2005.

15 Galindo CaSERo, Antonio: Formación, profesionalización e ideologías en enfermería (1953-2000). Tesis doctoral, Universidad de Extremadura, departamento de Historia. Cáceres 2003, p. 8.

${ }^{16}$ Ver SELlán Soto, María Carmen: La profesión va por dentro. FUDEN, Madrid, 2009, pp. 49-51.

17 Dentro de los textos escritos por Florence Nightingale, un total de ciento cuarenta y siete, Notas de enfermería: qué es y que no es, publicado en 1859, ha sido su principal obra y la que ha alcanzado mayor proyección.

${ }^{18}$ HERNÁNDEZ CONESA, Juana María: Un estudio de los paradigmas educativos enfermeros durante el siglo XIX. Diego Marín Librero-Editor, Murcia 2012.

${ }^{19}$ CoHEN, Helen A: La enfermera y su identidad profesional. Ediciones Grijalbo, Barcelona, 1988, p.178.
} 
decir que la figura de la mujer cuidadora, enfermera, no existiera anteriormente. Al contrario, las mujeres se han encargado a lo largo de la historia del cuidado de la familia, de los enfermos, niños y ancianos. A medida que la Edad Media avanza, la asistencia a los enfermos adquiere un carácter femenino y laico hasta la llegada del siglo XVI en el que las órdenes religiosas, como consecuencia del Concilio de Trento, adquirieron mayor protagonismo en el cuidado de los enfermos, pobres, indigentes, niños y ancianos ${ }^{20}$. De esta forma, la Enfermería ha estado influenciada por el trabajo realizado por las Hermanas de la Caridad ${ }^{21}$, que como señala Carmen González Canalejo, fueron las encargadas de distribuir el trabajo en los hospitales, además de organizar la asistencia de los enfermos y la contratación del personal, confiándolas la vigilancia de la moralidad del mismo $^{22}$.

Por su parte, en España, otras profesiones sanitarias, como practicantes y matronas, contaban desde la segunda mitad del siglo XIX con una regulación estatal y un programa general de estudios. La Ley de Instrucción Pública de 1857, o Ley Moyano, posibilitó que matronas y practicantes obtuvieran su titulación en las Facultades de Medicina, de esta forma se consiguió legitimar la enseñanza de estas profesiones. Entre los requisitos que debían reunir las matronas se encontraba el de estar casadas o viudas, tener más de veinte años, adjuntar un certificado de buena conducta moral expedido por un párroco, la autorización del padre o marido y tener aprobada la enseñanza elemental. Para los practicantes, por su condición de varones, los requisitos exigidos eran menos estrictos, tenían que ser mayores de dieciséis años y haber aprobado la enseñanza elemental ${ }^{23}$.

\footnotetext{
${ }^{20}$ Nicolas MASS, C. M: Notas para la historia de las Hijas de la Caridad en España. Tomo II: 1800 a 1850. Editorial CEME, Salamanca, 1988.

${ }^{21}$ Hijas o Hermanas de la Caridad, orden de enfermería femenina dedicada al cuidado de enfermos y necesitados, que apareció en Francia en 1633 de la mano de San Vicente de Paul, inicialmente laica, hasta 1634, año en que María Luisa de Marillac hizo los votos mientras estaba al frente de la organización. Los votos de las Hermanas de la Caridad eran: obediencia, castidad, pobreza y asistir corporal y espiritualmente a los enfermos pobres.

${ }^{22}$ GONZÁlez CANALEJO, Carmen: Las cuidadoras. Historia de las practicantes, matronas y enfermeras (1857-1936). Premio de ensayo "Carmen Burgos" 2005. Instituto de Estudios Almeriense, Almería, 2006. P. 86.

${ }^{23}$ Ibid., p. 32.
} 


\subsection{Inicio del camino hacia la profesionalización enfermera en España}

Como precedente de la profesionalización de la Enfermería española es necesario mencionar la Ley de 1904, que estableció la obligatoriedad de poseer un título oficial para poder trabajar en una profesión sanitaria. Esta legitimación de los títulos sanitarios consolidó las profesiones de practicante y matrona y dejó la puerta abierta a la creación de nuevas carreras sanitarias. Por lo tanto, a partir de ese momento, estar en posesión de un título legítimo, permitió una práctica profesional regulada, evitó el intrusismo y fomentó la formación reglada ${ }^{24}$.

En 1915, las Siervas de María, Ministras de los enfermos, solicitaron a Alfonso XIII, a través de una instancia, la autorización para ejercer la profesión a enfermeras pertenecientes o no a comunidades religiosas que acreditaran tener los conocimientos necesarios establecidos dentro de un programa oficial ${ }^{25}$. De esta forma, en la Real Orden de 7 de mayo de 1915 se aprobó el primer programa de estudios necesario para habilitar enfermeras; además de los conocimientos teóricos, se exigía a las alumnas la realización de prácticas tanto en instituciones públicas (hospitales, centros benéficos), como en clínicas o consultorios privados. E1 programa teórico constaba de un total de setenta lecciones, que se dividían en bloques generales de Anatomía, Fisiología y Patología, y temas específicos como: cualidades físicas, morales e intelectuales de la enfermera, deberes y obligaciones que debían cumplir y reglas generales a tener en cuenta en caso de intervención judicial, ante pacientes heridos y ante una persona muerta. Para obtener el título de enfermera las aspirantes tenían que aprobar ante un tribunal el examen teóricopráctico establecido por la Facultad de Medicina de la Universidad Central de Madrid $^{26}$. Puede decirse que la Enfermería empezaba su profesionalización a la vez que la mujer iniciaba su emancipación. Como señala Carmen Domínguez-Alcón, la formación de enfermeras tuvo una relación directa con este hecho, siendo una ocupación socialmente adecuada para la mujer que quería desempeñar un trabajo

\footnotetext{
${ }^{24}$ Sellán Soto, M. C: op.cit., p. 92.

${ }^{25}$ Ibid., p. 93 .

${ }^{26}$ Gaceta de Madrid, ${ }^{\circ}$ 141, 21 de Mayo de 1915, Real Orden que aprueba el programa de los conocimientos que son necesarios para habilitar enfermeras a las que lo soliciten, pertenecientes o no a comunidades religiosas, pp. 484 a 486.
} 
que le permitiera cierta independencia económica ${ }^{27}$. Cabe tener en cuenta algunas limitaciones de la Real Orden identificadas por María Elena González, la primera sería que únicamente los exámenes eran en Madrid, en la Facultad de Medicina de la Universidad Central, lo que dificultó a las alumnas de otras provincias presentarse a los mismos. La otra apreciación importante fue que estar en posesión del título oficial no fue un requisito indispensable para poder ejercer como enfermera, a diferencia de lo que sucedía con practicantes y matronas ${ }^{28}$.

La Enfermería española nacía como profesión para cubrir una parcela asistencial concreta, la del cuidado. Para ello necesitaban una formación sólida, amplia y reglada, oportunidad que la Ley Moyano había dado a practicantes y matronas, cincuenta y ocho años antes, pero no a las enfermeras. La situación sanitaria del país, unida a las teorías higienistas y a la importancia mayor que iba adquiriendo la Salud Pública, también propiciaron la necesidad de una figura sanitaria especializada, apoyada por la legislación sanitaria. Como señala Magdalena Santo Tomás, fue necesario que la Iglesia, los políticos, la nobleza y los médicos apoyaran la aparición de un cuerpo de enfermeras profesionales. Las congregaciones religiosas encargadas del cuidado, necesitaban consolidar su labor asistencial en los hospitales, de esta forma, las Siervas de María, apoyadas por el Obispo de MadridAlcalá y el papado, solicitaron a Alfonso XIII la legislación necesaria para establecer los estudios de Enfermería de una forma oficial y reglada, fomentado por la laicalización sanitaria. A nivel político, Santo Tomás expone que fue necesaria la implicación del presiente del Gobierno, Eduardo Dato, sensibilizado con el tema y precursor de las leyes sociales, y de Saturnino Esteban de Miguel Collanes, ministro de Instrucción Pública y Bellas Artes, partidario de la actualización universitaria, y cuya experiencia como corresponsal en la guerra Franco-Prusiana le permitió conocer el trabajo realizado por el personal sanitario. Respecto al papel de la nobleza en el apoyo a la profesión, Santo Tomás habla del marqués de Fontalba y

\footnotetext{
${ }^{27}$ DomíngueZ-Alcón, Carmen: Los cuidados y la profesión enfermera en España. Ediciones Pirámide, Madrid, 1986.

${ }^{28}$ GONZÁLEZ IGLESIAS, María Elena: El asociacionismo de las enfermeras: Los inicios de la Enfermería como profesión, p. 268. En VV. AA: El asociacionismo de la Enfermería... op.cit.,
} 
Cubas, senador que respaldó a las Siervas de María en su nueva empresa. La alianza de los médicos fue imprescindible para poder establecer una enseñanza reglada, principalmente de cuatro miembros de la Real Academia Española de Medicina, Ramón Jiménez y Antonio Simoneta, catedráticos de la Facultad de Medicina, Nicasio Mariscal, epidemiólogo e higienista, y Luciano Barjas, otorrinolaringólogo del Instituto de Terapéutica Operatoria. Todo esto, unido al papel que desarrollaron en la Primera Guerra Mundial las enfermeras contribuyó a la profesionalización de la Enfermería ${ }^{29}$.

La aparición de una nueva profesión sanitaria tuvo sus detractores, tal fue el caso de los practicantes, que vieron en la misma una intrusión en su trabajo. En 1915 solicitaron una derogación de la Real Orden y llegaron a interponer un recurso ante el Tribunal Supremo para conseguir anularla. Como medio de difusión y de reivindicación, cada colegio de practicantes utilizó sus boletines, principalmente para divulgar su disconformidad con la nueva profesión, y plasmar su opinión sobre las enfermeras ${ }^{30}$. Esta discrepancia se intensificó en los años veinte, como señala Carmen González Canalejo, impidiendo que las profesionales se organizaran o asociaran a través de colegios oficiales ${ }^{31}$. Los practicantes mantuvieron en este periodo una clara oposición hacia el reconocimiento laboral de las enfermeras, luchando por la supremacía masculina en las tareas asistenciales auxiliares de la Medicina. La tensión aumentó en 1927 cuando por la Real Orden de 24 de febrero se hizo obligatorio para las enfermeras estar en posesión del título oficial para poder ejercer. Según Manuel Ángel Calvo, en ese momento los practicantes comprendieron que el cuerpo de enfermeras se consolidaba, abriéndose mayores puertas laborales para las mismas, ya que dicha orden las autorizaba para "hacer todo lo que hacían los practicantes menos asistir partos". Estos motivos les impulsaron a oponerse a dicha orden, considerando que la figura sanitaria de la

\footnotetext{
${ }^{29}$ SANTO TOMÁS PÉREZ, Magdalena: Antecedentes de la Enfermería que contribuirán al reconocimiento legal de la profesión. En: Un siglo cuidando a la sociedad. Centenario del reconocimiento oficial de la Enfermería en España. Colegio Oficial de Enfermería de Cantabria, Santander, 2015, pp. 45 a 56.

30 Calvo Calvo, Manuel Ángel: La reacción de los practicantes en Medicina y Cirugía frente a la creación del título de Enfermera en 1915. Dynamis, 2013. Disponible en: [0211-9536] 201; 34 (2): http://dx.doi.org/10.4321/S0211-95362014000200008, pp. 425 a 446.

31 GonzÁlez CANAlejo, Carmen: Asistencia Sanitaria, género y cuestión social en Almería, (18571930). Tomo II, tesis doctoral. Departamento de Historia, Geografía, Historia del Arte y Sociología. Facultad de Humanidades y Ciencias de la Educación Universidad de Almería, 2005, pp. 200-203.
} 
enfermera no era necesaria, generaba dualismo de funciones y tenía mayores facilidades para obtener el título oficial que los practicantes. Su movilización y reivindicaciones fueron amplias, principalmente a través de las revistas de sus Colegios Oficiales, en las que solicitaban la derogación de la Real Orden de 1927, o en su defecto la clarificación de funciones asistenciales, en las que la enfermera se encargaría de los cuidados a la cabecera del enfermo, y los practicantes de la ejecución de las técnicas ${ }^{32}$.

La profesionalización de la Enfermería impulsó la creación de escuelas de enfermeras y la formación específica de las mismas; de esta forma aparecieron distintos centros de enseñanza reglada en España tales como la Escuela de Santa Madrona, fundada en 1917 con el objetivo principal de ampliar el campo laboral de las mujeres, encargada de formar enfermeras veladoras ${ }^{33}$ y hospitalarias ${ }^{34}$. En 1918 se constituyó en Madrid la Escuela de San José y Santa Adela dedicada a la formación de las enfermeras de Cruz Roja ${ }^{35}$. Posteriormente surgió la Escuela de Enfermeras Auxiliares de Medicina de la Mancomunidad de Cataluña, en $1919^{36}$. En 1923 se fundó la Escuela Nacional de Puericultura como centro docente y científíco para formar específicamente al personal sanitario interesado en asistir a la población infantil, sobre todo niñeras y enfermeras visitadoras, por lo que no fue una escuela de formación exclusiva de enfermeras, ya que tenía un carácter multidisciplinar ${ }^{37}$. Otra de las escuelas de enfermeras de gran trayectoria e importancia para la profesionalización fue la Escuela de Enfermeras de la Casa Salud de Valdecilla ${ }^{38}$, que se fundó en 1929 bajo la protección de la marquesa de Pelayo ${ }^{39}$.

\footnotetext{
${ }^{32}$ Calvo Calvo, Miguel Ángel: La reacción de los colegios oficiales de practicantes a la creación de la enfermera titulada en 1927, pp. 383-389. En VV. AA: El asociacionismo de la Enfermería ... op.cit.,

${ }^{33}$ Enfermeras que por las noches se encargaban de cuidar a los enfermos.

${ }^{34}$ SEllán Soto, M. C: op.cit., p. 96.

${ }^{35}$ Cruz Roja Española: Hospital Escuela de Damas de la Cruz Roja de Madrid, San José y Santa Adela. Memoria del año 1923. Blass, Madrid, 1924. p. 27.

${ }^{36}$ SELlán Soto, M. C: op.cit., p. 97.

${ }^{37}$ Ibid., p. 112.

${ }^{38}$ María de la Luz Fernández Fernández, profesora de la Escuela de Enfermería de la Universidad de Cantabria y Licenciada en Historia, está terminando su tesis doctoral sobre la historia de la Escuela de Enfermeras de la Casa de Salud Valdecilla (1929-1954).

${ }^{39}$ SANTo TOMÁs PÉREZ, Magdalena: Historia de la enfermería, en V.V.A.A: Enfermería Fundamental, Barcelona, Masson, 2003, p. 80.
} 
Capítulo I

\section{CRUZ ROJA ESPAÑOLA Y SU PAPEL EN LA FORMACIÓN DE} ENFERMERAS

Como es bien sabido, la fundación de Cruz Roja se debe a Henry Dunant, que en 1859 impresionado por la dureza de la batalla de Solferino y la falta de personal sanitario disponible para asistir a los heridos, decidió organizar y dirigir él mismo la ayuda sanitaria $^{40}$. Dicha batalla fue decisiva para la constitución de Cruz Roja como una asociación voluntaria de socorro, encargada inicialmente de apoyar en tiempos de guerra a la Sanidad Militar, y cuyo personal sanitario se ofreció voluntariamente a prestar sus servicios en tiempos de guerra. Como emblema identificativo y protector de la asociación se eligió la cruz roja sobre fondo blanco ${ }^{41}$.

El mayor estandarte de Cruz Roja fue el pacto de neutralidad y asistencia a todos los necesitados sin ningún tipo de diferenciación, gracias a la firma, el 22 de agosto de 1864 de los diez artículos del Convenio Internacional para mejorar la suerte de los militares heridos en campaña. En él se estableció la neutralidad de ambulancias y hospitales militares siempre que hubiera en ellos heridos o enfermos, y de todo el personal sanitario incluyendo los servicios de sanidad, administración, transporte de heridos y capellanes, siempre que estuvieran ejerciendo sus funciones de asistencia a los heridos ${ }^{42}$. En 1869 se amplió la ayuda y socorro voluntario a casos de calamidades, catástrofes o cualquier otra desgracia, además de continuar con la formación de su personal en tiempos de paz para conseguir prestar ayuda de forma eficaz y organizada ${ }^{43}$.

El Comité Central de Cruz Roja Española, que adoptó el nombre de Asamblea Suprema, se constituyó el 6 de julio de $1864^{44}$. Organizó su trabajo de acuerdo a los principios de la institución: humanidad, imparcialidad, neutralidad, independencia, carácter voluntario, unidad y universalidad. El Comité Central estaba en Madrid, pero tenía distintas secciones o comisiones en las provincias obligadas a

\footnotetext{
${ }^{40}$ Para más información consultar: DunANT, Henry: Un recuerdo de Solferino. Ediciones Botas-México, México, 1937.

${ }^{41}$ Clemente, Josep Carles: Historia de la Cruz Roja Española. Cruz Roja Española. Gráfica universal, Madrid, 1990, pp. 27-29.

${ }^{42}$ Gimenez EnRICH, S: Anales de la Cruz Roja. Espasa Hermanos, Barcelona, sin año de edición, p. 17.

${ }^{43}$ CLEMENTE, J. C: op.cit., p. 34.

${ }^{44}$ GimeneZ ENRICH, S: op.cit., p. 21.
} 
cumplir los acuerdos centrales y a dar cuenta de sus actos a la asamblea ${ }^{45}$. Los primeros estatutos y reglamentos datan de 1868, tras el reconocimiento legal de Cruz Roja. En ellos se especificaba que la Asamblea Suprema estaría formada por una Comisión o Junta de Gobierno, cuyos Protectores serían los miembros natos y ejecutivos, encargándose los últimos de la dirección de la misma ${ }^{46}$. Los reyes e infantes tenían reservado el cargo de Protectores, mientras que el de Presidente y Vicepresidentes natos lo ostentaban el Gran Prior de la Orden de San Juan ${ }^{47}$ y el ministro de Guerra y el de Marina respectivamente ${ }^{48}$.

Cruz Roja contó con una sección de Caballeros y otra de Señoras, los primeros se dividían a su vez en socios fundadores, de mérito, activos y de número, mientras que las señoras lo hacían en afiliadas de caridad, de mérito y de número.

\subsection{Sección de Señoras}

Las secciones de señoras, conocidas en un primer momento como secciones de señoras de caridad, colaboraban con la sección de caballeros en el socorro a los heridos. Su principal cometido fue la organización de fiestas con el objetivo de recaudar dinero para la obra social de Cruz Roja. La sede principal se encontraba en Madrid, pero además de esta sección central existían distintas subcomisiones de distrito y secciones provinciales ${ }^{49}$.

El reglamento de 1916 organizó el régimen interior de la asamblea de señoras de Cruz Roja, además de establecer que su presidenta sería la reina Victoria Eugenia $^{50}$, que fue la encargada de la reorganización y autonomía de la misma. También se constituyeron los cargos directivos y sus funciones, y se especificaron los pasos a seguir por las señoras interesadas en formar parte de Cruz Roja. La

\footnotetext{
${ }^{45}$ GIMENEZ ENRICH, S: op.cit., p. 402.

${ }^{46}$ Clemente, J. C: op.cit., p. 52.

${ }^{47}$ La Orden de los Hermanos Hospitalarios de San Juan de Jerusalén, fue la asociación que organizó la Cruz Roja en España, que terminó con su fusión en 1870.

${ }^{48}$ CLEMENTE, J. C: op.cit., p. 52.

${ }^{49}$ Ibid., p. 52-55.

${ }^{50}$ Diario Oficial del Ministerio de Guerra. no 145, sábado 1 de julio de 1916, p. 1.
} 
petición de ingreso la cursaba la presidenta de la junta implicada (local, provincial, central...) y una vez admitidas debían abonar una peseta mensual a la junta respectiva además de la cuota de derechos de ingreso a la asamblea central. En caso de no cumplir con las retribuciones mensuales o de incurrir en los impagos de las mismas, eran dadas de baja.

Las juntas de señoras provinciales y del distrito de Madrid $^{51}$, estaban obligadas a aportar un porcentaje trimestral del dinero recaudado a la asamblea central, además de enviar anualmente, en enero, la copia de sus cuentas y los comprobantes de las mismas. Por aprobación del Ministerio de Guerra y de acuerdo con la Asamblea Central de Cruz Roja, en 1917, se estableció el reglamento de recompensas para la asociación de señoras de Cruz Roja Española, incluyendo las insignias que podían ostentar. Es necesario conocer el tipo de condecoraciones a las que optaban por su labor dentro de la institución, ya que durante la campaña de Marruecos se concedieron dichos distintivos a las asociadas, sobre todo a las enfermeras, damas y hermanas ${ }^{52}$.

Eran cuatro los tipos de condecoraciones obtenidas que debían lucir siempre en el lado izquierdo del pecho: Placa de honor y mérito; Medalla de primera clase; Medalla de segunda clase y Diploma de gratitud. La placa de honor únicamente se concedía por méritos o por prestación de servicios muy excepcionales y las medallas por "méritos especiales y extraordinarios o por servicios importantes prestados a la Cruz Roja" ${ }^{53}$. Para poder obtener las recompensas de mayor prestigio, como la placa o la medalla de primera clase, era necesario estar en posesión de otra recompensa de inferior categoría como mínimo durante un año ${ }^{54}$. Únicamente se hacía la excepción con las señoras pertenecientes a la Asamblea Central de Cruz Roja, que podían obtener la medalla de primera clase sin estar en posesión de la de segunda ${ }^{55}$.

\footnotetext{
51 La sección de señoras de Madrid estaba distribuida en diez distritos, cada uno con su presidenta, vicepresidenta, secretaria, tesorera y vocales.

52 Para obtener dicho distintivo era necesario que llevaran como asociadas un mínimo de seis meses. También podrían optar, en caso de guerra, a la concesión de recompensa señoras ajenas a la Institución que hubieran desarrollado una labor importante y meritoria.

${ }^{53}$ La Cruz Roja. no 177, marzo 1917. p. 74.

${ }^{54}$ El precio de las condecoraciones oscilaba entre las veinticinco pesetas de la Placa a las quince y diez pesetas respectivamente por la Medalla de primera y de segunda.

${ }^{55}$ La Cruz Roja. n ${ }^{\circ} 177$, marzo 1917. p. 74.
} 
Las secciones de señoras de Cruz Roja permitieron a las mujeres, que poseían cierto poder adquisitivo, formar parte de la esfera pública en la parcela social reservada al auxilio de los necesitados. Como señala Margarita Nelken, la beneficencia era el único campo de actividad, cuyo privilegio no había sido nunca "regateado" a la mujer, demostrando su capacidad de organización, dirección y administración ${ }^{56}$.

A principios del siglo XX la sección de señoras se fue desligando de la de caballeros, a la que había estado unida y de la que dependía directamente en su origen. El trabajo benéfico y de auxilio, hizo que las juntas de señoras alcanzaran mayor proyección social, lo que supuso un conflicto dentro de Cruz Roja. Ya en 1918, el Dr. Calatraveño explicaba la necesidad de la unión firme y sincera entre los dos grupos, el de señoras y el de caballeros, que integraban la asociación, para el buen funcionamiento del cuerpo de damas enfermeras. Cada grupo tenía una "misión importante e irremplazable", las señoras gracias a su "dulzura y encanto" conseguían recaudar fondos para la institución y eran las encargadas de ayudar en los hospitales y dispensarios, mientras que los caballeros prestaban "servicios de índole facultativa",57.

Esta autonomía femenina en la parcela del cuidado y la obra social hizo que Eladio Mille, presidente de la Asamblea Suprema de Cruz Roja, dirigiera un escrito reivindicativo a Alfonso XIII, el 30 de junio de 1922, en el que explicaba la incomodidad que generaba la sección de señoras a la de caballeros:

[...] A pesar de lo dispuesto en los Estatutos y en el Real Decreto de 13 de Julio de 1916, en España no hay una Cruz Roja: hay dos entidades absolutamente distintas entre sí que llevan esta denominación, que no tienen de común nada más que el nombre y que viven y actúan en separación completa, cuando no en términos

\footnotetext{
${ }^{56}$ NELKEN MAUSBERGER, M: op.cit., p. 150.

57 SÁncheZ DE ARrojo, Elena: El consultor de la Dama Enfermera. Sucesores de Antero Concha, Guadalajara, 1918, p.15!
} 
de verdadera discordia, con manifiesto perjuicio de la eficacia de la obra benéfica de la Institución, aparte de lo deplorable del espectáculo $[\ldots]^{58}$.

La junta de caballeros se quejaba de que Cruz Roja era conocida principalmente por la función benéfica que realizaban sus damas enfermeras. Por lo tanto, las juntas de señoras tenían todo el protagonismo ya que eran las encargadas de la dirección y gobierno de los hospitales, que había pasado a ser la parte más representativa de la institución. De esta forma el trabajo desempeñado por la sección de caballeros pasaba a un segundo plano.

En este escrito, Eladio Mille reflejaba cómo en alguna ocasión, la sección de señoras había manifestado en documentos oficiales que la labor de la sección de caballeros era la de auxiliar y cooperar. Esto rompía con los esquemas de la época, ya que en lugar de ser las juntas de señoras las subordinadas, eran las que dirigían la vital labor de Cruz Roja en España. Parte de ese protagonismo y prestigio se debía a que la principal figura de la sección de señoras era la reina Victoria Eugenia, como presidenta de la misma.

Mille exponía que Cruz Roja se fundó, no para crear y sostener hospitales, sino para auxiliar a Sanidad Militar en la primera asistencia, en la evacuación y en la conducción de heridos. Pretendía dejar claro que la formación de damas y enfermeras, y su trabajo asistencial en los hospitales y dispensarios no era la principal misión de Cruz Roja. También consideraba indispensable modificar la organización, sin necesidad de que desaparecieran las juntas de señoras, siempre que hubiera una autoridad efectiva sobre las dos secciones, que combinara el funcionamiento de ambas desde la unidad y la eficacia, además de regular y dirigir sus relaciones ${ }^{59}$.

Mille propuso que la jefatura suprema de la institución estuviera en manos de la reina Victoria Eugenia ${ }^{60}$, respaldada y ayudada "en el despacho de los negocios de la Cruz Roja", ya que no era posible que ejerciera por sí misma a diario las

\footnotetext{
${ }^{58}$ Archivo Central de Cruz Roja Española (ACCRE), Caja 2061, Expediente 4.

59 ACCRE, Caja 2061, Expediente 4.

${ }^{60}$ La reina Victoria Eugenia ya era, según los Estatutos de la Cruz Roja, la jefa suprema pero de una forma transitoria y eventual, en el escrito se solicita que sea de forma permanente. La labor humanitaria y
} 
funciones inherentes al cargo y a la representación de la institución, ni en sus relaciones con el Gobierno y con las autoridades del país, ni en su vida internacional ${ }^{61}$. El encargado de apoyar a la soberana en dicha labor sería un hombre, legítimamente acreditado por Alfonso XIII. De esta manera se dejaba claro que la función de la mujer sería secundaria a la del hombre, menos importante, pero necesaria para el funcionamiento de la institución.

\subsection{Damas y Enfermeras de Cruz Roja Española}

La formación de damas y enfermeras fue uno de los principales cometidos de Cruz Roja desde el comienzo del siglo XX, ambas titulaciones tienen matices que las diferencian y ciertas similitudes que se abordarán en profundidad.

\subsubsection{Damas Enfermeras}

Anterior a la formación de enfermeras profesionales, Cruz Roja comenzó su tarea pedagógica con el cuerpo de damas enfermeras cuyos estudios se aprobaron de forma oficial en al año 1917, siendo la reina Victoria Eugenia su principal precursora. Las juntas de señoras de Cruz Roja fueron las encargadas de organizar el cuerpo de damas enfermeras que nació con el objetivo de auxiliar a Sanidad Militar y a los médicos de la institución, dentro de las "distintas formas de asistencia gratuita a los enfermos y heridos, tanto en tiempos de paz como de guerra" ${ }^{\text {"62 }}$. Un año después, en 1918, Cruz Roja estableció en Madrid su Escuela de Enfermeras en el Hospital de San José y Santa Adela ${ }^{63}$.

la implicación de la soberana en la organización de hospitales de la Cruz Roja en la guerra de Marruecos, había demostrado su capacidad organizativa y su interés por la institución.

${ }^{61}$ ACCRE, Caja 2061, Expediente 4.

${ }^{62}$ CRUZ Roja ESPAÑOLA: Reglamento del Cuerpo de Damas Enfermeras y programa para su enseñanza. Ernesto Catalá, Madrid, 1928, p. 14.

${ }^{63}$ Antes de la aparición de la Escuela de Enfermeras de Cruz Roja, la formación de las Damas Enfermeras se realizaba en diferentes locales que se prestaban a la institución para que se pudieran impartir las clases teóricas. Ejemplo de ello es el artículo publicado por Cruz Roja en su revista mensual número 178 de abril de 1917, en el que se hace referencia a la asistencia de la Reina Victoria Eugenia a la exposición de la lección décima, por parte del Dr. Calatraveño en el Colegio de Santa Isabel. 
Para poder pertenecer al cuerpo de damas enfermeras, las aspirantes debían cumplir una serie de requisitos: ser súbditas españolas, mayores de diecisiete años, (la edad mínima aumentó a veinte años en los reglamentos de 1928,) y ser asociadas de la institución ${ }^{64}$. Era necesario que aprobaran tanto el examen de la parte teórica del programa formativo que constaba de treinta y cinco lecciones, como la parte práctica que realizaban en los hospitales asignados por la asamblea central ${ }^{65}$. El título de dama enfermera únicamente tenía validez dentro de Cruz Roja, por lo que no servía para trabajar en hospitales y dispensarios ajenos a la institución ${ }^{66}$ (ver anexo I).

Además se las exigía reunir unas condiciones físicas y de suficiencia de los sentidos (vista, oído...) para evitar incapacidades laborales. Otro de los requisitos indispensables para las aspirantes era estar en posesión del reglamento y DeP LWUsus normas. Para aceptar la solicitud de matrícula de la futura alumna tenía que estar respaldada por dos damas enfermeras que respondieran por la interesada o en su defecto por la presidenta de honor ${ }^{67}$. Para cursar los estudios, las menores de edad tenían que adjuntar la autorización de sus padres o tutores y en el caso de las casadas, la de sus maridos.

Las damas enfermeras tenían un distintivo que las diferenciaba de las asociadas de Cruz Roja, que consistía en una medalla o insignia concedida por la asamblea central, en cuyo reverso estaba grabado el nombre y el número en el escalafón de damas enfermeras y que llevaban pendiente de una anilla con un lazo de seda con los colores de Cruz Roja ${ }^{68}$.

Entre las obligaciones de las damas enfermeras se encontraba la de presentar su carnet siempre que fuera requerido por las autoridades, avisar de los cambios de

\footnotetext{
${ }^{64}$ La Cruz Roja, no 177, año XIX, marzo 1917, Madrid, p. 67.

${ }^{65} \mathrm{La}$ asamblea central de Cruz Roja fue la encargada de redactar el reglamento del cuerpo de damas enfermeras, incluyendo sus obligaciones y los servicios que deberían presta en los hospitales de la Cruz Roja.

${ }^{66}$ Hay que tener en cuenta que anterior a esta disposición de 1917, Cruz Roja había comenzado a impartir los cursos de damas enfermeras en 1914 de la mano del Dr. Calatraveño. El problema era la carencia de un reglamento oficial que permitiera seguir una formación homogénea, por lo tanto en 1917 las asociadas que habían cursado las lecciones teóricas estaban obligadas a cursar las prácticas para poder ser damas enfermeras, esta nueva disposición afectó a cuarenta y dos señoras.

${ }^{67}$ CruZ RoJa Española. Reglamento del Cuerpo de Damas... op.cit., p 16.

${ }^{68}$ La Cruz Roja, ${ }^{\circ}$ 179, año XIX, mayo 1917, Madrid. Creación de la insignia de Damas Enfermeras, pp. 146-147.
} 
domicilio teniendo como plazo máximo ocho días y cumplir todos los requisitos expuestos en los artículos del reglamento, además de puntualidad a la hora de asistir a las clases prácticas ${ }^{69}$ (ver anexo II).

Es importante tener en cuenta que en caso de movilización del Ejército, de catástrofe o disturbios públicos, las damas estaban obligadas a presentarse ante el inspector general de la asamblea central de Madrid y en el caso de las provincias ante su presidenta, en un periodo no superior a las veinticuatro horas ${ }^{70}$.

Cuando prestaban servicio estaban obligDas a vestir el uniforme ${ }^{71}$ reglamentario de la institución, llevar la insignia, el título de dama enfermera y el carnet de identidad $^{72}$. La jornada laboral se dividía en turnos de mañana o de tarde, por semanas o quincenas, pasando por los distintos servicios y siendo la Madre Superiora la encargada de organizar la distribución de la rotación.

Tabla 1. Promesas que debían cumplir las damas enfermeras de Cruz Roja.

\begin{tabular}{|c|c|c|}
\hline $\begin{array}{l}\text { Comprometerse a servir } \\
\text { a los enfermos o heridos }\end{array}$ & $\begin{array}{c}\text { Esforzarse siempre en el } \\
\text { cumplimiento de su } \\
\text { misión }\end{array}$ & $\begin{array}{c}\text { Mantener el secreto } \\
\text { profesional }\end{array}$ \\
\hline
\end{tabular}

\begin{tabular}{ccc}
\hline $\begin{array}{c}\text { Reconocer la dignidad de } \\
\text { su misión }\end{array}$ & $\begin{array}{c}\text { Servir con lealtad y } \\
\text { obediencia a los } \\
\text { superiores }\end{array}$ & $\begin{array}{c}\text { Tener paciencia, bondad } \\
\text { y comprensión en el } \\
\text { desempeño de su trabajo }\end{array}$ \\
& &
\end{tabular}

Fuente: Reglamento del Cuerpo de Damas Enfermeras 1928.

\footnotetext{
${ }^{69} \mathrm{Al}$ darse de baja del cuerpo de damas enfermeras debían devolver en un plazo máximo de diez días el título, brazal e insignia y en caso de falta grave durante el servicio serían separadas del cuerpo.

${ }^{70}$ ACCRE. Caja 2531, expediente 13.

${ }^{71}$ El uniforme reglamentario constaba de cinco piezas: blusón, delantal, toca, corbata y capa. Los zapatos tenían que ser blancos, con tacón a la inglesa y medias blancas. Tenían prohibidas las alhajas, tales como pendientes y sortijas, únicamente podían utilizar un reloj de pulsera con minutero y sin ningún tipo de adorno.

${ }^{72}$ CRUZ Roja EsPañola: Reglamento del Cuerpo de Damas...op.cit., p. 22.
} 
Según el reglamento existían dos categorías de damas enfermeras: las de primera y las de segunda. Para obtener el título de dama de segunda, las alumnas debían haber asistido y aprobado el curso teórico establecido en el programa oficial, además de haber realizado el curso práctico de veintiún días. Para ser dama enfermera de primera, era necesario que las aspirantes estuvieran en posesión del título de dama de segunda, cursaran un año de clases teóricas, aprobaran los exámenes del mismo, y acreditaran sus prácticas asistenciales en hospitales o dispensarios durante un tiempo mínimo de seis meses ${ }^{73}$.

El examen era individual, se elegía al azar la lección a desarrollar, además de las preguntas que pudiera formular el tribunal examinador sobre la materia estudiada, incluyendo alguna práctica de vendaje, instrumental... ${ }^{74}$. Una vez concluido el curso de forma satisfactoria, la Asamblea Central de Cruz Roja organizaba el acto de imposición de brazales y de insignias a las damas enfermeras, presidido habitualmente por la reina Victoria Eugenia ${ }^{75}$.

Las damas enfermeras, además de realizar su labor en hospitales y dispensarios de Cruz Roja, también se encargaron de visitar a pobres y enfermos en sus domicilios $^{76}$, de favorecer a los necesitados con sus limosnas y al hospital con el material necesario para las curas, además de realizar sus funciones con celo y el interés propio de la gran responsabilidad inherente al cuidado de los heridos y enfermos $^{77}$. Cabe destacar que el trabajo de las damas era gratuito y altruista, y que no recibían ningún tipo de remuneración económica:

\footnotetext{
${ }^{73}$ CRUZ ROJA ESPaÑola: Reglamento del Cuerpo de Damas...op.cit., p. 15.

${ }^{74}$ El tribunal estaba constituido por un presidente, normalmente era el profesor del curso, y dos vocales, uno militar y otro civil, designados, el primero por el capitán general y el segundo por el comisario regio. Las notas obtenidas se entregaban de forma individual a cada alumna.

${ }^{75}$ La Vanguardia, 5 de junio de 1924, Información nacional, p.14.

${ }^{76}$ Se les asignaba un turno de visita una vez al mes, con un día fijo de la semana para cada una de las voluntarias, acudían al hospital a recoger el material necesario para realizar las curas y acudían al domicilio acompañadas de una Hermana de la Caridad, oscilando el tiempo de visita entre dos y tres horas.

${ }^{77}$ La Cruz Roja. $\mathrm{n}^{\circ}$ 305, noviembre 1927.pp. 958-959.
} 
Las Damas enfermeras de la Cruz Roja adquieren el compromiso de prestar su asistencia gratuita en los hospitales y demás servicios de índole sanitaria establecidos por la Institución en las localidades donde residan; y en tiempo de guerra y casos extraordinarios, allí donde sean destinadas por S. M. la Reina, teniendo en cuenta sus ofrecimientos y personales circunstancias ${ }^{78}$.

Es necesario abordar las instrucciones que se entregaban a las damas enfermeras interesadas en prestar servicio para Sanidad Militar durante la guerra o la campaña, para poder relacionarlo con el papel que desempeñaron en los conflictos bélicos de principios del siglo XX en España. Dentro de la labor voluntaria que iban a realizar, tenían que aceptar una serie de condiciones entre las que se encontraban: obedecer al jefe del servicio al que pertenecieran, tanto en los puestos de socorro, como en trenes hospitales o ambulancias y no cuestionar ni contradecir sus órdenes. No podían exigir comodidades y tendrían que adaptarse a las situaciones adversas, tales como la posible falta de luz y de agua. No se admitía que se quejaran o reflejaran estar disgustadas, ya que el objetivo era demostrar que las damas enfermeras no eran una carga para el campamento, sino mujeres capaces de realizar su trabajo adecuadamente. También se dejaba claro que no tenían autonomía para realizar las curas, modificar vendajes o poner inyecciones sin previa orden médica ${ }^{79}$.

El comportamiento de las damas en campaña sería el mismo que el exigido a las religiosas, por lo que tenían prohibido salir de los barracones-hospitales y entablar conversación con personas ajenas al mismo. Entre las funciones y las tareas que tenían que desempeñar las damas enfermeras, en el reglamento se exponía que la misión que iban a realizar era:

[...] noble y hermosa si la lleva a cabo en condiciones de prestar verdaderos servicios al herido, ayudando a hacer camas, fregar cacharros, cuidar de los alimentos, cambiar de postura al que sufre, alentarle con palabras dulces, velarle de noche: todos estos servicios, humildes y sin lucimiento, pero que son los que

\footnotetext{
${ }^{78}$ CruZ Roja EsPaÑola: Reglamento del Cuerpo de Damas...op.cit., p 14.

${ }^{79}$ Ibid., pp. 27-28.
} 
verdaderamente alivian y confortan al que padece en Hospitales que forzosamente han de carecer de mil cosas necesarias $[\ldots]^{80}$.

La formación de damas enfermeras de Cruz Roja se fue extendiendo paulatinamente a lo largo de la geografía española gracias a la labor que realizaron las juntas de señoras provinciales. Entre las primeras damas enfermeras tituladas en la Escuela de San José y Santa Adela se encontraban las infantas y las mujeres de la aristocracia española. Esto unido a las connotaciones de caridad y trabajo altruista no retribuido, generó en torno a la figura de la dama enfermera una aureola privilegiada, que fomentó su aceptación social. Las fotografías presentaban damas enfermeras, vestidas de uniforme, serias, regias y elegantes ${ }^{81}$, posando después de recibir su título. En el caso de que en la promoción de damas hubiera cursado sus estudios alguna alta personalidad, ocupaba el centro de la imagen, tal fue el caso de la infanta María Cristina ${ }^{82}$. Si en la fotografía aparecía la reina Victoria Eugenia o alguna de las aristócratas representantes de Cruz Roja, también figuraban en una posición central ${ }^{83}$. Este halo de prestigio se fomentó también por la participación de la reina en la entrega de brazales e imposición de insignias a las damas enfermeras al terminar sus estudios ${ }^{84}$ y en los actos benéficos y festivos organizados por la institución ${ }^{85}$.

La aparición del cuerpo de damas enfermeras de Cruz Roja permitió a las mujeres interesadas en la asistencia recibir una formación académica sólida. Inicialmente esto se vio como una amenaza dentro de los círculos masculinos, ya que la amplitud de lecciones teóricas del programa de estudios podría estimularlas a “aspirar al título de licenciados o doctores, o cuando menos se les reconozca, y

\footnotetext{
${ }^{80}$ CRUZ Roja EsPañola: Reglamento del Cuerpo de Damas...op.cit., pp. 28-29.

${ }^{81} A B C, 13$ de marzo de 1920, Melilla, la Cruz Roja y la policía indígena, p. 1.

${ }^{82} A B C, 5$ de julio de 1930, imagen damas enfermeras con la infanta María Cristina, p. 4. $A B C, 1$ de mayo de 1921, p. 5 imágenes distintas promociones damas enfermeras de granada, Lérida y Logroño.

${ }^{83}$ ABC, 24 de septiembre de 1925, I. S. M, La reina Victoria con las damas enfermeras de Cruz Roja de Pamplona, después de imponerles los brazales, p. 5. ABC, 1 de julio de 1922, Sevilla: en el hospital de la Cruz Roja, p. 3.

${ }^{84}$ La Vanguardia, 2 de julio de 1925, Entrega de medallas y brazaletes de la Cruz Roja, p. 12.

${ }^{85}$ La Vanguardia, 20 de marzo de 1921, Fiesta de la Cruz Roja, p. 12.
} 
estaría muy justificado, el diploma de practicantes, con iguales derechos que los que

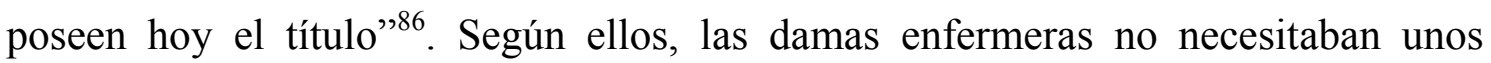
conocimientos teóricos tan amplios para desempeñar su labor, ya que hasta ese momento las mujeres encargadas del cuidado de los enfermos lo habían hecho bien, interesaba "que no sepan más de los que les conviene saber, sino que sepan con templanza". Tener un cuerpo "selectísimo" de damas enfermeras con una buena base teórica no era necesario, ya que lo importante era que fueran dulces, activas, cariñosas y diligentes. Tener damas enfermeras sería igual que contar con:

[...] practicantes honorarias, y no se trata de eso, sino de tener mujeres que asistan a los heridos, con toda ciencia posible o según Dios las dé a entender. Mucho puede saber del manejo del fonendoscopio, pero pueden más aún el amor al prójimo, la bondad, la ternura, el patriotismo; el patriotismo sobre todo ${ }^{87}$.

\subsubsection{Enfermeras profesionales de Cruz Roja}

Cruz Roja, además de tener su cuerpo de damas enfermeras también contó con el de enfermeras profesionales, que a diferencia de las primeras, estudiaban en régimen de internado. La edad mínima para poder cursar dichos estudios era de veinte años, quedando excluidas las menores y las mayores de treinta y cinco años, pidiendo a las mujeres casadas la autorización de su marido. Para poder entrar en la escuela, también se les exigían conocimientos de lectura, escritura y aritmética. Una vez admitidas se comprometían a cumplir lo estipulado en el reglamento referente a permanencia, estudios, exámenes y condiciones morales, ya que en caso de no ser así se les retiraba el título ${ }^{88}$.

Durante los dos años que duraba el régimen de internado ${ }^{89}$, acudían a las clases teóricas los días fijados en el calendario lectivo. Las prácticas las realizaban

\footnotetext{
${ }^{86}$ La Vanguardia, 23 de marzo de 1917, Las Damas de la Cruz Roja, p. 8.

${ }^{87}$ Ibid., p. 8.

88 ACCRE. Caja 2531, Expediente 31, Sección de enfermeras 1922, Reglamento para el Cuerpo de Enfermeras Profesionales creado por la Asamblea Central de Señoras de la Cruz Roja. Art. 20

${ }^{89}$ Cruz Roja tenía un local en el que se permitía vivir a las enfermeras tituladas pagando una pensión, de esta forma estarían siempre dispuestas a servir en las demandas de velas particulares, inyecciones,
} 
en los diferentes servicios del hospital, rotando cada tres meses hasta demostrar a través de un examen su capacidad para permanecer como primera enfermera en un mismo servicio ${ }^{90}$. Los exámenes se realizaban ante un tribunal constituido por un presidente, que normalmente era el Jefe de Sanidad Militar de la Plaza, y dos vocales, uno civil y otro militar. El primero era nombrado por el Colegio de Médicos de la localidad y el segundo por el General Inspector de Sanidad Militar de la región ${ }^{91}$. Una vez finalizado el periodo de formación se les entregaba el carnet que las acreditaba como enfermeras y las permitía ejercer su profesión libremente. Cabe señalar que no fue hasta el año 1923 cuando se celebró la verificación de los exámenes para la obtención del título de enfermera profesional de Cruz Roja. A pesar de haber cursado los dos años de internado no se examinó a las enfermeras hasta que la institución tuvo claro cómo sería la prueba que diera validez permanente al título ${ }^{92}$.

Cruz Roja especificaba que las enfermeras profesionales formaban:

[...] un cuerpo distinto y separado del de Damas Enfermeras, con el que no habrá de confundirse, siendo el espíritu y modo porque se rige uno y otro completamente diferentes. Si alguna dama enfermera solicitara ingresar como alumna profesional, será condición precisa que renuncie antes a aquel título, sea de la categoría que fuese. En el caso de prestar servicios reunidas las Damas Enfermeras con Enfermeras profesionales, éstas últimas reconocerán siempre en las primeras la representación de la Junta de Señoras $[\ldots]^{93}$.

Al igual que las damas, las enfermeras profesionales, como asociadas de Cruz Roja, estaban obligadas a prestar, en caso de guerra, catástrofe o calamidades, los

acompañamiento de enfermos, etc., peticiones que se hacían al hospital, y por las que recibían una compensación económica que les permitía ganarse la vida. Ver CRUZ ROJA: Enfermeras Profesionales y Damas Enfermeras. Informe presentado en la XIV Conferencia de la Institución de Bruselas. Ernesto Alcalá, Madrid, 1930.

${ }^{90}$ CRIADO Y DOMíngueZ, Juan, P: La enseñanza y la profesión enfermera en España. Liga de Sociedades de la Cruz Roja. Madrid, 1921, p.8.

${ }^{91}$ Como se ha visto, Cruz Roja nace para auxiliar a Sanidad Militar, por eso existe una relación entre las dos instituciones que hace que ambas participen en los tribunales examinadores. Las enfermeras profesionales debían estar preparadas para trabajar en los centros de Cruz Roja y en caso de catástrofe, calamidad o guerra en los de Sanidad Militar.

92 Asamblea Suprema de la Cruz Roja Española: Memoria del Hospital-Escuela de Damas de la Cruz Roja de Madrid San José y Santa Adela. 1923, Blass, Madrid, 1924, p. 27.

${ }^{93}$ ACCRE. Caja 2531, Expediente 31, Sección de enfermeras 1922, Reglamento para el Cuerpo de Enfermeras Profesionales...: op.cit., Art. 4. 
servicios que la institución estimara oportunos en su deber de auxilio a Sanidad Militar, tanto en los hospitales y ambulancias militares como en los de Cruz Roja. Entre las obligaciones inherentes al título de enfermera se encontraban la de cumplir y acatar las órdenes médicas prescritas, mostrar siempre que fuera requerido el carnet que acreditaba su titulación, en el que aparecían los servicios prestados y las notas académicas. En caso de cambio de domicilio, estaban obligadas a notificarlo a la junta del hospital, o en su ausencia a la secretaria de la junta de la asociación. Al igual que las damas, debían utilizar el uniforme reglamentario siempre que estuvieran de servicio ${ }^{94}$.

Las enfermeras podrían recibir premios o castigos, siendo la concesión de medallas y menciones honoríficas parte de los primeros y las amonestaciones y suspensiones de servicio, de hasta seis meses, de los segundos. En caso de falta grave o de reincidencia se les abría un expediente disciplinario, siendo la Asamblea Central la encargada de decidir la separación definitiva del Cuerpo de Enfermeras Profesionales ${ }^{95}$.

No podían sostener por sí mismas una casa de salud, consultorio o clínica, pero si podían, una vez terminados sus estudios, cursar una especialidad, que figuraría también en su carnet ${ }^{96}$.

Los cursos de enfermeras profesionales de Cruz Roja comenzaban todos los años en el mes de octubre y terminaban con los exámenes de junio. Para formalizar la matrícula, las futuras enfermeras tenían que ir acompañadas de padres o esposos. Además de la instancia de solicitud de matrícula, debían entregar una copia del certificado de la inscripción de su nacimiento en el registro civil, copia de su “...partida de bautismo, certificado de buena conducta, tener condiciones de

\footnotetext{
94 ACCRE. Caja 2531, Expediente 31, Sección de enfermeras 1922, Reglamento para el Cuerpo de Enfermeras Profesionales...: op.cit., Art. 4.

${ }^{95}$ Idid., Art. 12.

${ }^{96}$ Ibid., Art. 13.
} 
educación y cultura y sufrir un examen previo de suficiencia en instrucción y otro médico de capacidad física"97.

Al igual que las damas, las enfermeras podían prestar sus servicios en los domicilios particulares, de ocho a ocho, tanto en el turno de mañana como en el de noche, con la obligatoriedad de utilizar el uniforme del hospital. La superiora del centro, como responsable de la conducta y trabajo de las enfermeras, era la encargada de trasmitir cualquier irregularidad a la junta del hospital ${ }^{98}$.

El uniforme de las enfermeras era el mismo que el de las damas, la forma de diferenciar unas de otra eran los distintivos, las damas únicamente llevaban la cruz roja en el brazal y las enfermeras en la toca o cofia ${ }^{99}$.

A las profesionales se las exigía abnegación y caridad, además de prudencia, discreción, sentido común y "dulce firmeza” para poder realizar su misión con el enfermo de forma adecuada, y acatar unas normas de disciplina incluidas en el reglamento del cuerpo, además de cumplir con la distribución del tiempo, trabajo y programa lectivo. En caso de no aceptar dichos preceptos eran expulsadas del centro. Las Hermanas de la Caridad fueron las encargadas de guiar y vigilar a las enfermeras para evitar las faltas de disciplina:

[...] la conducta moral de estas jóvenes debe ser intachable, y, sin embargo, la vida de la Enfermera está expuesta a muchos peligros por deber atender a toda clase de enfermos y de ambos sexos. Esto era otra dificultad, porque no todas las familias cedían a los deseos de sus hijas para emprender esta carrera, puesto que para obtenerla deben pasar dos años internas en la Escuela. A esta y otras dificultades se ha remediado, respondiendo a las fundamentales costumbres de España, poniendo en dicho Hospital-Escuela a Hijas de la Caridad de San Vicente de Paúl, las cuales, en unión de las Damas de la Cruz Roja, contribuyen a la formación de dichas Enfermeras ${ }^{100}$.

\footnotetext{
${ }^{97}$ Caja 2531, Expediente 31, Sección de enfermeras 1922, Reglamento para el Cuerpo de Enfermeras Profesionales...: op.cit., Art. 15-16.

${ }^{98}$ Cruz Roja EsPañola: Creación de un Cuerpo de Enfermeras Profesionales. Blass, S.A. Madrid, 1924, p. 11.

${ }^{99}$ ACCRE. Caja 2531, Expediente 31, Sección de enfermeras 1922, Reglamento para el Cuerpo de Enfermeras Profesionales...op.cit., Art. 11.

${ }^{100}$ CRUZ ROJA: Creación de un Cuerpo de Enfermeras...: op.cit., p. 9.
} 
Por lo tanto, en la España de principios del siglo XX no era fácil para una mujer ser enfermera, estas dificultades iniciales quedan reflejadas en el informe presentado por Cruz Roja en Bruselas en 1930, en el que se señalaba que era "muy raro que la mujer en España dedicara sus energías y saber a una profesión poco conocida como medio de vida" ${ }^{n}$.

Las enfermeras, a diferencias de las damas, recibían un sueldo por el desempeño de su trabajo. Esto supuso una serie de problemas para las profesionales, ya que la asistencia remunerada a los enfermos era realizada en los sanatorios y hospitales por mujeres encargadas de trabajos materiales como la limpieza de suelos y platos. Por eso las señoras de cierta posición social y económica no querían que se les atribuyera el nombre de enfermera, por las connotaciones que llevaba implícito, ya que las interesadas en cuidar a los enfermos lo hacían por caridad y humildad sin recibir ningún tipo de salario, vista su labor en la sociedad con buenos ojos y admiración por su "noble misión"102. La Enfermería era una carrera para "señoras y señoritas de posición modesta, que no pudiendo encontrar medio honroso de vivir, lo tendrían en el ejercicio de su noble trabajo" ${ }^{" 103}$.

\subsubsection{Enfermeras visitadoras de Cruz Roja}

Será a partir de los años veinte del siglo XX, cuando empiece a adquirir cierta importancia la figura de la enfermera visitadora ${ }^{104}$. Cruz Roja, abierta siempre a las nuevas tendencias formativas, se implicó activamente en la formación de las mismas. Para dar difusión a esta especialidad, la Asamblea Central de Señoras publicó ese año La enfermera visitadora pro higiene pública, lo que es, lo que consigue, de la Liga de Asociaciones de la Cruz Roja.

\footnotetext{
${ }^{101}$ CRUZ ROJA: Enfermeras Profesionales y Damas Enfermeras ...: op.cit., p. 3.

${ }^{102}$ CRUZ RoJA: Creación de un Cuerpo de Enfermeras .... op.cit., p. 5.

${ }^{103}$ La Vanguardia, 10 de mayo de 1924, Conferencia del Dr. Martínez Vargas, p. 11.

104 Ver más en BERnABeu Mestre, Josep, y GASCÓn PÉREZ, Encarna: Historia de la Enfermería de Salud Pública en España (1860-1977). Publicaciones de la Universidad de Alicante, Alicante, 1999.
} 
Las enfermeras visitadoras eran enfermeras tituladas que se especializaban en Salud Pública y prevención de enfermedades en escuelas y fábricas, parturientas y recién nacidos, e higiene social y lucha antituberculosa. La Asamblea Central de Señoras consideraba a las enfermeras visitadoras el punto central de la previsión higiénica moderna, ya que el trabajo de las mismas se centraba en educar a la población en reglas de higiene personal y pública, siendo "heraldo de salud, que transmite de modo práctico los conocimientos científicos; a la madre, en el hogar; al obrero, en el taller; al niño, en la sala de la escuela [...]". La contribución de las enfermeras visitadoras al socorro social se fundamentaba en ser el nexo de unión entre el hospital y el hogar, visitaban al paciente hospitalizado y preparaban en su domicilio la habitación del mismo para su regreso. En casos de indigencia gestionaban la solicitud de ayudas, procurando dinero al enfermo y a la familia hasta su restablecimiento ${ }^{105}$.

La formación de las enfermeras visitadoras de Cruz Roja se hizo a través de cursillos específicos que empezaban a finales de enero y duraban hasta junio. Las clases teóricas las impartía la madre superiora, la inspectora general y el médico director del centro. El temario se dividía en "Moral profesional de la Enfermera Visitadora; Técnica de las visitas, y Estudio de las enfermedades infecciosas desde el punto de vista epidemiológico y profiláctico, así como la Higiene en sus distintos aspectos: individual, de las multitudes y urbano"106.

Cruz Roja no fue la única institución interesada en formar enfermeras visitadoras. La Escuela Nacional de Puericultura ofertaba cursos para formar visitadoras puericultoras, cuyo trabajo se encaminó a materias como la eugenesia y la puericultura intrauterina, y de la primera y segunda infancia. La Escuela Nacional de Sanidad formó a las enfermeras visitadoras sanitarias, a lo largo de un curso de dos años en los que se impartían materias de higiene general, escolar, del trabajo, de

\footnotetext{
105 Asamblea Central de Señoras de la CRUZ Roja Española: La Enfermera-Visitadora ProHigiene Pública. Lo que es, lo que consigue. Liga de las Asociaciones de la Cruz Roja Ginebra (Suiza). Tipográfica Fernando, Madrid, 1923, pp. 3-4.

106 Cruz Roja Española: Enfermeras visitadoras, Comité de Madrid, Memoria del año 1929. Ernesto Catalá, Madrid, 1930, p. 4.
} 
la alimentación y demografía y estadística sanitaria, además de administración y legislación sanitaria, y medicina social ${ }^{107}$.

A nivel mundial, la Liga de Sociedades de la Cruz Roja organizaba en el Bedford College for Women, de la Universidad de Londres, cursos internacionales para enfermeras visitadoras. Podían asistir tanto enfermeras profesionales como damas enfermeras de Cruz Roja Española, comenzaba en octubre y terminaba en julio, con dos periodos vacacionales de quince días en Navidad y Pascua. Se ofertaba el régimen de internado en la universidad pero no era obligatorio, siendo gastos aparte la manutención y viaje de las mismas ${ }^{108}$.

La edad mínima para ser admitidas en el curso internacional era de veintidós años, además, las candidatas debían incluir en su solicitud de ingreso un certificado médico, copia de los diplomas obtenidos y un certificado "firmado por su sociedad nacional de Cruz Roja” garantizando:

[...] La moralidad y cultura de la candidata (serán admitidas de preferencia las que hayan recibido instrucción general y mejor formación de enfermeras); un conocimiento del inglés que las permita poder comprender bien los cursos y tomar las notas necesarias; o la seguridad dada por la Facultad de la Cruz Roja nacional de que la candidata se ocupará en estudiar intensamente inglés antes de la apertura del curso; su empleo o una perspectiva razonable de empleo por la Sociedad de Cruz Roja de su país o por una organización pública o privada aprobada por la Sociedad de la Cruz Roja $[\ldots]^{109}$.

En el curso se alternaban las conferencias y lecciones teóricas con prácticas individuales y visitas a los centros de higiene. Las clases teóricas se centraban en enseñar higiene y sanidad pública, se hacía hincapié en la higiene personal, higiene colectiva, higiene escolar, higiene de los órganos sensoriales, profilaxis de las

\footnotetext{
107 Galiana SÁnchez, María Elena, Bertomeu Mestre, J., García Paramio, M. P: Enfermeras para una nueva patria. Género e ideología en la enfermería de Falange. pp. 203-216. En GonZÁlez CANALEJO, Carmen. MARTíNeZ LÓPEZ, F. (EDS): La transformación de la enfermería. Nuevas miradas para la historia. Comares, Granada 2010.

${ }^{108}$ LIGA DE Sociedades DE LA CRUZ RoJa: Sección de Enfermeras, París. Curso Internacional para Enfermeras Visitadoras dado en el Bedford College for Women. Universidad de Londres. 1923-1924, p.1.

${ }^{109}$ Ibid., p.11.
} 
enfermedades contagiosas, higiene dental, puericultura, higiene alimenticia. También se incluían lecciones de enseñanza de higiene, bacteriología y psicología elemental, higiene industrial moderna y organización social ${ }^{110}$. El programa incluía una lección semanal de Psicología, otra de Economía Política, dos de Higiene y una de Administración Social. También estaba programada la visita semanal a centros de desinfección y despiojamiento, casas para obreros, casas-cuna, sanatorios..., siempre relacionadas con las lecciones explicadas durante la semana lectiva ${ }^{111}$.

El curso se celebraba anualmente y con el tiempo se fue perfeccionando más. Terminó por dividirse en dos secciones: para Enfermeras de Salud Pública y para Enfermeras Directoras de Hospitales e Instructoras de Enfermeras ${ }^{112}$. La Liga de las Sociedades de Cruz Roja, además de los Cursos Internacionales, también organizó cursos de verano para enfermeras visitadoras, que se reunían durante tres semanas para participar en conferencias y debates, en los que se intercambiaban temas de interés para todas.

\footnotetext{
${ }^{110}$ Liga de Sociedades DE LA CRUZ RoJA: Sección de Enfermeras, París. Curso Internacional...: op.cit., p. 4.

${ }_{111}^{11}$ La Cruz Roja. $\mathrm{n}^{\circ}$ 258, diciembre 1923, pp. 686-697.

${ }^{112}$ La Cruz Roja. no 316, octubre 1928, p. 830.
} 


\subsection{Las enfermeras a través de los manuales y reglamentos de Cruz} Roja Española: perfilando una imagen

Describir la imagen de dama y enfermera proyectada a través de los manuales formativos y los reglamentos de Cruz Roja Española, permitirá completar la visión social de la Enfermería como profesión eminentemente femenina.

La mayoría de los manuales fueron escritos por hombres, concretamente por médicos, si bien, cabe destacar que hubo damas enfermeras que también participaron en la redacción de algunos, tal es el caso del Elena Sánchez de Arrojo, autora de El Consultor de las Dama Enfermera de 1918, María de los Dolores Bas Bonald y su Vademecum de la Dama Enfermera de Cruz Roja de 1921, o Mercedes Safont y el Manual de la Enfermera de 1923. Entre las características comunes de estas escritoras, hay que señalar que fueron alumnas aventajadas, mujeres cultas pertenecientes a una clase social acomodada y adinerada, que dedicaron su obra a la reina Victoria Eugenia y cuyos libros fueron prologados por médicos de Cruz Roja.

A través de los manuales se puede observar la ruptura que se produjo en la época entre la figura de dama enfermera y la de dama de las juntas de señoras de Cruz Roja:

[...] El tiempo y la práctica nos han enseñado que la Dama de la Cruz Roja tiene otros fines más que cumplir que los que hasta la fecha encomendados. No sólo está para pedir, recaudar, allegar fondos [...]. La Dama Enfermera de la Cruz Roja bien está en su papel de recaudar, de allegar recursos a la Asociación, pero también es cierto se siente la necesidad de instruirla necesariamente para cuando se conceptúe útil su concurso científico y poder llenar su cometido en el nombre que posee, Dama de la Cruz Roja, y por eso era de imprescindible necesidad crear un cuerpo de Dama enfermera de la Cruz Roja que fuese una auxiliar útil dentro de la Asociación y supiera administrar a su tiempo bajo dirección facultativa y de manera científica el socorro al herido o enfermo ${ }^{113}$.

\footnotetext{
${ }^{113}$ FERNÁNDEZ-CORREDOR y CHICOTE, Mariano: Manual de la enfermera de la Cruz Roja. Talleres tipográficos Cuesta, Valladolid, 1917. pp. 8-9.
} 
Para Cruz Roja era importante la formación de sus damas para poder auxiliar al médico en su trabajo y para atender correctamente a los enfermos. En los manuales se explicaba los problemas que ocasionaban, sin saberlo, las señoras de la institución dedicadas a visitar a los enfermos y a las obras benéficas antes de que existiera un cuerpo de damas enfermeras preparadas para asistir correctamente a los pacientes. Es por esto por lo que Cruz Roja consideraba necesario formar a:

[...] un personal subalterno que pueda desempeñar ese papel de colaboración médica, que ejecute fielmente las órdenes y prescripciones del médico, que vele a la cabecera del enfermo sustituyendo a sus seres queridos, y esta labor puede hacerla mejor que nadie la mujer, la enfermera ${ }^{114}$.

En los manuales se observa la relación directa que existía entre el título de dama enfermera y la pertenencia a las clases sociales más elevadas de la España de principios del siglo $\mathrm{XX}$, ejemplos de ello se encuentran en los distintos prólogos estudiados, dirigidos en ocasiones a las alumnas de buena sociedad: “...Para vosotras, damas ilustres, que representáis la más selecta sociedad de Barcelona, en quienes la hermosura y los encantos rivalizan con la estirpe linajuda y la bondad excelsa, acaso pareciera harto humilde la nueva disciplina que comenzáis"115.

La dama enfermera no tenía que ser ni la religiosa encargada de cuidar a los enfermos guiada por su amor a Dios, ni la profesional laica que vivía de su carrera, era la señora que guiada por sentimientos patrióticos y caritativos se dedicaba, algunas horas del día, al cuidado desinteresado de los enfermos, sin olvidarse de que esta labor de auxilio y consuelo tenía que ser compaginada con su faceta de hija, madre y esposa ${ }^{116}$.

En cuanto al tipo de lecciones impartidas se puede ver en la tabla 2 la distribución general de las mismas entre todos los manuales consultados, agrupándolas en bloques teóricos. Se analizará en profundidad el temario relacionado con las cualidades físicas y morales que debían reunir las damas y

\footnotetext{
${ }^{114}$ CRUZ ROJA: Contestaciones al programa de examen teórico para obtener el título de Dama Enfermera de $2^{a}$ clase. Artes Gráficas, Pamplona, 1923, p. 5.

${ }^{115}$ MARTíneZ VARGAS, Andrés: Manual de las Damas Enfermeras de Cruz Roja. Jaime Vives, Barcelona, 1917. p. 5.

${ }^{116}$ SÁNCHEZ DE ARROJO, E: op.cit., p.12.
} 
enfermeras profesionales, por ser reflejo del trabajo que se esperaba que desempeñaran.

Tabla 2. Principales lecciones teóricas.

\begin{tabular}{|c|c|c|c|}
\hline $\begin{array}{c}\text { Cruz Roja: su } \\
\text { importancia y } \\
\text { misión. Historia de } \\
\text { la Institución }\end{array}$ & $\begin{array}{c}\text { Cualidades de la } \\
\text { dama enfermera y } \\
\text { de la enfermera }\end{array}$ & $\begin{array}{c}\text { Cuidado de } \\
\text { enfermos y heridos }\end{array}$ & $\begin{array}{c}\text { Alimentación de } \\
\text { enfermos y heridos }\end{array}$ \\
\hline $\begin{array}{c}\text { Enfermedades } \\
\text { médico-quirúrgicas }\end{array}$ & $\begin{array}{c}\text { Anatomía y } \\
\text { Fisiología }\end{array}$ & $\begin{array}{c}\text { Enfermedades } \\
\text { contagiosas }\end{array}$ & $\begin{array}{c}\text { Puericultura y } \\
\text { cuidados del recién } \\
\text { nacido }\end{array}$ \\
\hline
\end{tabular}

Fuente: Manuales de damas enfermeras de Cruz Roja española 1918-1923.

Debían cuidar su alimentación, higiene y descanso para conseguir una mayor salud y resistencia física que les permitiera dedicarse a la profesión. Para conservar la salud se les sugería dormir entre seis y siete horas como mínimo, mantener un horario de comidas y salir a pasear todos los días, para disfrutar del sol y del aire libre. Además, también se les recomendaba realizar algún deporte como tenis, y gimnasia, con el objetivo de hacer ejercicio. Todo acompañado de una correcta alimentación necesaria para mantener un buen estado de salud, encaminada a evitar la diarrea o el estreñimiento ${ }^{117}$.

El aspecto exterior de las enfermeras también era importante, por eso se les exigía cuidar su aseo personal con el baño diario. Extremar la higiene evitaba el contagio de enfermedades, se les recomendaba un baño diario con jabón abundante, además de cambiarse de ropa cuando abandonaran el cuidado de los enfermos. También se aconsejaba mantener una buena higiene bucal cuidando el cepillado de los dientes. Además de cortarse las uñas y depilarse las manos y antebrazos en caso de tener abundante vello, debían lavarse las manos cada vez que salieran de la

${ }^{117}$ SAFONT, Mercedes: Manual de la Enfermera. Editorial Cervantes, Barcelona, 1923, p. 13. 
habitación del enfermo, usar soluciones antisépticas y cepillos para manos, y en caso de tener alguna herida o escoriación de la piel protegerse la zona $^{118}$.

Abnegación, devoción, sacrificio y caridad, sin olvidarse de la vocación, necesaria para enfrentarse al dolor y a la desgracia, eran las cualidades morales exigidas a las profesionales y damas enfermeras que más veces se repetían a lo largo de los manuales. Obediencia, paciencia, dulzura y cariño eran otras de las características que debían reunir, además de tener que mostrarse alegres y animosas. Cabe destacar el acrónimo DIOS utilizado por Elena Sánchez de Arrojo en su obra y que hace alusión a la: Discreción, Instrucción, Observación y Subordinación. Respecto a la discreción, la autora especificaba que la enfermera debía hablar poco con el enfermo, evitar los interrogatorios exhaustivos que eran competencia médica y ser capaz de proporcionar consuelo cristiano a los mismos, además de hacerse respetar pero sin ser altiva y dura, teniendo en cuenta la humildad cristiana ${ }^{119}$.

La enfermera tenía que ser "mujer hábil e instruida", por lo tanto, la formación era necesaria para entender "el tecnicismo" médico y cuidar correctamente a los enfermos, siendo precisas en las actuaciones ${ }^{120}$. La observación era una cualidad primordial, debían anotar y registrar el pulso, la temperatura, las respiraciones, la orina, deposiciones y el estado general del enfermo, sin olvidarse de observar el color de la piel, y si existía agitación, delirio y sudoración. Lealtad y veracidad también estaban ligadas al título de dama y enfermera, para ello, debían anotar todo lo que sucedía y observaban durante su jornada con el enfermo, los síntomas y los resultados de sus constantes. También tenían que registrar en las hojas específicas el horario y las observaciones siempre con letra clara y legible.

Eran las encargadas de ayudar al médico en su labor, realizando las curas, vendajes y tratando hemorragias. No debían cuestionar sus órdenes ni juzgarlas, dejando de esta forma clara su función subordinada: “...el papel que está llamada a

\footnotetext{
118 SAFONT, M: op.cit., p. 12.

${ }^{119}$ SÁNCHEZ DE ARROJO, E: op.cit., pp. 8-9.

${ }^{120}$ MARQUESA DE VALDEIGLESIAS: Memoria sobre el Congreso Internacional de Enfermeras celebrado en Ginebra en julio de 1927. Imprenta Gracigoy, Madrid, 1928, p. 9.
} 
representar la mujer a la cabecera de los enfermos o heridos es de consuelo, de sugestión, de auxilio maternal"121.

El secreto profesional y la tolerancia religiosa también eran cualidades morales que debían tener, por lo que tratarían a los enfermos por igual sin hacer ningún tipo de distinción, respetando sus creencias siguiendo los preceptos de Cruz Roja:

[...] respetar las creencias religiosas que profesen los enfermos a su cuidado, no forzando al enfermo a su manera de pensar, no queriendo con esto decir que prescindirá en momentos difíciles para el enfermo, el manifestarle las mieles que nuestra religión católica posee, pero nunca establecerá discusiones sobre ningún extremo $^{122}$.

Tendrían "suavidad de maneras", demostrando su delicadeza a la hora de cuidar a los enfermos, tanto en las palabras utilizadas como en las formas, dejando ver que la mujer es más fina y delicada que el hombre, y por lo tanto, mejor auxiliar del médico, ya que las manos femeninas permitían realizar el trabajo de forma ordenada, hábil y precisa ${ }^{123}$.

Trabajar con enfermos implicaba exposición a enfermedades contagiosas y enfrentarse a situaciones difíciles por lo que debían mantener la serenidad "y anteponer el cumplimiento de su deber al instinto de conservación", luchando contra el miedo al contagio al limpiar las exudaciones del enfermo. Por lo tanto, tenían que mantener la calma y realizar un trabajo inteligente y de responsabilidad alejado de la labor mecánica y rutinaria.

Debían ser activas y ordenadas, evitar la pereza y realizar sus deberes cumpliendo con el horario exigido. Su jornada de trabajo empezaba a la hora fijada, por lo que tenían que ser puntuales, y terminaba cuando llegaba el relevo. Siempre que estuvieran de servicio debían utilizar el uniforme reglamentario, sin alhajas ni

\footnotetext{
${ }^{121}$ Calatraveño, Fernando: Programa razonado para la enseñanza de las Damas Enfermeras de la Cruz Roja Española. Imprenta de la Rev. de Arch. Bibl. y Museos, Madrid, 1917, p. 14.

${ }^{122}$ FERNÁNDEZ-CORREDOR Y CHICOTE, M: op.cit., p 11.

${ }^{123}$ Calatraveño, F: op.cit., p. 14.
} 
encajes, llevando como único distintivo la insignia del cargo que desempeñaban. El rol femenino de la profesión influyó en el concepto del trabajo que se esperaba que desempeñaran:

[...] Ellas, que han nacido para amar, y para amar puramente, por más que el hombre llene de acechanzas sus caminos; ellas, que cuando esposas y cuando madres, dulcifican las horas de la vida en el hogar tranquilo de la familia, cuando madres y hermanas de todos los que padecen, dulcifican y atenúan los infortunios en el recinto de la gran familia, en el seno de la sociedad ${ }^{124}$.

También debían evitar ruidos molestos a los enfermos, por eso el calzado tenía suela de goma, para no incomodar al paciente ni importunarle. Se las instaba a evitar conversaciones excesivas y a saber guardar silencio, lo que hace pensar que por su condición de mujeres tenderían a lo contrario:

[...] pensad que estáis haciendo ejercicios espirituales; olvidad por un momento al que os habla, pero escuchad sus ruegos; cuando estéis en servicio de hospital, guardad silencio; ya sé que es un sacrificio muy grande el que os pido, pero el enfermo requiere silencio, el Médico lo necesita y la enfermera hará mejor las cosas cuanto más callada esté. La enfermera necesita estar callada para observar atentamente, para escribir los datos en las historias clínicas y para poner los papeles en su sitio; si está distraída con la conversación, las cosas no estarán en el lugar debido $^{125}$

Cómo tratar a los enfermos era otro de los puntos clave, debían evitar preguntas incómodas y centrar la conversación en temas alegres para no provocar sufrimientos inútiles. El hecho de ser mujeres hacía que se las viera como “...mensajeras de paz, de alegría, de bondad, de simpatía," cualidades que poseían por naturaleza, gracias a la educación que habían recibido y la religión que $\operatorname{profesaban}^{126}$.

\footnotetext{
${ }^{124}$ SAFONT, M: op.cit., p. 8.

${ }^{125}$ LUQUE BELTRÁN, Francisco: El Alma de la Enfermera. Imprenta y encuadernación de Julián Espinosa, Madrid, 1928, p. 6.

${ }^{126}$ Ibid., p 8.
} 
Las relaciones con los médicos y el personal de la institución debían basarse en el respeto y la dulzura "...sin melosidades, que siempre dan lugar a abusos o a torcidas interpretaciones, de firmeza o blandura, según las circunstancias las requieran y siempre de exquisita corrección y caridad cristiana"127.

Por lo tanto la imagen proyectada por los manuales dejaba claro la relación que existía entre las cualidades típicamente femeninas y las que debían reunir las enfermeras. Por eso tenían que ser pacientes con los enfermos e intentar ser silenciosas para no importunarlos, caritativas, bondadosas, dulces y cariñosas, características relacionadas con su rol femenino. Respecto a las relaciones profesionales con el médico, debían ser buenas subordinas obedeciendo sus órdenes sin cuestionarlas. La enfermera debía ser discreta, instruida y culta, delicada, ordenada y con capacidad de observación. Para el desempeño de su labor debía gozar de buena salud, por lo que se le recomendaba que llevara a cabo hábitos de vida saludables que le permitieran trabajar con los enfermos.

Esta relación entre el rol femenino y la Enfermería también se difundió a través de la prensa. La figura de mujer como madre, esposa, hija o hermana, se proyecta en ellas, capaces de consolar a los heridos con sus cuidados maternales, cariñosos $^{128}$, piadosos y caritativos ${ }^{129}$. Se hacía alusión a la "mano de mujer" en los hospitales y a la alegría que imperaba en ellos:

[...] Es una cosa absolutamente femenina. Un Médico con los mismos medios hubiera instalado un hospital ciertamente magnífico; pero le faltaría ese "cachet" especial, este ambiente de delicadeza, es algo que denota la ternura de una mano femenina que sabe que la compasión y el amor son medicinas tan poderosas como la más enérgica y eficaz de cuantas puede inventar la terapéutica moderna $[\ldots]^{130}$.

\footnotetext{
${ }^{127}$ SÁNCHEZ DE ARROJO, E: op.cit., p.9.

${ }^{128}$ La Cruz Roja. $\mathrm{n}^{\mathrm{o}} 232$, octubre 1921, p. 556.

${ }^{129} A B C, 4$ agosto 1921. Chispas del yunque. La mujer y la guerra, p.13.

${ }^{130}$ La Cruz Roja. $\mathrm{n}^{\mathrm{o}} 232$, octubre 1921, p. 554.
} 
Capítulo I

\subsection{Diferencias y similitudes entre damas enfermeras y enfermeras} profesionales y su imagen pública en la prensa

Las titulaciones de dama enfermera y enfermera profesional de Cruz Roja coexistieron dentro de la institución pero con algunas peculiaridades que hacen que difirieran unas profesionales de otras. La principal diferencia que existe entre ser dama enfermera o enfermera profesional radica en la remuneración económica, las damas prestaban sus servicios de forma altruista, voluntaria y desinteresada, sin recibir ningún tipo de compensación económica, mientras que las enfermeras recibían un sueldo por su trabajo (ver anexo III).

Respecto al tipo de formación, fue amplia para ambas, pero menor en el caso de las damas. Aun así, Cruz Roja abogó siempre por una buena instrucción y un nivel adecuado de cultura entre sus tituladas, aunque algunos dirigentes de la institución expusieron que la formación que recibían las damas era igual en conocimientos que la de las enfermeras profesionales, y que estas últimas eran las que hacían un modo de vida de la profesión ${ }^{131}$.

El cuerpo de damas enfermeras tuvo mucha importancia para Cruz Roja, de hecho fue el que contó con mayor número de alumnas en detrimento del cuerpo de enfermeras profesionales. Hay que tener en cuenta que la formación de damas se podía realizar en las distintas sedes provinciales de la institución, mientras que la de enfermeras profesionales únicamente se podía cursar en Madrid, en el Hospital de San José y Santa Adela. Como ejemplo cabe tener en cuenta que en enero de 1927 el número total de damas enfermeras, entre las de primera y segunda clase, era de 2.998, mientras que el de enfermeras profesionales era de $45^{132}$.

Cruz Roja impartía los cursos de damas enfermeras en las distintas provincias y localidades, ya que eran las juntas de señoras las encargadas de su organización. De esta forma, las alumnas no necesitaban cursar sus estudios en régimen de internado, ya que permanecían en su domicilio asistiendo a las clases y prácticas desde el mismo. Por el contrario, la formación de enfermeras profesionales se

\footnotetext{
${ }^{131}$ Discurso pronunciado por la Excma. Sra. Marquesa de Valdeiglesias, vocal de la Asamblea Suprema de la Cruz Roja Española, como representante de esta entidad en el Congreso Internacional de Enfermeras celebrado en Ginebra en julio de 1927.

${ }^{132}$ La Cruz Roja. no 296, febrero 1927, p. 118.
} 
cursaba en Madrid, lo que implicaba el desplazamiento de las alumnas, por eso permanecían internas durante su formación, para garantizar la protección de las mismas dentro de Cruz Roja. El título de dama únicamente tenía validez dentro de Cruz Roja, por lo que prestarían sus servicios en los hospitales o dispensarios de la institución, mientras que las profesionales podían trabajar en cualquier centro sanitario.

Otra de las principales diferencias es la relación directa entre el título de dama enfermera y las mujeres aristócratas ya que formaron parte del cuerpo desde sus inicios (ver anexo IV). Las damas enfermeras fueron más importantes para la institución que las enfermeras profesionales, debido a la relación directa entre las juntas de señoras y el cuerpo de damas. Al contrario, ser enfermera profesional y recibir un salario por el desempeño de su trabajo levantó inicialmente ciertas reticencias en la sociedad de comienzos del siglo XX, por lo que Cruz Roja intentó cambiar dicha visión y favorecer la formación de enfermeras:

[...] muchas jóvenes de buenas familias venidas a modesta posición económica se harían Enfermeras y todo el cuerpo, hoy reclutado en su mayoría entre categorías honorables pero más humildes, adquiriría mayor realce con evidente acrecentamiento y esplendor de los nobles fines que debe cumplir $[\ldots]^{133}$.

La prensa también reforzó el vínculo entre el título de dama y la aristocracia española. Eran habituales las alusiones a las características de abnegación, sacrificio, cariño, humanidad y valor que debían reunir. Con motivo de la inauguración de un nuevo curso para damas enfermeras, se hablaba en los siguientes términos de la labor de la infanta María Luisa: “... es una de las damas enfermeras más entusiastas y asiduas, recorrió luego todo el hospital, así como el consultorio, presenciando algunas curas, felicitando a todo el personal médico y hermanas de la Caridad por el

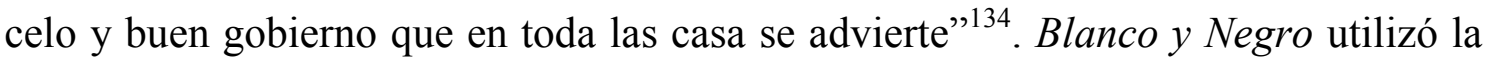
imagen de Pilar San Miguel y Martínez Campos, hijaПde los marqueses de Cayo del Rey, en una de sus portadas, en la que retrata a la dama enfermera vestida con el

\footnotetext{
${ }^{133}$ MARQUeSA DE VALDEIGLESIAS: Memoria sobre el Congreso Internacional de Enfermeras celebrado en Ginebra en julio de 1927. Imprenta Gracigoy, Madrid, 1928, p. 10.

${ }^{134} A B C .12$ noviembre 1920, p. 12.
} 
uniforme y la describe como "abnegada enfermera, atrevida deportista, de trato encantador siempre" la máxima representante del cuerpo de damas enfermeras y que esto contribuyó a ensalzar más la labor y la imagen de las damas ${ }^{136}$. La prensa presentaba a la soberana como un ejemplo a seguir, "hermosa, buena y amable", que "supo sentir la tradición de las santas y abnegadas reinas de Castilla”, para llevar a acabo una labor humanitaria y caritativa de reorganización de la institución y creando un cuerpo de “enfermeras científicamente instruidas"137. La reina Victoria Eugenia se convirtió en modelo de caridad para las mujeres españolas ${ }^{138}$ y sus damas enfermeras en un referente femenino de distinción y aristocracia:

Ved en las fotografías que ilustran estas páginas a las dos españolas figuras femeninas más elevadas de nuestro más alto plano social. Son hijas de Reyes; por donde ellas cruzan los soldados presentan sus armas, las autoridades callejeras se inmovilizan rígidas y saludan llevándose una mano hasta la sien; cuando entran en algún sitio las orquestas tocan la marcha de infantes [...]. Hijas de Reyes, que cuando el caso llega, visten la blusa blanca de las caridades y ven con ojos que no parpadean la miseria y el dolor humanos $[\ldots]^{139}$.

Las inauguraciones de los nuevos cursos de damas y las conferencias impartidas en los mismos, fueron noticias de interés en los distintos puntos de la geografía española. Cabe señalar que principalmente se hablaba de damas enfermeras y no de enfermeras profesionales, contribuyendo a ensalzar la figura de la dama y su posición social, posiblemente por la relación directa entre la Casa Real y Cruz Roja. La imposición de brazales e insignias a las recién tituladas era noticia, muchas veces motivada por presencia de la reina Victoria Eugenia en este tipo de actos:

\footnotetext{
135 Blanco y Negro. 10 de noviembre de 1929, Gran mundo, crónica de la semana, ecos varios de sociedad, p. 75.

${ }^{136}$ Blanco y Negro. 13 de noviembre 1921, Madrid, en el Hospital de la Cruz Roja, su Majestad la reina con las Damas Enfermeras, durante su reciente visita al benéfico establecimiento, p. 7.

${ }^{137}$ La Vanguardia, 21 de abril de 1921, La rosa de oro, p.12.

${ }^{138}$ La Vanguardia, 15 de enero de 1922, De sociedad, p. 14.

${ }^{139}$ Blanco y Negro. 13 de marzo de 1930, p. 92.
} 
[...] imposición de insignias a las damas de la Cruz Roja que han obtenido el título de enfermeras en los últimos exámenes, renovándose también la Junta de la Cruz Roja. La fiesta se celebró con gran solemnidad en el paraninfo de la Facultad de Medicina. Las enfermeras de la Cruz Roja, pertenecientes a familias muy distinguidas vestían el uniforme de la benéfica entidad $[\ldots]^{140}$.

El trabajo de la dama estaba pensado para que pudieran compaginar sus deberes como madres y esposas, y mantener sus relaciones sociales, por lo que acudían durante unas horas al hospital y de forma alterna por turnos semanales, mientras que las enfermeras profesionales desempeñaban su labor dentro de turnos de trabajo establecidos.

Respecto a las similitudes cabe destacar las cualidades físicas y morales exigidas a damas enfermeras y a enfermeras profesionales, resumidas en las tablas 3 y 4. Además, ambas tituladas de Cruz Roja estaban obligadas a utilizar el uniforme reglamentario durante la jornada laboral (Ver imagen I).

Tabla 3. Cualidades físicas exigidas a damas y enfermeras.

\begin{tabular}{|c|}
\hline Poseer buena salud \\
\hline $\begin{array}{l}\text { Resistencia física para enfrentarse al cuidado de } \\
\text { enfermos }\end{array}$ \\
\hline Correcta alimentación \\
\hline Pasear al aire libre \\
\hline Practicar algún deporte \\
\hline Dormir ocho horas \\
\hline Cuidar la higiene personal \\
\hline
\end{tabular}

Fuente: Manuales formativos de Cruz Roja española 1918-1923.

${ }^{140} A B C .19$ abril 1920 , p. 10. 
Capítulo I

Tabla 4. Cualidades morales exigidas a damas y enfermeras.

\begin{tabular}{cclcc}
\hline $\begin{array}{c}\text { Discretas y } \\
\text { abnegadas }\end{array}$ & $\begin{array}{c}\text { Dulces y } \\
\text { cariñosas }\end{array}$ & Obedientes & Observadoras & $\begin{array}{c}\text { Pacientes y } \\
\text { delicadas }\end{array}$ \\
\hline $\begin{array}{c}\text { Cultas e } \\
\text { inteligentes }\end{array}$ & $\begin{array}{c}\text { Silenciosas } \\
\text { para no } \\
\text { molestaran a } \\
\text { los pacientes }\end{array}$ & Serenas & $\begin{array}{c}\text { Joviales y } \\
\text { bondadosas }\end{array}$ & Leales \\
\hline
\end{tabular}

Fuente: Manuales formativos de Cruz Roja española 1918-1923.

La prensa de principios del siglo XX impulsó la imagen de damas y enfermeras y contribuyó a fijar su papel en la sociedad. La inauguración de Escuelas de Enfermeras, el inicio de los cursos, la duración de su formación y los tribunales encargados de los exámenes quedaron reflejados en prensa. La Primera Guerra Mundial propició los artículos sobre enfermeras extranjeras y su labor en los hospitales que sirvieron para afianzar más la imagen de la enfermera española ${ }^{141}$. La remuneración económica, su emancipación, todo ello ligado a su condición de mujeres y a su trabajo durante la Gran Guerra planteó un cierto debate en la prensa española de principios del siglo XX:

[...] Por saber más, no es una mujer menos mujer; por tener más conciencia y más voluntad, no es menos mujer una mujer; por haber vencido unas cuantas perezas seculares y encontrarse capaz de trabajo y de interés en la vida, no es una mujer menos mujer; por haber adquirido medios de defenderse y de defender a sus hijos sin ayuda ajena, no es una mujer menos mujer; al contrario, pues que todo esto: ciencia, conciencia, voluntad, capacidad, cultura a cabo, ó, si ustedes lo entienden mejor, cultivo, no puede dar de sí más que un perfeccionamiento de sus facultades naturales, nunca un cambio en su naturaleza $[\ldots]^{142}$.

\footnotetext{
${ }^{141}$ Blanco y Negro. 23 febrero 1919, p 51.

${ }^{142}$ ABC. 23 febrero 1917, p. 4.
} 
La profesión de enfermera se aceptaba socialmente como una salida para las mujeres que necesitaran "ganarse honradamente la vida en otras ocupaciones que en coser a máquina, bordar a precio vil, meterse a corista o bailarina, o lo que es aún peor, a literata" ${ }^{\prime 14}$.

Cabe señalar, que tanto en la prensa como en los textos analizados habitualmente se utiliza el término enfermera para referirse a las damas y no a las profesionales. Esto podría llevar a equívocos, ya que indistintamente aparecen imágenes de damas con la palabra enfermera, incluidos los cursos en los que fueron admitidas las infantas, que no cursaron los estudios de profesionales, sino los de damas ${ }^{144}$. Lo que está claro es que las damas llevaban el brazal de Cruz Roja en su uniforme y las enfermeras profesionales la cofia con la cruz de la institución, por lo que en las imágenes quedan diferenciadas unas de otras ${ }^{145}$ (ver imágenes II y III).

\footnotetext{
${ }^{143}$ La Vanguardia, 26 de julio de 1918, Bibliografía médica, p.4.

${ }^{144} A B C, 18$ de enero de 1928, Madrid, en el sanatorio de Cruz Roja su Alteza la Infanta Doña Beatriz en la inauguración del curso de enfermeras, el cual figura entre las aspirantes, p. 1, ABC, 7 de marzo de 1930, Madrid, en el dispensario de San José y Santa Adela. La infanta Doña María Cristina, que visitó por primera vez el uniforme de enfermera, presenciando una intervención quirúrgica, p. 4

${ }^{145}$ Asamblea SuPRema de CRUZ Roja EsPañola: Memoria del Hospital-Escuela ...op.cit., p. 7.
} 


\section{LA CAMPAÑA DE MARRUECOS (1921-1927): LABOR DE CRUZ ROJA ESPAÑOLA}

El desastre de Annual, las bajas ocasionadas por la sed, el hambre y la batalla con las tropas rifeñas hicieron que aumentara el envío de efectivos al protectorado marroquí a pesar del coste económico y del descontento de la población española. La evacuación desorganizada y precipitada, en la que se abandonaron armas y material, unida al ataque rifeño disminuyó el número de efectivos militares españoles $^{146}$. Según Rogelio González, el desastre de Annual fue la guerra que ocasionó más bajas en el Ejército español en el intento del general Silvestre por dominar la Bahía de Alhucemas y acabar con las tribus hostiles de la zona ${ }^{147}$. En este contexto $\mathrm{y}$ en el periodo de reconquista del territorio hasta el desembarco de Alhucemas, la ayuda sanitaria de Cruz Roja se hizo indispensable. La participación activa de las damas enfermeras, las enfermeras profesionales, Hermanas de la Caridad y las asociadas de Cruz Roja durante la campaña de Marruecos de 1921 a 1925 hace necesario su análisis. El papel destacado que desempeñaron en la guerra africana, muchas veces ignorado, les sirvió como experiencia asistencial, siendo muy valioso para la Guerra Civil lo que aprendieron.

\footnotetext{
${ }^{146}$ Ver MADARIAGA DE, María Rosa: Marruecos ese gran desconocido. Breve historia del protectorado español. Alianza Editorial, Madrid, 2013.

${ }^{147}$ GONZÁlez ANDRADAS, Rogelio: Campaña del Rif, Marruecos 1859-1927: final de un soldado español en Monte Arruit. CSED, Astorga, 2013, p. 15.
} 


\subsection{Papel de Cruz Roja Española en Marruecos a través de las memorias de las Juntas de Señoras}

Cruz Roja cumplió con su misión de ayudar y asistir a Sanidad Militar durante el conflicto bélico, ejemplo de ello fue la amplia labor realizada por las juntas de señoras tanto de la península como del mismo Protectorado ${ }^{148}$.

Dentro del trabajo desempeñado por la institución cabe destacar la constitución de nuevos hospitales para recibir a los heridos y enfermos de África. A través de las memorias se deja claro que la iniciativa de organizar estos centros asistenciales nació de las juntas de señoras, siempre secundada por la asamblea de la localidad y por las autoridades militares. La instalación de nuevos hospitales y la necesidad de organizarse y dotarse de material de forma rápida fue un hecho al que se enfrentó el personal de la institución:

[...] Al poco de llegar a Málaga se me nombró director de un Hospital de la Cruz Roja que a toda prisa se creó en dicha ciudad instalándolo en un edificio recién construido, que su propietario, un gran industrial, cedió galantemente. En pocos días llovieron sobre el incipiente hospital toda clase de donativos en metálico y en especie. Esto último, sobre todo, nos permitió hacerlo funcionar en brevísimo tiempo y no tardó en llenarse de heridos. Varias religiosas y enfermeras de la Cruz Roja, todas muy competentes, me ayudaron en su curación ${ }^{149}$.

Las donaciones permitieron la constitución de nuevos hospitales centrados en la asistencia a los heridos y enfermos, en la mayoría de las ocasiones de paludismo, que regresaban a la península después de haber estado en territorio africano, ejemplo

\footnotetext{
${ }^{148}$ Para el desarrollo de este apartado se han analizado las memorias de las Juntas de Señoras de Cartagena, Valencia, Málaga, La Coruña, Badajoz y Granada principalmente, además de valorar también las memorias de los hospitales de Larache, Tetuán, Cala bonita, y por supuesto, el de San José y Santa Adela de Madrid.

149 BAStOS ANSART, Manuel: De las Guerras Coloniales a la Guerra Civil, memorias de un cirujano. Ariel, Barcelona, 1969, p. 146.
} 
de ello fue el hospital El Progreso Pescador establecido en Valencia gracias a la donación de la casa social de la Sociedad de Pescadores a la Cruz Roja ${ }^{150}$.

La ocupación de hospitales civiles y de Cruz Roja por los heridos y enfermos de la campaña marroquí fue común en la península. Las damas enfermeras prestaron sus servicios en ellos, en turnos de ocho de la mañana a las dos de la tarde y de dos de la tarde a ocho de la noche. Las Hermanas de la Caridad se encargaban de la cocina y las damas enfermeras de los pacientes, menos por la noche que por "ser jóvenes" les dejaban esa tarea a dos hermanas, un practicante y un enfermero. Las damas también se ocupaban de despiojar a los soldados a su llegada, de asearles y atenderles según la instrucción recibida durante su formación académica ${ }^{151}$.

El déficit de personal hizo necesaria la ayuda de las damas enfermeras, ocasión que sirvió para reforzar su imagen de mujeres abnegadas, dulces y cariñosas:

[...] Testigos imparciales de su actuación continua en el Hospital, de las atenciones y cariños que como amantísimas madres prodigaron a los enfermos y convalecientes, no deploramos más que no se sepa en toda Valencia y mejor en toda España, que damas tan ilustres realizaran labor tan meritísima, que creemos merecedora de la más elevada recompensa y del reconocimiento eterno del noble pueblo valenciano $^{152}$.

Además de los hospitales diseñados para recibir a los heridos de Marruecos fue necesaria la coordinación de su evacuación y transporte a través de las ambulancias y de los trenes y buques hospitales, en los que las damas enfermeras trabajaron. El vapor Alicante, se convirtió en uno de los barcos-hospitales dotado de material para trasladar a los heridos y enfermos a los puertos de Cádiz, Valencia y Alicante ${ }^{153}$.

\footnotetext{
${ }^{150}$ CRUZ ROJA ESPAÑola: Memoria descriptiva de la instalación y funcionamiento del hospital de evacuación de enfermos y heridos de África, establecido por Cruz Roja en Valencia en "El Progreso Pescador" durante la Campaña de 1921-1922. Talleres tipográficos "La Gutemberg", Valencia, 1923.

${ }^{151}$ Cruz Roja Cartagena: Comisión departamental de la Cruz Roja de Cartagena, campaña de Marruecos 1921-1922. Imprenta de Emilio Garrido, Cartagena, 1923.

${ }_{152}$ CRuz Roja Española: Anales de la policlínica de la Cruz Roja de Valencia. Tipografía moderna, Valencia, 1922. p. 110.

${ }^{153}$ La Cruz Roja. $\mathrm{n}^{\circ}$ 230, agosto 1921.pp. 342-345.
} 
Las juntas de señoras obsequiaban a los soldados con vino, galletas, tabaco, escapularios y dinero a su llegada a las ciudades antes de partir a la zona del protectorado y luego a los enfermos y heridos durante su convalecencia y alta hospitalaria. En Málaga, por ejemplo, la junta de señoras se encargó de la organización de un ropero cuyo objetivo fue la confección de prendas de abrigo y ropa interior para los soldados y heridos de la campaña de Marruecos. También participaron en el reparto diario de ropa, la recogida de correspondencia y en el cuidado de los heridos del hospital militar. Esta junta tuvo la iniciativa de organizar en los hospitales de sangre una biblioteca del soldado con el objetivo de hacer más amenas las horas que debían pasar los heridos y enfermos hospitalizados ${ }^{154}$. Al igual que las juntas de señoras de la península, en el protectorado también se encargaron de recibir a las tropas para entregarles té, galletas, tabaco y medallas, llegando incluso con sus obsequios hasta los campamentos de soldados de la zona ${ }^{155}$.

Durante su estancia en el hospital, las señoras acudían diariamente a visitar a los heridos y enfermos, se encargaban de escribir y enviar las cartas de los mismos, y semanalmente les obsequiaban con fiambres, dulces, vinos y tabaco, además de prendas de ropa interior a los que las necesitaban. También recorrieron los comercios de la ciudad con el objetivo de recaudar dinero para comprar sardinas y sidra para los soldados, y ocuparse de la recaudación de ropa, además de obsequiar a las fuerzas expedicionarias de Sanidad que partían hacia Larache, con medallas, cajas de sidra y latas de conserva ${ }^{156}$.

Cuando terminaba el periodo de convalecencia y los soldados recuperados regresaban a su casa, la junta de señoras se encargaba de distribuir entre los mismos un donativo de diez pesetas y de veinticinco a los de la localidad, además de costear

\footnotetext{
${ }^{154}$ CruZ Roja MÁlaga: Memoria leída por la secretaria Doña Matilde Casanova, viuda de Cánovas en la Junta celebrada el 13 de septiembre de 1922. Tipografía de Enrique Montes, Málaga, 1922.

${ }^{155}$ CRUZ Roja LaRAChE: Memoria del año 1923 al 30 de junio de 1924, Cruz Roja Española, Junta de damas de Larache. Tip. Giménez y Vacas, Sevilla, 1924.

${ }^{156}$ Cruz Roja La CorUÑa: Memoria del año 1921, Junta de Señoras de La Coruña, Cruz Roja Española. Imprenta del Ideal Gallego, La Coruña, 1922.
} 
el entierro y funeral de los que fallecían en el hospital, llegando incluso a pagar el viaje a los padres que deseaban estar presentes en la despedida de sus hijos ${ }^{157}$.

[...] Las señoritas María Teresa Coello y María Marraco distribuyeron a los soldados de Gerona donativos en metálico. Los soldados besaron respetuosamente las manos de dichas aristocráticas señoritas. Varias casas comerciales obsequiaron con diversos géneros de ropa $[\ldots]^{158}$.

En algunas ocasiones, una vez recuperados y dispuestos a volver a sus casas o al campo de batalla, se les obsequiaba con una merienda compuesta por: "...una libra de pan, una tortilla de seis huevos, dos beafsteaf, cuatro ruedas de merluza, trozos de queso, dos manzanas o naranjas y una botella de vino [... $]^{\prime 159}$.

Las juntas de señoras, también se comprometieron a sostener las camas destinadas a los heridos de Melilla, a organizar el personal voluntario destinado a prestar servicios en los trenes y buques-hospitales y a la instalación de hospitales de sangre $^{160}$.

En todas las memorias se refleja la organización de fiestas y colectas para obtener fondos para poder ayudar a los soldados y heridos de la campaña de África, siendo la prensa el medio de difusión de las mismas ${ }^{161}$. En Larache se organizaron partidos de futbol, esgrima y boxeo, una velada de arte y venta de lotería, veladas de teatro y cine, y el festival de la Banderita, que permitieron recaudar suficientes fondos para sufragar la obra benéfica de Cruz Roja.

Dentro de los festejos organizados por la junta de señoras de Madrid para recolectar fondos para los militares de África, cabe destacar los que realizaron para el Aguinaldo del soldado y que consistió en el reparto de licores, de pastas, turrones y tabaco como obsequios navideños entre la tropa. Dentro de este Aguinaldo también se incluyeron los paquetes y provisiones que las familias de los combatientes querían mandarles con motivos de las fiestas pascuales. Para facilitar

\footnotetext{
157 Cruz Roja Badajoz: Actuación de la Junta de Señoras de la Cruz Roja de Badajoz durante la campaña de África 1921-1922. La Libertad, Badajoz, 1923.

${ }^{158} A B C, 14$ agosto 1921. p.22.

${ }^{159}$ CRUz Roja Española: Junta de Señoras de la Coruña, Memoria del año 1921. Imprenta del ideal gallego, 1922. p. 14.

${ }^{160} A B C, 28$ abril 1922. Función benéfica. p.16.

${ }^{161} A B C, 3$ agosto 1921, La fiesta del soldado. p.9.
} 
económicamente dicho envío, las compañías ferroviarias, por requerimiento del Gobierno, se comprometieron a reducir los precios en los puertos de Cádiz, Algeciras y Málaga siempre que los envíos fueran destinados a Larache, Ceuta y Melilla. Además de precintar perfectamente los paquetes, las familias debían señalar de forma clara el destino, la compañía y el nombre del soldado que debía recibir el envío. El Gobierno militar de Málaga distribuía los paquetes destinados a Melilla, el de Cádiz los de Larache y el de Algeciras los de Ceuta o Tetuán ${ }^{162}$.

En la zona del protectorado, la junta de señoras también distribuyó su ayuda entre la población. En Larache, establecieron una escuela gratuita para niñas pobres, instalada en el edificio del hospital a cargo de las Hermanas de la Caridad y la Gota de Leche que consistía en repartir biberones de leche entre las familias pobres con hijos pequeños para evitar el déficit nutricional.

Cabe señalar que tanto en la península como en el protectorado las juntas de señoras se encargaron de conseguir subvenciones para construir hospitales para los soldados heridos o enfermos de la contienda africana ${ }^{163}$. También dotaron de camas y de damas enfermeras a los centros sanitarios establecidos que necesitaron más recursos materiales y humanos debido al aumento de heridos ${ }^{164}$.

\footnotetext{
${ }^{162}$ La Cruz Roja. no 233, noviembre 1921.pp. 606-607.

${ }^{163}$ La Vanguardia, 20 de octubre de 1921, Despacho ordinario, p. 8.

${ }^{164}$ La Vanguardia, 9 de agosto de 1921, Telegramas, p. 6.
} 


\subsection{Hospitales de la Cruz Roja durante la Campaña de Marruecos}

Durante la guerra colonial, Cruz Roja constituyó una red asistencial importante gracias a la adaptación de sus hospitales y la formación de nuevos centros, en los que damas, enfermeras y hermanas prestaron sus cuidados. La institución se movilizó desde el comienzo de la campaña ${ }^{165}$, para cumplir su misión humanitaria de auxilio a los soldados heridos y enfermos ${ }^{166}$, participando también en el traslado de los mismos a la península en buques-hospitales: ${ }^{167}$

Ceuta 14, 7 mañana. En tren especial han llegado 42 soldados heridos en las últimas operaciones y 43 enfermos. Además han llegado cuatro oficiales y seis sargentos heridos. Todos han embarcado en el buque hospital Barceló, con rumbo a Málaga, juntamente con otros 106 heridos hospitalizados aquí.

Hicieron embarco los heridos, los sanitarios, los médicos y las damas enfermeras que vinieron acompañándolos desde Tetuán, y las damas del hospital de la Cruz Roja de esta plaza ${ }^{168}$.

A través de la memoria de la junta de la Asamblea Central leída el 3 de julio de 1922 se sabe que los hospitales de Cruz Roja Española aceptados por el Ministerio de la Guerra ${ }^{169}$ para asistir a los soldados fueron los de: Antequera, Barcelona, Bilbao, Cáceres, Cádiz, Cartagena, Ceuta, Córdoba, Granada, Huelva, Jerez, Linares, Madrid, Málaga, Melilla, Murcia, Puerto de Santa María, Ronda, San Sebastián, Santander, Sevilla, Valencia y Valladolid ${ }^{170}$.

Los soldados de la campaña de Marruecos atendidos en los hospitales de Cruz Roja eran aquellos que habían sido heridos durante la misma y todos los que contrajeron enfermedades, principalmente paludismo. Los hospitales de Marruecos se colapsaron de enfermos, siendo insuficiente el número de camas hospitalarias

\footnotetext{
${ }^{165}$ ABC, 6 agosto 1921. Cruz Roja española, p.12.

${ }^{166}$ La Vanguardia, 6 de agosto d 1921, Iniciativa de la reina Victoria, p.8.

${ }^{167} A B C, 24$ agosto 1921. Heridos a Málaga, p.8.

${ }^{168}$ ABC, 16 mayo 1922. Llegada de heridos, p.9.

${ }^{169}$ Los hospitales de Cruz Roja, en tiempos de guerra, debían ser militarizados, ya que el reglamento de la institución obligaba a dar cobertura a Sanidad Militar en todo lo necesario.

${ }^{170}$ ACCRE. Caja 253, Expediente 38.
} 
existentes en el Protectorado, lo que hizo necesario que en la península los hospitales se pusieran a disposición de los soldados ${ }^{171}$.

\section{El Hospital de San José y Santa Adela de Madrid}

Dentro del análisis de la amplia labor socio-sanitaria desarrollada por la Cruz Roja Española durante la campaña de Marruecos, el estudio del trabajo realizado en el Hospital de San José y Santa Adela de la institución es necesario por la implicación que tuvo en la formación de damas y enfermeras, además de la asistencia prestada a los heridos y enfermos.

La construcción del hospital comenzó el 16 de julio de 1893 aunque no empezó a funcionar hasta el 24 de mayo de 1912. Su fundadora fue Adela de Balboa y su primera presidenta la Reina María Cristina, siendo vicepresidenta la Marquesa de Alhucemas. Destinado en su origen a enfermos tuberculosos, tuvo que cerrar sus puertas el 31 de mayo de 1915 debido a que el gasto generado fue superior a los ingresos recibidos. En 1918 el hospital fue entregado a la reina Victoria Eugenia, como presidenta general de la Cruz Roja Española, siendo a principios de agosto de ese mismo año cuando “...entraron los primeros enfermos, recibidos por la excelentísima Duquesa de la Victoria, Presidenta de dicho Hospital; el Director Víctor Manuel Nogueras; cinco Hijas de la Caridad y dos jóvenes aspirantes a enfermeras profesionales"172. La junta administrativa del hospital estaba compuesta por la presidenta, tesorera, secretaria y dos vocales que respectivamente eran: la Duquesa de la Victoria, la Marquesa de Mina, Mercedes Castellanos, el Director del Hospital, Dr. Víctor Manuel Nogueras y la Directora que era la Superiora de las Hijas de la Caridad, Sor Isabel Moya.

El hospital disponía de dos tipos de pabellones para enfermos pobres y para distinguidos, los primeros eran dos, completamente separados, uno para pacientes de cirugía y el otro de medicina, cada uno de ellos tenía dos salas, cada una con doce

${ }^{171}$ CRUZ Roja EsPañola: Memoria Hospital María Cristina. Escuela de damas enfermeras en San Sebastián.

172 ASAMBlea CENTRAL DE SEÑORAS DE LA CRUZ ROJA ESPAÑOLA: Información sobre el hospitalEscuela de Madrid de San José y Santa Adela, calle del Doctor Santero. Imprenta Blass y CIA, Madrid, 1920, p.11. 
camas, una para hombres y otra para mujeres ${ }^{173}$. El pabellón de distinguidos tenía doce habitaciones individuales, en las que únicamente se hospitalizaban enfermos para intervenciones quirúrgicas, quedando excluidos los pacientes con enfermedades contagiosas o mentales ${ }^{174}$. El hospital también contaba con Capilla, sala de rayos X, servicio de mecanoterapia y masaje, laboratorio y farmacia, además de la Escuela de Enfermeras Profesionales y Damas Enfermeras ${ }^{175}$.

Las camas del hospital estaban sufragadas por distintas instituciones y centros, y por personas particulares, como ejemplo cabe citar que la calefacción central estaba costeada por el Marqués de Comillas, ya que aportaba el carbón necesario, la instalación de rayos X fue una donación del Hospital Español al cerrar el centro y el donativo de muebles e instrumental quirúrgico corrió a cargo de la señora Mille, esposa del presidente de la Asamblea Suprema de la Cruz Roja ${ }^{176}$.

\section{Red de hospitales de Cruz Roja en África}

Dentro de la amplia red de hospitales que Cruz Roja constituyó en el Protectorado cabe mencionar los hospitales de Tetuán, Larache, Cala Bonita y Melilla, en los que desarrollaron su trabajo las damas, enfermeras y hermanas y cuya organización estuvo en manos de la Duquesa de la Victoria.

Desde Madrid se organizó todo el material necesario para poder formar los nuevos hospitales, principalmente se transportó:

\footnotetext{
${ }^{173}$ ASAMBlea CENTRAL DE SEÑORAS DE LA CRUZ RoJa ESPAÑOLA: op.cit., p. 35.

${ }^{174}$ El precio por estancia era de quince pesetas para las habitaciones de primera clase y de diez pesetas para las de segunda, incluía la manutención y la asistencia sanitaria y debían pagar por adelantado la quincena de estancia hospitalaria. Los enfermos también pagaban por la intervención quirúrgica, incluyendo sala de operaciones, material y medicamentos, cuyo precio oscilaba entre las veinticinco y cien pesetas en función de la importancia de la operación, sin incluir los honorarios médicos por la intervención, que habitualmente se negociaban entre médico y enfermos. El dinero recaudado servía para sostener los pabellones para pobres. A los enfermos se les permitía estar acompañados por un familiar que también debía pagar el mismo precio por estancia en el hospital que los pacientes, para ambos el desayuno se servía de siete y media a ocho y media, la comida a las doce y media y la cena a las siete, sin olvidarse de que el familiar debía estar en el centro antes de las ocho de la tarde, ya que a partir de ese momento el establecimiento permanecía cerrado. El personal disponible para la asistencia del enfermo consistía en un médico de guardia las veinticuatro horas, las Hijas de la Caridad y las Enfermeras Profesionales. En el caso de que el enfermo quisiera disponer de personal exclusivo para él, la retribución del mismo correría de cuenta del paciente y estaría obligado a contratar a personal del centro. El horario de visitas era de nueve a doce por las mañanas y de tres a siete por las tardes y debían evitar los ruidos y tertulias con el fin de no molestar al resto de enfermos.

${ }^{175}$ Los médicos encargados de la formación fueron el Dr. Víctor Manuel Nogueras, el Dr. Francisco Luque y Dr. Leocadio Serrada, que compaginaron la asistencia clínica en el hospital con la docencia.

${ }^{176}$ La Cruz Roja. no 211, Enero 1920.p. 16.
} 
[...] material de operaciones, curas, instalación completa de Sala de Operaciones, instrumental, gasa, algodón, alcohol, iodo, inyecciones antitetánicas, antigangrenosas, ropa de lo más necesario, vendas; en una palabra: nada faltó cuando llegó el triste momento de ponerse a la obra ${ }^{177}$.

La iniciativa de organizar el Hospital-Ambulancia de la Cruz Roja de Tetuán $^{178}$ fue de la reina Victoria Eugenia, que consideró necesaria su instalación para descongestionar el Hospital Militar, saturado en ese momento ante la gran cantidad de heridos y enfermos que debía atender. La encargada de llevar a cabo dicho trabajo fue la Duquesa de la Victoria, que instaló el Hospital-Ambulancia en un ala de la futura escuela y residencia destinada a los Padres Franciscanos ${ }^{179}$.

Los hospitales del Protectorado estaban dotados de sala de operaciones, sala de curas, de rayos X, farmacia, laboratorio, cocina, despensa, un servicio de biblioteca para los convalecientes, amplios jardines y una Capilla. En algunos hospitales fue necesario ampliar la dotación del botiquín por la demanda de asistencia de la población civil, además de organizar escuelas y dispensarios.

La construcción de hospitales en la zona en algunas ocasiones fue dificultosa como el caso del de Cala Bonita, conocido como Villa Sanjurjo, instalado al pie del monte Malmusi, por deseo expreso de la reina Victoria Eugenia. La escasez de agua, el calor y el fuego enemigo dificultaron el desembarco y traslado del material necesario para su construcción ${ }^{180}$. El hospital de Cala Bonita, con capacidad para albergar de doscientas cincuenta camas a trescientas ${ }^{181}$, recibía a los heridos en ambulancias y una vez estabilizados eran evacuados para poder seguir acogiendo a nuevos pacientes. Para ello Cruz Roja contó con hidroaviones que también se encargaron de la distribución de material para las salas.

\footnotetext{
${ }^{177}$ Cruz Roja Española: Memoria del Hospital-Escuela de Damas de la Cruz Roja de Madrid San José y Santa Adela. 1920-1922, p. 50.

${ }^{178}$ En agosto de 1925 se clausuró el Hospital-Ambulancia de Tetuán, por lo que todo el material sanitario se trasladó al hospital de la Cruz Roja en Ceuta.

${ }^{179}$ CRUZ Roja EsPañola: Memoria del Hospital de la Cruz Roja en Tetuán, años 1924-1925. Balss, sin año de edición, Madrid.

${ }^{180}$ Cruz Roja EsPañola: Memoria del Hospital de la Cruz Roja en Cala Bonita, (Villa-Sanjurjo), 1926 1929. Balss, sin año de edición, Madrid.

${ }^{181}$ Archivo General de la Administración (AGA). Caja 81/09676.
} 
En Melilla, debido al gran contingente de heridos que recibían fue necesario organizar un nuevo centro asistencial, de forma que coexistieron los hospitales militares con los de Cruz Roja; por eso en 1921 la ciudad contaba con el Hospital Alfonso XIII dotado con setecientas cincuenta camas; el Hospital Central con doscientas camas civiles, pero que se había cedido a Sanidad Militar, el Hospital de infecciosos, con sesenta camas y con un Hospital de Indígenas dotado de cien camas $^{182}$.

Es interesante resaltar las impresiones recogidas por el Inspector de los Servicios de Intendencia del Ejército de África, sobre los hospitales de Cruz Roja en Melilla, que se podría extrapolar al resto de la institución en el Protectorado. Destacaba dos ideas, la primera era que a diferencia de los hospitales militares, los de Cruz Roja contaban con la labor de sus damas enfermeras y de la Duquesa de la Victoria:

[...]Y el segundo problema es la comparación técnico profesional. Nuestra primera observación al visitar los hospitales militares, ha sido la deficiencia de locales, la Cruz Roja tiene espléndidos ¿por qué? Muy sencillo, porque su instalación es limitada. La Cruz Roja ha montado y es de agradecer, hospitalitos dentro de sus fuerzas; el servicio militar tiene que atender a todo el dolor que diariamente derraman las ambulancias a sus puertas.

El material nuevo y escogido, el servicio libre y sin reglamentaciones coercitivas; el donativo nacional coadyuvando al servicio de la Institución; no es igual el esfuerzo a rendir ${ }^{183}$.

Cabe señalar que también por iniciativa de la reina Victoria Eugenia, comenzó en 1920 la construcción del hospital de Cruz Roja en Ceuta, terminándose a finales de ese mismo año y que dispuso de un total de cincuenta y dos camas, un dispensario y una Escuela para damas enfermeras ${ }^{184}$.

Dentro de este apartado es necesario tener en cuenta que la evacuación de soldados y heridos enfermos a la península, frecuente durante la guerra, generó

\footnotetext{
${ }^{182}$ La Cruz Roja. $\mathrm{n}^{\mathrm{o}}$ 230, agosto 1921.pp. 342-345.

${ }^{183}$ Archivo General Militar de Madrid (AGMM). Fondo de África. Caja no 57, Estante: 1, Cuerpo: 1, Tabla: 4, Legajo: 14, Carpeta: 2.

${ }^{184}$ La Cruz Roja. $\mathrm{n}^{\circ}$ 225, Marzo 1921.p 118.
} 
casos de desconfianza entre los mandos militares debido a los largos periodos de convalecencia, todo ello unido a las necesidades de campaña. Corroborar que los soldados evacuados estaban realmente enfermos, llevó al Ministro de Guerra a organizar una comisión de investigación en la península a su cargo y en Marruecos a cargo del Alto Comisario con el objetivo de solventar el problema en caso de que existiera y que estos hechos no quedaran impunes y fueran castigados los culpables. Así lo especifica la carta escrita por el Capitán General de la quinta Región (Sección Mayor Negociado segundo), al Ministro de Guerra, el 13 de diciembre de 1921. En dicha misiva adjunta el informe redactado por el Inspector de Sanidad de la Región:

[...]; tengo el honor de manifestar a V. E. como resultado de la mencionada investigación, que respecto a los hospitalizados en Guadalajara, la mayor parte de los enfermos ofrecían importancia, hasta el punto que por no hallarse en condiciones para ir a sus casas, no han podido salir de alta más que veinticuatro que lo efectuaron aún hace tres días, quedando en la actualidad cincuenta en muy deplorable estado y con huellas evidentes en su organismo que revelan intensa anemia palúdica.- En cuanto a los que ingresaron en el Hospital de esta Plaza, puedo asegurar a V. E: que todos ellos exigían hospitalización, siendo la inmensa mayoría de paludismo y los demás que presentaban en general buen aspecto, convalecientes de formas leves de dicha enfermedad y de afecciones gastrointestinales agudas de poca importancia $[\ldots]^{185}$.

Para conseguir el control exacto de la situación de los soldados convalecientes se exigió la notificación de los partes diarios de los hospitalizados y con licencia del Ejército de África ${ }^{186}$.

\footnotetext{
${ }^{185}$ AGMM. Fondo de África. Caja no 53: Armario: 44, Estante: $1 n^{\circ} 9$ Fila: 1, Carpeta: 4.

${ }^{186}$ La Real Orden de dieciséis de diciembre de 1921 exigía a los Gobernadores Militares emitir un parte diario con el número de soldados hospitalizados en su Plaza, con licencia y los que debían incorporarse nuevamente a filas.
} 
Capítulo I

\section{MUJER EN GUERRA: LAS ENFERMERAS EN LA CAMPAÑA DE MARRUECOS}

Durante el conflicto marroquí las damas y enfermeras de Cruz Roja participaron de forma activa, bien desde la península, o acudiendo al Protectorado para cuidar de los soldados heridos y enfermos en los hospitales, en los equipos quirúrgicos destinados al frente de batalla ${ }^{187}$, en los hospitales de sangre, cercanos al frente de batalla ${ }^{188}$ y en los buques hospitales que trasladaban a los heridos a la península $^{189}$.

\subsection{La Duquesa de la Victoria}

Dentro de la amplia labor desarrollada por damas y enfermeras durante la Campaña de Marruecos, cabe resaltar el papel que desempeñó la Duquesa de la Victoria $^{190}$, Carmen Angoloti y Mesa. Mujer inteligente, tenaz y enérgica, que tuvo la oportunidad de vivir en Alemania y viajar por Europa con su marido Pablo Montesinos y Espartero, primogénito de los Duques de la Victoria, nombrado en 1905 agregado militar en la Embajada española de Berlín ${ }^{191}$. El 2 de enero de 1911, Carmen Angoloti fue nombrada por Real Decreto, Dama de la Reina Victoria Eugenia:

He recibido como Dama que soy de la Reina Ntra. Sra. el distintivo creado para sus Damas por la Reina Doña Victoria Eugenia; alhaja de oro y platino formada por una corona de brillantes de la que pende un lazo de las mismas piedras sujetando una orla de rubíes que lleva su centro las cifras R.V. de brillantes y zafiros, sobre tres flores de lis, cuya insignia conforme a lo dispuesto, será devuelta a mi fallecimiento a la Camarería Mayor de Palacio, por ser propiedad de mi Augusta Soberana.

Y para que conste lo firmo en Madrid a 16 de febrero de $1911^{192}$.

\footnotetext{
${ }^{187} A B C, 2$ junio 1923. Llegada de enfermeras, p.8.

${ }^{188}$ La Vanguardia, 13 de mayo de 1924, Marruecos, p.22.

${ }^{189}$ La Vanguardia, 16 de septiembre de 1925, Regreso de damas enfermeras, p.13.

${ }^{190}$ Carmen Angoloti y Mesa (1875- 1959), hija de Carmen Mesa y Joaquín Angoloti y Merlo, diputado a cortes por el distrito de San Juan de Puerto Rico, Senador del Reino por Orense, jefe superior de Administración de Hacienda Pública y presidente de la Cámara de Comercio de Madrid.

${ }_{11}^{1}$ ANGOlOTI DE CÁRDENAS, Ignacio: La Duquesa de la Victoria. Cruz Roja, Madrid, 1958, p.26.

192 ARCHIVO PALACIO REAL. Caja 1330, Expediente 41.
} 
Desde un primer momento, la Duquesa de la Victoria participó en la constitución y organización de Cruz Roja Española, ya que entró a formar parte de ella en $1913^{193}$ y fue de las primeras asociadas que cursó los estudios de dama enfermera en $1917^{194}$. Además de ser la Presidenta de la Junta de Damas del Distrito Centro de Madrid, y la Presidenta de la Junta del Hospital-Escuela de San José y Santa Adela de Madrid ${ }^{195}$, el principal cargo que ostentó en la institución, a lo largo de todo el periodo en el que trabajó en ella, fue el de Presidenta de Hospitales de Cruz Roja Española.

Es importante analizar al figura de la Duquesa de la Victoria porque fue la encargada de organizar e instalar los hospitales de Cruz Roja en el Protectorado durante la Campaña de Marruecos, actividad que delegó en ella la reina Victoria Eugenia como dama de su máxima confianza ${ }^{196}$. Carmen Angoloti organizó el primer equipo de mujeres de Cruz Roja que acudió a Melilla para comenzar con la labor de auxilio a los heridos. Durante esta etapa fue capaz de compaginar su trabajo como dama enfermera con su cargo de presidenta de hospitales: “...Inspecciona, reorganiza, recibe a los heridos, los instala y cura incansable en un vértigo de acción" ${ }^{\prime 197}$.

A su llegada a Melilla organizó el hospital de Cruz Roja en la Casa-Escuela de los Hermanos de las Escuelas Cristianas. Permaneció allí cinco meses hasta que

\footnotetext{
${ }^{193}$ ACCRE. Caja 827, Expediente 9.

${ }^{194}$ Matriculada en Madrid en el curso de damas enfermeras de 1917-1918, ingresó en el Cuerpo de Damas con el número cuarenta y seis. El 12 de junio de 1917 aprobó satisfactoriamente el examen teórico en Madrid, en su expediente destacan las excelentes notas obtenidas durante su formación, siendo la alumna con mayor puntuación durante las prácticas realizadas del 27 de enero al 3 de febrero de 1918. La Duquesa cursó sus prácticas tanto en el Hospital militar de Urgencia como en el de Madrid-Carabanchel. Ver ACCRE. Caja 248, Expediente 1.

${ }^{195}$ CRUZ RoJa ESPañola: Memoria del Hospital-Escuela ... 1920-1922, op.cit., pp. 7 y 15.

${ }^{196}$ No era la primera vez que Carmen viajaba a África, en 1920, había estado en Ceuta en representación de la reina en el homenaje que le hicieron los ceutís con motivo de su nombramiento como hija predilecta de la ciudad, en agradecimiento a la instalación de un hospital de Cruz Roja completamente dotado para la asistencia de la población. Ver La Cruz Roja. n 214, abril 1920, pp.164-165.

${ }^{197}$ CruZ Roja ESPaÑola: Memoria del año 1923 al 30 de junio de 1924. Junta de Damas de Larache. Tip. Giménez y Vacas, Sevilla, 1926, p. 43.
} 
sus obligaciones como presidenta de hospitales le hicieron viajar para continuar con la fundación de nuevos centros de Cruz Roja en Tetuán, Larache, Ceuta y Arcila ${ }^{198}$ :

[...] Para ejecutar su idea, envió a su digna emisaria, la Excma. Sra. Duquesa de la Victoria, que batió el record de la actividad prodigiosa que la caracteriza, y con el don especial de organización con que Dios la dotó, a la par del estruendoso bombardeo de los picachos de Gorgues, que tenían a toda la población de Tetuán en anhelante expectación, hizo surgir como por arte de encantamiento un Hospital-Ambulancia perfectamente instalado $[\ldots]^{199}$.

La Duquesa de la Victoria también recorrió la línea del frente de batalla, estuvo en Río Martin, Monte-Arruit, Dar Drius, Kádur, Nador y Alhucemas. Para poder conocer el terreno donde se emplazarían los hospitales de Cruz Roja e ir dando la cobertura sanitaria al Protectorado. Realizó numerosos viajes dentro de la zona y entre Marruecos y la península ${ }^{200}$.

Como presidenta de hospitales de Cruz Roja, fue la encargada de solicitar en nombre de la misma los locales para habilitar los hospitales, el material para dotarlos e incluso el personal sanitario necesario para sostenerlos:

[...] Mi buen amigo: un millón de gracias por su amable carta. ¡Cuántos enfermos de la vista deberán su curación a V. por haberles enviado a Melilla quien pudiera atenderlos! Todos saben que es V. quién se acordó de ellos. Dios se lo pague con todo agradecimiento le saluda su siempre buena amiga: Carmen Victoria $^{201}$.

El comandante de ingenieros de Ceuta se dirige a la Duquesa en su carta de 1926 en estos términos:

[...] Muy distinguida amiga mía: Como continuación de los informes que he tenido el honor de dar a V. en fecha reciente sobre la parcela destinada a la Cruz Roja, me complazco en remitirle el plano del replanteo del ensanche en el que se señala la referida parcela rayándose la parte que está libre y a la que deben sujetarse

\footnotetext{
${ }^{198}$ CRUZ ROJA ESPAÑOla: Memoria del Hospital-Escuela ...1920-1922, op.cit., pp. 49-50.

${ }^{199}$ CRUZ Roja EsPañola: Memoria del Hospital de la Cruz Roja en Tetuán...op.cit., p. 10.

${ }^{200} A B C, 5$ enero 1922, p. 9.

${ }^{201}$ AGA. Caja 81/09676. Correspondencia entre Carmen Angoloti y el Conde de Jordana, en la que la Duquesa solicita la prestación de servicio médico militar al Hospital de Cruz Roja de Villa Sanjurjo y un oftalmólogo para el hospital de Pagés en Melilla.
} 
las primeras construcciones. El resto como ya sabe V. lo ocupan las carreteras señaladas en el plano y que en fecha no lejana deberán desviarse para ajustarse a la planta del ensanche aprobado, disponiendo entonces de la totalidad de la parcela.

Espero que dentro de poco se entreguen las calles al Ayuntamiento y las parcelas propuestas a Guerra con lo que fácilmente se podrá ceder la que corresponde a la Cruz Roja ${ }^{202}$.

El trabajo que desempeñó la Duquesa de la Victoria durante la Campaña de Marruecos fue ampliamente reconocido, motivo de ello fue la concesión de la Gran Cruz de la Orden Civil de Beneficencia con distintivo blanco el 22 de noviembre de 1921 “... por su hermosa labor, altamente humanitaria, caritativa y altruista, a favor de los heridos y enfermos del Ejercito de África, al que asiduamente y con notorio espíritu de sacrificio presta su personal cooperación"203.

El 2 de diciembre de 1921 fue nombrada hija predilecta de Madrid, como reconocimiento a su labor sanitaria y de auxilio en África ${ }^{204}$. La gratitud melillense hacia el trabajo realizado por la Duquesa hizo que en febrero de 1922 pusieran su nombre a la calle del hospital del Grupo Escolar ${ }^{205}$. Ese mismo año también se colocó en Melilla una placa para conmemorar la labor desempeñada por Carmen Angoloti y las primeras damas que llegaron a Marruecos para trabajar en los hospitales $^{206}$. En 1923 le concedieron la Banda de la Real Orden de la Reina María Luisa $^{207}$ y el Comité Internacional de Cruz Roja de Ginebra, en 1925 la Medalla Nightingale $^{208}$. El 27 de noviembre de 1925, la Duquesa recibió en Sevilla la Gran Cruz del Mérito Militar con distintivo rojo, era la primera vez que se otorgaba una insignia de este tipo a una mujer ${ }^{209}$ (ver anexo V).

\footnotetext{
${ }^{202}$ ACCRE. Caja 2528. Expediente 35.

${ }^{203}$ La Cruz Roja. no 233, noviembre 1921, pp. 607-608.

${ }^{204}$ La Cruz Roja. no 234, diciembre 1921, p. 700.

${ }^{205}$ ACCRE. Caja 827. Expediente 9.

${ }^{206}$ La Vanguardia, 4 de febrero de 1922, Descubrimiento de una lápida, p.13.

${ }^{207}$ Gaceta de Madrid, no 19. 19 enero 1923, Real decreto concediendo la Banda de la Real Orden de la Reina María Luisa a doña Carmen Angoloti y Mesa, Duquesa de la Victoria p. 262.

${ }^{208}$ La Cruz Roja. $\mathrm{n}^{\mathrm{o}} 275$, mayo 1925, p. 238.

${ }^{209}$ CruZ Roja EsPaÑola: Memoria del Hospital-Escuela ...1920-1922, op.cit., p. 90.
} 
El libro Homenaje a la Duquesa de la Victoria, es una recapitulación de los discursos celebrados en honor a la Duquesa en Madrid y Cádiz, con motivo de la inauguración de los monumentos ${ }^{210}$ erigidos en su memoria. Cabe destacar que en dicho volumen figuran textos de distintas personalidades tanto políticas como de la Casa Real que alababan el trabajo realizado en Marruecos por Carmen Angoloti ${ }^{211}$.

Por lo tanto, la Duquesa de la Victoria se convirtió en la figura principal de Cruz Roja durante la contienda africana y pasó a ser la imagen de las damas enfermeras, ejemplo de mujer "extraordinaria, alma gigante y corazón de fuego". Conocida como la heroína de Marruecos, simbolizaba el ideal perfecto de dama enfermera, capaz de abandonar las comodidades de la vida en la ciudad, para acudir de forma voluntaria al cuidado de los necesitados. "Ilustre dama", aficionada a los deportes, de "carácter jovial y encanto afable", con una buena relación con la Casa Real, pasó a ser el icono de las damas enfermeras gracias al trabajo que desempeñó durante la campaña de África ${ }^{212}$.

[...] La Duquesa intenta rechazar modestamente nuestras alabanzas. Viste de enfermera. Atenta a toda labor, sus manos, mientras habla, no cesan un momento de trabajar. Acaba de cortar unas vendas y se dispone, ahora, a abrir el correo. ¡Unos centenares de cartas!

La Duquesa de la Victoria es alta y fina de líneas. Su elegante silueta destaca con la blanca envoltura de su uniforme. Como ni un solo instante deja de sonreír, su sonrisa pone como una alada gracia en la expresión de su rostro ${ }^{213}$.

La Duquesa demostró que una mujer era capaz de realizar el trabajo desempeñado habitualmente por hombres en cuanto a las labores de gestión se refiere, a través de la organización de la red de hospitales de Cruz Roja en el

\footnotetext{
${ }^{210}$ El monumento de González Pola en Madrid se encuentra en la Avenida Reina Victoria a la entrada del hospital de Cruz Roja. El monumento de Cádiz, completamente idéntico al primero, se instaló en el Parque Genovés.

${ }^{211}$ CRUZ Roja Española: Homenaje a la Duquesa de la Victoria. Talleres Depósito de Guerra, Madrid, 1926. En esta obra, Alfonso XIII y la reina Victoria Eugenia agradecían y admiraban la labor patriótica y hermosa que había realizado en África la Duquesa. Hay una sección titulada pensamientos, en la que aparecen frases homenajeando a Carmen Angoloti, son de dirigentes políticos, artistas, pensadores y aristócratas, entre ellos cabe mencionar la participación de Niceto Alcalá Zamora, Alejandro Leroux, Indalecio Prieto, Ramón y Cajal y Ortega y Gasset.

${ }^{212} A B C, 7$ agosto 1921, Páginas femeninas. La mujer y la casa moderna, p.31.

${ }^{213}$ La Vanguardia, 5 de diciembre de 1921, La Duquesa de la Victoria y los Hospitales de la Cruz Roja, p.19.
} 
Protectorado. Intrépida y aventurera participó en las empresas difíciles como el desembarco de Alhucemas, inspeccionó directamente el terreno antes de instalar un hospital y para ello no le importó viajar en cualquier medio de transporte, incluidos los hidroaviones. Discreta y modesta, rehusó conceder entrevistas a la prensa y prefirió mantenerse al margen de los homenajes realizados en su memoria para continuar centrada en su trabajo.

\subsection{Damas, Enfermeras y Hermanas de la Caridad durante la Campaña de Marruecos}

La contienda de África impulsó la labor sanitaria de las mujeres que no dudaron en acudir a Marruecos a asistir a los heridos y enfermos a pesar de las condiciones climáticas y bélicas. El primer grupo en desembarcar el 28 de agosto de 1921 en África fue el compuesto por las Srtas. María Benavente y María del Carmen Merry del Val, cinco Hijas de la Caridad y tres enfermeras profesionales, que acompañaron a la Duquesa de la Victoria a Melilla, guiadas por el deseo de ayudar y auxiliar a los heridos ${ }^{214}$.

Ruego a V. A. R. ordene a Gobernador Militar de Málaga facilita pasaje para Melilla en las mejores condiciones a la Duquesa de la Victoria con un equipo de la Cruz Roja compuesto de dos Damas, cinco Hermanas y tres Enfermeras con material curación y ropas en paquetes total peso dos toneladas. Llegarán a Málaga procedentes de esta Corte mañana y la Duquesa pasado mañana procedente de Sevilla. Rogando a Gobernador Militar Málaga espere estación llegada Duquesa a quien facilitará cuanto sea necesario al benéfico servicio que realiza, el que avisará salida de dicha plaza de este equipo al Alto Comisario ${ }^{215}$.

\footnotetext{
${ }^{214}$ CRUZ RoJa ESPAÑOla: Memoria del Hospital-Escuela...1920-1922, op. cit., p. 49.

${ }^{215}$ AGMM. Fondo de África. Caja n ${ }^{\circ}$ 43, Carpeta: 44, Estante: 1, nº 4 Fila: 2 Carpeta: 6 Telegrama oficial de la Subsecretaria del Negociado de Marruecos, con número de registro 8850, a 27 de julio de 1921.
} 
Posteriormente llegaron a Marruecos más enfermeras, damas y Hermanas de la Caridad del Hospital Central de Cruz Roja de Madrid como las hermanas Sor Isabel Moya, Sor Teresa Cacho y Sor Carmen Bastos y las enfermeras profesionales Andrea López, Josefina Soria, María Rodríguez, Matilde Aguado, Concepción Ochoa, Pura López y Ana Gómez ${ }^{216}$.

La seguridad durante el viaje, tanto en tren como en barco, la expedición de pasaportes y pasajes fueron motivos de preocupación para las autoridades de la época $^{217}$. La llegada de Hermanas de la Caridad a Marruecos, "cumpliendo órdenes del ministerio de guerra"218, aumentó el personal sanitario femenino en los hospitales, lo que permitió solicitar el regreso de las enfermeras profesionales de Sanidad Militar a la península para poder incorporarse a su puesto de trabajo habitual, ya que la mayoría de ellas había acudido a África con sus equipos quirúrgicos $^{219}$. Únicamente se sustituyeron a las enfermeras por Hermanas de la Caridad que estuvieran en posesión del título oficial ${ }^{220}$.

De esta forma, se exigió a las religiosas que trabajaron en los hospitales militares del protectorado tener el título de enfermera. Esto no fue un hecho aislado, ya que Cruz Roja no permitió acudir como voluntarias a las asociadas que no estuvieran en posesión del título de dama enfermera ${ }^{221}$.

Por eso, Sanidad Militar estableció en 1922, de forma permanente, en el hospital militar de Carabanchel la enseñanza reglada como enfermeras de las Hermanas de la Caridad que trabajaban en los hospitales militares, con el objetivo de formar una plantilla:

\footnotetext{
${ }^{216}$ La Cruz Roja. $\mathrm{n}^{\mathrm{o}}$ 230, agosto 1921, p. 329.

${ }^{217}$ AGMM. Fondo de África. Caja n ${ }^{\circ} 43$, Carpeta: 44, Estante: 1, no 4 Fila: 2 Carpeta: 6 Telegrama oficial número 10123 del negociado de Marruecos de 8 de agosto de 1921 Fondo de África. Caja n ${ }^{\circ}$ 58: Armario: 45, Estante: $1 \mathrm{n}^{\mathrm{o}} 4$ Fila 1, Sala: 1 Carpeta: 16. Telegrama oficial de la Dirección General de preparación de Campaña de 15 de abril de 1926 del Ministro de Guerra a el Capitán General.

${ }^{218} A B C$, 4 septiembre 1921. Las Hijas de la Caridad, p.20.

${ }^{219}$ AGMM. Fondo de África. Caja ${ }^{\circ}$ 53: Armario: 44, Estante: $1 \mathrm{n}^{\circ} 9$ Fila: 1, Carpeta: 4. Telegrama oficial del negociado de Marruecos número 14043, con fecha 7 julio de 1922.

${ }^{220}$ Finalmente se decidió que solamente regresarían a la península las dos enfermeras del hospital Militar de la Corte, ya que los médicos de los equipos quirúrgicos a los que pertenecían ya se habían incorporado a sus anteriores puestos de trabajo.

${ }^{221}$ ACCRE Caja 2291, Expediente 2.
} 
[...] que además del alto espíritu religioso y altruista propio de la humanitaria Asociación de las Hijas de la Caridad, posean conocimientos especiales de índole sanitaria que completen y perfeccionen su función auxiliar del Cuerpo de Sanidad Militar en los hospitales, debiendo hallarse en posesión del certificado de aptitud todas aquellas que presenten sus servicios en los mismos ${ }^{222}$.

Otro aspecto a tener en cuenta dentro de esta movilización femenina en el campo sanitario, es que las damas enfermeras de Cruz Roja no recibieron ningún tipo de remuneración económica. Como damas no esperaban percibir una retribución por su trabajo voluntario, pero tampoco se les concedió una ayuda para su manutención y alojamiento en la zona. Por lo tanto, además de la voluntad física y el trabajo duro que tuvieron que realizar, hay que destacar que también hicieron un esfuerzo económico importante. Únicamente, en el caso de las hermanas, el Estado se hizo cargo de los gastos de viaje, que realizaban en primera clase. Cruz Roja no podía asumir la manutención de las damas enfermeras y el ministerio de guerra denegó por Real Orden la concesión de pagar un plus de enfermera a las damas.

[...] Las Damas que se encontraban ya en Melilla pagan todas sus gastos y aunque comprendo que muchas no podrán hacerlo espero que se reúna la Comisión Central de la Asamblea para que esta decida en definitiva que beneficios se las puede conceder $[\ldots]^{223}$.

A pesar de todo, las damas quisieron prestar sus servicios en la campaña de África y se presentaron como voluntarias. Un destino alejado del hogar y la familia llevó implícito que fueran acompañadas por asociadas de Cruz Roja y de Hermanas de la Caridad para garantizar la moralidad de su trabajo (ver anexo VI). De esta forma, la prensa valoró positivamente el trabajo que desempeñaron "silenciosas, anónimas, dejando atrás familia, lujo, ociosidad y amor"224.

\footnotetext{
${ }^{222}$ Diario Oficial del Ministerio de Guerra. no 112, de 21 de mayo de 1922, p. 541.

${ }^{223}$ ACCRE Caja 2991, Expediente 2001. Correspondencia entre el Marqués de la Ribera y María concepción Mato Dama Enferma de primera y vocal en funciones de vice secretaria de Logroño, agostoseptiembre 1921.

${ }^{224}$ La Vanguardia, 21 de octubre de 1921, La eterna lamparita, p. 10.
} 
En el Hospital de Melilla existía un pabellón destinado a alojar a las hermanas y las enfermeras profesionales, pero no a las damas, por lo que para facilitar su trasporte al hospital, contaron con una camioneta encargada de pasar a buscarlas sobre las nueve de la mañana y llevarlas a su casa una vez terminado su turno a la una del mediodía ${ }^{225}$. Sanidad Militar se interesó desde un principio por que las hermanas tuvieran un lugar adecuado para hospedarse durante su estancia en el Protectorado:

[...] Según me dicen. Hijas de la Caridad que prestan servicio Hospital Reina Victoria de Tetuán, se hallan alojadas provisionalmente en antiguo departamento de dementes en condiciones poco apropiadas a su categoría y misión y considerando que con ligeras obras pudiera subsanarse deficiencia. Sírvase informarse y ordenar remedio que considere más adecuado ${ }^{226}$.

También Cruz Roja solicitó para su personal sanitario femenino un alojamiento adecuado y específico para ellas:

[...] Accediendo a los deseos manifestados por V. E. en su escrito de 9 del actual, referente al destino a los Hospitales militares de Marruecos de personal de Hijas de la Caridad de San Vicente de Paúl, el Rey (q. d. g.) se ha servido otorgar la oportuna autorización para que una Comisión de la Asamblea Central de Señoras de la Cruz Roja y las Juntas de Damas de las plazas de aquellos territorios, estudien sobre el terreno, la posibilidad de establecer en los Hospitales militares tan benéfico servicio, a cuyo fin, sería conveniente manifestase V. E. a este Departamento los nombres de las personas que van a constituir aquella Comisión para comunicarlo al Alto Comisario de España en Marruecos, del que a la vez, se interesa preste toda suerte de facilidades para el cumplimiento de su cometido ${ }^{227}$.

\footnotetext{
225 OsSORIO DE GIL, Fernanda: Memorias de una Dama Enfermera. Recuerdos e impresiones del Servicio en el Hospital de Cruz Roja de Melilla. Monte Carmelo, Burgos, 1923, p.8.

${ }^{226}$ AGMM. Fondo de África. Caja $\mathrm{n}^{\circ} 70$ : Armario: 45, Estante: $2 \mathrm{n}^{\circ} 7$ Fila 1 carpeta 1. Telegrama oficial de 10 de septiembre de 1923 escrito por el ministro de guerra al comandante General.

${ }^{227}$ AGA. Caja 81/9683. Escrito de la Asamblea Central de Señoras de Madrid, de 7 de diciembre de 1920 al Comisario Regio de la Asamblea Suprema de la Cruz Roja Española-Madrid, el General EladioMille.
} 
Al igual que el Hospital de Melilla ${ }^{228}$, el de Cala Bonita también contó con un pabellón aparte para las Hermanas de la Caridad, damas enfermeras y enfermeras profesionales $^{229}$.

De forma habitual, las damas enfermeras eran las encargadas de preparar la sala y material de operaciones, hacer las curas en el dispensario y ayudar a los médicos en sus consultas ${ }^{230}$. Los turnos de trabajo podían realizarse de forma alterna o diaria, las damas que iban a permanecer poco tiempo en el hospital, elegían la última opción ya que es la que les permitía obtener más méritos para poder solicitar la medalla de África.

Durante la campaña, damas y enfermeras compartieron el trabajo procurando cubrir entre todas la jornada que ampliaron de ocho de la mañana a nueve de la noche ${ }^{231}$. En el vestíbulo del hospital de Melilla estaba el cuadro en el que semanalmente figuraba el nombre del personal sanitario femenino y la sala que les habían asignado para trabajar. La jornada se distribuía entre diez damas enfermeras, destinadas de dos en dos a la sala de operaciones, de curas, de oficiales, de cirugía y de medicina, además de velar cada cinco días a los enfermos, dedicando la mañana a dormir $^{232}$.

El trabajo desempeñado en la sala de operaciones consistía en la preparación de algodones, compresas y esterilización de material e instrumental, además de atender las necesidades del cirujano siempre que precisase ayuda. Las curas se hacían en una sala específica con el apoyo de una hermana de la caridad, atendiendo a las indicaciones del médico, que era el encargado de realizar las de mayor envergadura con la colaboración de las damas para instrumentarle. Una vez

\footnotetext{
${ }^{228}$ OSSORIO DE GIL, F: op.cit., pp.6-7.

${ }^{229}$ Cruz Roja ESPaÑola: Memoria del Hospital de la Cruz Roja en Cala Bonita ...op.cit., p.8.

${ }^{230}$ CRUZ RoJa EsPañola: Memoria del hospital María Cristina ...op.cit., p. 7.

${ }^{231}$ En el hospital María Cristina de San Sebastián se instalaron cuarenta camas, cedidas por la Intendencia militar, para asistir a los heridos y enfermos de África. Dicho hospital nació por iniciativa de la Reina María Cristina, que compró un chalet que habilitaron como hospital-escuela para poder formar a las Damas Enfermeras de la Cruz Roja. Durante la campaña de África, el hospital tuvo que ser ampliado para poder alberga mayor número de soldados, ya que llegaron a solicitarse cien camas más.

${ }^{232}$ La Cruz Roja. nº. 233, noviembre 1921, pp. 638-640.
} 
terminado el trabajo debían esterilizar todo el material e instrumental para estar disponible al día siguiente.

Las damas y hermanas de las salas de hospitalización acompañaban al médico durante la visita diaria, provistas de cuaderno y lápiz para anotar las indicaciones. Una vez finalizada, el médico se encargaba de administrar la medicación intravenosa y las damas y hermanas las inyecciones hipodérmicas ${ }^{233}$. El trabajo era duro y constante, en el caso de la sala de esterilización debían colocar los algodones y gasas en las bombonas que, una vez llenas, se introducían en el autoclave para su esterilización. En muchas ocasiones el personal era escaso e insuficiente, por lo que las salas se dotaban de menos plantilla de Enfermería:

[...] me fui primeramente a suministrar las dietas a los enfermos que no podían comer, para lo que fui a la despensa a pedirlas. Luego me dediqué a las camas, cosa que me hubiera resultado muy pesada, porque eran muchas, a no ser por la eficaz ayuda de los convalecientes, que siempre andan viendo la manera de sernos útiles en todo lo que pueden; lo mismo me ayudaron más tarde cuando me puse a renovar las flores, pues en cuanto me vieron con los floreros en la mano, salieron presurosos al jardín y me trajeron todas las que necesité 234 .

La recepción de los heridos a su llegada del frente de batalla también formaba parte del trabajo que debían desempeñar en el hospital: “...los días, y, sobre todo las noches más fatigosas, son las de combate. El día de Tizza fue tremendo. Llegaban heridos y más heridos del campo y algunos se nos morían en las camillas. Se estuvo operando durante toda la noche",235.

Todos los pacientes estaban debidamente identificados, en la cabecera de la cama donde estaban hospitalizados se encontraban los papeles en los que se especificaba el nombre del enfermo y su diagnóstico, además de un rosario utilizado durante las horas dedicadas a la oración ${ }^{236}$.

Enfermeras y damas eran respetadas y reconocidas gracias al uniforme de trabajo, que en ocasiones generaba manifestaciones públicas afectuosas en

\footnotetext{
${ }^{233}$ OSSORIO DE GIL, F: op.cit., p. 13.

${ }^{234}$ Ibid., p. 24.

${ }^{235}$ La Cruz Roja. $\mathrm{n}^{\circ}$ 233, noviembre 1921, pp. 639-640.

${ }^{236}$ La Cruz Roja. no 232, octubre 1921, p. 556.
} 
agradecimiento de la labor desempeñada por las mismas. Como expone Magdalena Santo Tomás, entre los arquetipos y símbolos, de larga trayectoria histórica en la Enfermería, se encontraría el uniforme, que ha ido variando y adaptándose al contexto histórico, pero que ha contribuido a dibujar la imagen de la enfermera ${ }^{237}$.

La religión estaba presente en la vida diaria de las damas y enfermeras que acudían a misa todos los domingos en compañía de los enfermos y del personal del hospital $^{238}$.

El personal sanitario femenino estuvo expuesto al contagio de enfermedades, ejemplo de ello fue el caso de la dama enfermera Merry del Val, que contrajo paludismo durante el desempeño de su labor en el hospital de la Cruz Roja en Melilla (ver anexo VII). Trabajar cerca del frente y en condiciones climatológicas adversas fue otro de los problemas a los que se tuvieron que enfrentar.

La labor que realizaron fue recompensada a través de la concesión de medallas, principalmente la de África. La prensa participó en la difusión de las noticias relacionadas con las condecoraciones, publicando la relación de nombres de todas aquellas galardonadas ${ }^{239}$. El papel de la dama enfermera en la campaña de África es el que alcanzó mayor proyección a través de la prensa, siendo la figura más representativa la Duquesa de la Victoria ${ }^{240}$. Son comunes los halagos dirigidos al personal sanitario femenino que acudió a Marruecos, sobre todo a las damas que abandonaron su vida acomodada para acudir de forma desinteresada a atender a los heridos, además de resaltar que eran aristócratas, mujeres elegantes, educadas y finas.

\footnotetext{
237 González CAnalejo, C; Martínez LóPez, F. (EDS.): op.cit., SAnto Tomás PÉrez, Magdalena. Líneas de investigación para avanzar en la Historia de la Enfermería .pp. 393-402.

${ }^{238}$ OSSORIO DE GIL, F: op.cit., p. 18.

${ }^{239}$ ABC, 7 julio 1922. La familia real y la corte, p.12.

${ }^{240}$ Blanco y Negro. 21 de agosto de 1921, La organizadora, duquesa de la Victoria, presenciando la visita a la sal de los soldados por el doctor Herranz, p.7.
} 
Respecto a las enfermeras profesionales que participaron en la campaña, cabe destacar el caso de Elvira López ${ }^{241}$, que tras su trabajo en el equipo quirúrgico de Dar- Drius recibió efusivas felicitaciones tanto por parte del Ejército como de Cruz Roja Española, reconociendo de esta forma el trabajo que desempeñó durante el conflicto $^{242}$ :

[...] Ruego V. E felicite en mi nombre a la enfermera Srta. Elvira López y Comandante de S. M. D. Víctor Manuel Nogueras por su loable conducta al incorporarse en la noche del primero del actual al campamento de Dar-Drius en aeroplano para proceder a la curación de sus heridos, así como a las demás personas que extrañas al ejército auxiliaron con sus cuidados a los heridos ${ }^{243}$.

En 1922 la reina Victoria Eugenia concedió la medalla de África a un total de dieciséis hermanas y once enfermeras, entre las que cabe destacar que se encontraban Sor Isabel Moya, Sor Carmen Bastos y Elvira López ${ }^{244}$. La labor desarrollada por las damas también fue reconocida, otorgándose en 1922 un total de veinticinco distintivos o medallas. Merry del Val recibió la Cruz de primera clase de la Beneficencia, la Medalla de África y la Medalla Militar ${ }^{245}$. Hay que señalar que la Medalla de África únicamente se concedió a las damas que acudieron a Melilla para atender a los heridos ${ }^{246}$.

Sor Josefina Pescador, Madre Superiora del hospital de la Cruz Roja en Melilla recibió la Cruz de Beneficencia de primera clase con distintivo blanco en $1924^{247}$. Ese mismo año la superiora del hospital de Cruz Roja en Madrid, Sor Isabel

\footnotetext{
${ }^{241}$ Elvira López Maurín, comenzó sus estudios de enfermera profesional en el Hospital de San José y Santa Adela, donde permaneció interna prestando sus servicios al lado de las Hijas de la Caridad. No pudo obtener el título de enfermera profesional de la institución hasta 1923, fecha en la que se constituyó, como se ha señalado, el primer tribunal examinador de enfermeras de la Cruz Roja.

Antes de ir a Marruecos, Elvira aprobó los exámenes de enfermeras de primera clase del Hospital Militar de Urgencia de Madrid que corroboraban su aptitud para el desempeño de la profesión. La Cruz Roja, $\mathrm{n}^{\circ}$. 230, agosto 1921, p. 337.

${ }^{242}$ ABC, 4 noviembre 1922. La asistencia a los heridos, p.10.

${ }^{243}$ AGMM. Fondo de África. Microfilm Rollo: 445, Carpeta 2, Legajo 302. Telegrama Oficial urgente de 5 de noviembre de 1922 del Alto Comisario al Comandante General de Melilla.

${ }^{244}$ CRUZ RoJa ESPAÑOla: Memoria del Hospital-Escuela ... 1920-1922, op.cit., pp. 61-62.

${ }^{245}$ Ibid., pp. 60-61.

${ }^{246}$ La Cruz Roja. $\mathrm{n}^{\circ} 241$, julio 1922, p. 455.

${ }^{247}$ La Cruz Roja. no 264, junio 1924, p. 372.
} 
Moya y Sor Marta Demoulín, superiora del de Ceuta, recibieron de la mano de la reina Victoria la Placa de la orden civil de Beneficencia ${ }^{248}$.

El trabajo que realizaron, damas y enfermeras durante la contienda las convirtió en un símbolo de heroísmo femenino y en una nueva imagen de mujer, alejada de los valores tradicionales:

Para los que todavía se entretienen en discutir si el tipo ideal femenino debe ser Mimí Pinsón, Agustina la artillera o Madame Sevigné, sean estas mujeres que en tierras africanas luchan con el Dolor y con la Muerte, lección viva de cómo pueden entenderse y hermanarse la gracia, la inteligencia y el heroísmo ${ }^{249}$.

El nacimiento de la Enfermería como profesión permitió a las mujeres interesadas en trabajar en el campo asistencial recibir una formación académica sólida para poder desempeñar un trabajo remunerado. Cruz Roja fue una de las instituciones que se vinculó de una forma directa con los estudios de enfermera contando con una titulación propia que no se ofrecía en otras escuelas, la de dama enfermera. La campaña de Marruecos demostró que la labor de las enfermeras era necesaria para dar la suficiente cobertura sanitaria a los heridos, además de facilitar que las mujeres participaran en la misma a través de la prestación de cuidados. Estos acontecimientos afianzaron la aceptación social de la incipiente profesión y abrieron las puertas a las mujeres interesadas en su emancipación. La Segunda República y su contexto socio-político facilitaron la consolidación de la profesión apoyada en los antecedentes laborales del conflicto marroquí.

\footnotetext{
${ }^{248}$ La Cruz Roja. $\mathrm{n}^{\circ} 264$, junio 1924, p. 353.

${ }^{249}$ La Vanguardia, 21 de octubre de 1921, La eterna lamparita, p. 10.
} 
ANEXOS I 

Anexo I. Título de Dama Enfermera de Cruz Roja.
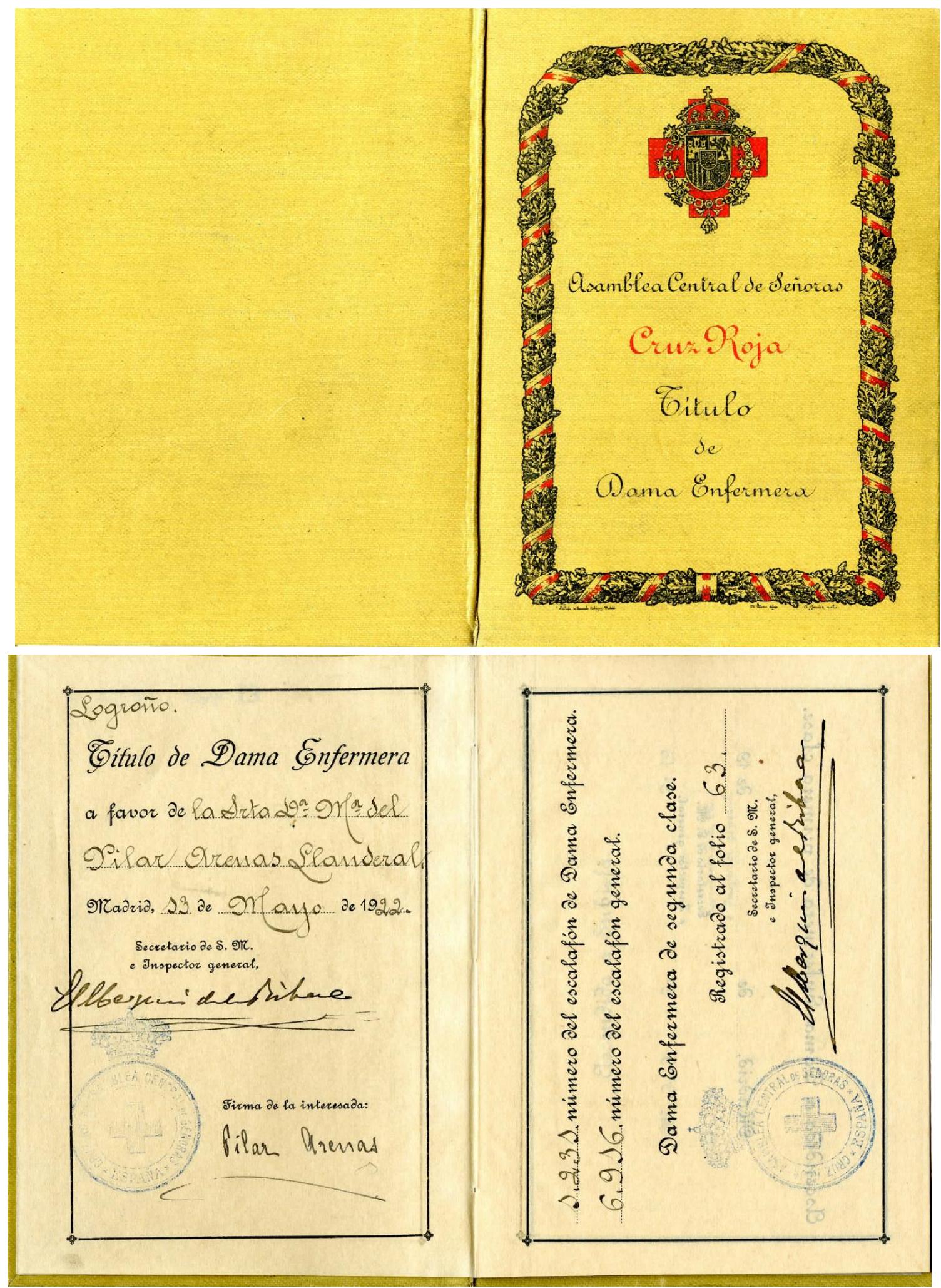

Fuente: ACCRE, Caja 2531, Expediente 1300. 
Anexo II. Obligaciones de las Damas Enfermeras de Cruz Roja.
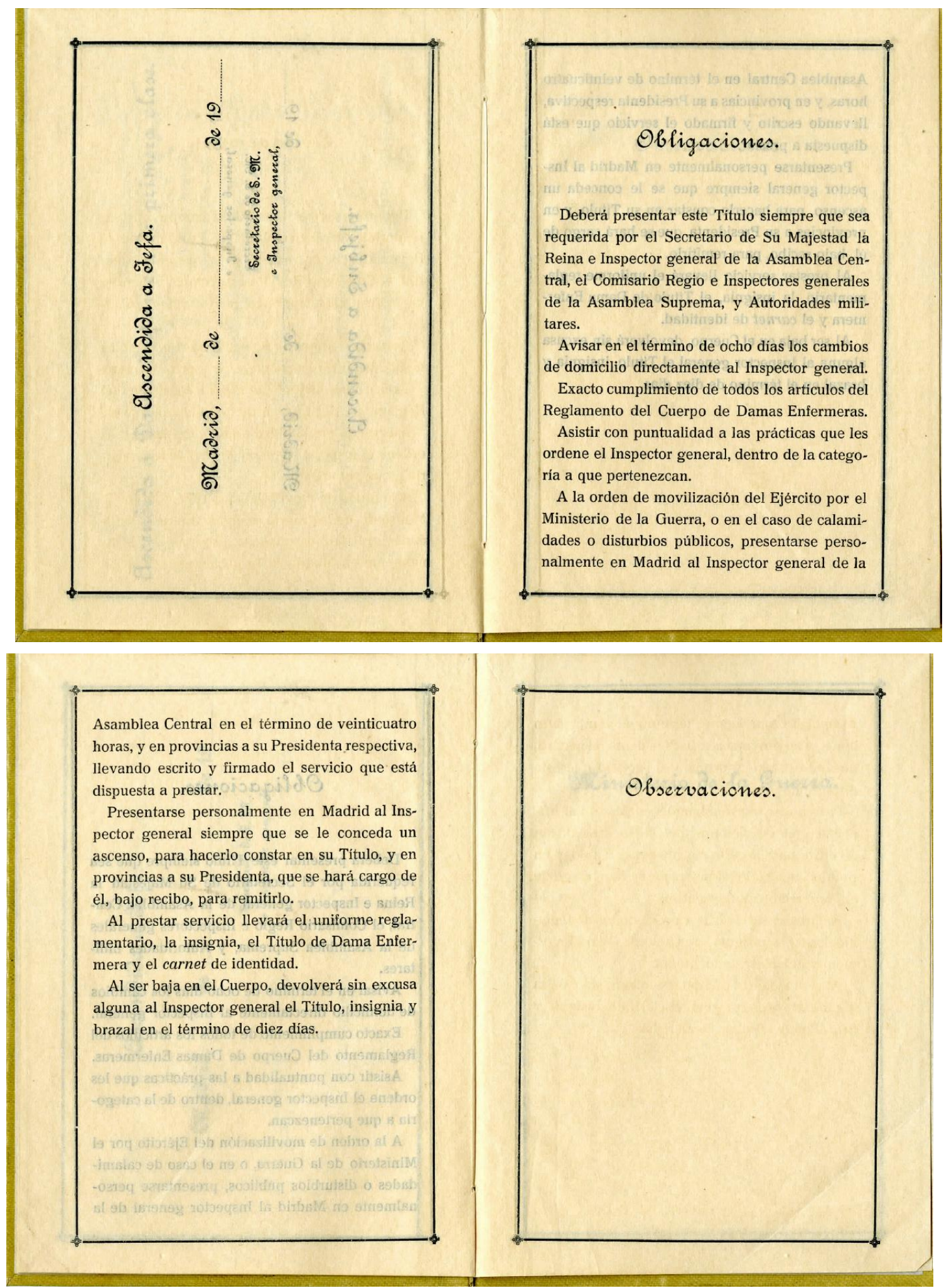

Fuente: ACCRE, Caja 2531, Expediente 13001. 
Anexo III. Entrevista a la Marquesa de Valdeiglesias. Diferencias y similitudes entre damas y enfermeras.

$\underline{2}$

ellas

M U J E R E S D E H O Y

\title{
LA MARQUESA DE VALDEIGLESIAS
}

\begin{abstract}
Tesorera durante varios años de la Cruz Roja Española.-La obra de esta Institución en el Hospital de San José y Santa Adela.-EI Dispensario, iniciativa personal de Doña Victoria Eugenia, es uno de los mejores del mundo.-Diez y ocho consultas de las distintas especialidades y un promedio diario de 500 enfermos asistidos.-Tres mil damas auxillares y ciento cincuenta enfermeras,- "Esta era la Cruz Roja tal como yo la conoci."
\end{abstract}

La marquesa de Valdeiglesias nos
ha recibido con esa llaneza de gran señora, que es su distintivo. Los unttimos el atropello de que fué victima sü re. nombrado director, imantaron todas sas miradas hacia la marquesa de Valdeiglesias, consagrada generosamente a
la benemérita institucicon. Ella podrá satisfacer mejor que na-
die el anhelo público de conocer la vidie el anhelo público de conocer la va-
da del perseguido hospital. La marquesa de Vaddeigiesias fué designada
tesurera de $\mathbf{~ I a}$ Cruz Roja por Doña Victoria, su presidenta de honor, $y$ ha asistido a los Congresos internacionales de Bruselas y de Oinebra, con una
activisima intervención en el desenvo:vimiento de ta obra.

Pedimos una interviú a la marquesa, y.... henos ya sentados "tête-a-t-té
en un acogedor salón de su casa. -Nuestro deseo es - exponemos con
cierta timidez-oirla hablar del hospital de la Cruz Roja y de esas dama pensarios, en clínicas, en gabinetes de odontologia, en todas partes, cunden de dian en an quiruirgico. La marquesa se sonrie, para disipar
nuestra timidez, y lucgo se ponc seria, como para controlar sus palabras. Un minio de discreción tamizan sus declaraciones:

Cuándo empezó la participación de Espanán en la
obra de la Cruz Roja

ce-Fué una verdadera suerte-nos diSan José y Santa Adela, de fundación se instalar en él sus servicios. Sl, fu una cesión felicicisima a la Institución

ZiAntes? Pues no teniamos hospital. Sabido es que España fué una de las primeras naciones que se unieron constituir una asociación de socorros a los heridos en campaña, según las Dases iorm yarios años, la vitulidad de la nueva' Institución se manifestó en obras exteriores de cierta resonancia,

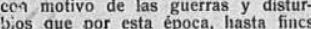
Sios que por esta epoca, hasta fincs
de 1874 , perturbaron nuestra patria. Despues entrou la Croun Reja en perio-
do de calma, casi de letargo, del ouve vinieron a sacarla las guerras de Afri-
ca, Cuba y Filipinas. En todas ellas prestó valiosisimos servicios, no siendo de los menos notables la repatriación de los soldados. A partir de este

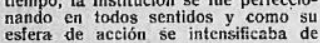
día en dia, fué nétest los servicios a los enfermos. Se tuv ta suerte, como he dicho a usted, $d$ Adela $y$ a partir de vidades hospitalarias de la Cruz Roj empezaron a tomar el incremento qu tan extraordinario ha llegado a ser es

\section{El hospital de San Jose $y$} sario es uno de los mejo. es uno de los mes.
res del mutindo - ¿Cómo funcionaba el hospital?
Muy sencillo. Este hospital ha funcioceîoras, compuesto de Presidenta, Se-

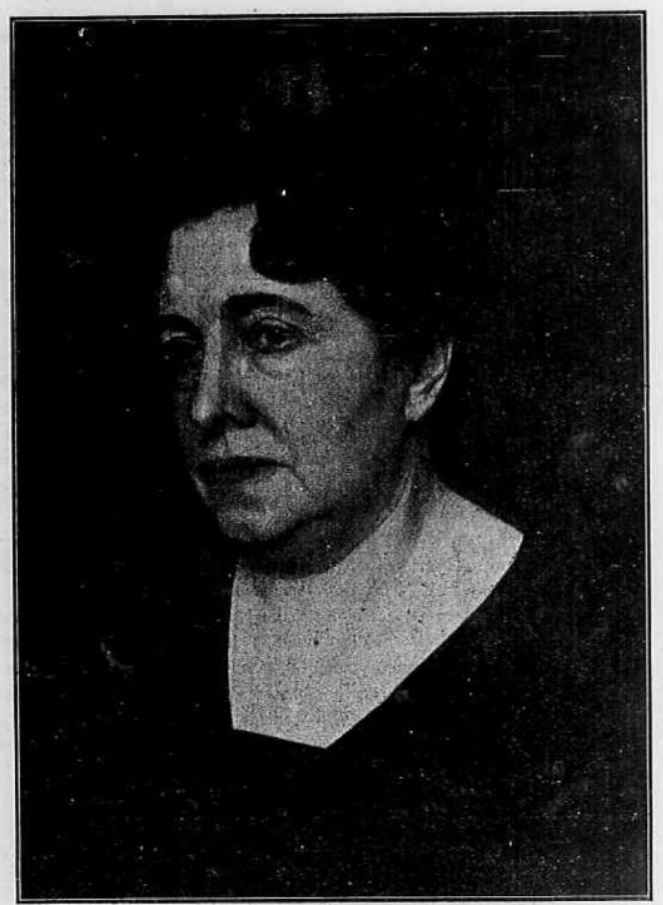

Doña Maria de la Concepción Kirpatrik, Marquesa de Valdeiglesias.

cretaria y Tesorera, y en esta fecha den en busca de alivio a sus padeci-

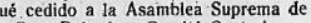

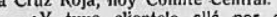

años, como ta tiene actualmente? - Fué tan grande al poco tiempo el
imero de enfermos que acudia a la número de enfermos que acudia a la pliar el local, y éste fué el origen del actual Dispensario, construido con
arreglo a los últimos adelantos de la
ciencia de diciembre de 1928 y considerado hoy como uno de los mejores del mundo, causando la admiración de cuantos extranjeros Jo visitan, segun
Esta fué iniciativa personal de la reina, justos.

- Diganos algo de la organización del Dispensario.

z y cionan, en este Dispensario cuadro general de las enfermedades a más de quitos enfermos que diariamente acu-

.

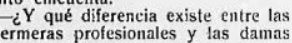

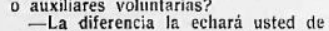
ver, sabiendo que las auxiliares volumtarias prestan un servicio completa-
mente gratuito y se dividen en dos camera y auxiliares voluntarias de sesumera y auxiliares voluntarias de segun-
da. Este titulo 10 adquieren desputés del examen del primer curso, que consiste en seis meses de estudios teörisiguiente sufren el segundo examen, después de otros seis meses de estudios $y$ otros seis de asistencia práctica. Las astifar a voluntarias no están ro de éstas pasa de tres mil, aunque no todas prestan servicio activo.
Damas y profesionales llevan et mismo uniforme, diferenciándose unicamente en que estas últimas lievan una cruz roja en la toca, mientras las
primeras la llevan en el brazal que postentan en el brazo. $-Y$ los exámenes, ilos verifican ante el mismo Tribunal?
$-\mathrm{El}$ Tribunal de exámenes, tanto para las profesionales como para tas or y varios médicos del Hospital, juntamente con dos médicos más, ajenos
a la Cruz Roja: uno militar y otro Colras algunos puntos de vista distintos...? Thas $y$ impática fraternidad; no es extraño que impulsadas por los mismos ideales de amor $y$ de sacrificio, se encuentre
unidas ante el lecho del dolor.

Antes $\mathrm{y}$ ahora - ¿2Puede usted decirnos algo sobre ias? Comprenda usted que es una res-
puesta muy delicada la que me exige. puesta muy delicada la que me exige. tiano que todas ponen en su benéfica
labor. En sintesis Je diré que, durante prestaron servicios dignos de recuerdo y de admiración: unas, abandonando las comodidades de su hogar para acudir a los hospitales del reente, y repa-
demás, asistiendo a los heridos reas a
triados. Unas y otras rivalizaron en heroismo $y$ abnegación. -Ya que nos habla usted de enfermeras, equiere darnos noticias del per-
sonal adscrito a los servicios hospitalarios?
Para el servicio del Hospital y Dismanas de la Crided provisa casi todas del título profesional, dos grupos de enfermeras: el de damas o au-
xiliares voluntarias, como hoy se las xiliares voluntarias, como hoy se las
denomina, por acuerdo de la XIV - Yo je hablo a usted-se adelanta a contestar la ilustre dema - de la Cruz de mi retirada, comprenderá usted que nada puedo decir de lo que alli pâsa - y con un ademán de discreción,

B. de \&.

Fuente: Hemeroteca de Madrid. Ellas, nº 9, 24 de julio de 1932, p. 2. 
Anexo IV. Aristócratas, ejemplo de damas enfermeras.

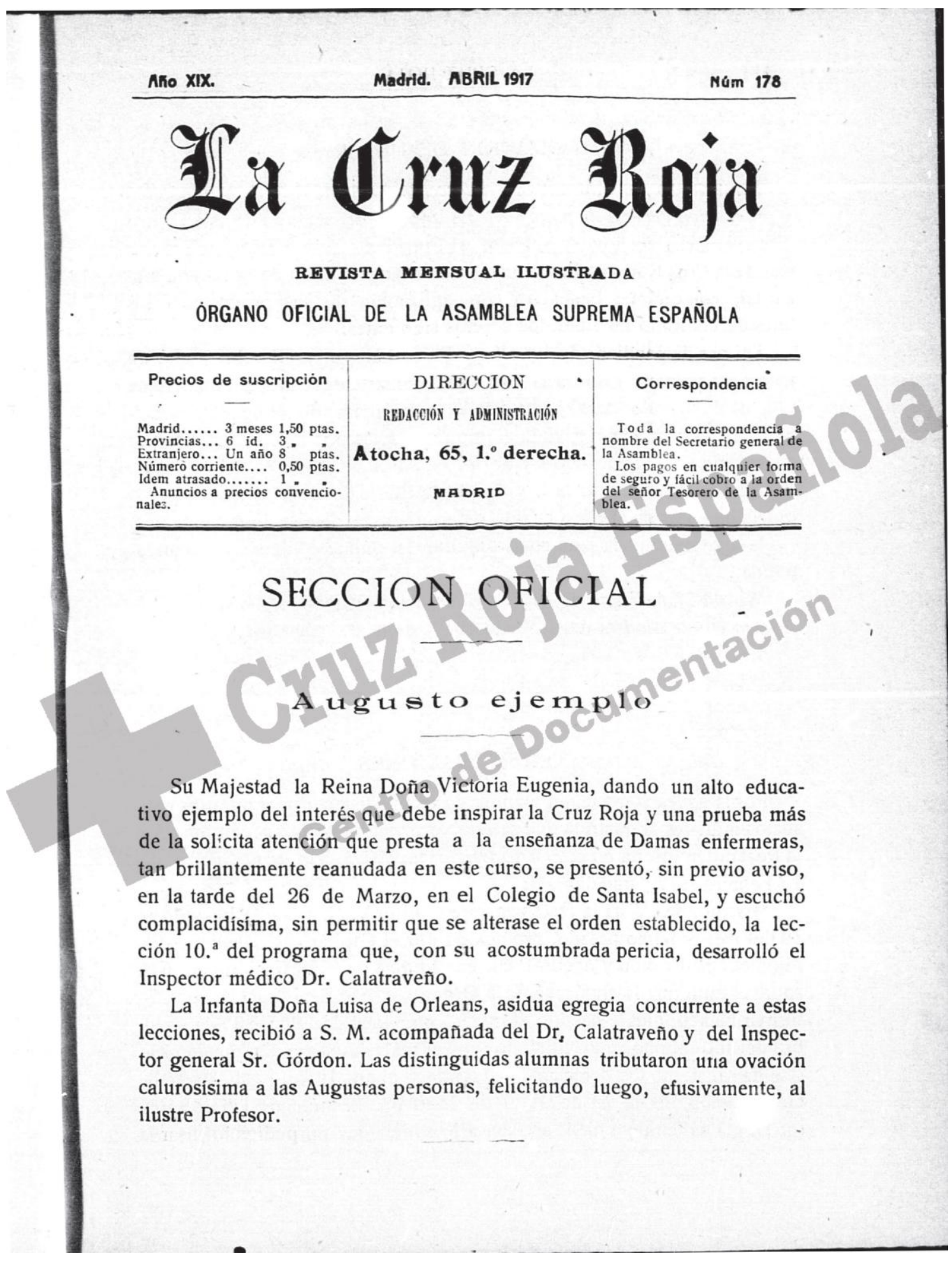

Fuente: ACCRE: La Cruz Roja, nº 178, abril 1917. 
Imagen I. Uniforme de enfermera y dama de Cruz Roja.

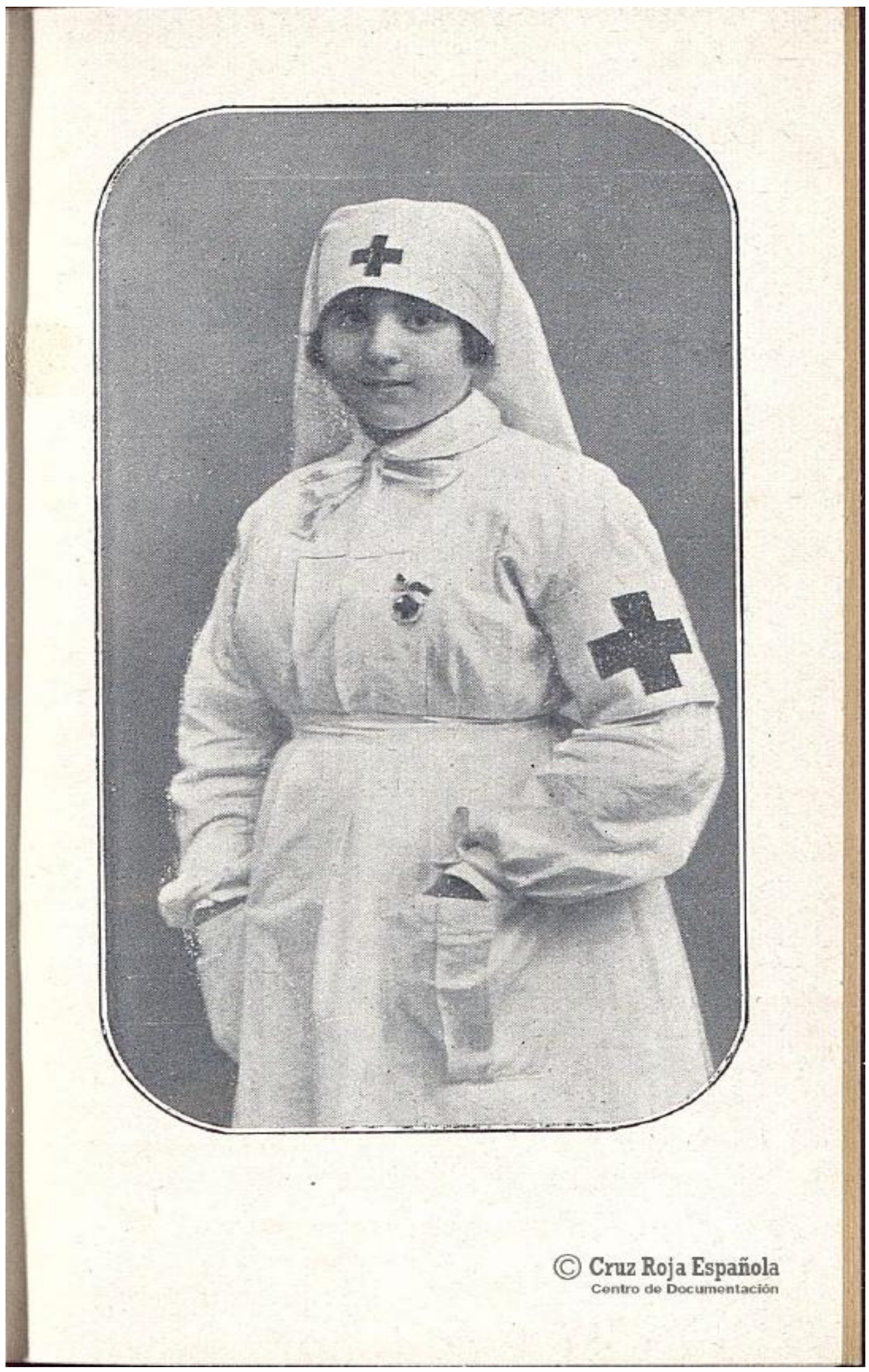

Fuente: ACCRE: BAS Bonald, María de los Dolores. Vademecum de la Dama Enfermera de la Cruz Roja. Cartagena, 1921. 
Imagen II. Damas enfermeras ayudando a los pobres.

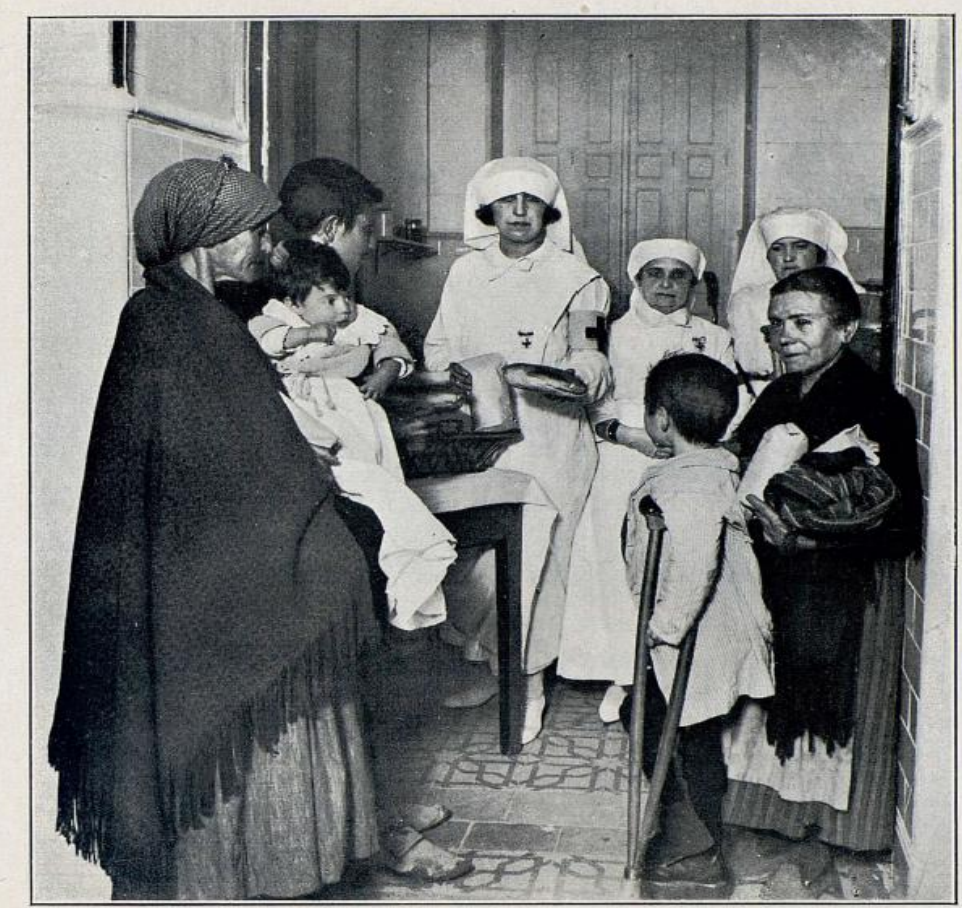

Las Damas haciendo la distribución a los pobres del dispensario, en la fiesta de San José.

Fuente: ACCRE: CruZ Roja Española. Memoria del Hospital-Escuela de Damas de la Cruz Roja de Madrid San José y Santa Adela. 1923, p. 25.

Imagen III. Enfermeras de Cruz Roja.

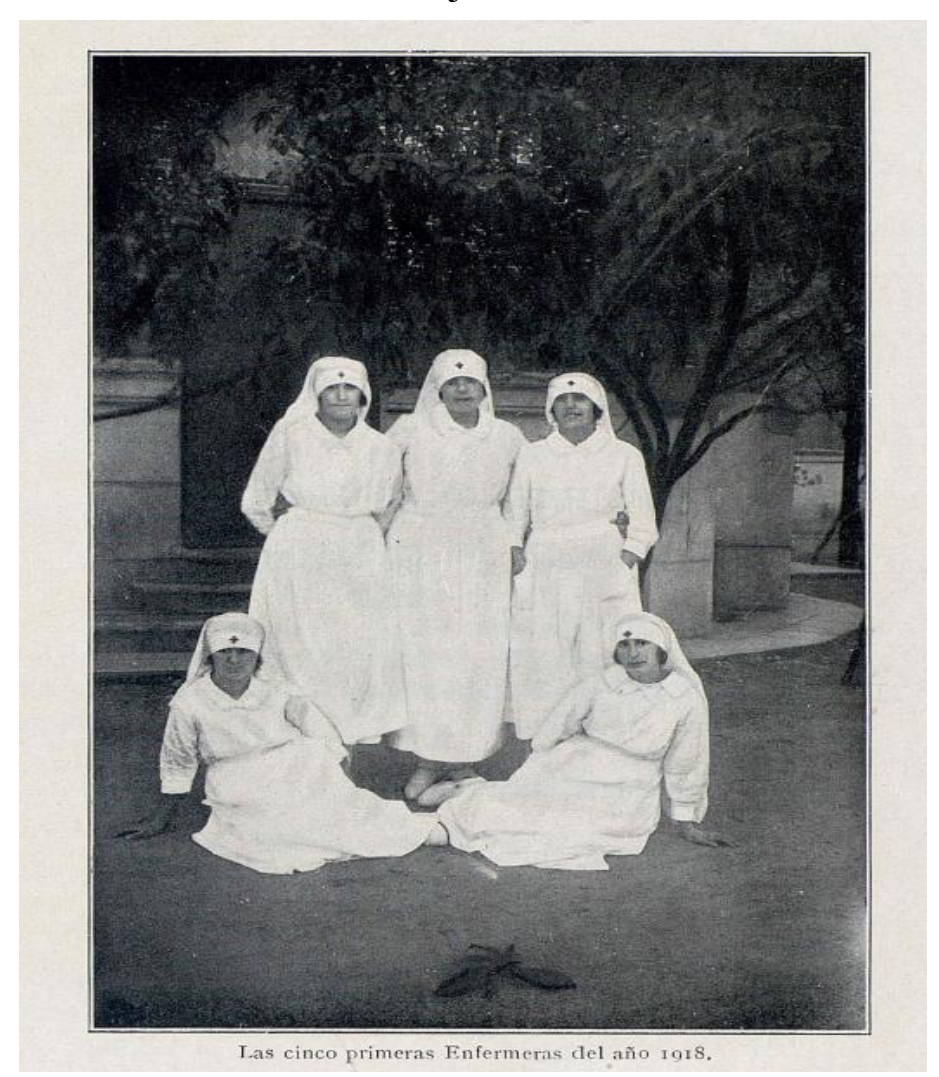

Fuente: ACCRE: CRUZ Roja Española. Memoria del Hospital-Escuela de Damas de la Cruz Roja de Madrid San José y Santa Adela. 1923, p. 33. 
Anexo V. Homenajes a la Duquesa de la Victoria.

«IN HOC SIGNO SALUS...

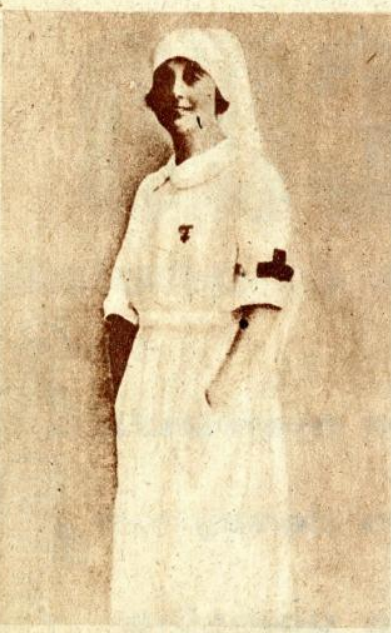

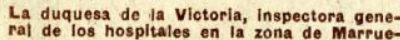
008 (1821).

\section{LA DUQUESA DE LA VICTORIA}

Por TOMAS GARCIA FIGUERAS

T A pacificacion de Marruecos, $\tan$ fecunda $y$ beneficiosa para el Imperin intento marroquí, ya que, sin ella nindejó honda huella en España, Las generaciones nuevas, nacidas a la vida después 1927, en que esa pacificación terminó, no pueden apreciar con exactitud to que signifić 6 aquella empresa llena de sacrificios y de generosida ane tealizo nuestro Ejército, con el aliento de la Nacion entera. Pero las generaciones que la esa lla reliquias espl chas veces se mezclo el en las que mucon el orgullo de la noble ejecutoria of España.

Para esas generaciones que la vivieron el nombre de la duquesa de la victoria. que acaba de morir, tlene su justa aureola de lads ha decida de quienes de ella recibieron blen en momentos de angustia o de amargura. Para las generaciones nuevas será ejemplar recordarles cómo fué de honda, de ancha, de cristiana y de patriotica la obra de la duquesa de la Victoria para que de una ena gas magnificas al deber $\mathrm{y}$ a la caridad de la que la duquesa de la Victoria, que acaba de morir, fue ejemplo of simbolo. Los dos momentos culminantes de la pacificacion corresponden a los anos 1921 Annula el primero, el revés daloroso de mertínes dificultan en barco de Allucemas fba a seguro 7 decislyo pare la total y raplda pacificación de Marruecos. Feos dos períodos duros de acción millitar al servicio de la pacificación habian de determinar el clima en el que iba a brotar lozana la caridad y el amor al que sufre a través de la institución de la Cruz Roja EspaEra, en Jullo de 1921, presidenta de la Cruz Roja la Reina Victoria Eugenia y. desde el momento mismo de producirse lente deseso la soberana se puso de amor de el que le co de cardad $y$ entera, incluidas las maciones americanas hijas de España Como delegada suya, con la misión de montar rápidamente cuanto se precisara para el cuidado de los heridos $y$ enfermos, la Reinz designó a la duquesa de la victoria, y puso de relieve con ello el extraordinario acierto

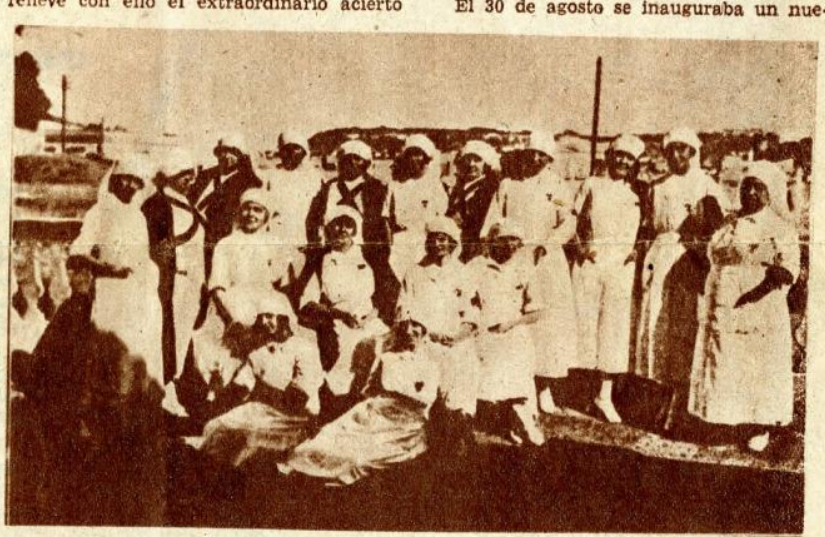

La duquesa de la Victoria, con las damas enfermeras de Melitia (1922).

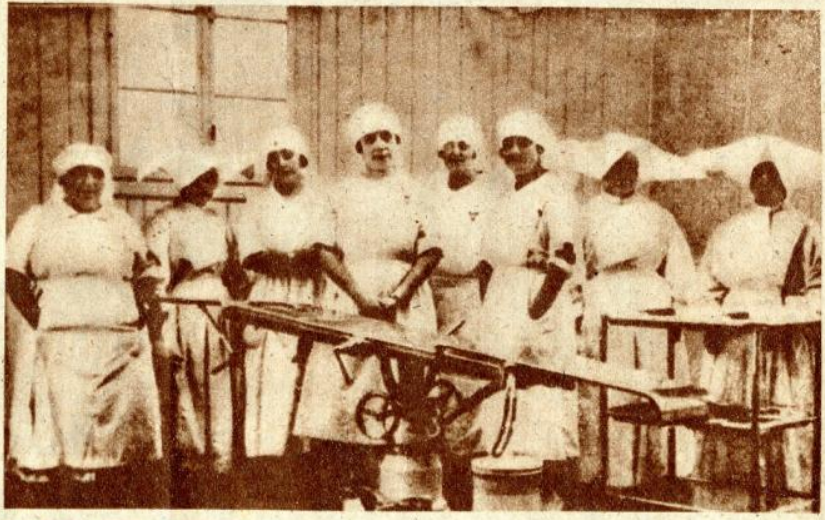

Primoras damas enfermeras y hermanas que prestaron serviclo en. el hospital de cala Bo-
nita (Alhucemas) (1926). de La elección. Llegando a Mellila el 30 de Juno, el 4 de agosto empezaba a funclonar el hospital-escuela de los Hermacio cedieron ellos gustosamente pars el objeto y en el que habllitaban 86 camas en tropa salas para oficiales $y$ en seis para este hospltal ni los que rápidamente habian de habilitarse tuvieron nunce el aspecto doloroso de los hospitales de sangre. En ellos, todo fué cuidado y allento $\mathrm{ms}-$ terial y espiritual a los heridos. De este primer hospital bastaria decir que por el pasaron, desde su fundacion hasta fin de las tivamec-

$\mathrm{La}$ duquesa de la Victoria se mostro desde el primer momento inteligente, en-

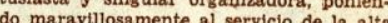
y noble misión que no perdí de la alta perfill, un montafe perfecto de los servicios $y$ una devoción y efictencia en las colabochentas damas beneméritas

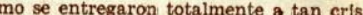

nue- 


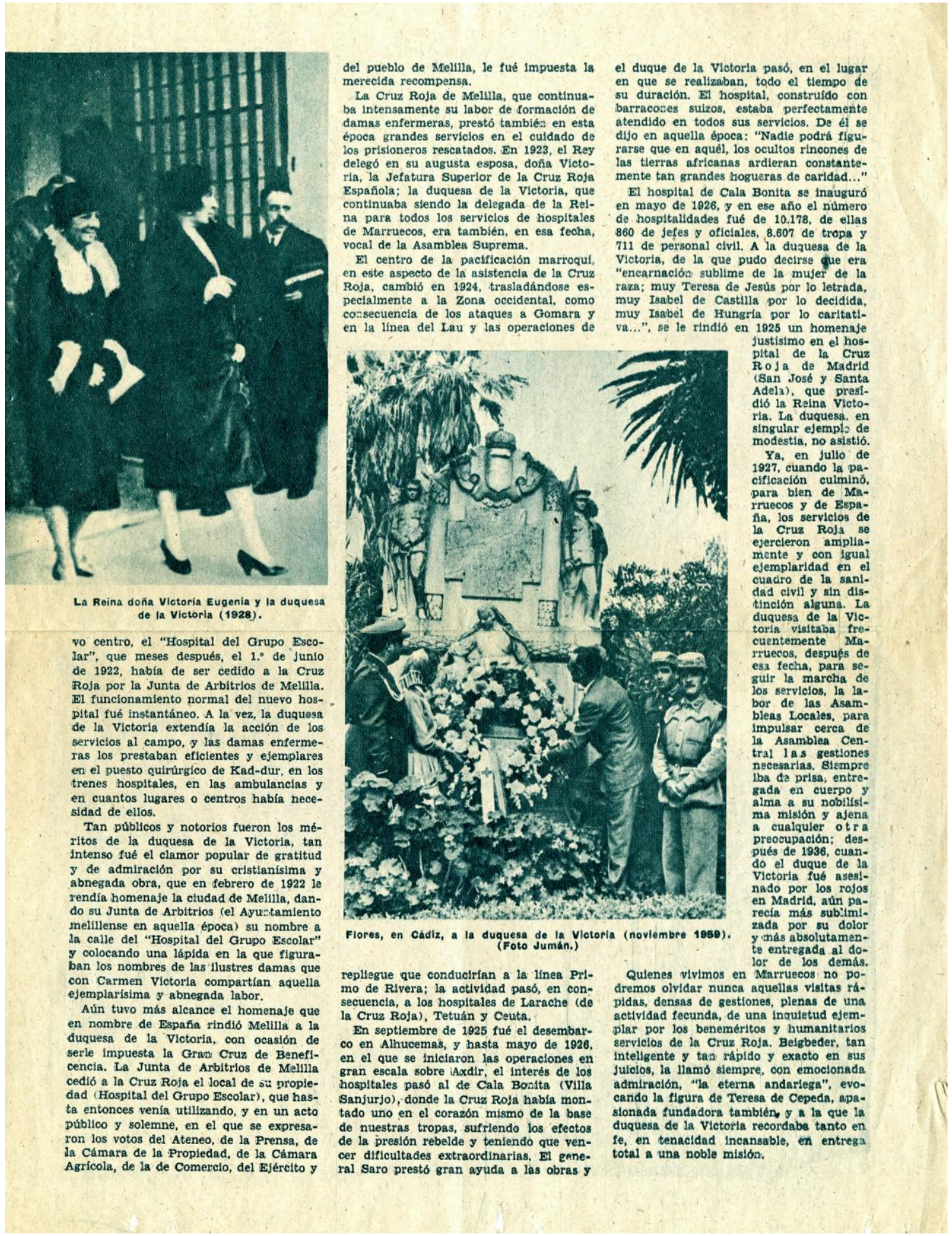

Fuente: ACCRE, Caja 827, Expediente 9. 
Anexo VI. Solicitud de ayudas económicas para damas enfermeras.

$$
\text { Logroño } 2 I \text { de agosto del2f }
$$

\% Són Marques de la Ribera

IHUT Señor mio $\mathrm{y}$ de mi consideracion mas distinguida;

Por ausencia eventual de la vicepresidenta $y$ como vocal en funciones de vicesecretaria, tengo el honor de acusarle recibo de su circular, con instruciones, para las Damas enfermeras que formen los equipos de evacuación, asi comolios cinco tituios y recibos de admisión de las nuevas asociadas. Ista sección de enfermeras de la Cruz poja, cuenta con una de ellas, Juana Vallejo, enfermera de segunda, que desea prestar sus servicios en Melilla y de no ser posible alli, en donde las necesidades del servicio lo requieran y solo espera, para poder salir, a que se le diga, forma on habriá de hacer el viaje $\mathrm{y}$ si dentro de los gastos que paga la Cruz Roja, entran los de manutención,

Conformes en todo, con lo que las instruciones dicen, de la formacion de equipos y tengo el gisto de comunicarle, que si esa dirección creyese convemiente el utilizar nuestros servicios, este pequeño grupo, de tan homroso cuerpo, cumpliría a satisfación con sus deberes,por tener profesores que las preparan para ello; le agradeceriamos nos contestase a las siguientes constl tas relacionadas con tales servicios; Digennos si dentro de lo que ustedes Ilaman gastos extraordinarios, entron los gastos de hospedaje, en los puntos a donde vayan a recojer heridos;Se les consulto, si caso de salir de aquit algun equipo $y$ de no ir con ellas, alguna enfermera casada, se nos autorizaba para que en representacion $\mathrm{y}$ como garantia de la mayor moralidad, que debe en todo monento, presidir todo acto del Cuerpo de enfermeras, podiamos en viar con ellas,alguna señora de la junta,y que esta se acojiese a los mismos 
beneficios que las enfermeras; ISta junta tiene dentro de la población tres enfermeras, que estudian libres $y$ esperen poder examinarse despues, con el curso oficial, tienen hechas las practicas con nuestro mismo profesor $\mathrm{y}$ asistendiariamente con nosotras, á los hospitales y piden por conducto nuestro si se las consentiria, previo certificado de aptitud del medict directar del Kospital Militar, que es el profesor de practica, formar parte de los equipos que de aqui saliesen.

Mucho se les agradeceria que tan pronto como sus michas ocupaciones se 10 p xitan, nos contestasen a estas consultas,para la mejor organizacion de 1 las enfermeras, Fl grupo de enfermeras, dispuesto a prestar sus servicios en el servicio de evacuacion de heridos, me pide, ruegue a usted, no olvide de utilizar sus servicios, tanto en transporte de heridos a esta capital como si lo cree conveniente, para hacer el transporte a otros ciudades donde no hubiese persogal que lo efectuase puea estamos deseosas de poder prestar servicios.

In cartas anteriores se les hizo la consulta, de si seria posible, se nos autorizase para quedarnos con las cinco pesetas de derechos, de las nuemas asociadas, pues como ya esa direcion sabe, esta junta esta falta de recursos, $\mathrm{J}$ apesar de organizar suscriptiones, por el monento no se recauda 10 suficih te $\mathrm{J}$ gracias a la buena voluntad de las selloras de esta junta y á el credi to que tiene, fasido posible, agasajar a los dos batallones que de aqui han salido $\mathrm{y}$ que fornan un total de 2500 hombres, habiendole costado a la junta, el obsequiarlos una cantidad, que escede con mucho a sus medios. Le suplico nos ềvien 10 antes posible hojas de inscripción para las asociadas por caracer de ellas,

$Y$ se reftera de usted affma $y$ s

La DAma ebfermeica de Io clase $\mathrm{y}$ vocal en funciones de vice secretaria

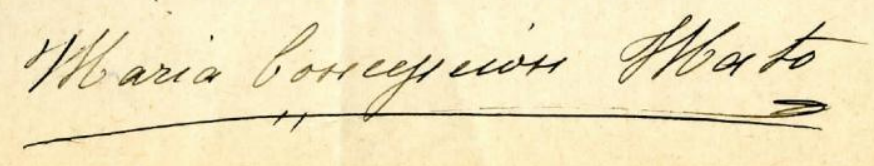

Fuente: ACCRE Caja 2991, Expediente 2001. 
Anexo VII. Carta comunicando la baja laboral de Merry del Val por enfermedad.

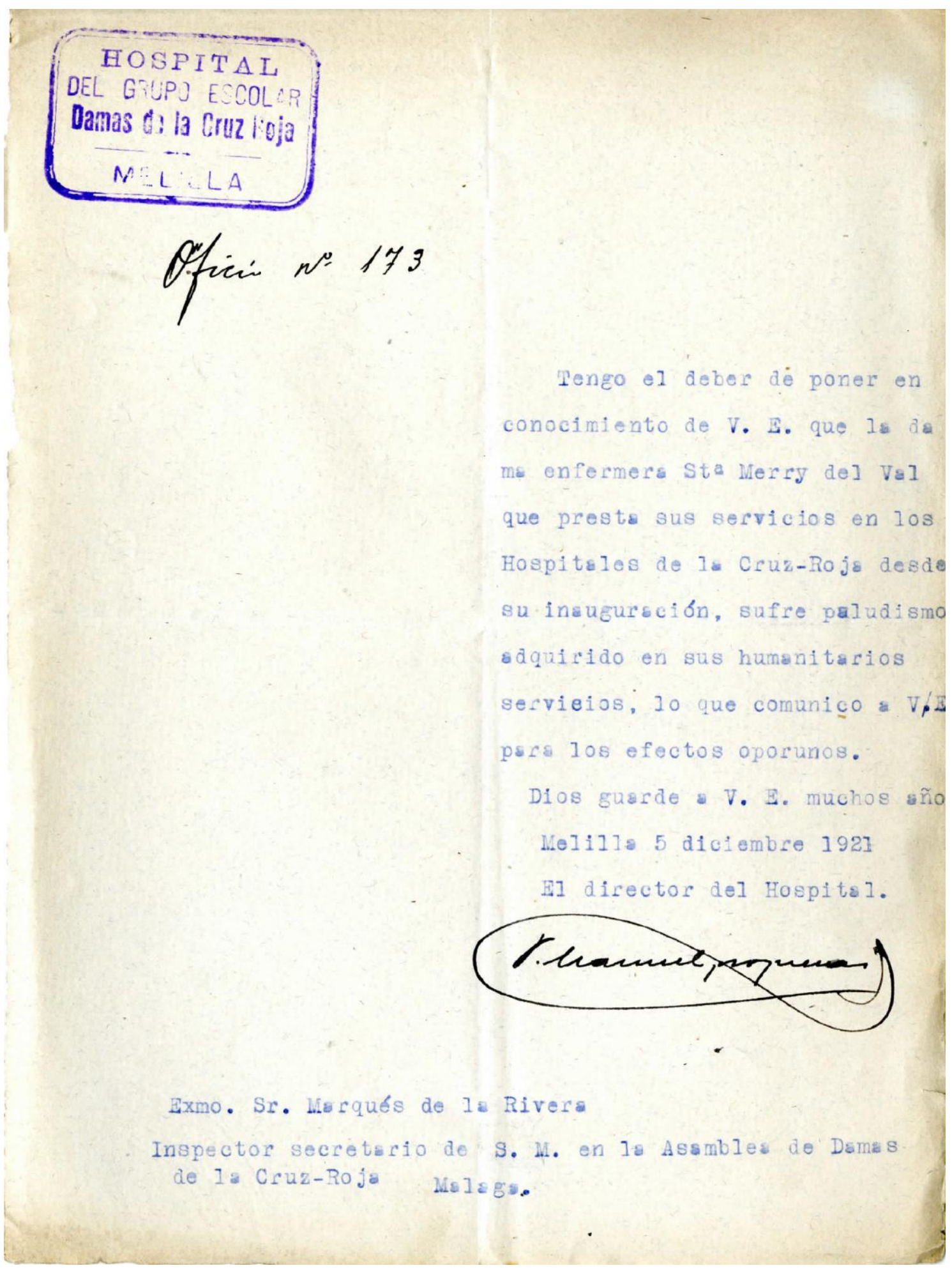

Fuente: ACCRE Caja 2291, Expediente 2/1001. 

CAPÍTULO ॥

CONSOLIDACIÓN DE LAS ENFERMERAS

PROFESIONALES DURANTE LA SEGUNDA

REPÚBLICA 

Capítulo II. Consolidación de las enfermeras profesionales durante la Segunda República

\section{LAS MUJERES EN LA SEGUNDA REPÚBLICA: UN BREVE} APUNTE

El advenimiento de la Segunda República el 14 de abril de 1931 supuso una ruptura con el régimen político anterior ${ }^{1}$, la ansiada democratización y la necesidad de un cambio desencadenó durante los primeros días de su proclamación una ola de entusiasmo y esperanza entre la población ${ }^{2}$, de forma que todo adquirió "un aire de verbena triunfante, un aire de alegría directa y desbordada"3.

Se abrió un horizonte nuevo a las mujeres y a su emancipación, gracias a las reformas legales que se fueron implantando. La Constitución republicana del 9 diciembre de 1931 fue una de las piezas claves para el avance de las aspiraciones femeninas ya que reconocía la igualdad de sexos y derechos, la prohibición de la discriminación laboral, la protección del trabajo de las mujeres, el seguro de maternidad, el derecho de voto y a ser elegible para las mayores de 23 años, y la reforma de la familia, con el reconocimiento del matrimonio civil y el divorcio ${ }^{4}$. Cabe destacar la concesión del voto femenino liderada por Clara Campoamor, diputada del Partido Radical. Defensora de los derechos de las mujeres en las Cortes, se opuso a los artículos que la dejaban en una situación de inferioridad frente al hombre o aquellos que le concedían privilegios especiales, ya que consideraba que se perdía el ideal igualitario ${ }^{5}$. Como señala Rosa María Capel, en torno al debate del sufragio femenino surgieron dos planos diferenciados, por un lado, el punto de vista ideológico, y por otro la oportunidad política. Respecto al primer supuesto, las

\footnotetext{
${ }^{1}$ PAYNE, Stanley George: El colapso de la República. Los orígenes de la Guerra Civil (1933-1936). La Esfera de Libros, Madrid, 2005, p. 25.

${ }^{2}$ BASTOS ANSART, M: op.cit., p. 235.

${ }^{3}$ Pla I CASAdevall, Josep: El advenimiento de la República. Destino, Barcelona, 1933, p. 21

${ }^{4}$ CAPEl MARTíneZ, Rosa María: El sufragio femenino en la $2^{a}$ República Española. Granada, Universidad de Granada, 1975, p.26.

${ }^{5}$ Ibid., p.328.
} 
minorías coincidían en que a la mujer, como ser humano, le correspondía el derecho al voto, basado en el principio de igualdad y libertad para todos, sin distinciones de ningún tipo. Mientras que a otros políticos la situación cultural y social de la mujer les generaba desconfianzas, ya que opinaban que el voto femenino no se dirigiría hacia los partidos de centro o de izquierdas ${ }^{6}$.

El miedo a la influencia del control de la Iglesia Católica y el hecho de que las mujeres de clase alta fueran claras opositoras del divorcio fueron algunos de los motivos que llevaron a Margarita Nelken, María Martínez Sierra y Victoria $\mathrm{Kent}^{7}$ a oponerse a la concesión del voto femenino. Por el contrario, para Campoamor no reconocer este derecho era aceptar que España era una República aristocrática, de privilegio masculino que creía en la inferioridad de la mujer ${ }^{8}$.

\section{La Asociación Nacional de Mujeres Españolas (ANME), liderada por Benita} Asas Manterola ${ }^{9}$, participó activamente en la lucha sufragista, dejando claro ante las Cortes que las mujeres no eran simples espectadoras. A través de octavillas o panfletos que entregaban a los diputados antes de entrar al debate de las Cortes, pedían votos a favor del sufragio femenino, declarándose en todo momento partidarias de la República. También reclamaban el derecho a empleos y cargos públicos y al divorcio por libre voluntad de la mujer ${ }^{10}$.

\footnotetext{
${ }^{6}$ Ellas, $\mathrm{n}^{\circ} 35,22$ de enero 1933, La mujer ante las elecciones, portada y p. 2.

${ }^{7}$ Propuso ante las Cortes aplazar la concesión del sufragio femenino, ya que, consideraba la instrucción y el trabajo como condiciones "sine qua non" que tenían que ser previas, o cuando menos, paralelas a toda liberación femenina. Ver CAPEL, R: El sufragio femenino en la $2^{a}$ República Española. Granada, Universidad de Granada, 1975.

${ }^{8}$ CAMPOAMOR ROdRíGUez, Clara: El voto femenino y yo. Mi pecado mortal. Horas y horas, Madrid, 2006, p. 97.

${ }^{9}$ Benita Asas Manterola (1873-1968). Maestra y militante sufragista, que luchó por la concesión del voto femenino durante la Segunda República. Su participación activa en los debates feministas y su compromiso social fueron un apoyo para Clara Campoamor. Benita Asas entró en la universidad con treinta y siete años, pasando a ser una de las pocas mujeres que consiguió acceder a la educación superior. Fue una de las fundadoras y dirigentes del periódico sufragista El Pensamiento Femenino, que abogaba por la mejora social, jurídica y económica de las mujeres. Formó parte de la ANME desde el inicio de su fundación y obtuvo el cargo de directora de la misma en 1924. Fue presidenta de la Asociación Nacional de Maestras. Feminista y clara defensora del sufragio femenino, Benita Asas se vio expulsada del cuerpo de maestras con la llegada de la dictadura franquista.

${ }^{10}$ FAGOAGa BARTOLOMÉ, Concha: La voz y el voto de las mujeres. El sufragismo en España 1877-1931. Barcelona, Icaria, 1985, p.189.
} 
Con el derecho al voto se rompió el tradicional aislamiento femenino, el censo electoral se duplicó en todas las provincias, y las mujeres acudieron por primera vez a las urnas. Aún así, un porcentaje elevado de ellas decidieron abstenerse y no participar en los comicios, inhibición propiciada por el ambiente sociocultural del momento ${ }^{11}$.

El Gobierno republicano también concedió el acceso a la mujer a los cargos de notarios y registradores, además de ofrecerles la posibilidad de ser candidato a las Diputaciones $^{12}$. La nueva normativa republicana favoreció que las madres y las mujeres casadas pudieran mantener su empleo, aunque la base legal no cambió el estatus social de la mujer. La reforma del Código Civil dio paso a la ley del divorcio acompañada de la ley del matrimonio civil ${ }^{13}$. Esta labor legislativa llevada a cabo en el ámbito familiar permitió mejorar la situación de la mujer, la igualdad entre hijos legítimos e ilegítimos y la investigación de la paternidad, "medidas de gran trascendencia" que modificaron la legislación vigente en torno a la familia, "además de suponer una mejora de la situación de la mujer en la misma"14.

\footnotetext{
${ }^{11}$ Marcos DEL Olmo, Concepción: Las mujeres en los procesos electorales de la Segunda República. 1931-1936 en SANTO TOMÁS, Magdalena. ET AL (COORDS). Vivir siendo mujer a través de la historia / Valladolid: Universidad de Valladolid, Secretariado de Publicaciones e Intercambio Editorial, 2005, pp. 177-192.

${ }^{12}$ DÍAZ FUENTES, José Manuel: República y Primer Franquismo: la mujer española entre el esplendor y la miseria, 1930-1950, en Alternativas cuadernos de Trabajo Social no 3, 1995, pp. 23-40.

${ }^{13}$ NÚÑEZ PÉREZ, María Gloria: Trabajadoras en la Segunda República, un estudio sobre la actividad extradoméstica (1931-1936), Madrid, Centro de publicaciones Ministerio de Trabajo y Seguridad social, 1989, p. 34.

${ }^{14}$ NASH, Mary: Mujer, familia y trabajo en España (1875-1936). Barcelona, Anthropos, 1983, p. 25.
} 


\subsection{Associaciones de mujeres}

El crecimiento del feminismo durante la Segunda República se vio reflejado en el aumento de las asociaciones de mujeres y el número de sus integrantes, cuya mayor participación se concentró en los núcleos urbanos ${ }^{15}$. La cuestión regional, religiosa y los problemas socio-económicos, dividieron a los diferentes partidos ${ }^{16}$, con una visión concreta de las mujeres y del papel reservado para ellas en la República. Hay que tener en cuenta que la concesión del voto femenino hizo que aumentara notablemente el electorado y que los partidos vieran en las mujeres una oportunidad para ganar las elecciones.

Las asociaciones femeninas que surgieron durante la Segunda República se podrían clasificar, en líneas generales, en dos grupos: republicanas aperturistas o liberales y las conservadoras o tradicionales.

Respecto a las asociaciones femeninas republicanas liberales existió una gran variedad, la Asociación Nacional de Mujeres Españolas (ANME), el Patronato de la Mujer, que apareció en el panorama español a mediados de septiembre de 1931, María Lejárraga de Martínez Sierra y Clara Campoamor, entre otras, formaron parte de la Junta Directiva; Unión Republicana Femenina que vio la luz por primera vez de la mano de Clara Campoamor a comienzos de octubre de 1931, trabajó en todo momento a favor del voto femenino y en 1936 quiso convertirse en partido político integrante del Frente Popular; otra de las asociaciones feministas republicanas fue Agrupación Socialista Femenina; El Comité Nacional de Mujeres contra la Guerra y el Fascismo(Mujeres Antifascistas), fue una sección delegada del Comité Mundial y se constituyó en España en 1933 después de la visita de un representante de éste. Dolores Ibarruri, La Pasionaria, presidía el Comité Nacional, en el que Victoria Kent era colaboradora. La asociación agrupaba a las mujeres demócratas de todas las ideologías políticas, aunque estaba dirigida por las comunistas. Asociación de

\footnotetext{
${ }^{15}$ CAPEL. R. M: Op.cit., p. 229.

${ }^{16}$ VARELA DíAz, Santiago: Partidos y parlamento en la II República española. Madrid, Fundación Juan March y Editorial Ariel, 1978, p. 308.
} 
Mujeres Republicanas, apareció en 1933, y en 1934, después del movimiento de octubre vio la luz la Sección Española del Socorro Rojo Internacional, otra de las organizaciones comunistas antifascistas. La Comisión Femenina del Frente Popular de Izquierdas, surgió en Madrid en 1936. Ese mismo año, en primavera, se constituía la Comisión Femenina Nacional del PCE, que pretendía que las comunistas se dedicasen a una acción política entre las trabajadoras ${ }^{17}$.

Otras asociaciones que no tuvieron un enfoque tan político como las anteriores serían el Lyceum Club, la Cruzada de Mujeres Españolas, la Federación Internacional de Mujeres Universitarias, la Asociación Universitaria Femenina, que dieron suma importancia a la integración de la mujer en el mundo de la política y a su intervención en las elecciones, ya que pensaban que era un aspecto más de la nueva valoración social que buscaba la mujer. Para Capel, los objetivos principales de dichas asociaciones eran la preparación cultural y la educación cívica de la mujer, además de la igualdad laboral del sexo femenino ${ }^{18}$.

Dentro de estas organizaciones republicanas cabe destacar, por el papel que jugaron en la Guerra Civil, las asociaciones de mujeres que se identificaron con el Frente Popular, por lo que se puede hablar de la siguiente coalición de organizaciones antifascistas femeninas unitarias: La Agrupación de Mujeres Antifascistas (AMA), que afirmaba ser una organización multipartidista que abarcaba tanto a mujeres politizadas como no politizadas, que integraba a comunistas, socialistas y republicanas, cuyo objetivo común era eliminar el fascismo $^{19}$. Otras organizaciones fueron: la Unió de Dones de Catalunya (UDC), que era la ramificación catalana de Mujeres Antifascistas, la Unión de Muchachas $(U M)$, que estaba controlada por las juventudes socialistas y comunistas, Alianza Nacional de la Dona Joven (ANDJ), homóloga catalana de UM, y el Secretariado Femenino del Partido Obrero de Unificación Marxista (POUM) ${ }^{20}$.

\footnotetext{
${ }^{17}$ NúÑ̃Z PÉREZ, M. G: op.cit., p.562.

${ }^{18}$ CAPEL, R. M: op.cit., p. 232-233.

${ }^{19}$ NASH, Mary: Rojas, las mujeres republicanas en la guerra civil. Madrid, Taurus, 1999, p. 358

${ }^{20}$ DíAZ FUENTES, J. M: op.cit., pp. 32-33.
} 
Respecto a las asociaciones de mujeres conservadoras cabe destacar la Sección Femenina de Falange fundada en 1934, cuya máxima representante y única líder fue Pilar Primo de Rivera, cargo que ocupó durante 43 años. El principal cometido de dicha asociación de mujeres durante la república fue ayudar a los falangistas en sus campañas, por eso se encargaron de la recogida de fondos para el partido, de la visita a los prisioneros falangistas y del sustento de la familia de los encarcelados $^{21}$. Este tipo de actividades aumentaron con la ilegalización de Falange en febrero de 1936 y con la detención de José Antonio, llegando a incrementarse durante los actos de vandalismo y violencia realizados por el partido en sus intentos de desestabilizar el Gobierno del Frente Popular.

Antes de la Guerra Civil, la doctrina joseantoniana no especificaba cómo contribuirían las mujeres a las aspiraciones de unidad nacional. El objetivo reflejado en los primeros estatutos de la Sección Femenina, “...se basaba en secundar a los militares nacionalsindicalistas en la lucha contra la antiespaña, [...]"22 pero apenas daban información de los planes que tenía el partido para las mujeres que estaban dentro de él. Lo único que especificaron fue la necesidad de educarlas en los valores de la Falange pero sin dar información de la función de la mujer en general.

Otra de las organizaciones conservadoras fue la formada por las Margaritas $^{23}$ afines al partido Carlista que apoyaban a los Requetés y a sus ideales de modelo femenino en contraposición al de la sociedad republicana. En un intento por captar y formar a las mujeres católicas tradicionalistas, se fomentó su participación, especialmente de las jóvenes, entre 1934 y 1936. Los requisitos que debían cumplir eran ser monárquicas, religiosas y con interés en la propaganda ${ }^{24}$. Durante la

\footnotetext{
${ }^{21}$ RichMOND, Kathleen: Las mujeres en el fascismo español: la sección femenina de la Falange, 19341959. Madrid, Alianza editorial, 2004, p. 277.

${ }_{22}^{22}$ Ibid., p. 105.

${ }^{23}$ El origen de las Margaritas se sitúa entre 1872 y 1876, durante la tercera guerra carlista en el siglo XIX. De las labores de asistencia sanitaria a los heridos se ocupó Margarita de Borbón, la primera esposa de Carlos VII, además de encargarse de los hospitales de campaña también organizó centros de beneficencia ganándose el apodo de Ángel de la Caridad. A partir de ese momento aparecieron las Juntas de Damas Católico-Monárquicas vinculadas a la comunidad, que darían paso a las secciones de Margaritas.

${ }^{24}$ MORAL RONCAL, Antonio Manuel: La cuestión religiosa en la Segunda República española: iglesia y carlismo. Madrid, Biblioteca Nueva, 2009, p. 159.
} 
situación política generada en la Segunda República, los carlistas se plantearon romper la marginación social y política a la que estaban sometidas las mujeres y darlas voz y voto, presentándolas en la propaganda como las únicas capaces de salvar la Patria de los partidos de izquierdas y sus ideas seculares. Entre los principios que debían cumplir las Margaritas se encontraban: la piedad, el autosacrificio y la modestia. La tarea principal que se las encomendó fue la educación de los futuros Requetés y Margaritas, unida a la dirección del Socorro Blanco, cuya actividad se centró en "...la asistencia material y espiritual a los carlistas perseguidos o presos, y a sus familias, con visitas a las cárceles, tarjetas y cartas de adhesión a los atropellos por venganzas políticas. [...]"25. María Rosa Urraca Pastor, católica y monárquica, fue líder indiscutible de la asociación, cuyos mítines y conferencias tuvieron repercusión entre las margaritas durante la República y la Guerra Civil española ${ }^{26}$.

Dentro las organizaciones femeninas conservadoras y católicas, cabe destacar la Asociación Femenina de Acción Popular (AFAP), que defendía que la mujer tenía que acudir a la política porque peligraban la fe y la religión, manteniendo las puertas abiertas a la beneficencia y la caridad, parcela de la esfera pública considerada propia de su rol femenino. La defensa de la familia y su jerarquía, en la que permanecía la autoridad marital, formaron parte del discurso de la AFAP, en el que la mujer era modelo de disciplina y sumisión, en línea con el papel que jugó la asociación a nivel político, con funciones subordinadas inicialmente a Acción Nacional y posteriormente con la unificación de los partidos católicos, a la Confederación Española de Derechas Autónomas (CEDA). El apoyo de las afiliadas a la AFAP incrementó el número de votantes de los partidos conservadores, cuya labor se centró en la propaganda femenina y asistencia $\operatorname{social}^{27}$ :

\footnotetext{
${ }^{25}$ MORAL Roncal, A. M: op.cit., p. 161.

${ }^{26}$ Ellas, n ${ }^{\circ}$ 58, 2 de julio 1933, Un magnifico discurso de María Rosa Urraca Pastor en Zaragoza, p. 4.

${ }^{27}$ MonTERO, José Ramón: La CEDA. El catolicismo social y político en la II República, Vol. I. Ediciones de la Revista de Trabajo, Madrid, 1977, pp. 663-705.
} 
Porque nos parece evidente que la mujer debe participar en política adhiriéndose a los partidos ya formados por los hombres y no pretendiendo formar partidos puramente femeninos. [...]

... a las mujeres corresponderá, desde un primer momento, un papel acaso menos brillante, pero no menos útil, hasta el punto de que su intervención puede asegurar el triunfo del partido que cuente con un núcleo femenino mejo preparado. En primer lugar, correspondería al grupo femenino la organización económica. [...] En segundo lugar, habrían de encargarse las señoras de los trabajo de propaganda constante. $[\ldots]^{28}$.

Es necesario este breve análisis sobre las asociaciones femeninas que se fraguaron y consolidaron durante la República por el papel importante que desempeñaron durante la Guerra Civil, ya que se encargaron de la movilización femenina y de gestionar parte de la ayuda socio-sanitaria que se llevó a cabo, incluida la dotación de enfermeras necesarias para cuidar de los soldados heridos.

${ }^{28}$ Ellas, no 2, 5 de junio de 1932, La mujer y la politica, p. 9. 


\section{Capítulo II}

\subsection{El trabajo femenino: nuevas expectativas}

La posición de neutralidad que mantuvo España durante los conflictos internacionales le permitió generar unas condiciones de mercado y capital favorable para la industrialización que generaron mayor mano de obra. Esto unido a las necesidades económicas familiares y a las circunstancias sociales, permitió a la mujer ampliar su campo laboral y salidas profesionales ${ }^{29}$.

El trabajo femenino se distribuía principalmente entre la agricultura, el sector servicios y la industria, siendo este último el que durante la Segunda República empleó al mayor número de mujeres en puestos peor remunerados, considerados inferiores. Los trabajos que se reservaban para las obreras eran los relacionados con las actividades realizadas en el interior de las casas y con su sexo femenino, todos aquellos subordinados como: limpiar; cocinar; cuidar de niños y enfermos... Estos roles productivos de los sexos, como señala Gloria Núñez, estaban muy diferenciados, lo que conllevaba una aceptación social de la desigualdad ${ }^{30}$.

En muchas ocasiones el trabajo realizado por las mujeres en el campo era considerado como una ayuda a sus familias y no como una faena desempeñada con el mismo objetivo que el trabajo del hombre. Respecto al sector servicios, la ocupación más importante era la de las empleadas domésticas, seguida de las profesiones liberales que presidían las maestras y por último el trabajo llevado a cabo por las mujeres en el comercio. La falta de instrucción y preparación académica de las trabajadoras, impedía la promoción laboral de las mujeres y justificaba sus bajos salarios ${ }^{31}$.

El estado civil de la mujer también repercutió en su situación laboral. Por ejemplo, la soltera no tenía las mismas restricciones laborales que la casada. Además, la legislación establecía y tipificaba los trabajos prohibidos para la mujer que se regían por diversos motivos como: la edad; la nocturnidad; los peligrosos o

\footnotetext{
${ }^{29}$ CAPEL MARTíneZ, Rosa María: Mujer y trabajo en el siglo XX. Madrid, Arco/libros, 1999, p. 42.

${ }^{30}$ NÚÑEZ PÉREZ, M. G: op.cit., p.184.

${ }^{31}$ Ibid., p.331.
} 
duros; los que implicaban paro involuntario masculino y los reservados exclusivamente para hombres ${ }^{32}$.

El derecho al trabajo de las mujeres, al igual que el derecho al voto, tuvo opiniones en contra apoyadas en los “...postulados de la ciencia y con principios de orden religioso-católicos preconizados por la Iglesia. [...]"33. La diferencia fisiológica entre los sexos era la base científica expuesta en contra del trabajo femenino. Gregorio Marañón, médico y endocrino, además de diputado republicano conservador opinaba que el cuerpo de la mujer era incapaz de realizar tareas físicas, con un sistema endocrino y nervioso inestable y sensible que la predisponía para la maternidad, y no para tareas creativas. Santiago Ramón y Cajal, premio Nobel en Medicina, exponía que el trabajo volvía fea a la mujer, la envejecía y la masculinizaba. Respecto al papel jugado por la jerarquía eclesiástica española, Núñez señala que el obispo de Oviedo veía el trabajo femenino como una amenaza para la familia, y consideraba una lacra social a la mujer obrera, de forma que desde el catolicismo se defendía la vuelta al hogar de la mujer trabajadora ${ }^{34}$.

Soy contrario a la intervención de la mujer en la vida pública. El fin de la mujer y su destino es la maternidad. Hasta los cincuenta años por lo menos, la mujer está empleada por Naturaleza en las funciones maternales. Si empieza a los veinte, los meses de gestación y cuidado de la prole, sumados, ocupan su vida hasta el lapso crítico, en el que se juega de nuevo la existencia. [...] como médico me niego a que la mujer se equipare con el varón, ni en el trabajo, ni en la política. Eso podría constituir, de generalizarse ampliamente, una catástrofe para la humanidad ${ }^{35}$.

Según Mary Nash, los cambios señalados en los puntos anteriores generaron una situación de hostilidad hacia la incorporación de la mujer al trabajo, la modernización ponía en peligro el sistema patriarcal. Trabajo doméstico y asalariado eran incompatibles. En algunas ocasiones, los salarios mal remunerados que recibían las impulsaban a buscar un marido que garantizara su supervivencia. El matrimonio

\footnotetext{
${ }^{32}$ NúÑ̃Z PÉREZ, M. G: op.cit., p.219.

${ }^{33}$ Ibid., p.453.

${ }^{34}$ Ibid., p.465.

${ }^{35}$ ABC, 28 de enero de 1934, El doctor Francisco Luque, p.4.
} 
seguía siendo el principal objetivo que debía alcanzar la mujer, aunque a partir de los años treinta del siglo XX se produjo un pequeño cambio de actitud de las mujeres jóvenes frente al mismo, que generó ciertas fisuras en la tradicional distribución sexual de papeles, sin que se produjera una "modificación substancial en las actitudes tradicionales frente a la mujer y sus opciones sociales" ${ }^{36}$.

En este contexto laboral, la Enfermería se afianzaba como profesión eminentemente femenina, socialmente aceptada. Es necesario establecer qué tipo de trabajo desempeñaron durante la República para analizar si hubo modificaciones en el mismo. Estudiar si mejoraron las condiciones laborales de las enfermeras y si aparecieron conflictos con otros profesionales sanitarios.

${ }^{36}$ NASH, M: Mujer, familia ...op.cit., p. 24. 


\subsection{Educación: otras alternativas formativas para la mujer}

Las mujeres a principios del siglo XX mantenían un papel secundario en la educación acorde con su posición en la sociedad, dentro de un sistema educativo “...androcéntrico que, lejos de tender a conseguir unas relaciones más igualitarias entre los sexos, acentúa la división entre ambos [...]"37.

La educación, al igual que la Enfermería, a lo largo de la historia ha mantenido y reproducido las relaciones de subordinación de las mujeres a los hombres. La sociedad patriarcal ha limitado el acceso de la mujer a la educación reglada, fomentando en la enseñanza los modelos de esposas y madres, como futuras educadoras de hijas e hijos. El mayor acceso de las mujeres a la instrucción elemental se consiguió con la llegada de la Segunda República y sus intentos por conseguir la integración de la mujer ${ }^{38}$.

El Gobierno republicano comenzó a prestar más atención a la educación e intentó disminuir las cifras de analfabetismo, la enseñanza privada pasó a ser gratuita, obligatoria y laica. Esta postura generó problemas dentro de los sectores más conservadores de la sociedad ${ }^{39}$. La República intentó facilitar el acceso a todos los grados de enseñanza ya que opinaba que la educación era el instrumento de transformación social. María Jesús Dueñas Cepeda señala que en 1931, las Corporaciones municipales concedieron mayor importancia a las escuelas de niñas consiguiendo un incremento de la escolarización femenina, ya que consideraban que era el sector con mayores carencias ${ }^{40}$.

Otra de las modificaciones más controvertidas que instauró la República fue la coeducación que se estableció como norma legal en los distintos niveles de enseñanza. Esto supuso "un gran avance para una sociedad tradicional y católica, fue

\footnotetext{
${ }^{37}$ DUEÑAS CEPEDA, María Jesús: Avances y retrocesos en la educación de las mujeres en Castilla y León, 1900-1970, en V.V.A.A., Oficios y saberes de mujeres, Valladolid, Universidad de Valladolid. Secretariado de Publicaciones e Intercambio Editorial, 2002, p.221.

${ }^{38}$ Ibid., pp. 222- 232.

${ }^{39}$ Ellas, $\mathrm{n}^{\circ}$ 67, 24 de septiembre de 1933, La escuela laica, portada.

${ }^{40}$ DueÑAS CEPEDA, M. J: op.cit., 234.
} 
un intento de modernización, la coeducación se entendía como la conversión de las escuelas de niñas y niños en mixtas, ${ }^{21}$ aunque con el cambio de Gobierno en 1934 se derogó dicha norma. También hay que tener en cuenta que en "ningún momento se cuestionaron las asignaturas discriminatorias como: Costura y Labores y Economía Doméstica" ${ }^{42}$. Por eso no se puede olvidar que en ese intento de conseguir una igualdad en el sistema educativo se mantuvo vigente el sesgo de género al mantener las diferencias de contenidos entre niños y niñas.

Este contexto social afectó directamente a las enfermeras y a su formación académica, que se consolidó durante la Segunda República y contribuyó a la emancipación femenina. Es importante identificar si hubo cambios en los planes de estudios, si continuaron con las lecciones teóricas que establecían las cualidades morales y físicas que debía reunir una enfermera o si la República rompió con el rol femenino de la profesión.

${ }^{41}$ DueÑAS CEPEDA, M. J: op.cit., p. 236.

${ }^{42}$ Ibid., p. 237. 


\section{CRUZ ROJA DURANTE LA SEGUNDA REPÚBLICA: ADAPTACIÓN A LA NUEVA SITUACIÓN POLÍTICA}

La Segunda República supuso una serie de cambios para la institución que desde un principio aceptó la nueva legislación, mantuvo su carácter de neutralidad y reconoció a las autoridades políticas republicanas, adaptándose a la nueva situación política. De esta forma, Cruz Roja pasó a depender directamente del Ministerio de Gobernación y por lo tanto, de la Dirección General de Sanidad, separándola definitivamente del Ministerio de guerra al que había estado ligada anteriormente.

Otro de los cambios importantes y trascendentales que se produjo fue la disolución de la Asamblea Suprema de Cruz Roja, de forma que se constituyó un Comité Central compuesto por representantes gubernamentales ${ }^{43}$, siendo el ministro de gobernación el presidente del mismo y el director general de sanidad el vicepresidente. El cambio legislativo también afectó a los comités locales, que al igual que sucedió con el central, tuvieron que reorganizarse ${ }^{44}$. Otra de las modificaciones fue reconocer como presidente honorífico de la institución al presidente de la República.

Una vez constituido el Comité Central, comenzó a redactar nuevos reglamentos y estatutos. La revista de la institución pasó de llamarse La Cruz Roja revista mensual ilustrada, órgano oficial de la Asamblea Suprema Española a conocerse como La Cruz Roja revista mensual ilustrada órgano oficial del Comité Central Español.

Durante toda la historia de la Segunda República, Cruz Roja mantuvo su actividad asistencial y social, también continuó con las fiestas benéficas, incluidas las de Navidad y Reyes, y las celebraciones de imposición de insignias y títulos al final de los diferentes cursos formativos.

\footnotetext{
${ }^{43}$ El Comité Central de la Cruz Roja y su labor desde el advenimiento de la República hasta el 30 de septiembre de 1933.

${ }^{44}$ Gaceta de Madrid, $\mathrm{n}^{\circ}$ 337, 3 de diciembre de 1935, Decreto modificando en los términos que se indican los de 13 de Octubre de 1931 y 2 de Junio de 1933, relativos a la Cruz Roja Española, p. 1891.
} 
En los nuevos reglamentos, Cruz Roja se comprometió a mantener su actividad sin entorpecer o paralizar la misma, además de conservar al personal en sus respectivos puestos, adoptó los colores de la bandera tricolor y sustituyó el emblema heráldico monárquico por la corona mural o cívica en todos sus escudos, sellos, documentación... ${ }^{45}$.

Todos los hospitales, dispensarios, ambulancias y centros sociales, pasaron a llamarse, de forma genérica y uniforme, de la Cruz Roja. Lo único que no sufrió ningún tipo de cambio dentro de la institución fue el nombre de las salas o pabellones que conservaron sus advocaciones religiosas ${ }^{46}$.

En noviembre de 1931 Cruz Roja expuso oficialmente, en sus nuevos estatutos, que funcionaba "bajo la protección del Gobierno y que seguía manteniendo su carácter benéfico y humanitario", además de continuar su labor dentro de las normativas internacionales y seguir con las relaciones de “confraternidad y solidaridad moral" con el comité Internacional de Ginebra ${ }^{47}$.

El Gobierno de la República reconoció a Cruz Roja como institución de utilidad y beneficencia pública en todo el territorio nacional, continuó autorizándola oficialmente para la asistencia de los heridos en campaña, le otorgó capacidad jurídica para los actos de la vida civil y reconoció que los bienes de la misma eran propiedad particular de la institución ${ }^{48}$.

El jefe del Estado pronunció breves palabras, dijo S. E. que la República no había abandonado a la Cruz Roja, sino que por el contrario, su presencia allí, ponía de relieve la alta consideración que el régimen se tenía a tan benemérita institución ${ }^{49}$.

La finalidad de Cruz Roja en tiempo de guerra y en tiempo de paz continuó centrada en su labor de ayuda y auxilio a Sanidad Militar y en su acción benéfico-

\footnotetext{
${ }^{45}$ Clemente, J. C: op.cit., p. 146.

${ }^{46}$ Ibid., p.146.

${ }^{47}$ La Cruz Roja. no 353, noviembre 1931.p. 538.

${ }^{48}$ La Cruz Roja. ${ }^{\circ}$ 353, noviembre 1931.pp.539-540.

${ }^{49}$ La Vanguardia, 19 de octubre de 1935, El hospital de la Cruz Roja, p. 27.
} 
social en la labor de asistencia a la población civil en caso de calamidad, catástrofe o epidemia:

En su actuación humanitaria, la Cruz Roja no distinguirá de amigos o enemigos, religiones, ideas políticas o sociales, nacionalidades, razas, etc., cuidando a todos con igual amor y solicitud y no mezclándose nunca en cuestiones distintas de las que le competen ${ }^{50}$.

Dentro del cambio de denominaciones sufridas en los distintos departamentos de Cruz Roja con la llegada de la Segunda República, las secciones de señoras pasaron a conocerse como comisiones, aunque siguieron manteniendo el carácter benéfico y recaudatorio del periodo anterior. A las señoras asociadas de Cruz Roja se las reconocieron los mismos derechos que a los asociados varones, impidiéndolas formar un organismo separado de la institución, excepto en casos especiales ${ }^{51}$.

Cruz Roja seguía manteniendo como una de sus misiones la formación de un cuerpo de enfermeras en tiempos de paz capaz de asistir a Sanidad Militar en caso de guerra. Las enfermeras de la institución eran de dos clases: damas auxiliares voluntarias y enfermeras profesionales. Como puede comprobarse hay un cambio de denominación dentro del cuerpo de las damas enfermeras que pasarían durante la República a conocerse como damas auxiliares voluntarias. Respecto a las Hermanas de la Caridad no hubo ningún tipo de modificación en sus funciones, ni en el trabajo desempeñado en los centros sanitarios de la institución.

Entre otros cambios, la llegada de la Segunda República modificó los cargos de responsabilidad dentro de Cruz Roja, por lo que hubo destituciones y nuevos nombramientos, entre ellos el de la presidencia de la institución que quedó en manos del teniente general Ricardo Burguete. En 1932 Cruz Roja destituyó a Víctor Manuel Nogueras, director del Hospital de San José y Santa Adela e inspector general médico de la institución, decisión que se acompañó de la dimisión de la

\footnotetext{
50 Gaceta de Madrid, $\mathrm{n}^{\circ}$ 287, de 14 de octubre de 1931, Decreto dictando nuevas normas para el funcionamiento de la Cruz Roja Española, p. 252.

${ }^{51}$ Gaceta de Madrid, $\mathrm{n}^{\circ}$ 222, de 10 de agosto de 1933, Decreto aprobando el Reglamento general orgánico de la Cruz Roja Española, p. 960.
} 
Marquesa de Valdeiglesias, responsable de la sección de enfermeras, cargo que fue ocupado temporalmente por Mercedes Milá y Nolla ${ }^{52}$ hasta 1934, fecha a partir de la cual Encarnación Luque y Beltrán pasó a ser la directora de la misma, tras cumplir las condiciones para cubrir dicha plaza entre las que se encontraban ser española, mayor de edad, poseer el título de enfermera y saber idiomas, por lo menos inglés y francés ${ }^{53}$.

\subsection{Damas Auxiliares Voluntarias}

Uno de los cambios importantes que supuso la llegada de la Segunda República para Cruz Roja española fue la nueva denominación del cuerpo de damas enfermeras que pasaron a conocerse como damas enfermeras auxiliares voluntarias, suprimiéndose con el tiempo el término enfermera y prevaleciendo el de dama auxiliar voluntaria.

El cuerpo de damas enfermeras auxiliares voluntarias de Cruz Roja española continuó teniendo como fin y objeto principal la asistencia gratuita en los establecimientos de la institución, tanto en tiempos de paz como de guerra. Como sucedía en los reglamentos de los años anteriores, en el de 1933 también se las exigía ser asociadas de Cruz Roja española y aprobar los exámenes para obtener el título. Para poder matricularse debían ser súbditas españolas, mayores de dieciocho años y menores de treinta y presentar una autorización de sus padres o tutores las menores de edad, y las casadas de su marido. Además de conocer y aceptar los preceptos del reglamento del cuerpo de damas enfermeras auxiliares voluntarias, las aspirantes no podían padecer ningún defecto físico que las incapacitara para el ejercicio de sus funciones. La solicitud, que tenía que estar avalada por dos damas

\footnotetext{
52 Dama Enfermera de Primera de Cruz Roja Española desde 1919, nació en Barcelona el 22 de septiembre de 1895. Fue una de las primeras damas en obtener el título de enfermera visitadora del Bedford College for Women, participó en los curso de verano organizados por Cruz Roja en Londres, lo que le sirvió para ampliar sus conocimientos en temas de higiene y salud pública. Esta amplia formación le permitió llegar a Inspectora de higiene social del comité central de Madrid en 1929. Durante la Segunda República, Mercedes Milá desarrolló de manera profusa su formación como enfermera visitadora, alcanzando, como se verá más adelante, su mayor proyección profesional durante la Guerra Civil Española como jefa de enfermeras de sanidad militar.

${ }^{53}$ ACCRE, caja 2291, expediente 10, Sección de enfermeras, 1934.
} 
auxiliares voluntarias, debían presentarla al director de la escuela donde desearan cursar sus estudios. En caso de asociadas extranjeras, Cruz Roja también les permitía seguir sus cursos pero con algunas salvedades:

Las señoras de nacionalidad extranjera, admitidas en la Institución como asociadas cooperadoras, podrán seguir los cursos de Damas Enfermeras Auxiliares Voluntarias en las mismas condiciones señaladas para las españolas. Aprobadas en los exámenes correspondientes, se les expedirá un certificado de los estudios hechos, reconociéndolas como Enfermeras Auxiliares honorarias. Para los actos de servicio usarán el uniforme reglamentario de la Institución, igual que las Auxiliares Voluntarias efectivas, aunque sin las insignias del mismo ${ }^{54}$.

Las asociadas interesadas podían asistir como oyentes a los cursos formativos pero sin derecho a examen ni título. La organización de los cursos era responsabilidad del profesor médico propuesto por el comité central, que debía seguir el programa oficial aprobado por el mismo. Los cursos únicamente se celebraban en las localidades que contaban con un hospital o dispensario donde, "al menos cinco asociadas" estuvieran dispuestas a comenzarlo.

Durante la Segunda República, además del cambio de denominación de las damas, también se modificó el periodo de prácticas, que pasó a ser, tanto en el primer como en el segundo curso, de tres meses de duración. Para poder presentarse al examen final, además de haber asistido a las clases teóricas, era un requisito indispensable que las alumnas hubieran cursado las prácticas. La duración de los estudios pasaba a ser de diez meses repartidos en dos cursos de cinco meses cada uno, la asistencia era obligatoria, ya que en caso de faltar durante seis días seguidos a las clases teóricas o durante veinte días a lo largo de todo el curso, las alumnas perdían el derecho a examen.

Como sucedía antes del advenimiento de la Segunda República, era necesario constituir un tribunal examinador propuesto por el comité local, y ratificado por el

${ }^{54}$ CRUz Roja ESPaÑola: Reglamento para las Enfermeras Auxiliares Voluntarias de la Cruz Roja Española. Gráfica Universal, Madrid, 1933, pp. 2-3. 
central $^{55}$. El examen, desarrollado al finalizar el curso, consistía en la realización de un ejercicio práctico y otro teórico, ambos de carácter público y cuya calificación máxima era de diez puntos ${ }^{56}$. Las alumnas que aprobaban el primer curso recibían el brazal de la institución y las del segundo curso la medalla de dama enfermera auxiliar voluntaria.

Las auxiliares voluntarias aceptaban prestar sus servicios sanitarios, tanto en "tiempos de guerra, desastre o calamidad pública", siempre que lo estimara oportuno el comité central o cualquiera de sus delegaciones. También se comprometían a desempeñar su trabajo con celo e interés, a comenzar la jornada a la hora señalada, de forma puntual, hasta terminar su trabajo o cuando fueran relevadas del puesto por otra compañera. Al igual que sucedía antes de la República, en caso de catástrofe o guerra, estaban obligadas a presentarse en un plazo de veinticuatro horas ante el comité central las que estuvieran en Madrid, y en los locales las de provincias, especificando en una nota los servicios que estaban dispuestas a prestar, además de comunicar al comité sus cambios de domicilio, y presentar, siempre que fuera requerido, su carnet de identidad y títulos.

Era obligatorio utilizar el uniforme reglamentario siempre que estuvieran de servicio, ostentando únicamente el brazal y la insignia de la institución, sin llevar joyas ni alhajas, únicamente un reloj de pulsera que debían quitarse siempre que tuvieran que descubrirse el brazo. El uniforme, que también sufrió alguna modificación durante la Segunda República, se componía de blusón, delantal, gorro, corbata y capa ${ }^{57}$. Los zapatos eran, igual que en los años anteriores, blancos con tacón a la inglesa, con medias blancas y guantes de hilo.

Su trabajo continuó siendo voluntario y gratuito. Se organizó teniendo en cuenta las necesidades del hospital o dispensario, y el número de auxiliares voluntarias de la localidad. Podían prestar servicio por días, semanas, quincenas o meses, acudiendo al centro por la mañana o por la tarde, según lo estableciera la

\footnotetext{
${ }^{55}$ El tribunal estaba compuesto por el director del hospital o dispensario que sería el presidente, un profesor de la escuela que actuaba como secretario y un médico militar o de la armada o de la beneficencia provincial o municipal, que era el vocal.

${ }^{56}$ CRUZ ROJA ESPAÑOLA: Reglamento para las Enfermeras Auxiliares...op.cit., p. 5.

${ }^{57}$ Se sustituyó la toca por el gorro.
} 
dirección. Las damas auxiliares voluntarias estaban bajo las órdenes del director del establecimiento y la supervisión de la directora de la escuela o en su defecto de la superiora, que se encargaba de velar por el cumplimento de las mismas. En caso de cometer faltas graves durante el desempeño de sus funciones eran separadas del cuerpo de auxiliares voluntarias.

Respecto a las instrucciones para el trabajo en campaña, eran prácticamente iguales a las exigidas a las damas enfermeras durante la etapa anterior ${ }^{58}$, con la salvedad de que durante la República se estableció que los gastos de manutención y desplazamiento en caso de movilización de las damas auxiliares voluntarias, fueran subvencionados por el hospital o centro en el que trabajaban.

\subsection{Enfermeras profesionales}

Durante la Segunda República no se produjo ningún cambio en la denominación ni en las funciones de las enfermeras de Cruz Roja. El cuerpo de profesionales, continuaba constituido por "todas las enfermeras que después de cursados los estudios reglamentarios en las escuelas autorizadas de la institución", habían obtenido el diploma de enfermera profesional de la Cruz Roja Española ${ }^{59}$.

Respecto a los requisitos de admisión en los estudios si hubo modificaciones, la edad mínima de ingreso en la escuela pasaba a ser de dieciocho años y la máxima de veinticinco ${ }^{60}$. Para poder matricularse se las pedía ser solteras o viudas, excluyendo de esta forma a las casadas ${ }^{61}$. Además de ser asociadas de Cruz Roja, presentar la autorización de padres o tutores las menores de edad y solicitar la admisión en la secretaría de la Escuela, se tenían que comprometer a conocer y

\footnotetext{
${ }^{58}$ CRUZ Roja ESPAÑOla: Reglamento para las Enfermeras Auxiliares...op.cit., pp.13-14.

${ }^{59}$ ACCRE, Caja ${ }^{\circ}$ 2291, expediente 10, sección de enfermeras 1934.

${ }^{60}$ En la etapa anterior la edad mínima de admisión era de veinte años y la máxima de treinta y cinco.

${ }^{61}$ Cruz Roja Española: Reglamento del Hospital Central de la Cruz Roja Española y su anejo de la Escuela de Enfermeras. Ernesto Catalá, Madrid, 1932, p.69.
} 
aceptar el reglamento del cuerpo de enfermeras, presentar una copia de su partida de nacimiento, pasar un reconocimiento médico ${ }^{62}$ y aprobar un examen de suficiencia ${ }^{63}$.

En la Segunda República se estableció que las alumnas, una vez admitidas, debían pasar un periodo de prueba de tres meses, tras el cual tenían que aprobar un examen para ser admitidas o rechazadas definitivamente como alumnas ${ }^{64}$.

Cruz Roja permitía a las religiosas interesadas en la profesión cursar los estudios de enfermeras, decisión que se mantuvo durante la República, con la condición de que no superaran el tercio del total de las alumnas enfermeras del curso. Las religiosas también debían aceptar y someterse al reglamento, exceptuando las normas que interfiriesen con las de su regla. De esta forma, no existió una desvinculación de la institución con las Hermanas de la Caridad, de hecho, la Madre Superiora continuó siendo la responsable de las alumnas y enfermeras durante su estancia, tanto práctica como asistencial, en el hospital. Esto también se aprecia en las fotografías de cada curso de enfermeras y damas recién tituladas, en las que la superiora aparece en el centro de la imagen ${ }^{65}$.

La duración de los estudios pasó a ser de veintinueve meses, en régimen de internado, con un mes de vacaciones al año en verano y diez días en Navidad. Las lecciones teóricas y prácticas eran impartidas tanto por el profesorado de la Escuela, como por el "personal médico del hospital y las enfermeras instructoras de servicio de los diferentes departamentos del establecimiento" ${ }^{\circ 6}$. Las clases teóricas se daban de forma simultánea a todas las alumnas, sin establecer ningún tipo de

\footnotetext{
${ }^{62}$ No podían padecer ninguna enfermedad ni defecto físico que les pudiera incapacitar para el ejercicio de la profesión.

${ }^{63}$ La Cruz Roja. $\mathrm{n}^{\circ}$ 363, septiembre 1933.p. 562. La prueba consistía en demostrar los conocimientos de instrucción general a través de un dictado en el que se exigía buena ortografía y caligrafia legible, de la resolución de problemas aritméticos y de un ejercicio de composición. En el caso de conocer algún idioma, también tenían que efectuar un ejercicio práctico de lectura y traducción.

El examen quedaba suprimido si la solicitante presentaba un certificado de estudios de algún centro oficial de enseñanza.

${ }^{64}$ Cruz Roja EsPañola: Reglamento de las escuelas de enfermeras de la Cruz Roja española. Madrid, 1934, Art.13.

${ }^{65}$ La Vanguardia, 8 de noviembre de 1934, Nuevas enfermeras de Cruz Roja, p. 2. La Vanguardia, 3 de octubre de 1934, Nuevas enfermeras de Cruz Roja, p. 3.

${ }^{66}$ Cruz Roja ESPaÑola: Reglamento del Hospital Central...op.cit., p.71.
} 
diferenciación, el horario se fijaba según la conveniencia más oportuna y se anotaban las faltas de asistencia ${ }^{67}$.

Respecto a las clases prácticas, se establecían de forma que se permitiera a todas las alumnas rotar por los diferentes servicios del hospital. Tras la finalización de las mismas se anotaba en la ficha de la alumna la aplicación y comportamiento observado, además de los trabajos realizados.

El examen ${ }^{68}$, que se realizaba al finalizar el curso consistía en dos ejercicios, uno oral y otro escrito, verificado por todas las alumnas de forma simultánea, a través del desarrollo de un tema elegido al azar del programa del curso y cuya duración no podía exceder de la hora y media ${ }^{69}$. Después de los exámenes del primer y segundo curso, las alumnas enfermeras obtenían un certificado con la nota recibida, siendo en el tercer curso cuando se entregaba el título, carnet e insignia de enfermera de la Cruz Roja ${ }^{70}$.

Durante el periodo republicano, Cruz Roja adquirió el compromiso de velar, siempre que le fuera posible, por el bienestar moral y material de sus enfermeras, por lo que intentó contratarlas en sus hospitales y dispensarios, además de proporcionarlas una bolsa de trabajo para su incorporación laboral ${ }^{71}$.

La institución también se ofreció a subvencionar y regir un “...pensionado donde puedan vivir aquellas cuyos empleos dentro o fuera de la Institución no les dé

\footnotetext{
${ }^{67}$ La alumna que dejaba de asistir a las lecciones teóricas y trabajos prácticos seis días consecutivos sin causa suficiente justificada, o veinte durante el año, perdía el derecho de presentarse a los exámenes, y repetía curso.

${ }^{68}$ En el examen oral las alumnas debían defender dos temas del programa oficial elegidos también al azar, además de responder a las preguntas aclaratorias que solicitaba el tribunal. La puntación obtenida era del uno al diez, aprobaban las que obtenían entre dos y cuatro puntos, de cinco a siete notable y de ocho a diez sobresaliente. Para poder presentarse al examen las alumnas debían mostrar su historial personal del curso, donde figuraban todos los trabajos efectuados. En el caso de suspender dichos exámenes, podrían presentarse nuevamente antes del comienzo del curso siguiente, siempre que hubieran permanecido en la escuela durante las vacaciones de verano. Si no aprobaban los exámenes repetían curso.

${ }^{69}$ CRUZ Roja EsPañola: Reglamento de las escuelas de enfermeras...op.cit., Art.21.

${ }^{70}$ Ibid., Art.23.

${ }^{71}$ ACCRE, Caja ${ }^{\circ}$ 2291, expediente 10, sección de enfermeras 1934. Reglamento de enfermeras profesionales de Cruz Roja. Art. 3.
} 


\section{Capítulo II}

derecho a vivienda. [...]" 72 y en caso de enfermedad, se encargó de su asistencia sanitaria.

El cuerpo de enfermeras de Cruz Roja se dividía en enfermeras hospitalarias y enfermeras instructoras, grados o categoría que no aparecen con anterioridad. Para ser instructora, tenían que realizar un curso especial, tener un historial laboral y académico intachable, reunir las aptitudes exigidas por el Comité Central y someterse a un concurso oposición ${ }^{73}$. En caso de incumplimiento de la misión exigida por el Comité Central, se las separaba del puesto de trabajo sin especial expediente, de forma que recuperaban la categoría de enfermera hospitalaria con destino a la primera plaza vacante que quedara en alguno de los hospitales o dispensarios de Cruz Roja.

En caso de cometer alguna falta durante su trabajo, las enfermeras eran sancionadas, en función de la gravedad de la misma eran amonestadas por el director, por la junta de gobierno o separadas de forma temporal del servicio, con suspensión de empleo y sueldo durante dos meses. En caso de mayor gravedad, se las apartaba definitivamente del cuerpo ${ }^{74}$.

Las enfermeras del Hospital Central de Cruz Roja estaban obligadas a prestar ayuda en caso de guerra, calamidad o desastre, compromiso que debían renovar anualmente ${ }^{75}$.

Durante la Segunda República, Cruz Roja decidió aumentar el número de enfermeras diplomadas destinadas en cada servicio del hospital, además de fomentar su especialización:

\footnotetext{
${ }_{72}^{72}$ ACCRE, Caja n ${ }^{\circ} 2291$ : op.cit., Art. 3.

${ }^{73}$ Ibid., Art. 5.

${ }^{74}$ Ibid., Art. 11.

${ }^{75}$ Cruz Roja EsPañola: Reglamento del Hospital Central de la Cruz Roja Española...op.cit., p. 76.
} 
[...] Con este sistema aspiramos también a ir creando especialidades que puedan acrecentar la valoración económica del trabajo de la Enfermera. El diploma les reconoce su capacidad para Enfermera de asistencia, pero la labor de un año o más en un laboratorio, en radiografía, en vías urinarias, en prótesis dental, etc., multiplica su aptitud y ésta se traduce en el aspecto económico $[\ldots]^{76}$.

Uno de los requisitos que debían cumplir era vestir el uniforme ${ }^{77}$ de la institución dentro del hospital; únicamente podían utilizarlo en los locales de Cruz Roja y en actos de servicio fuera de ella, pero nunca en la calle ni en locales públicos, excepto en casos especiales y con previa autorización ${ }^{78}$. Respecto a la remuneración económica, además del sueldo correspondiente a cada grado, percibían una gratificación anual de 5.000 pesetas por antigüedad ${ }^{79}$.

Cruz Roja se interesó por la situación de la Enfermería a nivel internacional, de manera que siempre promocionó la salida de sus enfermeras al extranjero para continuar su formación y la asistencia de las mismas a los congresos internacionales, convocando en algunas ocasiones becas que facilitaran este tipo de movilidad ${ }^{80}$. La experiencia de estudiar en el extranjero enriqueció la base formativa de las enfermeras, ya que conocieron otros planes de estudios, con una distribución de clases y prácticas diferente a la realizada en España ${ }^{81}$, en las que el dominio de la técnica no le restaba importancia al cuidado del enfermo ${ }^{82}$.

\footnotetext{
${ }^{76}$ La Cruz Roja. $\mathrm{n}^{\mathrm{o}}$ 367, enero de 1933, p.26.

${ }^{77}$ El uniforme era de propiedad privada y las enfermeras eran las encargadas de su adquisición.

${ }^{78}$ ACCRE, Caja n ${ }^{\circ}$ 2291: op.cit., Art. 12.

79 La antigüedad empezaba a contar tras cinco años de trabajo en la institución. Los derechos de quinquenio se les descontaban en caso de haberse separado de forma voluntaria o por sanción del servicio, y durante el mes anual de vacaciones percibían el sueldo de forma íntegra. El tiempo de excedencia concedido a las enfermeras no podía ser menor de un año ni mayor de diez, durante dicho periodo no podían participar en el concurso de plazas en propiedad.

${ }^{80}$ La Cruz Roja. no 369, marzo 1933.p. 187.

${ }^{81}$ María Rosa Bastarreche, fue una de las enfermeras de Cruz Roja que tuvo la oportunidad de estudiar durante dos años en Estados Unidos. Bastarreche explicaba que las alumnas admitidas en las escuelas norteamericanas asistían inicialmente a un curso teórico-práctico de entre tres y cuatro meses de duración, sin prácticas hospitalarias y una vez finalizado realizaban un examen eliminatorio, tras el cual podían comenzar las prácticas en el hospital. Los exámenes eran cada cuatro meses, y se podían repetir dos veces como máximo por cada curso. Al finalizar sus estudios, las alumnas enfermeras recibían el título de la escuela, que justificaba su formación pero que no las capacitaba para ejercer de enfermeras. Las alumnas debían verificar su diplomatura ante un tribunal del Estado, compuesto por médicos y enfermeras, que les
} 


\section{Capítulo II}

Durante la Segunda República Cruz Roja continuó con las celebraciones de imposición de brazales e insignias a sus damas y enfermeras, con la salvedad de que durante este periodo los actos estaban presididos por las autoridades gubernamentales republicanas, siendo el presiente del Gobierno su máxima representación en los mismos ${ }^{83}$.

A pesar de la proyección alcanzada por las enfermeras durante la Segunda República, en el $A B C$ y La Vanguardia, se puede observar todavía la preferencia por las damas. Bajo el titular Imposición de brazales y entrega de títulos a las damas enfermeras, se englobaban a las dos titulaciones, pero permitía que prevaleciera el título de dama, denominación que aparece siempre en primer lugar, seguido del título de enfermera profesional ${ }^{84}$. De hecho, de forma habitual, se publicaba la relación de damas de primera y de segunda que recibían el brazal y la medalla, apareciendo en último lugar una breve reseña sobre la entrega de títulos a las enfermeras profesionales pero sin figurar los nombres:

Luego se hizo entrega de títulos y diplomas a varias enfermeras profesionales, después de cuya distribución y de unas breves palabras de saludo, felicitación y agradecimiento pronunciadas por la presidenta, dióse por terminado el acto $^{85}$.

permitía obtener, a través de un examen el título oficial de enfermeras. Una vez obtenido el título oficial de enfermeras, podían continuar con sus estudios dos años más si querían obtener el título de Maestra Enfermera y en caso de interesarse por el título de enfermera visitadora, debían realizar un curso de nueve a doce meses de duración. Para poder ejercer como profesionales, tenían que formar parte de la Asociación de Enfermeras, en Estados Unidos existían cuarenta y nueve Asociaciones de Enfermeras, una por Estado, que contaban con una junta directiva en Nueva York, encargada de la coordinación y regulación de todas. De la formación de las alumnas profesionales en el hospital se encargaban las jefas de sala, profesoras e inspectoras del centro, se centraba en una rígida disciplina, no admitiendo más de tres faltas de asistencia a las alumnas por asignatura. En caso de llegar dos veces fuera de hora a la escuela, o sea, más tarde de las diez de las noche, las alumnas serían expulsadas.

82 BASTARRECHE, María Rosa: Impresiones sobre la formación de Enfermeras en los Estados Unidos. Conferencia pronunciada en el Hospital Central de la Cruza Roja el día 21 de marzo de 1935. Madrid, 1935, pp. 10-11.

${ }^{83}$ La Vanguardia, 19 de noviembre de 1935, El hospital de la Cruz Roja, p. 27.

${ }^{84}$ ABC, 10 de diciembre de 1933, En el Dispensario Central de la Cruz Roja p. 47. La Vanguardia, 21 de marzo de 1934, La fiesta de Santa Luisa de Marillac en el hospital de la Cruz Roja, p. 20.

${ }^{85}$ La Vanguardia, 5 de abril de 1933, Acto de entrega de brazales y medallas a las enfermeras, p. 18. 
Según avanza la República disminuyen los artículos dedicados a las damas, aumentando los centrados en las enfermeras, siendo comunes las noticias e imágenes de las recién tituladas en el acto de imposición de insignias ${ }^{86}$. A pesar de todo, la revista de Cruz Roja continuó reflejando la predilección de la institución por las damas, suprimiendo habitualmente el término auxiliar e intercalando en el texto el de dama y enfermera indistintamente ${ }^{87}$.

La prensa también siguió utilizando el término "dama" en lugar del de "auxiliar voluntaria", llegando incluso a utilizar únicamente la palabra enfermera ${ }^{88}$. Cabe señalar que a pesar del cambio de denominación, el título siguió vinculado a las mujeres de la aristocracia ${ }^{89}$. Las noticias que hacen referencia a la imposición de brazales y entrega de diplomas hablan de enfermeras de primera y de segunda y no de auxiliares voluntarias ${ }^{90}$. Hay una continua controversia entre ambos términos, utilizándose indistintamente en el mismo texto la palabra enfermera y dama. En los titulares se hablaba de "inauguración del curso de enfermeras" y en el contenido de la noticia se hacía referencia a las damas ${ }^{91}$.

La Enfermería continuó siendo una salida profesional socialmente aceptable para la mujer ${ }^{92}$, que no se desvinculó de la maternidad, la abnegación y el sacrificio, relacionados con el rol femenino, "sin los cuales pierde toda su nobleza para convertirse en un oficio mercenario de última categoría"93. La mujer "por naturaleza, por su especial psicología”, era apta para la Enfermería, aunque no era lo mismo la

\footnotetext{
${ }^{86} A B C$ Sevilla, 6 de diciembre de 1932, Portada, nota a pie de página.

${ }^{87}$ La Cruz Roja, no 404, abril 1936, Imposición de brazales a las Damas Enfermeras Auxiliares, pp. 159163.

${ }^{88} A B C, 10$ de diciembre de 1933, En el Dispensario Central de la Cruz Roja p. 47, ABC Sevilla, 6 de diciembre de 1932, Portada, nota a pie de página, ABC, 14 diciembre de 1933, Noticias diversas, p. 36, Blanco y Negro, 14 de febrero de 1933, Las damas enfermeras de la Cruz Roja Española, p. 146.

${ }^{89}$ ABC Sevilla, 9 de julio de 1932, Las damas enfermas de la Cruz Roja y el Doctor Nogueras, p. 5.

${ }^{90}$ La Vanguardia, 19 de noviembre de 1935, Inauguración del curso para damas enfermeras, p. 12. La Vanguardia, 29 de junio de 1935, Las damas de la Cruz Roja, p. 7. La Vanguardia, 23 de junio de 1934, El hospital de la Cruz Roja, p. 13. La Vanguardia, 2 de febrero de 1932, Información gráfica de Barcelona, p. 2.

${ }^{91}$ La Vanguardia, 1 de diciembre de 1933, Inauguración del curso de enfermeras de la Cruz Roja, p. 6.

${ }^{92}$ La Vanguardia, 13 de julio de 1935, Rasgos de una princesa, p. 3.

${ }^{93}$ La Vanguardia, 1 de diciembre de 1933, Inauguración del curso de enfermeras de la Cruz Roja, p. 6.
} 
que ejercía la profesión por vocación, que la que lo hacía "para poder lucir la indumentaria que la favorece y la hace aparecer mucho más atractiva"94.

\subsection{Escuela de Enfermeras del Hospital Central de Cruz Roja: nuevos reglamentos}

Durante la Segunda República el Hospital de San José y Santa Adela y por lo tanto su escuela de enfermeras, aneja a las instalaciones del mismo, pasó a llamarse Hospital Central de la Cruz Roja.

El hospital estaba constituido por las salas de hospitalización de enfermos, las consultas, el dispensario y la escuela de enfermeras. La misión del centro se dividía en cuatro aspectos: por un lado, atender en sus instalaciones a todo tipo de enfermos que no se pudieran permitir económicamente una asistencia privada; estar preparado para asistir las necesidades de los ciudadanos en caso de guerra, catástrofe o calamidad; encargarse de la enseñanza de la escuela de enfermeras de la Cruz Roja y contribuir al progreso de la Medicina en los aspectos científicos y técnicos ${ }^{95}$.

El tipo de personal adscrito a los distintos servicios del hospital se dividía en: facultativo, de asistencia ${ }^{96}$, administrativo y subalterno. La junta de gobierno estaba constituida por el médico director, el subdirector jefe de estudios, la tesorera, el contador, el jefe de material, la directora de la escuela de enfermeras, el representante de los médicos, la representante de las damas auxiliares voluntarias y la representante de las enfermeras ${ }^{97}$. Entre las funciones que debía desempeñar la junta de gobierno del hospital, cabe destacar que además de hacer cumplir los reglamentos del centro y asignar el número de camas de cada servicio hospitalario, se encargaba de la propuesta del número y clase de enfermeras alumnas que serían admitidas en el curso dos meses antes del comienzo del mismo ${ }^{98}$.

\footnotetext{
${ }^{94}$ La Vanguardia, 16 de abril de 1936, Vida cultural, p. 9.

${ }^{95}$ CRUZ Roja ESPAÑOLA: Reglamento del Hospital Central...op.cit., pp. 3-4.

${ }^{96}$ Enfermeras, auxiliares voluntarias, religiosas y alumnas, pertenecían al personal de asistencia.

${ }^{97}$ Todos los cargos eran reelegibles y la comisión central se encargaba de admitir los mismos.

${ }^{98}$ Cruz Roja EsPañola: Reglamento del Hospital Central...op.cit., p. 9.
} 
Respecto a las funciones que debía desempeñar el personal del centro únicamente se abordaran las que competen a la plantilla de Enfermería.

\section{Deberes y funciones del personal de asistencia femenino del Hospital}

\section{Central de Cruz Roja}

El Hospital Central de Cruz Roja contaba entre su personal con una representante de las damas auxiliares voluntarias que se encargaba de transmitir y defender ante la junta de gobierno todas las proposiciones e iniciativas de las damas auxiliares voluntarias adscritas al servicio del hospital. También presidía la agrupación de damas protectoras del hospital y velaba por el cumplimento de las misiones encargadas por la junta de gobierno que hicieran referencia al cuerpo de auxiliares voluntarias ${ }^{99}$. Igualmente, las enfermeras contaban con una representante en la junta de gobierno del hospital que se encargaba de exponer ante la misma todas las proposiciones e iniciativas de las profesionales.

La directora de la escuela de enfermeras, además de formar parte de la junta de gobierno, se encargaba de llevar un fichero con la relación de todas las enfermeras pertenecientes a los distintos servicios del hospital y de la escuela. También redactaba, con la ayuda del presidente del comité de la escuela, una memoria anual del funcionamiento de la misma ${ }^{100}$.

La superiora era vocal en la junta y se encargaba de exponer todos los temas relacionados con el servicio de las religiosas, además de velar:

[...] por el cumplimento de las órdenes de la Dirección respecto a las funciones que a las Damas auxiliares voluntarias les estén encomendadas y al régimen de su distribución y traslado a los diferentes servicios $[\ldots]^{101}$.

Las hermanas disponían de una capilla para sus prácticas religiosas, siendo las encargadas del arreglo y cuidado de la misma, incluida la sacristía ${ }^{102}$.

\footnotetext{
${ }^{99}$ CRUZ RoJa EsPañola: Reglamento del Hospital Central...op.cit., p. 20.

${ }^{100}$ Ibid., p. 21.

${ }^{101}$ Ibid., p. 45.
} 
Los deberes de las auxiliares voluntarias se centraban en prestar asistencia en los distintos servicios hospitalarios según el horario establecido, realizar los trabajos prescritos por los jefes de servicio y contribuir con su labor al buen funcionamiento del hospital y a los fines sociales de Cruz Roja ${ }^{103}$.

La labor de la agrupación de damas protectoras del hospital también aparecía en el reglamento del Hospital Central:

Las Damas auxiliares voluntarias que se hallen o hayan estado adscritas al servicio del Hospital constituirán la “Agrupación de Damas Protectoras del Hospital", con la misión de organizar fiestas y allegar recursos y de fomentar cuantas actividades puedan ser de utilidad e interés para el mayor realce de la Cruz Roja y enaltecimiento del Establecimiento, ajustando siempre las normas de su actuación a las generales contenidas en los Estatutos de la Institución, y procediendo de acuerdo con la Junta de gobierno del Hospital $[\ldots]^{104}$.

Respecto al cuerpo de enfermeras, el hospital se encargó de la organización, régimen de trabajo y distribución de las enfermeras en los diferentes servicios, plan que era aprobado por el Comité Central, y cuya disposición también afectaba a las alumnas $^{105}$. Las religiosas que eran enfermeras diplomadas de Cruz Roja también podían prestar servicio en el hospital, la junta de gobierno decidía el número de religiosas enfermeras que quedaban al servicio del establecimiento teniendo en cuenta que no podía ser superior a la tercera parte del total de la plantilla de enfermeras.

Las enfermeras, para ser nombradas personal del Hospital Central debían cumplir una serie de requisitos: tenían que tener el título oficial de enfermera profesional de Cruz Roja, solicitar a la junta de gobierno el ingreso en el mismo, realizar las pruebas de admisión, además de someterse y aceptar el reglamento del hospital. Tenían que reconocer como autoridad al jefe de servicio y a los médicos auxiliares. Únicamente podían desempeñar "la función peculiar de su misión

\footnotetext{
${ }^{102}$ CRUZ ROJa EsPaÑola: Reglamento del Hospital Central...op.cit., p. 51.

${ }^{103}$ Ibid., p. 45.

${ }^{104}$ Ibid., p. 46.

${ }^{105}$ Ibid., p. 47.
} 
sanitaria", ya que los "menesteres" que no eran "de competencia de su misión profesional" los desempeñaba "el personal subalterno" $"$.

Las enfermeras del Hospital Central de Cruz Roja residían como internas dentro de las dependencias del mismo, tenían derecho a disfrutar de un mes de vacaciones al año, en las fechas que decidía la junta de gobierno, cobrando el sueldo íntegro durante ese periodo. Las enfermeras seglares estaban obligadas a pasar un reconocimiento médico antes de formar parte del hospital por motivos legales, de cara a solicitar una "posible inutilidad adquirida en acto de servicio"107. También se sometían anualmente a un reconocimiento médico que garantizase su capacidad física para el desempeño de su labor. Además, el hospital estaba obligado a prestar asistencia médica de forma gratuita a las enfermeras, en caso de cronicidad de la enfermedad y de prolongación del periodo de convalecencia ${ }^{108}$, de esta forma algunas profesionales se vieron obligadas a solicitar el ingreso en los hospitales de la institución ${ }^{109}$.

\section{Escuela de enfermeras del Hospital Central de Cruz Roja}

La misión principal de la Escuela de enfermeras del Hospital Central de Cruz Roja fue la formación de damas auxiliares voluntarias y enfermeras diplomadas de Cruz Roja. La enseñanza de las primeras era únicamente técnica y la de las segundas profesional y técnica ${ }^{110}$.

El comité directivo de la escuela estaba constituido por un presidente, que normalmente era el subdirector del hospital, la directora de la escuela y una

\footnotetext{
${ }^{106}$ CRUZ RoJa EsPaÑola: Reglamento del Hospital Central...op.cit., p. 48.

${ }^{107}$ Ibid., p. 49.

${ }^{108}$ Ibid., p. 50. El hospital concedía a la enfermera un tiempo de licencia de tres meses durante los cuales percibía el sueldo íntegro. Si fuera necesario ampliar este periodo, se le concedía una prórroga de tres mes más en los que recibía la mitad del sueldo.

${ }^{109}$ ACCRE, Caja 2291, expediente 11, Sección de enfermeras 1935, 2 de noviembre de 1935. Carta de la enfermera Alfonsa Torrecilla Bravo enferma de tuberculosis después de haber trabajado en el hospital de Larache con enfermos pulmonares en 1925.

${ }^{110}$ CRuz Roja ESPaÑola: Reglamento Anejo de la Escuela de Enfermeras ...op.cit., p.67.
} 
secretaria que era una de las profesoras del centro ${ }^{111}$. Los profesores, nombrados por el Comité Central, eran el personal médico del hospital, las enfermeras profesoras de la escuela y las enfermeras instructoras ${ }^{112}$. La directora estaba obligada a residir en el hospital-escuela, tenía que ser española, mayor de edad, estar en posesión del título o diploma de enfermera de cualquiera de las escuelas oficiales o tener experiencia en el puesto y haber dirigido con anterioridad alguna de dichas escuelas. Como méritos especiales se reconocía el conocimiento de idiomas, tener el título de maestra y los servicios prestados en la institución ${ }^{113}$.

Durante la Segunda República se mejoraron las condiciones del internado, por lo que se reformaron los dormitorios, baños, comedor y la enfermería del centro, aun así, se consideraron insuficientes y solicitaron nuevas mejoras. La escuela también se comprometió a cuidar tanto la formación profesional de las alumnas como la espiritual.

Respecto a la formación profesional, el programa del curso lectivo confeccionado por Cruz Roja se había hecho teniendo en cuenta el de las escuelas de enfermeras extranjeras y otras nacionales. El programa teórico-práctico se dividía a lo largo de los tres cursos formativos ${ }^{114}$, durante el primer año se buscaba:

[...] en el contacto con los enfermos hospitalizados la comprobación de aptitudes y el contraste del deseo de la aspirante a dedicar sus actividades al cuidado de enfermos con la realidad, y la que reconozca su falta de aptitud para soportar la visión permanente del dolor y de la miseria ajenas, renunciará a su aspiración con el menor quebranto posible $[\ldots]^{115}$.

\footnotetext{
${ }^{111}$ El comité central sería el encargado de nombrar a la directora de la escuela y a la secretaria de la misma, teniendo en cuenta la propuesta de la junta de gobierno del hospital.

${ }^{112}$ Cabe destacar la figura de la enfermera instructora que aparece en este periodo, y que sería la encargada de apoyar al médico en su labor formativa.

Se consideraba enfermera instructora, auxiliar de enseñanza a las enfermeras diplomadas que trabajaban en cada servicio del hospital. Además de realizar su trabajo como enfermeras, se encargaban de la enseñanza práctica de las alumnas.

${ }^{113}$ La Cruz Roja. $\mathrm{n}^{\circ}$ 365, noviembre 1932, p. 743.

${ }^{114}$ El objetivo de esta distribución era evitar que las alumnas abandonaran sus estudios en el segundo o tercer curso.

${ }^{115}$ La Cruz Roja. $\mathrm{n}^{\circ}$ 367, enero 1933, p. 28.
} 
Las prácticas del segundo curso eran en el dispensario, laboratorio, farmacia $\mathrm{y}$ rayos $\mathrm{X}$, incluyendo las especialidades médicas $\mathrm{y}$ manteniendo la labor hospitalaria en los turnos de guardias y velas. Las prácticas en las especialidades quirúrgicas se realizaban en el tercer curso, además de completarlas en centros benéficos de maternidad, puericultura, hospital de infecciosos, escuela de enfermeras visitadoras...

Desde la escuela se fomentó la "formación espiritual" a través de charlas y conferencias, lecturas, recreos y clases de idiomas:

La aspirante a Enfermera ha de saber que su porvenir no está tanto en la obtención de un título que la capacite para ejercer la profesión, como en las condiciones personales de cultura, trato social, altruismo y capacidad para desempeñarlo. Es necesario conquistar una alta estimación social de la profesión de Enfermera, y ésta no se consigue más que sumando las actuaciones individuales, de las que sale el valor colectivo $[\ldots]^{116}$.

\section{Residencia-Pensionado de enfermeras profesionales diplomadas de Cruz}

\section{Roja Española}

En 1935, por acuerdo de la comisión permanente del Comité Central, Cruz Roja fundó en Madrid su residencia-pensionado ${ }^{117}$ de enfermeras profesionales diplomadas, que empezó a funcionar el uno de octubre de ese año. La principal finalidad de la misma era proporcionar a las enfermeras que no estaban adscritas al servicio de establecimientos y dependencias de la institución en Madrid, alojamiento en régimen de internado ${ }^{118}$. El régimen de pensión completa incluía el derecho a

\footnotetext{
${ }^{116}$ La Cruz Roja. no 367, enero1933. p. 29.

117 La Residencia-Pensionado dependía directamente del Comité Central que era el encargado de su mantenimiento económico.

${ }^{118}$ La cuota mensual que tenían que pagar las pensionistas era de cien pesetas, y las que estuvieran a media pensión sesenta y cinco, siendo expulsadas en caso de no cumplimentar los pagos establecidos. Las pensionistas estaban inscritas en un libro de registro en el que constaba su nombre y apellidos, su procedencia, destino, fecha de ingreso y de salida de las mismas en el establecimiento, equipaje que las pertenecía, estado de pagos de las mismas y acaecimientos o vicisitudes por las que hubieran pasado
} 
habitación con luz, calefacción y uso de teléfono, además del desayuno, comida y cena, el lavado y planchado de la ropa. Las pensionistas también tenían derecho de asistencia médico-farmacéutica gratuita.

Para ser admitidas debían pasar un reconocimiento médico, para verificar que no tenían ningún tipo de enfermedad y que gozaban de buena salud para el desempeño de la profesión. También tenían que ser enfermeras profesionales diplomadas de Cruz Roja y aceptar el reglamento del centro, además de tener "buena conducta y costumbres" $" 119$.

Una de las ventajas de formar parte de la residencia-pensionado, era que, anexa a la misma, funcionaba una bolsa de empleo u oficina de colocación de las enfermeras profesionales diplomadas de Cruz Roja, cuya principal misión era proporcionarlas trabajo en "condiciones honorables de remuneración y desempeño", de forma que el Comité Central garantizaba un trato igualitario a las inscritas en la misma. Cabe destacar su importancia porque todas las contrataciones se tramitaban a través de la bolsa de trabajo.

Toda enfermera profesional diplomada de Cruz Roja española podía solicitar la inscripción en la bolsa. Como requisito debían estar en posesión del diploma acreditativo y no tener trabajo fijo ni destino o colocación remunerada dentro o fuera de la institución. Además de la aptitud física para el desempeño del trabajo, también debían contar con buena conducta y costumbres, sin olvidarse de aceptar y cumplir la normativa establecida para el funcionamiento de la bolsa. Toda la información figuraba en el libro de registro, donde además del nombre y apellidos de las inscritas, también constaba la antigüedad profesional, la categoría dentro de la institución, si poseían alguna especialidad y los servicios prestados fuera y dentro de Cruz Roja, además del comportamiento, colocaciones obtenidas desde su inscripción

durante su estancia en el pensionado, además de un breve historial de su estancia y paso por el establecimiento.

${ }^{119}$ La Cruz Roja. no 398, septiembre 1935, p. 608. 
en la bolsa, honorarios percibidos y estado de la salud ${ }^{120}$. En caso de rechazar un empleo, la enfermera pasaba a ocupar el final de la bolsa de trabajo ${ }^{121}$.

Cuando una de las enfermeras inscritas en la bolsa comenzaba a trabajar, se le entregaba una tarjeta-ficha ${ }^{122}$ que debía presentar ante el jefe del establecimiento donde iba a prestar sus servicios. Si encontraban empleo debían comunicarlo a la gerencia de la bolsa, especificando condiciones de trabajo, centro y remuneración, para no ser sancionadas y separadas de la bolsa ${ }^{123}$.

${ }^{120}$ La Cruz Roja. no 398, septiembre 1935, p. 614.

${ }^{121}$ La jefa de la Residencia-Pensionado constituía con las enfermeras inscritas en la bolsa que se encontraran en el primer y segundo puesto en el turno de colocación, una guardia o retén para atender los servicios de urgencia que surgieran.

${ }^{122}$ En la tarjeta, los responsables de la contratación de la enfermera, registraban su comportamiento y desempeño de sus funciones, además de valorar el trato al enfermo, posteriormente las tarjetas se devolvían a la jefa de la Residencia-Pensionado. En el lugar de trabajo también presentaban su carnet de enfermera profesional diplomada de Cruz Roja Española y la tarjeta de inscripción en la bolsa de empleo.

${ }^{123}$ La Cruz Roja. no 398, septiembre 1935, p. 617. 


\section{LAS ENFERMERAS EN LA SEGUNDA REPÚBLICA: SITUACIÓN PROFESIONAL}

Durante la Segunda República adquiere gran importancia la formación de enfermeras, que se plasma en el valor que obtienen las Escuelas Profesionales. La Enfermería se revaloriza en el periodo republicano gracias a la incorporación femenina al mundo laboral, de forma, que recibir un salario por trabajar en un hospital comenzó a verse bien en la sociedad española que dejaba atrás los prejuicios relacionados con el cuidado, ligado a las obras benéficas y caritativas. Además, la desvinculación de la monarquía y la aristocracia con la profesión contribuyó a romper con esa aureola de inaccesibilidad a los estudios, lo que posibilitó el aumento de profesionales. También hay tener en cuenta la influencia que tuvo la República en la educación de las mujeres, lo que facilitó el acceso de las mismas a los estudios de Enfermería. A pesar de los cambios políticos, el trabajo femenino seguía ligado al rol tradicional de las mujeres, por lo que ser enfermera era una alternativa profesional aceptada por todos los sectores políticos ya que no suponía ningún peligro para la jerarquía social establecida.

El nuevo marco legal de 1932 unificaba el contenido de los estudios de Enfermería en todo el país, de forma que se estableció un nuevo programa dividido en tres cursos académicos con un total de treinta y cuatro lecciones con los siguientes contenidos ${ }^{124}$ :

\footnotetext{
${ }^{124}$ Líneas actuales de investigación, como la seguida por la profesora María de la Luz Fernández Fernández señalan la posibilidad que ese plan de estudios fuese el de la escuela de Enfermeras de la Casa de Salud Valdecilla, que se generalizó para toda España.
} 
Tabla 5. Lecciones teóricas Enfermería Segunda República.

\begin{tabular}{|c|c|c|}
\hline Primer Curso & Segundo Curso & Tercer Curso \\
\hline Anatomía & Química & $\begin{array}{l}\text { Especialidades médico- } \\
\text { quirúrgicas }\end{array}$ \\
\hline Fisiología & Dietética & Acción Social \\
\hline Patología & Farmacología & \\
\hline Bacteriología & Terapéutica & \\
\hline Higiene & & \\
\hline $\begin{array}{l}\text { Técnicas del cuidado de } \\
\text { enfermos I }\end{array}$ & $\begin{array}{l}\text { Técnicas del cuidado de } \\
\text { enfermos II }\end{array}$ & $\begin{array}{l}\text { Técnicas del cuidado de } \\
\text { enfermos III }\end{array}$ \\
\hline
\end{tabular}

En la Segunda República el Cuerpo de Enfermeras especializadas en la lucha antituberculosa alcanzó mayor importancia y difusión. En 1932 se constituyó el título de enfermero psiquiátrico estableciendo un programa de estudios específico de veinticuatro lecciones ${ }^{125}$. Este diploma acreditaba la especialización de los practicantes en psiquiatría $^{126}$. En 1935, a través de la orden del 14 de junio, se fundó el Cuerpo de Practicantes de Asistencia Pública Domiciliaria.

Hasta 1935 únicamente el Estado tenía permiso para la expedición de certificados oficiales de prácticas de enfermeras, a partir de noviembre de ese año se empezó a autorizar la misma “... para exámenes y concursos oficiales, a los Hospitales de carácter particular [... $]^{\prime 127}$ siempre que lo solicitaran por escrito en el plazo de un mes desde la publicación de dicha orden en la Gaceta de Madrid y que la institución garantizase la formación práctica reglada. La principal motivación de la orden ministerial fue el exceso de alumnas enfermeras en los hospitales y centros

\footnotetext{
125 Gaceta de Madrid, $\mathrm{n}^{\circ}$ 141, de 20 de mayo de 1932, Orden aprobando el programa para obtener el certificado de aptitud de "Enfermero psiquiátrico", p. 1335-1336.

${ }^{126}$ Gaceta de Madrid, $\mathrm{n}^{\circ} 215$, de 2 de agosto de 1932, Orden resolviendo escritos de Practicantes y Enfermeros de Establecimientos Psiquiátricos, en súplica de que se dicte una disposición aclaratoria a la Orden de 16 de Mayo del año actual (GACETA del 20), por virtud de la cual queden dispensados de las pruebas de aptitud y estudios necesarios para obtener el Diploma de "Enfermero Psiquiátrico" creado por la mencionada disposición, p. 867.

${ }^{127}$ Gaceta de Madrid, $\mathrm{n}^{\circ}$ 334, de 30 de noviembre de 1935, Orden autorizando la expedición de certificados de enfermeras, valederos para exámenes y concursos oficiales, a los Hospitales de carácter particular que lo soliciten, p. 1797.
} 
del Estado que dificultaba su formación, con esta medida se pretendía disminuir el número de estudiantes por hospital de forma que la enseñanza práctica mejorara ${ }^{128}$.

La legislación republicana permitió la constitución de nuevas escuelas de enfermeras profesionales, como fue el caso de la Escuela de Enfermeras de la Generalitat de Catalunya, que surgió en 1933 con planteamientos vanguardistas en los que no existía la discriminación de sexos en la atención al enfermo. Ese mismo año, la Escuela Nacional de Sanidad fundó la Escuela Nacional de Enfermeras Visitadoras, que expedía el título de enfermera visitadora, de forma que habilitaba a las profesionales para trabajar en dispensarios antituberculosos, servicios de higiene infantil y centros de higiene rural. Otra de las principales escuelas de enfermeras en ver la luz durante la Segunda República fue la Escuela Nacional de Enfermeras Sanitarias y de Asistencia pública constituida en 1935.

\subsection{Las enfermeras a través de los manuales: consolidación de una imagen}

La formación de las enfermeras alcanzó gran importancia y proyección durante la República, por eso los manuales consultados durante este periodo se centran exclusivamente en la formación de las enfermeras y no de las damas auxiliares voluntarias, acorde con la revaloración de la profesión ${ }^{129}$.

Los contenidos teóricos generales que se desarrollaron durante la Segunda República se pueden resumir, en líneas generales en el siguiente recuadro:

\footnotetext{
${ }^{128}$ ACCRE, Caja 2291, expediente 11, Sección de enfermeras 1935.

129 UsAndizaGA, Manuel: Manual de la enfermera. Librería internacional, San Sebastián, 1934, PitTalugA, Gustavo: Técnica y vocación de la enfermera. Madrid, 1933, SAlAS, J: Manual de la enfermera general y psiquiátrica. Hermanas Hospitalarias del Sagrado Corazón de Jesús, Madrid, 1935, PIJOAN, Baltasar: La enfermera moderna, conocimientos necesarios para el cuidado de enfermos. Segunda edición, Barcelona, sin año de edición.
} 
Tabla 6. Contenidos teóricos formación de enfermeras.

\begin{tabular}{|c|c|}
\hline Temas Generales & Temas específicos Enfermera \\
\hline Anatomía y Fisiología & Actividades de la enfermera \\
\hline Patología & Cualidades físicas y morales \\
\hline Higiene: concepto de infección & Deberes/ Obligaciones de la enfermera \\
\hline $\begin{array}{c}\text { Técnica del cuidado de enfermos: } \\
\text { vendajes, material de ligaduras, } \\
\text { inyecciones hipodérmicas e intravenosas, } \\
\text { cuidados postoperatorios, limpieza del } \\
\text { enfermo... }\end{array}$ & La enfermera modelo \\
\hline Química & \\
\hline Farmacología & \\
\hline Dietética & \\
\hline Fisioterapia & \\
\hline Puericultura & \\
\hline
\end{tabular}

Fuente: ver nota 129.

Algunos libros formativos, como El Manual del practicante y la enfermera $\mathrm{o}$ Temas prácticos de vendajes, no abordan los temas relacionados con las cualidades físicas y morales que debían reunir las enfermeras, únicamente estudian los contenidos generales y científicos de la profesión.

Además de los manuales, se analizarán las charlas del ciclo de conferencias organizado en 1933 por Cruz Roja Española dentro del programa del curso de enfermeras hospitalarias del Hospital Central, recopiladas y editadas en un libro y publicadas en la revista de la institución ${ }^{130}$.

\footnotetext{
${ }^{130}$ Charlas de: MAEZTU WhitNEY, María: El trabajo de la mujer, nuevas perspectivas. Conferencia pronunciada el día 8 de abril de 1933, Madrid, 1933, JUNQUERA, María. Teresa: Lo que puede y debe ser la enfermera. Conferencia pronunciada el día 6 de abril de 1933, Madrid, 1933.
} 


\section{Capítulo II}

En líneas generales el concepto de enfermera que primaba en la Segunda República estaba relacionado con los cuidados que prestaban las profesionales:

La enfermera tiene por misión el asistir a los enfermos: todos los cuidados que haya que prestarles, sean de la clase que sean, médicos, higiénicos, personales, corresponden a la enfermera. Debe ser el único intermediario entre el médico y el enfermo; la única persona que entre en contacto con éste.

Aún hoy día existe entre nosotros una confusión en este concepto: estas funciones auxiliares se intentan dividir en dos categorías, unas que llaman técnicas, inyecciones, curas, anestesias, etcétera; otras que se consideran de orden secundario, como alimentación, limpieza del enfermo, etc., y también se pretende que haya dos categorías de personal auxiliar que se encargue de esas funciones $[\ldots]^{131}$.

Adquirir una preparación práctica y teórica adecuada a través de una enseñanza competente era fundamental para que la enfermera se encargara correctamente del cuidado de los enfermos ${ }^{132}$.

Las Enfermería era una profesión con dos vertientes, por un lado la técnica encaminada a adquirir la competencia ligada al saber y a la remuneración económica, y por otra parte, la vocacional que requería una disposición moral para poder desempeñar el trabajo. La enfermera debía estar bien preparada para desempeñar correctamente su labor técnica, trabajar con exactitud, primor, rapidez y “con los gestos justos". La experiencia práctica y su preparación profesional debían contribuir a la adquisición de esas competencias profesionales, de forma que plasmara inteligentemente sus conocimientos en el cuidado de los enfermos, sin olvidarse de la sensibilidad femenina, cualidad intrínseca, y de la vocación profesional $^{133}$. De esta forma, durante la Segunda República, se dejaba claro que las funciones de la enfermera debían centrarse en el dominio de la técnica y del conocimiento científico ${ }^{134}$.

\footnotetext{
${ }^{131}$ UsAndiZAGA, M: op.cit., p. 2.

132 Ibid., p. 2.

${ }^{133}$ PITTALUGA, G: op.cit., pp. 6-7.

${ }^{134}$ MAEZTU WhitNEY, M: op.cit., p. 25.
} 
Por otro lado la Enfermería continuaba considerándose una "actividad netamente femenina," con la salvedad de que en este periodo pasa a ser una profesión "fácilmente asequible a la mujer de todas clases sociales, en cuyas manos pone un instrumento útil de trabajo que la redime económicamente"135.

Durante la Segunda República se siguen estableciendo las cualidades físicas y morales que debían reunir las enfermeras, entre las que destacaban la resistencia física, un sistema nervioso equilibrado, fortaleza, buen estado de los órganos de los sentidos y estar saludable ${ }^{136}$.

La higiene personal continuaba siendo un punto esencial, debían cuidar su aseo, ya que "por ninguna causa debe el enfermo contemplar el espectáculo de una persona despeinada o desarreglada". Debían llevar el uniforme limpio, sin almidón, ni adornos, y con un calzado adecuado que no molestara a los enfermos, por lo que también debían evitar el ruido innecesario, por eso tenían que evitar los gritos, el tono de voz alto y cerrar puertas y ventanas con suavidad ${ }^{137}$.

Toda enfermera debía poseer conocimientos elementales sobre el sistema métrico decimal, las operaciones básicas de aritmética, leer y escribir, además de poseer cierto nivel cultural que le permitiera amenizar la conversación con el enfermo $^{138}$. Esta preparación académica le permitiría ser crítica en su trabajo de una forma inteligente, "aun dentro de la obediencia más ciega""139.

Las enfermeras tenían que inspirar confianza, bondad y dulzura, siendo capaces de transmitir al enfermo paz y confort, además de evitar irritarlos o contagiarlos el mal humor ${ }^{140}$. Para ser una buena profesional era necesario temple moral, energía y perseverancia, además de poseer un espíritu vocacional, ser sinceras y bondadosas ${ }^{141}$. Tenía que profesar amor a sus semejantes, espíritu de

\footnotetext{
${ }^{135}$ JUNQUERA, M. T: op.cit., p. 14.

${ }^{136}$ SALAS, J: op.cit., p. 102.

${ }^{137}$ PIJOAN, B: op.cit., p. 51.

138 SALAS, J. op.cit., p. 103.

${ }^{139}$ PITTALUGA, G: op.cit., p. 16.

${ }^{140}$ UsANDIZAGA, M: op.cit., p. 12.

${ }^{141}$ Ibid., p. 3-6.
} 


\section{Capítulo II}

sacrificio e interés por la profesión, poseer tranquilidad, reflexión, resolución y prontitud de juicio, sin olvidarse de la comprensión espiritual del enfermo, la paciencia y la observación ${ }^{142}$. La enfermera debía poner su técnica al servicio del enfermo, con la finalidad de aliviar sus dolores y de aminorar sus "penas y su padecimiento", consiguiendo que aceptase los "remedios más molestos", además de trasmitirle la esperanza de la mejora y "el cariño protector, en cierto modo maternal" $" 143$.

La técnica sería la base, el contenido y la materia de la competencia profesional de las enfermeras, pero sin olvidar que inteligencia y aptitud no eran cualidades suficientes para desempeñar su trabajo, era necesario que se acompañaran de perseverancia, voluntad, constancia, paciencia, hábito de silencio ${ }^{144}$, espíritu de obediencia, entusiasmo, serenidad, tolerancia y responsabilidad ${ }^{145}$. La pereza era un "vicio" que no podían permitirse, debían aceptar el trabajo sin vacilación ni dilaciones $^{146}$.

Para evitar equivocaciones debían procurar que sus relaciones con el personal y los enfermos no traspasaran "los límites de una sencilla amistad" y debían evitar la crítica ya que "los hospitales son lugares donde la chismografía cunde fácilmente" ${ }^{\text {147 }}$. Las relaciones entre médico y enfermera serían estrictamente profesionales, "[...] La coquetería, la frivolidad ante el médico es una grave falta en las enfermeras; quienes así proceden causan un grave daño al prestigio de sus compañeras, al de la profesión. [...]"148 Con los enfermos, únicamente podían ver "al hombre que sufre", sin establecer más relación que la estrictamente profesional,

\footnotetext{
${ }^{142}$ SALAS, J: op.cit., p.102.

${ }^{143}$ Pittaluga, G: op.cit., p. 11.

${ }^{144}$ No sólo ayuda a observar y a clasificar las observaciones, sino que es exigido por el secreto profesional. Exigen también el silencio, el orden y el buen aspecto de los hospitales; lo exigen los enfermos, a quienes una charla incesante cansa e irrita: una buena enfermera no debe hablar la primera, salvo en casos especiales, y sobre todo jamás debe empezar una conversación ni insistir en continuarla. Declaración de María Teresa Junquera.

${ }^{145}$ JUNQUERA, M. T: op.cit., p. 4-11.

${ }^{146}$ PIJOAN, B: op.cit., p. 53.

${ }^{147}$ Ibid., p. 54.

${ }^{148}$ UsandiZAGA, M: op.cit., p. 9.
} 
por lo que mantendría siempre una posición de austeridad digna en todo momento $^{149}$.

La enfermera era la "secretaria cuidadosa" del médico, encargada de preparar sus papeles, las fichas de los pacientes, la estadística y los cálculos demográficos, además de:

[...] poner su instinto femenino, siempre pulcro y delicado, en adivinar aquello que puede ser útil y agradable a la tarea que han de llevar a cabo juntos durante la jornada de trabajo. Cualquiera de las muchachas que me escuchan sabe perfectamente lo que la gracia de la sonrisa, la seguridad de la contestación, la corrección y justeza del gesto, en el cumplimiento de una orden, significan en la conducta profesional.

Ahora bien: para que la gracia no se trueque en coqueteo, ni la delicadeza en debilidad, ni la cortesía en transigencia; para que la seriedad no degenere en tosquedad, ni la corrección en frialdad, ni la severidad en dureza; para que el ambiente en que la enfermera desenvuelve su actividad profesional o lleva a cabo su aprendizaje no se contamine de ligereza y de olvido, ni se apesadumbre con suspicacias y enconos; para todo eso, y para que las relaciones de las enfermeras y los médicos por un lado, las enfermeras y los enfermos por otro, se mantengan en un tono sereno y sin tacha, es preciso salvar dos grandes escollos: el de la ñoñería y el de la frivolidad $[\ldots]^{150}$.

Los deberes de la enfermera con los enfermos se centraban principalmente en el secreto profesional y respetar sus creencias religiosas ${ }^{151}$. Respecto al médico, debía cumplir estrictamente sus órdenes sin juzgar sus decisiones, ni emitir comentarios al respecto. La enfermera tenía unas funciones auxiliares bien determinadas, por lo que salirse de ellas era una ilegalidad profesional ya que incurriría en una falta de moralidad y en un delito ${ }^{152}$. Con la institución, los deberes que adquiría se centraban principalmente en facilitar su funcionamiento y evitar

\footnotetext{
${ }^{149}$ USANDIZAGA, M: op.cit., p. 7.

${ }^{150}$ PitTAlugA, G: op.cit., pp. 24-25.

${ }^{151}$ SALAS, J: op.cit., p. 103.

${ }^{152}$ UsANDIZAGA, M: op.cit., p. 9.
} 
cualquier tipo de conflictos que pudieran perjudicarla. Debían seguir siempre el reglamento del centro y mantener la disciplina en el mismo. Entre las compañeras tenían el deber de hacerse cumplir las obligaciones unas a otras, conservando el "espíritu de fraternidad"153.

Respecto a los deberes de la enfermera consigo misma se centraban en mantener el estado de salud, por lo que llevarían una "vida higiénica", por la noche debían dormir con la ventana abierta, intentando permanecer al aire libre por el día, dormir siete horas y realizar comidas adecuadas en cuanto a cantidad y calidad. También debían imponerse autoridad moral y exigirse aprender más ${ }^{154}$.

Debían anotar y registrar en las gráficas los datos del paciente, durante la visita médica, para ello, utilizaban una libreta donde apuntaban todas las órdenes médicas y observaciones, además de ejecutar cuanto antes las prescripciones para evitar errores ${ }^{155}$. Debían plasmar por escrito los síntomas del paciente, su temperatura, pulso, respiración..., de forma que la información se transmitiera correctamente al médico ${ }^{156}$.

Respecto al trabajo diario lo primero que tenían que hacer las enfermeras era la limpieza de la sala y enfermos, para que todo estuviera listo para la visita del médico. Eran las encargadas de mantener la disciplina y observar "de forma rápida y eficiente" a los objetos y enfermos, centrándose en los detalles, para evitar el desorden en las salas de hospitalización. También eran las responsables de autorizar las visitas de los enfermos según lo prescrito por el médico ${ }^{157}$.

Los relevos o cambios de turnos se realizaban a la hora establecida, momento en el que la enfermera que terminaba su jornada informaba de las órdenes médicas pendientes de cumplir y de las observaciones anotadas a la enfermera que comenzaba el turno ${ }^{158}$.

\footnotetext{
${ }^{153}$ USANDIZAGA, M: op.cit., p. 10.

${ }^{154}$ Ibid., p. 11.

${ }^{155}$ Ibid., p. 311-313.

${ }^{156}$ SALAS, J: op.cit., p.103.

${ }^{157}$ PIJOAN, B: op.cit., p. 56-57.

${ }^{158}$ SALAS, J: op.cit., p. 275.
} 
El trabajo estaba sistematizado, de forma que debían seguir un orden, durante el turno de mañana, se ventilaba la sala, para ello tapaban primero a los enfermos y abrían las ventanas durante unos minutos. Después se pasaban los orinales y administraban los enemas e irrigaciones vaginales. Posteriormente, se hacían las curas pautadas, se aseaba a los enfermos y se les cambiaba la ropa de cama. Una vez ordenada la sala, se repartían las medicinas y desayunos, se tomaban las temperaturas y pulsos y se registraban. Este trabajo matutino debía estar terminado a la hora de la visita del médico, después de la cual la enfermera cumplía las órdenes $\operatorname{prescritas}^{159}$.

Durante el turno de tarde, además de cumplir las órdenes médicas y reparto de medicinas, se encargaban del baño de los enfermos, la limpieza del pelo..., todo aquello que suponía un tiempo extra para el turno de mañana. Una vez servidas las cenas, se dejaba la sala preparada para la enfermera de noche, se revisaban los vendajes de los enfermos, debían controlar si sucedía algo anormal, llenar las bolsas de hielo y agua caliente y pasar los orinales. Cuando llegaba la enfermera de noche se le exponían las órdenes médicas pendientes de ejecutar y una relación del estado de los pacientes, centrándose en los más graves. Al empezar el turno visitaba a todos sus enfermos para ver su estado, evitando molestarlos, ya que debía contribuir a su descanso, mediante un silencio absoluto en la sala. Por eso debía prescindir de las conversaciones y realizar su trabajo de forma que molestara lo menos posible al enfermo, como podía ser en el caso de la administración de medicación. La enfermera apagaba las luces directas, evitaba las corrientes y los cierres bruscos de ventanas, además de acomodar al paciente para que descansara y acudir ante el menor ruido en su ayuda ${ }^{160}$.

\footnotetext{
${ }^{159}$ USANDIZAGA, M: op.cit., p. 343.

${ }^{160}$ Ibid., p. 343-344.
} 
A pesar de los avances de la Segunda República, la profesión de enfermera seguía encasillada en su rol femenino, como "soberanas del hogar" dedicadas a proporcionar bienestar y alegría a la familia y por ende a los pacientes ${ }^{161}$. La parte técnica de los cuidados había adquirido mayor importancia, pero sin desligarse de la dulzura, el cariño, la piedad y la abnegación, cualidades que continuaban unidas al trabajo de la enfermera.

\subsection{Una apuesta por las enfermeras laicas}

Como señala Carmen González Canalejo, “...es a partir de 1935 cuando se atisba el comienzo de aceptación de igual capacidad de las mujeres para desarrollar el trabajo sanitario $[\ldots]^{\prime 162}$.

La jornada laboral de las enfermeras era de quince horas diarias incluyendo en ella las tareas realizadas fuera del hospital en otro tipo de cometidos, por eso en el congreso de 1932 de UGT se denunciaba el problema y se aprobó una política sanitaria en la que se incluyó la jornada de ocho horas para todo el personal del hospital. Entre las demandas expuestas, UGT pedía la eliminación del internado en la profesión ya que lo consideraban un "método indirecto de explotación" "163. Hasta ese momento los centros sanitarios habían estado bajo la custodia de las religiosas, consideradas una mano de obra barata. Los socialistas planteaban sustituir a las monjas por enfermeras tituladas laicas en las instituciones sanitarias públicas, alegando que así el enfermo recibiría unos cuidados de mayor calidad asistencial. Algunas enfermeras como Trinidad Gallego participaron activamente en el debate, por eso "formaron un comité para pedir en el congreso que hubiera plazas de enfermeras en los hospitales porque sólo había comunidades religiosas" $" 164$.

\footnotetext{
${ }^{161}$ La mujer en su casa. no 360, diciembre 1931, La mujer en su casa, en el año 1932.

162 GONZÁlez CANALEJO, Carmen: Las cuidadoras. Historia de las practicantes, matronas y enfermeras (1857-1936). Premio de ensayo "Carmen Burgos" 2005. Instituto de Estudios Almeriense, Almería, 2006, p. 12.

${ }^{163}$ NÚÑEZ PÉREZ, M. G: op.cit., p.39.

${ }^{164}$ Domingo Álvaro, Alfonso: Retaguardia. La Guerra Civil tras los frentes. Oberon, Madrid, 2004, pp. 359-36.
} 
En la lucha contra el dominio de las órdenes religiosas en las instituciones sanitarias se organizó en 1932 la Federación del Personal de ambos sexos al servicio de Hospitales, Sanatorios, Manicomios y similares de España en la que se incluía a las enfermeras. "Algunas sociedades socialistas pidieron al gobierno la creación de un cuerpo de enfermeras para reemplazar a las monjas de las clínicas"165. Otro de los intentos de los socialistas en el gobierno fue el de convocar oposiciones para cubrir las plazas de enfermeras de hospitales públicos, lo que generó enfrentamientos entre éstas y las Hermanas de la Caridad. Ignorancia profesional, fanatismo, abandono del enfermo, monopolio sobre el material sanitario y excesivo control eran las acusaciones principales de las enfermeras hacia las monjas que según el personal laico, obstaculizaban el trabajo. La prensa conservadora se posicionó a favor de las Hermanas de la Caridad, exponiendo que recibían un salario inferior al de las enfermeras laicas. La expulsión de las religiosas por parte del personal hospitalario se siguió pidiendo hasta 1936, Núñez destaca el eslogan "monjas no, enfermeras sí" de uno de los carteles de la manifestación obrera del 1 de mayo de ese mismo año ${ }^{166}$.

A pesar del movimiento anticlerical característico de la Segunda República, las religiosas continuaron con su formación como enfermeras:

[...] Se han celebrado en la Facultad de Medina los exámenes para obtener el título de enfermeras. Veinte monjas de la Congregación de las Siervas de María han logrado brillantísimas calificaciones $[\ldots]^{167}$.

Se observa como la sustitución de monjas por enfermeras titulares laicas tuvo mayor alcance al final de la Segunda República, la prensa exponía así los nuevos cambios organizativos:

\footnotetext{
${ }^{165}$ NúÑEZ PÉREZ, M. G: op.cit., p. 394.

${ }^{166}$ Ibid., pp. 394-395.

${ }^{167}$ ABC, 9 de junio de 1933, Brillantes exámenes de unas religiosas, p. 48.
} 
Logroño, 2, 10 mañana. La comisión gestora provincial ha acordado la substitución de las monjas del hospital Provincial por enfermeras. Se les ha concedido un plazo de dos meses para abandonar el hospital. La capilla será destinada a sala de maternidad $[\ldots]^{168}$.

El conflicto social que se produjo en torno a la demanda de enfermeras laicas fue importante, sobre todo porque serían las encargadas de sustituir a las Hermanas de la Caridad en los hospitales. Entre las alegaciones en defensa de las profesionales se decía que las religiosas dormían durante las velas nocturnas, que se negaban a poner las inyecciones de morfina o dar de comer a los enfermos laicos que no fueran católicos y se negaran a rezar ${ }^{169}$.

Al igual que se pedía la sustitución de religiosas por enfermeras, en algunas ocasiones sucedió lo contrario, como es el caso del hospital provincial de Badajoz. Los trescientos telegramas que envió la población a la diputación para que reinsertaran nuevamente a las Hermanas de la Caridad, favorecieron que la comisión gestora del mismo, acordara que las religiosas ocuparan las plazas de nueva creación tras haber sido obligadas a abandonar los establecimientos provinciales de beneficencia al inicio de la República ${ }^{170}$.

El doctor Bastos en sus memorias reflejaba esta movilización de las enfermeras laicas ya que le afectó directamente, debido a que su mujer trabajaba como enfermera a su lado en todas las intervenciones quirúrgicas sin poseer ningún título o certificado que avalara su formación. Abandonó su puesto como médico en el Instituto Rubio tras una protesta de las enfermeras contra su mujer: "Acusándola de suplantarlas en la ayudantía de las operaciones y exigiendo que se le prohibiera trabajar a mi lado en el pabellón Romanones"171.

La Ley de Confesiones y Congregaciones religiosas no afectó especialmente a las monjas dedicadas al cuidado de los enfermos, ya que no se especificaba la prohibición de trabajar en hospitales ni de ejercer como enfermeras, a diferencia de

\footnotetext{
${ }^{168} A B C, 3$ de abril de 1935, Substitución de las monjas del hospital de Logroño por enfermeras, p. 21. ${ }^{169} A B C, 11$ de abril de 1934, La campaña infamante contra las Hermanas de la Caridad, p. 17.

${ }^{170} A B C, 21$ de marzo de 1935, Las hermanas de la Caridad vuelven a prestar sus servicios en el Hospital de Badajoz, p. 32.

${ }^{171}$ BASTOS ANSART, M: op.cit., p. 282.
} 
lo que sucedió con la enseñanza. Como se ha señalado, las Hermanas de la Caridad podían cursar los estudios de enfermeras en Cruz Roja y trabajar en sus centros asistenciales. Eso sí, con la llegada de la Segunda República se empezó a exigir a las religiosas estar en posesión del título oficial para poder ejercer la profesión y a la hora de cursar los estudios no podían superar en número a las alumnas enfermeras laicas de la institución. El cargo de superiora se mantuvo a pesar del anticlericalismo republicano y continuó ejerciendo el mismo papel de supervisión sobre las damas y enfermeras de Cruz Roja ${ }^{172}$.

En general la República conservó en los diferentes centros asistenciales a las religiosas, no tanto por sus caritativos cuidados y la disciplina de su labor, sino por motivos económicos, ya que en caso de sustituirlas, tendrían que contratar más enfermeras profesionales y pagar mejores salarios:

Las religiosas desempeñan en un hospital servicios de verdadera enfermera, cuyos haberes, en caso de ser sustituidas, no podrían ser semejantes a los de una vulgar doméstica que acredita por sus servicios, además de su sustento, una mensualidad como mínimum, de 50 pesetas. Una enfermera titular que trabajase ocho horas diarias, debería percibir, además de la alimentación, unas cien pesetas mensuales como mínimum. Las hermanas de la caridad trabajan el máximo de horas, que muchas veces llegan a diecisiete, y para llevar a cabo el servicio que realiza una religiosa serían necesarias dos enfermeras durante el día y una con doble sueldo durante la noche ${ }^{173}$.

Esta demanda de enfermeras laicas y los cambios políticos que afectaron a las mujeres, se tradujo en un aumento del número de profesionales tituladas a lo largo de la República cuyo diploma les abría las puertas al mundo laboral y a la independencia económica. El número total de alumnas inscritas para la enseñanza de

\footnotetext{
${ }^{172}$ CRUZ Roja EsPaÑola: Reglamento del Hospital Central de la Cruz Roja Española ...: op.cit., p. 22.

${ }^{173}$ La Vanguardia, 11 de octubre de 1931, La asistencia hospitalaria, p. 13.
} 
enfermeras pasó de 62 en el curso de $1929-1930$ a 1.776 en el de $1932-1933^{174}$ (ver anexo VIII).

\subsection{Enfermeras visitadoras: importancia socio-política para la higiene}

\section{y la Salud Pública}

Las enfermeras visitadoras eran las encargadas de mejorar las condiciones sanitarias de la población, colaborar en el diagnóstico de la enfermedad a través de la observación y contacto directo con el enfermo, y administrar el tratamiento adecuado. Debían tener formación específica, centrada sobre todo en los conocimientos sobre el contagio por contacto de la enfermedad y su pronóstico, la transmisión por vía directa e indirecta y medidas de higiene, además de dominar los procedimientos técnicos como toma de temperatura, curas, aseo y limpieza del enfermo $^{175}$.

Durante la Segunda República, la figura de la enfermera visitadora alcanzó gran proyección debido al impulso e interés suscitado por la salud pública, sobre todo por el avance en medicina social. España caminaba hacia una sanidad integral con una participación activa del Gobierno ${ }^{176}$.

La nueva normativa republicana unida a la formalización de los servicios de higiene infantil encaminados a dar mayor cobertura sanitaria hizo necesaria la contratación de enfermeras especialistas capacitadas para cubrir las nuevas necesidades sociales:

\footnotetext{
${ }^{174}$ INE, Anuario Estadístico de España, fondo documental 1931-1940.

Consultado en: http://www.ine.es/inebaseweb/25687.do

${ }^{175}$ CABOT, Richard: Ensayos de Medicina Social (La función de la inspectora a domicilio). Calpe, Madrid, 1920, pp. 64-65.

${ }^{176}$ NÁJeRA ANGUlo, Luis: Libro de actas del Primer Congreso Nacional de Sanidad (6-12 mayo de 1934). Tomo I, Gráfica Literaria, Madrid, 1935, p. 56.
} 
[...] Reconocida hoy la necesidad de las Enfermeras Visitadoras (Instructoras Sanitarias) en todo Instituto en que se vaya hacer profilaxis, carecemos de ellas en la inmensa mayoría, y eso da lugar a que la actividad sanitaria sea débil y en los servicios la mera acción clínica prepondere. Precisan más, muchísimas más, y con urgencia. Mientras no haya un número de Instructoras suficiente, la organización sanitaria será débil, falta de un órgano tan importante. El Ministro, el Subsecretario y yo hemos pensado muchas veces en el modo de aumentar su número rápidamente. Acaso no sea difícil conseguirlo $[\ldots]^{177}$.

Esto propició un aumento de la demanda del número de escuelas de enfermeras visitadoras de higiene maternal e infantil ${ }^{178}$.

A partir del Primer Congreso Nacional de Sanidad las enfermeras visitadoras pasaron a denominarse Instructoras Públicas o de Sanidad. A las encargadas de trabajar en los servicios de higiene infantil se las exigía especializarse en puericultura a través de un curso de nueve meses en la Escuela de Puericultura en el que estudiaban higiene social y rural ${ }^{179}$.

En 1935 se aprobó la insignia y carnet para el cuerpo de instructoras sanitarias que dependía de la subsecretaría de Sanidad. La expedición de los mismos estaba a cargo de la Asociación Profesional de Visitadoras Sanitarias y servía para que las profesionales pudieran acreditar su condición de funcionarias de sanidad ${ }^{180}$.

Durante la Segunda República se convocaron distintos concurso-oposición para visitadoras en los que se exigía a las aspirantes ser españolas menores de cuarenta y un años y mayores de veinte ${ }^{181}$, además de ser aptas para el servicio, sin antecedentes penales ni enfermedades contagiosas ${ }^{182}$.

\footnotetext{
${ }^{177}$ La visitadora sanitaria, $\mathrm{n}^{\mathrm{o}} 1,4^{\mathrm{o}}$ trimestre 1934, p. 11.

${ }^{178} A B C, 15$ de abril de 1933, Conclusiones del Congreso de Pediatría en Granada, p. 33.

${ }^{179}$ NÁJERA ANGULO, L: op.cit., pp. 295-296.

${ }^{180}$ Gaceta de Madrid, $\mathrm{n}^{\mathbf{0}}$ 313, 9 noviembre 1935, Orden disponiendo se expida al personal de Industrias de Sanidad carnet e insignias con arreglo al modelo, que se inserta, p. 1129.

${ }^{181}$ En otros concursos como el destinado a cubrir cincuenta plazas en dispensarios antituberculosos de Madrid y provincia, las aspirantes debían ser mayores de veintiún años y menores de treinta y cinco.

182 Gaceta de Madrid, $\mathrm{n}^{\mathrm{o}}$ 234, 21 agosto 1932, Dirección general de Sanidad.- Convocando a concursooposición para proveer 21 plazas de Enfermeras visitadoras, p.1375-1376.
} 
También se las pedía estar en posesión de uno de los siguientes títulos: Practicante de Medicina, Enfermera de Facultad, Cruz Roja, Instituto Rubio, Casa de Salud Valdecilla o de Instituciones similares. Las interesadas debían presentar en el registro el certificado de nacimiento, certificado de aptitud física y negativa de enfermedad contagiosa, certificado del registro central de penados y rebeldes, los títulos profesionales y documentación referente a méritos de trabajo, estudios, etc. ${ }^{183}$. También se convocaron plazas como alumnas en centros antituberculosos, en ese caso los méritos y servicios de interés que se valoraban positivamente a la hora de cubrir las vacantes era que las aspirantes estuvieran en posesión del título facultativo, de Maestra Nacional, de Bachiller, de Perito o Profesor Mercantil o el de Taqui-mecanografía ${ }^{184}$.

\section{La Asociación de Enfermeras Visitadoras}

La Asociación Profesional de Enfermeras Visitadoras Sanitarias se fundó el 25 de marzo de 1934 en uno de los locales de la Escuela Nacional de Sanidad ${ }^{185}$. El órgano oficial de la asociación fue La visitadora sanitaria ${ }^{186}$, revista trimestral que comenzó su edición en 1934 y que sirvió para describir las funciones de la asociación y el trabajo de las enfermeras visitadoras ${ }^{187}$. El objetivo principal de este boletín era llevar a las asociadas, sobre todo a las que estaban en los centros rurales, las noticias y artículos de interés sobre la profesión, además de buscar "el espíritu de unión, seriedad y disciplina ya logrado en otros sitios y que constituye, junto con los

\footnotetext{
${ }^{183}$ La Cruz Roja. no 363, septiembre 1932, pp. 560-561.

${ }^{184}$ Gaceta de Madrid, no 46, 15 febrero 1933, Dirección general de Sanidad.- Convocando a un curso para proveer 50 plazas de Enfermeras alumnas con destino a los Dispensarios antituberculosos de las provincias que se mencionan, p. 1261.

${ }^{185}$ La visitadora sanitaria, $\mathrm{n}^{\mathrm{o}} 1,4^{\mathrm{o}}$ trimestre 1934 , p. 3.

186 Se han consultado en la Biblioteca Nacional de España (BNE) los siguientes volúmenes de $L a$ Visitadora Sanitaria: Año 1, $\mathrm{n}^{\mathrm{o}} 1$ (4. Trimestre 1934), año 2, $\mathrm{n}^{\mathrm{o}} 2$ (1. Trimestre 1935), $\mathrm{n}^{\mathrm{o}} 3$ (2. Trimestre 1935), $n^{\circ} 4$ (3. Trimestre 1935), $n^{\circ} 5$ (4. Trimestre año 1935).

187 Mercedes Mila y Nolla fue presidenta de la asociación y directora de la revista La visitadora Sanitaria. Ese mismo año Milá obtuvo el cargo de Inspectora-Secretaria de la Escuela de Instructoras de Sanidad, además de formar parte del profesorado de la Escuela Nacional de Sanidad. En 1935 Milá fue nombrada por concurso Jefe Sección Juvenil de Cruz Roja Española.
} 
conocimientos técnicos, base principal para el progreso y desarrollo de la profesión $[\ldots]^{\prime, 188}$.

El boletín, además de incluir artículos técnicos, permitía la colaboración de las asociadas, también publicaba información de interés laboral como datos sobre plazas vacantes, oposiciones, exámenes, conferencias y congresos, y sirvió como órgano de comunicación entre las mismas ${ }^{189}$.

La Asociación entendía como enfermera visitadora sanitaria a aquellas profesionales cuyas actividades se desarrollaban en el campo de la medicina preventiva y únicamente admitían a aquellas cuya conducta moral y profesional fuera intachable, con el objetivo de velar por el prestigio del cuerpo. Desde un principio la asociación defendió los derechos de las enfermeras visitadoras, entre ellos la igualdad de sueldos dentro de la misma categoría profesional y exigir que las plazas de enfermeras en preventorios antituberculosos fueran cubiertas por visitadoras pertenecientes a Sanidad Nacional, además de solicitar que las plazas de los centros de higiene infantil dejaran de estar cubiertas por personal sin titulación de puericultoras y "...Que no se permita que señoritas que no sean Enfermeras Visitadoras ocupen puestos y perciban honorarios como si lo fueran [... $]^{\prime 190}$.

La visitadora sanitaria también publicó artículos que hacían alusión a las cualidades físicas y morales que debía reunir una buena enfermera y por lo tanto la visitadora sanitaria. Cabe destacar que debían ser humanas, con una gran fortaleza interna para comprender a los enfermos, acompañada de educación, simpatía innata, inteligencia, caridad y bondad ${ }^{191}$. El Comité de Educación del Consejo Internacional de Enfermeras exigía cumplir a las profesionales:

\footnotetext{
${ }^{188}$ La visitadora sanitaria, $\mathrm{n}^{\mathrm{o}} 1,4^{\mathrm{o}}$ trimestre 1934, p. 1 .

${ }^{189}$ La visitadora sanitaria, $\mathrm{n}^{\mathrm{o}} 1,4^{\mathrm{o}}$ trimestre 1934, p. 6.

${ }^{190}$ La visitadora sanitaria, $\mathrm{n}^{\mathrm{o}} 1,4^{\mathrm{o}}$ trimestre 1934, p. 20.

${ }^{191}$ La visitadora sanitaria, $\mathrm{n}^{\mathrm{o}} 3,2^{\circ}$ trimestre 1935, p. 7.
} 
Capítulo II

Tabla 7. Requisitos que debían cumplir las visitadoras sanitarias.

\begin{tabular}{|c|c|c|c|c|c|}
\hline $\begin{array}{l}\text { Salud perfecta } \\
\text { y aceptable }\end{array}$ & $\begin{array}{c}\text { Entendimiento } \\
\text { claro, juicio } \\
\text { sereno, } \\
\text { discreción }\end{array}$ & $\begin{array}{c}\text { Perspicacia } \\
\text { y } \\
\text { penetración } \\
\text { observadora }\end{array}$ & $\begin{array}{l}\text { Resolución } \\
\text { y eficacia } \\
\text { en la } \\
\text { práctica }\end{array}$ & $\begin{array}{c}\text { Que sea } \\
\text { equilibrada y } \\
\text { tenga espíritu } \\
\text { de disciplina, } \\
\text { dominio de sí } \\
\text { misma y } \\
\text { confianza }\end{array}$ & $\begin{array}{l}\text { Conciencia de } \\
\text { su condición } \\
\text { de } \\
\text { subordinación, } \\
\text { paciencia y } \\
\text { ser sufrida y } \\
\text { firme }\end{array}$ \\
\hline $\begin{array}{c}\text { Lealtad y } \\
\text { compañerismo } \\
\text { y diligencia }\end{array}$ & $\begin{array}{l}\text { Que se haga } \\
\text { cargo de las } \\
\text { cosas, tenga } \\
\text { tacto y } \\
\text { ademanes } \\
\text { corteses }\end{array}$ & $\begin{array}{c}\text { Espíritu } \\
\text { comprensivo } \\
\text { y criterio } \\
\text { amplio }\end{array}$ & $\begin{array}{l}\text { Suavidad, } \\
\text { habilidad y } \\
\text { destreza } \\
\text { táctil }\end{array}$ & $\begin{array}{l}\text { Orden e idea } \\
\text { de } \\
\text { organización y } \\
\text { administración }\end{array}$ & $\begin{array}{c}\text { Que inspire } \\
\text { confianza a su } \\
\text { alrededor y } \\
\text { haga una labor } \\
\text { de } \\
\text { proselitismo }\end{array}$ \\
\hline
\end{tabular}

Fuente: La visitadora sanitaria, $\mathrm{n}^{\circ} 3,2^{\circ}$ trimestre 1935, pp. 9-10.

La visitadora, al igual que la enfermera, debía ser:

[...] Agradable a la vista: yendo bien peinada, impecablemente limpia, con las manos cuidadas y procurando manifestarse suavemente. Agradable al olfato: no usando jabones perfumados, ni esencias, ni nada que en este sentido pueda ser molesto. Agradable al oído, muy sensible en los enfermos: adoptando un tono de voz velado, no riéndose con estridencia. Debe andar silenciosamente y evitar todo ruido innecesario. Serenidad en su paso, armonía y dulzura en sus movimientos [...]. La puntualidad es cualidad esencial de la Enfermera, y, en realidad, la única indispensable para que inspire confianza $[\ldots]^{192}$.

Obediencia, orden, lealtad, espíritu de fraternidad y vocación eran características propias de las enfermeras visitadoras ${ }^{193}$.

\footnotetext{
${ }^{192}$ La visitadora sanitaria, $\mathrm{n}^{\mathrm{o}} 3,2^{\circ}$ trimestre 1935 , p. 11 .

${ }^{193}$ La visitadora sanitaria, $\mathrm{n}^{\circ} 5,4^{\circ}$ trimestre 1935, p. 9.
} 


\subsection{Las enfermeras: una amenaza para practicantes y matronas}

Con la llegada de la Segunda República los Practicantes pensaron que obtendrían mayores beneficios profesionales, centrados en la ampliación de sus estudios y en el reconocimiento médico y del Estado. Para decepción y frustración de estos auxiliares médicos, las enfermeras consolidaron su misión y función durante la Segunda República, además de contar con el apoyo de Sanidad y de la clase médica en general. Estos conflictos de lucha por la supremacía de los practicantes sobre las enfermeras quedaron plasmados en la prensa republicana, sobre todo en los boletines de los colegios oficiales de practicantes.

Ambas profesiones eran auxiliares de la Medicina, con distinta trayectoria profesional $\mathrm{y}$, según los practicantes, con funciones diferentes ligadas principalmente a los roles femenino y masculino. Las enfermeras no suponían un ataque directo para la profesión de matrona ya que sus funciones asistenciales eran diferentes, pero este colectivo se unió a los practicantes en la defensa por la legitimidad de sus profesiones frente a la incipiente Enfermería.

\subsubsection{Los practicantes y su enfrentamiento laboral}

La profesionalización de la Enfermería no fue aceptada por los practicantes, ya que veían a las enfermeras como rivales que estaban invadiendo su campo de trabajo (ver anexo IX). La profesión de practicante estaba consolidada en España y contaba con una amplia red de colegios oficiales con sus correspondientes órganos de difusión ${ }^{194}$. Los practicantes buscaron mayor legitimación durante la Segunda República, además de una modificación del plan de estudios, solicitaban reemplazar su nombre por el de auxiliar en Medicina y Cirugía, respaldado legalmente con una

\footnotetext{
${ }^{194}$ Se han consultado los siguientes ejemplares de prensa especialista relacionada con los practicantes: $E l$ Auxiliar del Médico, revista profesional y científica del Colegio Oficial de Practicantes de Medicina y Cirugía de Córdoba, números del 107 al 118, año 1935. El Auxiliar Médico Aragonés, número 1 a 12, año 1932, números 14, 16 a 24, año 1933. Gaceta del Practicante, Órgano de la Federación Nacional de Colegios Oficiales de Practicantes, $\mathrm{n}^{\circ} 1$ 1936. Boletín del Colegio Oficial de Practicantes en Medicina y Cirugía de Madrid y su Provincia, no 263 de 1930, no 269 a 279 de 1931, nº 280 a 287 de 1932.
} 
definición de su campo de actuación para evitar el intrusismo y conseguir sanciones para los que incurrieran en el mismo ${ }^{195}$.

El auge de la Enfermería y su consolidación en la etapa republicana impulsó a los practicantes a proponer una serie de medidas para no perder capacitación profesional ni prestigio social. Desde los colegios de practicantes se fomentó la lucha por la desaparición de la Enfermería del mundo de la Medicina y la Sanidad españolas. Los practicantes pedían que la Segunda República legislara y reglamentara el trabajo y las competencias de las enfermeras para poderse amparar en la ley a la hora de denunciar el "intrusismo" laboral cuando estas realizaban técnicas exclusivas de su profesión tales como poner inyecciones o practicar curas. Los médicos podían denunciar a los practicantes que se extralimitaban en sus funciones pero los practicantes no podían hacer lo mismo con las enfermeras ${ }^{196}$. De esta forma, solicitaban que en la Ley de Sanidad Nacional se definiera "taxativamente" la profesión de practicante, determinando con claridad y precisión sus funciones auxiliares exclusivas ${ }^{197}$.

Según los practicantes, las enfermeras debían encargarse exclusivamente de la alimentación, el aseo y la administración de medicación al enfermo, es decir, todas las labores manuales y mecánicas relacionadas con su rol de mujeres en la sociedad, prohibiéndolas llevar a cabo todo tipo técnicas: curas, vendajes, inyecciones, lavados de estómago... ${ }^{198}$ Por lo tanto, la imagen social de la enfermera seguía ligada a su condición de mujer y no tanto a la profesional. La prensa, como medio de divulgación y referente de comunicación, contribuyó a ello, ser jóvenes y guapas, abnegadas y cariñosas, fueron atributos que continuaron ligados a las profesionales $^{199}$.

\footnotetext{
195 Álvarez Nebreda, Carlos: Semblanzas de la profesión enfermera (1862-1953). Colegio Oficial de Enfermería de Madrid, Madrid, 2011, En I Asamblea extraordinaria de colegios (1931), p.548.

${ }^{196}$ Boletín del Colegio Oficial de los Practicantes en Medicina y Cirugía de Madrid y su provincia. $\mathrm{n}^{\mathrm{o}}$ 274, junio 1931, La enfermera, p. 5.

197 Álvarez NeBredA, C: op.cit., Gran asamblea de clases sanitarias (1932), p. 570.

${ }^{198}$ Boletín del Colegio Oficial de los Practicantes en Medicina y Cirugía de Madrid y su provincia. $\mathrm{n}^{\circ}$ 274, junio 1931, La enfermera, p. 5.

199 Blanco y Negro, 3 junio de 1934, Crónica del bien, Asilo Hospital del Niño Jesús, p. 154, Blanco y Negro, 8 de septiembre de 1935, Los ejercicios modernos. La aviación militar, p. 164 ABC, 20 de junio
} 
El Practicante era el único auxiliar del médico; la matrona la experta en partos normales, y la enfermera la intérprete de los preceptos domésticos, higiénicos y espirituales del enfermo ${ }^{200}$. Los practicantes se consideraban una clase auxiliar superior a las enfermeras y no entendían porqué la Sanidad española incurría en el error de copiar el sistema médico establecido en los países extranjeros, ya que en España ya existía la figura del auxiliar del médico y eran ellos los llamados a cumplir esa función y no las enfermeras. En su defensa seguían manteniendo los argumentos relacionados con su rol masculino, capaz de imponer autoridad moral a los enfermos y de cumplir de forma exacta y precisa las órdenes médicas, e incluso capacitados para actuar en caso de urgencias, mientras que las enfermeras, por el hecho de ser mujeres, no tendrían autoridad con los enfermos, pero si amor y ternura (ver anexo X). Los practicantes eran el único personal sanitario autorizado para aplicar inyecciones y realizar curas, ya que las enfermeras eran el "personal subalterno técnico de asistencia doméstica de los enfermos"201.

A pesar de sus intentos por desprestigiar la Enfermería, los practicantes vieron que durante el periodo republicano continuaron perdiendo poder a nivel sanitario en beneficio de las enfermeras, a las que seguían considerando una amenaza profesional:

[...] Existe en el intrusismo, un tercer grupo, constituido por enfermeras y Hermanas de la Caridad; las primeras intrusean en nuestra profesión protegidas por un título, que da derecho a figurar en festivales benéficos, a aparecer fotografiadas en la prensa ilustrada, luciendo un flamante uniforme o leyendo las Fábulas de Iriarte a cualquier enfermo impedido, pero no a practicar curas, ni a poner inyecciones; además, imaginaos unas manitas blancas como la nieve, finas y elegantes como recién arregladas por la manicura, maniobrando en un absceso lleno de pus y de otras materias sucias y repugnantes, o practicando un sondeo uretral en un enfermo ¡Qué horror!

de 1933, Las nuevas enfermeras de niños, p. 39, ABC, 6 de septiembre de 1935, Diputación provincial. Entrega de titulos de enfermeras, p. 45.

${ }^{200}$ El Auxiliar Médico Aragonés. n ${ }^{\circ}$, mayo 1932, p. 3.

201 ÁlvareZ NeBredA, C: op.cit., II asamblea nacional de colegios oficiales de practicantes (1934), p. 648. 


\section{Capítulo II}

A las Hermanas de la Caridad hay que perdonarlas, no son ellas las culpables; al prestar servicio en un Sanatorio, Hospital, etc., tienen que obedecer a las órdenes del Médico, y si éste les manda inyectar, tienen que hacerlo, ahora, que me voy a permitir a hacerles una advertencia.

¡Si practican el intrusismo dentro de nuestra profesión, no hacéis una obra de caridad, sino todo lo contrario! $[\ldots]^{202}$

Los practicantes llegaron incluso a dirigir una instancia escrita por el comité ejecutivo de la Federación Nacional de Colegios Oficiales de Practicantes a la dirección general de Sanidad, en la que recordaban a los inspectores cuales eran las funciones privativas de los practicantes y las atribuciones de las enfermeras. El comité ejecutivo quería delimitar, basándose en la legislación vigente, las funciones "técnicas y auxiliares" de los practicantes y las "mecánicas y domésticas" de las enfermeras. La petición enviada en 1935 seguía la línea de comienzos de la Segunda República de conseguir definir, en función del rol femenino y masculino, las funciones de la enfermera, para poder denunciar la extralimitación de las mismas. Después de exponer la base legal en la que fundamentaban su argumentación, los practicantes solicitaban en su instancia que las funciones técnico auxiliares de la Medicina y la Cirugía fueran prestadas únicamente por ellos y la aplicación de medicación tópica, el cumplimiento de las disposiciones dietéticas, la observación de las alteraciones térmicas, la conservación y recogida para su examen clínico de orinas, heces y esputos, la higiene de la habitación y aseo de las ropas, utensilios y objetos del uso de los enfermos, aparte de la asistencia moral y distracción de éstos, fueran las únicas funciones de las enfermeras ${ }^{203}$.

González Canalejo señala que fue en julio de 1935 cuando el conflicto de los practicantes con las enfermeras comenzó a disiparse, gracias al trabajo asistencial desempeñado por las primeras, la consolidación de su labor social en la Salud Pública y la lucha de las mujeres por la igualdad de derechos ${ }^{204}$.

\footnotetext{
${ }^{202}$ El auxiliar médico. Órgano Oficial del Colegio de Practicantes de Medicina y Cirugía de Córdoba. $\mathrm{n}^{\mathrm{o}}$ 111, mayo 1935, pp. 23-24.

${ }^{203}$ El auxiliar médico. Órgano Oficial del Colegio de Practicantes de Medicina y Cirugía de Córdoba. ${ }^{\circ}$ 112, junio 1935, p. 7.

${ }^{204}$ GonZÁlez CANALEJo, C: Asistencia Sanitaria, género y cuestión social en Almería ... op.cit., p. 215.
} 


\subsubsection{Matronas: colegiación y conflictos profesionales}

El 7 de mayo de 1930 quedó constituido de forma oficial el colegio de matronas, a partir de ese momento se exigió la colegiación para ejercer la profesión ${ }^{205}$. A cada colegiada se le entregaba un carnet y se le abría un expediente personal, en el que figuraba su historial científico, profesional y social, además de exigirlas el título oficial para ejercer la profesión. Su órgano de difusión fue el Boletín del Colegio Oficial de Matronas de Madrid y sus Provincias, de publicación mensual ${ }^{206}$.

En el boletín se hablaba constantemente de la lucha contra el intrusismo, la exigencia de un sueldo digno y de la unión profesional, del registro civil de los recién nacidos y su importancia para las matronas, ya que como responsables de atender el parto eran las encargadas de firmar el documento. Respecto a sus críticas y enfrentamientos con la Enfermería son menores que las realizadas por los practicantes ya que las matronas no veían un peligro directo en las enfermeras pero sí tenían en cuenta su consolidación y auge profesional dentro de la Segunda República:

[...] Ya tenemos encima el peligro que tanto se venía anunciando; ya están las cacareadas enfermeras aprestándose a la lucha dispuestas a formar su Colegio Oficial para hacer valer sus derechos; ahora es cuando hace falta más tacto para que cada uno ocupe el puesto que le corresponde; ahora es cuando nuestra unión es más necesaria, puesto que las autoridades sanitarias, lejos de ayudarnos, son las más interesadas en que nuestra clase, ya bastante vejada, acabe de hundirse; es necesario que nuestros derechos se respeten, que nuestras fuerzas se unan y que al ver que nos disputan lo que de derecho nos pertenece lo defendamos con uñas y dientes; bien que la reorganización de las clases sanitarias, al ejemplo de otros países, sea un hecho en España, pero dejando a cada uno su vida: que estas enfermeras sean lo que

\footnotetext{
${ }^{205}$ Boletín del Colegio Oficial de Matronas de Madrid y sus provincias. ${ }^{\circ}$ 5, enero 1931, p. 22

${ }^{206}$ Se han consultado todos los números del Boletín del Colegio Oficial de Matronas de Madrid y sus provincias, desde el año 1931 al 1935. Se ha encatrado información relevante para el estudio en los: $\mathrm{n}^{\circ} 5$, 6, 7, 11 de 1931, n 19, 25, 26 de 1932, nº 29, 30,31,33, 35 de 1932, nº 471934.
} 
indica su nombre; pero lógicamente pensando, nunca podrán ejercer de lo que no han estudiado, $[\ldots]^{207}$.

Las matronas proponían luchar por sus derechos profesionales y por una ampliación de sus estudios ya que veían como eran las enfermeras las que contaban con el apoyo del Gobierno y conseguían mayores logros profesionales, a pesar de ser, a los ojos de las matronas, un sector profesional "inferior" al de ellas ${ }^{208}$. La orden del 10 de septiembre de 1931 autorizaba a todas las Facultades de Medicina a establecer la formación de enfermeras profesionales teniendo en cuenta la R. O de 1915. En Barcelona en 1932 se utilizó el título de "Escuela de enfermeras especializadas para la asistencia a puérperas" lo que motivó que las matronas cursaran una instancia en el Ministerio de Instrucción Pública y Bellas Artes para evitar la nueva titulación, alejada del concepto de enfermera profesional, entendida como una especialidad que suponía una intrusión directa para las comadronas. El título no llegó a expedirse con el consiguiente alivio de las matronas ${ }^{209}$.

Las matronas utilizaron su boletín oficial como órgano de expresión de sus inquietudes profesionales, de la lucha por conseguir una mejora en su profesión, en los salarios y un mayor reconocimiento social. Formar parte del seguro obligatorio de maternidad fue uno de sus principales objetivos, que les sirvió para lograr la autonomía profesional que se las negaba por el hecho de ser mujeres:

[...] Está demostrado hasta la evidencia que las mujeres tenemos en todos los terrenos las mismas aptitudes que los hombres: prueba de ello es que cuando para la asistencia a partos no existían tocólogos, las matronas se bastaban solas, y se sabe que la primera cesárea la llevó a cabo una mujer en Inglaterra Mne. May Dunay. Pero si los estudios son limitados, no puede exigirse más; y menos censurarlo por las mismas personas que se aprovechan de que en la Facultad se expidan títulos con un reducido campo de acción $[\ldots]^{210}$.

\footnotetext{
${ }^{207}$ Boletín del Colegio Oficial de Matronas de Madrid y sus provincias. $n^{\circ} 35$, septiembre 1933, Peligro inminente, portada.

${ }^{208}$ Boletín del Colegio Oficial de Matronas de Madrid y sus provincias. ${ }^{\circ}$ 33, julio 1933, No hay que acobardarse, portada.

${ }^{209}$ La Vanguardia, 4 de mayo de 1932, Sobre un cursillo de enfermeras, p. 2.

${ }^{210}$ Boletín del Colegio Oficial de Matronas de Madrid y sus provincias. $\mathrm{n}^{\circ}$ 31, mayo 1933, Triste realidad, portada.
} 
Pedían la autorización para poder recetar ciertos medicamentos o prescribir material como gasas, algodón, alcohol o tintura de yodo y poner inyecciones hipodérmicas. Abogaban por un matrona culta, con conocimientos sobre higiene social, y una participación activa en la misma, como educadoras de madres y familiares en beneficio del recién nacido. La colegiación permitió a las matronas unificar criterios y luchar en una dirección concreta. Tras la VIII Asamblea nacional de colegios oficiales de matronas, celebrada en Valencia en agosto de 1935, se aprobaron una serie de conclusiones entre las que cabe destacar la exigencia de una delimitación entre las funciones de matronas, practicantes y enfermeras, ser la matrona el único auxiliar del médico tocólogo y que las obreras afiliadas al Seguro de Maternidad no pudieran prescindir de la matrona en ningún caso de parto ${ }^{211}$.

El Seguro Obligatorio de Enfermedad sirvió para consolidar el papel de la matrona en la asistencia sanitaria de la mujer embarazada, por eso es necesario analizar brevemente el mismo y sus beneficios.

\section{Seguro Obligatorio de Maternidad}

La Constitución de 1931 reconoció el derecho al seguro de enfermedad, por lo tanto admitió el Seguro Obligatorio de Maternidad $^{212}$, con repercusiones favorables para las trabajadoras, matronas y enfermeras visitadoras. Las beneficiarias fueron las mujeres de clase obrera, que recibieron asistencia sanitaria gratuita durante el embarazo y el parto. El seguro incluía a todas las trabajadoras entre los 16 y los 49 años y excluía a las empleadas del servicio doméstico ${ }^{213}$.

\footnotetext{
${ }^{211} A B C, 8$ de agosto de 1935 , p. 37.

${ }^{212}$ El 22 de marzo de 1929 se estableció por Real Decreto la protección de la maternidad y de la infancia, por lo tanto se sentaban las primeras bases para el Seguro Obligatorio de Maternidad. Ver CABEZA SÁNCHEZ-ALBORNOZ, Sonsoles: Legislación protectora de la maternidad en la época de la Restauración española, Madrid, Departamento Historia Contemporánea, Cuadernos de Historia Moderna y Contemporánea, Universidad complutense, 1985, pp. 148-162.

${ }^{213}$ A partir de 1934 el seguro se amplió a las trabajadoras autónomas y a las mujeres de los trabajadores inscritos en el retiro obrero obligatorio.
} 
Las aseguradas tenían garantizada la asistencia domiciliaria y la complementaría en el caso de que apareciera algún tipo de enfermedad durante el embarazo. También eran beneficiarias de un subsidio por lactancia, indemnizadas por descanso y en caso de enfermedad del hijo, parto múltiple o ausencia de trabajo. Además, se las permitía acceder de forma gratuita a todas las actividades de protección a la maternidad y a la infancia ${ }^{214}$. Los derechos del seguro de maternidad se perdían si las beneficiarias atentaban contra la vida de su hijo o lo abandonaban y si trabajaban durante el periodo de descanso establecido en el postparto ${ }^{215}$.

Dentro de la propaganda llevada a cabo a partir de la implantación del seguro se incluyó la divulgación de tipo sanitario y los preceptos generales de "maternología y puericultura",216. También se difundió el reglamento y las normas que debían cumplir. A pesar de todo, al principio existió cierta oposición, sobre todo de las obreras que por su situación no se iban a beneficiar del seguro. Posteriormente, las prestaciones no llegaron a todas las afiliadas debido al incumplimiento de los requisitos por parte de las mujeres y a la falta de coordinación entre los elementos de la sanidad pública ${ }^{217}$. Aún así, como señala Mónica Orduña, no se puede negar el avance que supuso la implantación del Seguro Obligatorio de Maternidad para el reformismo social de la Segunda República. “...Evitar que la obrera perdiera los beneficios del Seguro, por el hecho de no estar inscrita en el Régimen del Retiro Obrero por culpa del patrono, y la fijación de cantidades redondas $[\ldots]^{\eta, 218}$, son dos hechos importantes a tener en cuenta.

Como expone Dolores Ruiz-Berdún, es necesario analizar el papel de la matrona en la puesta marcha y evolución posterior del seguro. La aprobación de la Ley del Seguro de Maternidad benefició a las matronas ya que sirvió para legitimar su trabajo en los partos de las obreras, evitando así el intrusismo por parte de personal no cualificado. Por lo tanto, las matronas se encargaron de los

\footnotetext{
${ }^{214}$ El Estado era el encargado de las aportaciones, el ayuntamiento se encargaba del reconocimiento médico y las diputaciones de la disponibilidad de clínicas y hospitales.

${ }^{215}$ Boletín del Colegio Oficial de Matronas de Madrid y sus provincias. ${ }^{\circ}{ }^{5}$, enero 1931

${ }^{216}$ NÚÑEZ PÉREZ, M. G: op.cit., p. 265.

${ }^{217}$ Ibid., p. 671.

218 ORDUÑA PRADA, Mónica: Asistencia y Beneficencia Públicas, Buenos Aires, Cuadernos de Historia del Derecho 11, Ciudad Argentina, 1999, p. 35.
} 
reconocimientos de las gestantes aseguradas, de asistir los partos eutócicos, y en el caso de aparecer durante el mismo algún tipo de complicación debían avisar al médico. Estaban obligadas a realizar los cursos formativos ofertados por las entidades administradoras del Seguro de Maternidad, para garantizar la calidad asistencial a las parturientas. A pesar de todo, para Ruiz-Berdún "el Seguro de Maternidad también contribuyó a la progresiva institucionalización del parto que tuvo lugar durante el siglo XX y que, [...] redundó en la pérdida de protagonismo de la matrona como de la propia mujer $[\ldots]^{p 219}$.

Esta mirada retrospectiva a la situación profesional de las enfermeras en la Segunda República permite constatar la consolidación de la Enfermería como profesión. Las lecciones técnicas adquieren más importancia durante este periodo pero sin desligarse de la vertiente vocacional necesaria para el cuidado de los enfermos. La existencia de una mayor aceptación social del trabajo femenino encuadrado en su rol como mujeres, fomentó que las interesadas en percibir un salario se decantaran por ser enfermeras. Pero fue la Guerra Civil la que realmente impulsó la profesión debido a la gran demanda de personal sanitario femenino necesario para atender a los heridos en ambos bandos.

${ }^{219}$ RUIZ-BERDún, Dolores; GoMIS, Alberto: La matrona y el Seguro de Maternidad durante la Segunda República (1931-1936). Matronas Profesión, 15(3), pp.76-84. 
ANEXOS II 

Anexo VIII. Número de alumnas matriculadas para los estudios de enfermera en la Segunda República.

Centros profesionales y especiales de enseñanza

\section{XVII d) Enseñanza de Enfermeras}

Datos estadísticos relativos a los años académicos que se expresan

\begin{tabular}{|c|c|}
\hline$A \tilde{N} O S A C A D E M I C O S$ & $\begin{array}{l}\text { Número } \\
\text { de alumnas inscritas, } \\
\text { en total. }\end{array}$ \\
\hline 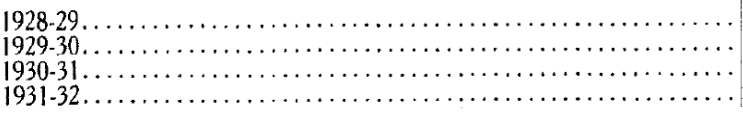 & $\begin{array}{r}35 \\
62 \\
366 \\
841\end{array}$ \\
\hline
\end{tabular}

Curso académico de 1931-32

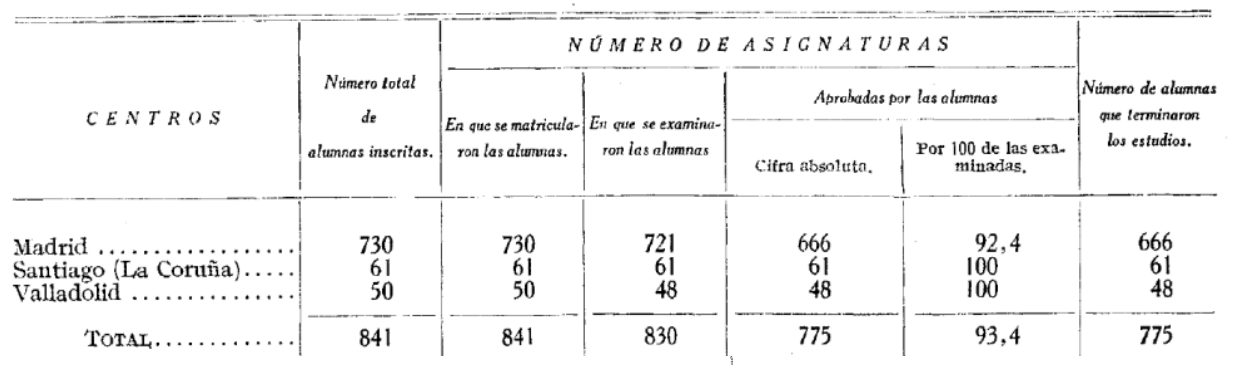

Centros profesionales $y$ especiales de enseñanza

I $d$ Enseñanza de Enfermeras

Datos estadísticos relativos a los años académicos que se expresan

\begin{tabular}{|c|c|}
\hline$A N O A C A D E M I C O$ & $\begin{array}{l}\text { Núnero } \\
\text { de alumnas inscritas, } \\
\text { en total. }\end{array}$ \\
\hline $1928-29 . \ldots \ldots \ldots \ldots \ldots$ & 35 \\
\hline $1929-30 \ldots \ldots \ldots \ldots \ldots \ldots \ldots$ & 62 \\
\hline $1930-31 \ldots \ldots \ldots \ldots \ldots \ldots \ldots \ldots \ldots \ldots \ldots$ & 366 \\
\hline 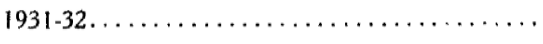 & 841 \\
\hline $1932-33 \ldots \ldots \ldots \ldots \ldots \ldots$ & 1776 \\
\hline
\end{tabular}

Curso académico de 1932-33

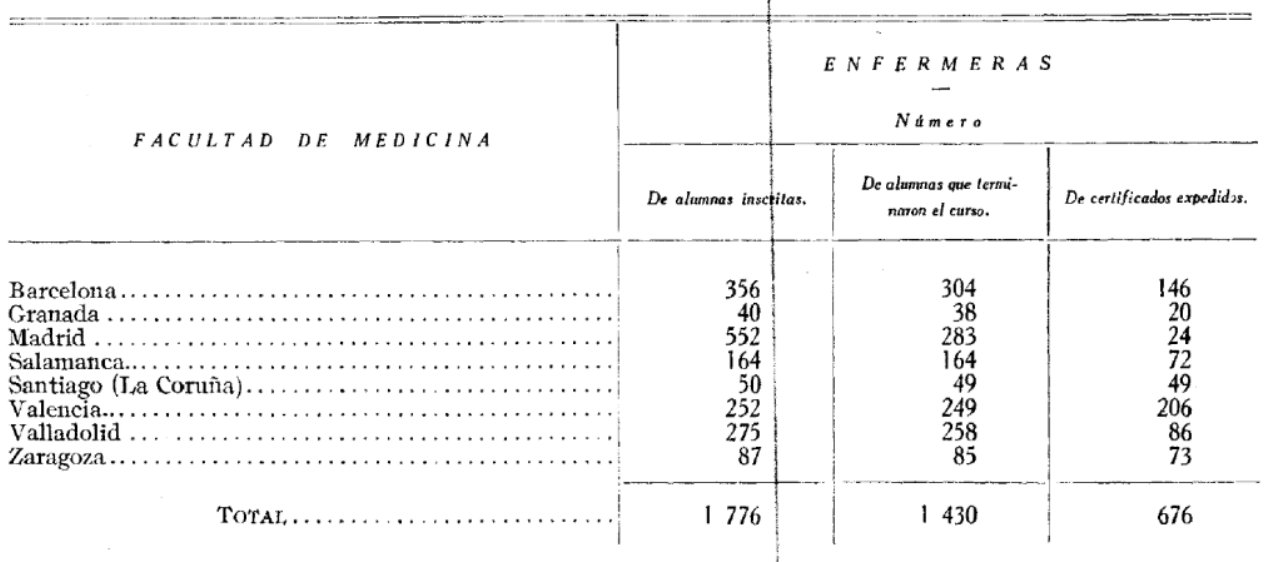

Fuente: INE, Anuario Estadístico de España, fondo documental 1931-1940.

http://www.ine.es/inebaseweb/25687.do 
Anexo IX. Conflictos con los practicantes.

\section{Por dignidad profesional}

To quiero que pasen los mionentos de jutlen'sa enıoción vividios en esstos días de regeneración política de España, sin que mi morlesta pluma los comenten.

Ansias del pueblo español de virla re meneradora, vida de dig’nificación social, vida de reorganización ciudadana y hcra suprema de libertad $y$ de justicia.

Nuestra clase profesional de Practicantos esperãoles eistá der entiorabuena, y digo esto, rorque tiengo la semguridard de que el actual Poder desharí tanta injus ticia, tanta opresión como viene parleciendo nuestra sufrida Clase.

Habrá, :quién lo durla!, Classes perseguidas y reja.las por la antigua política como los Practicantes no creo que hubo ni habrá nadie, porqua en todos los ór denes de la vida profesional se crearon al amparo, claro está, $\mathrm{y}$ con la amuencia de toda la Olase sanitaria española, comme tikores nulestros que, sin otro título facultativo, que el otorgado por el capricho de unas damas, no's dejaron jostergailos.

Se crearon las enfermerras, que fué la puñalada taidora-dígamoslo así-, que se le dlió en Fiønaña al Practicante, esas damas, desde luego, muy respetables on su vida particular, pero poco censuradas en sut vida oficial sanitaria, contaron con toda clase de complacencias y aptoyo por partle de las autoridades sa nitiarias, que, por ser vos quien sois, las dejaron hacer libremente cuanto quisieron, tirando, por no emplear otra frase más dura para nosotros, a los compañer rosı que desempeñaban mejor los puestos que ellas han venido a ocupar.

Pues, biens; esto, comn digo, lo vieron con una pasividad que ravaba en el desprecio hacia nosotros, todas las Clases españolas. Pocas fueron las voces de protesta que se alzaron en favor nuestiro. lan pocas, que sólo uncs cuantos maes-

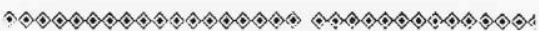

EI BOLETIN pertenece a todios Ios colegiados, que tienen el deber de aportar su colaboración, y a quienies asiste el derecho de exponer libremente sus opinienes, siean cuales fueren, sin más limitaciones que las determinadas en el $R e$ glamento, siempre, claro está, bajo la responsabilidad de su firma,

कृ. tros nurestros y defensores de la Olase nos apoyaron con el teșón caxacterístico de su sabiduría, a cuyas personası estamos y estaremos siempre muy agradlecidos.

Otro tanto puedie decirse de las Ordene religiosas. Estas, amparadas en sus hábitoss se mezclan e invadien la esfera de acción de nuestras actividadles. Pro eso, deben desaparecer también en ese aspectó y quedar limitada su acción a lo que compete a sus obligaciones, es decir, a lo puramente higiénico y al cuidarto de la alimentación y limpieza de salas en los Hospitales y Sanatorios, pero la parte profiesional de auxilios, esa drebe estar reservadia úmica y exclusinamentie a los Practicantes. A nosotros incumbe el interpretar las órdenes que recibamos de nifistros maestros y cmplinlas fielmennosotros. Dejen ya los intrusos e intursas de operar en nuestro campo, quitśndonos los movimientos profesionales y el par de nuestros hijos: prues si los dle aloumos de ellas (va cune las otras no los tifnen) son dignos de alimentarse, justo es ane nosotros, aue tenemos un TITLI, PROF]iSTONAI, die mayor o menor cuantía, tengamos más derechos.

Tuchemos por lin Clase: si hay que harer sacrificios, se hacen: todo antes aue sucumbir sin lucha y sin prestigio. Que Jos Médicos creen que diebemos estudiar nás: estudiemois en buena hora, cuanto sea necesario para mejorar ntrestra caparidlard profesicnal. Volvamos a la Universidad si hace falta: hagamos todio wnanto sea necesario por elevantos y ser dignos profesionalmentie: pero atuer por caprichos reales o ficticios de algumtais persomals se nos nostergue, eso no lo xlebemos consentir ni lo consentiremos jamás. Si no servimos. quie nos eniseñen cuan to rquieran, neso despreciarnos $y$ postergarnos como hasta ahora, no debemos tolerarlo, porque antes que eso es prefer ribile desaparecer en el orden social como tiales Practicantels.

Perrdonad, pues, estias mal escritas lineas $y$ queden en pie mis d'eseos de Clase.

Al Gobiernio actual, libre de compromisis, corressponde reparar tanta injusticia $y$ estoy serguro que seremos atendidlos ein mestras leogítimas aspirraciomes.

Os saluida a todos, vuestro comípiañero en el Servicio Sanitario de la Compañía de los Ferrocarriles del Oeste de España.

FELIPE CARRETERO

Fuente: Boletín del Colegio Oficial de los Practicantes en Medicina y Cirugía de Madrid y su provincia. №273, junio 1931, Por dignidad profesional, p. 15. 


\section{La enfermera}

\section{clandestina}

Algunos diarios de Madrid han publicado a título de anuncio la convocatoria para la matricula de enfermeras en el Hospital de San José y Santa Adela (tipo reaccionario) como hicieran en tiempos del absolutismo, cuando prevalecía la injusticia con el quebrantamiento de las leyes.

Los que sentimos en nuestra alma el espíritu puro de amor a nuestra profesión y cariño a la clase y que pensamos con la instauraciún del régimen de la justicia en una España democrática y liberal, en la que protegidos sus ciudadanos del descarado absolutismo coquetón, haciendo cumplir las leyes en vigencia, cayera quien cayera, nos hemos de sentir -lefraudados ante la repetición de hechos que en otros tiempos condenáramos.

Se dice que en régimen de justicia en el que son atendibles cuantas peticiones se eleven a los poderes siempre que sean jus tas, nadie debe tomar la justicia por su mano, y yo p egunto: ¿Es que no fueron justas, justísimas las peticiones que los practicantes elevamos al Gobierno de la República con motivo de la reorganización de la Cruz Roja? ¿Por qué no se nos atendió como era justo? ¿Qué causas pudieron determinar la oposición a que formáramos parte en cuantas Juntas y Comités se creaban? A mi juicio fué una soia: la de estar constituido por elementos, unos, reaccionarios al régimen, y otros, a la justicia social y profesional del practicante. Solamente hubo uno (representante de la Casa del Pueblo) que exgió figuráramos al menos en el Comiié central, como también figuran todas las clases e individuos de la Cruz Roja; existe, sin embargo, un dato interesante: las que llaman damas enfermeras y enfermeras profesionales tienen representación en todos los Comités, tanto centrales como permanente, etc... ¿Por qué esos distingos y prefe-

La unión hace la fuerza. Nuestro triunfo debe ser obra de todos sin que se hurte ni una sola colaboración. El clamor gereral llega a lo alto; las voces de unos cuantos se pierden en el espacio antes de llegar a su destino.

rencias? ¿Existe algo oculto que determine esta anormalidad? Pero hemos de ponerlo en claro y pese a quien pese y por encima de todo, pasando por quien fuese necesario, conseguiremos por nuestra mano lo que por justicia no se nos ha concedido, ya que, parodiando una frase muy traida estos días, si ellos tiran la silla nosotros tiraremos hasta la casa.

Es intolerable e inicuo seguir en este es- 
BOLETIN DEL COLEGIO OFICIAL

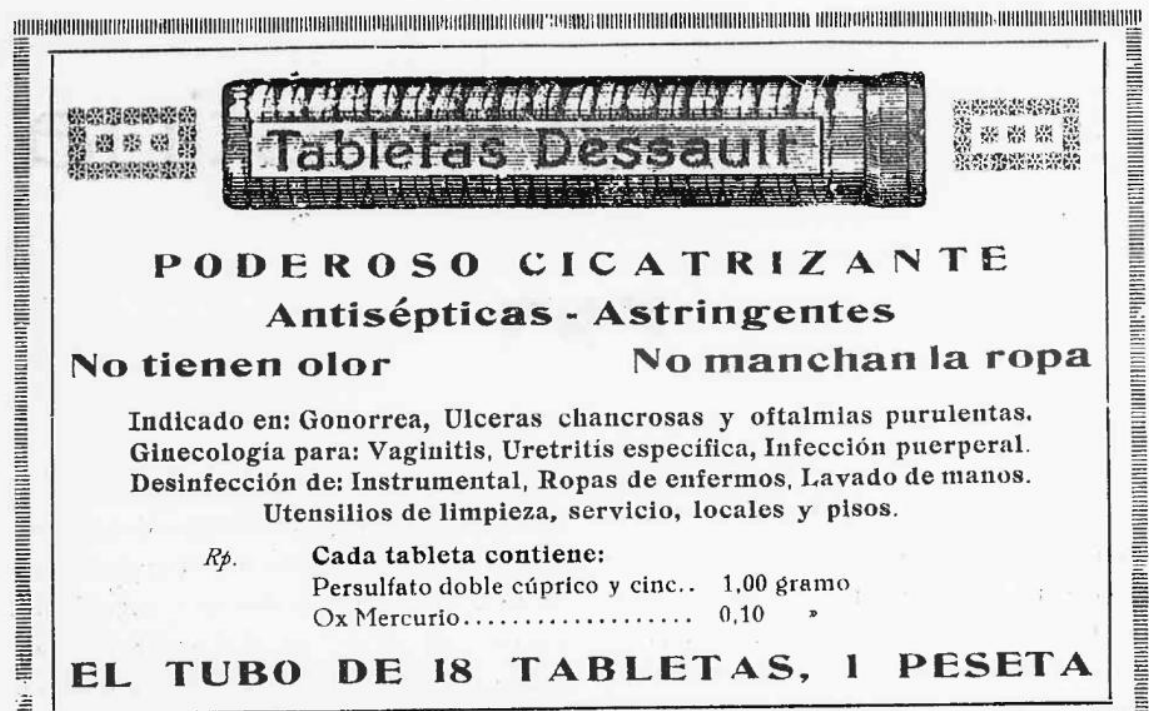

衰

tado de cosas; salen enfermeras por doquier, se las capacita por quien fuere para anxiliar en una función que ellas demuestran no conocer, y a todo esto están clamando por trabajár muchos compañeros, como todos dignos y honrados, nobles $y$ humanitarios, advirtiendo que vale más la vida de uno de éstos que toda esa pléyade de roedoras de salud y halagadoras de vicios, la mayor epidemia que puede sufrir la humanidad Existiendo una Facultad de Medicina con un profesorado gloria de la medicina patria, no se explíca que el Estado sc deje arrebatar de la manera más descarada esa preparación, esa vigilancia que debe ejercitar sobre quien por imprudencia temeraria puede ocasionar extragos en las generaciones y provocaciones al dolor. Los menesterosos, los honrados, son aquellos que quiesen vivir dentro de la ley, ganar con el sudor de su frente y con decoro el sustento diario y rechazar con honor lo que desvergonzadamente se les ofrece, prefiriendo la muerte digna a la vida deshonrada.
Nos hemos de oponer los practicantes, de una manera terminante y con toda la fuerza de la razón, a que continue este estado de cosas,

Pensamos en una España libre y próspera, mas no es el emprendido el camino a seguir, que conducirá por la dirección tomada a un estado caótico, sembrando el odio y el rencor y arrojando a la lucha a los pacíficos riudadanos que oprimidos constantemente, limitándoles el medio de sustento y haciéndoles imposible la paz deseada, para por otra parte darlo a la incapacidad, al lujo, a la vanidad, se conseguirá herirnos en lo más íntimo de nues tras conciencias, atacando nuestra dignidad profesional y ultrajando nuestro derecho.

\section{PRATICANTES}

Al efectuar cualquier compra, tened en cuenta las casas y artículos que se anuncian en nuestro BOLETIN

Fuente: Boletín del Colegio Oficial de los Practicantes en Medicina y Cirugía de Madrid y su provincia. No 281, febrero 1932, La enfermera clandestina. 
Con el título de «La mujer como enfermera», ha publicado el Dr. Usandizaga en la páøina médica de El Sol, correspondiente a los días 20 y 27 de septiembre y 4 de octubre del pasado año, una serie de trabajos que por la defensa que hace de una función secundaria en la medicina y la ofensa que diplomáticamente infiere a otra clase eminentemente técnica, también de la niedicina, requiere la rápida y urgente rehabilitación de estos meritísimos profesicnales, que justificadamence se sienten agraviados.

Nació la clase de Practicantes en Medicina y Cirugía por una imperiosa necesí dad de los tiempos; los grandes adelantos en la Sanidad se sucedían con verdadera rapidez; el médicu dedicaba la mayor parte de su tiempo a investigar con todo interés el medio más eficaz para arrebatar a la muerte sus víctimas stguras; en tanto, las funciones secundarias a éste pero también técnicas, estaban algo abandonadas; toda su pericia iba a estrellarse contra la incomprensión de los profanos; era, pues, de imperiosa necesidad la creación de un cuerpo auxiliar que, reconocido por el Estado y amparado por la ley, prestara su cooperación en hospitales, clínicas y dispensarios para que los nuevos progresos tuvieran la efectividad deseada. Al correr de los años han continuado las nuevas sorpresas en el campo de la Sanidad; sus sabios dan en ocasiones sus vidas; inoculados por el germen terrible descubierto. mueren satisfechos porque han proporcio nado con su descubrimjento una nueva defensa a la humanidad; son avances pro- pios de los hombres en su afán de superación. En las Facultades se exige al futuro médico conocimientos muy superiores a los que aprendió Hipócrates o Galeno. ¡Cómo es posible pensar que el practicante, mezclado con su maastro y consagrado como él a la ciencia, no tenga derecho también a ampliar sus conocimientos! Esta es la realidad; el mundo evoluciona para todos y a todos nos debe ser aplicada.

Sentadas estas afirmaciones del porqué de la creación de la carrera de practicante y su derecho a mejorar su caudal de conocimientos, voy a contestar muy ligéramente al Dr. Usandizaga.

Empieza manifestando que en España se tiene un concepto equivocado de lo que es la enfermera y en realidad así es, pero advirtiendo que la equivocación parte de él mismo. A la enfermera, para poder apreciar su labor sin apasionamiento y sin sentir el influjo de ella, hay que estar en otro plano distinto al del Dr. Usandizaga; hay que conocer a la mayor perfección su función a las órdenes de sus inmediatos superiơres los practicantes, y entonces, en estas circunstaneias, se podrá juzgar y ex-

Practicantes: Saquemos a la luz de nuestros debates toda iniciativa. Salgamos del cf́rculo vicioso de la discusión privada. Sugestiones, ideas, actividad incansable. He aquí el triunfo. 


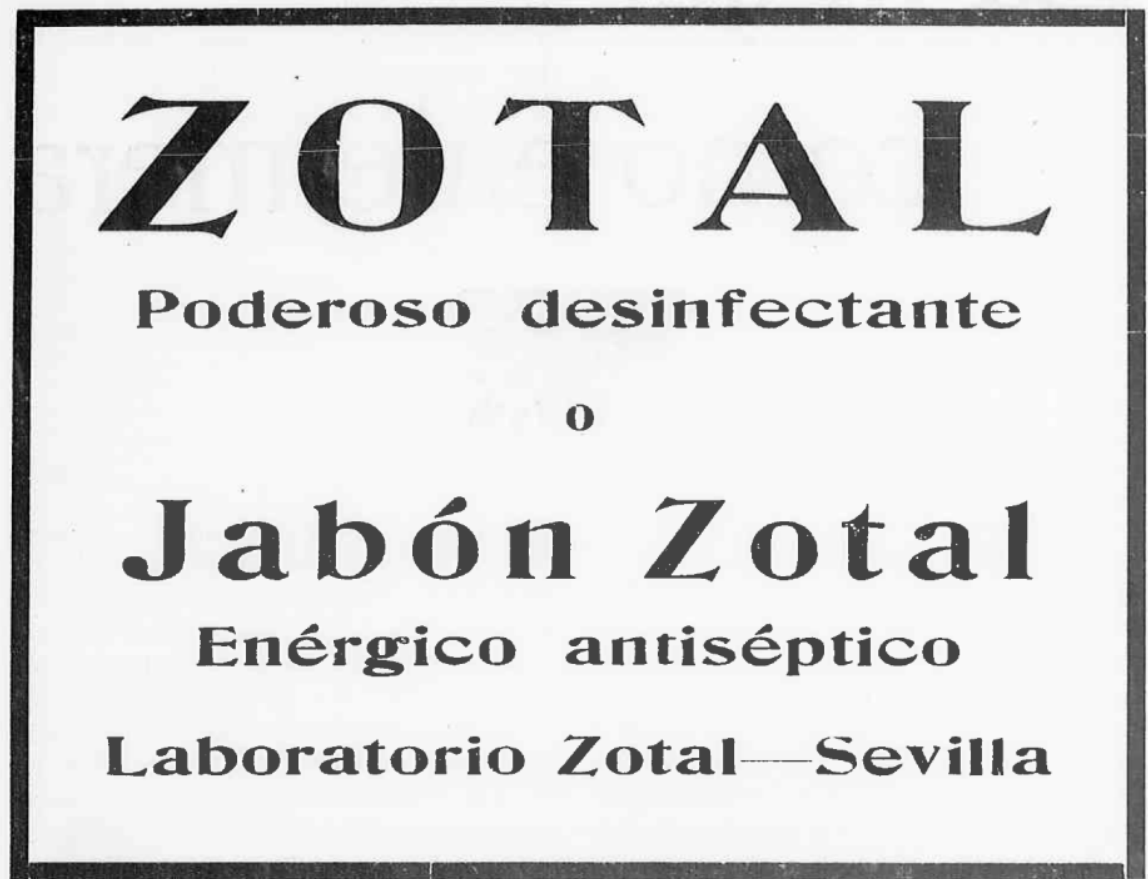

presar claramente lo que es la enfermera, cuál es la misión de la enfermera, dónde está indicada la enfermera y qué conocimientos debe poseer la enfermera; en tanto, respetable Dr., ni la enfermera tiene porqué aprender a poner inyecciones mientras exista una clase auxiliar superior a la suya ni tampoco dar esa predilección a ese grupo que $\mathbf{S}$. S. patrocina, siendo en realidad una más entre todas.

Estamos de completo acuerdo en la necesidad de que subsista un solo título de enfermera, no dando estado legal para el ejercicio libre a las damas de la Cruz Roja, Casa de Salud de Valdecillas, etc., y que sólo y exclusivamente las Facultade: de Medicina sean el único centro autorizado para la expedición de tal diploma. Pero pensar que el título o diploma de enfermera sea único en toda la función auxiliar, es la idea más descabellada que se conozca, sin base y sobre un pedestal que por su propio peso se derrumba. ¿Qué idea tiene el respetable Dr. de la justicia e igualdad? IHasta qué grado de apasionamiento llega en su defensa por un grupo de enfermeras! iQué finalidad se per- seguirá! Esa obcecación por la mujer (y yo no soy sospechoso) le prohibe ver la realidad en España. Aquí lo que se debe exigir es que exista una clase auxiliar única en la que puedan estar incluidos los dos sexos y ayudarse mutuamente en su función, mas como esa clase auxiliar ya existe legalmente, su titulo está expedido por el Estado y su función reconocida oficialmente de utilidad e interés público, no cabe (sin cometer la mayor de las arbitrariedades jamás perdonables) pensar en la nueva creación de una clase auxiliar de la medicina en la que para ello se haga monopolio de la mujer.

El grave error de los sanitarios españoles estriba en querer copiar cuanto en materia medica subsista en países extranjeros, no ya en técnica que es superior en el nuestro, sino en el nombre que se quiere dar a sus inmediatos subordinados en je rarquía. Lo que se debe exigir es que el auxiliar del médico sea un perfecto técnico, que su función sea fiel interpretación de los consejos que reciba, que su capacidad intelectual esté en relación a su importante misión y que en ausencia del 


\section{DE PRACTICANTES EN MEDICINA Y CIRUGIA}

profesor pueda resolver con plena responsabilidad cualquier caso de urgencia que se le presentare; pero es un absurdo pedir en una República de Trabajadores que sea función de un sólo sexo.

Nuestra experiencia en la lucha diaria con el enfermo, nos ha demostrado que es necesaria cierta autoridad moral para poder dominar y resolver cuestiones difíciles que se presentan, casos que la enfermera que se presentán de mujer y tal vez de madre tierna y melosa, ni tiene autoridad firme ni la obediencia que se le puede prestar es la que requieren casos extremos. En cuanto al amor y ternura para con el enfermo, el mismo médico se degradaría si afirmara que es monopolio de la mujer o enfermera. El hombre siente el cariño paternal hacia el que sufre en grado tanto como la mujer, pone por encima de sus pasiones $\mathrm{y}$ apetitos personalessu dignidad profesional y destruye su dicha en aras de la salud del enfermo, llevando hasta él su consuelo más afecto.

No existe, como se dice, problema legal de competencia entre una función auxiliar técnica y otra auxiliar mecánica; sus campos están bien separados, mas si con la ayuda de ignorantes y desaprensivos los segundos intentaran usurparles los derechos a los primeros, los practicantes haremos descargar el gran insecticida, por la justicia o por nuestra mano, sobre los parásitos visibles o invisibles que intentan destruir su organismo.

Es, pues, España una de las naciones que mejor tiene planteado el problema de la Sanidad en su parte auxiliar; por eso en cuanto se ayude moral, intelectual y materialmente al practicante, éste, por su entusiasmo en la medicina, su amor a la clase y su cariño por la humanidad, será sin ningún genero de dudas el mejor auxiliar de la sanidad europea, y España a su vez en este sector la admiración una vez más del mundo entero.

$Y$ como final y ya que públicamente lo hizo, $y^{\text {rn }}$, en nombre propio y creyendo interpretar el sentir de mi clase, públicamente le ruego, Dr. Usandizaga, rectifique su erróneo criterio, defienda dentro de su área profesional a la enfermera, no ofenda injustamente al practicante atacándole en lo más íntimo de su corazón como propoiier la extinción de su carrera, que él considera su más caro ideal, y ponga por encima de todo sentimiento y cuestiones personales si las hubiere, la tranquilidad de España, ya que, como es lógico y humano, los practicantes, antes de consentir su extinción, lucharán sin reparar en ningún sacrificio para conservar su dere cho que la ley les reconoce.

José MEDINA

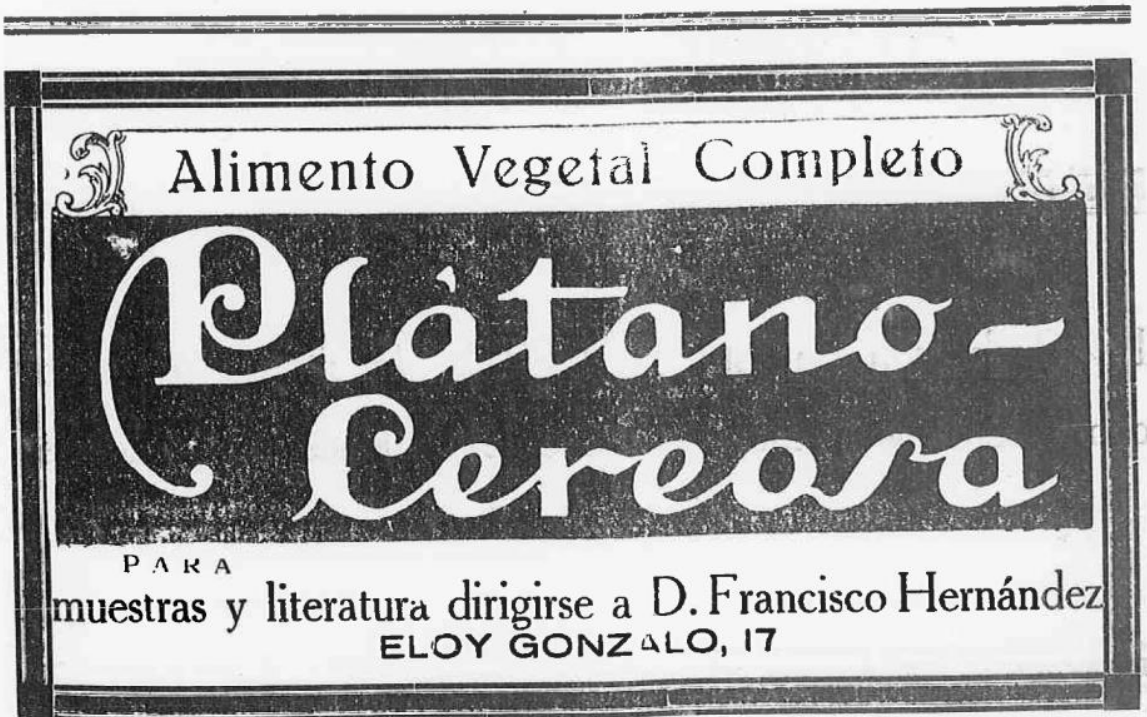

Fuente: Boletín del Colegio Oficial de los Practicantes en Medicina y Cirugía de Madrid y su provincia. $\mathrm{n}^{\circ} 280$, enero 1932, La mujer como enfermera. 

CAPÍTULO III MOVILIZACIÓN FEMENINA Y PAPEL ASISTENCIAL DE LAS ENFERMERAS EN LA ZONA REPUBLICANA 

Capítulo III. Movilización femenina y papel asistencial de las enfermeras en la zona republicana

\section{MUJERES REPUBLICANAS Y SU IMPLICACIÓN EN LA}

\section{GUERRA}

Durante la Segunda República se empezó a vislumbrar el nuevo papel que la esfera pública abría a las mujeres. Los ansiados cambios sociales y legales fueron paulatinos y poco marcados y no fue hasta la Guerra Civil cuando realmente se vio una modificación de los roles tradicionales. Durante el conflicto las mujeres asumieron con determinación el nuevo papel que las necesidades impuestas por la guerra las ofrecía, participando voluntariamente en el frente, en las fábricas, en el campo, en la asistencia a los heridos o cuidando del sustento de la familia. El objeto del presente capítulo es analizar la labor que realizaron en el ámbito sanitario, estudiando brevemente los otros roles que llevaron a cabo que permitan identificar el trabajo de las enfermeras dentro del conjunto de la amplia movilización femenina republicana.

\subsection{La mujer en el frente: el coyuntural auge de las milicianas}

Según Mary Nash, la figura de la miliciana fue un símbolo de revolución y resistencia antifascista dentro de la iconografía de guerra ${ }^{1}$. Los carteles propagandísticos, de influencia soviética, representaban a mujeres jóvenes, atractivas, emprendedoras, activas, decididas y con aire de autoconfianza, rompiendo de esta forma con la imagen tradicional femenina. Este icono respondió a las necesidades bélicas, más que a un nuevo modelo de mujer "surgida del contexto

\footnotetext{
${ }^{1}$ NASH, Mary: Rojas, las mujeres republicanas en la Guerra Civil. Taurus, Madrid, 1999, pp.93 a 96.
} 
sociopolítico"2. Para Antonia Rodrigo, las imágenes de las milicianas fueron reflejo de "orgullo y satisfacción" ante las nuevas responsabilidades, incluida la posibilidad de tomar las decisiones por sí mismas ${ }^{3}$. "En el verano de 1936, la figura de la miliciana se convirtió rápidamente en el símbolo de la movilización del pueblo español contra el fascismo", su vestimenta masculina era una reivindicación a favor de la igualdad sexual, aunque la realidad fue que las mujeres obreras prefirieron vestir de forma tradicional y femenina ${ }^{4}$ (ver imagen IV y V).

Las milicianas también alcanzaron proyección a nivel internacional, Angela Jackson compara diferentes artículos de prensa inglesa de la época que hacían alusión al nuevo fenómeno. Los periódicos afines a la República utilizaron la imagen de la mujer guerrera como propaganda para buscar el apoyo de la población, por ejemplo, la revista Woman To-day hablaba de "amazonas" y las erigía como símbolo de "autosacrificio" de la mujer española". A pesar de todo, en sus publicaciones procuraron que no hubiera una ruptura completa entre el papel de la miliciana y su rol femenino, por eso diarios como el News Chronicre, reflejaban también la función doméstica de la mujer española, insistiendo en que tenían marido, hijos y un hogar. No todos los medios de comunicación fueron partidarios de la imagen de la miliciana como heroína sino más bien como un factor desestabilizador de la sociedad. Según The Times, Catholic Herald o el Daily Express, las milicianas eran el "terror de España". Jackson especifica que: "Estaba bastante extendida la aceptación de las actitudes negativas hacia las mujeres que desafiaban los roles de género tradicionales, y no parece que ese punto de vista suscitara protestas enérgicas"

\footnotetext{
2 FAURÉ, Christine (dir.): Enciclopedia histórica y política de las mujeres, Europa y América. Diccionarios Akal, Madrid, 2010, en NASH, Mary. La acción de las mujeres en la Revolución española., pp. 569-571.

${ }^{3}$ Rodrigo, Antonia: Rosario Sánchez Mora, La Dinamitera. Cuadernos Hispanoamericanos $\mathrm{n}^{\circ} 503$, mayo 1992, p.13.

${ }^{4}$ NASH, M: op.cit., pp. 93 a 96.

${ }^{5}$ JACKSON, Angela: Las mujeres británicas y la guerra civil española. Valencia, Universitat, 2010, p. 204.

${ }^{6}$ Ibid., pp. 204-206.
} 
Conocer el número exacto de milicianas es complejo y difícil, sobre todo porque estuvieron sometidas a un proceso importante de descrédito posterior al conflicto que contribuyó a su olvido. Como señala Shirley Mangini "los textos tradicionales [historiográficos] no tratan adecuadamente el fenómeno de las milicianas", de forma que prevalece la imagen negativa de las mismas, rodeada de menosprecio y difamación, acompañado todo ello de la falta de datos estadísticos exactos sobre el número de mujeres que fueron al frente de batalla ${ }^{7}$. Símbolo de guerra y revolución, las milicianas se convirtieron en un prototipo femenino diseñado para cumplir con las necesidades bélicas, además de ser un modelo poco representativo de las mujeres en la guerra. La imagen beligerante de la miliciana se centró principalmente en captar la atención de los hombres para que cumplieran con su deber de combatientes contra el fascismo, de forma que se "instrumentalizó a la mujer con fines bélicos", ya que se buscaba desafiar a la identidad cultural masculina para que asumieran sus roles tradicionales de soldados. En realidad, su labor estuvo completamente ligada a su rol social, por eso las destinaron a realizar tareas auxiliares como cocina, asistencia sanitaria, administración y aprovisionamiento, más que en su participación en el combate ${ }^{8}$.

Memorias como las de María de la Luz Mejías Correa ${ }^{9}$ o la de Mika Etchebéhère $^{10}$, o relatos como los de Rosario La Dinamitera ${ }^{11}$, Elizaveta Parshina,

\footnotetext{
${ }^{7}$ Mangini, Shirley: Recuerdos de la Resistencia, la voz de las mujeres de la Guerra Civil Española. Península, Barcelona, 1997, p. 92.

${ }^{8}$ Las mujeres en la Guerra Civil. Madrid, Ministerio de Cultura, Dirección General de Bellas Artes y Archivos, 1989, pp. 25 a 27.

${ }^{9}$ María de la Luz Mejías Correa, miliciana de las Juventudes Socialistas Unificadas de Extremadura, concretamente de la columna Pedro Rubio. Se unió a las milicias en la defensa de Badajoz, al lado de su padre, hermano y novio, con el que contrajo matrimonio al inicio de la contienda. Ver MEJÍAs CORREA, María de la Luz: Así fue pasando el tiempo. Memorias de una miliciana extremeña. Renacimiento, Sevilla, 2006.

${ }^{10}$ Mika Etchebéhère asumió la jefatura del POUM tras la muerte de su marido, Hipólito Etchebéhère, en el frente de combate. Conocida como la Capitana, tras la integración de la milicia poumista en el ejército republicano, Mika obtuvo el grado de capitana en la división del comandante Cipriano Mera, permaneciendo de este modo a cargo de la tropa durante todo el conflicto bélico. Ver ETCHEBÉHĖRE, Mika: Mi guerra de España. Testimonio de una miliciana al mando de una columna del POUM. Alikornio ediciones, Barcelona, 2003.

${ }^{11}$ Rosario Sánchez Mora, cuando estalló la guerra en 1936 tenía 17 años, hija de obrero, había visto en su pueblo natal, Villarejo de Salvanés, la realidad que vivía el campesinado bajo el caciquismo de la época. En 1935 se trasladó a Madrid donde tuvo la oportunidad de aprender corte y confección con las Juventudes Socialistas Unificadas. Perdió la mano derecha en el frente de Buitrago por evitar herir a sus compañeros con la dinamita que debía lanzar. Tras el incidente fue destinada a la centralita telefónica de la Plana Mayor de la División, trabajo que no le satisfacía porque quería volver al frente. Posteriormente
} 
conocida como Josefa, Fidela Fernández o Julia Manzano, sirven para demostrar y esclarecer la labor olvidada que llevaron a cabo algunas mujeres durante el conflicto $^{12}$.

Hay que tener en cuenta que fueron pocas las mujeres ${ }^{13}$ que se sintieron impulsadas a defender la república a través de las armas, entrando a formar parte de las milicias populares. Dolores Ibárruri consiguió que el Quinto Regimiento contara con su batallón femenino que al igual que el masculino, se preparó y formó para combatir en el frente ${ }^{14}$. Las mujeres también recibieron instrucción militar pero en batallones femeninos y no mixtos (ver imagen VI).

Hubo milicianas que se integraron en compañías masculinas, por ejemplo, Rosario La Dinamitera, se alistó voluntariamente para ir al frente con las milicias obreras, siendo la única mujer de su expedición, destinada tras su bautismo de fuego a la sección de dinamiteros, en la que compaginaba las guardias con la fabricación de bombas y los ejercicios para probarlas ${ }^{15}$. Fidela Fernández de Velas Pérez, Fifí, también optó por la milicia porque deseaba "detener a los fascistas", siendo una de las pocas mujeres que permaneció en el frente hasta el final de la contienda. Fifí luchó en primera línea, ya que perteneció "a una tropa de choque que era siempre enviada al lugar más peligroso", también participó en "el transporte de heridos y de cadáveres" porque sabía conducir el camión destinado a dicha evacuación ${ }^{16}$. Julia Manzano conocida como Chico, fue comisaria política del batallón municipal de Madrid y cumplió su deseo de ir a la vanguardia, encargándose de "informar a los

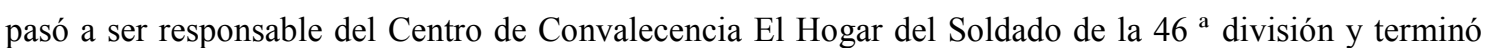
como jefa de cartería de la División, lo que la permitió acudir al frente a entregar la correspondencia a los soldados.

${ }^{12}$ STROBL, Ingrid: Partisanas: la mujer en la resistencia armada contra el fascismo y la ocupación alemana (1936-1945). Virus, Barcelona, 1996; PARSHINA, Elizaveta: La brigadista, diario de una dinamitera de la Guerra civil. La Esfera de los Libros, Madrid, 2002; MEJ́As CoRREA, María de la Luz: Asi fue pasando el tiempo. Memorias de una miliciana extremeña. Renacimiento, Sevilla, 2006; ETCHEBÉHÈRE, Mika: Mi guerra de España. Testimonio de una miliciana al mando de una columna del POUM. Alikornio ediciones, Barcelona, 2003;

${ }^{13}$ Mary Nash señala en su trabajo que fueron una minoría las mujeres que optaron por ser milicianas.

14 GINARD I FÉRON, David: MATILDE Landa, de la institución libre de enseñanza a las prisiones franquistas. Flor del Viento, Barcelona, 2005, pp. 39-40.

${ }^{15}$ RODRIGO, A: op.cit., pp. 15-16.

${ }^{16}$ STROBL, I: op.cit., pp. 51 y 53. 
soldados sobre los acontecimientos del frente y sobre la evolución política", además de impartir cursos de alfabetización y cursillos de política ${ }^{17}$.

Otro ejemplo de mujer decidida a ir al frente fue el de Elizaveta Parshina. Su destino en el Estado Mayor de aviación no acababa de satisfacer sus deseos de ayudar y participar activamente en la defensa de la República, de forma que sus primeros meses en España en el aeródromo de Albacete le resultaron tediosos. A finales de 1936 consiguió un nuevo destino como intérprete del XIV Cuerpo de Guerrilleros del Ejército Republicano, conocidos como los Niños de la Noche, siendo el enlace y la principal vía de comunicación entre el jefe del destacamento de origen Ruso, Artur Sprogis, consejero de asuntos de inteligencia militar del Ejército Republicano, y la brigada formada por campesinos y mineros andaluces ${ }^{18}$. La alegría de ser la elegida para desempeñar esa labor queda plasmada en su relato:

Corrí a mi habitación para prepararme, aunque no tenía nada que recoger, simplemente quería tener en las manos mi gabardina de viaje y convencerme de que no era un sueño, de que realmente me iba al frente. Estaba feliz, aunque tenía que reconocer que en mi obsesión por ir al frente no había mucha lógica. Ni siquiera sabía disparar y, probablemente, sólo sería un estorbo para mis nuevos compañeros. ${ }^{19}$

Elizaveta permaneció al lado de los combatientes como un soldado más acompañándolos en todas las misiones independientemente de lo peligrosas que fueran, principalmente detrás de las líneas enemigas ya que perteneció a un grupo de reconocimiento encargado de minar puentes y vías de ferrocarril para cortar la comunicación en la zona sublevada. Ser la única interprete la obligó a "permanecer junto al jefe del destacamento" siempre que "quedara con vida un solo combatiente" ${ }^{\prime 20}$. Otras mujeres desempeñaron la misma labor que Elizaveta en el Ejército republicano, tal fue el caso de Ludmila, que sufrió un envenenamiento del que consiguió salvarse, o Masha Levina, intérprete del consejero del frente, el

\footnotetext{
${ }^{17}$ STROBL, I: op.cit., p. 63.

${ }_{18}^{18}$ PARSHINA, E: op.cit., pp.10-30.

${ }^{19}$ Ibid., p. 24.

${ }^{20}$ Ibid., p. 267.
} 
coronel V. I. Kiselev ${ }^{21}$. Ellas fueron algunas de las jóvenes rusas de la misión militar soviética enviadas a España "dispuestas interiormente a sufrir penalidades, peligros, e, incluso, esos instantes terribles que llaman la muerte"22.

Ingresar en la milicia implicaba adoptar el "atuendo guerrero" de los milicianos $^{23}$, para ello se cortaron el pelo, lo cubrieron con Kepis y se vistieron con monos azules iguales a los de los hombres ${ }^{24}$. El uniforme revolucionario o miliciano rompió con la forma de vestir tradicional de las mujeres. Nash señala cómo la "indumentaria masculina" disminuyó las "diferencias sexuales en busca de un estatus más igualitario", a pesar de todo fueron pocas las que optaron por este tipo de uniforme ${ }^{25}$. Las milicianas destinadas al frente recibieron "un mono, un gorro, plato, cubierto, sujetos por una anilla, además de unas cartucheras, municiones y un fusil" ${ }^{26}$. Que una mujer vistiera igual que un hombre y asumiera los mismos papeles que él, unido al hecho de que algunas prostitutas se unieron a la milicia y a la propaganda del Gobierno que culpaba a las mujeres y su promiscuidad del contagio de enfermedades venéreas que ocasionaban bajas en el frente, sirvió para devaluar el papel de las milicianas:

Nos acusaban a las milicianas de ser prostitutas o mujeres que se acostaban con todos y que contagiaban enfermedades venéreas. Alguna habría, no digo que no. Pero eso era una calumnia para la mayoría de los casos de las milicianas que luchábamos valientemente en el frente. Yo fui a la milicia por convicción, pero sobre todo por necesidad de seguir a mi padre, a mi hermano y a mi marido. Como muchas otras seguí a la milicia para no quedar sola en el otro lado del frente. Y si había contagios de venéreas, digo yo que tanta culpa tendrían los hombres como las mujeres, sobre todo los de retaguardia, y estando de permiso, se iban a los burdeles. Sin embargo, nos culparon sólo a nosotras, las milicianas. Y todo porque había

\footnotetext{
${ }^{21}$ PARSHINA, E: op.cit., p.31 y p. 213.

${ }^{22}$ Ibid., p. 35.

${ }^{23} A B C, 1$ de agosto de 1936, p. 37, Foto milicianas.

${ }^{24}$ Bingham DE UrQuidi, Mary: Misericordia en Madrid. B. Costa-Amic Editor, México, 1975, p.53.

${ }^{25}$ FAURÉ, C (dir.): op.cit., En NASH, M: op.cit., p. 570.

${ }^{26}$ RodrigO, A: op.cit., p. 16.
} 
mucho machismo y los hombres tenían miedo de que las mujeres dejaran la cocina y la colada para irse al frente a luchar ${ }^{27}$.

Según Fifí el mono azul fue un "traje de honor" para los hombres, mientras que para las mujeres se convirtió en un "símbolo de prostitución", totalmente falso y alejado de las mujeres que lucharon en las "trincheras tan sucias y empiojadas" como el resto de milicianos ${ }^{28}$. Además de ser calumniadas, las milicianas sufrieron en ocasiones un trato vejatorio por parte de las propias mujeres que las insultaban y trataban de prostitutas ${ }^{29}$, esa devaluación fue más agresiva y mayor en el bando de los sublevados. Como exponía Rosario La Dinamitera "el asombro de los fascistas fue tan grande que nunca entendieron lo que realmente representaba la participación de la mujer en la guerra" ${ }^{\prime 30}$.

El papel de las milicianas en algunas ocasiones estuvo ligado a su rol de mujeres, Mika lo reflejaba así en sus memorias cuando hablaba de la llegada a su unidad de dos chicas procedentes de la columna Pasionaria, renegadas porque únicamente las habían dejado lavar platos y ropa y no se habían molestado en dejarles un fusil ${ }^{31}$. A diferencia de lo que sucedía en otras unidades, en la columna del POUM, al mando de Mika, no se hacían diferencias entre hombres y mujeres, tenían los mismos derechos y deberes, las milicianas no eran "criadas", habían ido al frente a luchar por la revolución ${ }^{32}$ y no a "morir con un trapo en la mano"33. María de la Luz explicaba que "su trabajo en la milicia era como el de otro miliciano cualquiera" ${ }^{34}$, aprendió a cargar y descargar un arma rápidamente, igual que el resto de su compañeros que "tampoco sabían mucho más" que ella ya que ninguno era militar $^{35}$. Fifí se sintió un hombre más en su batallón, cocinaban por turnos, sin hacer diferencias, explicaba que fueron tratadas como un miliciano más porque ellas se

\footnotetext{
${ }^{27}$ MeJÍAS CORREA, M. L: op.cit., p.88.

${ }^{28}$ STROBL, I: op.cit., p. 54.

${ }^{29}$ MEJÍAs CORREA, M, L: op.cit., p. 79.

${ }^{30}$ RoDRIGO, A. op.cit., p. 26.

${ }^{31}$ ETCHEBÉHÈRE, M: op.cit., p. 73.

${ }^{32}$ Ibid., p. 39.

${ }^{33}$ Ibid., p.74.

${ }^{34}$ MejÍAs CORREA, M. L: op.cit., p. 66.

${ }^{35}$ Ibid., p. 67.
} 
comportaban igual que ellos, incluso fueron "más valientes que los hombres, más resistentes", capaces de aguantar más, incluido el dolor físico ${ }^{36}$.

El principal problema no fue que las mujeres no supieran manejar un arma, sino que no se las entregaba una: "Claro que sabemos, y hasta desmontarlo, engrasarlo, todo (...). También sabemos llenar cartuchos de dinamita"37. Desde la prensa se podía observar la ambivalencia del nuevo rol, de forma que contrastan las imágenes de milicianas en el frente con sus fusiles, aprendiendo su manejo ${ }^{38}$, y las que plasmaban su rol como mujeres, por eso eran comunes las fotografías que las presentaban dejando "su puesto de lucha para coser la ropa de sus compañeros", o las que explicaban que las milicianas dejaban el fusil para "entregarse a la prosaica tarea de mondar patatas", o cocinar para sus compañeros y preparar el almuerzo. Incluso llegaron a establecer "la estampa reiterada de las milicianas que lavan la ropa de sus compañeros, mientras éstos, para hacer agradable la espera, dedican a las abnegadas muchachas sus más encendidos madrigales" ${ }^{39}$ (ver imagen VII).

Las desigualdades sexuales quedaron patentes en algunas ocasiones, por ejemplo, Elizabeta explicaba que a diferencia de sus compañeros ningún soldado se atrevió a llevarla a hombros al regresar agotada de una de las misiones, estos prefirieron permanecer a su lado "incómodos" al observar sus pies descalzos. Tampoco era lo mismo desnudarse delante de hombres que de mujeres, Elizabeta relataba una misión en la que sus compañeros debían cruzar el rio y para ello tenían que quitarse la ropa. A pesar de ser noche ninguno entró en el agua hasta que ella no se retiró: "No se me podría ocurrir que mi presencia podía causar tantos problemas. Simplemente me había olvidado que yo no era un hombre..."40 La lucha por la igualdad hizo que las milicianas se tuvieran que enfrentar a situaciones comprometidas y violentas, Julia Manzano, como comisaria del batallón y única

\footnotetext{
${ }^{36}$ STROBL, I: op.cit., pp. 53-54.

${ }^{37}$ ETCHEBÉHÈRE, M: op.cit., p. 73.

${ }^{38} A B C, 2$ de octubre de 1936, p. 3.

${ }^{39} A B C, 3$ de noviembre de 1936 , p. 5; $A B C, 4$ de agosto de 1936, p. 6; $A B C, 5$ de noviembre de 1936, p. 5; $A B C, 6$ de agosto de 1936, p. 6; $A B C, 13$ de noviembre de 1936, p. 4.

${ }^{40}$ PARSHINA, E: op.cit., p. 275 y p. 118.
} 
mujer del mismo, tuvo que reprender y castigar a la tropa por abusar sexualmente de la mula de la unidad. En otra ocasión se vio obligada por un oficial a demostrar su valía y tuvo que acompañarle a un burdel, fue "una especie de heroicidad, pero completamente absurda". Julia únicamente pensaba en defenderse y hacerse valer, ya que "las mujeres en el frente tenían que ser constantemente el doble de valientes que sus camaradas masculinos" $" 41$.

Como milicianas se enfrentaron a los mismos peligros del frente que los hombres, se "batieron con el mismo coraje" 42 , estuvieron en la línea de fuego y sufrieron los continuos bombardeos, montaron guardia en las trincheras y se enfrentaron al frío, al miedo y a la muerte ${ }^{43}$ igual que sus compañeros, ya que fueron a combatir como ellos:

Cuatro mujeres jóvenes, vestidas con mono y gorro cuartelero, van con un fusil en la mano entre los muchachos de las milicias a combatir, como si fueran un hombre más. La presencia de estas muchachas es acogida con grandes ovaciones y vítores, porque al igual que sus compañeros y despreciando el peligro, se lanzan a la lucha ${ }^{44}$.

Murieron durante la contienda o fueron heridas igual que cualquier soldado republicano $^{45}$ (ver imagen VIII). Lina Odena se convirtió en un "ejemplo de heroísmo" cuando perdió la vida mientras visitaba "los parapetos de las líneas avanzadas del sector de Guadalix" ${ }^{\prime 4}$. Hambre, sed y cansancio afectaron por igual a todos los combatientes, las penurias impuestas por la guerra no concedieron privilegios a las milicianas que se guiaron siempre por el sentido del deber, dispuestas a "cumplir la última orden de su vida" 47 :

Caminar por el fondo del desfiladero se hacía cada vez más difícil y doloroso. Las piedras, sembradas por doquier, obligaban a desplazarse saltando de una a otra. Cada salto repercutía dolorosamente en los pies y en las rodillas. Las

\footnotetext{
${ }^{41}$ STROBL, I: op.cit., p. 65.

${ }^{42} A B C, 14$ de noviembre de 1936, p. 3.

${ }^{43}$ ETCHEBÉHÈRE, M: op.cit., p. 216; p. 220; p. 225.

${ }^{44} A B C, 26$ de julio de 1936, p. 34.

${ }^{45}$ MeJÍAs CORREA, M. L: op.cit., p.82.

${ }^{46}$ Juventud, $\mathrm{n}^{\mathrm{o}}$ 25, 23 de septiembre de 1936, portada.

${ }^{47}$ PARSHINA, E: op.cit., p. 80.
} 
piernas obedecían mal. Continuamente los pies no atinaban con la piedra... [...] Mi cabeza se había quedado totalmente vacía, tenía que emplear toda mi energía en colocar las piernas una tras otra. Intentaba tranquilizarme pensando que todo se acababa alguna vez. También se acabaría aquella marcha... ${ }^{48}$

Demostraron gran capacidad de organización, por eso se les encomendaron tareas complejas como "conseguir dinamita" y trasladarla al frente, la vigilancia de prisioneros o ir a las líneas enemigas a recuperar armamento y destruir el que no se pudiera transportar, además de llevar a cabo funciones como cabo furriel ${ }^{49}$.

A diferencia de otras mujeres las milicianas disfrutaron de cierta libertad e independencia:

Yo viajaba sola por la España republicana, como cuando fui a recuperarme de mi salud debilitada a Fuencaliente. Esto no era muy normal entre las mujeres de esa época. Pero entonces yo ganaba mi dinero trabajando en la milicia e iba armada. No tenía que dar explicaciones en qué gastaba mi sueldo, era joven, sin mayores responsabilidades a mi cargo y no tenía miedo de nada. $[\ldots]^{50}$

A pesar de todo, los estereotipos de la época ayudaron a confundir la imagen que tenían los periodistas de ellas, por eso a Mika se la imaginaban como a "un marimacho con trazas de soldadote", debido principalmente al hecho de que fuera una mujer la que estuviera al mando de la unidad del POUM y realizara "una tarea" que no era acorde con "las labores propias de su sexo" 51 . Mika contó con el apoyo y el respeto de su columna que se había ganado con su esfuerzo y valentía, la dificultad fue mantenerlo, ya que los milicianos veían en su Capitana los roles de la mujer como madre, esposa e hija:

-En primer lugar, yo soy la madre de todos, luego tienen derecho a ser los únicos para el querer. Por otra parte, y este aspecto es más sutil, yo soy la mujer de todos ellos. Intocable, colocada en un altar. Pero si por cualquier razón voy a ver a otros hombres, ya no estoy en el altar, ando por lo el llano, como las demás mujeres.

\footnotetext{
${ }^{48}$ PARSHINA, E: op.cit., pp. 254-255.

${ }^{49}$ Ibid., pp.69, 109, 141, 225.

${ }^{50}$ MeJÍAs CORREA, M. L: op.cit., p.87.

${ }^{51}$ ETCHEBÉHÈRE, M: op.cit., p. 214.
} 
Como ellas, puedo pecar. En una palabra, llego a ser capaz de provocar en los míos malos pensamientos. $[\ldots]^{52}$

En otras ocasiones, la prensa hizo alusión a sus características físicas y morales asociadas a su rol femenino. El $A B C$ se refería a ellas como "bellas" milicianas que luchaban en los frentes ${ }^{53}$, e incluso hablaba de su "coquetería de mujeres" ya que "se retocaban y componían con el mismo cuidado que en Madrid"54.

Ahí las tenéis, alegres, entusiastas, dispuestas al sacrificio, con la sonrisa en la boca, la serenidad en el corazón en plena conciencia del peligro que las amenaza. No se arrendan fácilmente. $\mathrm{Y}$ en su cinto el metal bruñido de las balas finge un adorno más de su coquetería femenina ${ }^{55}$.

En un ambiente bélico donde escaseaba el agua y la comida, donde el peligro, el frío y la dureza de las largas guardias en las trincheras hacían mella en hombres y mujeres, se seguía asociando al rol femenino la preocupación por estar "guapas", cosa que difiere de la realidad, ya que relatos como los de Mika, Elizabeta, María de la Luz, Rosario La Dinamitera, Fifí o Julia Manzano, dejan claro el papel real que jugaron las milicianas en la contienda. Su condición de mujer hizo que se tuvieran que esforzar más que sus compañeros para demostrar en todo momento su valía, la "coquetería" se reducía a la intimidad necesaria exigida por las características propias de su sexo, ir al lavabo o tener la menstruación suponía en muchas ocasiones un problema. Fifí explicaba que siempre llevaba algodón en los bolsillos “y cuando podía desaparecía un momentito, me cambiaba el algodón y lo echaba al fuego o lo enterraba en un agujero" sin que nadie la viese ${ }^{56}$. Julia Manzano se vendó los pechos para que no se le notaran por eso se ganó el apodo de Chico. "No se quitaba nunca la ropa de hombre" y dormía vestida sobre una manta o colchón, en muchas ocasiones esperaba a que callera la noche para buscar un arbusto y utilizarlo como improvisado lavabo. Al igual que Fifí el principal problema fue la menstruación, Julia explicaba

\footnotetext{
${ }^{52}$ ETCHEBÉHÈRE, M: op.cit., p. 252.

${ }^{53} A B C, 23$ de noviembre de 1936, p. 8, $A B C, 16$ de agosto de 1936, p. 4, $A B C, 6$ de agosto de 1936, p. 6.

${ }^{54} A B C, 6$ de agosto de 1936, p. 17.

${ }^{55}$ La Vanguardia, 2 de agosto de 1936, La actuación de las milicias femeninas, p. 10.

${ }^{56}$ STROBL, I: op.cit., p. 54.
} 
que hubo ocasiones en las que no se "podía cambiar el algodón en todo el día", de forma que la sangre seca llegó a producirle llagas en los muslos. Estar embarazada y permanecer en el frente luchando no era posible, por eso Julia decidió abortar sin que sus compañeros se enteraran, se incorporó a su puesto de trabajo al día siguiente de la intervención y fue capaz de ocultar durante cuarenta días la hemorragia producida por el mismo ${ }^{57}$. Por lo tanto, tal y como expresaba Mika, ser una mujer soldado llevaba implícito ser una "mujer sin sexo"58.

Las imágenes de inicios de la contienda en las que aparecían sonrientes milicianas con sus batallones y fusiles en alto, en el primer plano de la avanzadilla preparadas para montar guardia en el pico de una sierra, quedaron pronto olvidadas tras su retirada del frente ya que dejaron de ser portada y noticia ${ }^{59}$ (ver imagen IX). Como explica Carmen Domingo, las milicianas fueron el símbolo de la movilización antifascista al inicio de la guerra, reflejando una imagen nueva de mujer fuerte, militarizada y revolucionaria diferente a la tradicional, que tras su represión en la retaguardia quedó olvidada y pasó a ser ridiculizada y desacreditada ${ }^{60}$.

Su retirada oficial del frente comenzó en octubre de 1936, a través de una disposición militar de Largo Caballero en la que se adoptaron las primeras instrucciones, de forma que se obligó a las mujeres a replegarse a la retaguardia. De hecho, en diciembre de 1936 "se advirtió a las oficinas de enganche en el extranjero que no se admitirían mujeres”, siendo el Gobierno de Negrín, en mayo de 1937, el que las desplazó definitivamente de los frentes de combate al imponer la militarización de las tropas sin dar opción a que las mujeres estuvieran en ellas ${ }^{61}$. Nash describe como a partir de diciembre de 1936 se redujeron de forma importante

\footnotetext{
${ }^{57}$ STROBL, I: op.cit., pp. 65-66

${ }^{58}$ ETCHEBÉHÈRE, M: op.cit., p. 255.

${ }^{59} A B C, 11$ de septiembre de 1936, p. 3, $A B C, 11$ de noviembre de 1936, p. 8; $A B C, 1$ de agosto de 1936, p. 37; $A B C, 2$ de agosto de 1936, p. 9; $A B C, 14$ de octubre de 1936, portada. La Vanguardia, 6 de agosto de 1936, La lucha contra los facciosos en Castilla, p. 4; La Vanguardia, 9 de agosto de 1936, El batallón femenino de Madrid, portada; La Vanguardia, 26 de septiembre de 1936, En el frente, p.3; La Vanguardia, 27 de enero de 1937, La mujer madrileña y la lucha contra el fascismo, portada.

60 Domingo, Carmen: Nosotras también hicimos la guerra. Defensoras y sublevadas. Flor del Viento, Barcelona, 2006, pp. 38-42.

${ }^{61}$ RodríGUez Álvarez, Mikel: Mujeres en las trincheras. Historia, no 349, mayo 2005, pp. 15-16.
} 
los carteles y la propaganda destinada a las milicianas, pasando a asociare su imagen con la de mujeres "poco decentes" que no contribuían al progreso de la contienda bélica $^{62}$.

El fenómeno fue fugaz y pronto se desvanecieron las imágenes que las apoyaban. Las milicianas dejaron de ser heroínas y se vieron desplazadas por otro icono femenino, la madre combativa, protagonista de la retaguardia y no de la trinchera. La falta de apoyos políticos unida a la propaganda destinada a disuadir a las mujeres que querían acudir al frente, junto con las medidas ofíciales, impidieron la presencia de las milicianas en los frentes ${ }^{63}$. Los partidos políticos, los sindicatos y las asociaciones femeninas apoyaron conjuntamente la permanencia de las mujeres en la retaguardia y su desaparición de los frentes, aludiendo a la falta de experiencia militar, a la necesidad de su trabajo en el campo y en las fábricas, además de destacar que su papel era "poco apropiado" por tener un carácter con mayor predisposición a la paz y no a la contienda bélica ${ }^{64}$.

La desaparición de las milicianas no impidió que las mujeres continuaran desempeñando una importante labor en los frentes de batalla. Permanecieron cerca del ejército ya que fueron las encargadas de la limpieza de los cuarteles, de las cocinas, del cuidado de los heridos, además de desempeñar diferentes trabajos necesarios para el sostenimiento de la guerra, tales como el servicio de cartería o de traducción como intérpretes. De hecho, en algunas ocasiones los milicianos republicanas optaron por llevarse a las presas "al frente como cocineras, y allí estuvieron hasta el final de la guerra guisando para los soldados"

Una vez finalizada la guerra la propaganda de los vencedores potenció los atributos negativos relacionados con las milicianas, desprestigiando su labor durante el conflicto y el papel que realmente jugaron en el mismo. Relatos como los de Concha Espina fomentaron dicha imagen como ejemplo de lo que una buena mujer nacional no debía ser. La escritora las describía como "un cortejo de furias" de pelo

\footnotetext{
${ }^{62}$ FAURÉ, C (dir.): op.cit., En NASH, M: op.cit., p. 570.

${ }^{63}$ Las mujeres en la Guerra Civil. Madrid, Ministerio de Cultura, Dirección General de Bellas Artes y Archivos, 1989, pp. 25 a 27.

${ }^{64}$ FAURÉ, C (dir.): op.cit., En NASH, M: op.cit., p. 573.

${ }^{65}$ JARAÍz FrANCO, Pilar: Historia de una disidencia. Plantea, Barcelona, 1981, p. 124.
} 
y semblante ariscos, con voz agresiva llena de blasfemias e insultos, cuyo "vocabulario soez" estaba cargado de odio y envidia, ya que eran incapaces de albergar sentimientos de amor al prójimo y caridad $^{66}$. Para Cristina Segura "reconocer que las mujeres podían tener una actuación independiente y destacada en un campo asignado a los hombres, como era el de las armas, era un riesgo grave para el mantenimiento del sistema" ${ }^{\prime 67}$, por eso el trabajo de las milicianas y su verdadera labor quedó olvidada para dar paso de esta forma a una imagen errónea y devaluada de las mismas.

Las milicianas no fueron las únicas que tuvieron la oportunidad de acudir al frente, las enfermeras también lo hicieron. El hecho de ser mujeres impidió que estuvieran en los puestos de socorro de primera línea, pero sí trabajaron en los hospitales de sangre cercanos al frente y se encargaron de atender a los soldados heridos en improvisados centros asistenciales como cuevas o túneles. Los bombardeos y el fuego enemigo no impidieron que desempeñaran su labor y que continuaran presentándose como voluntarias para cuidar a los enfermos. También hay que tener en cuenta que cuando se prohibió a las milicianas su estancia en el frente una de las alternativas que se les ofertó fue la de trabajar como enfermeras a pesar de no tener formación específica en la materia ${ }^{68}$.

\footnotetext{
${ }^{66}$ EsPINA, Concha: Princesas del martirio. Ediciones Afrodisio Aguado S.A. Madrid, 1941, pp. 60-71

${ }^{67}$ ACOSTA RAMíreZ, Francisco, Coord: Conflicto y sociedad civil: la mujer en la guerra: actas de las "Cuartas Jornadas sobre la Batalla de Bailén y la España Contemporánea. Organizadas por el Ayuntamiento de Bailén. Jaén, Universidad de Jaén, 2003. En SEGURA GRAIÑO, Cristina. La guerra y las mujeres, p. 102.

${ }^{68}$ La Voz de Sanidad, no 7, 27 de julio de 1937, Escribe Gregoria Jiménez de Schneider y Sanidad Popular p. 7, n 5, 15 de junio de 1937, La camarada enfermera, p. 2.
} 


\subsection{Movilización femenina: el trabajo de la mujer en la retaguardia}

La Guerra Civil supuso un cambio en la vida social y política de las mujeres, además de impulsar su movilización, las obligó a asumir nuevos papeles. Este reajuste del rol femenino hizo que se convirtieran en un elemento clave para la República durante la guerra, ya que fueron las encargadas de sostener la economía y la seguridad familiar. Como señala Carmen Alcalde, "el activismo de la mujer republicana constituyó una etapa singular y aparte dentro del marco de la mujer española en general" ${ }^{169}$. Para Nash, las organizaciones femeninas durante la guerra coincidieron en los conceptos relacionados con el acceso de la mujer a la educación, al trabajo remunerado y su compromiso bélico, pero la pluralidad y la heterogeneidad que primaban en ellas, hicieron que no compartieran un programa común en torno a las mujeres. Todo ello unido a las distintas tendencias políticas de las organizaciones femeninas supuso una pérdida de la perspectiva de género a la hora de elaborar sus programas ${ }^{70}$.

De hecho, "las nuevas posibilidades políticas" canalizadas principalmente en la movilización femenina, siguieron fieles a los roles tradicionales de esposas, hijas y madres, encargadas del cuidado de la familia y de la casa ${ }^{71}$. Por lo tanto, a pesar de ser organizaciones femeninas, todas secundaron el rol social impuesto a las mujeres y como afirma Nash, coincidieron en la idea de que la movilización de la mujer debía ser en la retaguardia, centrada en el apoyo antifascista y el respaldo a la guerra a través de roles complementarios ${ }^{72}$. A pesar del auge asociativo durante la Guerra Civil, Anna Caballé afirma que muchas mujeres españolas quedaron fuera de este tipo de organizaciones "ignorantes de la situación social que las envolvía y condicionaba" ${ }^{73}$.

\footnotetext{
${ }^{69}$ ALCALDE, Carmen: La mujer en la Guerra Civil Española. Cambio 16, Madrid, 1976, p. 117.

${ }^{70}$ NASH, M: op.cit., pp.109-110.

${ }^{71}$ ALCALDE, C: op.cit., p. 122.

${ }_{73}^{72}$ NASH, M: op.cit., pp. 155-156.

${ }^{73}$ Caballé Masforroll, Anna: El feminismo en España. La lenta conquista de un derecho. Cátedra, Madrid, 2013, p. 213.
} 
Tabla 8. Asociaciones de mujeres republicanas durante la Guerra Civil.

\begin{tabular}{|c|c|c|c|c|}
\hline ASOCIACIONES & MISIÓN & IDEOLOGÍA & ACTIVIDADES & PRENSA \\
\hline $\begin{array}{c}\text { AMA: Agrupación } \\
\text { de Mujeres } \\
\text { Antifascistas }\end{array}$ & $\begin{array}{l}\text { Lucha contra el } \\
\text { fascismo } \\
\text { Defensa de la } \\
\text { República } \\
\text { Liberación de la } \\
\text { mujer a través de la } \\
\text { democracia } \\
\text { Incorporación } \\
\text { femenina al trabajo } \\
\text { en la retaguardia } \\
\text { Formación cultural }\end{array}$ & $\begin{array}{c}\text { Todas: integró a las } \\
\text { mujeres } \\
\text { comunistas, } \\
\text { socialistas y } \\
\text { republicanas, } \\
\text { siendo la parte } \\
\text { comunista la que } \\
\text { más peso tuvo en la } \\
\text { toma de decisiones } \\
\text { Respaldo oficial } \\
\text { del Gobierno }\end{array}$ & $\begin{array}{l}\text { Recabar fondos } \\
\text { para refugiados y } \\
\text { soldados } \\
\text { Comisión de } \\
\text { Auxilio Femenino: } \\
\text { abastecer a los } \\
\text { frentes y auxiliar a } \\
\text { los soldados }\end{array}$ & Mujeres \\
\hline $\begin{array}{l}\text { Agrupación de } \\
\text { Mujeres Libres }\end{array}$ & $\begin{array}{c}\text { Liberación de la } \\
\text { mujer de la triple } \\
\text { esclavitud: como } \\
\text { mujeres, como } \\
\text { trabajadoras y de la } \\
\text { ignorancia } \\
\text { Destrucción del } \\
\text { Capitalismo } \\
\text { Abolición del } \\
\text { Estado } \\
\text { Emancipación } \\
\text { obrera = } \\
\text { Emancipación } \\
\text { femenina }\end{array}$ & Anarquistas & $\begin{array}{c}\text { Guarderías } \\
\text { gratuitas en } \\
\text { fábricas } \\
\text { Comedores } \\
\text { populares } \\
\text { Escuelas de cultura } \\
\text { general y de oficios }\end{array}$ & $\begin{array}{c}\text { Mujeres } \\
\text { Libres }\end{array}$ \\
\hline $\begin{array}{c}\text { Unión de } \\
\text { Muchachas }\end{array}$ & $\begin{array}{l}\text { Movilización de } \\
\text { mujeres jóvenes en } \\
\text { la defensa de } \\
\text { Madrid } \\
\text { Incorporación } \\
\text { laboral femenina: } \\
\text { igualdad } \\
\text { Mejor formación: } \\
\text { profesional, cultural } \\
\text { y artística }\end{array}$ & $\begin{array}{l}\text { Controlada por } \\
\text { JSU (Unión de } \\
\text { Juventudes } \\
\text { Socialistas) } \\
\text { Se definen como } \\
\text { movimiento } \\
\text { femenino } \\
\text { independiente }\end{array}$ & $\begin{array}{c}\text { Apoyo a los } \\
\text { soldados en el } \\
\text { frente } \\
\text { Confección de ropa } \\
\text { Petición de } \\
\text { donativos } \\
\text { Impartían cursos de } \\
\text { política y cultura } \\
\text { general a las } \\
\text { mujeres, además de } \\
\text { cursos para } \\
\text { analfabetas }\end{array}$ & Muchachas \\
\hline
\end{tabular}




\section{Capítulo III}

\begin{tabular}{|c|c|c|c|c|}
\hline ASOCIACIONES & MISIÓN & IDEOLOGÍA & ACTIVIDADES & PRENSA \\
\hline $\begin{array}{l}\text { Unión de Dones de } \\
\text { Catalunya }\end{array}$ & $\begin{array}{l}\text { Incorporación } \\
\text { política de las } \\
\text { mujeres en la lucha } \\
\text { antifascista } \\
\text { Igualdad laboral }\end{array}$ & $\begin{array}{c}\text { Mujeres } \\
\text { antifascistas de } \\
\text { Cataluña } \\
\\
\text { Frente unido } \\
\text { transpolítico, } \\
\text { distintas } \\
\text { tendencias: más } \\
\text { fuerza los } \\
\text { comunistas }\end{array}$ & $\begin{array}{l}\text { Defensa de la } \\
\text { retaguardia } \\
\text { Mejora de la } \\
\text { educación y la } \\
\text { salud }\end{array}$ & Companya \\
\hline $\begin{array}{l}\text { Aliança Nacional } \\
\text { de la Done Jove }\end{array}$ & $\begin{array}{l}\text { Acceso de la mujer } \\
\text { al trabajo } \\
\text { Formación y } \\
\text { educación de la } \\
\text { mujer } \\
\text { Igualdad laboral }\end{array}$ & $\begin{array}{c}\text { Asociación } \\
\text { homóloga a Unión } \\
\text { de Muchachas pero } \\
\text { en Barcelona }\end{array}$ & & \\
\hline $\begin{array}{c}\text { Secretariado } \\
\text { Femenino del } \\
\text { Partido Marxista } \\
\text { Disidente } \\
\text { (SFPOUM) }\end{array}$ & $\begin{array}{l}\text { Atraer mujeres al } \\
\text { POUM (Partido } \\
\text { Obrero de } \\
\text { Unificación } \\
\text { Marxista) y } \\
\text { educarlas en el } \\
\text { marxismo } \\
\text { Preparación política } \\
\text { de las mujeres } \\
\\
\text { Revolución meta a } \\
\text { largo plazo }\end{array}$ & $\begin{array}{c}\text { Sección } \\
\text { dependiente del } \\
\text { POUM }\end{array}$ & $\begin{array}{l}\text { Programas de } \\
\text { alfabetización y } \\
\text { formación a } \\
\text { mujeres } \\
\text { Formación militar } \\
\text { a las milicianas }\end{array}$ & Emancipación \\
\hline
\end{tabular}

Fuente: nota 74, elaboración propia ${ }^{74}$.

${ }^{74}$ En CABrera Bosch, María Isabel; Folguera, Pilar: El feminismo en España: dos siglos de historia. Editorial Pablo Iglesias, Madrid, 1988, ver MorCILla GóMEZ, Aurora: Feminismo y lucha política durante la II República y la Guerra Civil, pp. 57 a 83. NASH, Mary: Rojas, las mujeres republicanas en la Guerra Civil. Taurus, Madrid, 1999, pp. 109 a 154. Muchachas, $\mathrm{n}^{\circ} 2$ y n 10. 
Antonia Rodrigo refleja la importancia del papel de la mujer en la guerra y cómo su colaboración contribuyó al fracaso del levantamiento militar ${ }^{75}$. Nash especifica que la situación bélica fue un "catalizador de la movilización femenina", que dio paso a una nueva imagen y a un discurso político con dos perfiles diferentes, el de la mujer luchadora "símbolo de la resistencia del pueblo frente a la amenaza fascista" y el de madre como defensora del hogar y de sus hijos desde la retaguardia. De esta forma, la guerra permitió la participación activa de las mujeres a nivel político y social, su movilización y la manifestación de sus opiniones ${ }^{76}$, ya que se unieron para luchar por la conservación de las libertades adquiridas durante la Segunda República y contra el fascismo ${ }^{77}$. Las enfermeras formaron parte de ese grupo de mujeres que participaron activamente en el conflicto, tanto en el frente como en la retaguardia, desempeñando su trabajo con celo e interés.

Las mujeres sufrieron las consecuencias de la guerra y lucharon por sus familias $^{78}$. Fueron ellas las que se encargaron de sostener a la población a través de la obtención de comida y bienes de primera necesidad, además de incorporarse a las fábricas para mantener la producción mientras el Gobierno legítimo se reorganizaba ${ }^{79}$. La propaganda republicana presentaba mujeres capaces de realizar los trabajos propios del hombre para que éstos pudieran ir al frente pero sin suplantarlos en los mismos ${ }^{80}$. Independientemente de la labor realizada, durante la guerra permanecieron los papeles asignados tradicionalmente a su rol femenino,

\footnotetext{
${ }^{75}$ Rodrigo, A: op.cit., p. 13.

${ }^{76}$ MoRAnT, Isabel: en VV.AA. Historia de las mujeres en España y América latina del siglo XX a los umbrales del XXI. Cátedra, Madrid, 2006. NASH, Mary. Republicanas en la Guerra Civil: El compromiso antifascista. pp. 123-150.

${ }^{77}$ DomingO, C: op.cit., pp. 29-31.

${ }^{78}$ Usandizaga, Aránzazu: Ve y cuenta lo que pasó en España, Mujeres extranjeras en la guerra civil. Editorial Planeta, Barcelona, 2000, p. 390.

79 Serrallonga UrQuidi, Joan. SANTIRSO, Manuel. CASAS SorIANO, Just: Vivir en guerra. La zona leal a la república (1936-1939). Ediciones UAB, Barcelona, 2013.

80 Filmoteca Nacional Española: 558. A-7724. La mujer en la guerra. Productora PCE, 1938 España, 2'8" El film especifica que la mujer quiere trabajar para que el hombre pueda ir al frente. Aparecen mujeres trabajando en el taller, en las fábricas, reparando coches, en los hospitales, en las escuelas y en el campo. Hace hincapié en que la mujer no va a quitar trabajo al hombre, que después de la guerra se necesitará el trabajo conjunto para levantar la nueva España, resalta que las mujeres no van a suplantar a los hombres en los trabajos.
} 
como madres, esposas e hijas ${ }^{81}$. Los esquemas sociales sobre el papel de la mujer no desaparecieron a pesar de su participación en el conflicto. Nash destaca que se consiguió la integración de la mujer en los ámbitos públicos de la política y la cultura, pero que fueron las organizaciones femeninas las que agruparon a las mujeres en la lucha antifascista ante el desinterés de los partidos políticos y del Gobierno. La guerra transformó la condición social de la mujer reforzando su identidad política e individual gracias a las actividades llevadas a cabo en la retaguardia, "se produjo un despertar" 82 .

Desde el inicio de la contienda se fomentó el papel de la mujer en la retaguardia y su movilización, asegurando que su lugar no se encontraba en los frentes, sino detrás de la línea de combate. Fueron ellas las encargadas de confeccionar la ropa de abrigo para los combatientes y ayudarles con su trabajo ${ }^{83}$ (ver imagen X). Aceptaron el papel impuesto y se ofrecieron como voluntarias para cualquier tipo de tarea "sin poner precio a su generoso esfuerzo" 84 .

$\mathrm{Ni}$ una sola mujer debe permanecer inactiva, aún dentro de sus faenas peculiares. Ellas pueden transformarse en nuestros mejores aliados para el saneamiento de la retaguardia, sí saben comprender que el bulista, el emboscado, y el neutral son los mayores enemigos de la causa. No basta que ellas sepan soportar estoicamente todos los sacrificios que impone la guerra, sino que son ellas las que deben estar más interesadas en que a sus compañeros e hijos, que luchan en los frentes y caen cada día en honor y gloria de nuestras reivindicaciones [...]

Ayudémoslas y ellas sabrán ayudarnos, porque de su aptitud para la lucha antifascista no hay que olvidar. Pero no olvidemos el papel de la mujer como feliz cooperadora de los hombres en todas las luchas sociales y políticas ${ }^{85}$.

81 GonZÁlez Allende, Iker: Líneas de fuego. Género y nación en la narrativa española durante la Guerra Civil (1936-1939). Biblioteca Nueva, Madrid, 2011.

${ }^{82}$ Las mujeres en la Guerra Civil. Madrid, Ministerio de Cultura, Dirección General de Bellas Artes y Archivos, 1989, p.34.

${ }^{83}$ La Vanguardia, 13 de septiembre de 1936, Para los que luchan en el frente: Llamamientos a las mujeres catalanas, p. 3; La Vanguardia, 29 de mayo de 1937, Reflejo del día, p. 2.

${ }^{84}$ Potencia. Órgano del parque automóvil del ejército del centro. Año I. Madrid, $\mathrm{n}^{\mathrm{o}} 1,1$ de diciembre de 1937, sin página.

${ }^{85}$ ¡Ofensiva! Portavoz de los obreros y campesinos de Almería y su provincia. Año I, $\mathrm{n}^{\mathrm{o}} 17,3$ de agosto de 1937 , portada. 
A pesar del valioso trabajo desempeñado por las mujeres, su reconocimiento quedó supeditado a un segundo plano, detrás del hombre y en una categoría secundaria. De forma solidaria contribuyeron al mantenimiento de la guerra, su esfuerzo quedaría a la sombra de los "valientes guerreros", aunque sabían que de "su fortaleza y su confianza dependía la resistencia de las líneas de fuego"86. Las asociaciones femeninas pedían el "reconocimiento de la mujer española que se había sacrificado tanto por la guerra, había trabajado tanto, que su nivel cultural y político había alcanzado el mismo de los compañeros" ${ }^{\text {87 }}$. La mujer durante la Guerra Civil percibió la libertad a través de las responsabilidades que adquirió pero sin olvidarse de que "las nuevas relaciones entre los sexos no estaban incorporadas a la sociedad española en general" ${ }^{\prime 88}$.

Una de las principales consignas de guerra fue "hombres al frente, mujeres al trabajo". Aunque la mano de obra femenina mantuvo la producción, existió una falta de colaboración masculina ante su incorporación al mundo laboral, monopolizado hasta ese momento por los hombres, manteniéndose "la segregación ocupacional y la discriminación salarial" ${ }^{\prime 89}$. Los hombres tenían la obligación de acudir al frente y las mujeres de dejarles partir: "Vale más ser viuda de un héroe que mujer de un miserable"90. La propaganda se centró en hacer un llamamiento masivo a las mujeres $^{91}$, eran necesarias para el sostenimiento de las ciudades y el campo. Por eso documentales como La mujer en la guerra y La mujer y la guerra, dejaron claro que las mujeres tenían que trabajar para que los hombres pudieran ir al frente, y se acompañaban de imágenes de mujeres trabajando en talleres y fábricas, reparando coches, en los hospitales, en las escuelas, en el campo y en el frente ${ }^{92}$. Por lo tanto, la propaganda republicana se centró en captar la atención de las mujeres para

${ }^{86}$ ABC, 18 de noviembre de 1936, Un discurso de María Teresa de León, p. 11.

${ }^{87}$ Muchachas, Madrid, 10 de julio de 1937, p. 3.

${ }^{88}$ MANGINI, S: op.cit., p. 92.

${ }^{89}$ Las mujeres en la Guerra Civil. Madrid, Ministerio de Cultura, Dirección General de Bellas Artes y Archivos, 1989, p 29.

${ }^{90}$ El miliciano rojo. 25 de octubre de 1936, Barcelona, portada.

${ }^{91}$ La Vanguardia, 21 de febrero de 1937, La mujer y la guerra, pp. 2 y 3.

92 Filmoteca Nacional Española, 558. A-7724 La mujer en la guerra. Productora PCE, 1938 España, 2'8”, 559. A- 7724 La mujer y la guerra. 1938, España, productora Film popular. Documental republicanos, 9'30” dirección A. M. Sol. 
animarlas a trabajar en la fábrica y el campo ya que eran mano de obra necesaria para sostener la República. Los carteles muestran mujeres decididas, fuertes y contentas de ayudar con su esfuerzo al sustento de los soldados y la población ${ }^{93}$.

Como señala Nash, la contribución de la mujer desde la retaguardia fue decisiva, aunque menos espectacular, siempre desde el rol tradicional femenino, permitiendo la supervivencia de la población civil ${ }^{94}$. En los carteles de guerra se utilizaron las imágenes tradicionales de las mujeres como amas de casa, siempre en tareas acordes con su rol, tales como: la asistencia social, sanitaria y hospitalaria y los trabajos domésticos en casa, dedicadas a cuidar los "intereses materiales y morales de los seres queridos. Las madres combativas aparecían como heroínas de la retaguardia, era el modelo imperante a imitar por las mujeres"95, que tenían que defender a sus hijos del fascismo ${ }^{96}$. Este tipo de propaganda reclamaba la maternidad, ya que insistía en la idea de que las madres eran las encargadas de suministrar soldados para el frente en la lucha antifascista, resaltando que las "Madres españolas que por saber ser españolas y querer una España independiente, libre y feliz" darían "con valentía, la sangre de su sangre, los seres más queridos", sus hijos ${ }^{97}$. Nash destaca que en este contexto las hijas carecían de importancia, ya que eran los hijos los que se presentaban como los salvadores de la República. En las imágenes de la maternidad las hijas no cobraban valor, al no formar parte del Ejército no se daba importancia a su contribución en el esfuerzo bélico. ${ }^{98}$ Como señala Iker González, la imagen de la mujer como madre fue un importante símbolo propagandístico que sirvió para "infundir valor" a los soldados en la "defensa de la

\footnotetext{
93 Centro Documental de la Memoria Histórica PS-CARTELES, 415. Alianza de Intelectuales para la Defensa de la Cultura. Taller Titulo: Ganar la batalla de la siembra de primavera es la mejor ayuda a nuestro Ejército. Editor: España. Instituto de Reforma Agraria Imprenta: Litografía S. Durá socializada, U.G.T.-C.N.T. Fechas: 1937.

Centro Documental de la Memoria Histórica PS-CARTELES, 409. Horacio, Germán (1902-1975) Titulo: Campesinos / dad vida a la tierra: otros os la dan y defienden. Editor: Asturias. Frente Popular Imprenta: Luba, Control de Litografía Fechas: 1936.

${ }_{94}^{94}$ NASH, M: op.cit., p 176.

${ }^{95}$ Ibid., p. 99.

96 Centro Documental de la Memoria Histórica PS-CARTELES, 15, Autor: Tejada, Aníbal Titulo: Defiende a tu hijo! Editor: Altavoz del Frente. Información y Propaganda para el pueblo en armas. Servicio de Mundo Obrero. Imprenta: Rivadeneyra, S.A. Fechas: 1936.

${ }^{97}$ Mutilado. Año I. no 2, 5 de agosto de 1938, p. 3.

${ }^{98}$ NASH, M.: op.cit., p. 103.
} 
Madre/Nación que se encontraba en peligro"99, que según Nash "vino a simbolizar el nuevo valor social de las mujeres y sustituyó rápidamente a la imagen más rupturista de la miliciana en armas"

Otra figura interesante de la retaguardia republicana fueron las madrinas de guerra que se encargaron de enviar cartas a los soldados del frente. Como apunta Nash, este tipo de correspondencia fue acorde con la figura tradicional de la mujer, ya que en muchas ocasiones los soldados buscaban entablar una amistad que les llevara al matrimonio. Su papel fue efímero ya que desaparecieron ante el miedo de que las cartas sirvieran para trasmitir información trascendental que pudiera perjudicar el avance de las tropas ${ }^{101}$. Carmen Ortiz y Manuel de Ramón señalan que las madrinas de guerra republicanas además de cartearse con los soldados manteniendo la formalidad en el contenido de sus misivas y hablar abiertamente de política, preferían ir al frente para ayudarles en tareas propiamente femeninas como el lavado de ropa y la preparación de comida ${ }^{102}$.

Independientemente del papel que jugaran las mujeres en la guerra, ya sea como milicianas, madres, madrinas, presas o enfermeras entre otros, hay que tener en cuenta que ellas también sufrieron la represión franquista. Fueron encarceladas por su ideología política o su participación en el conflicto bélico, sobre todo tras la derrota, sufriendo abusos físicos y psicológicos, todo ello unido a un déficit alimentario e higiénico. Como señala Fernando Hernández, con el fin de la Guerra Civil el encarcelamiento de mujeres estuvo guiado no tanto por su condición política o su ideología sino al hecho de ser madres, esposas, hijas o hermanas de hombres perseguidos por el régimen. Hernández destaca la condición de madres de un porcentaje importante de las presas durante la represión femenina de la posguerra,

\footnotetext{
${ }^{99}$ GonZÁleZ Allende, I: op.cit., p. 44.

${ }^{100}$ NASH, M: op.cit., p. 104.

101 Ibid., p. 176.

102 RAMÓn CARrión, Manuel de; Ortiz SÁnChez, Carmen. Madrina de guerra. Cartas desde el frente. La Esfera de Libros, Madrid, 2003, pp. 59-63.
} 
que entraban en la cárcel embarazadas y parían allí a sus hijos en condiciones deficitarias de higiene y personal sanitario ${ }^{103}$.

Dentro del grupo de mujeres republicanas encarceladas durante la Guerra Civil cabe resaltar la experiencia de Carlota $\mathrm{O}^{\prime} \mathrm{Neill}^{104}$ en la prisión de Melilla. Carmen Alcalde explica que Carlota había trabajado activamente en el Partido Comunista desde 1930, fundó la revista "Nosotras, órgano expresión de las mujeres comunistas, en la que plasmó una inclinación ideológica que marcaría su carácter feminista, por primera vez planteada en el partido revolucionario de los trabajadores" ${ }^{\prime 105}$. Escritora y periodista, durante el franquismo se vio obligada a utilizar el seudónimo de Laura de Noves para poder publicar sus obras. Gracias a su relato biográfico de este periodo, Una mujer en la guerra de España, O’Neill describe el estado de las cárceles franquistas y el trato que recibían las presas durante la contienda bélica:

Noche y día llegaban mujeres y mujeres como nosotras; unas arrastraban de los brazos a sus hijos en su resistencia por meterse en el agujero; otras los cargaban en el vientre. Llegaban viejas, jóvenes, muy jóvenes. Unas lloraban; algunas reían. Entraban otras con rojeces en el alma y en la cara; con palidez de cadáver después de ser violadas. Fuera, en Melilla, los falangistas habían entrado en delirio. Escapaban las denuncias de las bocas de todos; bocas convertidas en venganza ${ }^{106}$.

El hacinamiento y la falta de higiene hicieron que proliferaran las enfermedades como la disentería, el tifus o la sarna, ya que eran muchas las mujeres que compartían celda y suelo para dormir, dentro de una mezcla de "sudores y cuerpos, día y noche" sin "posibilidad de limpieza"107. Estas condiciones deficitarias, los parásitos y la mala alimentación favorecieron que Carlota cayera

\footnotetext{
${ }^{103}$ HeRnÁNDEZ Holgado, Fernando: Mujeres encarceladas. La prisión de las Ventas: de la República al franquismo, 1931-1941. Marcial Pons, Ediciones de Historia, Madrid, 2003, p. 304 a 305.

${ }^{104}$ Esposa de Virgilio Leret, fusilado el 23 de julio de 1936, capitán de aviación republicano, Carlota fue encarcelada en Melilla, en la fortaleza de Victoria Grande, desde el inicio de la contienda, permaneciendo separada de sus hijas. Tras dos consejos de guerra y cinco años en la cárcel, Carlota consiguió salir de prisión y de Melilla.

${ }_{105}$ ALCALDE, C: op.cit., p. 120

${ }^{106}$ O' NeILl, Carlota: Una mujer en la guerra de España. Anaya, Madrid, 2003, p. 67.

${ }^{107} \mathrm{Ibid}$., p. 68.
} 
enferma en la cárcel, donde no había "médico, medicinas ni enfermería", siendo trasladada al hospital de la Cruz de Roja de Melilla por su grave estado de salud ${ }^{108}$.

Una vez finalizada la Guerra Civil, fueron muchas las mujeres encarceladas por su implicación en la defensa de la República. Relatos como el de Matilde Landa ${ }^{109}$ describen la represión que sufrieron y la situación de las mismas en prisión, principalmente en la cárcel madrileña de Ventas, en la que las milicianas Fifí y Julia Manzano también terminaron al finalizar el conflicto, condenadas a muerte por delito a la rebelión, pena que les fue conmutada. Según Domingo, las condiciones de vida en prisión y el trato que recibieron las reclusas fue muy duro, siendo la cárcel de Ventas la "prisión del horror", donde se practicaron fusilamientos continuamente, además de vejaciones y torturas. Según este autor a partir de abril de 1939 las cárceles en España se llenaron de "miles de mujeres" denunciadas y detenidas tanto por motivos políticos y civiles como por odios y envidias. También apunta lo complejo que es conocer con exactitud el número de presas ya que ingresaban en las cárceles como reclusas comunes, sin ninguna entidad política. Las mujeres continuaban "siendo las segundas de abordo" ya que no se las "podía acusar de lo mismo que a los hombres" a pesar de que sufrieron los mismos fusilamientos, torturas y condenas que ellos ${ }^{110}$. Domingo expone como el nuevo régimen "negó el carácter político a las presas, algo que no hizo con los hombres", de esta forma los franquistas dejaban claro que "ni la guerra ni la política eran cosa de mujeres"111.

Las empleadas de las cárceles franquistas consintieron los abusos, el hacinamiento, las condiciones de insalubridad y de déficit nutricional de las presas republicanas. La orden de 30 de agosto de 1939 permitió a las monjas ocupar los puestos de funcionarias de prisiones, con el objetivo de educar a las reclusas en la fe

\footnotetext{
${ }^{108}$ O' NeILl, C: op.cit., p. 98.

109 Matilde Landa Vaz, dirigente comunista, miembro del Socorro Rojo Internacional, con una participación activa en la evacuación y traslado de refugiados, además de inspeccionar el estado de los comedores y las colonias infantiles. Finalizado el conflicto luchó desde la clandestinidad contra la dictadura franquista, encarcelada, terminó con su vida el 26 de noviembre de 1942 en la cárcel de Palma.

${ }^{110}$ Domingo, Carmen: Coser y Cantar. Las mujeres bajo la dictadura franquista. Lumen, Barcelona, 2007, pp. 155-160.

111 Ibid., p. 178.
} 
católica, por lo que la asistencia a misa, los bautizos, las confesiones y las comuniones les fueron impuestos ${ }^{112}$.

El número de muertes fue elevado durante los primeros días de la represión franquista debido a las condiciones de las cárceles y su régimen de internamiento ${ }^{113}$. Esta carestía y situación afectó por igual a todas a las mujeres, independientemente de su edad o situación física, con peores consecuencias para los recién nacidos y las parturientas $^{114}$. De esta forma, Julia Manzano vio enfermar y morir a su hija de meningitis en la cárcel ${ }^{115}$.

En las Ventas, la masificación de mujeres impidió que torturaran a todas, aún así, vivieron una situación de desconcierto y desasosiego continuo ya que no sabían cuando les llegaría el turno para ser ejecutadas ${ }^{116}$. La mayoría de los juicios fueron llevados a cabo sin la presencia de las reclusas, cuyos abogados dejaron el destino de las presas "en manos de la acusación”, de forma que aceptaron la pena impuesta sin luchar por una defensa justa. Matilde Landa se enfrentó a esta situación y se dedicó a defender a las reclusas durante su internamiento ${ }^{117}$, llegando a "organizar en la prisión un verdadero despacho de asesoría jurídica" "118. Las mujeres se reorganizaron en la cárcel de Ventas, de forma que cada galería contó con su comité cuyas reuniones clandestinas se llevaban a cabo en diferentes celdas, en las que se hablaba de política y se daban clases de alfabetización ${ }^{119}$.

\footnotetext{
112 DomingO, C: op.cit., pp. 165-167.

${ }^{113}$ Ibid., p. 17.

114 Ibid., pp. 194-19.

${ }^{115}$ STROBL, I: ob. cit., p. 67.

${ }^{116}$ Ibid., p. 56.

${ }^{117}$ DomingO, C: op.cit., p. 186.

${ }^{118}$ STROBL, I: op.cit., p. 57.

${ }^{119}$ GINARD I FÉRON, D: op.cit., p.99.
} 
Uno de los iconos indiscutible del conflicto bélico, poco analizado y estudiado fue el de las enfermeras, cuya participación tanto en vanguardia como en retaguardia fue indispensable para dar cobertura sanitaria a los soldados heridos. Encuadrar el papel que jugaron las mujeres durante el conflicto y su movilización, ha sido necesario para desarrollar y estudiar el desempeñado por las enfermeras, ya que fue una de las alternativas laborales que se dio a las mujeres que querían ayudar a la República. 


\section{SANIDAD REPUBLICANA: ESTRUCTURA HOSPITALARIA Y} RED ASISTENCIAL

La organización de un servicio sanitario adecuado que diera cobertura al frente y fuera capaz de atender a los heridos en la retaguardia fue compleja. Inicialmente fue un sistema sanitario fragmentado y desorganizado que se enfrentó a la falta de personal y material, su reorganización fue complicada ya que dependió de las necesidades del frente y del avance de las tropas franquistas que obligaban a replegarse y a instalar nuevos hospitales tras la desarticulación de los ya existentes.

Como señala Jesús Bescós, "la organización sanitaria militar en el ejército republicano era prácticamente inexistente", inicialmente Cruz Roja asumió su papel de ayuda a Sanidad Militar y se encargó de la recogida de heridos y su transporte hacia los puestos de socorro y hospitales de la asociación ${ }^{120}$. En un primer momento hubo una proliferación de hospitales fundados principalmente por los distintos partidos políticos y sindicatos, Madrid se llenó de centros sanitarios, algunos mejor organizados que otros, de forma que con el paso del tiempo se suprimieron los que no fueron necesarios ${ }^{121}$.

El día 21 de julio, a las seis de la tarde, nos incautamos del edificio [Hospital Obrero de Madrid, dirigido por el Dr. Planelles y liderado por el Socorro Rojo Internacional] en compañía de algunos milicianos. A las doce horas siguientes comenzaron a funcionar todos los servicios, con el personal nuevo. $\mathrm{Y}$ al otro día quedaba montado por completo uno de los mejores quirófanos de España y un gabinete de rayos $\mathrm{X}^{122}$.

Entre las medidas que terminó tomando el Gobierno en enero de 1937 cabe resaltar que los hospitales civiles con un mínimo de 300 camas pasaron a ser hospitales militares bajo inspección sanitaria y administrativa. Lo mismo sucedió con los hospitales del Socorro Rojo Internacional, las Brigadas Internacionales y Cruz Roja. El Ministerio de Guerra también se encargó de la normativa relativa al

\footnotetext{
${ }^{120}$ Sanidad Militar, Volumen 43, $\mathrm{n}^{\circ} 1$ año 1987. BESCÓs ToRRES, Jesús. La Sanidad Militar en la Guerra de España (1936-1939) 1 ${ }^{a}$ Parte: La Sanidad en el Ejército Republicano, p.99.

${ }_{121}$ BeECham, MONOGRAFÍAs: Los médicos y la medicina en la Guerra Civil Española. Saned, Madrid, 1986, p. 41

${ }^{122}$ Ayuda, $\mathrm{n}^{\circ}$ 13, 15 de agosto de 1936, p. 4. El Sanatorio de Milicias Populares.
} 
personal de dichos centros, nombrando por cada provincia un inspector de Sanidad y otro de Intendencia. De esta forma se clausuraron todos los establecimientos sanitarios con menor número de camas, permitiendo funcionar por su cuenta y con independencia del Ministerio de Guerra a todos aquellos hospitales que no quisieran participar de la orden, sin recibir ningún tipo de ayuda económica o de material e instrumental sanitario. A partir de ese momento únicamente se abrirían los hospitales que dispusiera el Cuerpo de Sanidad Militar, y se prohibió la fijación de carteles o membretes que no fueran los de "Hospital de Sanidad Militar" en todos los hospitales civiles que pasaran a cargo del mismo ${ }^{123}$.

El trabajo de Cruz Roja al inicio de la contienda se centró en la asistencia a los heridos de guerra hasta que Sanidad Militar se reorganizó, y la institución se encargó de la asistencia civil durante los bombardeos:

En los primeros tiempos, la Sanidad Militar quedó desarticulada y Cruz Roja Española se aprestó y apresuró a substituirla en los frentes de lucha: su personal, con abnegación, competencia y valor, recogió heridos en las mismas líneas de fuego, evacuándolos en ambulancias, camiones y coches de turismo a los numerosos Puestos de Socorro y Hospitales que aquella había instalado, donde se les practicaba la primera cura, operando los que debían serlo urgentemente y trasladando a los hospitales de retaguardia, los que no exigían intervenciones inmediatas ${ }^{124}$.

Desde la República se intentó consolidar "un solo bloque sanitario", capaz de asistir a los heridos, guidado siempre por su carácter humanitario ${ }^{125}$. Según explicaba Federica Montseny, Ministra de Sanidad durante la Guerra Civil, existió una oferta de atención sanitaria variada ${ }^{126}$. Por lo tanto fue necesaria una centralización sanitaria, una coordinación y una organización. Los hospitales y su

\footnotetext{
123 Gaceta de la República. no 26, 26 de enero de 1937, Orden circular convirtiendo en Hospitales militares todos los Hospitales civiles del territorio de la República que se hallen en las condiciones que se indican, como igualmente los del Socorro Rojo Internacional, Brigadas Internacionales y de la Cruz Roja Española, y cuyo régimen queda de la competencia de este Ministerio, p. 510.

${ }^{124}$ AGMM. Ejército Republicano. R. 501.

${ }^{125}$ Ayuda, $\mathrm{n}^{\mathrm{o}}$ 21, 10 de octubre de 1936, p. 5. Lo que ha sido de la solidaridad en el pasado y lo que es en el presente.

${ }^{126}$ BeEcham, MONOGRAFÍAs: op.cit., en MontSEny, Federica, La Sanidad y la Asistencia Social durante la Guerra Civil, p. 96.
} 
personal solían estar vinculados a los partidos políticos (ver imagen XI), lo que ocasionó problemas, sobre todo cuando las necesidades del frente obligaron a trasladarlos a otras poblaciones:

[...] Hay algo de disensión en cuanto a que este hospital siga adscrito al batallón Carlos Marx, es decir, al PSUC. Si nos quedamos aquí, o nos integramos en la CNT o estaremos a la greña con la FAI; si seguimos con el Carlos Marx tendremos que trasladarnos a otro pueblo, a un kilometro y medio de Grañén ${ }^{127}$.

\subsection{Recursos materiales}

La situación sanitaria en Madrid al inicio del conflicto se caracterizó por la falta de organización y material. De hecho las ambulancias necesarias para trasladar a los heridos del frente a los hospitales escaseaban, por eso fue necesaria la incautación de camiones para equiparlos con colchones, destinados a suplir temporalmente esa carencia ${ }^{128}$. La improvisación de nuevos medios de traslado para los heridos fue una realidad en la zona republicana, ya que las ambulancias del ayuntamiento de Madrid estaban en la zona ocupada por los sublevados porque antes de que "estallara la insurrección" los golpistas se habían encargado del traslado de las mismas y de los equipos médicos a Burgos ${ }^{129}$. La falta de ambulancias fue un problema que perduró durante el conflicto, ya que debido al exceso de trabajo sufrieron averías, además de recibir los impactos de obuses y morteros que en muchas ocasiones las inhabilitaron definitivamente ${ }^{130}$. Eran necesarias para evacuar a los heridos, ya que de su transporte rápido y eficaz dependía su recuperación. Por eso la donación de las mismas por parte de los comités de ayuda a España extranjeros siempre fue motivo de alegría y una noticia divulgada rápidamente a través de la prensa ${ }^{131}$.

\footnotetext{
${ }^{127}$ Hodson, Agnes: A una milla de Huesca. Diario de una enfermera australiana en la Guerra Civil española. Rodle, Zaragoza, 2005, p. 305.

${ }^{128}$ BIngham DE URQUIDI, Mary: Misericordia en Madrid. B. Costa-Amic Editor, México, 1975, p.43.

${ }^{129}$ Ibid., p.52.

${ }^{130}$ Nuestra Sanidad, ${ }^{\circ}$ 4, 1 de abril de 1937, portada.

${ }^{131} A B C, 1$ de septiembre de 1936, La primera ambulancia de la Cruz Roja Inglesa, p. 8, ABC, 19 de junio de 1937, Las ambulancias escandinavas en España, p. 7. La Vanguardia, 11 de octubre de 1936,
} 
El volumen de heridos era mayor que las camas hospitalarias disponibles por lo que fue común la aparición de improvisados centros de atención sanitaria instalados en "hoteles, clubes, escuelas y casas particulares incautadas por los distintos comités, incluido el nuevo Frontón y el propio Casino de Madrid"132 (ver imagen XII). El hecho de instalar hospitales en casas, casinos, colegios y en locales libres cercanos al frente de batalla, implicaba que en muchas ocasiones no estuvieran dotados de calefacción o de luz eléctrica, por lo que tuvieron que trabajar "a la luz de las velas y con linternas de bolsillo atadas a la cabeza", y esterilizar el instrumental "en el fogón de la cocina" "133. Tal fue el caso del "Hospital Quirúrgico número uno" instalado en el hotel Palace, tras la rápida evacuación del situado en Carabanchel debido al avance de las tropas y de la línea del frente. Para ello tuvieron que trasladar a los heridos y el material sanitario, además de instalar en el hotel una sala de operaciones, de rayos $\mathrm{X}$, de curas $\mathrm{y}$ de farmacia ${ }^{134}$. Los hospitales provisionales situados cerca del frente terminaron por instalarse en cuevas, túneles y refugios antiaéreos para protegerse de los bombardeos ${ }^{135}$.

A la falta de hospitales, también se unió el déficit de personal, no había suficientes enfermeras y respecto a los médicos muchos fueron asesinados o bien se posicionaron del lado sublevado, o se marcharon al extranjero ${ }^{136}$. Además, los puestos de socorro instalados al inicio de la guerra carecían de camas, colchones, ropa limpia y mantas ${ }^{137}$, por lo que utilizaron catres y cuando no hubo suficientes, directamente se tumbó a los heridos en el suelo. "El equipo quirúrgico consistía en una mesa de tablas corrientes, un pequeño botiquín de la Cruz Roja, una botella de agua oxigenada, y otra más pequeña de alcohol que estaban sobre el piso, en una

Ambulancia británica a España, p. 16; La Vanguardia, 19 de marzo de 1937, La ambulancia sueconoruega, p. 11.

${ }^{132}$ BINGHAM DE URQUIDI, M: op.cit, p.46.

${ }^{133}$ EBY, Cecil: Voluntarios norteamericanos en la Guerra Civil española. Ediciones Acervo, Barcelona, 1974, p. 270.

${ }^{134}$ BASTOS ANSART, M: op.cit., pp. 310-312.

135 DerbY, Mark: Compañeros “kiwis” Nueva Zelanda y la guerra civil española. Ediciones de la Universidad de Castilla la Mancha, Cuenca, 2001, p. 117.

${ }^{136}$ BASTOS ANSART, M: op.cit., p. 308.

${ }^{137} A B C, 13$ de octubre, 1936, p. 10, El Gobierno requisará colchones y mantas sobrantes. 
esquina de lo que era la cocina de la casa"138. La iluminación fue otro contratiempo, ante la ausencia de luz eléctrica tuvieron que utilizar velas o mecheros, y en el caso de los hospitales instalados en los túneles de los ferrocarriles poner generadores que permitieran realizar el trabajo, además de utilizar cazos situados en estufas y alcohol quemado para esterilizar el material ${ }^{139}$. Urgía el traslado de los heridos a los hospitales de la retaguardia y por eso, la carencia de ambulancias repercutió en el mismo. La Sanidad republicana también se enfrentó a la dispersión de los centros asistenciales, sobre todo los de convalecencia, organizados según las demandas del frente y el avance de las tropas enemigas ${ }^{140}$. Proveer de material para poder dar cobertura a todos los hospitales de reciente aparición y contribuir al sostenimiento de los que ya existían fue otra de las necesidades importantes que resolvieron favorablemente:

Teníamos tantos heridos que nuestro instrumental y equipo de quirófano no bastaban. [...] Fuimos a una casa alemana en la calle del Carmen. Allí encontramos muchos colegas buscando lo mismo que nosotros para dotar a los múltiples hospitales de sangre que estaban brotando como hongos en todas partes de Madrid. Nadie pagaba; solamente se extendía un pedazo de papel con las letras UHP. [...]

Después fuimos a otros almacenes de instrumental. Me llamaba la atención que todos los dueños fueran alemanes. Uno de ellos se empeñó en informarnos que algunos médicos militares se habían llevado cantidades de instrumentos y material quirúrgico unos días antes de la insurrección, todo muy bien empacado para un largo viaje. $[\ldots]^{141}$

Otro de los contratiempos constantes fue la necesidad de reorganizarse según se modificaban los frentes de batalla, sobre todo durante la retirada de las tropas hacia la retaguardia. Esto suponía desmontar los improvisados hospitales cercanos al frente, trasladar su material y personal, e instalar otro en un local que debía habilitar

\footnotetext{
${ }^{138}$ BINGHAM DE URQUIDI, M: op.cit., p. 61.

${ }^{139}$ DERBY, M: op.cit., pp. 116-117.

140 NúÑEZ DÍAZ-BALART, Mirta: La disciplina de la conciencia: las Brigadas Internacionales y su artillería de papel. Flor del viento ediciones, Barcelona, 2006, p. 231.

${ }^{141}$ BINGHAM DE URQUIDI, M: op.cit., p. 107.
} 
con anterioridad ${ }^{142}$. Como ejemplo se puede señalar el caso del hospital de Huete cuya evacuación, impuesta por las necesidades de la contienda y la inseguridad generada por el avance de las tropas enemigas, se tuvo que realizar en pocas horas, por la noche, a lo largo de tres días en el último tren que pudo cruzar el Ebro ${ }^{143}$.

A pesar de las dificultades, durante la Guerra Civil española aparecieron avances en medicina que posteriormente se llevaron a la práctica en otros conflictos. Entre ellos cabe destacar el "método español" "144 realizado en heridos con fracturas abiertas $^{145}$. Ana Pibernat ${ }^{146}$ hablaba en sus memorias de la cura al aire libre que el Doctor Trueta llevó a cabo en el hospital de la Sabinosa con los heridos de traumatismo y que más tarde se utilizó en la Segunda Guerra Mundial, exponiendo las heridas al aire y al sol. También describe las operaciones de los heridos de pulmón, posteriormente este tipo de intervenciones se practicaron en enfermos de tuberculosis $^{147}$. Aunque sin ninguna duda la técnica principal fue la transfusión sanguínea que ayudó a salvar muchas vidas. Fue común la donación directa al herido, siendo, en muchas ocasiones las propias enfermeras las encargadas de donar la suya y de reclutar voluntarios, por eso "abordaban a los conductores de los camiones que iban y venían del frente para conseguir un trago de ron a cambio de sangre" ${ }^{\not 48}$. El principal trabajo realizado en transfusión sanguínea fue el llevado a cabo por el equipo ambulante del banco de sangre de Canadá a cargo del doctor

\footnotetext{
${ }^{142}$ AMI, $\mathrm{n}^{\mathrm{o}}$ 10, 1 de marzo de 1938, Frente Popular en el frente, p. 5.

${ }^{143}$ DERBY, M: op.cit., p. 131.

144 NAVARro CARBALlo, José Ramón: La sanidad en las Brigas Internacionales. Estado Mayor del Ejército, Madrid, 1989, p. 163.

${ }^{145}$ El método español lo desarrolló principalmente el Dr. Tureta, aunque el Dr. Bastos Ansart también habla de esta técnica en sus memorias. Consistía en limpiar la herida con agua y jabón, retirar los cuerpos y los tejidos muertos en quirófano, para posteriormente inmovilizar la extremidad con un yeso. De esta forma no se podían hacer curas de la herida hasta la retirada del yeso.

${ }^{146}$ Ana Pibernat, enfermera que nació en 1920 en Anglés, Gerona, en el seno de una familia republicana de pequeños industriales zapateros. Al contrario de lo que sucedió con algunas de sus coetáneas, Ana estudió el bachillerato elemental, apoyada por sus padres que querían la independencia económica de su hija. En 1936, con dieciséis años, obtuvo el título de enfermera en Gerona. Cuando estalló la Guerra Civil se presentó como enfermera voluntaria. Trabajó en los distintos hospitales militares de los frentes de la República en Cataluña. Terminada la guerra acabó en Francia, en un campo de refugiados, para ser repatriada a España en 1940.

${ }^{147}$ Hurtado AlbIR, Amparo: Un testimonio de la Guerra Civil Española. Ana Pibernat: mis memorias. Arenal: Revista de historia de mujeres, Vol. 7, $\mathrm{n}^{\mathrm{o}}$ 2, 2000, (Ejemplar dedicado a: Mujer y medicina en el mundo antiguo), pp.445-446.

${ }^{148}$ JACKSON, A: op.cit., pp.161-162.
} 
Bethune $^{149}$. Fue necesario establecer un local y dotarlo de material y personal técnico capacitado para trabajar en él. A través de la radio y la prensa se solicitaban donantes de sangre, cuyas muestras se almacenaban en cámaras frigoríficas hasta su utilización. Los hospitales de vanguardia contaron con ambulancias de transfusión dotadas de neveras para cubrir las necesidades del frente ${ }^{150}$. Tampoco se puede olvidar que la antibioterapia no apareció hasta después de la Guerra Civil, por lo que la evolución de las heridas y de la patología quedó en manos de cirujanos y enfermeras, además de depender de la propia salud de los pacientes ${ }^{151}$. El médico neozelandés, Doug Jolly, desarrolló por primera vez durante la guerra española un sistema de atención y triaje que permitió atender de forma simultánea a un elevado número de heridos. Jolly también realizó un trabajo importante en el abordaje de las heridas abdominales que plasmó en su libro Field Surgery y que contribuyó a mejorar la labor de otros compañeros ${ }^{152}$.

La ayuda sanitaria internacional fue importante para sacar adelante una sanidad desestructurada y con carestía de medios. El Socorro Rojo Internacional y las Brigadas Internacionales a través de Ayuda Médica Extranjera, participaron activamente en el establecimiento de hospitales y en la dotación de material y personal de los mismos ${ }^{153}$. El Servicio Sanitario de las Brigadas Internacionales se organizó tanto en la retaguardia como en el frente, y también se enfrentó, en un primer momento, a la falta de medios materiales y sanitarios. El aumento de las bajas en los frentes, unido a la aparición de enfermedades epidémicas y el crecimiento del ejército, hizo que aumentara la demanda de los servicios sanitarios. Los heridos de las Brigadas Internacionales, se encontraron la barrera del idioma durante su convalecencia, unido a la dificultad de localizarlos en los hospitales. Esta situación, como apunta Navarro, propició la aparición de un Servicio Sanitario propio de las Brigadas Internacionales que fuera capaz de atender a los soldados brigadistas heridos en el frente y encargarse de su recuperación en la retaguardia ${ }^{154}$.

\footnotetext{
${ }^{149}$ BINGHAM DE URQUIDI, M: op.cit., p. 126.

${ }^{150}$ Revista de Sanidad, no 5, septiembre 1937, p. 198.

${ }^{151}$ BASTOS ANSART, M: op.cit., p. 314.

${ }^{152}$ DERBY, M: op.cit., p. 120.

153 Ayuda, $\mathrm{n}^{\circ}$ 13, 15 de agosto de 1936, Los auxilios sanitarios, p. 5.

${ }^{154}$ NAVARRO CARBALLO, J. R: op.cit., p. 83.
} 
El primer grupo americano de ayuda llegó a España en 1937, constituyendo la American Medical Unit, una unidad muy bien preparada ya que con ella acudieron médicos, enfermeras, farmacéuticos y conductores, provistos de quirófanos, ambulancias y abundante material sanitario ${ }^{155}$. Los servicios médicos norteamericanos se encargaron de prestar ayuda en los frentes y establecieron "estaciones de atención inmediata a los heridos, así como de cirugía de urgencia", además de estar preparados para evacuar a los heridos a los hospitales de $\operatorname{retaguardia}^{156}$.

En otras ocasiones la ayuda sanitaria internacional se centró en la dotación de material para establecer una clínica, tal fue el caso del Hospital Sueco-Noruego de Alcoy, con una distribución inicial de 100 camas, que finalmente se convirtieron en 650 a petición del Gobierno republicano debido a las demandas del frente. Los escandinavos participaron activamente en la recopilación de dinero para ayudar a España enfocado principalmente en el establecimiento del hospital. Ellos aportaron gratuitamente todo el material y la dotación logística a condición de que el Gobierno se encargara de habilitar un centro para su instalación. Se eligió una escuela de maestría situada en la retaguardia, en Alcoy, y durante seis meses fueron los escandinavos los que llevaron la gestión del centro y de su personal. Finalizado dicho periodo la República se encargó de sostenerlo y dotarlo de personal, ya que los médicos y enfermeras extranjeros regresaron a Suecia y Noruega ${ }^{157}$. La organización del centro asistencial, su dotación y la ayuda del pueblo escandinavo quedó reflejada en el $A B C$ que en todo momento se hizo eco de la noticia y siguió de cerca la instalación del hospital Sueco-Noruego ${ }^{158}$. Inicialmente fue un hospital de retaguardia para enfermedades nosocomiales debido a su situación geográfica alejada del frente. Con el transcurso del conflicto y el avance de las tropas pasó a ser

\footnotetext{
${ }^{155}$ NAVARro CARBALlo, J. R: op.cit., p. 84.

${ }^{156}$ UsANDIZAGA, Aránzazu: Escritoras al frente. Intelectuales extranjeras en la Guerra Civil. Nerea, San Sebastián, 2007, p. 214.

157 BenEITO LlORIS, Ángel: El Hospital Sueco-Noruego de Alcoi durante la Guerra Civil española. Producciones Visual, 2004, pp. 15-50.

${ }^{158} A B C, 5$ de febrero de 1937, p. 14, Magnífico donativo de las organizaciones obreras de Suecia y Noruega, ABC, 27 de abril de 1937, p. 13, Entrega de un hospital Sueco-Noruego, ABC, 25 de junio de 1937, p. 6, Ampliación del hospital Noruego, ABC, 18 de febrero de 1938, p. 4, Noruega ayuda a España
} 
un hospital de heridos de guerra dirigido por el Dr. Manuel Bastos Ansart. La nueva carga asistencial obligó a la ampliación del centro con la instalación de más quirófanos y salas de radio-diagnóstico, con cuartos de cura y de apósitos ${ }^{159}$.

Respecto al personal médico que trabajó para la sanidad republicana hay que tener en cuenta que:

Los cirujanos más destacados y más importantes, sin que nadie se rompa las vestiduras, estaban en la zona gubernamental. Eran los de la Facultad de Medicina de Barcelona, de Valencia, de Madrid, etcétera. En el Hospital Provincial de Madrid trabajaban cirujanos muy notables, la mayor parte profesores universitarios de cirugía. Es decir, las diferencias se dieron, no en la técnica, sino en la organización sanitaria ${ }^{160}$.

Por el contrario a los médicos brigadistas se les describe como jóvenes ${ }^{161} \mathrm{e}$ inexpertos, llenos de ilusión y con ganas de trabajar, pero pocos preparados para asumir la cirugía de guerra ${ }^{162}$. Bastos expresaba que no conoció "a ninguno que demostrara saber su oficio", incluso llegó a afirmar que "muchos de ellos eran puros farsantes que carecían de todo título"163. Navarro recoge testimonios de médicos militares españoles en los que recopila las opiniones que tenían de sus homólogos extranjeros a los que atribuían falta de preparación y competencia técnica en medicina de guerra y sanidad militar, muchas veces ligado a su juventud. Sobre el tema existen comentarios más mordaces en los que se refieren a los médicos de las Brigadas Internacionales como a "unos aventureros y osados, que no tenían unas ideas claras de cirugía y que venían a España a aprender y practicar con los heridos"164.

\footnotetext{
${ }^{159}$ BASTOS ANSART, M: ob. cit., pp. 334-338.

${ }^{160}$ BEECHAM, MONOGRAFÍAS: op.cit., En ZuMEL, Mariano, F. Cirugía de Guerra, p. 86.

${ }^{161}$ Como ejemplo de esto se puede citar el caso del médico neozelandés, Doug Jolly, que terminó los estudios de Medicina en 1930, tras dos años de prácticas como cirujano viajó a Inglaterra para continuar su formación académica y obtener el título de doctor del Real Colegio de Cirujanos de Inglaterra. Jolly se presentó como voluntario y abandonó los últimos exámenes por lo que no llegó a obtener el reconocimiento de doctor. Ver más en DERBY, Mark. Compañeros "kiwis" Nueva Zelanda y la guerra civil española. Ediciones de la Universidad de Castilla la Mancha, Cuenca, 2001, pp. 111-122.

${ }^{162}$ BEECHAM, MONOGRAFÍAS: op.cit., En ZUMEL, Mariano, F: op.cit., p. 87.

${ }^{163}$ BASTOS ANSART, M: op.cit., p. 327.

${ }^{164}$ NAVARRo CARBALlo, J. R: op.cit., p. 96.
} 
Ana Pibernat, en sus memorias, contradice lo expuesto por Navarro, ya que se refiere a ellos como grandes cirujanos que "colaboraron con sus técnicas más avanzadas en cirugía" 165 . Patience Darton, enfermera inglesa, "admiraba el talento de muchos cirujanos españoles", pero para ella los médicos brigadistas eran más conscientes de "la importancia de la atención postoperatoria" de los heridos ${ }^{166}$.

Por último, cabe resaltar que la sanidad republicana contó con prensa especializada que se encargó de divulgar conocimientos básicos sobre primeros auxilios y condiciones de salubridad. A nivel médico se hicieron publicaciones de interés que sirvieron para perfeccionar las técnicas quirúrgicas y tratamientos. Sus artículos también se dirigían a los camilleros, chóferes y sanitarios en general, cuya labor fue fundamental, por eso La Voz de Sanidad, Sanidad Popular, La Revista de la Brigada Sanitaria, La Revista de Sanidad de Guerra, Nuestra Sanidad, Hospitales, Ayuda, o AMI (Ayuda Médica Internacional), fueron publicaciones que describieron el trabajo sanitario en los frentes, la red hospitalaria republicana y se centraron en educar y enseñar a los soldados las medidas de salubridad necesarias para la prevención de enfermedades infecto-contagiosas. Como señala Mirta Núñez, la prensa sanitaria además de hacer una labor propagandística importante, basada en el sostenimiento moral, no se olvidó del personal sanitario, objetivo principal de la misma ya que ellos eran "los primeros que debían mantener el entusiasmo" a pesar de las duras condiciones impuestas por el frente ${ }^{167}$. Sanidad y educación estuvieron ligadas durante la Guerra Civil, ya que desde los hospitales se fomentó la lectura de libros, además de organizarse bibliotecas populares para enseñar a leer a los heridos y al personal ${ }^{168}$. La prensa sanitaria tenía un claro objetivo formativo, por eso era necesaria la alfabetización, los soldados debían aprender primeros auxilios y las medidas higiénicas para evitar enfermedades de transmisión tanto venéreas como las asociadas a la insalubridad. Sanidad Militar fomentó el control higiénico y sanitario

\footnotetext{
${ }^{165}$ HURTADO ALBIR, A: op.cit., pp.445.

166 JACKSON, Angela.: Para nosotros era el cielo. Ediciones San Juna de Dios, Campus Docent, Barcelona, 2012, p. 61.

${ }^{167}$ NÚŃEZ DÍAZ-BALART, M: op.cit., p. 222.

${ }^{168} A M I, n^{\circ}$ 6, 15 de diciembre de 1937, Dos muestras de la reorganización de los hospitales de Murcia, p.1.
} 
a través de un grupo de "cuatro heridos, un médico y una enfermera, elegido por combatientes en los hospitales" que controlaban el suministro de agua potable y las condiciones adecuadas de las instalaciones hospitalarias ${ }^{169}$. De esta forma, cabe resaltar que la sanidad en la zona republicana dio mucha importancia a la prevención como medida esencial para frenar la propagación de enfermedades contagiosas.

\subsection{Tipos de hospitales, traslado y evacuación de heridos}

El objetivo principal de Sanidad Militar era dar servicio a la línea de combate, para ello contaron con puestos de clasificación y triaje, puestos de socorro y curación, servicios de transporte, incluidos las ambulancias y trenes hospitales, además de los hospitales situados en la retaguardia. El servicio en la línea de combate contó principalmente con camillas y sus correspondientes camilleros en cada batallón, "donde existía un equipo de curaciones o mochila de batallón, completado por bolsas sanitarias en cada compañía, y un paquete de cura individual que portaba cada soldado como parte de su equipo y que permitía practicar una primera cura elemental de urgencia" ${ }^{170}$.

Los puestos de clasificación o triaje eran los encargados de recibir a los heridos evacuados de los batallones, se situaban en tiendas de campaña o caseríos habilitados para atenderlos, sin olvidarse de tener cerca una carretera que permitiera su evacuación hacia los hospitales de la retaguardia. Era necesario que estuvieran camuflados adecuadamente y que contaran con cobertizos de ramajes para las ambulancias. En el puesto de triaje se "rectificaban o completaban las curas torniquetes o inmovilizaciones; se administraban sueros, tónicos o calmantes y se extendían o completaban los partes de evacuación, con el diagnóstico, la hora de herida, la medicación empleada, la forma en que debía hacerse la evacuación"171.

\footnotetext{
${ }^{169}$ NÚÑEZ DÍAZ-BALART, M: op.cit., p. 240.

170 BEECHAM, MONOGRAFÍAS: op.cit., en RoJo FERNÁNDEZ, Vicente: Algunos aspectos de la Sanidad Militar durante las operaciones de Teruel, p. 143.

171 BEECHAM, MONOGRAFÍAS: op.cit., en PICARDO CASTELlÓN, Manuel: Experiencia personal en un hospital quirúrgico de primera línea durante nuestra guerra civil, p. 180.
} 
Respecto a los puestos de socorro podían ser de primera línea, del batallón, regimental y divisionario. En el de primera línea se recogía a los heridos y se trasladaban al puesto de socorro del batallón donde se hacían las primeras curas y clasificación en función de la gravedad, posteriormente se evacuaba al herido al puesto de socorro regimental donde se rectificaba la cura y se perfeccionaba la clasificación. En el puesto de socorro divisionario que se situaba a unos 4-8 kilómetros del frente se volvía a rectificar la cura y clasificar a los heridos, para después distribuirlos por los diferentes hospitales de campaña y de sangre especializados en las distintas patologías diagnosticadas ${ }^{172}$ (ver imagen XIII).

Los puestos de socorro optimizaron su atención con los quirófanos móviles de campaña o Auto-chirs, que permitieron mantener unas mejores condiciones de antisepsia y de evacuación de heridos con mayor estabilidad ${ }^{173}$. La utilización de estos hospitales móviles, enviados en su mayoría por la Ayuda Médica Extranjera, fue común durante la guerra y consistieron en dotaciones de ambulancias o camiones equipados para operar de forma urgente cerca del frente de batalla ${ }^{174}$.

Los hospitales de campaña o de sangre, instalados normalmente en barracones, antiguos hospitales, escuelas, casas solariegas..., eran pequeños ya que debían ser fáciles de transportar, por eso los heridos leves se trasladaban antes para dejar espacio para los nuevos, dejando únicamente los casos graves ingresados hasta conseguir estabilizarlos para su evacuación a la retaguardia. En ellos se realizaban todo tipo de intervenciones quirúrgicas y los primeros vendajes, yesos y curas, todo tras la previa clasificación de heridos y la administración de la inyección antitetánica $^{175}$. También contaron con un servicio de medicina interna y uno antivenéreo, que en caso necesario se podían convertir en quirúrgicos ${ }^{176}$.

\footnotetext{
172 BeECham, MONOGRAFÍAS: op.cit., en Herraiz MuÑoz, M: Aplicación y avances en el tratamiento de los heridos en la guerra civil de España, p. 282.

${ }^{173}$ BEECHAM, MONOGRAFÍAS: op.cit., en ROJO FERNÁNDEZ, V: op.cit., p. 144.

${ }^{174} A M I, \mathrm{n}^{\circ} 10$, Un hospital móvil para el frente ha sido enviado por el pueblo americano al pueblo español, portada.

${ }^{175}$ AMI, n ${ }^{\circ} 10,1$ de marzo de 1938, Frente Popular en el frente, p. 5.

${ }^{176}$ NAVARro CARBALLO, J. R: op.cit., p. 134.
} 
A la Sanidad republicana también se la dotó con un laboratorio ambulante, ubicado en una ambulancia rehabilitada ${ }^{177}$ cuya instalación fue muy costosa y difícil de mantener, sobre todo los reactivos y el instrumental específico, además de la necesidad de combustible y luz eléctrica que en muchas ocasiones fue complicado conseguir. El trabajo que realizaba se centraba en el análisis de muestras de orina y heces principalmente, pero también de la dotación de sangre para transfusiones, sobre todo centrado en la transfusión directa debido a la falta de condiciones que tenían para almacenar la misma ${ }^{178}$.

Hospitales de retaguardia, una vez atendidos y estabilizados los soldados heridos, todos aquellos que se podían trasladar eran evacuados a estos hospitales para su total curación y recuperación, ya que allí pasaban el periodo de convalecencia alejados del frente ${ }^{179}$. La evacuación se realizó en muchas ocasiones en trenes hospital, que contaban con vagones con mesas de operaciones, suministros de oficina y un aparato de rayos $\mathrm{X}^{180}$.

No se puede hablar de la Sanidad republicana durante la guerra sin tener en cuenta a Federica Montseny ${ }^{181}$, política anarquista que fue la primera mujer Ministra de la historia de España y que estuvo a cargo de la cartera de Sanidad y Asistencia Social. Asumió su trabajo en el ministerio a pesar de no contar con el beneplácito de la mayoría política, ya que no todos sus compañeros de Gobierno apoyaron su nuevo cargo. Según Montseny, el propio Largo Caballero en un primer momento tampoco tenía muy clara la decisión tomada: "no disimulaba, o disimulaba mal, la poca gracia que le hacía ver a una mujer perdida en ese grupo de hombres, todos encanecidos ya

\footnotetext{
${ }^{177}$ El laboratorio ambulante estaba dotado de una mesa, un refrigerador, un autoclave, un esterilizador de calor seco y una incubadora, que necesitaban una buena red eléctrica para su funcionamiento.

${ }_{178} A M I, \mathrm{n}^{\circ} 11,13$ de marzo de 1938, El laboratorio ambulante de una División, pp. 4 y 5.

${ }^{179}$ Nuestra Sanidad, $\mathrm{n}^{\circ}$ 2, 1 de marzo de 1937, La Sanidad en la Retaguardia, portada.

${ }^{180}$ HodsON, A: op.cit., p. 334.

181 Federica Montseny Mañé (1905-1994). Escritora y dirigente anarquista, clara defensora de los derechos de la mujer. Recibió una educación alejada de los colegios de monjas y guiada por su madre, maestra de profesión, y su padre que fomentaron su aprendizaje que culminó con los estudios de Filosofía y Letras. En su obra literaria habla de la independencia de la mujer y de una maternidad alejada del hombre. Después del desenlace de la guerra se vio obligada a huir a Francia con su familia.
} 
en política, con excepción de los ministros comunistas, tan noveles como nosotros" $" 182$. Con el paso del tiempo esas reservas fueron desapareciendo, de hecho, a la última conferencia de Montseny como Ministra en la que expuso la gestión que había llevado a cabo durante la legislatura "asistió Largo Caballero, distinción que agradecí mucho y con la que el viejo socialista demostró que me tenía simpatía y que mi paso por su Gobierno le había hecho quizá modificar el concepto que tenía de las mujeres"183. Federica apostó por la incorporación femenina al mundo de la política, de forma que nombró como Subsecretaria de Sanidad a la doctora Mercedes Maestre, perteneciente a la UGT, y como directora de la Asistencia Social a la doctora Amparo Poch, afiliada de la CNT, rechazando la propuesta del doctor Marañón como Subsecretario, a pesar de ser una figura de gran renombre en el panorama médico español ${ }^{184}$.

La labor que llevó a cabo en el Ministerio de Sanidad y Asistencia Social se centró en la creación de liberatorios de prostitución que facilitaran a las mujeres unas condiciones adecuadas de alojamiento y trabajo. Fue pionera y revolucionaria cuando decidió redactar con la ayuda de Mercedes Maestre un proyecto de Decreto que autorizaba legalmente la interrupción artificial del embarazo, medida que no fue apoyada por sus compañeros de Gobierno, reacios a la legalización del aborto. En el campo de la asistencia social creó Hogares de Acogimiento para la Infancia y la Vejez, con el objetivo de mejorar las condiciones de vida de niños y ancianos. A nivel sanitario apoyó la investigación científica, ayudando al doctor Trueta a que pusiera en marcha sus ensayos sobre la gangrena seca en el Instituto Pedro Mata de Reus, además de participar en la organización de hospitales en la retaguardia que permitieran atender a los heridos que se evacuaban de los hospitales de sangre ${ }^{185}$.

\footnotetext{
182 MontSEnY MAÑÉ, Federica: Mis primeros cuarenta años. Barcelona, Plaza y Janes, 1987, p. 105.

${ }^{183}$ Ibid., p.132.

${ }^{184}$ Ibid., p.106.

${ }^{185}$ Ibid., pp. 132-133.
} 


\section{LAS ENFERMERAS REPUBLICANAS Y SU PARTICIPACIÓN EN EL CONFLICTO: LABOR ASISTENCIAL}

Las fuentes sobre enfermeras republicanas españolas son escasas ya que una vez terminado el conflicto permanecieron en el anonimato para evitar represalias, o se vieron obligadas a partir hacia el exilio, por lo que es complicado encontrar diarios o memorias escritas durante el periodo bélico. El relato de Ana Pibernat es uno de los pocos ejemplos que describen el trabajo de las enfermeras republicanas y cabe destacar que no lo escribió hasta la última etapa de su vida ${ }^{186}$. Otros casos, como el de Trinidad Gallego, encarcelada en la prisión de Ventas junto con su madre $\mathrm{y}$ abuela ${ }^{187}$, demuestran la dificultad a la hora de encontrar testimonios de las enfermeras republicanas que una vez terminado el conflicto se vieron obligadas a permanecer en silencio y en la clandestinidad. Cierto es que algunas se reinsertaron en nuevos puestos de trabajo como enfermeras ${ }^{188}$ pero dejando atrás los recuerdos de la guerra. Han sido las enfermeras brigadistas extranjeras las que han dejado mayor constancia de su trabajo durante la Guerra Civil en sus memorias. Trabajos recientes como el realizado por Anna Ramió, Carme Torres, Roser Valls, Carme Vives, Virtudes Rodero, Almerinda Domigo, Aurora Roldán y Carmen Domínguez-Alcón, sobre las enfermeras catalanas que participaron en el conflicto facilitan la divulgación del trabajo que llevaron a cabo las profesionales españolas ${ }^{189}$.

\footnotetext{
${ }^{186}$ HURTADO ALBIR, A: op.cit., p.456.

${ }^{187}$ DOMINGO Álvaro, A: op.cit., p. 368.

${ }^{188}$ HURTADO AlBIR, A: op.cit., p.458.

189 RAMIÓ, Anna; TORRES, Carme; coordinadoras: Enfermeras de guerra, Ediciones San Juan de Dios, Barcelona, 2015.
} 


\subsection{Nuevas enseñanzas: auge de los cursillos de capacitación}

A la inicial falta de organización sanitaria, de material y de infraestructuras también su unió la de personal sanitario. La carencia de enfermeras impulsó a las mujeres a presentarse como voluntarias en los hospitales para atender a los heridos y enfermos, tenían ganas de ayudar y colaborar pero la mayoría no contaba con la formación sanitaria necesaria ni con en el título oficial que avalara su preparación académica y práctica. ${ }^{190}$

A pesar de los continuos avisos y llamamientos para presentarse en las oficinas del comité central de Cruz Roja o del comité provincial de las Juventudes Socialistas Unificadas o en la Casa del Pueblo de la localidad ${ }^{191}$, las enfermeras tituladas no fueron suficientes para cubrir la gran demanda de su trabajo. Además de la labor asistencial, las enfermeras profesionales desempeñaron puestos de responsabilidad centrados en la organización y gestión de los hospitales y se encargaron de la formación de voluntarias en cuidados básicos. Mary Bingham de Urquidi $^{192}$ fue un claro ejemplo, ya que de forma voluntaria y altruista se encargó del sostenimiento del Hospital Obrero de Madrid, incautado por el Socorro Rojo Internacional, de 450 camas y con 120 voluntarias, la mayoría de ellas obreras sin conocimientos sanitarios ${ }^{193}$.

Muchas enfermeras acababan de recibir su título tras haber cursado sus estudios durante la República. Tal fue el caso de Ana Pibernat que apenas tenía experiencia práctica porque finalizó Enfermería al inicio de la contienda. A pesar de no tener la mayoría de edad, Ana se presentó como voluntaria en el hospital de Gerona dispuesta a ayudar. Allí aprendió los primeros auxilios en el frente, que consistían en prácticas en salas de hospitalización donde ya había heridos, y de auxilio en el frente de batalla en la montaña situada detrás del hospital, donde

\footnotetext{
${ }^{190}$ Nuestra Sanidad, $\mathrm{n}^{\circ}$ 4, 1 de abril de 1937, La mujer en la guerra, p.3.

$191 A B C, 22$ de marzo de 1938, p. 5, Sanidad: enfermeras y sanitarias, $A B C, 10$ de noviembre, 31 de julio de 1936, p.30, Aviso a las enfermeras tituladas, $A B C, 26$ de julio de 1936, p. 25.

${ }_{192}$ Mary Bingham de Urquidi, enfermera titulada en la Escuela de Enfermeras del Monte Sinaí de Nueva York en 1916. Casada con Juan Francisco Urquidi, ingeniero diplomático de carrera y embajador de México en España, se ofreció como voluntaria para atender a los heridos durante la Guerra Civil.

${ }^{193}$ BINGHAM DE URQUIDI, M: op.cit., p. 46.
} 
estudió la forma adecuada y rápida de rescatar a un herido, hacer un torniquete e inutilizar un miembro si había traumatismo ${ }^{194}$. Carmen Bueno tenía dieciocho años cuando comenzó la guerra y trabajaba en un sanatorio. La necesidad de enfermeras tituladas hizo que la CNT la reclamara para trabajar en el Hotel Ritz, en el que se había instalado un hospital de sangre, donde ella era la responsable de una sala de 62 camas y de algunas voluntarias ${ }^{195}$. Trinidad Gallego trabajó durante todo el conflicto en el frente de Madrid como enfermera jefe del Hospital Clínico con veintiún años hasta que el centro quedó adscrito al servicio civil tras la reorganización militar, y Trinidad pasó a ser enfermera de Sanidad Militar ${ }^{196}$. Eulalia Montfort, tenía veintitrés años cuando comenzó la Guerra Civil. Como enfermera titulada además de realizar el trabajo asistencial correspondiente se encargó de hacer funciones de anestesista durante las intervenciones quirúrgicas de menor envergadura, además de participar activamente en la formación de voluntarias ${ }^{197}$.

En relación a la falta de enfermeras también hay que tener en cuenta que los hospitales y centros sanitarios que habían estado en manos de las monjas durante la República quedaron a disposición de Sanidad pero sin mano de obra, ya que en algunas ocasiones las religiosas se negaron a asistir a los republicanos heridos y en otras fueron expulsadas de los hospitales:

[...] Ya me había dado cuenta de que en tiempos normales había falta de buenas enfermeras en España, porque todos estos trabajos estaban monopolizados por religiosas que no eran enfermeras. En esos momentos estaban echándolas de los hospitales pues rehusaban ayudar, en el momento en que había tanto trabajo inesperado ${ }^{198}$.

Por el contrario, también hubo casos de religiosas que optaron por cuidar a los heridos, como las monjas del Hospital Clínico y el Cívico Militar de Mahón que renunciaron a salir de la isla en uno de los canjes propuestos por el cónsul inglés,

\footnotetext{
${ }^{194}$ HURTADO AlBIR, A: op.cit., p.444.

195 DOMINGO Álvaro, A: op.cit., pp. 359-362.

${ }^{196}$ Ibid., pp. 363-368.

${ }^{197}$ NASH, Mary; TAVERA, Susana: Las mujeres y las guerras. El papel de las mujeres en las guerras de la Edad Antigua a la contemporánea. Icaria, Barcelona, 2003, p. 548.

${ }^{198}$ BINGHAM DE URQUIDI, M: op.cit., p. 33.
} 
aduciendo que "habían sido tratadas con cariño y consideración" "199. El hospital de sangre de Toledo tuvo una amplia plantilla formada por enfermeras voluntarias del Frente Popular, personal de Cruz Roja y religiosas que se prestaron a colaborar en la labor asistencial ${ }^{200}$.

Esta situación propició la aparición de cursos de capacitación de enfermeras a lo largo de todo el conflicto, tanto por parte del Estado como por iniciativas particulares. El doctor Planelles, Jefe de la Sanidad del $5^{\circ}$ Regimiento y de Madrid, constituyó una Escuela de enfermeras, con el objetivo de preparar a mujeres, de forma prematura, para que pudieran encargarse del cuidado de los heridos ${ }^{201}$. Cruz Roja organizó en Barcelona ${ }^{202}$, Madrid y Murcia cursos de enfermeras "eventuales de guerra", además de continuar con la formación de enfermeras profesionales en la Escuela de Madrid $^{203}$. La Jefatura de Sanidad también organizó cursillos de capacitación de enfermeras para cubrir las necesidades de este tipo de personal en los Hospitales Militares ${ }^{204}$. En Cataluña, la Generalitat impartió cursos de seis meses de duración, distribuyendo las clases teóricas por la mañana y las prácticas por las tarde, para permitir a las voluntarias obtener el título de enfermera de sangre o de guerra $^{205}$.

A principios de 1937 el Ministerio de Sanidad organizó cursos de capacitación en la Escuela de Enfermeras de la Facultad de Medicina de Valencia en colaboración con el comité de Mujeres Antifascistas. Esta preparación complementaria, que fue inicialmente de un mes, pasó a ser de tres meses, durante los cuales las alumnas permanecían en régimen de seminternado, ya que contaban con comedor. Las clases prácticas se impartían de las 9:00h a las 13:00h y las

\footnotetext{
${ }^{199} A B C, 2$ de octubre de 1937, Las monjas no quieren abandonar Mahón, p. 9.

${ }^{200} A B C, 30$ de julio de 1936, Foto de toda la plantilla del hospital de sangre de Toledo, $\mathrm{p} 7$.

${ }^{201}$ NAVARRO CARBALlO, J. R: op.cit., p. 86.

${ }^{202}$ La Vanguardia, 2 de febrero de 1937, Curso de enfermeras de Cruz Roja, p. 2.

203 AGMM, Ejército Republicano, R. 501.

${ }^{204}$ Gaceta de la República, $\mathrm{n}^{\circ}$ 91, 1 de abril de 1937, Orden reconociendo validez a los certificados de Enfermeras expedidos por la Jefatura de Sanidad del Ejército del Centro, mientras persistan las actuales circunstancias de guerra, p. 10.

${ }^{205}$ RAMIÓ, A; TORRES, C: op.cit., p. 126.
} 
teóricas de $15: 00 \mathrm{~h}$ a $18: 00 \mathrm{~h}^{206}$. Las cuarenta plazas ofertadas se cubrieron tras la selección realizada por parte de las organizaciones sindicales médicas, que eligieron a las mejores aspirantes en función de su nivel de cultura general siempre que estuvieran entre los 18 y los 35 años, siendo la escuela la encargada de realizar la elección final a través de una prueba de aptitud ${ }^{207}$.

Algunos cursos de los que se ofertaron únicamente tuvieron una semana de duración y contaron con veinte alumnas cada uno de ellos. El objetivo era formar en los "conocimientos más rudimentarios que implica la función de asistencia a heridos, así como las prácticas más simples de clínica y laboratorio"208.

La prensa se encargó de publicar la diversa oferta educativa, insistiendo en la demanda de profesionales y la necesidad de obtener una buena formación ${ }^{209}$. El enfoque del trabajo de la enfermera a través de los diarios se centró en su papel como mujer y en su rol femenino. "Cariño, amor y gratitud" hacia los heridos eran las cualidades que se les pedían a la hora de prestar sus cuidados ${ }^{210}$. Se hablaba de dos tipos de capacitación, la técnica y la de carácter psicológico-sexual, centrada en un rechazo hacia el pudor y hacia la vergüenza de ver el cuerpo desnudo del hombre. También se animaba a las enfermeras con experiencia a participar activamente en la formación de las nuevas voluntarias ${ }^{211}$.

No todas las mujeres pudieron terminar los cursos formativos debido a las cargas familiares y personales de las que se tuvieron que hacer responsables durante la guerra. Ana Viñas Puig, explicaba que de las 100 voluntarias que pasaron la prueba de acceso a uno de los cursos que organizó la CNT, únicamente lo terminaron veinticinco. Los motivos de este absentismo fueron la dificultad de las

\footnotetext{
206 Gaceta de la República, nº 6, 6 de enero de 1937, Orden organizando una serie de cursillos para preparación complementaria de Enfermeras, p. 97.

${ }^{207}$ Gaceta de la República, nº $.132,12$ de mayo de 1937, Orden autorizando a la Facultad de Medicina de la Universidad de Valencia para interrumpir los Cursos de Enfermeras que en la actualidad se vienen celebrando mensualmente, subtituyéndolos por otro de tres meses de duración que comience en la segunda quincena del mes actual, p. 647.

${ }^{208}$ La Vanguardia, 20 de agosto de 1936, Cursillo para enfermeras, p. 3.

${ }^{209}$ Nuestra Sanidad, n ${ }^{\circ} 41$ de abril de 1937, p.3. La Vanguardia, 4 de agosto de 1936, Un cursillo para enfermeras auxiliares, p. 2; La Vanguardia, 13 de agosto de 1936, Cursillo de enfermeras, p. 4.

${ }^{210}$ Hospitales, Valencia, noviembre-diciembre de 1938, p. 14-15.

${ }^{211}$ La Voz de Sanidad, $\mathrm{n}^{\circ}$ 6, 31 de mayo de 1938, La enfermera y la mujer, p. 14.
} 
mujeres para compaginar las clases con su rol de madres, esposas e hijas que se vieron obligadas a trabajar para ayudar en sus casas ${ }^{212}$.

La necesidad de profesionales hizo que se aceptara a todas las mujeres dispuestas a contribuir con su labor aunque no tuvieran la formación, ni la experiencia adecuada ${ }^{213}$, por eso, durante la guerra, se las dio la oportunidad de presentarse a una serie de exámenes que les facilitaran la obtención del título de enfermeras a través de una convalidación de los conocimientos adquiridos durante su trabajo voluntario en los hospitales ${ }^{214}$. Las interesadas primero tuvieron que realizar los cursos de capacitación, y pasar un examen previo de cultura general que era eliminatorio ${ }^{215}$, y un reconocimiento médico ${ }^{216}$. Entre los requisitos exigidos también se encontraba el de estar sindicadas o pertenecer a algún partido político del Frente Popular $^{217}$. Sanidad Militar llegó a ofertar 1.500 plazas de enfermeras de guerra que se cubrieron tras la realización de un examen ${ }^{218}$. Una vez obtenido el título debían consolidar su plaza:

De orden superior, se advierte a todas las enfermeras de Sanidad Militar (que estén o no actualmente colocadas) que hayan conseguido su título oficial mediante los cursillos organizados por esta Dirección, que para ingreso definitivo oficial en el Cuerpo de Enfermeras de Sanidad Militar, deben presentar, lo antes posible, una solicitud pidiéndolo así, acompañada del aval político o sindical y el correspondiente título ${ }^{219}$.

\footnotetext{
${ }^{212}$ RAMIÓ, A; TORRES, C: op.cit., pp. 81-82.

${ }^{213}$ La Vanguardia, 3 de septiembre de 1936, Invitación a las actrices, p. 12.

${ }^{214}$ NAVARRO CARBALLO, J. R: op.cit., p. 87.

215 ABC, 4 de marzo de 1937, Cursillos de enfermeras, p. 9, ABC, 8 de mayo de 1937, Curso de enfermeras, p. 8.

${ }^{216} A B C, 12$ de marzo de 1937, Cursillo de enfermeras, p.14, ABC, 31 de marzo de 1937, Enfermeras de guerra, p. 10.

${ }^{217} A B C, 26$ de febrero de 1937, Cursillos para enfermeras, p. 12, ABC, 12 de febrero de 1937, Cursillos para enfermeras de guerra, p. 15.

${ }_{218} A B C, 12$ de abril de 1938, Dirección de Sanidad del Ejército del Centro, p. 4. La Vanguardia, 10 de abril de 1938, Enfermeras de guerra, p. 7.

${ }^{219} A B C, 13$ de abril de 1938, Preparación de enfermeras, p. 4.
} 
Trabajos como el de Navarro señalan la existencia de enfermeras que actuaban como titulares sin estar en posesión de la acreditación necesaria, de hecho refleja que el Comisario de Sanidad del Ejército del Este, en sus memorias hablaba de intrusión en la Enfermería, ya que consideraba que no todas las mujeres que acudían como voluntarias lo hacían de forma vocacional sino movidas por el hambre, por la aventura e incluso para la obtención de un escudo político ${ }^{220}$.

Cabe señalar que la buena voluntad y las ganas de ayudar no fueron suficientes para aprobar los exámenes oficiales, por eso no todas las aspirantes obtuvieron el título de enfermera de guerra. De esta forma se puede plasmar, que a pesar de las facilidades que dio la República, la dificultad de compaginar el trabajo en los hospitales con las horas de estudio y las clases, impartidas principalmente por médicos y enfermeras profesionales, no fueron suficientes para lograr el título oficial $^{221}$.

\subsection{Las enfermeras extranjeras y su implicación en la Guerra Civil}

La llegada de enfermeras extranjeras contribuyó a suplir la carencia de personal cualificado, ya que todas contaban con una amplia formación y experiencia profesional en sus países de origen. Fredericka Martin, enfermera del Crotona Park Hospital de Nueva York, fue directora del primer hospital norteamericano en España $^{222}$. Lini Vries además de ser enfermera también era especialista en Salud Pública $^{223}$, Dorothy Law era enfermera del ejército británico con una amplia experiencia laboral ${ }^{224}$, René Shadbolt enfermera jefe del servicio de urgencias del Hospital de Auckland e Isobel Dodds con plaza fija de enfermera en el hospital de Wellington $^{225}$, son algunos ejemplos de voluntarias que dejaron sus trabajos para ayudar a España en el campo sanitario.

\footnotetext{
${ }^{220}$ NAVARRO CARBALlO, J. R: op.cit., p. 87.

${ }^{221}$ RAMIÓ, A; TORRES, C: op.cit., pp. 98-115.

${ }^{222}$ USANDIZAGA, A: op.cit., p. 213.

${ }^{223}$ Ibid., p. 220.

${ }^{224}$ PRESTON, Paul: Palomas de guerra. Plaza y Janes, Barcelona, 2001, p. 125.

${ }^{225}$ DERBY, M: op.cit., pp. 124-125.
} 
Angela Jackson tuvo la oportunidad de entrevistar a las enfermeras británicas que acudieron a España con las Brigadas Internacionales, todas con la titulación reglamentaria y con experiencia profesional, tal fue el caso de Patience Darton que además de enfermera también era matrona ${ }^{226}$.

Según Jackson, las enfermeras británicas que acudieron a trabajar a España lo hicieron de forma voluntaria, fue una elección personal y particular guiada principalmente por el sentimiento humanitario de ayuda y de deber ante la falta de personal sanitario, más que por cuestiones políticas o ideológicas. A todas les unía la conciencia social, las ganas de llevar a cabo una labor humanitaria y la empatía por el pueblo español ${ }^{227}$. Tal fue el caso de Agnes Hodson, enfermera australiana, que explicaba en su diario que no tenía "una tendencia política clara", pero que estaba "en contra de la guerra" y simpatizaba con "el Gobierno Español"228.

En algunas ocasiones no les fue fácil ser admitidas en los equipos quirúrgicos de ayuda a España, pero gracias a su perseverancia consiguieron formar parte del grupo de voluntarios enviados por el Comité de Ayuda Médica que se gestionó desde Gran Bretaña. Su decisión de acudir como enfermeras voluntarias y renunciar a sus puestos de trabajo en muchas ocasiones no fue aceptada ni aprobada por sus superiores, llegando a ser penalizadas con la denegación de permisos de descanso e incluso en alguna ocasión, con una indemnización económica por no avisar al hospital con un mes de antelación de su partida a España ${ }^{229}$. Las enfermeras neozelandesas fueron retenidas por la policía antes de iniciar su viaje a España, intentaron retirarles sus pasaportes y las sometieron a un interrogatorio sobre su ideología política y su interés de presentarse como voluntarias. La actuación de la policía se justificó aludiendo al "pánico gubernamental ante el panorama de tener a tres devotas revolucionarias enarbolando la bandera neozelandesa en España"230.

\footnotetext{
${ }^{226}$ JACKSON, A: Para nosotros...op.cit., p. 24-27.

${ }^{227}$ JACKSON, A: Las mujeres...op.cit., pp. 144-145.

${ }^{228}$ HODSON, A: op.cit., p. 257.

${ }^{229}$ JACKSON, A: Las mujeres...op.cit., pp. 146.

${ }^{230}$ DERBY, M: op.cit., pp. 126-127.
} 
Las enfermeras extranjeras ${ }^{231}$ hicieron una labor "excelente y perfecta",232, por lo general trabajaron juntas en los hospitales en función de su nacionalidad, tal fue el caso de las enfermeras británicas, las norteamericanas y las escandinavas ${ }^{233}$. El idioma, en ocasiones supuso una dificultad añadida al trabajo diario ya que debían entender las órdenes médicas y ser capaces de comunicarse con los heridos. Tenían que conocer el español, pero al trabajar en los hospitales de las brigadas estaban obligadas a estar en contacto con personas de otras nacionalidades. Las enfermeras neozelandesas hablaban de la dificultad que les supuso entender las instrucciones que recibieron como ayudantes de quirófano de los médicos holandeses y franceses $^{234}$. Además de realizar el trabajo asistencial también se encargaron de la formación de voluntarias en los pueblos donde se instalaban los hospitales de las brigadas $^{235}$, dejándolas principalmente las tareas relacionadas con la limpieza del hospital y su abastecimiento, más que "molestarse en enseñarlas" a atender heridos $^{236}$. De hecho, lo común fue que las mujeres del pueblo donde se instalaba un hospital se ofrecieran como voluntarias para la limpieza del mismo, lavar, cocinar, coser, etc., todas ellas tareas auxiliares pero necesarias para el buen funcionamiento del centro ${ }^{237}$.

Las enfermeras extranjeras demostraron sus aptitudes profesionales y tuvieron puestos de responsabilidad. Peny Phelps, enfermera especializada en enfermedades infecciosas, fue capaz de organizar al personal para realizar un programa de desinfección, fumigación y vacunación del batallón Garibaldi para hacer frente a un brote de escarlatina ${ }^{238}$. Patience Darton asumió el mando en el hospital de Valls cuando el médico del mismo fue enviado al frente, ocupando el

\footnotetext{
${ }^{231}$ Las enfermeras extranjeras quedaron adscritas a las Brigadas Internacionales que pasaron a pertenecer al Ejército Republicano.

${ }_{232}$ AMI, $\mathrm{n}^{\mathrm{o}}$ 5, 1 de diciembre de 1937, Relato del Dr. M. Broggi Vallés, p. 1.

${ }^{233}$ AMI, $\mathrm{n}^{\circ}$ 9, 1 de febrero de 1938, American Nurses in Southern Spain!, p. 9.

${ }^{234}$ DERBY, M: op.cit., p. 139.

${ }^{235}$ AMI, ${ }^{\circ}$ 9, 1 de febrero de 1938, Anglo-American Nurses in Benicasin, p. 19.

236 JACKSON, A: Para nosotros ...op.cit., p. 53.

${ }^{237} A B C, 2$ de marzo de 1937, El primer hospital americano en España, p. 11.

${ }^{238}$ JACKSON, A: Las mujeres...op.cit., p. 158.
} 
puesto de oficial médico, "atendía a los enfermos y sólo mandaba llamar a otro médico si veía que el problema superaba sus capacidades"239. También se encargó del control del hospital $\mathrm{N}^{\circ} 2$ de la 35 División en Marsá debido a su cualificación para hacer sola el triaje de los heridos. Posteriormente la ofrecieron "organizar una ambulancia con ocho camas, con el personal y los camilleros necesarios para acudir al frente" 240 . Las enfermeras neozelandesas también demostraron sus aptitudes avaladas por su experiencia laboral, Una Wilson trabajó en los quirófanos de los frentes del Jarama, Brunete y Teruel ${ }^{241}$, y Dorothy Morris fue la enfermera jefe de la XIII Brigada Internacional ${ }^{242}$.

Tras el viaje duro y difícil hasta España, las enfermeras extranjeras tuvieron que pasar una serie de trámites burocráticos en el departamento de extranjería y obtener en ocasiones autorizaciones que las permitieran realizar su trabajo en el frente $^{243}$. Mary Bingham de Urquidi contó con un salvoconducto del Socorro Rojo Internacional firmado por el Doctor Planelles que le permitió salir de España para poder encontrase con su familia gracias al trabajo desempeñado de forma voluntaria en Madrid al inicio de la contienda como "encargada responsable del quirófano habiendo desarrollado una labor inestimable al servicio de los heridos en la lucha por la libertad"244. Las enfermeras españolas también necesitaron autorizaciones específicas para moverse por Madrid, sobre todo cuando fueron movilizadas para ir de un hospital a otro para prestar sus servicios ${ }^{245}$. Ramona Guernés i Costa, jefa de enfermeras en la clínica del Remei necesitó un salvoconducto para poder ir a la Generalitat a recoger el dinero necesario para gestionar el hospital y pagar a las compañeras $^{246}$.

\footnotetext{
${ }^{239}$ JACKSON, A: Para nosotros...op.cit., p. 67.

${ }^{240}$ Ibid., p. 86.

${ }^{241}$ DERBY, M: op.cit., p. 137.

${ }^{242}$ Ibid., p. 146.

${ }^{243}$ HODSON, A: op.cit., p. 265 y 281.

${ }^{244}$ BINGHAM DE URQUIDI, M: op.cit., p. 164.

245 Archivo General Militar de Ávila (AGMAV), C. 3675,3, Isabel López Méndez, 1936-1939.

${ }^{246}$ RAMIÓ, A; TORRES, C: op.cit., p. 89.
} 
La Guerra Civil abrió un horizonte nuevo para las enfermeras, tanto españolas como extranjeras ya que como señala Aránzazu Usandizaga:

A causa de la dura depresión de los primeros años de la década de los treinta, la mujer occidental asiste a un vertiginoso retroceso en su derecho al trabajo $\mathrm{y}$, sobre todo, en su libertad expresión, adquiridos con tanta dificultad unos años antes. Sus derechos sufren grave merma, y la búsqueda de su identidad y de su posición social se pone de nuevo en cuestión. En tales circunstancias, la Guerra Civil se presentó para muchas extranjeras como una oportunidad de acción y de expresión. $^{247}$

\subsection{Formación e imagen de las enfermeras republicanas a través de} los manuales

La situación bélica modificó los contenidos lectivos que se centraron mayoritariamente en la atención a heridos de guerra y en la adquisición rápida de conocimientos básicos para poder auxiliarlos ${ }^{248}$. Conocer los tipos de gases y el tratamiento de las intoxicaciones de los mismos, las curas de urgencia y los primeros cuidados, pasaron a ser contenidos indispensables en los manuales de enfermeras:

La guerra impone la improvisación del personal auxiliar encargado de la asistencia de los heridos, ya que el existente en tiempos de paz es francamente insuficiente. Si este personal improvisado quiere adquirir unos conocimientos teóricos, se encuentra con que los manuales publicados le resultan excesivamente extensos y le es difícil separar aquello que es más urgente de aprender. Pensando en ello hemos preparado estas cuartillas, extraídas de nuestro Manual de la Enfermera,

\footnotetext{
${ }^{247}$ UsANDIZAGA, A: op.cit., p. 236.

${ }^{248}$ Se han analizado un total de ocho manuales formativos: UsANDIZAGA, Manuel: Asistencia a los heridos de guerra. Normas elementales para el personal auxiliar. Aldus, Santander, 1936; CRUZ ROJA FrANCESA. Unión de Mujeres de Francia: Manual de la enfermera Hospitalaria. Segunda edición. Espasa-Calpe, Madrid, 1937; NAYA CASADEMONT, Pascual: Apuntes de la enfermera. Huesca, Abril 1936; FONTÁN CALVO, DAPORTA GONZÁLEZ. Contestaciones al programa de la carrera de la enfermera. Librería Gali, Santiago, 1936; GARCíA TORNel, Lorenzo: Manual del practicante y de la enfermera. Quinta edición Tomo I. Bosch, Barcelona, 1938; PIGA, Antonio: Terapéutica de los gaseados de guerra. Rivadeneyra, Madrid, 1936. El criterio seguido para diferenciar entre la zona republicana y la nacional ha sido el año y el lugar de edición de los mismos. Los manuales publicados en 1936 anteriores al comienzo de la Guerra civil se han incluido en el análisis de la imagen de la enfermera en la zona republicana.
} 
que no tienen más finalidad que servir de iniciación a ese personal auxiliar que carece de toda formación anterior ${ }^{249}$.

Tabla 9. Contenidos formativos de los manuales de enfermeras republicanas.

\begin{tabular}{|c|c|c|c|c|}
\hline \multicolumn{5}{|c|}{ NUEVOS CONTENIDOS FORMATIVOS } \\
\hline $\begin{array}{c}\text { Contusiones y } \\
\text { heridas }\end{array}$ & $\begin{array}{c}\text { Complicaciones } \\
\text { infecciosas de las } \\
\text { heridas }\end{array}$ & Esterilización & $\begin{array}{c}\text { Curas } \\
\text { quirúrgicas }\end{array}$ & Vendajes \\
\hline Hemorragias & $\begin{array}{c}\text { Fracturas, } \\
\text { esguinces y } \\
\text { luxaciones }\end{array}$ & $\begin{array}{c}\text { Accidentes } \\
\text { producidos por } \\
\text { el calor/ frío }\end{array}$ & $\begin{array}{c}\text { Asistencia a los } \\
\text { heridos en el } \\
\text { hospital }\end{array}$ & $\begin{array}{c}\text { Complicaciones } \\
\text { que presentan los } \\
\text { heridos y } \\
\text { operados }\end{array}$ \\
\hline
\end{tabular}

Fuente: UsANDIZAGA, M: Asistencia a los heridos de guerra. Normas elementales para el personal auxiliar. Aldus, Santander, 1936.

Además de la aparición de nuevos manuales formativos que hacían hincapié en los conocimientos relacionados con la situación bélica, otros añadieron lecciones enfocadas en esa misma dirección, centradas en la Enfermería y la guerra química y la administración militar ${ }^{250}$.

Las cualidades físicas, morales e intelectuales que debían reunir las enfermeras eran las mismas que las exigidas durante el periodo republicano ${ }^{251}$. Las alusiones al espíritu de sacrificio, sentimiento del deber, prudencia, paciencia y caridad continuaban apareciendo en las lecciones teóricas ${ }^{252}$. Debían contar con un excelente estado de salud y llevar una "vida higiénica, acompañada de una buena

\footnotetext{
${ }^{249}$ USANDIZAGA, M: op.cit., p. 2.

${ }^{250}$ CRUZ RoJA FRANCESA. Unión de Mujeres de Francia: op.cit.

${ }^{251}$ NAYA CASADEMONT, P: op.cit., p. 9.

${ }^{252}$ FonTÁN CALVO, DAPORTA GONZÁLEZ: op.cit., Lección 13.
} 
alimentación, ejercicio físico y horas regulares de sueño"253. Evitar la propagación de enfermedades infecciosas y cuidar la higiene personal era importante por lo que se las enseñaba a realizar de forma correcta el lavado de manos:

El aseo de las enfermeras debe ser minucioso, evitando todo medio de propagación de procesos infecciosos, así por la limpieza de las partes descubiertas como por la parte de la ropa, siendo necesario que en el ejercicio de su cargo separe, en bien propio, en bien del enfermo y en bien de los suyos, las ropas de vestir del ambiente que le rodea, mediante el traje reglamentario o una larga blusa abotonada hasta el cuello y cubriendo la cabeza en forma que se evite la caída del pelo durante el servicio. $[\ldots]^{254}$

La obligación humanitaria de la enfermera se seguía enfocando hacia la bondad, la dulzura y el altruismo, sin olvidarse de la actitud cariñosa que debían dispensar a todos los enfermos, manteniendo siempre la discreción y el secreto profesional $^{255}$. Debía ser siempre dulce y paciente, además de evitarles "toda fatiga inútil y toda preocupación"256.

Es importante reseñar que la instrucción, la inteligencia y la formación continuaban ligadas a la profesión, enfocados hacia el beneficio del enfermo y los médicos. Tampoco hay modificaciones respecto los deberes que debían tener las enfermeras con los enfermos, los médicos y las propias compañeras, destacando la disciplina y el respeto, además de fomentar la armonía en el trabajo ${ }^{257}$.

La Enfermería seguía ligada a las mujeres por su rol en la sociedad y sus mejores "aptitudes" para el desempeño del trabajo, ya que sus "manos blancas y dulces" ${ }^{258}$ eran necesarias para atender a los heridos:

\footnotetext{
${ }^{253}$ GARCÍA TORNEL, L: op.cit., p.171.

${ }^{254}$ Ibid., p. 171.

${ }^{255}$ Ibid., p. 172.

${ }^{256}$ CRUZ RoJA FranCESA. Unión de Mujeres de Francia: op.cit., p. 797.

${ }^{257}$ GARCÍA TORNEL, L: op.cit., pp.173-174.

${ }^{258}$ PIGA, A: op.cit., p. 6.
} 
Sólo una mujer puede llenar debidamente la noble misión de la enfermera cuando en el ejercicio de la misma la esperan dificultades, peligros para su propia vida, condiciones todas que sólo es capaz de vencer el alma de la mujer que lleva en germen, ya desde su juventud, el alto espíritu de su misión consoladora ${ }^{259}$.

\subsection{Vida y trabajo de las enfermeras durante el conflicto}

Durante el inicio de la contienda fue común la imagen en prensa de enfermeras trabajando cerca de la "línea de fuego" realizando una cura de urgencia, “prestando sus humanitarios servicios en los puestos avanzados de la Cruz Roja”, en los hospitales de sangre y en el tren sanitario. Las enfermeras ocuparon portadas, fueron noticia, su trabajo fue importante y necesario, estaban presentes en el frente, pero a pesar de todo, como sucedió con las milicianas, su labor en el mismo se fue desdibujando para dar paso a su trabajo en la retaguardia ${ }^{260}$. Las enfermeras no querían estar inactivas y preferían en muchas ocasiones el trabajo duro de la vanguardia al llevado a cabo en la retaguardia ${ }^{261}$ (ver imagen XIV).

Trabajar en primera línea suponía afrontar diversas adversidades, entre ellas la exposición continua a los bombardeos de la aviación enemiga ${ }^{262}$, lo que propició que las enfermeras fueran heridas mientras realizaban su labor ${ }^{263}$ : "En Pompenillo, del frente de Huesca, ha sido herida en ambas piernas, cuando auxiliaba a un alemán de la columna Thaelmann, la enfermera inglesa Margaret Miller, que solía situarse siempre en las primeras líneas. Ha quedado atendida en el hospital inglés de Grañén"264. Algo parecido le sucedió a Peny Phelps que durante un bombardeo que

\footnotetext{
${ }^{259}$ GARCÍA TORNEL, L: op.cit., p.175.

${ }^{260} A B C, 8$ de diciembre de 1936, p. 8; $A B C, 6$ de octubre de 1936, p. 5, $A B C, 18$ de agosto de 1936, p. 5; $A B C, 16$ de agosto de 1936, p. 16, $A B C, 17$ de septiembre de 1936, p. 13; $A B C, 16$ de septiembre de 1936, p. 2; $A B C, 24$ de septiembre de 1936, portada; $A B C, 26$ de febrero de 1937, p. 5.

${ }^{261}$ HodsON, A: op.cit., p. 290.

${ }^{262}$ La Voz de Sanidad, no 3, 29 de marzo de 1938, La moral del personal de hospitales, p. 14. La Vanguardia, 26 de noviembre de 1936, Emocionante relato del bombardeo criminal del Hospital Clínico de Madrid, hecho por el decano de la Facultad de Medicina, p. 4.

${ }^{263}$ La Vanguardia, 23 de julio de 1936, Los servicios de la Cruz Roja, p. 1.

${ }^{264} A B C, 15$ de octubre de 1936, Una enfermera inglesa herida, p. 12.
} 
afectó a su unidad quirúrgica recibió una bala que la obligó a hospitalizarse ${ }^{265}$. Patience Darton hablaba de la vulnerabilidad que sentía ante las balas de ametralladoras y los morteros, unido a la dificultad para refugiarse ${ }^{266}$. En algunas ocasiones las enfermeras llegaron a perder la vida durante el conflicto ${ }^{267}$ :

En el sector de Tardienta ha muerto, a consecuencia de haberle alcanzado los cascos de unas bombas lanzadas por los aviones facciosos la enfermera de la Cruz Roja Elisa García, de veinte años. Al estallar la sublevación se alistó en la Cruz Roja, y días antes de su muerte su madre recibió una carta en la que Elisa decía: "No paséis pena por mí; procuraré que no me pase nada; pero si por casualidad me sucediera algo, pensad que otros como yo también habrán caído. Si yo supiera que dando mi vida se podría terminar con los asesinos de la clase trabajadora, gustosa la daría. Si os dijeran que la lucha no es propia de las mujeres, decid que el cumplimiento del deber revolucionario corresponde a toda persona que no sea cobarde ${ }^{268}$.

Ana Pibernat relataba en sus memorias el bombardeo que sufrió junto a otras dos enfermeras mientras cruzaban el patio central del hospital para ir a comer. Únicamente se salvó ella, aunque tras el impacto de la explosión se quedó sorda del oído derecho ${ }^{269}$. El caos de la guerra, sobre todo al inicio de la misma, propició la muerte de algunas enfermeras, en ocasiones a manos de los insurrectos como el caso de las enfermeras del sanatorio de la Lanzada de Pontevedra que "abandonaron su trabajo ante la agresividad de los moros. Estos, al día siguiente de la huida de las enfermeras, se dedicaron a buscarlas. A las que encontraron se las llevaron a un monte, y a algunas, después de abusar de ellas, las mataron" ${ }^{\text {"270 }}$. Otras veces fueron fusiladas, después de haber caído prisioneras siendo "para el enemigo prueba suficiente de su condición revolucionaria"su labor sanitaria ${ }^{271}$. Habitualmente los

\footnotetext{
${ }^{265}$ PRESTON, P: op.cit., p. 132.

${ }^{266}$ JACKSON, A: Para nosotros...op.cit., p. 71.

267 ABC, 24 de octubre de 1936, Muere un comunista belga y una enfermera alemana, p. 12. La Vanguardia, 25 de octubre de 1936, Entierro de una enfermera, p. 4.

${ }^{268} A B C, 4$ de septiembre de 1936, Muerte de una heroica enfermera, p. 8.

${ }^{269}$ HURTADO ALBIR, A: op.cit., p.445.

${ }^{270} A B C, 5$ de diciembre de 1937, El terror vuelve a imperar en el campo rebelde. El odio a los intelectuales, p. 3.

${ }^{271} A B C, 10$ de noviembre de 1936, Un enfermera alemana y tres francesas fusiladas, p. 10.
} 
asesinatos de heridos iban unidos a los de sus enfermeras que preferían permanecer a su lado antes que abandonarles ${ }^{272}$.

Este no fue el único riesgo que corrieron, ya que estar expuestas a las duras condiciones climáticas, de insalubridad, de escasez de comida y a las largas jornadas de trabajo, hizo que muchas de ellas enfermaran. Patience Darton padeció pleuritis como consecuencia de haber permanecido en cama por una quemadura en la piel $^{273}$. En una de sus cartas explicaba que tenía "gripe, un brazo infectado y estaba muerta de cansancio" ${ }^{274}$, tampoco se libró de sufrir disentería y de un accidente de tráfico en una ambulancia que la desfiguró por completo la cara y la obligó a realizarse varias intervenciones quirúrgicas ${ }^{275}$. Mary Bingham de Urqudi hablaba de sus piernas y pies hinchados por la falta de descanso y del día que se quemó en el quirófano cuando se reventó un tubo de gas del esterilizador ${ }^{276}$. Las largas e intensas jornadas laborales mermaron la salud de las voluntarias, Una Wilson describía que estaba agotada y deprimida, esta situación mantenida en el tiempo le llevó a enfermar, a padecer dolores gástricos y a sufrir una crisis nerviosa ${ }^{277}$, su compatriota Isobel Dodds estuvo hospitalizada por padecer una úlcera de estómago ${ }^{278}$. Las epidemias que afectaron a los soldados también hicieron mella entre las enfermeras, la contaminación bacteriológica de las aguas del Ebro dio lugar a la aparición de un brote de tifus entre los soldados que colapsaron el hospital de sangre situado en Valls donde trabajaba Ana Pibernat. A pesar de estar vacunadas y tomar precauciones, tres enfermeras perdieron la vida a consecuencia de la propagación de la enfermedad ${ }^{279}$.

El uniforme blanco e inmaculado, asociado a la imagen de la enfermera, fue difícil de mantener durante la contienda, además de ser poco práctico para

\footnotetext{
${ }^{272} A B C, 1$ de octubre de 1936, Asesinatos de heridos y enfermeras, p. 7.

273 JACKSON, A: Para nosotros...op.cit., p. 60.

${ }^{274}$ JACKSON, A: Las mujeres...op.cit., p. 72.

275 JACKSON, A: Para nosotros...op.cit., pp. 86-87.

${ }^{276}$ BINGHAM DE URQUIDI, M: op.cit., pp. 93-94 y 104.

277 DERBY, M: op.cit., pp. 140-142.

278 Ibid., p. 148.

${ }^{279}$ HuRTADO AlbIR, A: op.cit., p. 448
} 
enfrentarse al frío y a las condiciones duras de trabajo. Agnes Hodgson explicaba que llevaban "pantalones y botas de montar, jerséis y calcetines de lana y, encima el uniforme" ${ }^{, 280}$. Patience Darton en su relato describe el uniforme que recibían las voluntarias británicas que acudieron a España que consistía en "tres vestiditos azules de cuello blanco y con puños vueltos" que a ojos de la enfermera británica resultaban "ridículos". La bata era incómoda porque se desabrochaba fácilmente y los tocados grandes y blancos que también formaban parte del uniforme eran innecesarios, además de no proveerlas de ropa interior, calcetines o compresas ${ }^{281}$. A pesar de todo, "la blanca toca de la enfermera" seguía siendo el distintivo que caracterizaba al personal femenino, ligado siempre a sus "abnegados" y "solícitos" cuidados $^{282}$ (ver imagen XV).

El trabajo en los hospitales de vanguardia fue duro, la carga laboral dependía directamente de las demandas del frente. Las enfermeras se adaptaron a la situación bélica, tuvieron que atender a los heridos en tiendas de campaña y participar en las operaciones que se realizaban en las unidades médicas móviles, situadas en el frente de combate. Los edificios, se convirtieron en hospitales improvisados y cuando la guerra empeoró, atendieron a los heridos en trenes, en túneles y en cuevas, sobre todo durante la batalla del Ebro $^{283}$. También participaron activamente en la evacuación de hospitales, en los traslados y en la instalación de nuevos centros sanitarios, lo cual en muchas ocasiones fue difícil debido a las duras condiciones climáticas, al hambre y a las enfermedades epidémicas ${ }^{284}$.

Es complejo describir un turno concreto de trabajo ya que en muchas ocasiones las enfermeras adaptaban su jornada a las demandas asistenciales, por eso fue común que ante la avalancha de heridos del frente, se vieran obligadas a trabajar día y noche $e^{285}$. Lini de Vries explicaba que llegaron a pasar cuatro días sin dormir,

\footnotetext{
${ }^{280}$ HodsOn, A: op.cit., p. 300.

${ }^{281}$ JACKSON, A: Para nosotros...op.cit., p. 33.

${ }^{282} A B C, 10$ de febrero de 1937, Primero de Guerra, p. 7.

283 JACKSON, A: Las mujeres...op.cit., pp.154 y 325.

284 ÁlvAREZ, Santiago: Historia política y militar de las Brigadas Internacionales. Compañía literaria, Madrid, 1996, p. 216.

${ }^{285}$ HoDSON, A: op.cit., p. 320.
} 
dando "algunas cabezadas apoyadas en la pared"286. Ana Pibernat relataba que trabajaban "sin cesar", ya que al terminar su turno, "que era muy duro", salían con la ambulancia a buscar heridos civiles después de los bombardeos ${ }^{287}$. También explicaba que "cada semana les cambiaban de sala y turno, que el horario era ocho horas, mañana, tarde y noche" y que se iban turnando, "dos semanas de día y la tercera de noche" 288 . Patience Darton contaba que durante la batalla del Ebro las enfermeras trabajaban más durante "las guardias nocturnas" de forma que dedicaban las horas diarias a dormir "un poco" porque era cuando ingresaban menos heridos ${ }^{289}$. Ana Viñas Puig explicaba que en el hospital de la Garriga los turnos eran de veinticuatro horas con cuatro días de descanso ${ }^{290}$, hay que destacar que estaba situado en la retaguardia por lo que fue más fácil establecer una jornada concreta, a diferencia de los de vanguardia que dependían de las demandas del frente (ver imagen XVI).

Además de enfrentarse a turnos de trabajo largos, también asumieron unas condiciones inadecuados de salubridad, ya que no contaron con un suministro continuo de agua, ni de electricidad, lo que las obligó a trabajar a la luz de las velas. La falta de agua impedía que pudieran asearse de forma adecuada. Tampoco tuvieron una alimentación saludable debido a que la comida escaseaba, llegando a ser monótona y deficitaria, las enfermeras británicas en sus relatos recordaban el dolor de estómago que padecieron, unido a cuadros de disentería y de déficit nutricional $^{291}$ :

La mayoría de los días no comemos carne, y para desayunar, un huevo y agua (todavía nos queda algo de té). El comité local no nos adelanta nada. Paulino busca caracoles y setas con que cocinar. Todos notamos las molestias abdominales en la zona epigástrica, que se suavizan un poco con la comida. No queda

\footnotetext{
${ }^{286}$ USANDIZAGA, A: op.cit., p. 138.

${ }^{287}$ HURTADO ALBIR, A: op.cit., p.445.

288 Ibid., p. 447.

${ }^{289}$ JACKSON, A: Para nosotros...op.cit., p. 110.

${ }^{290}$ RAMIÓ, A; TORRES, C: op.cit., p. 74.

${ }^{291}$ JACKSON, A: Las mujeres ...op.cit., p. 157.
} 
mermelada, así que comemos pan duro y seco; aún hay alubias y un poco de miel. Con suerte, tal vez nos llegue pronto un poco de fruta ${ }^{292}$.

Respecto al trabajo que realizaron en los hospitales y las funciones de cada puesto, cabe tener en cuenta los relatos de las enfermeras catalanas que explicaban que durante el turno de mañana se levantaba y aseaba a los pacientes, se hacían las camas y se comenzaban las curas con la supervisión del médico que visitaba a los heridos y consultaba sus historiales. Una vez finalizados estos cuidados se encargaban de dar de comer a los convalecientes. A las diez de la noche se apagaban las luces "por miedo a los bombardeos", ponían las inyecciones correspondientes y doblaban vendas y $\operatorname{gasas}^{293}$. Las funciones asistenciales que llevaron a cabo las auxiliares o ayudantes se centraron principalmente en la higiene y alimentación de heridos y enfermos, mientras que las enfermeras profesionales fueron las que ocuparon los puestos de jefas de sala, además de pasar visita con el médico y anotar las prescripciones ${ }^{294}$.

El trabajo de las enfermeras no fue fácil, se enfrentaron a un déficit de material y de personal que las obligó a tomar decisiones complejas. Además de atender a los heridos e instrumentar en los quirófanos, tenían que encargarse de la limpieza del material y de su esterilización. Los hospitales estaban llenos de pacientes a los que debían atender, no tenían espacio suficiente para desarrollar su labor, ni tiempo para asistirlos ${ }^{295}$. Las avalanchas de heridos que llegaban del frente las obligaba a priorizar y las exigía elegir a quién debían atender primero, estas decisiones les generaban situaciones de estrés y sobrecarga moral ${ }^{296}$. Las enfermeras participaron en el sistema de triaje que llevaron a cabo en las distintas unidades de asistencia, evaluaban el estado de los heridos decidiendo a quienes se intervenía primero; a los graves se les atendía de urgencia, siendo operados inmediatamente si era necesario, mientras que los que se encontraban en mejores condiciones eran trasladados al hospital de base, de esta forma consiguieron un mayor índice de supervivencia entre los heridos.

\footnotetext{
${ }^{292}$ HoDSON, A: op.cit., p. 329.

${ }^{293}$ RAMIÓ, A; TORRES, C: op.cit., pp. 75-76.

294 Ibid., p. 120.

${ }^{295}$ DERBY, M: op.cit., pp. 139-141.

${ }^{296}$ JACKSON, A: Las mujeres...op.cit., p. 161.
} 
La falta de material aparece en todos los relatos de las enfermeras, por ejemplo durante la batalla del Ebro afilaban las agujas en piedras para poder utilizarlas $^{297}$. Las malas condiciones de la carretera dificultaban el traslado de heridos, por eso se instalaban los puesto de socorro lo más cerca posible del frente, como sucedió en la batalla del Ebro en la que se habilitó como hospital la cueva de Bisbal de Falset ${ }^{298}$, que fue elegida por su emplazamiento pero sobre todo por la protección que ofrecía durante los bombardeos. Las camas para atender a los heridos estaban situadas de forma "caótica" debido a las irregularidades del terreno, lo que ocasionaba que las enfermeras se tropezaran en la oscuridad con ellas. El triaje lo hacían en una tienda situada en el valle, porque era hasta allí donde llegaban las ambulancias, luego los camilleros subían a la cueva a los heridos graves para ser intervenidos ${ }^{299}$.

Las enfermeras también se encargaron de la evacuación de los hospitales y sufrieron traslados de puesto de trabajo en función de las demandas del frente y del avance de las tropas enemigas que obligaba a establecer nuevos puestos de socorro:

El acoso de la aviación era constante. Fueron muchas las veces que, en medio del campo, tuvimos que improvisar puestos de socorro, pues eran cientos de familias, unas con carros, otras a pie, viejos, niños y mujeres, con hambre y miedo pues la aviación no cesaba de perseguirnos, camino del exilio.

La llegada al hospital de Figueres fue una visión dantesca, pues era tal la cantidad de heridos, evacuados de tantos hospitales, que improvisaron un almacén grandioso enfrente de la estación de tren. Humanitariamente era imposible atenderlos adecuadamente. Una situación desesperante. Aún ahora, al recordarlo después de tantos años, lloro pensando en la impotencia delante del dolor: cientos de camillas en el suelo, sin techo ni protección, pues el hospital estaba saturado; gritos de angustia y desesperación; y la aviación, sembrando con bombas incendiarias el hospital, sus alrededores, $\mathrm{y}$ toda la ciudad. [...] $]^{300}$

\footnotetext{
${ }^{297}$ ÁLVAREZ, S: op.cit., p. 215.

${ }^{298}$ PRESTON, P: op.cit., p. 135.

${ }^{299}$ JACKSON, A: Para nosotros...op.cit., pp. 109-111.

${ }^{300}$ HURTADO AlBIR, A: op.cit., p.450.
} 
Mary Bingham de Urqudi relataba el bombardeo de la aviación enemiga al hospital San Carlos y de cómo ella y sus enfermeras participaron en la evacuación de los heridos ${ }^{301}$. Patience recordaba la rapidez con la que montaban los improvisados hospitales durante la retirada, todo valía, incluso un túnel ferroviario en desuso capaz de protegerles de los bombardeos ${ }^{302}$.

Las enfermeras además de contribuir con su trabajo, también lo hicieron con sus donaciones de sangre ${ }^{303}$. Todas coinciden en sus relatos en los beneficios que supuso para la salud la transfusión sanguínea y la satisfacción que las producía formar parte activa de ello ${ }^{304}$. La técnica se fue perfeccionando, al principio fue común la donación directa de brazo a brazo, pero luego, con las amplias campañas de prensa $^{305}$ y radio que pedían la colaboración de la población civil, la extracción se hacía al donante, se clasificaba por grupos sanguíneos y se reservaba para el herido $^{306}$. Hubo ocasiones, como durante la batalla del Ebro, en la que los bancos de sangre no pudieron proveer de la misma a los hospitales debido a las malas condiciones de la carretera y los bombardeos continuos, por lo que se volvió a recurrir a la donación directa de brazo a brazo ${ }^{307}$.

En sus escritos dejan constancia del sufrimiento y las consecuencias de la guerra como testigos directos. La muerte y el dolor estaban presentes en los hospitales, Patience Darton recordaba a los heridos de gangrena gaseosa por su agonía antes de la muerte a pesar de la morfina, sin que ella pudiera hacer nada más por ellos. También describe las penurias que pasaron los refugiados durante la retirada y los bombardeos a los que se enfrentaron ${ }^{308}$.

\footnotetext{
${ }^{301}$ BINGHAM DE URQUIDI, M: op.cit., p. 337.

${ }^{302}$ JACKSON, A: Para nosotros...op.cit., p. 78.

${ }^{303}$ Sanidad Popular, ${ }^{\circ}$ 10, 1 de septiembre de 1937, Dos casos de abnegación y sacrificio, p. 2.

${ }^{304}$ HoDSON, A: op.cit., p. 285.

${ }^{305}$ ABC, 5 de mayo de 1937, Donadores de sangre, p. 12.

${ }^{306}$ JACKSON, A: Para nosotros...op.cit., pp. 111-112.

${ }^{307}$ UsANDIZAGA, A: op.cit., p. 134.

${ }^{308}$ JACKSON, A: Para nosotros.... op.cit., pp. 78-79.
} 
Las enfermeras atendieron heridos de ambos bandos sin hacer ningún tipo de distinción entre ellos, Mary Bingham describía el revuelo que ocasionó el primer soldado fascista que intervinieron en el hospital obrero ya que fue ingresado en la misma sala que los milicianos. El conflicto se solventó rápidamente $\mathrm{y}$ posteriormente los heridos nacionales que atendieron en el centro se integraron sin problemas con los republicanos hospitalizados ${ }^{309}$. La propia Agnes reflejaba en su diario que habían atendido en su hospital "una docena de heridos fascistas", y que recibieron el "mismo trato que los demás pacientes, ante su propio asombro" 310 . Ana Pibernat recordaba que en los hospitales republicanos se atendió a "heridos nacionales", españoles, alemanes e italianos ${ }^{311}$.

Algunas enfermeras republicanas cayeron prisioneras ${ }^{312}$ por lo que el canje de rehenes entre ambos bandos también las afectó, sin conseguir su liberación en algunas ocasiones a pesar de los trámites realizados ${ }^{313}$. También fueron acusadas de "auxilio a la rebelión", tal fue el caso de Guadalupe Jiménez y Constantina Sánchez ${ }^{314}$ que fueron juzgadas y encarceladas por trabajar "para las fuerzas marxistas". Tras su procesamiento pasaron a prisión preventiva hasta que finalizó su juicio:

Adjunto remito a V. S. información abierta con motivo de haber sido detenidas Guadalupe Jiménez y Constantina Sánchez en el frente rojo donde prestaban servicios como enfermeras por si hubiera materia en la misma para deducir la comisión de delito por las mismas a fin de que proceda a instruir el

\footnotetext{
${ }^{309}$ BINGHAM DE URQUIDI, M: op.cit., pp. 121-123.

${ }^{310}$ HodsOn, A: op.cit., p. 320.

${ }^{311}$ HurTado AlBIR, A: op.cit., p. 457.

${ }^{312}$ La Vanguardia, 21 de noviembre de 1936, Nuevos atropellos de los fascistas contra el personal de la Cruz Roja, p. 7.

${ }^{313}$ GIRAL, José: Año y medio de gestiones de canje. Monografías de Cruz Roja Española, subsecretaria de propaganda, $1938, \mathrm{p}, 46$.

${ }^{314}$ Es difícil acceder a información de este tipo, es el único caso que se ha encontrado ya que el acceso a expedientes de enfermeras del Archivo Militar están clasificados.
} 
correspondiente procedimiento, sirviéndose acusar recibo para constancia de este centro $^{315}$.

En su defensa explicaron que acudieron a ofrecer sus servicios ante el aviso por radio de Cruz Roja de Madrid que solicitaba la ayuda de enfermeras tituladas. Estaban obligadas a presentarse en el Comité Central de la institución para recibir destino, en su caso, al hospital de sangre de Puente del Arzobispo:

De el examen de las declaraciones prestadas por las detenidas Constantina Sánchez y Guadalupe Jiménez se deduce que ambas son vecinas de Madrid y que habiendo oído el aviso por radio de presentarse voluntariamente a prestar servicios como enfermeras como también aceptaron voluntariamente la venida a Oropesa al Hospital de sangre que tenían en dicha localidad instalado por los marxistas, servicios que estuvieron prestando hasta su detención por las fuerzas leales ${ }^{316}$.

Debido al carácter benéfico y humanitario que llevaron a cabo, su trabajo durante la guerra se consideró como asistencia a heridos, de forma que se las condenó a sobreseimiento provisional:

[...] dado el carácter benéfico y humanitario de los servicios prestados por las procesadas, en las columnas enemigas y no acreditándose que desempeñaran otra función que la de enfermeras, es procedente decretar el sobreseimiento provisional de la causa conforme el artículo $583 \mathrm{n}^{\circ} 1^{\circ}$ del Código de Justicia militar, puesto que el servicio de asistencia de heridos, no debe estimarse como auxilio a la rebelión, en atención a su imprescindible necesidad, y a que sus fines más inmediatos, no son favorecer el progreso de los rebeldes ${ }^{317}$.

\footnotetext{
${ }^{315}$ Archivo Histórico de la Defensa. AGMM. Fondo: Madrid, SIG: 3251, Sumario: 583. Leg: 2696. Guadalupe Jiménez Jiménez y Constantina Sánchez Martínez.

${ }^{316}$ Ibid.,

${ }^{317}$ Ibid.,
} 
Además del caso de Guadalupe y Constantina, también se tiene constancia de que otras nueve enfermeras fueron detenidas por trabajar en la zona republicana y juzgadas para determinar la responsabilidad en que pudieran haber "incurrido por haber prestado sus servicios en el frente rojo" ${ }^{318}$.

Entre las enfermeras republicanas hubo casos de espionaje ya que algunas se infiltraron para dar información y ayudar a los sublevados. Este tipo de situaciones generó un estado de psicosis colectiva, de forma que en algunas ocasiones las acusaciones fueron falsas como sucedió con las enfermeras alcoyanas del hospital Sueco-Noruego:

No puede evitar, sin embargo, que una comisión más o menos oficial se me presentara exigiendo la cesantía inmediata de unas cuantas enfermeras que la población entera consideraba, según ellos, indignas de atender a heridos republicanos. Yo me negué en absoluto a tal insensatez, entre otras cosas, porque aquellas muchachas eran precisamente, las que habían demostrado mayor celo y competencia en su trabajo ${ }^{319}$.

Mary de Urquidi recordaba que para poder trabajar era necesario obtener un brazalete identificativo que emitía el departamento de seguridad, ya que Cruz Roja había "rehusado dar avales y brazaletes" a los médicos y enfermeras voluntarias, por lo tanto, la policía tenía la obligación de controlar a las personas que prestaban los servicios voluntarios. Para obtener el brazalete acreditativo les tomaban las huellas digitales y les hacían una foto, posteriormente sellaban el brazalete blanco con una cruz roja cosida a máquina, el sello decía: "Departamento de Seguridad de Madrid"320. Desde el Departamento de policía se instaba a que los hospitales tuvieran cuidado al aceptar enfermeras voluntarias ya que se había comprobado que algunas de ellas eran "fascistas disfrazadas" $" 321$ que se hacían pasar por republicanas. "Investigar la procedencia e intenciones de cinco mil mujeres que se ofrecieron

\footnotetext{
${ }^{318}$ AGMAV, C.2375, L.147, Cp.57. Procedimientos: mando de instruir contra varias mujeres prisioneras en el frente que estaban servicio de enfermeras, 1936.

319 BASTOS ANSART, M: op.cit., p. 337.

${ }^{320}$ BINGHAM DE URQUIDI, M: op.cit., p. 40.

${ }^{321}$ Ibid.,p. 42.
} 
como voluntarias" fue muy complicado, en algunas ocasiones imposible. Mary relataba el caso de una mujer que "confesó que tenía intenciones de envenenar a todo enfermo o herido que cayera en sus manos"322, Tina Modotti también hablaba de una enfermera falangista que intoxicó a los enfermos con cianuro que echaba deliberadamente en la comida ${ }^{323}$. Mary describe en sus memorias el caso de una enfermera que consiguió ir al frente con el objetivo de quitar las tarjetas identificativas, que carecían de fotografía de identidad, a los muertos y heridos graves para entregárselas a los miembros de la quinta columna, que las utilizaban para "infiltrarse en la milicia y matar a los compañeros o entregarlos al enemigo durante la batalla" ${ }^{\text {324 }}$. La literatura también dejó constancia de los casos de espionaje en el cuerpo de enfermeras. En Su línea de fuego, Benjamín Jarnés, relata el trabajo y la vida de Ofelia, enfermera voluntaria durante la Guerra Civil y espía, cuya misión fue pasar información sobre las milicias y su avance en la contienda, con el objetivo vengar la muerte de su madre a manos de los republicanos ${ }^{325}$. Ana Pibernat recordaba en sus memorias la vigilancia a la que estuvo sometida debido al trato cercano y humano que mantuvo con los heridos que habían caído prisioneros. El principal motivo de las sospechas fue suscitado por el gusto de Ana por la música ya que se aprendió los himnos italianos y nacionales como el Cara al sol "Por lo visto creían que yo era una espía a favor de los nacionales. Pasé por una vigilancia severa $\mathrm{y}$, desde luego, fue una experiencia muy amarga. Al fin pude demostrarles que mis

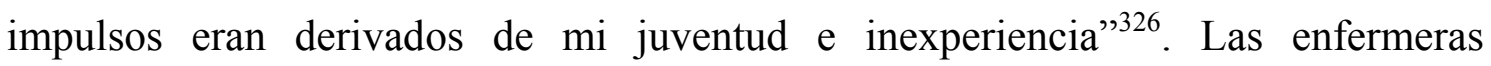
neozelandesas Shadbolt y Dodd sufrieron las consecuencias políticas de la guerra, sus cartas fueron censuradas y destruidas, lo que imposibilitó la comunicación con sus familiares ${ }^{327}$.

\footnotetext{
${ }^{322}$ BINGHAM DE URQUIDI, M: op.cit., p. 106.

${ }^{323}$ PONIATOWSKA, E: op.cit., pp. 478-479.

${ }^{324}$ BINGHAM DE URQUIDI, M: op.cit., p. 106.

${ }^{325}$ JARNÉS MilláN, Benjamín: Su línea de fuego. Guardia Editorial, Zaragoza, 1980.

${ }^{326}$ HuRTADO AlBIR, A: op.cit., p. 447.

${ }^{327}$ DERBY, M: op.cit., p. 132.
} 
Las enfermeras republicanas no contaban con muchos ratos para el ocio ni con unas dependencias adecuadas para el descanso. Fue común que tuvieran que dormir en desvanes, en colchones instalados en el suelo, además de no contar con lavabos independientes, los sanitarios eran comunes, por lo que solían estar sucios y mojados, sin las "comodidades modernas"328. Patience Darton explicaba que había "pocos retretes" en el frente y que lo normal era ir al campo en busca de unos matorrales para "hacer sus necesidades",329. Agnes Hodgson expresaba su alegría al ver la nueva habitación destinadas para las enfermeras en Poleñino, que aunque no era muy grande, contaba con "seis camas en una superficie de 7 por 4 metros" y estaba limpia ${ }^{330}$. Patience fue una de las enfermeras que compartió esa habitación con Agnes, en sus memorias especificaba que "tenían que caminar de lado" y que como único retrete contaron con "un agujero en el suelo de piedra", que estaba situado en el piso inferior ${ }^{331}$. Bañarse con agua templada era un lujo, lo normal fue tener una palangana pequeña que les permitiera asearse ${ }^{332}$. Mary Bingham de Urquidi explicaba que las enfermeras apenas tenían tiempo para ir al cine, que alguna vez disponían de un rato de libre para tomar un café o una cerveza ${ }^{333}$. Agnes Hodgson en su diario hablaba abiertamente de sus ratos de ocios que se centraron en bañarse en el río, tomar el sol (cosa que hacía con el resto de enfermeras, Patience Darton también lo recordaba en su relato) ${ }^{334}$, además de jugar al tenis y pasar sus días de descanso lejos del frente ${ }^{335}$. Durante su estancia en España como voluntaria tuvo dos permisos, uno de ellos, de diez días, lo pasó en Barcelona, en la playa, ante la imposibilidad de viajar a Inglaterra y el segundo, de una duración aproximada, en Escocia $^{336}$. Por el contrario en las memorias de Ana Pibernat no aparece ningún dato sobre los ratos de ocio, únicamente recordaba que pidió un permiso para despedirse

\footnotetext{
${ }^{328}$ HodsOn, A: op.cit., p. 297 y 300.

${ }^{329}$ JACKSON, A. Para nosotros...op.cit., p. 33.

${ }^{330}$ Hodson, A: op.cit., p. 314.

331 JACKSON, A: Para nosotros...ob. cit., p. 50.

${ }^{332}$ DERBY, M. op.cit., p. 132.

${ }^{333}$ BINGHAM DE URQUIDI, M: op.cit., p. 161.

${ }^{334}$ JACKSON, A: Para nosotros ... op.cit., p. 55.

${ }^{335}$ Hodson, A: op.cit., pp. 322-324.

${ }^{336}$ Ibid., pp. 352-357.
} 
de sus padres cuando estuvo trabajando de cerca de su pueblo ${ }^{337}$. Eulalia Montfort explicaba que el hecho de tener que trabajar los fines de semana les dejaba poco tiempo libre, en ocasiones iban al cine, pero "en caso de emergencia sanitaria se

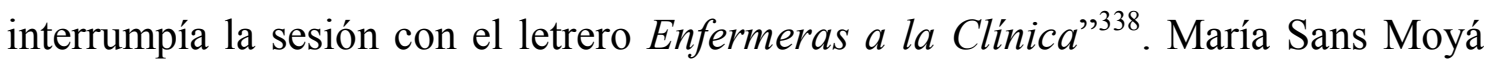
que trabajaba doce horas al día, comía en el hospital y no volvía a su casa hasta el final de la jornada, nunca pidió un día de fiesta para descansar ${ }^{339}$.

Si hubo desavenencias y problemas entre las enfermeras no aparecen reflejados en los relatos analizados, únicamente Agnes Hodson hablaba de una reunión entre las enfermeras del hospital de Grañén porque una de ellas se negaba a cumplir con el turno establecido y de otra posterior "para protestar contra varias irregularidades en la distribución de tareas, y para aclarar cierto malentendido entre las españolas y nosotras". No relata cuál fue el problema pero sí que se solventó "amigablemente"340. Según Agnes, en el hospital hubo conflictos con el personal inglés por problemas ideológicos. Estos hechos no aparecen en los relatos de las enfermeras británicas, además la australiana opinaba abiertamente sobre sus compañeras en su diario:

Hoy por hoy, las cosas van bastante bien entre las enfermeras, exceptuando una que es una idiota y una charlatana, y que sólo es feliz limpiando orinales. Nadie quiere trabajar con ella. Quiere probar con los quirófanos, pero tiene miedo y, de hecho, no creo que esté capacitada. Nuestro jefe no quiere verla por allí. Sin embargo hemos decidido que con este cambio ella también va a hacer su turno en los quirófanos, más que nada para que se calle ${ }^{341}$.

El último conflicto que relata Agnes en su diario le afectaba directamente a ella, lo describía como una "crisis con el resto" de las compañeras originada porque no le habían consultado si otra de las enfermeras podía dormir con ella. Como estaba "harta" expresó abiertamente que prefería no compartir habitación con nadie, fue calificada de "egoísta, que siempre se escaqueaba con la excusa de no encontrarse

\footnotetext{
${ }^{337}$ HURTADO Albir, A: op.cit., p. 449.

${ }^{338}$ NASH, M. TAVERA, S: op.cit., p. 548.

${ }^{339}$ RAMIÓ, A, TORRES, C: op.cit., p. 121.

${ }^{340}$ HoDSON, A: op.cit., p. 304.

${ }^{341}$ Ibid., pp. 311 y 335.
} 
bien, y que le habían tolerado muchas cosas porque estaban obligadas a vivir con ella". Esta discusión motivó que Agnes hiciera las maletas y se marchara de $\operatorname{España~}^{342}$.

Mary de Bingham de Urquidi no se pronunció políticamente y no se afilió a ningún partido, esto generó cierta suspicacia entre el personal del hospital, por ejemplo, a Tina Modotti le extrañaba que Mary no fuera a escuchar el parte diario de la radio y que prefiriera "trajinar allá en el quirófano vigilando el hervor de sus agujas mientras enrolla vendas ayudada por una de reciente ingreso" ${ }^{, 343}$. Ana Pibernat dejaba claro en sus memorias que "la convivencia con todos los compañeros del hospital era inmejorable" ${ }^{, 44}$. De hecho hablaba con sufrimiento y pena de sus compañeras muertas durante la guerra, de forma que deja constancia de los vínculos que generó el conflicto y las largas jornadas entre el personal: "La despedida fue angustiosa. Habíamos permanecido juntas dos años en los hospitales, y un año y medio, refugiadas en un país inhóspito, pasando toda clase de peripecias trágicas y divertidas, pero siempre juntas" ${ }^{345}$.

Tampoco ha sido común encontrar sanciones impuestas por los organismos superiores a las enfermeras, Cruz Roja suspendió de empleo y sueldo a una de sus profesionales por pernoctar fuera del hospital, avisando a la interesada que en caso de reincidir en dicha acción sería expulsada de la institución ${ }^{346}$.

El trato con los heridos en ocasiones generó conflictos, no por parte de las enfermeras, sino de los propios pacientes, tal fue el caso de Agnes Hodson que recibió una bofetada ${ }^{347}$. Aunque lo normal fueron las muestras de gratitud, algunos convalecientes faltaron al respeto al personal.

\footnotetext{
${ }^{342}$ HodsOn, A: op.cit., p. 364.

${ }^{343}$ PONIATOWSKA, E: op.cit., p. 464.

${ }^{344}$ HurTado AlBIR, A: op.cit., p. 447.

345 Ibid., p. 456.

${ }^{346}$ ACCRE, caja 2022, expediente 3, Actas de sesiones del Comité Central 1938-1939.

${ }^{347}$ HodsON, A: op.cit., p. 322.
} 
A pesar de los cambios que introdujo la republica y la Guerra Civil, las mujeres seguían ancladas en los roles y en la moralidad tradicional, por eso la situación de las enfermeras no fue diferente, el uniforme "blanco" no representaba únicamente higiene sino la "pureza de sentimientos, de trabajo, de contacto con los heridos". Estas connotaciones defendían la imagen de la enfermera como "paloma blanca, mensajera del cariño y del buen trato" que cuidaba a los heridos como a sus propios hijos o hermanos en su "misión sagrada",348, por lo que continuó asociada a los tópicos de belleza, dulzura y cariño maternal ${ }^{349}$.

Esta visión tradicional de la mujer supuso un problema para las enfermeras extranjeras que no se ajustaban a las "normas de conducta" exigidas en España, Aránzazu Usandizaga habla de una "irreverencia constante" hacia estos valores ${ }^{350}$. Estas restricciones sociales llamaron la atención de las brigadistas que se sorprendían al ver que las mujeres del pueblo "no podían bailar con hombres que no fueran sus prometidos o maridos" 351 , o como en una comuna anarquista primero comían los hombres y luego lo hacían las mujeres después de haberles servido. Patience Darton explicaba los problemas que tuvo por bañarse en el río, a pesar de hacerlo alejada del pueblo y con un traje adecuado, los anarquistas se lo prohibieron. Muchas de las enfermeras extranjeras fumaban, lo que contrastaba en la España tradicional. La falta de tabaco también las afectó, llegando en algunas ocasiones a recibir menos cigarrillos por parte de los comisarios políticos que desaprobaban que las mujeres fumaran porque consideraban que privaban a los hombres de ellos ${ }^{352}$. Encontrar tabaco fue difícil, por eso las enfermeras, al igual que los soldados, recogían colillas para poder liarse nuevos cigarrillos ${ }^{353}$.

Esta visión diferente entre los sexos a ojos de las enfermeras británicas también ocasionó problemas asistenciales ya que describían a las voluntarias españolas como "demasiado recatadas". El tipo de pacientes que tuvieron que atender eran hombres y el aseo de los heridos formaba parte del trabajo asistencial,

\footnotetext{
${ }^{348}$ La Voz de Sanidad, $\mathrm{n}^{\circ}$ 12, febrero-marzo de 1939, La enfermera ante el herido, p. 15.

${ }^{349}$ Sanidad Popular, no 9, 1 de septiembre de 1937, portada.

${ }^{350}$ USANDIZAGA, A: op.cit., p. 216.

${ }^{351}$ PRESTON, P: op.cit., pp. 126-127.

352 JACKSON, A: Las mujeres...op.cit., pp. 174-175.

353 JACKSON, A: Para nosotros...op.cit., p. 62.
} 
por lo tanto era normal lavar el cuerpo desnudo de un hombre ${ }^{354}$. Patience Darton consideraba "muy valientes" a todas las mujeres que se presentaron como voluntarias en los hospitales ya que en España "no era en absoluto lo que se suponía que debía hacer una buena chica", también explicaba que una "española no podía charlar con los hombres y dar órdenes, ni tocar o lavar a un desconocido"355.

La iconografía republicana cuidó la imagen de las mujeres enfocada al papel que debían desempeñar. Por eso es necesario analizar las imágenes de las enfermeras como modelo de mujer republicana con una labor socialmente aceptada. Las fotografías de enfermeras atendiendo a los soldados heridos, representaban mujeres bellas y dulces, contentas de aliviar el sufrimiento de los enfermos (ver imagen XVII).También reflejaron la participaron de forma activa en las campañas de recolecta de dinero para los hospitales de sangre ${ }^{356}$ y en las manifestaciones convocadas durante la guerra, para plasmar que eran mujeres implicadas en la defensa de la República ${ }^{357}$. De forma que su imagen se utilizó para captar la atención de la población a la hora de conseguir mayores recaudaciones para los hospitales republicanos y para Cruz Roja ${ }^{358}$. En ellos aparecían enfermeras llamativas de labios rojos, con bonitos ojos, imágenes cargadas de sensualidad (ver anexo XI).

La iconografía presentaba enfermeras contentas y orgullosas de su profesión y de la labor desempeñada durante el conflicto. Concentradas en su trabajo, a la cabecera de los heridos o sonrientes posando con ellos (ver imagen XVIII). De esta forma se convirtieron en un icono para el resto de mujeres, su trabajo, tanto en el

\footnotetext{
354 JACKSON, A: Las mujeres...op.cit., p. 185.

355 JACKSON, A: Para nosotros...op.cit., p. 53.

${ }^{356}$ La Vanguardia, 17 de enero de 1937, foto enfermeras en el festival de teatro organizado para recaudar fondos, p. 4; La Vanguardia, 13 de abril de 1937, foto enfermeras en la Monumental en el acto de clausura de la recaudación de dinero para los hospitales de sangre, portada.

${ }^{357}$ AGA, fotografías Sanidad Militar, enfermeras, caja (03)084.001. F/00768, sobre $\mathrm{n}^{\mathrm{o}} 1$.

${ }^{358}$ Centro Documental de la Memoria Histórica PS-CARTELES, 213.Cartelistas C.N.T.-A.I.T. Titulo: ¿Cómo ayudar a los hospitales de sangre? / adquiriendo números para esta rifa benéfica. Editor: Confederación Nacional del Trabajo-Asociación Internacional de los Trabajadores. Sindicato Único Regional de Peritos y Técnicos Industriales. Comis. Organiz. Hospitales de Sangre y Guarderías de Niños Imprenta: Ortega, Comité Obrero de Control U.G.T.-C.N.T.

Centro Documental de la Memoria Histórica PS-CARTELES, 2194. Autor: Mezquita Titulo: ¡Ayudad! a la Cruz Roja Española en su labor humanitaria. Editor: Cruz Roja Española Imprenta: Rivadeneyra, S.A. Madrid Fechas: 1936-1939 [APR].
} 
frente como en la retaguardia fue valorado positivamente por una sociedad patriarcal en la que el rol de enfermera era completamente compatible con el desempeñado por los hombres, médicos, practicantes y camilleros. Por eso se plasmaba que la enfermera cuidaba a la población, siendo el practicante el que los vacunaba y el camillero el que los transportaba ${ }^{359}$.

La prensa dejó claro que las enfermeras movilizadas realizaron su trabajo con una "abnegación admirable", jóvenes, femeninas, enérgicas y heroicas, capaces de soportar con "entereza" los ataques enemigos sin perder la "serenidad", eran un "honor" para España ${ }^{360}$. Esto contribuyó a una mitificación del trabajo de la enfermera enfocado a captar nuevas voluntarias. Los carteles de guerra, también contribuyeron a ello, ya que perfilaron una imagen concreta de la enfermera. En ellos representaban mujeres bellas y esbeltas, de facciones dulces, capaces de ayudar a los soldados y a la población. Vestidas siempre con el uniforme reglamentario identificativo de la profesión y sosteniendo en sus brazos a los heridos, protegiéndolos, en actitud de madres compasivas. De esta forma la imagen de la enfermera se identifica con la sanidad republicana, con conceptos tan importantes como ayuda y solidaridad (ver anexo XII). Por eso su trabajo tiene que ser respetado y valorado positivamente por la sociedad, porque ellas se dedicaban a cuidar de otros en lugar de encargarse de su familia, se sacrificaban por la República ${ }^{361}$.

Esta relación entre lo femenino y la Enfermería fue una constante durante el conflicto. Como señala Iker González la figura de la enfermera mantuvo un "aura de prestigio" porque estuvo ligada al papel tradicional de las mujeres de entrega al cuidado de los hombres, unido a la visión de madre, hermana y esposa de los heridos $^{362}$. Es complejo dar visibilidad al trabajo desempeñado por las enfermeras republicanas debido a la falta de fuentes primarias y al hecho de que fueron mujeres y no hombres las que se encargaron del cuidado de los heridos y enfermos. Lo que sí

\footnotetext{
359 Centro Documental de la Memoria Histórica PS-CARTELES, 469. Autor: Mezquita Titulo: Cruz Roja Española / ;Ayudadla! Editor: Cruz Roja Española Imprenta: Rivadeneyra, C.O.

${ }^{360}$ La Vanguardia, 24 de septiembre de 1936, La misión de las enfermeras en el frente, p. 3.

${ }^{361}$ Centro Documental de la Memoria Histórica PS-CARTELES, 843. Autor: Córdoba Titulo: Respeta a la enfermera / por cuidarte dejó a los suyos. Editor: España. Ejército de la República. Inspección General de Sanidad Militar Imprenta: Seix i Barral, I.G., E.C. Fechas: 1938.

${ }^{362}$ GONZÁLEZ ALLENDE, I: op. cit., p.124.
} 
se puede constatar es la voluntad de trabajo y la responsabilidad con la que lo afrontaron, demostrando su capacitación profesional y su compromiso de ayuda desinteresada.

Es innegable la amplia labor asistencial que llevaron cabo todas las mujeres republicanas que se ofrecieron como enfermeras voluntarias, sin esperar a cambio ningún beneficio económico, ni reconocimiento social. Principalmente se guiaron por las ganas de ayudar a los heridos y demostrar su apoyo a la República. En la zona nacional también hubo mujeres dispuestas a realizar la misma labor, entrando a formar parte de los servicios sanitarios femeninos. Conviene analizar qué diferencias y similitudes tuvieron con sus homónimas republicanas, tanto a nivel laboral, como académico y cultural. 
ANEXOS III 

Imagen IV. Milicianas apuntando a los aviones

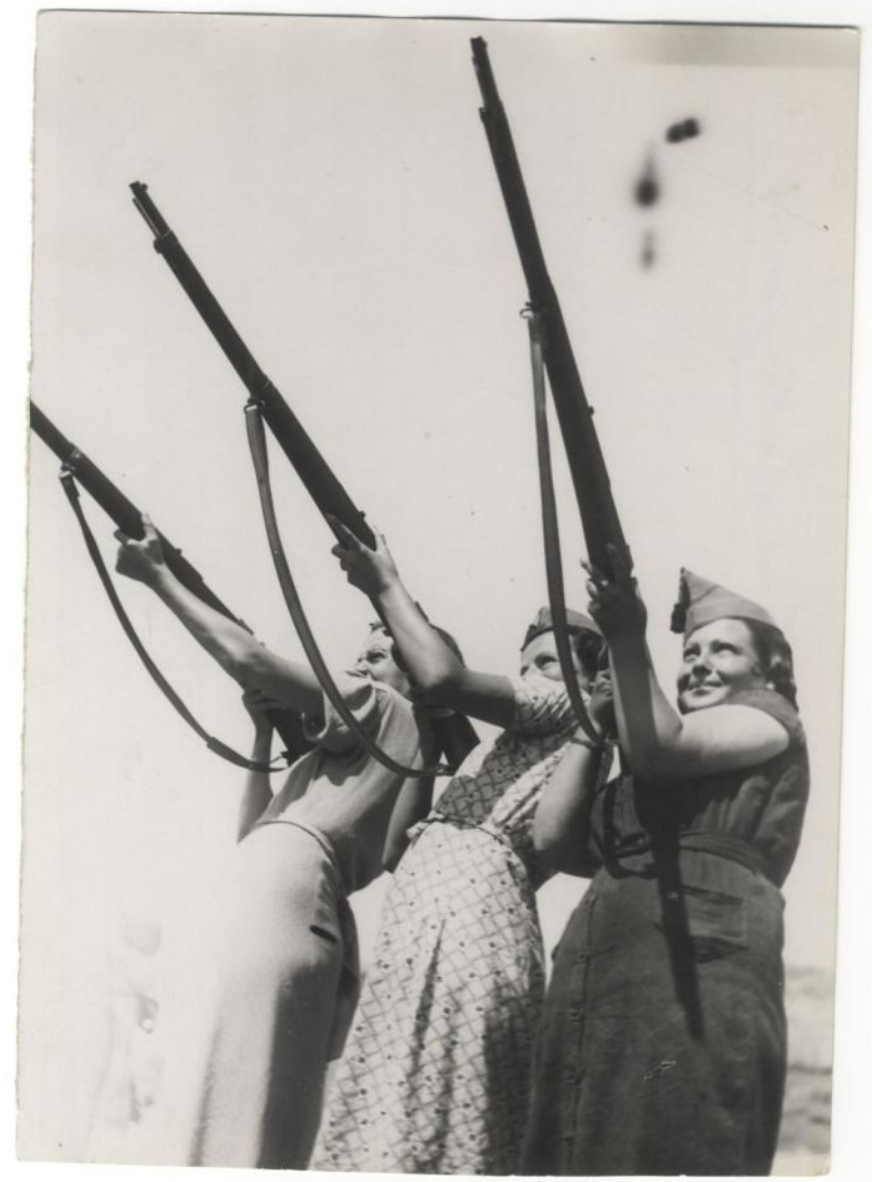

Fuente: Archivo General de la Administración, fotografías retaguardia, caja (03)084.001. F/00768 sobre $\mathrm{n}^{\mathrm{o}} 1$.

Imagen V. Milicianas en misión especial en la línea de fuego.

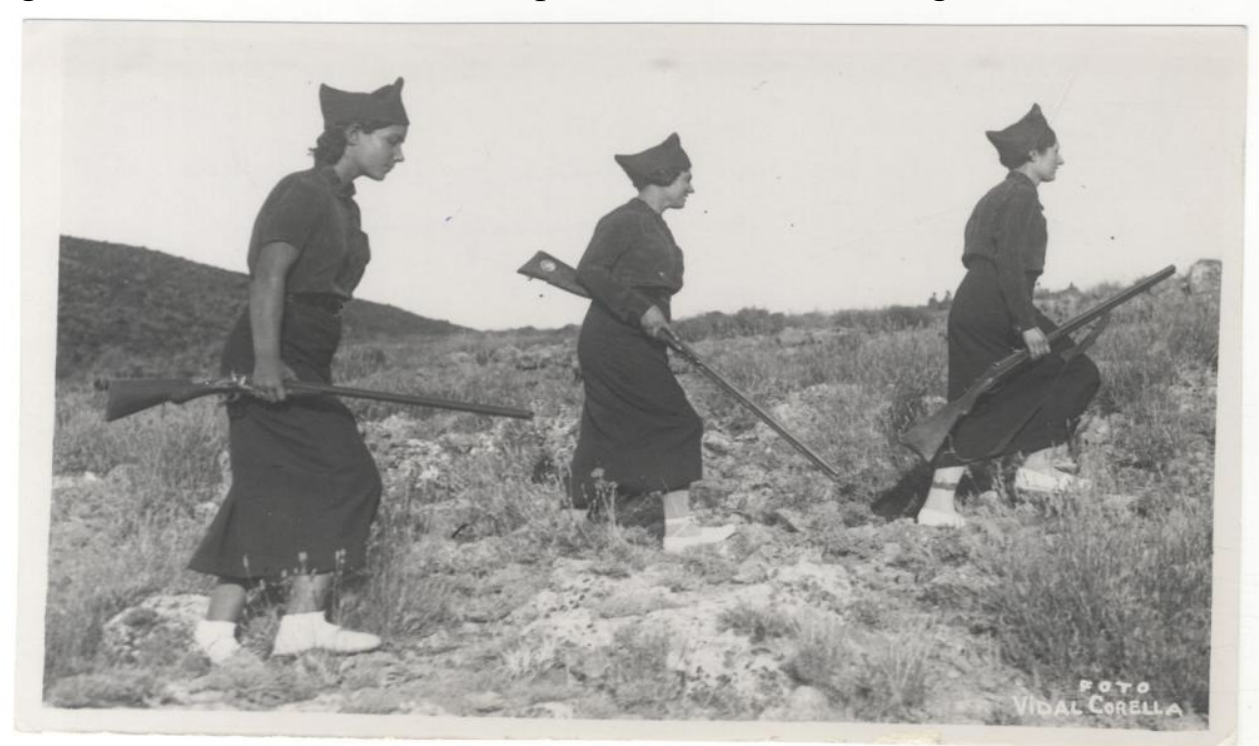

Fuente: Archivo General de la Administración, fotografías retaguardia, caja (03)084.001. F/00768 sobre $\mathrm{n}^{\mathrm{o}} 1$. 
Imagen VI. Milicianas del Batallón Largo Caballero practicando la instrucción en el patio del cuartel.

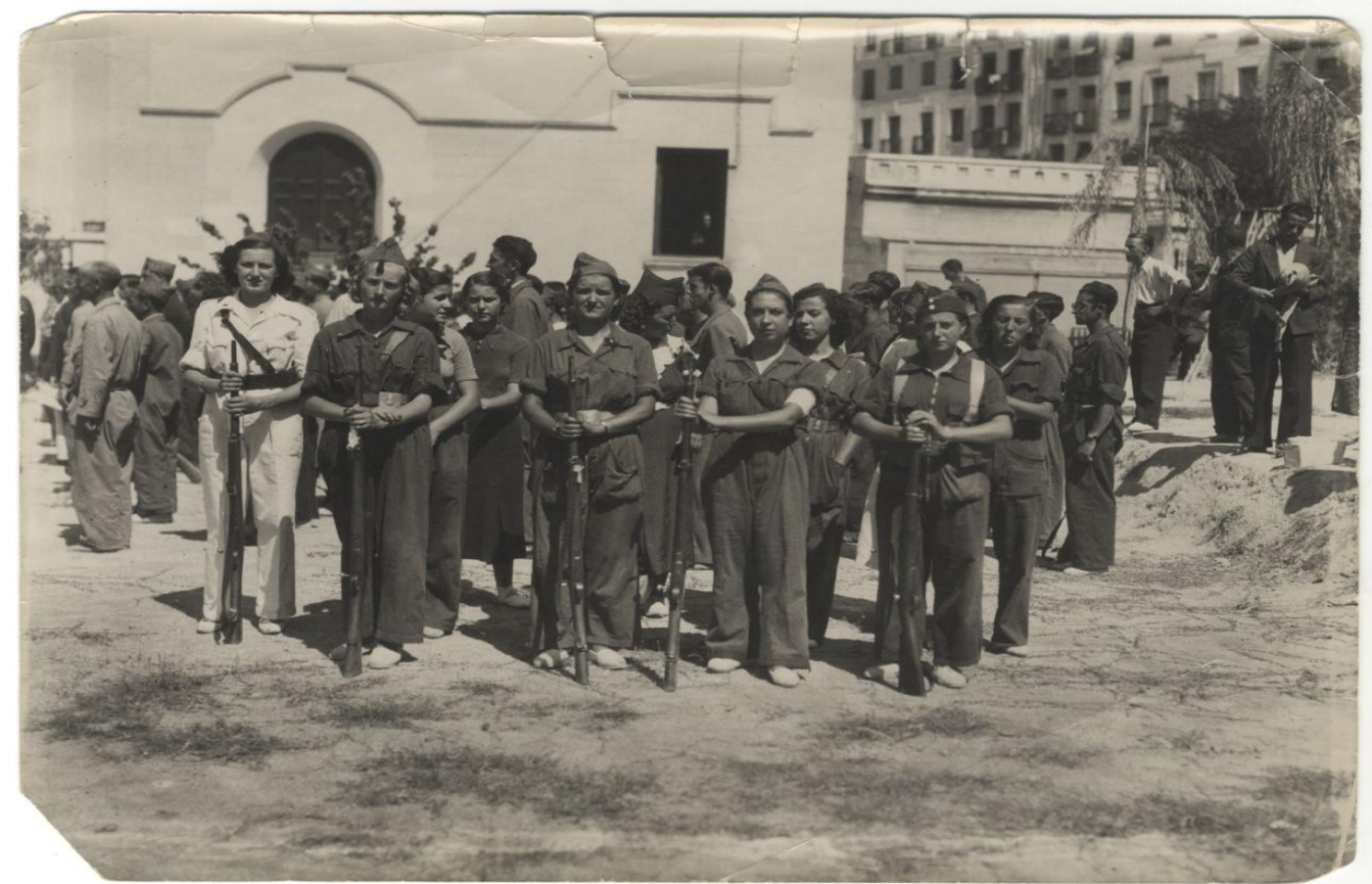

Fuente: Archivo General de la Administración, fotografías retaguardia, caja (03)084.001. F/00768 sobre $\mathrm{n}^{\mathrm{o}} 1$.

Imagen VII. Miliciana tendiendo la ropa recién lavada en el frente.

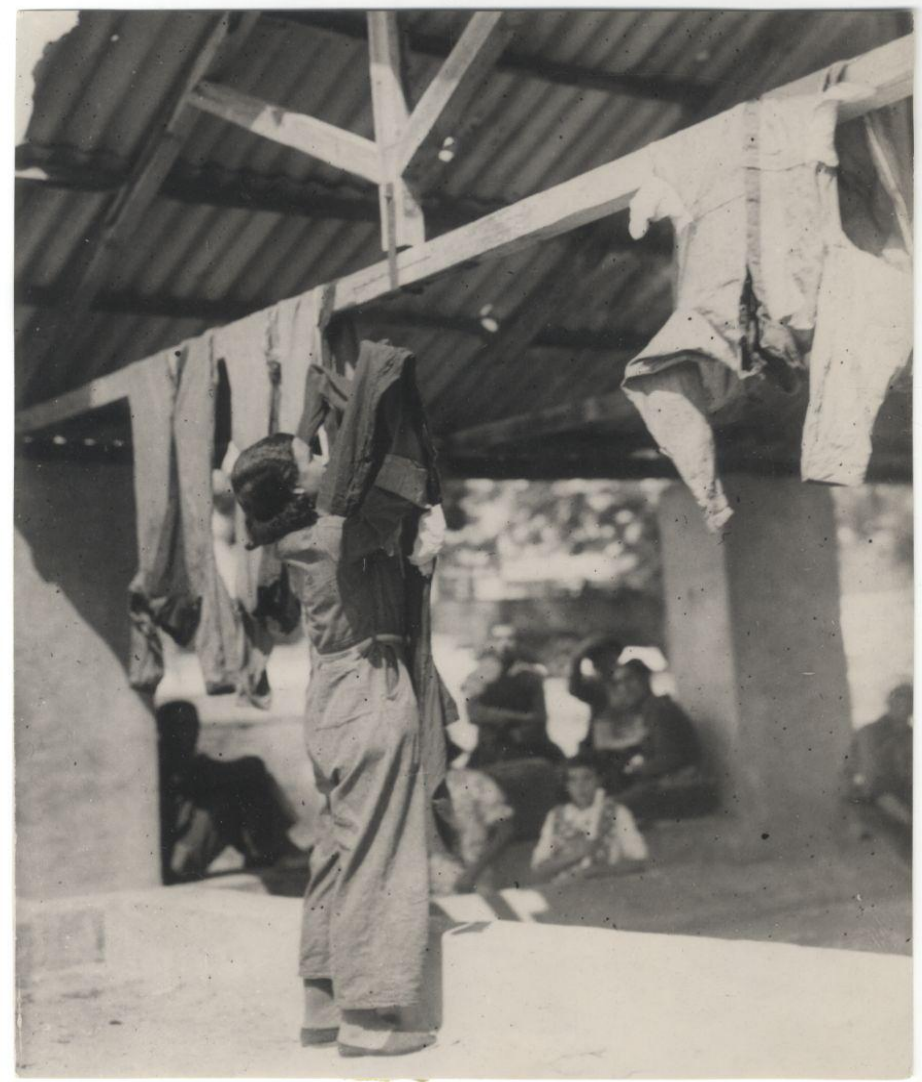

Fuente: Archivo General de la Administración, fotografías retaguardia, caja (03)084.001. F/00768 sobre $\mathrm{n}^{\mathrm{o}} 1$. 
Imagen VIII. Miliciana herida atendida por una enfermera.

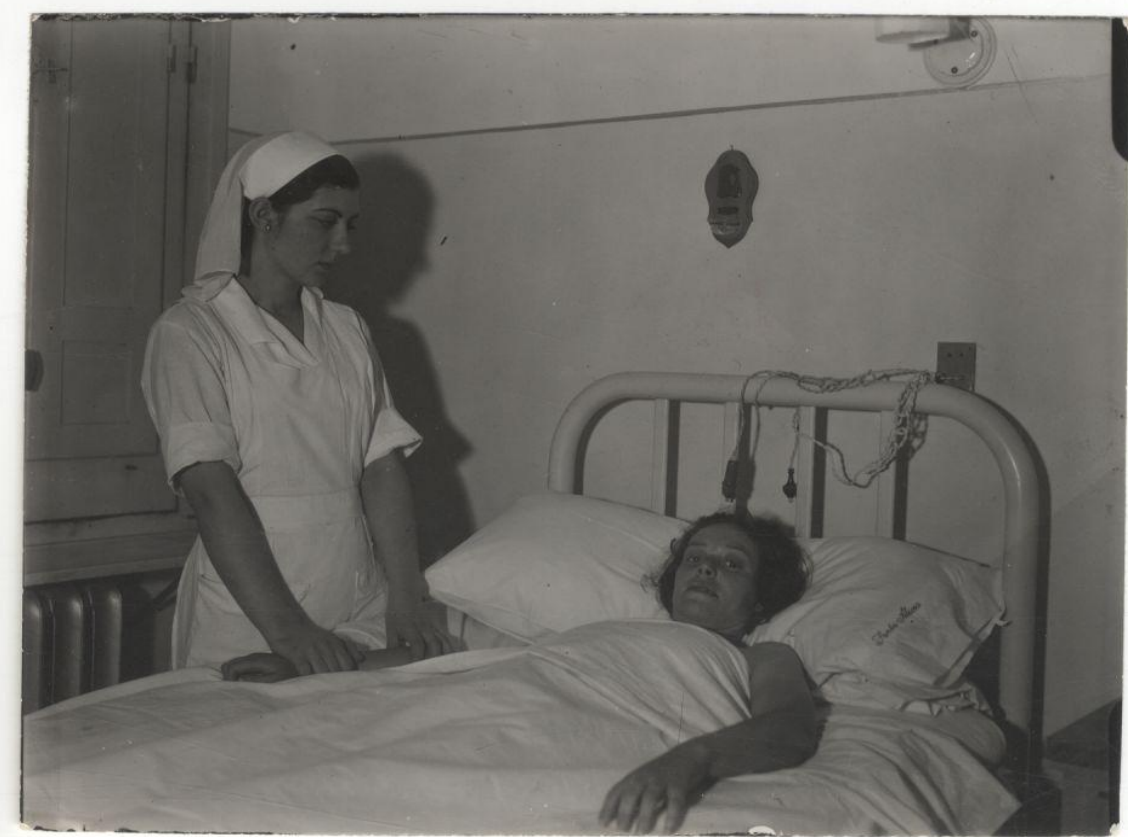

Fuente: Archivo General de la Administración, fotografías Sanidad Militar, enfermeras, caja (03)084.001. $\mathrm{F} / 00768$ sobre $\mathrm{n}^{\circ} 1$.

Imagen IX. Milicianas en el frente.

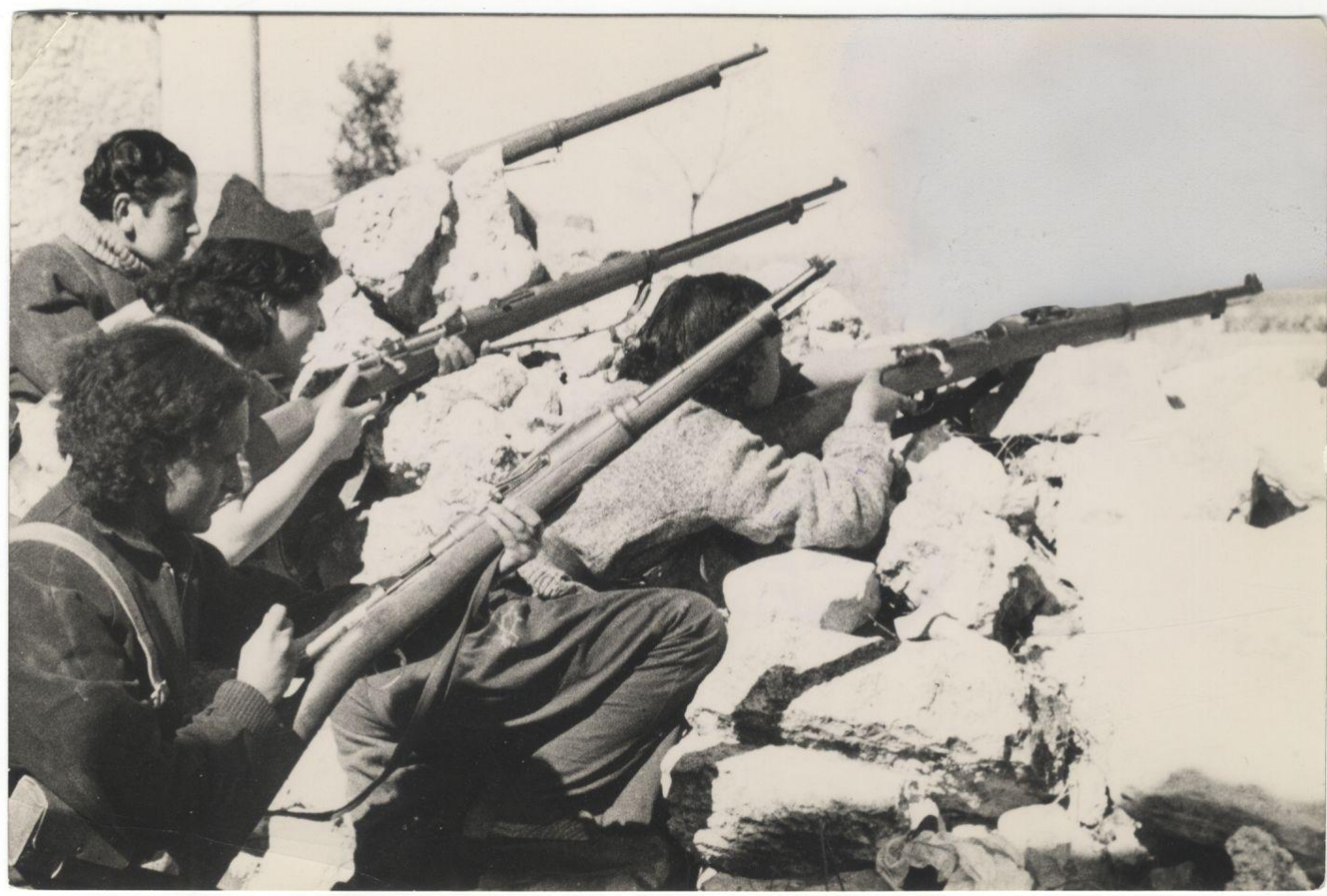

Fuente: Archivo General de la Administración, fotografías retaguardia, caja (03)084.001. F/00768 sobre $\mathrm{n}^{\mathrm{o}} 1$. 
Imagen X. Mujeres en el taller confeccionando ropa de abrigo para los combatientes.
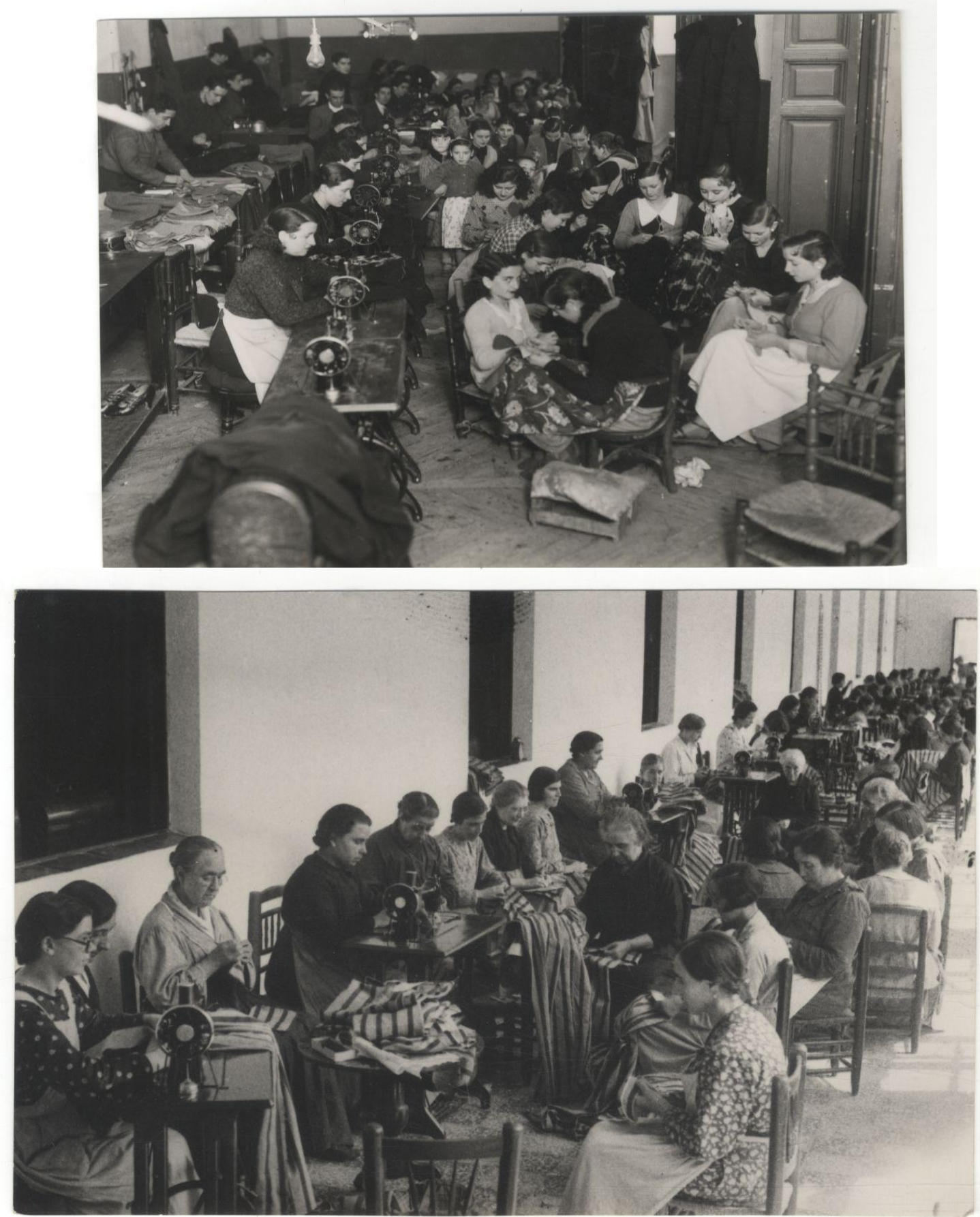

Fuente: Archivo General de la Administración, fotografías retaguardia, caja (03)084.001. F/00768 sobre $\mathrm{n}^{\mathrm{o}} 1$. 
Imagen XI. Enfermeras de la CNT que marchaban voluntarias a Zaragoza a asistir a sus compañeros.

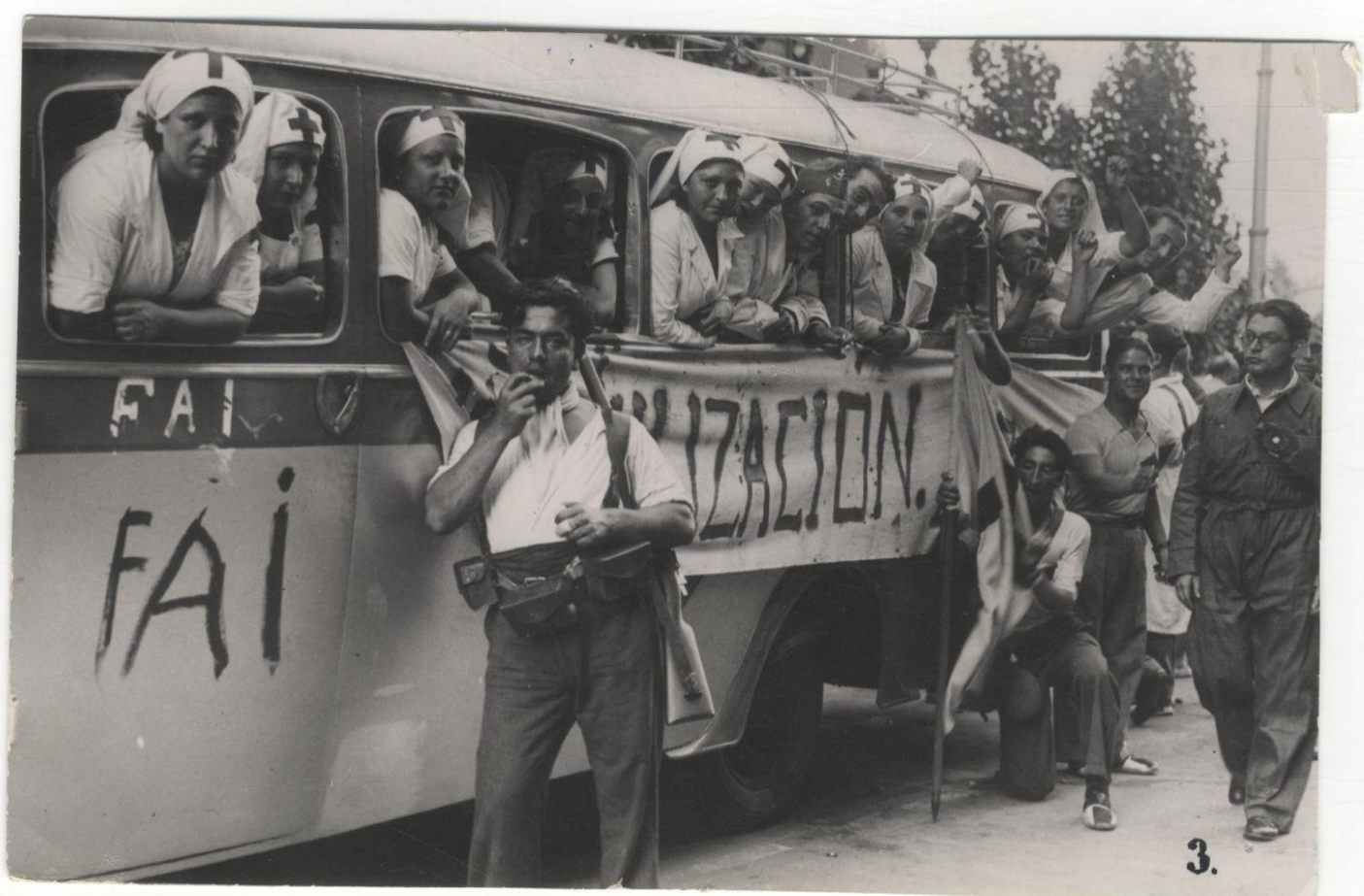

Fuente: Archivo General de la Administración, fotografías Sanidad Militar, enfermeras, caja (03)084.001. $\mathrm{F} / 00768$ sobre $^{\circ} 1$.

Imagen XII. Casino de Madrid convertido en un hospital de sangre.

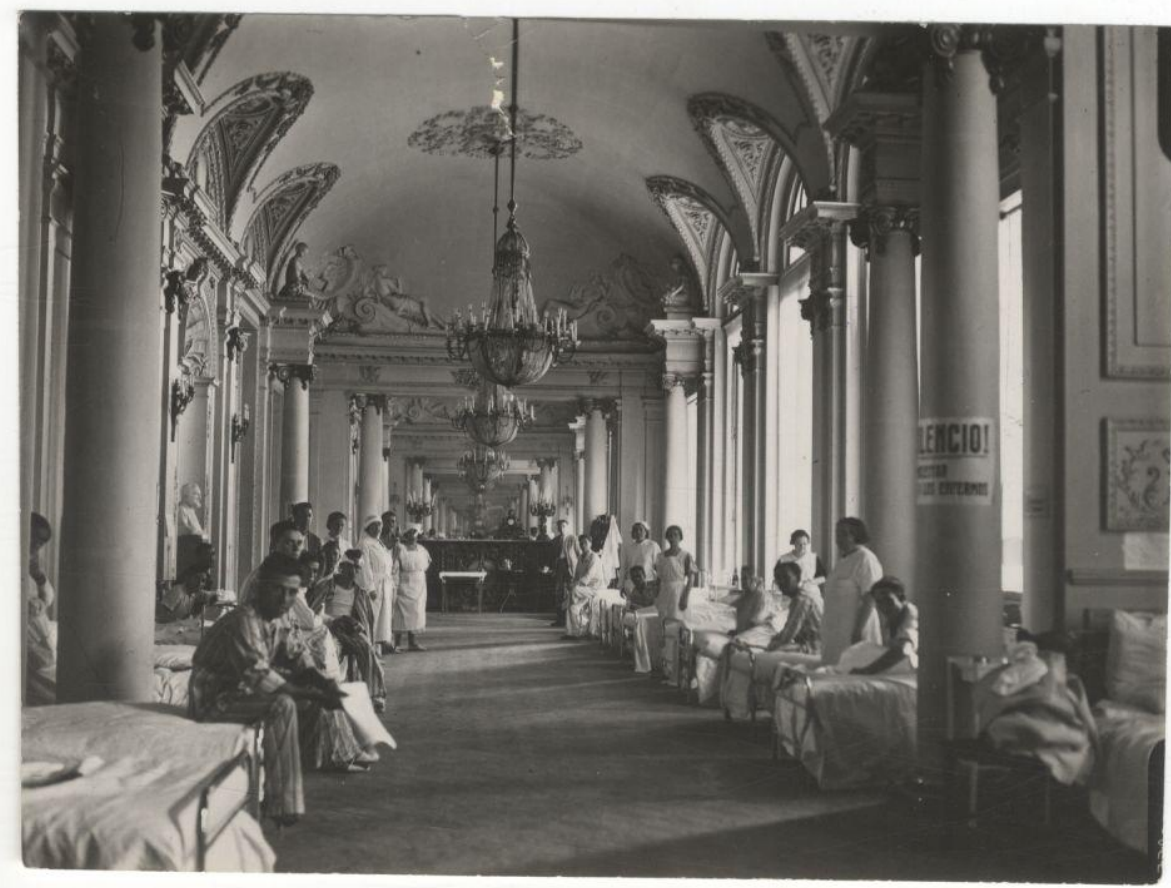

Fuente: Archivo General de la Administración, fotografías Sanidad Militar, enfermeras, caja (03)084.001. F/00768 sobre $n^{\circ} 1$. 
Imagen XIII. Puesto de Socorro de Cruz Roja en el frente de Aragón.

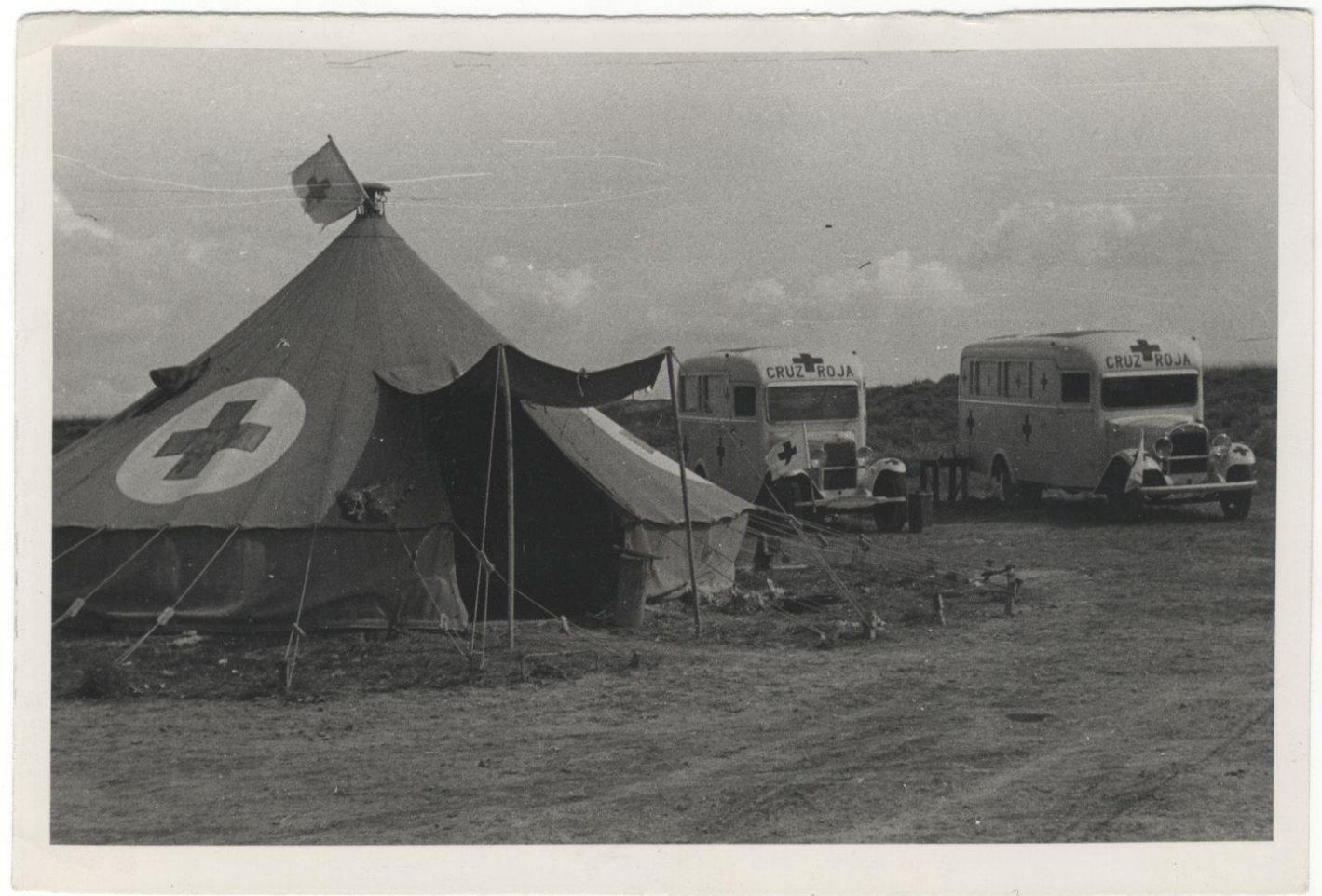

Fuente: Archivo General de la Administración, fotografías Sanidad Militar, enfermeras, caja (03)084.001. F/00768 sobre $\mathrm{n}^{\mathrm{o}} 1$.

Imagen XIV. Enfermeras en el frente.

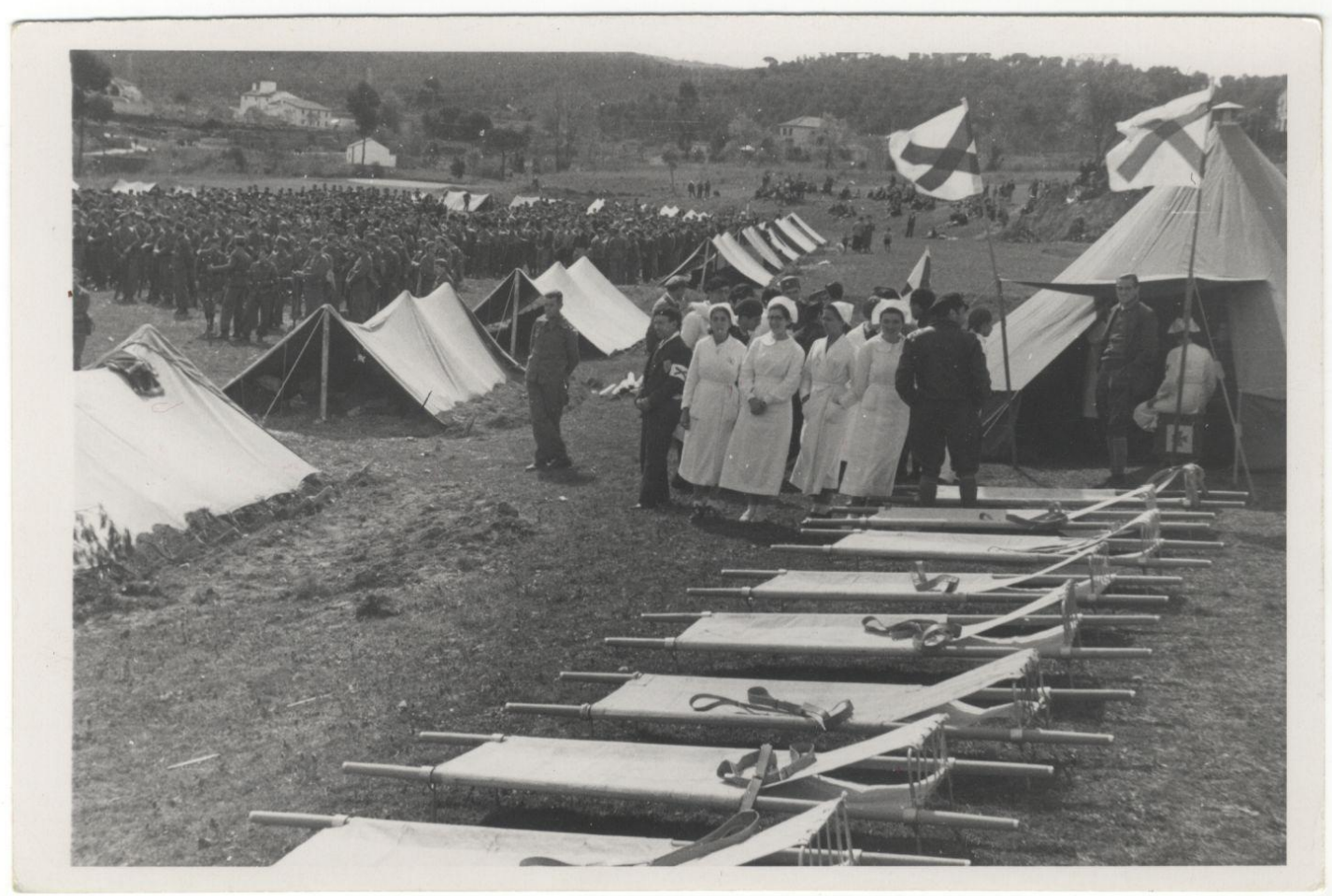

Fuente: Archivo General de la Administración, fotografías Sanidad Militar, enfermeras, caja (03)084.001. $\mathrm{F} / 00768$ sobre $\mathrm{n}^{\mathrm{o}} 1$. 
Imagen XV. Enfermeras de uniforme en el frente.

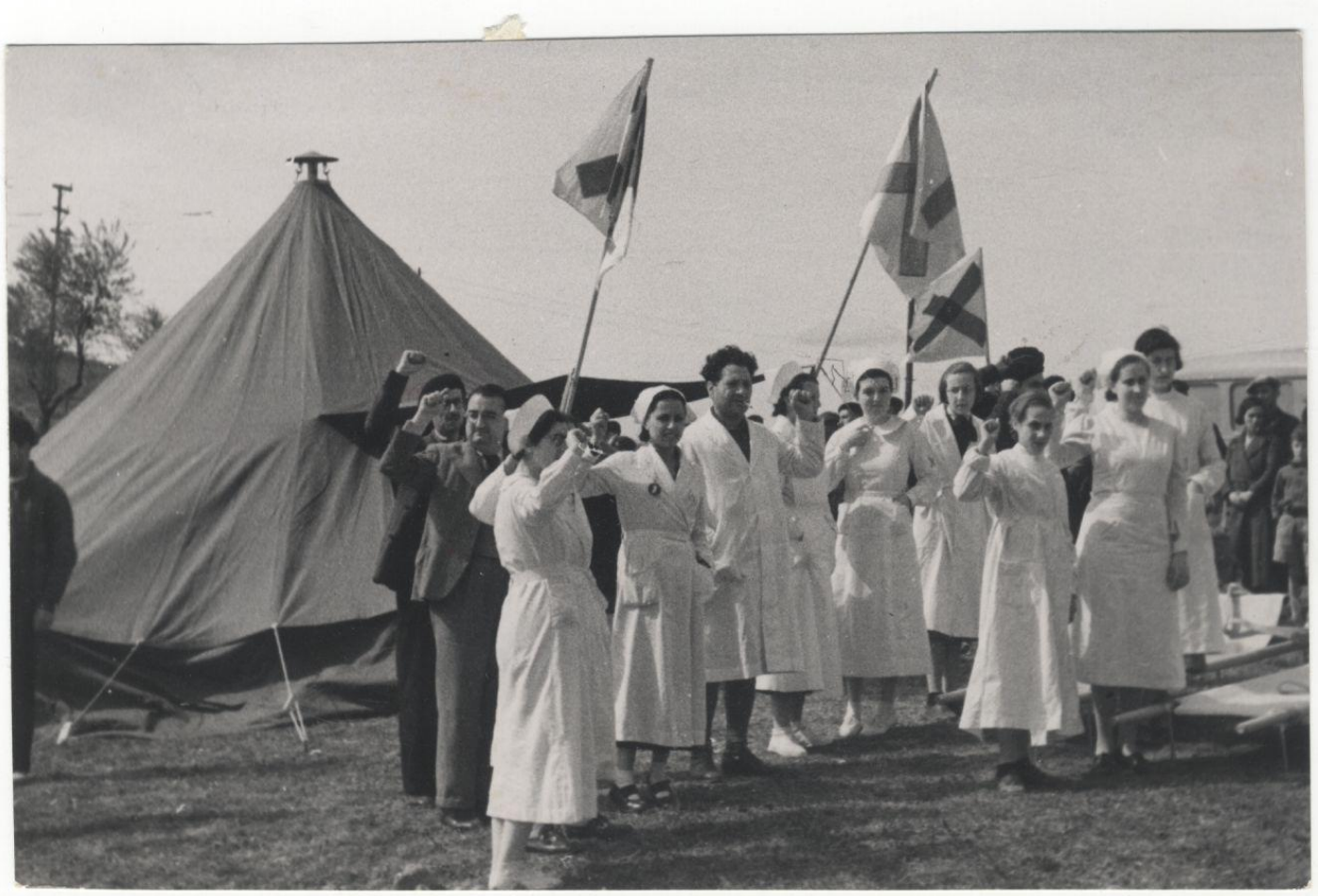

Fuente: Archivo General de la Administración, fotografias Sanidad Militar, enfermeras, caja (03)084.001. F/00768 sobre $\mathrm{n}^{\circ} 1$.

Imagen XVI. Enfermeras trabajando en quirófano del hospital de sangre del Casino de Madrid.

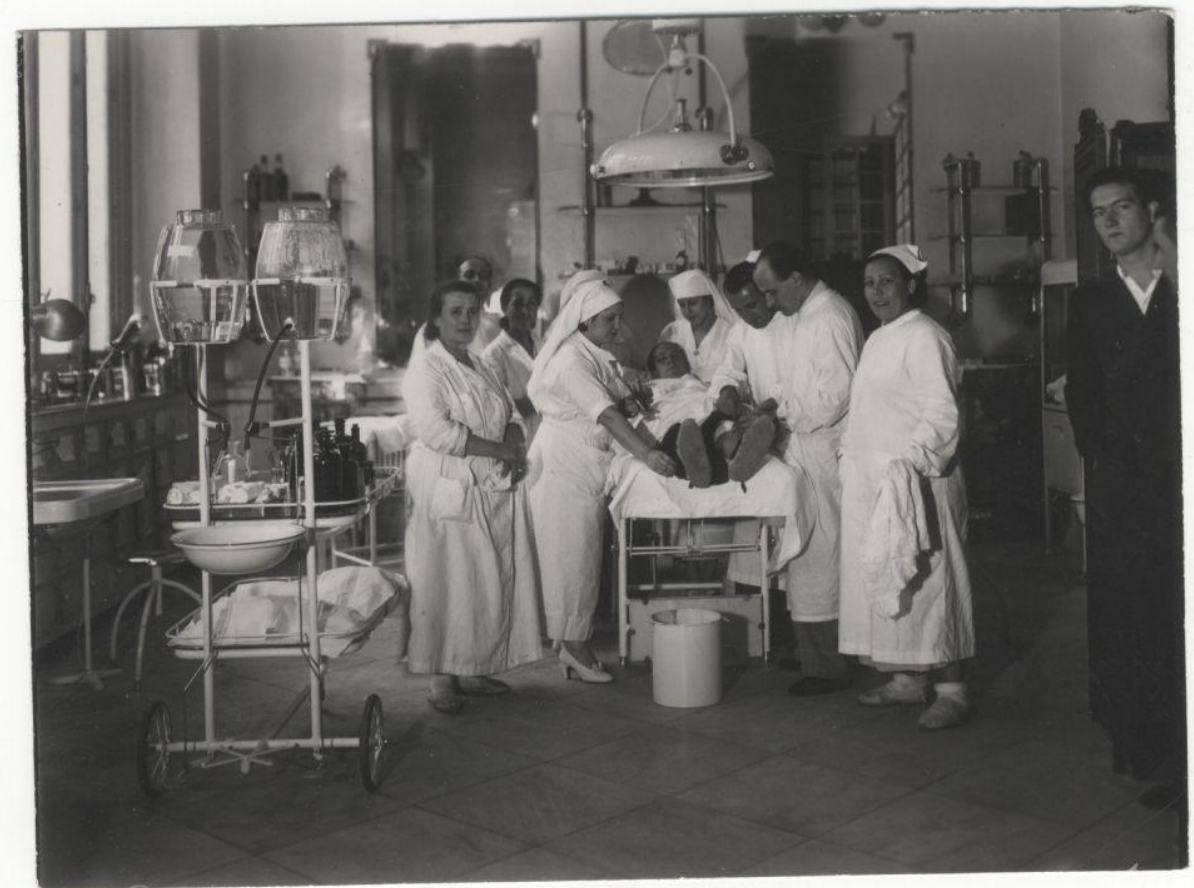

Fuente: Archivo General de la Administración, fotografías Sanidad Militar, enfermeras, caja (03)084.001. F/00768 sobre $n^{\circ} 1$. 
Imagen XVII. Enfermera leyendo un libro a un herido.

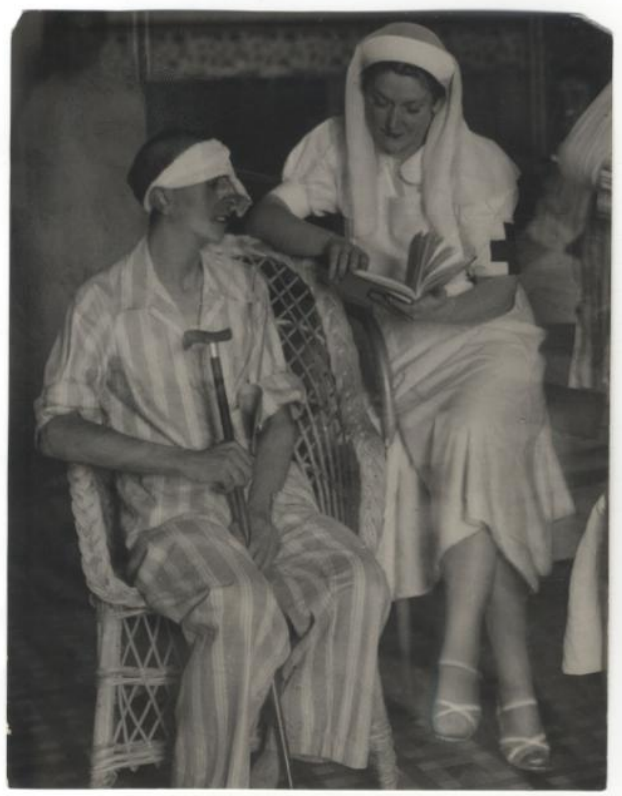

Fuente: Archivo General de la Administración, fotografías Sanidad Militar, enfermeras, caja (03)084.001. $\mathrm{F} / 00768$ sobre $^{\circ} 1$.

Anexo XI. Ayuda para hospitales de sangre

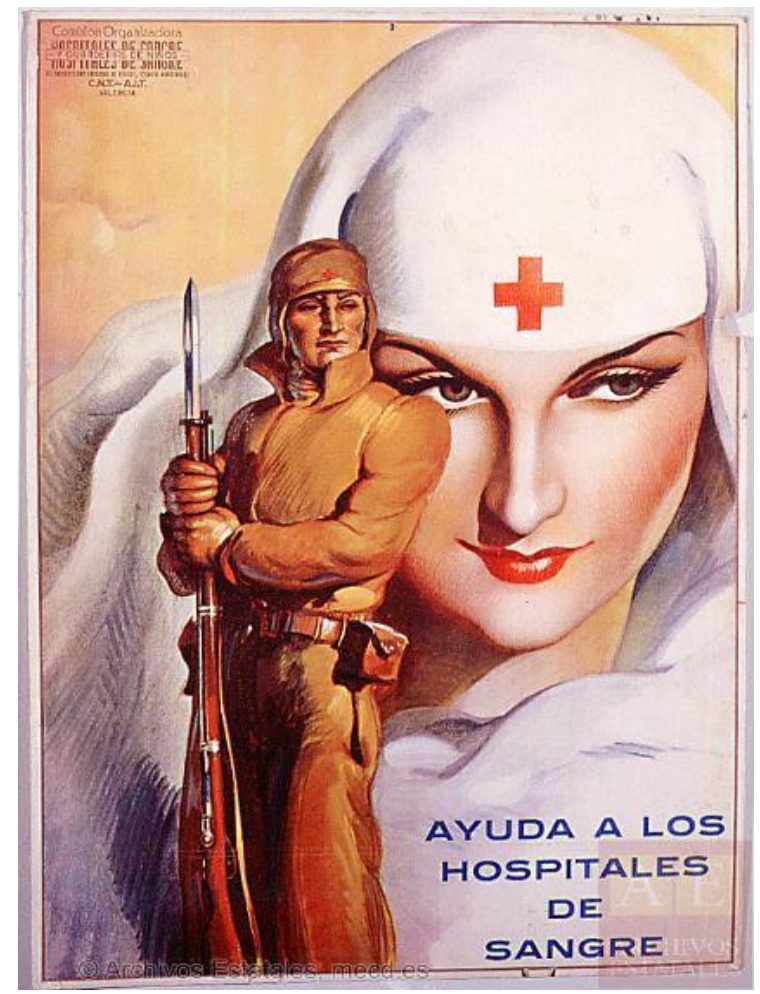

Centro Documental de la Memoria Histórica PS-CARTELES, 1547

Autor: Anónimo español (S. XX) Titulo: Ayuda a los hospitales de sangre. Editor: CNT. Sindicato Único Regional de Peritos y Técnicos Industriales de Valencia. Comisión Organizadora de Hospitales de Sangre y Guarderías de Niños [y otros ed.] Imprenta: Litografía S. Durá socializada, UGT-CNT. Valencia Fechas: 1936. 
Imagen XVIII. Enfermeras con sus heridos.
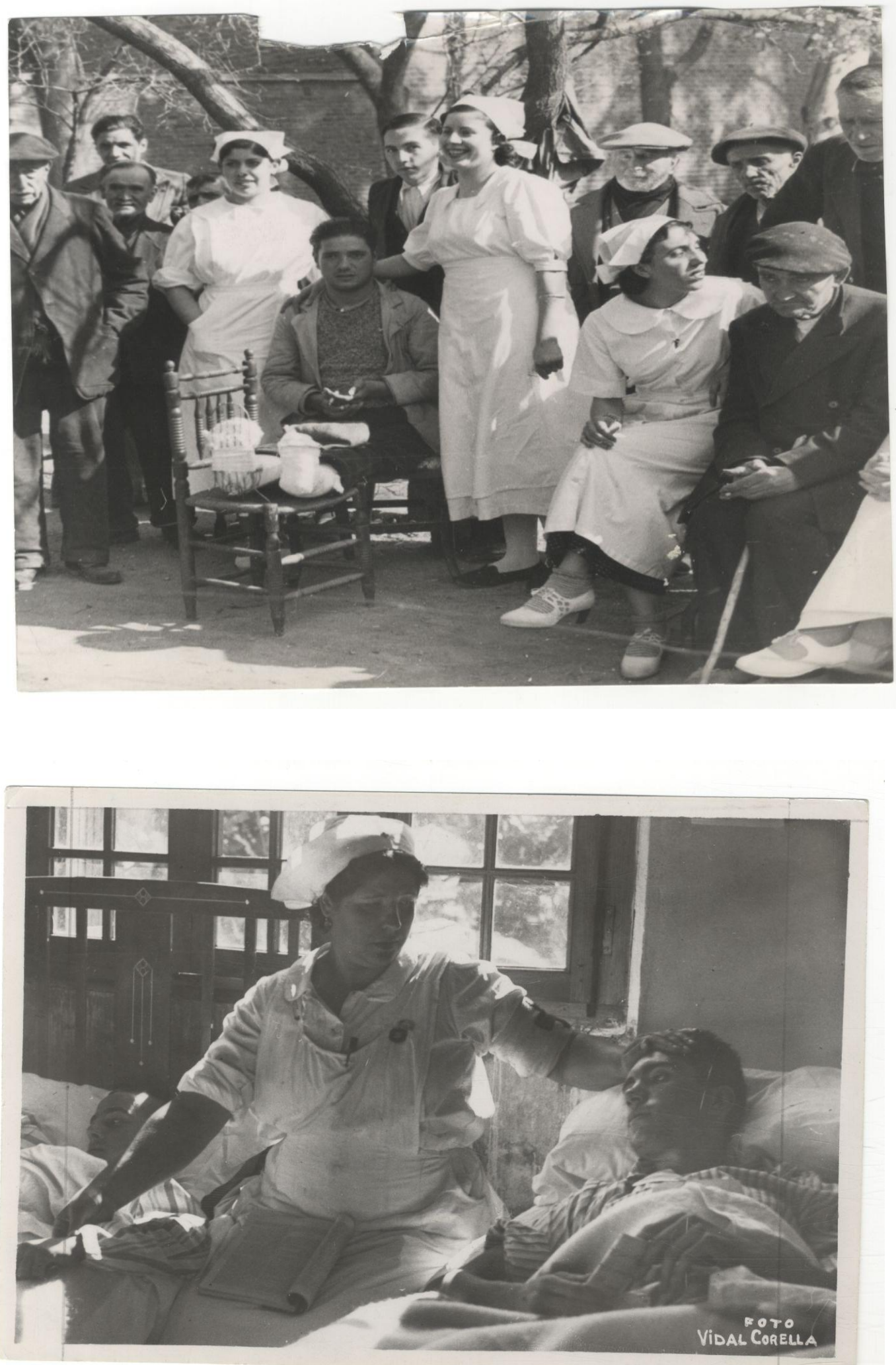

Fuente: Archivo General de la Administración, fotografías Sanidad Militar, enfermeras, caja (03)084.001. F/00768 sobre $\mathrm{n}^{\mathrm{O}} 1$. 
Anexo XII. Carteles de enfermeras.

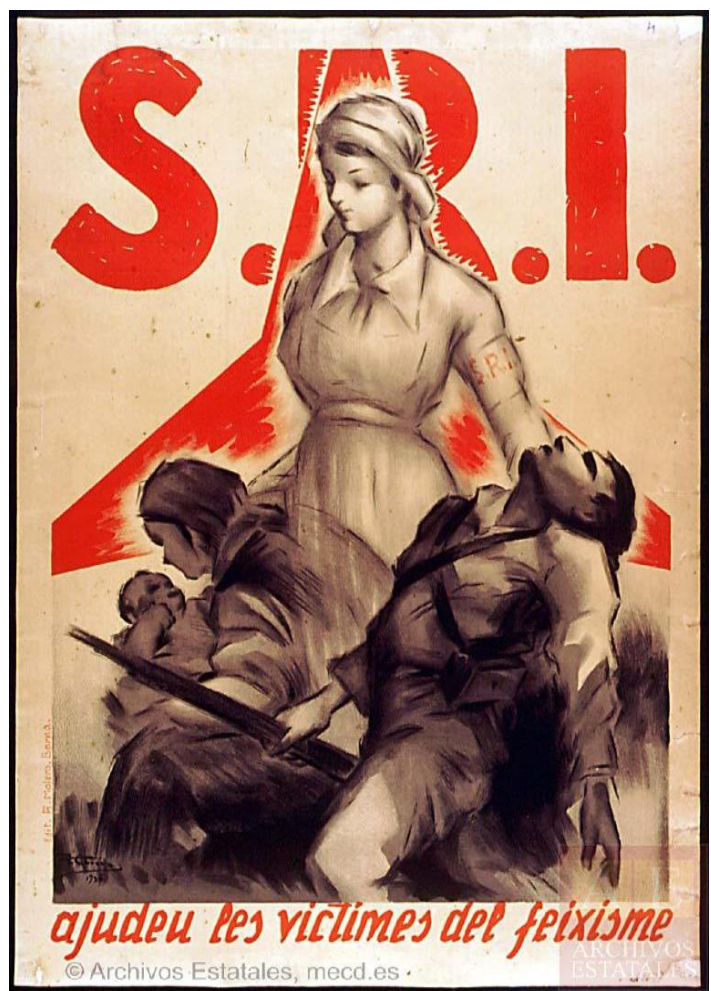

Centro Documental de la Memoria Histórica PS-CARTELES, 4

Autor: García, A. Titulo: Ajudeu les victimes del feixisme. Editor: Socorro Rojo Internacional Imprenta: R. Molero Fechas: 1936.

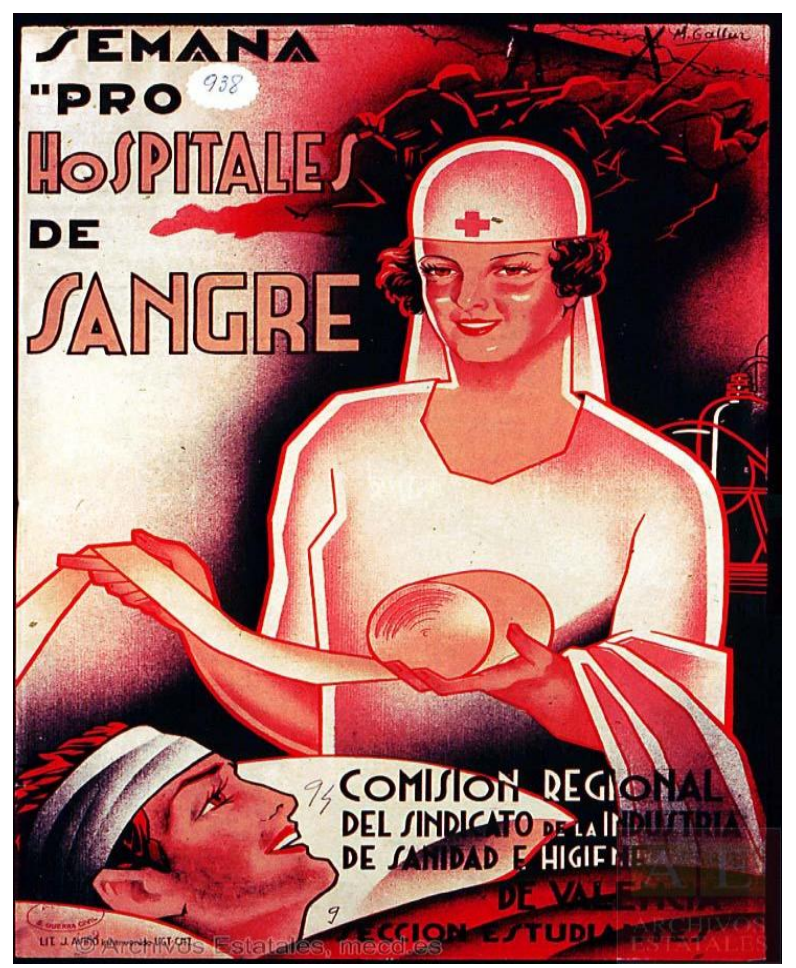

Centro Documental de la Memoria Histórica PS-CARTELES, 938

Autor: Gallur, M. Titulo: Semana "pro Hospitales de Sangre". Editor: Sindicato de la Industria de Sanidad e Higiene de Valencia. Comisión Regional. Sección Estudiantes Imprenta: Litografía J. Aviñó, intervenido U.G.T.-C.N.T. 
CAPÍTULO IV

MOVILIZACIÓN FEMENINA Y SITUACIÓN

SANITARIA EN LA ZONA NACIONAL 



\section{LA MUJER EN LA NUEVA ESPAÑA: PARTICIPACIÓN EN EL CONFLICTO}

Al igual que sucedió en la zona leal a la República, el trabajo de las mujeres en la zona de sublevación fue necesario para el desarrollo y sostenimiento de la guerra, pero con la peculiaridad de que toda su movilización se centró en los trabajos típicamente femeninos, acordes con su rol, principalmente en la retaguardia y siempre en tareas auxiliares. La figura de la miliciana en armas no se llegó a contemplar entre los nacionales, poco partidarios de la participación activa de la mujer en la guerra:

Al hablar del heroísmo de la mujer española, no necesitaremos representarla en figura de soldado que lucha, fusil en mano, sobre el perfil de las trincheras. Pero hay muchas formas de heroísmo, muchas ocasiones para servir en la guerra y mostrar el firme temple de las almas. Y si la primera condición heroica es la voluntad de sacrificio, no hay duda que las mujeres españolas están ofreciendo el más admirable ejemplo de entereza moral.

A ellas les duela la guerra más que a nadie; por naturaleza son especialmente sensibles al dolor, al miedo, al espanto $[\ldots]^{1}$;

Por lo tanto, la mujer debía colaborar sin copiar los modos de la sufragista, ni la de aquella que "disputaba al hombre una plaza en la sociedad o un acta en el Congreso". Se tenían que encargar de la reconstrucción, de "hacer la nueva Patria", con su "fina sensibilidad y vibrante entusiasmo", sin participar activamente en la lucha ${ }^{2}$ :

\footnotetext{
${ }^{1}$ ABC Sevilla, 1 de agosto de 1938, Heroísmo y abnegación de la mujer, p. 3.

${ }^{2}$ FALANGE ESPAÑOLA TRADICIONALISTA Y DE LAS J.O.N.S.: Formación de enfermeras sociales. Ajustado al programa oficial de la Delegación Nacional de Sanidad. Editado por la Delegación Provincial de Sanidad de Segovia. Imprenta Provincial, 1938, p. 3.
} 
Cada uno podemos y debemos servir a España en el preciso lugar donde Dios nos ha colocado. Los rojos llevan al frente muchas mujeres, sin duda, porque les hacen falta. Del lado de acá, sobran brazos masculinos que puedan empuñar las armas. No precisa la ayuda nuestra que, además, es impropia de la delicadeza de nuestro sexo ${ }^{3}$.

En el frente las mujeres estorbaban, pero en la retaguardia, su intuición instintiva para el peligro, les daría claridad de juicio para advertir a tiempo al hombre. Allí estaban llamadas a ejercer su labor de esposas y madres piadosas, con abnegación y sacrificio ${ }^{4}$. De esta forma se dignificó la maternidad, que pasó a ser el principal rol de la mujer nacional, "erigiéndose como modelo de víctima inocente y de sufrimiento", utilizada por su simbolismo "impactante y poderoso" capaz de influir en la moral de los soldados ${ }^{5}$. Las madres tenían que hacer el sacrificio de entregar sus hijos a la Patria para que la defendieran, por eso la propaganda se centró en ensalzar la figura materna y la maternidad:

Pedro, de lo que me dices de que te vas a la Legión, sólo te diré que Dios te dé buena suerte, porque como española y católica que soy, viendo a nuestra Patria en el estado en el que se encuentra, comprendo que hay que defenderla. Con orgullo veo ya la sangre de un hijo derramada en defensa de ella; pero como madre mis ojos se humedecen cuando pienso que a un hijo ya no lo veré y al otro por un milagro de tantos como Dios dispensa a su Ejército cada día, le vi, pero no sé lo que le tendrá dispuesto. [...]

El gesto de una madre española es el verdaderamente sublime y hace recordar al de aquellas nobles matronas de Esparta que pasaron a la Historia por su abnegación y heroísmo. No cabe mayor fe en Dios, mayor amor a la Patria, ni más caudal de resignación cristiana. Así son las mujeres católicas ${ }^{6}$.

\footnotetext{
${ }^{3}$ UrRaca PASTOR, María Rosa: Asi empezamos: memorias de una enfermera. La editorial Vizcaína, Bilbao, 1939, p.54.

${ }^{4}$ Ibid., p. 105.

${ }^{5}$ GONZÁlEZ Allende, I: op.cit., p. 44.

${ }^{6}$ Hogar Español. no 5, septiembre/octubre 1937, Mujeres españolas, p. 4.
} 


\section{Capítulo IV}

Debían rezar por sus hijos "a solas con su pena, a merced de Dios y del Estado de Franco, para poder seguir viviendo, comiendo, trabajando, sufriendo""7. Las mujeres "bajo un mismo espíritu de sacrificio y trabajo" debían dedicar su tiempo a las tareas auxiliares de la guerra, necesarias para el sostenimiento de la misma y enfocadas al cuidado de los soldados, los verdaderos protagonistas de la contienda y los salvadores de España. "Incansable y silenciosa, de dulce espíritu cristiano y noble corazón" debían sacrificarse y cumplir su deber como buenas españolas $^{8}$, ya que tenían "la tarea histórica de restaurar España", mientras los hombres se encargaban de ganar la guerra?

Las mujeres también desempeñaron un papel importante como madrinas de guerra, siendo un apoyo para los soldados a través de sus cartas. Como señalan Carmen Ortiz y Manuel de Ramón existió una "aureola casi patriótica" en torno a las madrinas, cuya misión principal fue "levantar la moral" a los combatientes a través de una correspondencia regular, con uno o más soldados, encaminada a "preservar la ilusión" de los mismos. Las madrinas en ocasiones acompañaban sus misivas con tabaco, comida, medallas religiosas, ropa de abrigo... regalos apreciados por sus $\operatorname{ahijados}^{10}$.

También fue común el hecho de que un soldado tuviera más de una madrina con la que cartearse, llegando incluso a mostrar sus preferencias por unas u otras:

En aquel mes sólo escribía de vez en cuando a mi tía Paz en Langa, pero en cambio me gustaba escribir muy a menudo a mis amistades y madrinas. Mi joven madrina Julia Berciano era la más asidua en sus cartas. Tendría unos 15 años y ya tenía conceptos de mujer mayor, de fina cultura unida a su escritura amable y sencilla que denotaba cualidades de buena estudiante; en fin, que siendo tan joven, desempeñaba el cargo de madrina de guerra a las mil maravillas. [...]

\footnotetext{
${ }^{7}$ ABC Sevilla, 5 de abril de 1938, Las combatientes de segunda línea, p. 3.

${ }^{8}$ Hogar Español. $\mathrm{n}^{\mathrm{o}}$ 6, noviembre/diciembre 1937, Las mujeres en la retaguardia, p. 3.

${ }^{9}$ Hogar Español. $\mathrm{n}^{\mathrm{o}}$ 7, enero/febrero 1938, La mujer al servicio de España, portada.

${ }^{10}$ RAMÓn CARRIÓn, Manuel de; OrTIZ SÁNCHEZ, Carmen: Madrina de guerra. Cartas desde el frente. La Esfera de Libros, Madrid, 2003, pp. 64-66.
} 
En cambio, Pilar Moreno, desde Langa, me escribía poco: estaba algo enfadada conmigo, pero yo no hacía caso, porque ya tenía suficiente con las chicas de Vitigudino, que también me escribían a menudo ${ }^{11}$.

La prensa apelaba al espíritu caritativo de las mujeres para que escribieran a los soldados del frente que carecían de madre, hermana, esposa o novia. Para ello utilizaban frases recurrentes sobre la muerte, el frío invierno y el sufrimiento del soldado, destacando el papel de las madrinas y haciendo alusión a la posibilidad de encontrar a través de las misivas "el germen" de la felicidad. De esta forma, fue común la aparición de anuncios en prensa en los que se solicitaban madrinas de guerra $^{12}$, instando a las mujeres a "manifestar los fervores de la retaguardia hacia los heroicos combatientes", ya que eran demasiados soldados a los que no podían "complacer por falta de ofrecimientos femeninos"13. Además de las cartas, también estaban interesados en recibir "pasamontañas, guantes, medias de lana y chalecos de punto", aunque tampoco rechazaban el tabaco o el alcohol como otros obsequios ${ }^{14}$.

Fue necesario organizar el servicio de madrinas de guerra, para ello se exigió a los militares que hacían sus solicitudes a través de la prensa que especificaran nombre, empleo y unidad a la que pertenecían, sin detallar la compañía o sección, ni el lugar en el que estaban prestando servicio. Las madrinas debían remitir las cartas y objetos siguiendo las mismas pautas, nombre, empleo y destino del cuerpo al que pertenecían sus ahijados ${ }^{15}$. Su función era alegrar con sus palabras las horas tristes de los soldados, sus ratos de ocio, además de ser un consuelo y una ayuda moral, capaz de hacerles cumplir su deber con "Dios y la Patria". Ser madrina de guerra no debía verse como un simple entretenimiento:

\footnotetext{
${ }^{11}$ LLORDÉS BADÍA, José: Al dejar el fusil. Memorias de un soldado raso en la guerra de España. Ariel, Barcelona, 1969, p. 189.

${ }_{12} A B C$ Sevilla, 11 de octubre de 1936, p. 21; $A B C$ Sevilla, 5 de noviembre de 1936, p. 21; $A B C$ Sevilla, 12 de abril de 1938, p. 26; $A B C$ Sevilla, 2 de noviembre de 1938, p. 22; $A B C$ Sevilla, 6 de noviembre de 1938, Anuncios por palabras, clasificados por secciones: Madrinas de guerra, p. 21.

${ }_{14}^{13} A B C$ Sevilla, 19 de octubre de 1937, Madrinas de guerra, p. 18.

${ }_{14}^{14}$ ABC Sevilla, 3 de diciembre de 1937, Madrinas de guerra ... y otras cosillas, p. 14.

${ }^{15}$ ABC Sevilla, 17 de diciembre de 1936, De la emisión "Salamanca habla." Madrinas de guerra, p. 6.
} 


\section{Capítulo IV}

Es lazo que una la vanguardia a la retaguardia; brazo de la Patria encarnada en una mujer que se alarga al soldado, que por ella lucha para secar su sudor, restañar su sangre, comunicarle aliento, darle, en fin, la sensación de que no está sólo ni olvidado, de que su sacrificio es conocido y estimado no sólo de Dios, sino también de los hombres ${ }^{16}$.

Las mujeres, además de reorganizarse en la retaguardia también lo hicieron detrás de las líneas enemigas, tal fue el caso del Auxilio Azul, María Paz, una de las primeras organizaciones femeninas clandestina de Madrid que surgió el 14 de marzo de 1936 cuando los dirigentes de Falange fueron encarcelados. Las mujeres falangistas, a diferencia de los hombres, ya contaban con una organización clandestina cuando empezó la Guerra Civil y con experiencia para poder hacer frente a las nuevas tareas impuestas por el conflicto. A sus diecinueve años, María Paz Martínez Unciti, fue la figura principal de la organización hasta su asesinato el 3 de octubre de 1936, quedándose al frente de la misma su hermana Carina. Falangistas, tradicionalistas y antirrepublicanas formaron parte de Auxilio Azul, conectadas a través de un "sistema de organización celular" de núcleos independientes que impedían que sus miembros se conocieran. La captación se hizo principalmente a través de amistades y por afinidad política, su consigna se centró en socorrer únicamente a la gente que conocían, de forma que su sistema fue sólido y no sufrió contraespionaje ${ }^{17}$.

La labor de Auxilio Azul se concentró en ayudar a los prisioneros y a sus familias, a los refugiados y a todos aquellos perseguidos por la República. Obtener alimentos, ropa de abrigo o documentación falsa para salir de la zona republicana fueron las principales tareas de la organización. Para ello necesitaron apoyos económicos como donaciones de particulares, venta de objetos personales e incluso la confección de ropa para venderla y conseguir sufragar los gastos. Las mujeres de Auxilio Azul se encargaron de "repartir los partes de guerra de Burgos y darles difusión en colas, cuarteles, oficinas, etcétera, e intentar desmontar la información

\footnotetext{
${ }^{16}$ ABC Sevilla, 11 de junio de 1937, Madrinas de guerra para el frente de Aragón. La mujer por el combatiente, p. 12.

${ }^{17}$ CerverA, Javier: Madrid en Guerra, la ciudad clandestina, 1936-1939. Alianza, Madrid, 2006, pp. 270-276.
} 
oficial del parte republicano". También se dedicaron a esconder las joyas, objetos y documentación comprometedora de sus protegidos y de conseguir sentencias favorables en los tribunales que beneficiaban a los encarcelados. La asistencia religiosa fue otra de sus tareas, lo que hicieron fue "montar y atender capillas clandestinas", además de "procurar los auxilios espirituales a personas escondidas o refugiadas (los sacramentos: confesión, comunión, extremaunción, bautismo e, incluso, matrimonio)". La organización también asistió a enfermos y les procuró medicinas, se encargaron de los niños huérfanos y de aquellos que tenían a sus familiares encarcelados ${ }^{18}$. A pesar de la importante labor que realizaron las militantes de Auxilio Azul, como señala Javier Cervera apenas tuvieron reconocimiento cuando finalizó la guerra y únicamente la Sección Femenina les concedió alguna condecoración ${ }^{19}$.

A pesar de las dificultades impuestas, algunas mujeres trabajaron en vanguardia. Tal fue el caso de las cantineras, "pequeño ejército de mujeres" que acompañó a los legionarios durante la contienda, capaces de realizar todo tipo de tareas, desde encargarse de la comida, del lavado de la ropa y del cuidado de los heridos, hasta llegar a participar en la lucha de forma activa. José Larios las definía como "mujeres recias, de mucho ánimo, valientes como leonas". ${ }^{20}$ Peter Kemp, herido durante la guerra fue atendido por una de ellas:

Oí una estridente voz femenina cerca de mí, y vi a una muchacha, vestida con el uniforme de la legión, hablando con un sargento de la 53 compañía. Tenía unos 30 años, pero parecía más vieja; su cara era atezada, y corto su cabello negro. Era corriente ver a aquellas legionarias en todas las banderas; generalmente cocinaban, lavaban y zurcían la ropa de los hombres, procurando ser siempre útiles, pero raramente seguían a la Bandera al entrar en fuego. Aquella muchacha llevaba mucho tiempo con la Legión, poseía grandes conocimientos sanitarios y ayudaba al

\footnotetext{
${ }^{18}$ CERVERA, J: op.cit., pp. 277-278.

${ }^{19}$ Ibid., pp. 279-285.

${ }^{20}$ LARIOS, José: Combate sobre España. Memorias de un piloto de caza. Editorial San Martín, Madrid, 1982, p. 59.
} 


\section{Capítulo IV}

practicante de la 53 compañía. Era tan fuerte y valiente como cualquiera de los hombres $^{21}$.

Las enfermeras que desarrollaron su trabajo en los hospitales cercanos al frente, al igual que las mujeres de Sección Femenina encargadas de los lavaderos y de la limpieza de las ropas de la tropa, también estuvieron en puestos de vanguardia. Las labores de propaganda y ayuda al frente acercaron a algunas mujeres a la línea enemiga, tal fue el caso de los altos mandos de Sección Femenina. Irene Larios se encargó durante la contienda de organizar "cantinas, depósitos de alimentos y ropas para la tropa, cooperativas, así como hospitales en primera línea y retaguardia", además de transportar ella misma en su furgoneta los suministros para el frente, llegando en una ocasión a evacuar en dicha camioneta a los heridos de la batalla de Brunete $^{22}$. Gracias al trabajo desempeñado recibió la cruz del Mérito Militar con distintivo rojo ${ }^{23}$.

La participación activa de las mujeres en la Guerra Civil o su relación personal y familiar con los líderes del levantamiento militar fueron algunos de los motivos que las llevaron a ser encarceladas durante el conflicto. Pilar Jaraíz Franco, de familia tradicionalista y militar, sobrina del general sublevado, fue una de ellas. Durante su estancia en prisión, que duró veinticinco meses, no tuvo malos tratos, hablaba principalmente del frío y la falta de mantas. El penal de Valencia contaba con varios dormitorios generales y no con celdas, las presas tenían colchones en el suelo que debían enrollar durante el día y se las permitía lavarse tranquilamente esperando cada una su turno. Pilar explicaba que para su hijo tenía una cuna y que no le faltó comida para poder criarlo. Aún así, el niño contrajo meningitis, enfermedad que superó gracias a la asistencia de una pediatra encarcelada. Los últimos meses antes de su canje y liberación, estuvo en la cárcel de Murcia donde apenas había comida y las presas debían trabajar en la huerta y en el estercolero, condiciones que hicieron que muchas de ellas murieran. Fue allí donde estuvo a punto de perder una pierna debido a una infección causada por la picadura de una

\footnotetext{
${ }^{21}$ KEMP, Peter: Legionario en España. Luis de Caralt editor, Barcelona, 1975, pp. 168-169.

${ }^{22}$ LARIOS, J: op.cit., pp. 171-173.

${ }^{23}$ ABC Sevilla, 5 de noviembre de 1938, De sociedad ecos diversos, p. 12.
} 
mosca gangrenosa del estiércol, que desapareció gracias a las curas realizadas por la enfermera del centro penitenciario ${ }^{24}$.

En la cárcel de Valencia Pilar Jaraíz coincidió con Carmen Primo de Rivera y su tía María, hermana del marqués de Estella, y con las hermanas Larios, Marilu y Maribel, hijas de los marqueses de Marzales y enfermeras voluntarias que fueron arrestadas en Brunete. José Larios, hermano de las detenidas explicaba que la cárcel de Valencia estaba destinada a criminales y prostitutas. Que en ella se sometía a las presas a trabajos sucios y desagradables como si fueran esclavas, recibían una comida "inmunda", y se impedía que recibieran los paquetes que les llegaban del exterior. Además, durante los ataques aéreos las presas permanecían encerradas en sus celdas sin poder refugiarse en los sótanos ${ }^{25}$.

Las organizaciones femeninas se encargaron de la movilización de las mujeres desde el inicio del conflicto. La fusión de las distintas fuerzas políticas en una única entidad tras el decreto de unificación de abril de $1937^{26}$ las afectó directamente, sobre todo a sus órganos de control. Cabe analizar el papel desempeñado por Sección Femenina de Falange, Frentes y Hospitales y Auxilio Social, organizaciones que se consolidaron después del decreto y cuyo enfrentamiento por el control de la movilización femenina generó tensiones y disputas entre ellas.

\footnotetext{
${ }^{24}$ JARAÍZ FRANCO, P: op.cit., pp.120-134.

${ }^{25}$ LARIOS, J: op.cit., 177-179.

${ }^{26}$ Boletín Oficial del Estado (BOE) no 182, 20 de abril de 1937, pp. 1033-1034.
} 


\section{Capítulo IV}

\subsection{La mujer nacional a través de Sección Femenina y su movilización durante la Guerra Civil}

Sección Femenina dirigió y organizó férreamente el trabajo de la mujer nacional, acorde con sus principios jerárquicos y su estructura piramidal, cuya cadena de mando estaba liderada por Pilar Primo de Rivera. Este control totalitario generó desavenencias con las otras dos organizaciones encargadas de organizar la movilización femenina en la zona nacional: Frentes y Hospitales, dirigida principalmente por María Rosa Urraca Pastor, y Auxilio Social, encabezada por Mercedes Sanz Bachiller. Como señala Katheleen Richmond, el cuerpo de mando de Sección Femenina estaba organizado en "dos jerarquías gemelas", una política y otra de servicio, vinculada la primera a Pilar Primo de Rivera y su equipo de trabajo en provincias, y la segunda integrada por las especialistas en el reglamento de Sección Femenina ${ }^{27}$. De esta forma, la delegada nacional luchó desde un primer momento por tener bajo su mando a todas las mujeres movilizadas durante la Guerra Civil, lo que generó situaciones tensas con Auxilio Social y Frentes y Hospitales.

Sección Femenina había aumentado su actividad de apoyo a Falange durante el encarcelamiento de José Antonio, siendo la Guerra Civil la que consiguió impulsar a la asociación. Desde un primer momento apoyó el levantamiento de forma que su número de afiliadas aumentó notablemente. Como señala Richmond, las mujeres nacionales se unieron a la Sección Femenina por un interés común, la "victoria ibérica", más que seguir la doctrina joseantoniana ${ }^{28}$. Pilar Primo de Rivera estaba en Madrid cuando comenzó la guerra por lo que tuvo que esconderse para evitar su encarcelamiento ${ }^{29}$. Para salir de la zona republicana consiguió documentación falsa que la permitió viajar hasta Salamanca, donde estableció una jerarquía sólida con tres niveles: nacional, provincial y local, para conseguir llevar la obra falangista a todas las mujeres de España ${ }^{30}$.

\footnotetext{
${ }^{27}$ RICHMOND, K: op.cit., p.86.

${ }^{28}$ Ibid., p. 29.

${ }^{29}$ Ibid., p. 30.

${ }^{30}$ FernÁNDEZ JimÉnez, María Antonia: Pilar Primo de Rivera. El falangismo femenino. Editorial Síntesis, Madrid, 2008, pp.128-136.
} 
Durante el primer Consejo Nacional de Sección Femenina, celebrado en Salamanca el 6 de enero de 1937, la secretaria general, Marichu de la Mora, fue la encargada de leer los estatutos de la organización. En ellos se estableció la función de la mujer dentro de la institución como un "complemento perfecto del hombre", al igual que Sección Femenina lo era para Falange Española. También se instauró un uniforme único como distintivo de las asociadas, cuyo objetivo fue evitar los “peligros de la masculinización”. El discurso de Pilar Primo de Rivera en ese primer consejo dejaba claro que en Sección Femenina se cumplían las órdenes "sin excusa" a pesar de ser difíciles, duras o desagradables ${ }^{31}$. La organización jerárquica y piramidal se mantuvo durante la Guerra Civil, perdiendo durante la misma, como señala Teresa Gallego, la poca independencia de la rama masculina que tuvieron durante la Segunda Republica, de forma que tras los estatutos de 1937 prevaleció la sumisión a Falange ${ }^{32}$. La misión y papel que debía jugar la mujer en la nueva España nacional quedaron establecidos tras el consejo:

José Antonio os diría a vosotras si estuviese presente, cómo no queremos que las mujeres sean meras destinatarias de piropos y galanterías, cómo no queremos que tampoco sean aspirantes a cargos que sólo al hombre corresponde desempeñar, sino que cumpláis vuestro magnífico destino de mujer: en la vida como esposa, como madre, como hija, como equilibrio armónico de todas las cualidades y de todas las virtudes inherentes a vuestra feminidad. Y os diría también como la abnegación, que es virtud femenina, es la principal virtud de Falange, que ha nacido y se ha formado en la aspereza y la contrariedad $[\ldots]^{33}$.

Según Carmen Domingo, la vida de la mujer quedó directamente relacionada con "la Iglesia, la cuna o la cocina". Franco fomentó el papel de madre, reina del hogar para alejarla de la vida laboral y dificultar la igualdad con el hombre. Pilar Primo de Rivera fue la principal defensora de estos postulados centrándose en la "resignación, sumisión, entrega, sacrificio, aceptación y renuncia" femenina, siendo

\footnotetext{
${ }^{31}$ Revista " $Y$ ", $\mathrm{n}^{\mathrm{o}} 1$, febrero de 1938, Historia del primer consejo, p. 5.

${ }^{32}$ GALlego MÉndEZ, Teresa: Mujer, falange y franquismo. Taurus, Madrid, 1983, p. 29.

${ }^{33}$ ABC Sevilla, 25 de enero de 1938, En Segovia se clausura con solemnidad del II Congreso Nacional de las Secciones Femeninas de Falange Española Tradicionalista, p. 9.
} 


\section{Capítulo IV}

el papel de la mujer "una de las principales cuestiones nacionales"34. José Antonio no lo había definido de forma clara, por lo que fue su hermana la que estableció el rol femenino en la sociedad, centrado principalmente en su labor doméstica. Según Richmond, Pilar fue el vínculo de unión entre Falange y el Movimiento Nacional. Por eso, su visión de la mujer "como participante activa en la reconstrucción económica y espiritual de la nación armonizaba con el ideal fascista de una población movilizada". Otro punto a tener en cuenta en Sección Femenina fue la religión, que fue adquiriendo mayor protagonismo, sobre todo a partir de 1938, cuando "su compromiso con el catolicismo fue más allá del apoyo a la causa nacionalista". De esta forma, Pilar integró la religión en los programas formativos de Sección Femenina ${ }^{35}$.

Las mujeres de Falange participaron activamente en la Guerra Civil sin salirse de su rol, siempre secundario, de ayuda a los hombres. Se organizaron y se presentaron como voluntarias en los hospitales, lavaderos, comedores, y talleres ${ }^{36}$. Sección Femenina apoyó el levantamiento a través de la recaudación de fondos y la costura de banderas, hasta conseguir establecerse como la organización femenina más preparada para asumir "el control de las operaciones asistenciales, especialmente en las provincias recién conquistadas"37.

Ya de noche, al pasar por Logroño, muchachas de Falange y del Frente de Juventudes subieron por los vagones repartiendo pastas y un buen tazón de café con leche caliente, que nos sentó a las mil maravillas. Las autoridades de Logroño, enteradas de que pasaba un tren especial con heridos y enfermos para Bilbao, organizaron un pequeño obsequio para los combatientes que iban evacuados hacia otros hospitales ${ }^{38}$.

\footnotetext{
${ }^{34}$ Domingo, Carmen: Coser y Cantar.... op.cit., 12-13.

${ }^{35}$ RiCHMOND, K: op.cit., pp. 32-33, 107-109.

${ }^{36}$ Falange Española Tradicionalista y DE LaS J.O.N.S.: Misión y organización de la S. F. (Sección Femenina, Gráfica Imperium, Madrid, 1941, pp. 11-14.

${ }^{37}$ RICHMOND, K: op.cit., pp. 30-31.

${ }^{38}$ LLORDÉS BADÍA, J: op.cit., p. 253.
} 
Esta movilización femenina únicamente estuvo justificada por la guerra y la necesidad de su colaboración. Pilar tenía claro que era un deber de las mujeres ayudar a los hombres, pero que una vez finalizado el conflicto debían volver a sus hogares, para "reintegrarse en el seno de la familia" que era donde estaba su sitio ${ }^{39}$.

\subsection{La mujer a través de la revista " $Y$ "}

El órgano de difusión de Sección Femenina que le permitió transmitir sus valores sociales y morales fue " $Y$ ": revista de la mujer nacionalsindicalista, de tirada mensual, en la que se aprecia un mayor adoctrinamiento y contenido político en sus primeras publicaciones. Pilar Primo de Rivera la utilizó para dar a conocer la historia de Sección Femenina a través de una crónica publicada a lo largo de varios números de la revista, desde febrero de 1938 hasta mayo de 1939, en los que describía los inicios de la asociación política y su trayectoria a lo largo de la guerra, además de homenajear a los caídos. Como señala María Antonia Fernández, "este trabajo evidenciaba el papel tutelar que en la vida de Pilar Primo de Rivera ejercieron José Antonio y Franco ${ }^{40}$.

La elección de la inicial $Y$ como nombre y emblema de la revista de la mujer nacionalsindicalista no fue al azar, Sección Femenina optó por la misma dentro de su labor propagandística y de adoctrinamiento. La Y representaba unión, estaba directamente relacionada con el nombre de Isabel de Castilla y con el yugo "símbolo matrimonial y disciplinario" del gobierno de Fernando el Católico. No era una revista feminista ya que no buscaba la independencia del "Robinsonismo femenino", sino la "compañía, de amoroso complemento e integración del hombre y elevación sacramental de las dos mitades a la redonda tarea común". De esta forma, la mujer nacional, al igual que Isabel la Católica, permanecería en el lugar que le

\footnotetext{
${ }^{39}$ PrImo De RIVERA, Pilar: Escritos. Discursos, circulares, escritos Sección Femenina de F. E. T. y de las J. O. N. S. Gráficas Afrodisio Aguado, Madrid, 1942, p. 7.

${ }^{40}$ FERNÁNDEZ JiMÉNEZ, M, A: op.cit., p. 154.
} 


\section{Capítulo IV}

correspondía tradicionalmente junto al hombre, como esposa y madre de sus hijos ${ }^{41}$. Ya que como señala Elena Maza, "la dimensión militar y política de la reina no impide el ejercicio de las labores propias de su sexo"42. Para Sección Femenina el feminismo alejaba a la mujer de su destino al lado de la familia ya que la acercaba a funciones masculinas en lugar de fomentar la abnegación femenina como baluarte de su sexo ${ }^{43}$.

Los artículos iniciales de la revista se centraron en establecer las diferencias entre mujeres y hombres, las primeras tendrían menos fuerza física pero mayor resistencia "para continuar sin interrupción los deberes domésticos". A falta de la seriedad y entereza masculina, la mujer utilizaba la "insinuación y la gracia" para obtener los mismos fines y gracias a su "sensibilidad más fina y delicada" era capaz de afrontar grandes sufrimientos. Mientras la razón predominaba en el hombre, el corazón lo hacía en la mujer, por lo que la sociedad debía a los primeros "el desarrollo de las ciencias, el florecimiento de las artes, el desarrollo de las industrias, la construcción de barcos, puertos, puentes, túneles y otros análogos” y a las mujeres "el conjunto de sentimientos bellos y delicados que el hombre no puede adquirir

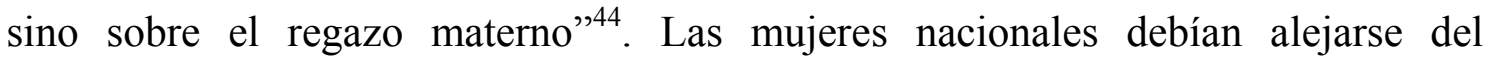
feminismo republicano que buscaba "la excelencia ideal y activa de la mujer en el ejercicio y cultivo de los valores específicamente viriles", y acercarse a la caridad $\sin$ miedo ${ }^{45}$.

En la revista también se plasmaron las "normas de conducta, basadas en el espíritu de la nueva España", haciendo hincapié en las "orientaciones" que debían seguir las mujeres. También publicó artículos de labores, moda y cocina e incluyó una sección para que las lectoras plantearan sus dudas sobre cuestiones amorosas o domésticas ${ }^{46}$.

\footnotetext{
${ }^{41}$ Y: revista de la mujer nacional sindicalista, $\mathrm{n}^{\mathrm{o}} 1$, febrero de 1938, p. 2.

${ }^{42}$ MAZA Zorrilla, Elena: Miradas desde la historia. Isabel la Católica en la España Contemporánea, Ámbito, Instituto Universitario de Historia Simancas, Valladolid, p. 132.

${ }^{43}$ Y: revista de la mujer nacional sindicalista, $\mathrm{n}^{\circ}$ 1, febrero de 1938 , Feminismo y Falange, p. 3.

${ }^{44}$ Y: revista de la mujer nacional sindicalista, $\mathrm{n}^{\circ} 1$, febrero de 1938, La voluntad y el sexo femenino, $\mathrm{p}$. 16.

${ }^{45} Y$ : revista de la mujer nacional sindicalista, $\mathrm{n}^{\mathrm{o}} 2$, marzo de 1938, p. 60.

${ }^{46} Y$ : revista de la mujer nacional sindicalista, $\mathrm{n}^{\circ} 1$, febrero de 1938, ¿Qué dudas tienes?, p. 44.
} 
Además de dar importancia a la moda y a la costura, la revista también dedicó una sección al ejercicio físico en la que explicaba distintas actividades acompañadas de dibujos aclaratorios ${ }^{47}$. La utilización de viñetas cómicas también sirvió para consolidar la imagen de la mujer nacionalsindicalista, siempre dentro de los tópicos femeninos y con el objetivo de agradar a los hombres ${ }^{48}$. Son artículos escritos por varones, en el caso de los relacionados con cuestiones de tipo sanitario, maternidad e infancia, eran los médicos los elegidos a la hora de dirigirse a las mujeres con el objetivo de fundamentar y justificar su imagen en la España nacional. Marichu de la Mora y Concha Espina participaron con la publicación de cuentos y novelas cortas. Como órgano de difusión dio a conocer a todas las líderes de Sección Femenina incluyendo su fotografía y cargo jerárquico dentro de la misma.

La mujer nacionalsindicalista, la "verdaderamente española", era la que comprendía la "misión del hombre como hombre, la de la mujer como mujer y la de la mujer como apoyo del hombre". Era femenina pero nunca feminista, dedicada a la oración y al cuidado de la casa y la familia, tenía que "ser justa sin pedir justicia", y haber aprendido que "la verdadera independencia es vivir pendiente de todo". Este prototipo de mujer se alejaba de las que habían coexistido durante la Segunda República, las "agitadoras políticas, afiliadas a los diferentes partidos comunistas, socialistas, etc.," las mujeres "rojas, feas conscientes de serlo; contrahechas, patizambas, bizcas y amargadas de la vida" ${ }^{49}$. Es curioso cómo se asociaban las cualidades físicas, entre ellas la belleza, a las mujeres nacionales, mientras que a las republicanas se las relacionaba con atributos negativos y defectos físicos. La Revista " $Y$ " publicaba un artículo sobre la ejecución de Carmen Tronchoni Soria en el castillo de Montjuich. El relato sensacionalista y propagandista, hace alusión a las características físicas de la prisionera, "rubia de piel tostada, ojos verdes, dientes

\footnotetext{
${ }^{47}$ Y: revista de la mujer nacional sindicalista, $\mathrm{n}^{\mathrm{o}} 3$, abril de 1938, Cultura física, p. 8.

${ }^{48}$ Y: revista de la mujer nacional sindicalista, $\mathrm{n}^{\circ} 3$, abril de 1938, Lo que odian los maridos, lo que les gusta a los novios, p. 9; Y: revista de la mujer nacional sindicalista, $\mathrm{n}^{\circ}$ 6-7, julio-agosto de 1938, vida de la mujer buena y la mala; Y: revista de la mujer nacional sindicalista, $\mathrm{n}^{\mathrm{o}} 12$, enero de 1939 , no hagas... y si procura, p.19 y 39.

${ }^{49} Y$ : revista de la mujer nacional sindicalista, $\mathrm{n}^{\circ}$ 6-7, julo-agosto de 1938, Mujeres verdes, mujeres rojas, mujeres lilas, mujeres grises y mujeres azules, pp. 36 a 37.
} 


\section{Capítulo IV}

muy blancos y bonitos, estatura media, de espíritu alegre y animoso". La revista dejaba claro que como creyente y religiosa, no perdió la esperanza hasta el último momento en que "supo dar su vida como mujer española", siendo "digno ejemplo de la primera mártir de nuestra causa en Cataluña"50. La contraposición entre los atributos de la mujer nacional y la republicana fue constante, las primeras, abnegadas, creyentes y entregadas al sacrificio de la guerra por vocación, eran el ejemplo a seguir, mientras que las segundas eran "arpías que superaron sacrilegios masculinos y que hicieron de la emulación hombruna y de la blasfemia marxista un constante ejercicio" $" 51$.

Respecto al trabajo que debían desempeñar las mujeres como buenas samaritanas durante el conflicto, la revista tuvo claro que el calor femenino debía llegar a los corazones de los soldados gracias a la ternura de las madrinas y al trabajo incansable y alegre realizado en los lavaderos:

[...] Llevan el pan al hambriento, la sonrisa al lecho del dolor, el calor al hogar, la fertilidad a los campos, la higiene a la trinchera y sus canciones son como una oración de esperanzas claras para el mañana de nuestras ilusiones. [...] La mujer en la guerra es como el ángel que aquilata con esplendidez el valor del guerrero y se rinde ante una laureada ${ }^{52}$.

\footnotetext{
${ }^{50}$ Y: revista de la mujer nacional sindicalista, $\mathrm{n}^{\mathrm{o}}$ 14, marzo de 1939, La primera mujer caída en Cataluña por el ideal durante la época roja, pp. 34-35.

51 Y: revista de la mujer nacional sindicalista, $\mathrm{n}^{\circ}$ 16, mayo de 1939, Las mujeres nacionales en las retaguardias rojas.

${ }^{52}$ Y: revista de la mujer nacional sindicalista, $\mathrm{n}^{\circ} 15$ abril 1939, La mujer española, símbolo y esperanza en la paz y la guerra, pp. 14-15.
} 


\subsection{Auxilio Social y su papel en la movilización femenina}

Auxilio Social nació en Valladolid como Auxilio de Invierno de la mano de Mercedes Sanz Bachiller, viuda de Onésimo Redondo, al poco tiempo de estallar la Guerra Civil, al comprobar la falta de atención y cuidado que presentaban los niños cuyos padres estaban muertos o encarcelados. Tanto la beneficencia pública como privada eran incapaces de dar cobertura a las nuevas necesidades impuestas por el conflicto, siendo los niños los grandes perjudicados, por lo que Sanz Bachiller decidió institucionalizar este tipo de asistencia en la retaguardia nacional ${ }^{53}$.

En mayo de 1937 Auxilio de Invierno pasó a ser Auxilio Social, abarcando la obra de Auxilio de Invierno, de Protección a la Madre y el Niño y Auxilio al enfermo entre otras obras sociales ${ }^{54}$. Mercedes Sanz Bachiller pasó a ser la Delegada Nacional de Auxilio Social, ratificando así su labor al frente de su organización y de todas las organizaciones benéficas de la España nacional ${ }^{55}$.

La junta directiva se centró en su obra y siempre que pudo se mantuvo al margen de las polémicas políticas, pero aun así la organización tuvo que enfrentarse a serias dificultades para consolidar su papel y conseguir sus objetivos. Inicialmente necesitaron las aportaciones económicas de benefactores o colaboradores y las cuestaciones públicas para conseguir fondos. La unificación política y la nueva legislación hizo que Auxilio Social temiera por sus intereses, duda que desapareció con la aparición de la nueva normativa, que como señala Mónica Orduña "reforzó la institución en unos términos casi desconocidos en la historia de las organizaciones socio-benéficas" ${ }^{, 56}$ :

\footnotetext{
${ }^{53}$ ORdUÑa PRADA, Mónica: El Auxilio Social (1936-1940). La etapa fundacional y los primeros años. Escuela Libre Editorial, Madrid 1996, pp. 32-44.

${ }_{54}^{54}$ ABC Sevilla, 22 de mayo de 1937, La Delegación Nacional de Auxilio social, p. 6.

${ }_{55}^{5}$ ORDUÑA PRADA, M: op.cit., pp. 92-95.

${ }^{56}$ Ibid., pp. 48-49 y pp.83-86.
} 


\section{Capítulo IV}

Después de la postura enérgica adoptada por nosotros con respecto al sentido y libertad de acción del Auxilio de Invierno, hemos podido llegar, a instancia del Gobierno General, a un acuerdo con él tan favorable para nosotros que nos coloca en una situación privilegiada que puede traducirse fácilmente en un monopolio de la asistencia social de la nueva España si seguimos trabajando con entusiasmo y disciplina.

El acuerdo ha sido ya llevado al Boletín Oficial y aparecerá hoy o mañana. Como veréis en él, se nos concede plenamente el producto de la cuestación, se autoriza la ficha azul y se nos deja abierta la puerta de las subvenciones para el caso de que llegáramos a necesitarlas por el volumen de nuestra obra ${ }^{57}$.

A través de las cuestaciones, la Ficha Azul, donativos, Caja de Compensaciones, Subvenciones de distintos organizaciones, fondos asignados a la beneficencia, franquicias concedidas por el Estado y ayudas económicas extranjeras, Auxilio Social aumentó su capital de ayuda. Las cuestaciones se celebraban periódicamente en las instalaciones de la institución o en la calle, gracias a la colaboración de personal voluntario, mujeres que estaban cumpliendo el Servicio Social o afiliadas de Sección Femenina, encargadas de la venta de emblemas y del depósito del dinero en huchas precintadas antes de su distribución ${ }^{58}$ :

[...] El emblema que lo mismo puede ser de metal, madera, cuero, tejido, bakelite, pasta de serrín, cerámica, etc., nos sirve para diferenciarnos de modo radical de las decaídas y decadentes Fiestas de la flor, el coste del emblema (4 o 6 céntimos) es de por sí instrumento primerísimo de nuestra obra [...]. El emblema sirve, por último, para mantener el interés, la solicitud y la tensión de nuestras cuestaciones que bajarían rápidamente, después de un plazo largo de funcionamiento, si no cuidásemos este factor decisivo del emblema ${ }^{59}$.

\footnotetext{
${ }^{57}$ Boletín Auxilio de Invierno. Cuaderno n ${ }^{\circ}$ 2, Valladolid, abril de 1937, Situación general, portada. ${ }^{58}$ ORDUÑA PRADA, M: op.cit., pp. 211-212.

${ }^{59}$ Boletín Auxilio de Invierno. Cuaderno $\mathrm{n}^{\circ}$ 2, Valladolid, abril de 1937, El problema de los emblemas, p.11.
} 
Las cuestaciones terminaron por ser de carácter oficial, por lo que fue obligatorio llevar el emblema ${ }^{60}$ de Auxilio Social para acceder a diferentes centros de ocio, llegando a sancionar a las personas que no lucían la insignia el día de la cuestación en teatros, bares o cafés ${ }^{61}$.

La Ficha Azul en un primer momento estaba constituida por las aportaciones que hacían en especie ${ }^{62}$, de forma voluntaria, los simpatizantes de la asociación y que posteriormente pasaron a ser en metálico ${ }^{63}$. Las mujeres se encargaron de la suscripción y el cobro, contribuyendo de esta forma "a satisfacer las necesidades de los que sufren hambre y miseria" ${ }^{64}$.

La principal herramienta utilizada por Auxilio Social para conseguir los donativos y la filiación a su asociación fue la propaganda. La Oficina Central de Propaganda se encargó de dar visibilidad a la institución y el trabajo benéfico realizado por la misma, a través de carteles, equipos de oradores, reportajes, artículos y publicaciones, espectáculos y festivales, cinematografía, exposiciones y campañas de propaganda en el extranjero ${ }^{65}$. El principal medio de difusión utilizado fue la prensa, en la que aparecían noticias diversas sobre la inauguración de comedores y locales nuevos, fiestas conmemorativas, asistencia a refugiados, cuestaciones y donativos realizados ${ }^{66}$. También fue común dar visibilidad a la figura

\footnotetext{
${ }^{60}$ Únicamente se podía dar uno por persona y en caso de tenerlo, no debería "ser molestada más por ninguna de las postulantes". Tenían prohibido recibir en mano los donativos, los donantes debían depositarlos directamente en las huchas. Las voluntarias que realizaban la cuestación debían entregar las huchas con el precinto intacto al finalizar la misma y la relación de emblemas vendidos y devueltos, además de una recaudación mínima acorde con el número de emblemas vendidos. Ver $A B C$ Sevilla, 9 de febrero de 1937, Disposiciones oficiales, p. 17.

${ }^{61}$ ORDUÑA PRADA, M: op.cit., pp. 214-218.

${ }^{62}$ La cuota era de una cantidad fija, nunca inferior a una peseta, y de una periodicidad mensual. Dejó de aceptarse el donativo en especie por la dificultad de contabilizar los mismos y su difícil distribución y manejo.

${ }^{63}$ ORDUÑA PRADA, M: op.cit., pp. 214-218.

${ }^{64}$ Boletín Auxilio de Invierno. Cuaderno no 2, Valladolid, abril de 1937, Ficha Azul, p. 11.

${ }^{65}$ ORDUÑA PRADA, M: op.cit., pp. 242-256.

${ }^{66}$ ABC Sevilla, 1 de noviembre de 1938, La conmemoración del segundo aniversario de Auxilio social, p.13; $A B C$ Sevilla, 8 de junio de 1938, p. 5; ABC Sevilla, 10 de noviembre de 1938, Inauguración de los comedores de auxilio social, p. 5; ABC Sevilla, 11 de marzo de 1938, Auxilio Social se extiende por España, p. 1; ABC Sevilla, 12 de enero de 1939, Riotinto- de la fiesta de los Reyes, p. 4; ABC Sevilla, 14 de febrero de 1939, La asistencia a los refugiados, p.11. ABC Sevilla, 15 de julio de 1938, Santander: los comedores de Auxilio Social, p. 4; ABC Sevilla, 19 de enero de 1938, Vigo: el Auxilio social y la fiesta de
} 


\section{Capítulo IV}

de Mercedes Sanz Bachiller, por lo que se divulgaban las apariciones públicas de la líder de Auxilio Social $^{67}$ y los discursos que pronunciaba con tintes propagandísticos ${ }^{68}$.

Desde sus inicios Auxilio Social cuidó su imagen y estilo con el fin de mostrar "una obra íntimamente social, alegre y dignamente nacional". La ayuda económica fue necesaria para su mantenimiento y la propaganda fue su principal aliada, entendida como una "comunicación constante al exterior de los auxilios que logra y representa". Debía ser "sencilla, eficaz y directa", estar bien dirigida y conseguir la colaboración de todas las delegaciones provinciales que debían repartir las misivas "cuidadosamente" de forma "metódica y continuada" en casas, cafés y calles $^{69}$. Mercedes Sanz Bachiller, con su "patriótico entusiasmo", ayudó "valiosamente, desde el puesto encomendado a su clara inteligencia y gran corazón, a la mayor eficacia" de Auxilio Social ${ }^{70}$.

Como expone Orduña, Sanz Bachiller no estaba muy de acuerdo con los postulados sobre la posición de la mujer defendidos por la Sección Femenina. Auxilio Social contaba en sus puestos directivos con hombres y mujeres, decisión que no aprobaba Pilar Primo de Rivera que prefería un monopolio exclusivamente femenino. La Líder de Sección Femenina partidaria del concepto unitario de su organización, veía en Auxilio Social una intromisión y en Mercedes Sanz Bachiller una competidora que poco a poco iba adquiriendo mayor reconocimiento social a nivel nacional gracias a su obra ${ }^{71}$.

\footnotetext{
Reyes, p. 4; ABC Sevilla, 25 de octubre de 1938, Auxilio social es uno de los jalones de nuestra tarea revolucionaria, p. 10; ABC Sevilla, 26 de enero de 1939, Toda España se apresta a socorrer a Barcelona, p 13; ABC Sevilla, 29 de enero de 1937, Jerez de la Frontera: Los comedores de Auxilio Social, p. 1.

${ }^{67} A B C$ Sevilla, 10 de agosto de 1938, La delegada de auxilio social en Bilbao, p. 11; ABC Sevilla, 10 de diciembre de 1938, Mercedes Sanz Bachiller en Palma de Mallorca, p. 8; ABC, Sevilla, 9 de noviembre de 1938, Personalidades en Bilbao, p. 17; ABC Sevilla, 26 de marzo de 1938, La delegada nacional de Auxilio Social en Algeciras, p. 15.

${ }^{68}$ ABC Sevilla, 2 de noviembre de1938, De la pasada fiesta de Auxilio Social: La Delegada de Auxilio social dirige un mensaje a los delegados provinciales, p. 15. ABC Sevilla, 30 de noviembre de 1938, Palabras autorizadas, p. 19.

${ }^{69}$ Boletín Auxilio de Invierno. Cuaderno $\mathrm{n}^{\circ}$ 3, Valladolid, mayo de 1937, La propaganda al servicio de “Auxilio Social." Normas y orientaciones, p. 10.

${ }^{70}$ ABC Sevilla, 26 de enero de 1938, Noticias de libros y revistas, informaciones y juicios: Normas y ${ }_{71}^{\text {orientaciones para Auxilio Social, p. } 21 .}$

${ }^{71}$ ORDUÑa PRADA, M: op.cit., pp. 44-48.
} 
Para Pilar Primo de Rivera fueron las mujeres de Falange las primeras en prestar ayuda al movimiento nacional y por lo tanto en participar activamente en la obra de Auxilio Social ${ }^{72}$. En Misión y organización de la S. F. (Sección Femenina), se explicaba que en octubre de 1936 se fundaba "la obra de Auxilio de Invierno", que nacía "bajo la disciplina de la Sección Femenina". Relatan como "toda el alma de Falange" se puso en esa obra social, apoyada desde el principio por sus delegadas provinciales que fueron nombradas delegadas de Auxilio de Invierno"73.

A pesar de contar con la colaboración voluntaria de 40.000 mujeres, la organización tenía un déficit de recursos humanos. Esto les llevó a idear un servicio obligatorio para las mujeres, similar al militar realizado por los hombres, conocido como Servicio Social, cuya institucionalización "supuso una verdadera ruptura con la Sección Femenina"74. Pilar Primo de Rivera no estaba conforme con la situación por lo que el enfrentamiento entre Sección Femenina y Auxilio Social por el control del Servicio Social fue mayor ya que estaba en juego el monopolio de la actividad femenina. Orduña expone que el trasfondo de dicha rivalidad era de tipo político, Pilar partidaria del fascismo y los principios de José Antonio, y Mercedes y su cúpula directiva del jonismo de Onésimo Redondo ${ }^{75}$. El nombramiento de Mercedes como Delegada Nacional de Auxilio Social ${ }^{76}$, la consolidó como ejemplo de mujer española, "dotada de una aliento espiritual incalculable"77, de gran corazón, inteligente y patriótica ${ }^{78}$. Su idea de la participación de las mujeres en la esfera política y pública supuso otra línea de tensión y enfrentamiento con la líder de Sección Femenina. El 28 de diciembre de 1939 Pilar Primo de Rivera consiguió su propósito, que Franco firmara un Decreto de traspaso del Servicio Social a la Sección Femenina que hizo que prevaleciera el pensamiento de Pilar y la visión de

\footnotetext{
${ }^{72}$ ABC Sevilla, 10 de agosto de 1938, Conferencia de Pilar Primo de Rivera, p. 11.

${ }^{73}$ Falange ESPaÑola TRAdicionalista Y DE LAS J.O.N.S. Misión y organización de la S. F...: op.cit., p. 11.

${ }^{74}$ ORDUÑA PRADA, M: op.cit., p.60.

75 Ibid., pp. 202-208.

${ }_{77}^{76}$ ABC Sevilla, 22 de mayo de 1937, La Delegada Nacional de Auxilio Social, p. 6.

${ }^{77}$ ABC Sevilla, 30 de octubre de 1938, Gloria y eficacia de Auxilio Social, p. 19.

${ }^{78}$ ABC Sevilla, 26 de enero de 1938, Normas y orientaciones para Auxilio Social, p. 21.
} 


\section{Capítulo IV}

la mujer en su casa como papel fundamental y prioritario. Según Orduña, los principios igualitarios postulados por Mercedes Sanz Bachiller para el Auxilio Social sin discriminación, desaparecerían bajo el mandato de Pilar Primo de Rivera $^{79}$.

\section{Servicio Social Femenino}

El 11 de octubre de 1937 se declaraba obligatoria la prestación del Servicio Social para la mujer. Hasta ese momento habían sido los hombres los únicos movilizados de forma oficial por el Estado a través del servicio militar obligatorio, manteniendo a la mujer apartada del mismo. De esta forma el establecimiento del Servicio Social femenino sirvió para "aplicar las aptitudes femeninas en alivio de los dolores producidos en la presente lucha de las angustias sociales de la postguerra". El Servicio Social pasaba a ser un deber de las mujeres con el Estado, que aceptarían "llenas siempre de generosidad y de espíritu de sacrificio" 80 . Mónica Orduña considera sorprendente el carácter de igualdad que se concedía en ese momento, en algunos casos concretos, entre el Servicio Social y el Militar realizado por los hombres ${ }^{81}$.

Por lo tanto, el Servicio Social pasaba a ser un deber nacional de todas las mujeres con edades comprendidas entre los diecisiete y los treinta y cinco años, excluyendo del mismo a las que tuvieran algún defecto físico o enfermedad que imposibilitara su realización y a las casadas o viudas. También estaban exentas las mujeres que habían colaborado en hospitales de sangre y obras de asistencia al frente, con una duración mínima de seis meses. Por el contrario, pasaba a ser de obligatorio cumplimento para todas aquellas que estuvieran pendientes de la expedición de un título, de presentarse a oposiciones o que quisieran desempeñar un cargo de función pública o responsabilidad política. La duración mínima del Servicio Social era de seis meses que se podía cumplir de forma ininterrumpida o

\footnotetext{
${ }^{79}$ ORDUÑA PRADA, M: op.cit., pp. 202-208.

${ }^{80}$ Boletín Auxilio de Invierno. Cuaderno $\mathrm{n}^{\circ}$ 5, Valladolid, noviembre de 1937, Decreto estableciendo deber nacional el Servicio Social de la mujer comprendida entre los 17 a 35 años, p. 2.

${ }^{81}$ ORdUÑA PRADA, M: op.cit., p. 181.
} 
por fracciones dentro de un plazo máximo de tres años ${ }^{82}$. Las funcionarias públicas podían espaciar en uno, dos o tres años la prestación, mientras que las "empleadas en entidades individuales o colectivas dedicadas a cualquier género de actividad industrial o mercantil" se las reservaba su puesto mientras estuvieran prestando el Servicio Social ${ }^{83}$. Como señala Orduña, esto suponía un "trato de preferencia en una sociedad donde el papel desempeñado por la mujer estaba por debajo de este perfil" ${ }^{\prime 4}$. Los certificados que acreditaban su realización los expedían los delegados provinciales de Auxilio Social de Falange Española Tradicionalista y de las J.O.N.S ${ }^{85}$.

Cumplir el Servicio Social era un "honor" que permitía a las mujeres reconstruir España, "como exponente de virtudes y sacrificios" alejado del cumplimiento pasivo de los actos y centrado en "imprimir a éstos el sello de una hermandad efectiva entre los españoles que sufren y los que les socorren en su dolor". Se las exigía disciplina, dignidad y compostura durante el cumplimento del mismo, siendo las insignias y los certificados un "título de arraigo en la nueva España, fundada sobre la sangre vertida por sus mejores hijos y mantenida por la unánime colaboración de todos en las tareas de justicia y hermandad" ${ }^{\prime 86}$.

Para formar parte del Servicio Social, las interesadas debían solicitarlo por escrito en el documento oficial establecido por la Delegación Nacional de Auxilio Social, siendo las afiliadas de Falange Española Tradicionalista y de las J.O.N.S. las únicas que debían cursar la "instancia por el conducto jerárquico de la organización” ${ }^{\sharp 7}$. Para Orduña esto supuso una intrusión de Sección Femenina ya que

\footnotetext{
${ }^{82}$ Boletín Auxilio de Invierno. Cuaderno $\mathrm{n}^{\circ}$ 5, Valladolid, noviembre de 1937, Decreto estableciendo deber nacional el Servicio Social de la mujer comprendida entre los 17 a 35 años, p. 2.

${ }^{83}$ Boletín Auxilio de Invierno. Cuaderno n ${ }^{\circ} 6$, Valladolid, diciembre de 1937, Decreto del Jefe del Estado, aprobando el Reglamento para la aplicación del "Servicio Social" de la mujer española, p. 2.

${ }^{84}$ ORDUÑa PRADA, M: op.cit., p. 181.

${ }^{85}$ Boletín Auxilio de Invierno. Cuaderno ${ }^{\circ}$ 5, Valladolid, noviembre de 1937, Decreto estableciendo deber nacional el Servicio Social de la mujer comprendida entre los 17 a 35 años, p. 2.

${ }^{86}$ Boletín Auxilio de Invierno. Cuaderno ${ }^{\circ}$ 6, Valladolid, diciembre de 1937, Decreto del Jefe del Estado, aprobando el Reglamento para la aplicación del "Servicio Social" de la mujer española, p. 2.

${ }^{87}$ Ibid., p. 2.
} 


\section{Capítulo IV}

de esta forma todas sus afiliadas necesitarían su autorización para poder realizar el Servicio Social ${ }^{88}$. En la solicitud debían señalar sus "conocimientos técnicos, profesionales o especializados" y especificar si lo realizarían en seis meses o fraccionado. En función de la preparación de las aspirantes, Auxilio Social las destinó a los diferentes puestos de trabajo dentro de la provincia de residencia de las solicitantes. En caso de prestar el Servicio Social fuera de su localidad la organización se encargó de facilitar el traslado, alimentación y residencia de las mismas. Los gastos los asumían las voluntarias o en su defecto, sus familias, en caso de no disponer de medios económicos, sería Auxilio Social el encargado de cubrir los $\operatorname{mismos}^{89}$.

\subsection{Frentes y Hospitales: las Margaritas}

La Delegación Nacional de Asistencia a Frentes y Hospitales fue constituida de forma oficial en abril de 1937 tras la unificación política llevada a cabo por Franco. María Rosa Urraca Pastor ${ }^{90}$, que había pertenecido al partido de Comunión Tradicionalista, quedó al mando de la misma gracias a "sus repetidas y arriesgadas visitas a los frentes", además de haber "dado pruebas de gran simpatía por las actividades de protección a los combatientes y preparación para dirigir esta Obra" ${ }^{\text {. }}$. Urraca Pastor destacó por su labor política y propagandística a lo largo del conflicto, trabajó como enfermera y siempre que pudo permaneció al lado de los requetés en el frente $^{92}$. Richmond señala que a Pilar Primo de Rivera no le agradó el "ascenso de una margarita al puesto de directora nacional de un nuevo departamento del Gobierno", ya que ese nombramiento hizo que Sección Femenina perdiera poder en el campo de la asistencia a los soldados heridos. Pilar tuvo especial interés en que

\footnotetext{
${ }^{88}$ ORDUÑA PRADA, M: op.cit., p. 182.

89 Boletín Auxilio de Invierno. Cuaderno $\mathrm{n}^{\circ}$ 6, Valladolid, diciembre de 1937, Decreto del Jefe del Estado, aprobando el Reglamento para la aplicación del "Servicio Social" de la mujer española, p. 2.

${ }^{90}$ María Rosa Urraca Pastor. (1907-1984). Pedagoga, escritora y propagandista tradicionalista. Sus ideas y labor antirrepublicanas desencadenaron su cese como Inspectora de Trabajo en Vizcaya. Directora desde su fundación del Boletín de Acción Católica. Durante la Guerra Civil compaginó su trabajo como enfermera con su labor propagandística. Ver más en Enciclopedia general ilustrada del País Vasco: Cuerpo A. Diccionario enciclopédico vasco. Auñamendi, San Sebastián, 1979-2008.

${ }^{91}$ ACCRE, caja 994, expediente 5, Falange Española y Tradicionalista de las J.O.N.S., Delegación Nacional de Asistencia Frentes y Hospitales.

${ }^{92}$ ABC Sevilla, 1 de agosto de 1937, Una conferencia de la señorita Urraca Pastor, p. 17.
} 
las margaritas se afiliaran a su organización y siempre que pudo las situó en puestos de responsabilidad, sin lograr la cooperación deseada. Como sucedió con Auxilio Social, Pilar Primo de Rivera actuó “entre bastidores como si la SF siguiera teniendo el control general de la enfermería",93.

La misión principal de la delegación fue la asistencia a frentes y hospitales, que además de centrarse en el aspecto sanitario a través de la distribución de medicamentos y apósitos para curas, también llevó una labor religiosa, cultural, higiénica, alimenticia, recreativa e informativa. El envío de lecturas y objetos piadosos a los combatientes formaba parte de la misión religiosa de la delegación, las lecturas y conferencias cubrían la cultural, el suministro de utensilios y de productos de tocador o limpieza, la higiénica. La entrega de licores y cigarrillos a los soldados, además de los obsequios que fueran comida cubría su labor alimentaria. El suministro de prendas la ropera. La recreativa la llevaron a cabo a través de "representaciones y fiestas en las salas de los hospitales y en los frentes, facilitación de localidades a combatientes y heridos para asistir a teatros y cines, envío a los hospitales y frentes de instrumentos músicos y juegos de solaz y esparcimiento", y la informativa se centró en contactar con las familias de los heridos ${ }^{94}$.

Cada Delegación Provincial de Frentes y Hospitales se encargaba de dar cobertura a todos los hospitales situados en su provincia y a las unidades de combatientes enclavadas en esa zona. La asistencia especial al frente la constituían los lavaderos, estaciones sanitarias y enfermerías ${ }^{95}$. También establecieron Hogares del Herido situados en la retaguardia con el fin de ser un centro de ocio que permitiera a los combatientes hacer salidas del hospital durante su convalecencia. Principalmente fueron lugares en los que "la previsión maternal, la delicadeza femenina y la protección de personas pudientes, velan, tanto o más que por el bien

\footnotetext{
${ }^{93}$ RICHMOND, K: op.cit., pp. 134-135

${ }^{94}$ ACCRE, caja 994, expediente 5, Falange Española ...: op. cit.

${ }^{95}$ Según la Real Academia de la Lengua, enfermería, a nivel etimológico se refiere no únicamente a la profesión y titulación de la persona dedicada al cuidado de los enfermos, sino al local o dependencia para enfermos o heridos. Las enfermerías entendidas como centros de asistencia sanitaria nacen en los monasterios medievales como dependencias destinadas a los enfermos y peregrinos.
} 


\section{Capítulo IV}

material, por el bien moral de los heridos que convalecen y, en alto nivel moral, disfrutan de comodidades semejantes a las que pudieran tener en su propio hogar". Se solían instalar en locales céntricos, confortables y de ambiente militar, contaban con biblioteca y hemeroteca, radio, cine, billares, música... ${ }^{96}$

El servicio de información de Frentes y Hospitales contó con equipos Auxiliares de Hospitales que se encargaron de elaborar las fichas de altas y bajas de heridos, tanto de puestos de socorro, evacuación u hospitales de sangre, médicos o quirúrgicos, y enviarlas a las oficinas de información. También organizaron el servicio de Auxiliares de Oficina cuya función fue localizar los informes de un herido o combatiente a petición de un familiar, excepto en los casos de muerte ${ }^{97}$.

Organizar el Aguinaldo del Combatiente también fue labor de Frentes y Hospitales. Confeccionaron paquetes-aguinaldo para obsequiar a los soldados nacionales, tanto los hospitalizados como los movilizados en el frente. El aguinaldo variaba dependiendo de la localidad en la que se preparaba el paquete, pero normalmente contenía tabaco, licores, embutidos, turrón y pastas ${ }^{98}$.

La organización de las Margaritas participó activamente en la sección de Frentes y Hospitales. Desde un principio se presentaron como voluntarias en los talleres de costura para la confección de uniformes y prendas de abrigo para los soldados, el avituallamiento de las columnas de requetés y la asistencia a heridos en a los hospitales militares. Además de su amplia labor como enfermeras tanto en centros asistenciales de retaguardia como en vanguardia, las margaritas también participaron en el servicio de paquetería y correos a los frentes, recogida de fondos, organización de grupos de maestros para los hospitales, visitas de apoyo y distribución de ropa y víveres a los combatientes situados en el frentes, además de colaborar en el Aguinaldo del Soldado ${ }^{99}$.

\footnotetext{
${ }^{96}$ ACCRE, caja 994, expediente 5, Falange Española ...: op. cit.

${ }^{97}$ Ibid.

${ }^{98}$ ACCRE, caja 994, expediente 5, Falange Española ...: op.cit.

${ }^{99}$ LARRAZ ANDíA, Pablo: Entre el frente y la retaguardia. La sanidad en la Guerra Civil: El hospital

"Alfonso Carlos" Pamplona 1936-1939. Editorial Actas, Madrid, 2004, pp. 104-107.
} 
Las margaritas eran las mujeres tradicionalistas afines al partido Carlista cuyo ideario era: Dios, Patria y Rey, basado en la fe y en los valores éticos y morales ${ }^{100}$. Existían tres tipos de afiliadas: las aspirantes; las socias de número y las honoríficas. Las primeras eran las hijas de los afiliados, hasta que cumplían los dieciséis años. Las socias de número eran las hijas, hermanas o mujeres de activistas carlistas mayores de dieciséis años y las socias honoríficas u honorarias encargadas de mantener el espíritu de continuidad y la defensa de los principios esenciales del Carlismo $^{101}$. Durante la Guerra Civil participaron activamente en la Sección de Frentes y Hospitales, cuyo trabajo se caracterizó por la caridad cristiana que ejercieron como buenas católicas. Desde el punto de vista organizativo, las margaritas debían obediencia y subordinación a las órdenes de las autoridades jerárquicas, además de tener que cotizar para el mantenimiento de la causa, y cumplir los reglamentos de la organización ${ }^{102}$.

Urraca Pastor ejerció una importante labor propagandística a lo largo del conflicto. A pesar de ser una clara defensora del trabajo femenino en la retaguardia ella no fue un ejemplo de ello. Para Urraca su labor era un hecho aislado y que no se podía extrapolar al resto de las mujeres. Ya que como líder político y delegada de Frentes y Hospitales, tenía que estar cerca de los combatientes:

Yo voy a los frentes no por ser mujer, pues, como tal, poco sirvo. Voy porque quiero ser consecuente y es mi deber, ahora de cara a la verdad, estar junto a los hombres que por España dan la vida, de acuerdo, con la doctrina, los principios y la única táctica que yo defendí y propagué en conferencias y discursos ${ }^{103}$.

Las margaritas, también trabajaron clandestinamente en la zona republicana, sobre todo las madrileñas, que actuaron dentro del Socorro Blanco que ya funcionaba en la República con el objetivo de recaudar fondos para los presos carlistas. Durante la guerra "se jugaban sencillamente la vida. Sin alientos, sin

\footnotetext{
${ }^{100}$ MORAL RonCAL, A: op cit., p. 16.

101 Ibid., p. 160.

${ }^{102}$ Ibid., pp. 162-164.

${ }^{103}$ URRACA PASTOR, M.R: op.cit., p. 54.
} 


\section{Capítulo IV}

aplausos, desfalleciendo muchas veces entre el hambre y la persecución, se las ingeniaban para aliviar a sus hermanos en su doloroso calvario". La organización clandestina estaba formada por "pequeños grupos diseminados que se ocupaban alternativamente en recaudar ropas, víveres, dinero... que luego distribuían en las cárceles valiéndose de jefes que en ellas había". También visitaron a los presos que no tenían familia y establecieron una "comunicación de los de dentro con los de fuera. El paso de cartas, los partes de guerra... agudizaban el ingenio, la tenacidad y el valor; fuertes y prudentes, llegaron a vencer los obstáculos más insuperables". También dieron asistencia espiritual a los encarcelados, enfermos y refugiados ${ }^{104}$.

\footnotetext{
${ }^{104}$ LARRAZ ANDíA, Pablo; SIERRA-SESÚ MAGA, Víctor: Requetés: de las trincheras al olvido. La esfera
} de libros, Madrid, 2010, p. 588. 


\section{LA SANIDAD EN LA ZONA NACIONAL: INSTALACIÓN DE UNA NUEVA RED ASISTENCIAL}

La Guerra Civil obligó a una restructuración de la infraestructura sanitaria, sobre todo a nivel militar, para poder dar cobertura a los soldados. Las grandes demandas sanitarias derivadas de la contienda bélica y la carencia de recursos materiales y personales, impulsó la militarización de los médicos civiles, cuya elección se hizo en función de su "antecedentes profesionales, morales y políticos". A pesar de todo, se procuró que los altos mandos estuvieran en manos de médicos militares con experiencia, capaces de organizar la asistencia sanitaria en campaña. Para un mejor funcionamiento se dividió la Sanidad en el Ejército Nacional en diferentes jefaturas capaces de gestionar una red asistencial eficiente y con funciones diferentes pero complementarias ${ }^{105}$.

\subsection{Dotación de recursos sanitarios}

Sanidad Militar contó con la ayuda de Cruz Roja internacional y nacional que fue un apoyo importante para el funcionamiento y dotación de su red asistencial. Desde el inicio de la contienda el comité de Cruz Roja Española de Burgos fue el encargado de la inspección general del resto de centros de la institución, "sin menoscabar" la libertad de los mismos, con el objetivo de unificar criterios y dictaminar disposiciones. Fue necesario establecer un centro directivo que supliera al Comité Central de Madrid en sus funciones ${ }^{106}$, ya que los fondos y edificios oficiales estaban en la capital ${ }^{107}$. Para consolidar su labor solicitaron el apoyo y el reconocimiento del Comité Internacional, disolvieron los comités locales y provinciales establecidos durante el periodo republicano para volverlos a reorganizar

\footnotetext{
${ }^{105}$ Bescós TORRes, Jesús: La Sanidad Militar en la Guerra de España (1936-1939). Segunda Parte. La Sanidad en el ejército nacional. Revista de Medicina Militar 1987, Vol. 43, nº 4, p. 434.

${ }^{106}$ Boletín de la Junta de Defensa Nacional de España, $\mathrm{n}^{\circ}$ 17, Burgos 7 de septiembre de 1936, Orden de 2 de septiembre de 1936 cconcediendo al Comité local de la Cruz Roja de Burgos facultades inspectoras, que permitan unificar las actividades peculiares de la Institución, p.67.

${ }_{107}$ ABC Sevilla, 5 de julio de 1938, Acto solemnísimo en Burgos. Medallas y Brazales de la Cruz roja sobre los blancos uniformes, p. 11.
} 


\section{Capítulo IV}

y establecieron nuevos hospitales y recaudaciones, ya que el grueso de la institución estaba en Madrid, Valencia y Barcelona ${ }^{108}$. El encargado de dirigir toda la "reorganización" de Cruz Roja nacional fue el conde de Vallellano, como delegado de la misma ${ }^{109}$. En su colaboración con Sanidad Militar, Cruz Roja puso a su disposición a todo su personal sanitario: médicos, enfermeras, damas, técnicos, practicantes y Hermanas de la Caridad; además de aportar el material e instrumental sanitario necesario, tanto quirúrgico como médico ${ }^{110}$.

Respecto a la dotación inicial de camas en los hospitales nacionales pronto pasó a ser insuficiente debido al aumento del número de heridos que recibían del frente. Por ejemplo, en marzo de 1937 se dio la orden de aumentar a cuatrocientas el número de camas para el hospital de Sigüenza con la finalidad de mejorar la dotación de la División de Soria y cubrir las necesidades de campaña ${ }^{111}$. El contingente de heridos seguía creciendo y los hospitales habilitados para su atención no fueron suficientes, por eso, en 1937 fue necesario, por orden de Franco, aumentar la dotación de camas a seis mil en el territorio nacional. Para ello tuvieron que desalojar edificios oficiales para poder instalar allí nuevos hospitales, tal fue el caso del "Reformatorio" situado en el pinar de Valladolid que estaba ocupado por las fuerzas de la Guardia Civil y que se habilitó para dar cobertura sanitaria con

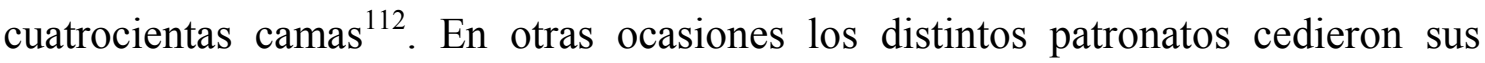
instalaciones de forma voluntaria, como el Patronato del Hospital de Nuestra Sra. de la Piedad de Zamora y del Círculo de Recreo de la misma localidad, que contaron con doscientas camas entre ambos centros asistenciales ${ }^{113}$. Los hospitales civiles dieron una cobertura importante a Sanidad Militar, tal fue el caso del centro de Burgo de Osma, "pequeño y antiguo" que sirvió para albergar a los heridos trasladados desde Valladolid en tren hospital, para posteriormente distribuirlos a

\footnotetext{
108 ABC Sevilla, 20 de marzo de 1937, Dice el Conde de Vallellano. La Cruz Roja Nacional y la humanización de la guerra, p. 9.

${ }^{109}$ Boletín de la Junta de Defensa Nacional de España, $\mathrm{n}^{\circ}$ 26, Burgos 23 de septiembre de1936, Orden de 18 de septiembre de 1936 nombrando Delegado Nacional de la Cruz Roja al Excmo. Sr. D. Fernando Suárez de Tangil y de Angulo, Conde de Vallellano, p. 103.

${ }^{110}$ AGMAV, C.1248, 12/Carpeta, Ejército Nacional/Ejército del Norte, Carta de la Duquesa de la Victoria, 30 de abril de 1937.

${ }_{111}^{11}$ AGMAV, C. 1243, 25/Carpeta. Dirección de Servicios Sanitarios del Ejército del Norte, nota n ${ }^{\circ} 211$.

${ }^{112}$ AGMAV, C. 1243, 25/Carpeta. Dirección de Servicios Sanitarios del Ejército del Norte, nota no 203.

${ }^{113}$ AGMAV, C. 1243, 25/Carpeta. Copia del escrito del Inspector Médico de la $3^{\mathrm{a}}$ Inspección de Sanidad Militar, 14 de marzo de 1937.
} 
otros centros sanitarios $^{114}$. La necesidad de nuevos locales para instalar hospitales, obligó a utilizar antiguos asilos como el de San José de Jerez ${ }^{115}$.

Cruz Roja también contribuyó a aumentar el número de camas hospitalarias con sus hospitales de Oña y de Leganés ${ }^{116}$. El objetivo fue evitar el traslado de los heridos leves a los hospitales de retaguardia, alejados del frente, para impedir que tardaran tiempo en incorporarse a sus puestos, no tanto por su patología, sino por la distancia que tenían que recorrer para volver al mismo. Para lograr dicho propósito, en Vinaroz, se requisó el Convento de las Clarisas con capacidad para albergar doscientas camas ${ }^{117}$.

He recibido un oficio de la Jefatura de Sanidad Militar de Vitoria

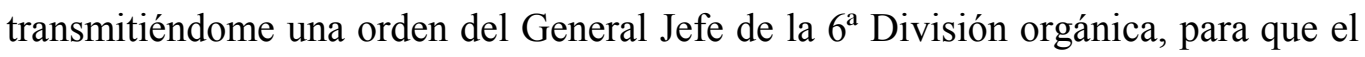
Hospital de la Cruz Roja sea transformado, previas las formalidades e inventario de rigor, en Hospital militar de la Plaza. Excuso decirle que la orden será cumplida con todo respeto. Se solicita además, mi colaboración que yo no he de regatear $^{118}$.

El régimen mixto de asistencia entre Sanidad Militar y Cruz Roja se llevó a cabo principalmente en los hospitales de Oña, Leganés y Seminario de Rozas de Puerta Real, este último instalado en el antiguo monasterio y más tarde colegio de Jesuitas. Cruz Roja se encargó de la dotación de médicos, enfermeras, personal de ambulancias, material, farmacia y ropa. Respecto al hospital de Oña situado en el monasterio de la localidad, contó con una farmacia, un laboratorio de análisis clínico, instalaciones radiológicas fijas y portátiles, material de curas e instrumental quirúrgico, además de tener biblioteca particular, capilla y parques para que los enfermos pudieran pasear. El hospital estaba dividido en tres plantas, en la primera se recibía y clasificaba a los heridos, en ella estaba situada la "cocina, despensa,

\footnotetext{
${ }_{114}$ AGMAV, C. 1243, 25/Carpeta. Carta de la Inspección General del Ejército, 14 de marzo de 1937.

${ }^{115}$ ABC Sevilla, 1 de enero de 1937, p. 15, Para el establecimiento de los hospitales de sangre.

${ }^{116}$ AGMAV, C.1248, 12/ Carpeta, Ejército Nacional/Ejército del Norte, Carta de la Duquesa de la Victoria, 30 de abril de 1937.

${ }_{117}^{11}$ AGMAV, C. 1248, 50/ Carpeta. Ejército Nacional, hoja 52, Zaragoza, 26 de junio de 1938.

118 ACCRE, C. 994, Exp. 4, correspondencia entre la Duquesa de la Victoria y Don Manuel Martinez de Tena, 13 de abril, 1937.
} 


\section{Capítulo IV}

almacén, comedor para suboficiales y clases, almacén de ropas, salón de representaciones teatrales, servicio de duchas, peluquería y depósito de cadáveres". La sala de curas, la consulta de otorrinolaringología y odontología, el comedor, los baños y las salas de oficiales se encontraban en la segunda planta del edificio. Los quirófanos, sala de yesos, esterilización, sala de rayos $\mathrm{X}$, consultas de medicina $\mathrm{y}$ oftalmología estaban ubicados en la tercera. Las Hijas de la Caridad y las enfermeras contaron con su pabellón particular. Respecto al número de camas cabe reseñar que se llegaron a ocupar mil ciento cincuenta, siendo durante tres meses un hospital de sangre debido a su proximidad del frente, a tres horas en ambulancia del mismo. El centro estuvo en funcionamiento durante casi veintiocho meses, del 13 de marzo de 1937 al 1 de julio de $1939^{119}$.

Esta colaboración, en ocasiones, generó alguna desavenencia:

El Hospital será pues, entregado con todo su contenido, a Sanidad Militar pero no he de ocultarle el efecto deprimente que esto ha causado en el personal de la Cruz Roja, pues el Hospital funcionaba como nunca, lo mismo bajo el punto de vista técnico que el económico.

En él teníamos acumulados materiales de muchos miles de duros, y trabajaban gratuitamente cientos de personas para sostenerlo.

Me parece de justicia reconocer el mérito y trabajo de cada uno y darles oficialmente las gracias y recompensas honoríficas de rigor, yo no sé si podré continuar en el Hospital pues las relaciones con el Director han de ser siempre enojosas pero haré lo posible por evitar conflictos ${ }^{120}$.

Memorias como la de José Llordés permiten conocer cómo eran los hospitales nacionales situados en la retaguardia. El militar hablaba de camas y sábanas nuevas y limpias, describía el contraste entre la suciedad con la que llegaban los heridos del frente y la blancura característica de las salas y de los uniformes del personal de las mismas. Llordés reconstruye el ala de hospitalización instalada en la

\footnotetext{
${ }^{119}$ VAlero CARRERAS, Luis: Memoria del Hospital de Oña, Cruz Roja Española, Madrid, 1940, pp. 736.

${ }_{120}$ ACCRE Caja 994, Expediente 4, Correspondencia entre la duquesa de la Victoria y D. Manuel Martínez de Tena, 13 de abril, 1937.
} 
sala de fiestas del Casino de Cáceres, suntuosa y lujosa ${ }^{121}$. Las salas tenían distinto número de camas en función de la amplitud del hospital que también contaba con quirófanos, cuarto de curas y de reconocimiento, además de comedor y cocina ${ }^{122}$. Los centros sanitarios estaban dotados de dependencias para la farmacia, despensa y almacenes, además de disponer de calefacción, lavabos y baños. Para mantener la higiene y la salubridad y evitar la propagación de enfermedades fue necesario instalar en los hospitales estufas de desinfección o estaciones de despiojamiento ${ }^{123}$.

Era necesario mantener unas buenas condiciones de higiene para evitar las epidemias que también afectaron al ejército nacional y a la población civil, sobre todo las causadas por fiebre tifoidea, ocasionada por la falta de medidas de salubridad y potenciada por el hacinamiento. Como señala Bescós, las secciones de higiene encargadas de la desinfección y la depuración no funcionaron bien durante el conflicto por lo que las epidemias fueron inevitables, a pesar de las vacunaciones masivas llevadas a cabo en algunas ocasiones. También contaron con un instituto de higiene militar adscrito al laboratorio central de análisis situado en Valladolid encargado de la fabricación y adquisición de sueros y vacunas, y de la desinfección e higiene $^{124}$. Esta situación se vio potenciada durante los asedios a las distintas poblaciones, en los que escaseó el agua, los alimentos y el material sanitario, unido a unas condiciones higiénicas deficientes ${ }^{125}$.

Las enfermedades venéreas también fueron causantes de bajas entre los soldados nacionales. Para evitar su hospitalización y por lo tanto, la "disminución de efectivos en las Unidades Armadas", se constituyeron puestos antivenéreos que permitieron el tratamiento ambulatorio de dichas patologías, de forma que los soldados pudieron permanecer en sus puestos de batalla ${ }^{126}$. Por lo tanto, los médicos

\footnotetext{
${ }^{121}$ LLORDÉS BADÍA, J: op.cit., p. 106.

${ }^{122}$ AGMAV, C. 1243, 25/Carpeta. Copia del escrito del Inspector Médico de la $3^{\text {a }}$ Inspección de Sanidad Militar, 14 de marzo de 1937.

${ }^{123}$ AGMAV, C. 1243, 25/Carpeta. Carta de la Inspección General del Ejército, 14 de marzo de 1937.

${ }^{124}$ BESCÓS TORRES, J: op.cit., pp. 437-438.

${ }^{125}$ Ibid., pp. 439-442.

${ }^{126}$ AGMAV, C. 1243, 25/Carpeta. Dirección de Servicios Sanitarios del Ejército del Norte, 27 de marzo de 1937.
} 


\section{Capítulo IV}

militares también se centraron en la prevención de la enfermedad a través de la conservación de la salud. La higiene y la profilaxis ayudaron a disminuir el número de soldados enfermos, gracias a las vacunaciones preventivas, la utilización de estufas de desinfección y máquinas esterilizadoras, además de hornos de incineración y laboratorios de investigación ${ }^{127}$. En los hospitales también se instalaron laboratorios de análisis necesarios para hacer exámenes parasitológicos, químicos, bromatológicos, etc.

El suministro de agua potable a los soldados hizo que diariamente se realizara un análisis químico-bacteriológico de la misma, para garantizar su salubridad. Esta función la llevaron a cabo, inicialmente, los laboratorios fijos. El avance de tropas obligó a implantar dispositivos transportables que facilitaran el análisis químico del agua de una forma rápida. Los laboratorios móviles se desplazaban hasta el frente y analizaban, además del agua de consumo, las muestras serológicas y bacteriológicas de las investigaciones clínicas. Durante la guerra el servicio de higiene contó con “automóviles laboratorio afectos a los distintos Cuerpo del Ejército, furgones de Higiene, potabilizadoras, camiones con remolque que facilitaban el transporte de las Secciones de Higiene, con el correspondiente personal y material, así como un crecido número de estufas de desinfección automóviles"128.

\footnotetext{
${ }^{127}$ Revista Española de Medicina y Cirugía de Guerra. $\mathrm{n}^{\circ}$ 6, febrero 1939. La evacuación en el campo de batalla con relación a los modernos medios de combate, pp. 174-178.

${ }^{128}$ Revista Española de Medicina y Cirugía de Guerra. $\mathrm{n}^{\circ}$ 28, diciembre 1940. Laboratorios de análisis y furgones de higiene automóviles, pp. 377-383.
} 


\subsection{Tipos de servicios sanitarios y hospitales militares}

$\mathrm{Al}$ igual que sucedió en la zona republicana las necesidades impuestas por la guerra hizo que cualquier edificio público sirviera para instalar un hospital. En las poblaciones cercanas al frente se recomendó utilizar barracones como centros de asistencia, mejor que viejos caseríos deficientemente dotados y con escasas medidas higiénicas. Jesús Bescós señala que en la zona nacional existieron hospitales para musulmanes y para italianos, estos últimos contaron con un buque hospital en Málaga. También se organizaron hospitales de especialidades capaces de dar cobertura a heridos de cirugía plástica y torácica, y a enfermos infecciosos ${ }^{129}$.

El servicio de transfusión sanguínea quedó constituido en enero de 1937 bajo la jefatura del doctor Elosegui, que contó con diferentes centros de referencia situados cerca del frente como el de Toledo, capacitado para suministrar sangre a los hospitales cercanos a Madrid. Según Jesús Bescós, el ejército Nacional contó con "33 equipos quirúrgicos, dos laboratorios automóviles, nueve estufas de desinfección automóviles, dos potabilizadoras y tres equipos de depuración de aguas", además de disponer de ambulancias encargadas de abastecer con medicamentos y material de cura a los hospitales ${ }^{130}$. La organización sanitaria nacional tuvo unidades de servicio antigás, cuyo objetivo fue la recogida y evacuación de los gaseados de guerra, cuyo equipo sanitario estaba compuesto por "un Sargento Practicante y 16 sanitarios (ocho camilleros y ocho auxiliares)"131.

Puestos de socorro: La unidad de curación y evacuación estaba compuesta por los servicios de socorro de primera línea, el puesto de socorro del batallón, el puesto de socorro regimental, el puesto de socorro divisionario y la columna de evacuación de cuerpo de ejército. En los servicios de socorro de primera línea, los camilleros se encargaban de la recogida de los heridos y su traslado al puesto de socorro del batallón, situado en la inmediación de línea de fuego, en el que se

\footnotetext{
${ }^{129}$ BESCÓs TORRES, J: op.cit., p. 437.

${ }^{130}$ Ibid., pp. 437 y 444.

${ }^{131}$ Revista Española de Medicina y Cirugía de Guerra. $\mathrm{n}^{\circ}$ 5, enero 1939. Servicios Sanitarios de Antigás. Táctica y organización de estos servicios en el Ejército, pp. 49-63.
} 


\section{Capítulo IV}

realizaban las primeras curas de urgencia y clasificación, además de identificar a los muertos. Posteriormente se trasladaba a los heridos al puesto de socorro regimental, situado en las proximidades del puesto de mando de la media brigada. En el mismo se rectificaban las curas y se perfeccionaba la clasificación, para proceder a la evacuación del herido al puesto de socorro divisionario situado a cuatro u ocho kilómetros del frente de combate. Se volvía a rectificar la cura y la clasificación, para distribuir a los heridos entre los puestos quirúrgicos y médicos avanzados o al hospital de campaña, en función de que fueran transportables o intransportables, en leves o graves. La columna de evacuación del cuerpo del ejército se situaba en los distintos puestos de socorro divisionarios, además de contar con una reserva en el cuartel general del ejército. Su misión era evacuar a los heridos intransportables a los puestos quirúrgicos avanzados y a los transportables al hospital de campaña ${ }^{132}$.

El hospital de campaña era "la primera formación sanitaria de tratamiento" propia del cuerpo del ejército, que contó con servicios médicos y quirúrgicos. Debía seguir el avance de las divisiones y situarse cerca del puesto de socorro divisionario para encargarse de de las intervenciones quirúrgicas de urgencia, del tratamiento de los heridos que no eran transportables y de los heridos leves de recuperación temprana. Una vez estabilizados los pacientes graves se trasladaban al hospital de evacuación, mientras que los leves, una vez recuperados debían regresar a sus unidades. Por lo tanto, al hospital de evacuación únicamente llegaban los heridos graves para perfeccionar el abordaje terapéutico de forma más específica y completar su convalecencia. También se ingresó en el mismo a todos aquellos enfermos que necesitaban pruebas diagnósticas o tratamientos médicos específicos que no se podían hacer en los hospitales de campaña ${ }^{133}$.

\footnotetext{
${ }^{132}$ Revista Española de Medicina y Cirugía de Guerra. $\mathrm{n}^{\circ}$ 7, marzo 1939. Apostillas a los servicios de sanidad militar en campaña. pp. 254-261.

${ }^{133}$ Ibid., pp. 259-260.
} 
El transporte de heridos y su evacuación a los hospitales de retaguardia se hizo principalmente en tren, medio de transporte por excelencia debido "al gran rendimiento, ahorro de gasolina y relativa seguridad" garantizada por la distancia con la artillería enemiga ${ }^{134}$. Otro de los medios de transporte necesarios para la evacuación fueron las ambulancias. La dotación inicial de las mismas no fue suficiente para cubrir las demandas del frente. Cruz Roja contribuyó con las suyas a la hora de suplir dichas carencias, incorporando tres de sus auto-ambulancias a la columna de evacuación de Soria ${ }^{135}$. El traslado de heridos graves se hizo principalmente en ambulancia, optando por el tren en los casos leves o de menor $\operatorname{gravedad}^{136}$

La falta de ambulancias y el volumen de heridos, hizo que en algunas ocasiones se utilizaran autocares para llevarlos desde los hospitales de vanguardia a los trenes destinados a su evacuación. Los leves se instalaban en los vagones con asientos, mientras que los graves permanecían en camillas durante el trayecto ${ }^{137}$. Los trenes-hospitales necesitaron autorizaciones específicas que permitieran su paso por la zona nacional. En muchos casos estos trámites burocráticos, pero a su vez necesarios dificultaron su labor, alargando el viaje en lugar de agilizarlo ${ }^{138}$.

Sanidad Militar Nacional también contó con buques-hospital como otra de las alternativas para la evacuación de heridos y enfermos desde los puertos de embarque hacia la retaguardia. Lo habitual fue que estos fueran clasificados y atendidos hasta su desembarque. El personal sanitario a cargo de los mismos podía variar, en el buque-hospital Ciudad de Palma trabajaron tres "médicos de la armada, uno de ellos cirujano. El de mayor graduación, que era comandante, ostentaba el cargo de jefe Militar y de Sanidad. Con ellos viajaban cuatro practicantes, cuatro Hermanas de la

\footnotetext{
${ }^{134}$ BESCÓS TORRES, J: op.cit., p. 434.

${ }^{135}$ AGMAV, C. 1243, 25/Carpeta. Dirección de Servicios Sanitarios del Ejército del Norte, nota no 294.

${ }^{136}$ AGMAV, C. 1248, 50/ Carpeta. Ejército Nacional, Zaragoza, 5 de junio de 1938.

${ }^{137}$ LLORDÉS BADÍA, J: op.cit., p. 105.

${ }^{138}$ AGMAV, C. 1248, 12/Carpeta. 04-1938. Ejército Nacional/ Ejército del Norte.
} 


\section{Capítulo IV}

Caridad, un capellán, un teniente de Intendencia, una auxiliar de oficina y varios marineros"139.

En algunas ocasiones las largas distancias que tenían que recorrer obligó a instalar hospitales para disminuir el tiempo de atención sanitaria:

[...] No ya los graves, sino los menos graves, no podrán, en general, soportar siete horas de evacuación hasta el ferrocarril como hay desde el Valle de Arán.

Por ello me permito rogar a V. E. que establezcan Hospital del Ejército en el local adecuado de la zona Almacellas- Balaguer, que permita que el Cuerpo del Ejército entregue sus heridos rápidamente en organismo que con mejores medios atienda a su curación y evacuación ${ }^{140}$.

Cuando no fue posible se instalaron enfermerías, atendidas por un médico y un practicante, de veinticinco camas como la de Caspe. Cuyo cometido fue atender a los heridos leves sin alejarse del frente, de forma que en cuanto estaban recuperados ocupaban nuevamente sus puestos en la batalla ${ }^{141}$.

\section{Protocolo de evacuación}

La evacuación de los heridos fue un punto importante, por eso contaron con una organización táctica específica y con la Compañía Mixta de Evacuación. El principal objetivo fue que el soldado herido pasara por menos puestos de triaje y se le transportara lo antes posible y de la forma más directa al hospital de referencia. Para ello contaron con compañías de camillas, de montaña y de auto-ambulancias. Los camilleros se encargaron de la evacuación de los heridos hasta el puesto de socorro, siendo la compañía de montaña la que realizó esta función cuando el terreno era escarpado. Respecto a las auto-ambulancias, las había diseñadas específicamente para operar en el frente, utilizadas por los puestos de clasificación y

\footnotetext{
${ }^{139}$ BEECHAM, MONOGRAFÍAS: op. cit., La sanidad de la Armada en la zona nacional durante la guerra de 1936-1939, p. 113.

${ }^{140}$ AGMAV, C. 1248, 12/Carpeta. 04-1938. Ejército Nacional/ Ejército del Norte, telegrama postal $\mathrm{n}^{\circ}$ 1731, Cuerpo del Ejército de Navarra.

${ }^{141}$ AGMAV, C. 1248, 50/ Carpeta. Ejército Nacional, Zaragoza, 5 de junio de 1938.
} 
cura, ya que debían adaptarse a todo tipo de terrenos. Otras se destinaron a carreteras en buenas condiciones, aún así debían contar con pala y cadenas para la nieve. Las auto-ambulancias ligeras, se encargaron de la evacuación periódica y constante, destinadas a evitar aglomeraciones de heridos graves en los antequirófanos. Eran de mayor rendimiento porque regresaban antes al puesto de combate. También las había de dos camillas, dotadas de calefacción y generador de agua. Eran prácticas porque permitían la movilidad entre los puestos de clasificación y cura. Sanidad nacional contó con auto-ambulancias de carrocería blindada que se utilizaron en las evacuaciones del frente de Madrid y con ambulancias quirúrgicas automóviles, en las que se realizaban las intervenciones de urgencia antes de su transporte. Para descongestionar los hospitales utilizaron autobuses que permitían el transporte de mayor número de heridos. En el puesto de socorro se debía seleccionar el medio de transporte, el lugar al que se enviaría al herido y el tratamiento inmediato ${ }^{142}$.

Respecto al personal encargado de realizar la evacuación, los camilleros debían saber armar y desarmar con rapidez la camilla, saber cargarla y conducirla, adaptándose siempre al tipo de herida del paciente que transportaba. El personal de las secciones de montaña debía saber que los heridos tenían que cargarse de distinta forma, en función del tipo de herida y su localización. Lo principal era que el enfermo se moviera lo menos posible durante el transporte, por lo que debían evitar los movimientos bruscos. El personal de las ambulancias debía tener conocimientos sanitarios específicos porque atendían a los heridos durante el traslado al hospital, por eso prefirieron que fueran los practicantes los encargados de esta labor $^{143}$.

Los convalecientes leves permanecían en los puestos de socorro cercanos al frente, mientras que los graves eran trasladados a los hospitales de retaguardia. Los camilleros tenían la obligación de recoger a los heridos del frente y llevarlos lo más rápidamente posible a los puestos de socorro donde recibían una nueva camilla y

\footnotetext{
${ }^{142}$ Revista Española de Medicina y Cirugía de Guerra. $n^{\circ}$ 6, febrero 1939, La evacuación en el campo de batalla con relación a los modernos medios de combate, pp. 174-191.

${ }^{143}$ Revista Española de Medicina y Cirugía de Guerra. n ${ }^{\circ} 12$, agosto 1939. Servicios divisionarios de sanidad, pp. 104-114.
} 


\section{Capítulo IV}

dejaban al herido en la misma que habían utilizado para su transporte. Realizada la primera cura se proveía a todos los heridos de una tarjeta de evacuación, además de hacer un registro de los pacientes atendidos en el puesto de socorro ${ }^{144}$.

La evacuación era dirigida y coordinada por el oficial médico, como principal responsable de la misma. Si era posible preferían realizarla por la noche porque implicaba menos peligro y pérdida de personal. Además de heridos, también se encargaban de evacuar a los muertos que se hacía sobre mulos sin ningún tipo de urgencia $^{145}$. El capitán médico se encargaba de marcar la dirección y las normas generales de la columna de evacuación, para ello debía conocer el plan de operaciones e inspeccionar el terreno antes de instalar las unidades asistenciales. La rapidez y la inmediatez fueron necesarias, además de elegir un camino alejado del fuego enemigo "paralelo a la dirección general de los accidentes del terreno (montañas y valles)", e “inmediato a la línea de posiciones propias”, que debía ser único para todo el sector. En todas las inmediaciones de los puestos de socorro del batallón se situaban destacamentos de sanidad encargados de la evacuación de las bajas. En ocasiones construyeron "nidos de heridos" que servían para acumular a todos los que estaban esperando su turno de evacuación. Estos nidos permitieron a los heridos estar relativamente cómodos y seguros, protegidos del clima, del fuego enemigo y de la vista de otros combatientes para evitar el daño moral que podía causar ver a los caídos durante la batalla ${ }^{146}$.

Puede observarse una mejor estructuración y organización de los servicios sanitaros nacionales que republicanos. Los tipos de hospitales fueron los mismos, pero no su dotación. La sanidad nacional avanzaba con sus tropas mientras que la republicana retrocedía con las suyas, de esta forma les fue más difícil mantener una buena organización.

\footnotetext{
${ }^{144}$ BESCÓS TORRES, J: op.cit., p. 443.

145 Revista Española de Medicina y Cirugía de Guerra. n 26, octubre 1940. La evacuación hasta el automóvil-ambulancia, pp. 236-248.

${ }^{146}$ Revista Española de Medicina y Cirugía de Guerra. № 27, noviembre 1940. La evacuación de heridos hasta la ambulancia, pp. 299-310.
} 
Se ha visto que en la República hubo una amplia tirada de prensa sanitaria especializada, mientras que en la zona nacional existió una menor diversidad a la hora de divulgar los conocimientos médicos. Entre las escasas cabeceras cabe resaltar la Revista Española de Medicina y Cirugía de Guerra. Esta publicación mensual, cuyo primer volumen aparecía en septiembre de 1938, surgió como órgano de expresión y "portavoz de la cultura Médica de la España Tradicional y Universal". Además de elevar la capacitación de los médicos, pretendía orientar y resolver los problemas quirúrgicos que pudieran tener los cirujanos que trabajaban en los hospitales de vanguardia. Todo gracias al interés que tenía el "Caudillo" en proteger "todo lo que signifique difusión de la cultura, perfeccionamiento científico y mejoramiento de asistencia al herido, al enfermo y al desvalido" ${ }^{147}$. Medicina Española, aparecía por primer vez en noviembre de 1938, revista mensual que se editaba en la Coruña, contenía secciones fijas en las que abordaban distintos casos clínicos y patologías. Medicina y Cirugía, también fue una revista mensual, que empezó a editarse en Santiago de Compostela en octubre de 1938. En sus artículos hacía una recopilación médica y quirúrgica por especialidades, además de tratar temas de higiene y sanidad ${ }^{148}$.

${ }_{147}^{148}$ Revista Española de Medicina y Cirugía de Guerra. n $^{\circ}$ 1, septiembre 1938, pp. 1-3 y 13-14.

${ }^{148}$ Ambas se pueden consultar en la Hemeroteca Municipal de Madrid, signaturas: 1079-1081 3; 10562 


\section{Capítulo IV}

\section{NUEVO MODELO DE ENFERMERA: HACIA UNA IMAGEN DE}

\section{MUJER IDEAL}

La figura de la enfermera alcanzó gran proyección en la zona nacional, por lo que se promocionó su imagen abnegada y piadosa al lado de los heridos, ligada a las damas de la aristocracia o a las "distinguidas señoritas de la sociedad"149:

Otra emoción es la presencia hoy ante nosotros de S. A. R. la princesa Esperanza de Borbón, que ha puesto en la práctica de la Cruz Roja, a su servicio, su inteligencia, su tiempo y su voluntad.

Os habéis consagrado princesa a esta profesión, la más noble, al pisar de nuevo la tierra española que un día os visteis forzada a dejar. Seguid el ejemplo de vuestra madre, la infanta Luisa, y de vuestras augustas primas. Os habéis inclinado sobre el dolor ajeno, para mitigarlo. Habéis prescindido de vuestro propio dolor, para aliviar los otros dolores de España. En nombre de la Cruz Roja, os lo $\operatorname{agradezco}^{150}$.

En contraposición a las milicianas, las enfermeras eran heroínas sin armas que se entregaban al trabajo hospitalario con "voluntad y sacrificio", dentro de los papeles tradicionales como madre, esposa e hija ${ }^{151}$. Eran un claro ejemplo del espíritu patriótico ya que desde el comienzo de la guerra se presentaron como voluntarias en los hospitales y soportaron duros turnos de trabajo sin quejarse, siempre dispuestas a atender a $\operatorname{los} \operatorname{heridos}^{152}$. Eran mujeres "extraordinarias", capaces de abandonar sus ocupaciones anteriores para dedicarse "a la piadosa y patriótica labor de enfermeras" $" 153$. La retaguardia, donde imperaba el orden y la caridad, era el lugar en el que debían "organizarse las piadosas huestes femeninas, especialmente las juveniles", para “auxiliar" al enfermo y al herido ${ }^{154}$.

\footnotetext{
149 ABC Sevilla, 1 de diciembre de 1938, De sociedad, ecos diversos. ABC Sevilla, 9 de diciembre de 1937, p. 4, Jerez de la Frontera, enfermeras al servicio de España, p. 10.

150 ABC Sevilla, 20 de noviembre de 1938, Se celebró solemnemente la imposición de brazaletes y medallas a las alumnas enfermeras de la Cruz Roja, p. 17.

${ }_{151}$ ABC Sevilla, 1 de agosto de 1938, Heroísmo y abnegación de la mujer, p. 3.

152 ABC Sevilla, 2 de mayo de 1937, El patriotismo de las muchachas cordobesas. Alternan en su sagrada misión de enfermeras con otros trabajos de guerra, p. 19.

${ }_{153}^{15 B C}$ Sevilla, 9 de marzo de 1937, Informaciones y noticias varias de la región andaluza. Cádiz, p. 19.

${ }^{154}$ ABC Sevilla, 21 de enero de 1938, Informaciones y noticias de la España liberada, p. 21.
} 
La Enfermería era una profesión aprobada por los hombres ya que consideraban que era una labor propia de mujeres. Esa aceptación permitió que la Sección Femenina formara a muchas enfermeras durante la contienda contando siempre con el apoyo de las religiosas que se encargaron de reforzar las connotaciones piadosas y abnegadas de la profesión. Aún así, según Katheleen Richmond, algunos sacerdotes no admitieron que las mujeres fueran a prestar ayuda asistencial a las zonas conquistadas por los nacionales, ya que hubieran "preferido apoyarse en los programas tradicionales de asistencia social de las órdenes religiosas" ${ }^{\prime 155}$.

La Revista " $Y$ " ensalzó en sus artículos el trabajo de las enfermeras, llegando a ser portada en julio-agosto de 1938. En ella aparece un herido apoyado en el regazo de una enfermera de Falange, esbelta, señorial y guapa (ver anexo XIV). En sus fotografias las presentaban sonrientes, siempre vestidas con su uniforme blanco, su cofia y su insignia de Falange, símbolo de mujer abnegada y risueña "gran auxiliar en la obra de reconstrucción de España" 156 (ver anexo XV). Los modelos de enfermera nacional se relacionaron con mujeres afines al régimen capaces de sacrificarse por España, elegantes, piadosas y de clase social acomodada.

\footnotetext{
${ }^{155}$ RICHMOND, K: op.cit., p.112.

${ }^{156}$ Y: revista de la mujer nacional sindicalista, septiembre de 1938, El día de la enfermera, pp. 30-31.
} 


\section{Capítulo IV}

\subsection{Formación: nuevas necesidades sanitarias}

Antes incluso del inicio de la contienda, en febrero de 1936, ya habían empezado a organizar cursillos clandestinos de enfermeras en el Círculo Carlista navarro ${ }^{157}$ :

La guerra se veía venir, era inminente, y desde el círculo se prepararon unos cursos de enfermeras. El doctor Galdeano, médico de Larrión, nos enseñó lo indispensable para saber hacer curas de urgencia. La verdad es que no hubo tiempo de nada más, porque los acontecimientos se precipitaron ${ }^{158}$.

Antes de la guerra había hecho unos cursos muy básicos sobre cosa de enfermería en el primer piso del Círculo Carlista de Pamplona. Muy poca cosa, casi una tontería, pero ya se veía que venía algo e iban preparándolo. Fueron por las tardes y durarían unos cuatro meses; nos enseñaron a colocar vendajes, hacer curas, poner inyecciones... ${ }^{159}$

A pesar de todo, al comienzo de la guerra no hubo suficientes profesionales para realizar el trabajo en los hospitales. Esta necesidad inicial de enfermeras impulsó a las mujeres a presentarse como voluntarias. Aunque no tenían la preparación y formación sanitaria adecuada, los hospitales las aceptaron "en calidad de enfermeras" sin tener el "correspondiente título profesional con evidente perjuicio del servicio y del paciente". Por eso, a partir de noviembre de 1936, Sanidad Militar empezó a exigir que en sus hospitales las enfermeras tuvieran el diploma expedido por las Facultades de Medicina, Cruz Roja Española y Casa de Salud Valdecilla, y que todos los nombramientos los hiciera el Jefe de Sanidad Militar de la plaza donde estuviera instalado el centro sanitario. Podrían trabajar como voluntarias aquellas que no tuvieran el título oficial "pero en servicios no profesionales y sin que en caso alguno disfruten haberes como tales enfermeras" ${ }^{160}$ La falta de profesionales se reemplazó con auxiliares y Hermanas de la Caridad, ya que en los hospitales existió una gran

\footnotetext{
${ }^{157}$ LARRAZ ANDÍA, P: op.cit., p. 60.

${ }^{158}$ LARRAZ ANDÍA, P; SIERRA-SESÚ MAGA, V: op.cit., p. 597.

${ }^{159}$ Ibid., p. 797.

${ }^{160} \mathrm{BOE} \mathrm{n}^{\mathrm{o}} 19,2$ de noviembre de 1936, Orden.- Disponiendo que no podrán prestar servicio como enfermeras en el ramo de Guerra más que las personas que ostenten diploma, p. 92.
} 
demanda de personal, constante a lo largo del conflicto que se adaptó al número de camas de los diferentes centros y a las necesidades del frente ${ }^{161}$.

Las mujeres de los pueblos donde se instalaban los hospitales se presentaron como voluntarias, pero "su buena voluntad" no suplió la carencia de conocimientos técnicos ${ }^{162}$, ya que se necesitaban enfermeras cualificadas capaces de asumir la demanda de cuidados. Por eso, desde un principio, se promocionó la formación de las mismas, de forma que cada institución se encargó de preparar a su personal. Por eso, el panorama profesional alcanzó una gran diversidad: auxiliares enfermeras de Sanidad Militar, de Cruz Roja, de Falange y visitadoras de Auxilio Social.

Entré sin saber apenas nada, el doctor Madoz comenzó a darnos clase por las tardes, mientras por la mañana ayudaba en lo que podía, no había tiempo para nada más.

En el hospital había de todo: chicas de pueblos, de Pamplona, de familias de lo más sencillas, y también de gente distinguida de la ciudad. Hasta hubo una princesa, Isabel, una hermana de don Javier de Borbón Parma, que trabajó en una de las salas y que actuó como una más, lo mismo para lavar las vendas que para repartir la comida, como la primera ${ }^{163}$.

Los cursos para formar a las voluntarias "que debían colaborar con las ya diplomadas en el cuidado de los heridos de guerra", empezaron a organizarse. Falange Española Tradicionalista y de las J.O.N.S inicialmente impartió cursillos de damas enfermeras, cuyos títulos tenían un carácter provisional, ya que debían validarlos a través de un examen oficial si querían solicitar plazas del Estado ${ }^{164}$. Posteriormente se especializaron en la formación de enfermeras sociales, cuya misión no fue la atención de heridos, sino aquella relacionada con la puericultura. La enseñanza que recibieron fue en beneficio de la "Patria" ya que se encargaron del cuidado y educación de los niños internos en casa-cunas, guarderías, comedores,

\footnotetext{
${ }^{161}$ AGMAV, C. 42069,2/18. Correspondencia de Mercedes Milá, 9 de septiembre de 1938.

162 AGMAV, C. 420068,3, Correspondencia de Mercedes Milá, 20 de agosto de 1938.

${ }^{163}$ LARRAZ ANDÍA, P; SIERRA-SESÚ MAGA, V: op.cit., p. 798.

${ }^{164} \mathrm{BOE} \mathrm{n}^{\mathrm{o}}$ 186, 24 de abril de 1937, Orden.- Autorizando a Falange Española Tradicionalista y de las JONS para organizar un cursillo de Damas enfermeras, p. 1092.
} 


\section{Capítulo IV}

hogares infantiles, colonias, etc., que serían "los hombres de mañana, [...] las piedras angulares" encargadas de "sustentar el Imperio de España"165 (ver anexo XVI).

Las militantes de Falange interesadas en los cursos de damas sociales, podían inscribirse en los mismos ${ }^{166}$. El número máximo de alumnas fue de cuarenta $\mathrm{y}$ debían realizar un examen previo que ayudaba a hacer la selección de aspirantes. Tenían preferencia de admisión todas las que fueran damas enfermeras españolas, maestras nacionales y aquellas que hubieran prestado servicio en Auxilio Social. La solicitud se acompañaba de certificado de buena conducta, partida de nacimiento y títulos académicos. La edad mínima exigida era de veinte años y la máxima de cuarenta, siendo requisito indispensable que fueran españolas y afiliadas de Falange $^{167}$. La entrega de títulos se hacía en el domicilio social que tenía Falange en cada localidad $^{168}$. El acto solía estar presido por el gobernador civil de la provincia, el director del hospital civil y el del militar, el jefe local de Falange y de Sección Femenina $^{169}$.

Auxilio Social también desarrolló una actividad formativa de forma conjunta con Falange a través de los cursos para enfermeras puericultoras o visitadoras, encargadas de la asistencia domiciliaria y de informar de la situación médico-social de la población. En ellos se desarrollaban unas nociones de higiene general, del lactante y de pedagogía que las permitiría trabajar en los comedores, hogares de embarazadas e infantiles. La aprobación del programa lectivo dependía de la jefa nacional de Sección Femenina y de la jefatura de Sanidad ${ }^{170}$. Los médicos de la institución eran los encargados de impartir los cursos, con el objetivo de "preparar a las camaradas femeninas", en conocimientos específicos de puericultura y maternología. El periodo formativo no podía implantarse más de treinta días hábiles

\footnotetext{
165 FAlange Española Tradicionalista y DE LAS J.O.N.S. Formación de enfermeras sociales... op.cit., p. 1.

${ }_{166}^{16 B C}$ Sevilla, 2 de diciembre de 1938, Falange Española y Tradicionalista de las J. O. N. S., p. 19.

${ }^{167} A B C$ Sevilla, 28 de octubre de 1937, Cursos de enfermeras Sociales de Falange Española Tradicionalista y de las JONS, p. 17.

${ }^{168}$ En otras ocasiones los actos se celebraron en el anfiteatro de la Facultad de Medicina.

${ }^{169}$ ABC Sevilla, 9 de marzo de 1937, Informaciones y noticias varias de la región andaluza. Cádiz, p. 19.

${ }^{170}$ Boletín de Auxilio de Invierno. $\mathrm{n}^{\mathrm{o}} 2$, abril de 1937, Formación de camaradas puericultoras necesarias para todas nuestras obras, pp. 7-8.
} 
ya que prolongarlo ocasionaba "desaliento y desánimo". Las lecciones tenían una duración de tres cuartos de hora y las aspirantes debían pertenecer a Falange Española y ser enfermeras con título del Estado o del departamento de Sanidad ${ }^{171}$. Las enfermeras puericultoras se encargaron de cumplimentar la "Ficha Social" de todos los niños que asistían a los centros de alimentación infantil, en la que se incluían datos de la vivienda y la familia del "niño asistido" para posteriormente archivarla por orden alfabético. Además de contener datos de tipo sanitario, sobre todo los relacionados con la higiene y distribución de la vivienda, también registraban el colegio, el barrio en el que vivían, el salario de la familia y los subsidios que recibían. Además de la "Ficha Social", las normas de vigilancia de los niños asistidos en los comedores exigían la "Ficha Médica" que incluía los antecedentes médicos de la familia, el estado de salud de los padres y el apartado relacionado con la anamnesis del niño, vacunas, enfermedades y datos de la exploración física ${ }^{172}$. Las enfermeras también trabajaron en los comedores dietéticos para personas enfermas, sobre todo diabéticas, en los que se suplían la carencia de vitaminas y de proteínas de la población ${ }^{173}$.

Los requetés también contaron con su cuerpo de enfermeras, "las Margaritas" que se formaron en los centros que habilitaron con el consentimiento y la colaboración del delegado de Sanidad de cada provincia. Los cursillos tenían una duración mínima de cuatro meses, en los que no podía faltar la disciplina y la seriedad. Por eso se exigió a las alumnas puntualidad y asistencia obligatoria a las clases, en caso de incumplimiento de estas normas no podían presentarse al examen final. Las clases teóricas se centraron en conocimientos básicos sanitarios, de forma que las clases prácticas, que realizaban en hospitales de requetés, eran las que tenían mayor importancia. Entre los requisitos de matrícula exigidos estaba el de ser margaritas y tener más de diecisiete años. Para obtener el título debían aprobar el

\footnotetext{
${ }^{171}$ Boletín de Auxilio de Invierno. ${ }^{\circ}$ 5, noviembre de 1937, Camarada asesor médico de Auxilio Social, pp. 10-11.

172 Boletín de Auxilio de Invierno. $\mathrm{n}^{\circ}$ 2, abril de 1937, Normas de vigilancia médico-social de los niños que asisten a comederos de Auxilio de Invierno, pp. 9.

${ }_{173}$ ORDUÑa PRADA, M: op.cit., p.311.
} 


\section{Capítulo IV}

examen final ante el tribunal ${ }^{174}$. Todas las margaritas que tuvieran el título oficial de enfermera expedido tanto por Sanidad Militar, como por las Facultades de Medicina o Cruz Roja, o que ya tuvieran experiencia en clínicas u hospitales de sangre ocuparon los puestos de mando y responsabilidad en los centros asistenciales ${ }^{175}$.

En ocasiones eran las propias voluntarias las que demandaban una mayor formación teórico-práctica, por eso desde los diferentes hospitales militares solicitaban a la autoridad competente permiso para impartir cursillos de enfermeras en sus dependencias a cargo de sus médicos ${ }^{176}$. Las facultades se sumaron a la iniciativa de ofrecer cursos de enfermeras que eran de una duración aproximada de treinta días, tras los cuales las aspirantes debían realizar un examen de aptitud para obtener el certificado acreditativo ${ }^{177}$.

Cruz Roja continuó teniendo dos clases de enfermeras, las damas y las profesionales. Durante el conflicto desarrolló ampliamente la formación de las enfermeras auxiliares voluntarias que volvieron a retomar su tradicional nombre de damas enfermeras. Su labor, tanto en tiempos de paz como de guerra siguió siendo gratuita, desempeñándola únicamente en los establecimientos de Cruz Roja. El cuerpo de damas enfermeras auxiliares voluntarias estaba formado por todas las asociadas que habían aprobado los estudios correspondientes. Para poder matricularse se exigió a las futuras alumnas ser españolas mayores de dieciocho años y menores de treinta ${ }^{178}$. Además de contar con la autorización de padres $\mathrm{o}$ tutores las menores de edad y del marido las casadas. Debían estar sanas, ya que en caso de tener algún defecto físico o inutilidad que las incapacitase para el ejercicio de su misión no eran admitidas. Respecto a las voluntarias extranjeras, al finalizar los estudios recibían el título de enfermera auxiliar honorífica, aunque podían llevar

\footnotetext{
${ }^{174} A B C$ Sevilla, 18 de abril de 1937, Creación de un cuerpo de enfermeras del Requeté, p. 4.

${ }^{175}$ ABC Sevilla, 25 de abril de 1937, Otras informaciones. Cuerpo de Enfermeras del Requeté. Aviso a las Margaritas que tienen título o prácticas de enfermeras, p. 4.

${ }^{176}$ AGMAV, C. 1243, 25/Carpeta, 1937, Hospitales-enfermeras.

${ }^{177} A B C$ Sevilla, 4 de diciembre de 1936, Informaciones de enseñanza. Facultad de Medicina, cursillo teórico-práctico para enfermeras, p. 11. ABC Sevilla, 27 de febrero de 1937, Informaciones y enseñanza. Cursillo teórico-práctico para enfermeras, p. 12. ABC Sevilla, 29 de diciembre de 1936, Informaciones de enseñanza. Facultad de Medicina de la Universidad de Sevilla. Cursillo teórico-práctico para enfermeras, p. 18.

${ }^{178}$ En casos especiales, la Asamblea Suprema a propuesta del director de la escuela, podría aceptar alumnas con más de treinta de años.
} 
el mismo uniforme que el resto de damas su insignia era diferente. La duración de los estudios era de dieciséis meses que se dividía en dos cursos teórico-prácticos de ocho meses, cuya asistencia era obligatoria. Si faltaban más de quince días seguidos o treinta durante un curso sin causa justificada, las alumnas perdían su derecho a examen. Una vez finalizados los estudios y aprobados los exámenes finales las alumnas de primer curso recibían el brazal de la institución y las de segundo la medalla y el título ${ }^{179}$.

Por lo tanto, al inicio de la contienda existía una gran diversidad educativa con el mismo fin, formar personal auxiliar con unos conocimientos teóricos y prácticos que les permitiera asistir adecuadamente a los heridos. Los cursos que tuvieron mayor aceptación a lo largo de todo el conflicto fueron los impartidos en los hospitales militares que permitían obtener el título de auxiliar de enfermeras de Sanidad Militar necesario para trabajar en el frente y en los centros sanitarios militares (ver anexo XVII). Inicialmente debido a la gran demanda de personal, la edad de admisión en los mismos fue de dieciocho años pero posteriormente, cuando se fueron cubriendo las necesidades asistenciales, se dejó en veinte ${ }^{180}$. A pesar de todo, las chicas de 18 y 19 años también querían presentarse como voluntarias, por lo que fue común que las distintas delegadas escribieran a Mercedes Milá y Nolla, Inspectora General de los Servicios Femeninos de Hospitales de Sanidad Militar, solicitando excepciones. ${ }^{181}$ Para Mercedes las menores de veinte eran "demasiado jóvenes para estar en los hospitales”, por lo que únicamente podían prestar servicio en los roperos y para ese trabajo no necesitaban hacer los cursillos ${ }^{182}$. A veces se hicieron excepciones con las voluntarias de 18 y 19 años aludiendo al hecho de que eran "señoritas que por sus condiciones excelentes son acreedoras a esta concesión y que prestarían un buen servicio como enfermeras" ${ }^{" 183}$, pero no con las más jóvenes:

\footnotetext{
179 CRUZ ROJA ESPAÑOLA: Reglamento para las enfermeras auxiliares voluntarias de la Cruz Roja Española. Imprenta Aldecoa, Burgos, 1938, pp. 1-5.

${ }^{180}$ AGMAV, C. 42068,2, C/5. Correspondencia de Mercedes Milá, 24 diciembre 1937.

${ }^{181}$ AGMAV, C. 42069,2/120. Correspondencia de Mercedes Milá, 26 de noviembre de 1937.

${ }_{182}$ AGMAV, C. 42069,2/266. Correspondencia de Mercedes Milá, 9 de diciembre de 1937.

${ }^{183}$ AGMAV, C. 42068,2, Correspondencia de Mercedes Milá, 24 de diciembre de 1937.
} 


\section{Capítulo IV}

Me mandáis a una chiquita que habéis dejado examinar en los exámenes de Auxiliares a pesar de que en las normas dice que la edad mínima será de 20 años y tiene 16 ¡Es un disparate que esas niñas anden en los hospitales en lugar del colegio por lo que no se les podrá dar carnet. No siendo movilizadas ni en guardias de noche se las puede dejar con un poco de manga ancha desde los 18 pero menos de ninguna manera. No sé esos padres en qué piensan! ${ }^{184}$

Estos cursillos únicamente podían ser organizados y dirigidos por Sanidad Militar y no por otras instituciones, en alguna ocasión, y de forma excepcional, se admitieron los realizados por Frentes y Hospitales ${ }^{185}$. El número máximo de alumnas matriculadas en los cursillos de Auxiliares de Sanidad Militar era de cincuenta (ver anexo XVIII). Tener cien alumnas obligó a dividirlas en grupos más pequeños para impartir las clases ${ }^{186}$. De esta forma, siempre que hubo muchas voluntarias, impartieron varios cursos para evitar que fueran grupos muy numerosos ${ }^{187}$. Las aspirantes debían acreditar su buena conducta moral y social, además de tener favorables antecedentes políticos tanto personales como familiares. Las pertenecientes al cuerpo de damas de Cruz Roja estaban exentas de realizar los cursillos. El título de auxiliar de enfermera no daba derecho a ningún otro, por lo que las que estuvieran interesadas en poseer el título oficial de enfermera debían realizar el examen de las Facultades de Medicina. Su trabajo era completamente gratuito y únicamente tenían derecho a manutención y alojamiento en caso de ser movilizadas $^{188}$. La duración de los cursos era de dos meses, se exigía a las aspirantes aprobar el examen para poder ejercer y obtener el diploma y el carnet que acreditara su formación ${ }^{189}$.

\footnotetext{
${ }^{184}$ AGMAV, C. 42067,2, Correspondencia de Mercedes Milá, 25 de junio de 1938 ${ }^{185}$ AGMAV, C. 42068,2, C/39. Correspondencia de Mercedes Milá, 1 de junio 1938.

${ }^{186}$ AGMAV, C. 42069,2/260. Correspondencia de Mercedes Milá, 29 de septiembre de 1937.

${ }^{187}$ AGMAV, C. 42069,2/262. Correspondencia de Mercedes Milá, 22 de septiembre de 1937.

${ }_{188}$ AGMAV, C. 42068,2, Correspondencia de Mercedes Milá, 30 de agosto de 1937.

189 AGMAV, C. 42069,2/60. Correspondencia de Mercedes Milá, 8 de enero de 1939. AGMAV, C. 42069,2/237. Correspondencia de Mercedes Milá, 2 de diciembre de 1938.
} 
Las clases teóricas se impartían habitualmente por la tarde, en horario de 18:00h a 20:00h, o de 18:00h a 19:00h, o de 19:00h a 20:00h, dependiendo del hospital. Mientras que las prácticas las realizaban en horario de mañana de 10:00h a 13:00h, ayudando en el hospital a la vez que se formaban ${ }^{190}$. Las clases teóricas eran impartidas por los médicos y las prácticas por las Hermanas de la Caridad $^{191}$. No todas las alumnas matriculadas llegaron a completar los cursos formativos ${ }^{192}$. Por lo general, las voluntarias que aprobaron los exámenes se enfrentaron al tribunal de forma "brillante" (ver anexo XIX). Habitualmente su trabajo en prácticas era valorado positivamente porque ayudaban en su labor a las enfermeras profesionales y suplían la carencia de personal ${ }^{193}$. Además de los cursillos, en muchos hospitales se dieron conferencias a las enfermeras para ampliar su formación ${ }^{194}$, tanto en conocimientos sanitarios, como morales, a las que podían asistir tanto las alumnas de Sanidad Militar como de Cruz Roja o Falange ${ }^{195}$.

Mercedes Milá y Nolla, era la que autorizaba la impartición de los cursos formativos en las distintas provincias y la que establecía el tribual examinador, además de recibir la relación de alumnas y las actas del examen ${ }^{196}$ (ver anexo XX). Por lo tanto, todos los cursillos debían ser aprobados con anterioridad a su realización por la inspección de Sanidad Militar ${ }^{197}$, siendo ellos los únicos con capacidad para organizar y dirigir esta formación y expedir el título de Auxiliares de Sanidad Militar ${ }^{198}$.

El examen consistía en una prueba teórica y otra práctica, la primera eligiendo al azar una bola o un papelito dentro de un bombo o "saquito" con el

\footnotetext{
190 AGMAV, C. 42069,3/38-42-48. Correspondencia de Mercedes Milá, 10 de marzo de 1938, 30 de mayo de 1938 y 8 de julio de 1937.

${ }_{191}$ AGMAV, C. 42069,3/52-53. Correspondencia de Mercedes Milá, 20 de mayo de 1938.

${ }_{192}$ AGMAV, C. 42069,5/29. Correspondencia de Mercedes Milá, 23 de febrero de 1939.

193 AGMAV, C. 42069,3/4. Correspondencia de Mercedes Milá, 1 de mayo de 1937.

${ }^{194}$ AGMAV, C. 42069,2/21 y 37. Correspondencia de Mercedes Milá, 11 de mayo de 1938 y 3 de marzo de 1938.

195 AGMAV, C. 42069,2/270. Correspondencia de Mercedes Milá, 21 de enero de 1938.

${ }^{196}$ AGMAV, C. 42069,5/65. Correspondencia de Mercedes Milá, 18 de junio de 1937. AGMAV, C. 42069,3/10-11. Correspondencia de Mercedes Milá, 20 de enero de 1939.

${ }^{197}$ AGMAV, C. 42068,2, Correspondencia de Mercedes Milá, 24 de diciembre de 1937.

${ }^{198}$ AGMAV, C. 42068,2, Correspondencia de Mercedes Milá, 1 de junio de 1938.
} 


\section{Capítulo IV}

número de la lección que debía exponer la alumna, y la segunda a elección de los examinadores. Cabe señalar que entre los miembros del tribunal siempre debía haber una enfermera como vocal del mismo, que habitualmente era la propia Mercedes o en su defecto, alguna de sus delegadas (ver anexo XXI). La vocal de enfermeras evaluaba los conocimientos de las alumnas sobre la misión fundamental de la profesión ${ }^{199}$. El acta de examen debía enviarse a la Inspectora General de Servicios Femeninos de Hospitales Militares para solicitar el certificado de auxiliares junto con las tasas para costear la expedición del mismo que eran de 0.50 céntimos por cada uno $^{200}$. Posteriormente, Mercedes Milá, confirmaba la recepción de la documentación enviada por las distintas jefaturas sanitarias ${ }^{201}$. Era importante que las alumnas valieran para la práctica y la teoría, pero también se valoraba positivamente la dignidad de las mismas, que se portaran bien y fueran constantes en sus estudios ${ }^{202}$.

En alguna ocasión, debido a las demandas del frente, algunas voluntarias obtuvieron su título a pesar de no estar tan bien preparadas como se esperaba, contestando con poco "lucimiento" a las preguntas, siendo algo "flojillas" en la parte teórica. Según las delegadas el sacrificio y la buena voluntad, unido a necesidad de auxiliares en los hospitales suplieron esas pequeñas carencias ${ }^{203}$. Lo habitual fue que las alumnas aprobaran los exámenes con buenas notas, en caso de suspender los mismos, debían realizar nuevamente el cursillo ${ }^{204}$.

Los cursos podían hacerlos todas aquellas mujeres interesadas en ayudar a las enfermeras y hermanas a cuidar heridos. Hubo voluntarias que no quisieron asistir a este tipo de formación y no obtuvieron la titulación sanitaria. A pesar de ello, se englobaron dentro del cuerpo de Enfermería, ya que según la propia Mercedes: “Al hablar de enfermeras en la labor diaria del hospital se entiende desde luego toda aquella que hace labor de tal aunque no tenga título alguno aunque oficialmente sean

\footnotetext{
${ }^{199}$ AGMAV, C. 42069,3/5. Correspondencia de Mercedes Milá, 21 de octubre de 1937.

${ }^{200}$ AGMAV, C. 42069,3/10 a 13. Correspondencia de Mercedes Milá, enero- marzo de 1939.

${ }^{201}$ AGMAV, C. 42069,3/28. Correspondencia de Mercedes Milá, 26 de junio de 1938.

${ }^{202}$ AGMAV, C. 42069,5/26-29. Correspondencia de Mercedes Milá, 29 de febrero de 1939.

${ }^{203}$ AGMAV, C. 42067,2, Correspondencia de Mercedes Milá, 29 de julio de 1937.

${ }^{204}$ AGMAV, C. 42067,2, Correspondencia de Mercedes Milá, 3 de marzo de 1939.
} 
más que auxiliares sin título" ${ }^{205}$. Cabe señalar que a las Hermanas de la Caridad no se las exigió realizar los cursillos ni presentarse a los exámenes, por lo que muchas carecieron de titulación ${ }^{206}$. De esta forma se expidieron muy pocos diplomas de auxiliar de enfermera entre las hermanas ${ }^{207}$.

Cruz Roja además de seguir con su actividad formativa, promocionó sus tradicionales imposiciones de brazales y entrega de medallas a las damas enfermeras $^{208}$. En estos actos, ampliamente divulgados a través de la prensa participaron las principales figuras de la época. Era habitual que Carmen Polo, presidenta honoraria de Cruz Roja, entregara las medallas y brazales a las damas recién diplomadas ${ }^{209}$. La Duquesa de la Victoria, presidenta de hospitales ${ }^{210}$, o la Marquesa de Valdeiglesias, presidenta de enfermeras de la institución, también participaron en los actos de graduación de las voluntarias ${ }^{211}$.

Sanidad Militar llevó a cabo actos de imposición de insignias y entrega de diplomas siempre que fue posible, presididos por las autoridades de la zona ${ }^{212}$, en un acto oficial al que acudían los altos cargos de la plaza, tanto civiles como militares $^{213}$. En algunas localidades solicitaron la asistencia de Carmen Polo para imponer las medallas a las enfermeras ${ }^{214}$.

Las que lo eran de Cruz Roja se hicieron de Facultad, y viceversa; para ello, y a más de la enseñanza que práctica y teóricamente se recibe en una continua y prolongada vida clínica, se dieron lecciones por grupos, adaptándose a los programas correspondientes. Fueron profesores todos los Médicos del Hospital, y de

\footnotetext{
205 AGMAV, C. 42068,2, Correspondencia de Mercedes Milá, 29 de noviembre de 1939.

${ }^{206}$ AGMAV, C. 46761,2/79. Correspondencia de Mercedes Milá, 11 de julio de 1940.

${ }^{207}$ AGMAV, C. 46761,2/79. Correspondencia de Mercedes Milá, 5 de julio de 1940.

${ }^{208}$ ABC Sevilla, 2 de diciembre de 1938, Imposición de brazales a sesenta damas enfermeras, p. 17.

${ }^{209}$ ABC Sevilla, 5 de julio de 1938, Acto solemnísimo en Burgos. Medallas y Brazales de la Cruz Roja sobre los blancos uniformes, p. 11.

${ }^{210}$ ABC Sevilla, 14 de octubre de 1938, Palencia, las nuevas enfermeras de la Cruz Roja, p. 3. ABC Sevilla, 22 de diciembre de 1938, Imposición de medallas en Zaragoza a cuatrocientas enfermeras. La esposa del Caudillo impone, p. 15.

${ }^{211} A B C$ Sevilla, 20 de noviembre de 1938, Se celebró solemnemente la imposición de brazaletes y medallas a las alumnas enfermeras de la Cruz Roja, p. 17.

${ }_{212}$ AGMAV, C. 42069,2/142. Correspondencia de Mercedes Milá, 9 de febrero de 1938.

${ }^{213}$ AGMAV, C. 42069,3/82. Correspondencia de Mercedes Milá, 7 de julio de 1938.

${ }^{214}$ AGMAV, C. 46761,2/38. Correspondencia de Mercedes Milá, 15 se junio de de 1939.
} 


\section{Capítulo IV}

manera especial los Doctores Manresa, Giménez Guinea (D. Luis), Jorge Martínez y Bermejillo. El éxito de exámenes de la Cruz Roja, verificado en el mismo Oña y con presencia de la Presidenta de Enfermeras de la Institución, Excma. Sra. Marquesa de Valdeiglesias, fue rotundo, y poco después acudí a la Facultad de Medicina de Valladolid con 14 señoritas que obtuvieron 14 sobresalientes. De la preparación técnica de nuestras Enfermeras nada queremos decir; pero todos sabemos lo bien que valen ${ }^{215}$

El número de auxiliares fue superior al de enfermeras diplomadas, ya que llegaron a estar movilizadas durante la guerra unas ocho mil, siendo el cincuenta por cien de las mismas de Cruz Roja ${ }^{216}$. Los continuos cursillos formativos tuvieron gran difusión y contribuyeron a aumentar el número de voluntarias formadas, por ejemplo en 1937 en la provincia de Cádiz obtuvieron el título de Cruz Roja "cerca de doscientas señoras y señoritas" ${ }^{217}$, y en Zaragoza en 1938 unas cuatrocientas ${ }^{218}$. Ese mismo año el Conde de Vallellano hablaba de cómo durante el conflicto se había duplicado el total de damas enfermeras de la institución, llegando a ser unas cuatro mil $^{219}$. El elevado número de alumnas obligaba a realizar más cursillos, y a dividirlas en grupos ya que ni el material ni los locales estaban adaptados para tanto personal $^{220}$. Respecto a Sanidad Militar expidió más de cinco mil quinientos diplomas de auxiliar enfermera a lo largo del conflicto, por lo que contó con suficientes voluntarias, sin necesidad de mayor número de enfermeras profesionales $^{221}$.

Las voluntarias tenían la oportunidad de presentarse a los exámenes de Enfermería de las Facultades de su provincia para obtener el título oficial de enfermera profesional. Lo normal fue que compaginaran su trabajo en los hospitales con las clases formativas que las preparaban para el examen. Pilar Díaz Iribarren,

\footnotetext{
${ }^{215}$ CRUZ Roja EsPañola: Memoria..op.cit., p. 48.

${ }^{216}$ ABC Sevilla, 24 de noviembre de 1938, Imposición de Brazales en Córdoba a las damas de la Cruz Roja, p. 10.

${ }^{217} A B C$ Sevilla, 9 de marzo de 1937, Informaciones y noticias varias de la región andaluza. Cádiz, p. 19.

${ }^{218}$ ABC Sevilla, 22 de diciembre de 1938, Imposición de medallas en Zaragoza a cuatrocientas enfermeras. La esposa del Caudillo impone, p. 15.

${ }^{219}$ ABC Sevilla, 23 de noviembre de 1938, Imposición de brazales y medallas a las enfermeras de la Cruz Roja, p. 14.

${ }^{220}$ ABC Sevilla, 15 de diciembre de 1936, Informaciones de enseñanza. Cursillo para enfermeras, p. 18.

${ }^{221}$ AGMAV, C. 46761,2/79. Correspondencia de Mercedes Milá, 11 de julio de 1940.
} 
margarita Navarra, explicaba que "Por las tardes, en los pocos ratos que podía sacar, estudiaba para hacer los cursos de dama enfermera de la Cruz Roja. Después, en 1937, ya me examine en la Facultad de Medicina de Zaragoza y obtuve el titulo de enfermera diplomada". ${ }^{222}$ Otra de sus compañeras, María Dolores Viscarret lo explicaba así:

Nos propusieron entonces que podíamos marchar a examinarnos a Zaragoza, y con los cursos y estudiando un poco podríamos obtener el título de enfermera oficial del Estado si pasábamos el examen.

Estudié lo que pude, y recuerdo que las dos últimas lecciones que me faltaban, la de enfermedades venéreas y la cosa sexual, y la de las heridas en la cabeza me las estudié en el autobús, por el camino. Llegué al examen teórico y me tocó el tema de las heridas de la cabeza, recién leído, y me pensé: jvaya!, iqué casualidad!, y me salió muy bien. Luego también tuve una suerte bárbara en el examen práctico: había un aparato de ventosas para descongestionar a los que tenían pulmonías, y me lo pusieron delante. Era el mismo que teníamos en el Alfonso Carlos y que yo utilizaba a diario con los enfermos de mi sala. Le coloqué al muñeco todas las ventosas y me salió bordado. Por eso digo que tuve mucha suerte. Una amiga, a la salida, me pidió el escudo de Navarra que llevaba en el uniforme, porque decía que le traería suerte ${ }^{223}$.

Inicialmente, debido a las necesidades impuestas por la guerra y a la orden de Sanidad Militar de exigir un diploma de enfermera a las voluntarias, los títulos expedidos fueron provisionales (ver anexo XXII). A partir del decreto $\mathrm{n}^{\circ} 314$ de $06 / 07 / 1937^{224}$, todos los títulos de damas enfermeras provisionales tuvieron que ser revalidados $^{225}$. Sanidad Militar podía ratificar los títulos de auxiliares voluntarias que eran los únicos que tenía autorizado expedir ${ }^{226}$ (ver anexo XXIII).

\footnotetext{
${ }^{222}$ LARRAZ ANDÍA, P; SIERRA-SEsÚ MAGA, V: op.cit., p. 602.

223 Ibid., p. 798.

224 Dicho Decreto establecía que todos los empleos y categorías concedidas por las necesidades perentorias de la campaña, fueran revalidados, quedando nulos los que no fueran ratificados.

${ }_{225}^{22}$ AGMAV, C. 42068,2/4. Correspondencia de Mercedes Milá, 20 de octubre de 1937.

${ }^{226}$ AGMAV, C. 42068,2/3. Correspondencia de Mercedes Milá, 22 de octubre de 1937.
} 


\section{Capítulo IV}

\subsection{Los manuales y su enfermera modelo}

Respecto al tipo de manuales formativos analizados correspondientes al periodo bélico, no se aprecia una modificación en los contenidos teóricos pero si en los valores que debía tener la enfermera ${ }^{227}$.

El contenido teórico se centraba en unas nociones de Anatomía, Fisiología e Higiene, Medicina y Cirugía, cuyo objetivo era ayudar a la mejor comprensión de la parte práctica de la profesión. Los temas de puericultura y cuidados de la madre y el niño se abordan con mayor profundidad en la formación de las enfermeras sociales.

La principal misión de la enfermera era la asistencia al enfermo centrada en los cuidados médicos, higiénicos y personales, además "de servir al médico ayudándole asidua y desinteresadamente". En el caso de las visitadoras o las instructoras de sanidad su papel se centró en la prevención de enfermedades y la promoción de la salud ${ }^{228}$. En cuanto a las enfermeras sociales su labor era la recogida de datos sanitarios a través de la observación y la entrevista con el enfermo, con el fin de evitar la propagación de la enfermedad y la recuperación de la salud. Para ello debían conocer y valorar los antecedentes personales y familiares del enfermo, su alimentación, higiene, su hábitat (vivienda, habitación y entorno) y el riesgo de infección para lo que debían coger muestras de orina, heces, etc. ${ }^{229}$.

Dentro de las cualidades físicas que debían reunir continuaba prevaleciendo tener un buen estado de salud que permitiera llevar a cabo la "ardua y penosa" labor de enfermera. Todos sus sentidos tenían que funcionar correctamente para poder observar y llevar a cabo los cuidados sanitarios ${ }^{230}$. Debían llevar "una vida higiénica tanto por parte de los paseos y de las horas regulares de sueño, como por parte de la alimentación”. También tenían que cuidar minuciosamente su higiene personal,

\footnotetext{
${ }^{227}$ Se han consultado los siguientes libros: Romo AldANA, Emilio; BerzosA ReCiO, Emiliano: Manual de la enfermera adaptado al cuestionario oficial. Talleres Tipográficos Cuesta, Valladolid, 1937; ENCISO VIANA, Emilio: La enfermera de Acción Católica. Editorial social Católica, Vitoria, 1937; ${ }^{227}$ ZBIKOWSKI: Elementos de oftalmología indispensables a enfermeras, maestros, visitadoras, puericultores, practicantes. Imprenta y Librería Eulogio de las Heras, Sevilla, 1938; GARCíA TORNEL, Lorenzo: Manual del practicante y la enfermera. Sexta edición. Bosch, Barcelona, 1939.

${ }_{228}^{228}$ ROMO Aldana, E; BerZosa Recio, E: op.cit., pp. 332-333.

${ }^{229}$ FALANGe ESPaÑOLA TRAdicionalista Y DE LAS J.O.N.S. Formación de enfermeras sociales...op. cit., pp. 9-11.

${ }^{230}$ ROMO Aldana, E; Berzosa Recio, E: op.cit., p. 333.
} 
principalmente para evitar la propagación de la enfermedad, por eso era importante la utilización del uniforme y su adecuada limpieza y el lavado de las partes que no estaban cubiertas por el mismo y entraban en contacto con el enfermo ${ }^{231}$. Debían cuidarse bien la uñas, además de mantenerlas siempre lisas y en buen estado, en el caso de que tuvieran algún tipo de herida o arañazo en las manos tenían que cubrirlos con un apósito. Además de limpias, las manos debían estar esterilizadas siempre que fuera posible, evitando tocarse la boca y los ojos cuando estuvieran de servicio $^{232}$.

Las cualidades morales exigidas por su obligación humanitaria eran: bondad, dulzura, altruismo y discreción. Debían ser cariñosas con todos los pacientes y tratarles con una educación "exquisita" para conseguir el cumplimento del tratamiento médico ${ }^{233}$. En todos sus cuidados debía imperar la caridad cristiana acompañada del sentimiento del deber y de responsabilidad, siendo obedientes para cumplir con exactitud las órdenes médicas, además de ser pacientes, sobre todo con los enfermos ${ }^{234}$. La enfermera también tenía que ser inteligente y no perder el interés por ampliar sus conocimientos ya que "el contacto directo diario con diversos médicos, durante el curso de su profesión, la obliga moralmente a poner de relieve sus buenas condiciones sociales y educativas para que el profesional deposite una mayor confianza en su subalterna",235.

\footnotetext{
${ }^{231}$ GARCÍA TORNEL, L: op.cit., p. 171.

${ }^{232}$ ZBIKOWSKI: op.cit., p. 78.

${ }^{233}$ GARCÍA TORNEL, L: op.cit., pp. 172-173.

${ }^{234}$ ROMO AldANA, E; BerZOSA RECIO, E: op.cit., p. 334.

${ }^{235}$ GARCÍA TORNEL, L: op.cit., p. 173.
} 


\section{Capítulo IV}

Tabla 10. Cualidades físicas y morales de las enfermeras nacionales de Falange.

\begin{tabular}{|c|c|c|c|}
\hline $\begin{array}{l}\text { Salud perfecta y } \\
\text { adaptable }\end{array}$ & $\begin{array}{l}\text { Entendimiento claro, } \\
\text { juicio sereno y } \\
\text { discreción }\end{array}$ & $\begin{array}{l}\text { Perspicacia y } \\
\text { penetración } \\
\text { observadora }\end{array}$ & $\begin{array}{l}\text { Resolución y eficacia } \\
\text { en la práctica }\end{array}$ \\
\hline $\begin{array}{c}\text { Equilibrada y con } \\
\text { espíritu de disciplina, } \\
\text { dominio de sí misma } \\
\text { y confianza }\end{array}$ & $\begin{array}{l}\text { Conciencia de su } \\
\text { subordinación, } \\
\text { paciencia y ser } \\
\text { sufrida y firme }\end{array}$ & $\begin{array}{c}\text { Lealtad, } \\
\text { compañerismo y } \\
\text { diligencia }\end{array}$ & $\begin{array}{l}\text { Que se haga cargo de } \\
\text { las cosas, tenga tacto } \\
\text { y ademanes corteses }\end{array}$ \\
\hline $\begin{array}{l}\text { Espíritu comprensivo } \\
\text { y amplio }\end{array}$ & $\begin{array}{l}\text { Urbanidad, habilidad } \\
\text { y destreza táctil }\end{array}$ & $\begin{array}{l}\text { Orden e idea de } \\
\text { administración y } \\
\text { organización }\end{array}$ & $\begin{array}{l}\text { Imprimir confianza a } \\
\text { su alrededor y hacer } \\
\text { labor de proselitismo }\end{array}$ \\
\hline
\end{tabular}

La profesión llevaba implícito el cumplimiento de una serie de deberes, tales como obediencia al médico y obligación de guardar el secreto profesional. Debían evitar la enfermedad y mantener la salud. Respecto a los pacientes, únicamente verían en ellos "exclusivamente al doliente, al hombre que sufre, prodigándole toda clase de cuidados, pero sin que entre ambos exista otra clase de relaciones" que no fueran las profesionales, manteniendo la amabilidad y la dulzura en el trato. Debían facilitarles la asistencia religiosa y "en caso de un recién nacido, en peligro de muerte y en ausencia del médico, la enfermera procederá, sin pérdida de tiempo, a derramar el agua bautismal sobre la cabeza del recién nacido, pronunciando las palabras rituales "Yo te bautizo en el nombre del Padre, del Hijo y del Espíritu Santo" 236 .

El trabajo de la enfermera giraba en torno al enfermo, su cuidado iba desde la asistencia propia de la profesión hasta conseguir su mayor confort, por eso debían evitar los ruidos innecesarios, inspirar confianza y resolución, evitar fatigarle con

${ }^{236}$ Romo AldANA, E; BERZosa Recio, E: op cit., pp. 334-335. 
sus preguntas y vigilarle tanto a él como a sus visitas ${ }^{237}$. Debían ser buenas, alegres y simpáticas, hablar poco y al hacerlo no utilizar un tono elevado para no molestar al convaleciente $^{238}$.

Tú debes ser faro de optimismo. Tu sonrisa ha de brillar en la negrura del ambiente, disipando tristezas.

Que donde tú estés haya alegría; no la alegría bulliciosa, que aturde en un momento, y después produce mayor amargura; sino la alegría serena, que tiene como base la ilusión y la esperanza.

No hables jamás al herido de cosas tristes o para él desagradables, no comentes con él acciones guerreras o que puedan deprimirle. Suple tú el cariño de la familia; háblale de los suyos, de su tierra, de triunfos y de éxitos; sobreexcita en él la esperanza en la victoria definitiva, que con la ayuda de Dios llegará ${ }^{239}$.

Cabe resaltar que en la formación impartida a las enfermeras nacionales adquiere gran fuerza la vocación unida a la caridad cristiana que sería el modelo de perfección al que deberían acercase, sin esperar más reconocimiento profesional que el de Dios ${ }^{240}$. El adoctrinamiento religioso se fue afianzando con el avance de la guerra, se pedía que las enfermeras profesaran amor a Dios "mediante la práctica de la vida cristiana de meditación y de piedad", para poder dedicarse después a cuidar a los enfermos. De esta forma, se empezaron a hacer comparaciones entre distintos episodios del Evangelio y el trabajo en los hospitales, el sacrificio iba unido a la profesión. Misa, oraciones y comunión formaban parte de la jornada diaria, ya que "una verdadera enfermera católica" debía "difundir por doquier el buen olor de Jesucristo", siendo "la mortificación cristiana", la "compañera inseparable, el amor al sacrificio y la humildad y modestia"241. Debían "instruir su alma" con las lecturas del Evangelio y la vida de los Santos y evitar frecuentar lugares "demasiado

\footnotetext{
${ }^{237}$ Romo Aldana, E; Berzosa Recio, E: op cit., p. 335.

238 ZBIKOWSKI: op.cit., p. 78.

${ }^{239}$ ENCISO VianA, Emilio: La enfermera de Acción Católica. Editorial social Católica, Vitoria, 1937, p. 9.

${ }^{240}$ FALANGE ESPAÑOLA TRADICIONALISTA Y DE LAS J.O.N.S. Formación de enfermeras sociales: op. cit., pp. 14-15.

${ }^{41}$ PÉREZ, Idelio, Padre Camilo: Jornada de la enfermera. Hijos de F. Núñez Ramos del Manzano, Salamanca, 1939, pp. 8-2.
} 


\section{Capítulo IV}

mundanos", cines y espectáculos libertinos, siendo mejor que buscaran la naturaleza y el aire fresco después de la jornada laboral ${ }^{242}$.

La enfermera tenía que alejarse de toda frivolidad y coqueteo, además de evitar la vanidad por lo que pintarse los labios era "una risa sarcástica del dolor", una demostración de que a ella le importaba muy poco que el soldado sufriera. Debían ser puras, piadosas y sacrificarse por los enfermos ${ }^{243}$. La asistencia sanitaria era un trabajo duro, lleno de dificultades y peligros, "condiciones todas que sólo es capaz de vencer el alma de la mujer que lleva en germen, ya desde su juventud, el alto espíritu de su misión consoladora"244.

Tabla 11. Guión de conducta de la enfermera de Acción Católica.

\begin{tabular}{lccc}
\hline $\begin{array}{c}\text { Acuérdate que eres } \\
\text { mujer, cristiana y de } \\
\text { Acción Católica }\end{array}$ & $\begin{array}{c}\text { Tu móvil será la } \\
\text { caridad }\end{array}$ & $\begin{array}{c}\text { Pasarás por el } \\
\text { hospital haciendo } \\
\text { bien }\end{array}$ & $\begin{array}{c}\text { No seas Eva de } \\
\text { seducción, sino María } \\
\text { de salvación }\end{array}$ \\
\hline $\begin{array}{c}\text { Despierta siempre en } \\
\text { tu derredor } \\
\text { optimismo }\end{array}$ & $\begin{array}{c}\text { Para que te respeten, } \\
\text { hazte respetar }\end{array}$ & $\begin{array}{c}\text { La vanidad de la } \\
\text { enfermera es un } \\
\text { insulto a los heridos }\end{array}$ & $\begin{array}{c}\text { Vive la pureza } \\
\text { cristiana en toda tu } \\
\text { actuación }\end{array}$ \\
Sacrifícate & Apóyate en la piedad & Se apóstol & $\begin{array}{c}\text { Supérate a ti misma } \\
\text { por Dios y por } \\
\text { España }\end{array}$ \\
\hline $\begin{array}{l}\text { Fuente: ENCISO VIANA, Emilio: La enfermera de Acción Católica. } \text { Editorial social Católica, Vitoria, 1937, } \\
\text { p.4. }\end{array}$
\end{tabular}

Las enfermeras como mujeres debían ser delicadas y finas, se respetaba que las profesionales recibieran una remuneración económica por su trabajo, pero se continuaba valorando positivamente la labor de las damas auxiliares voluntarias que se entregaban al cuidado de los enfermos guiadas por su amor a la Patria y a Dios ${ }^{245}$.

\footnotetext{
${ }^{242}$ PÉREZ, I: op.cit., pp. 30-33.

${ }^{243}$ ENCISO VIANA, E: op.cit., pp. 11-13.

${ }^{244}$ GARCÍA TORNEL, L: op.cit., pp. 175.

${ }^{245}$ ENCISO VIANA, E: op.cit., pp. 5-6.
} 
Una vez encuadrada la formación de las enfermeras nacionales es necesario analizar la labor que desempeñaron durante la Guerra Civil. A pesar de existir gran variedad de titulaciones y cursillos formativos, la gestión de todo el personal auxiliar femenino que colaboró en los hospitales militares estuvo a cargo de Mercedes Milá y Nolla, Inspectora de Sanidad Militar. 
ANEXOS IV 

Anexo XIV. Imagen de enfermera nacional.

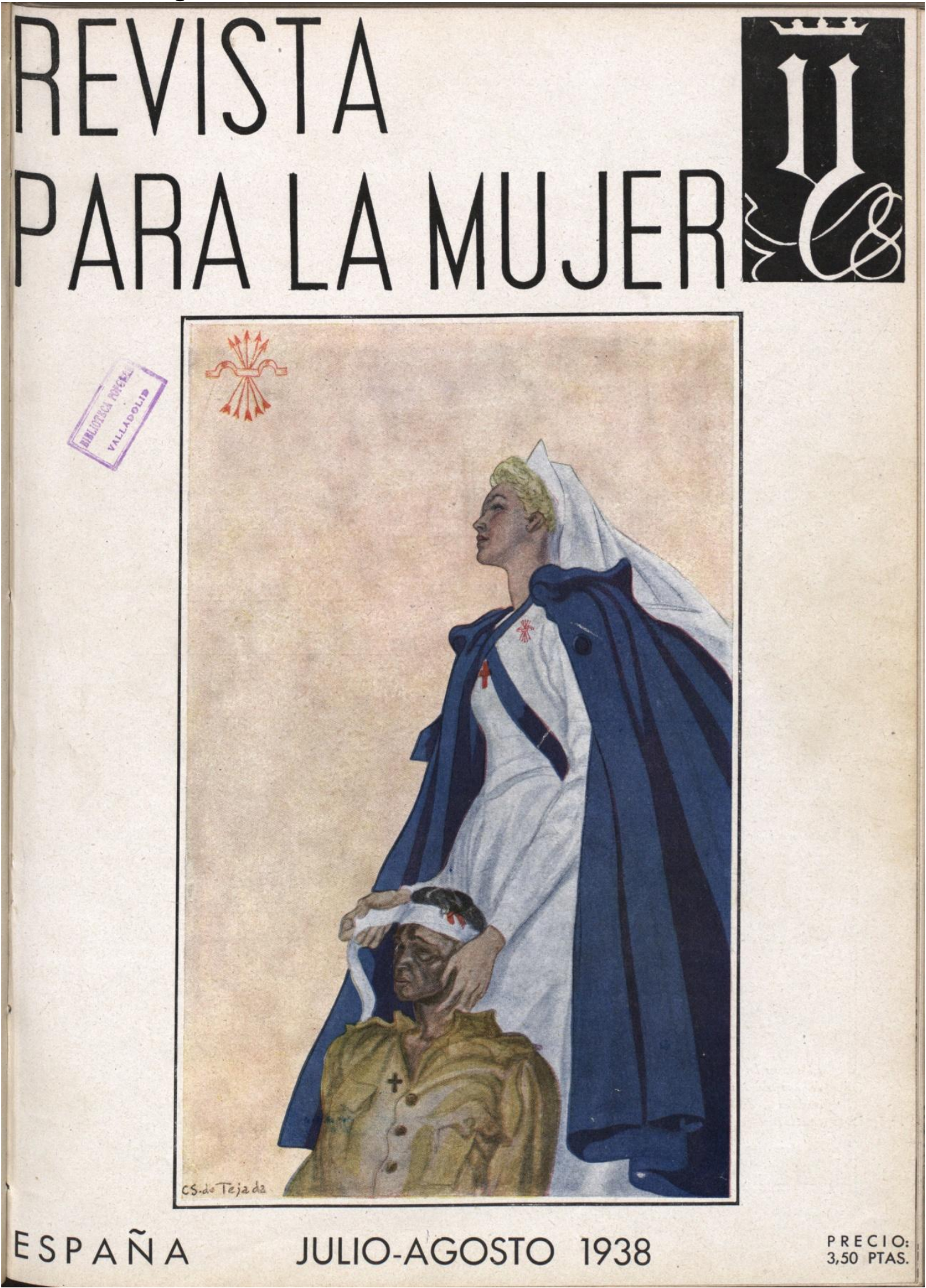

Fuente: Y: revista de la mujer nacional sindicalista, julio-agosto 1938, portada. 
Anexo XV. Enfermeras durante un día de trabajo.

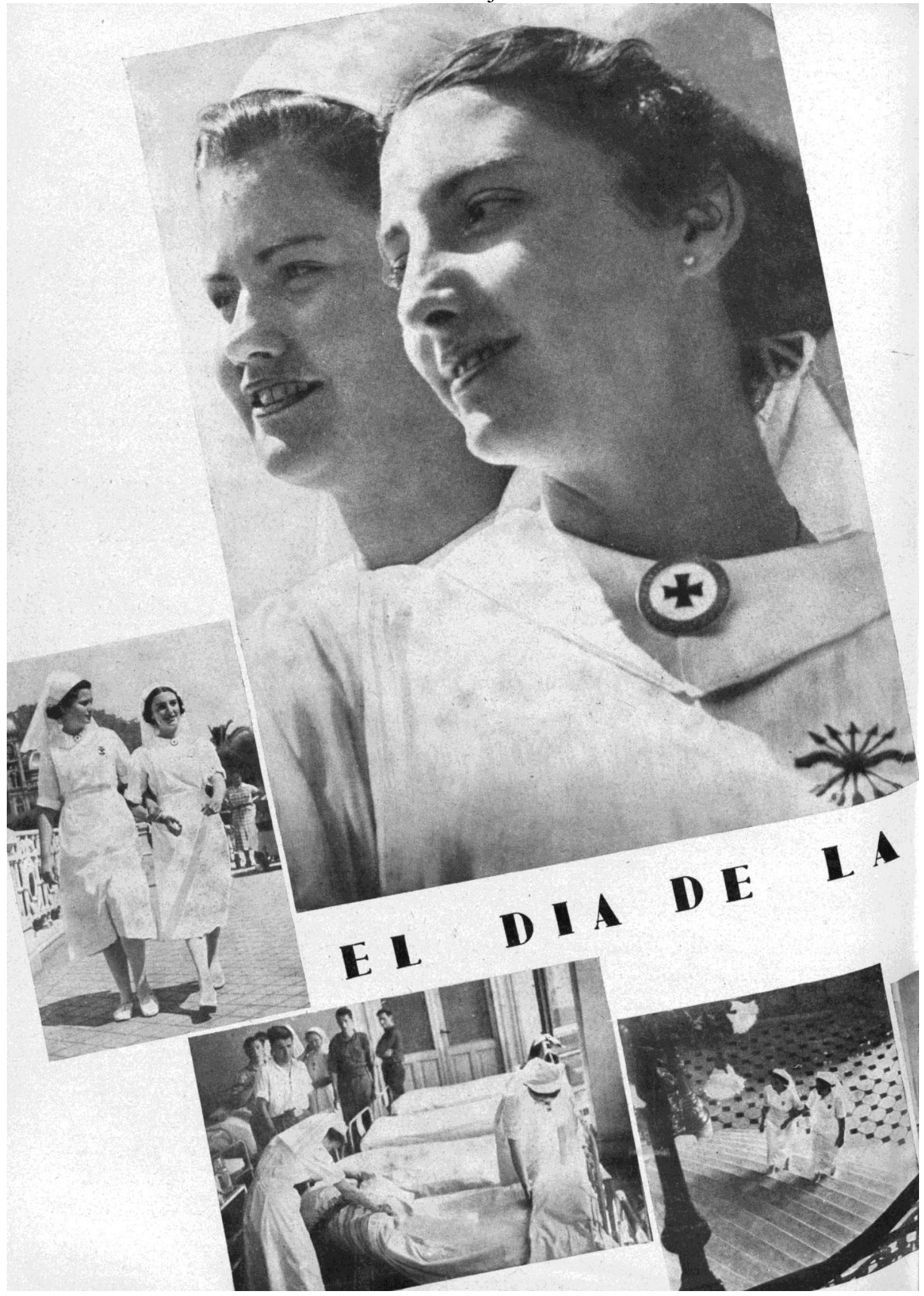

Fuente: Y: revista de la mujer nacional sindicalista, septiembre de 1938, El día de la enfermera, pp. 3031. 


\section{Anexo XVI. Programa formativo enfermeras voluntarias de Falange.}

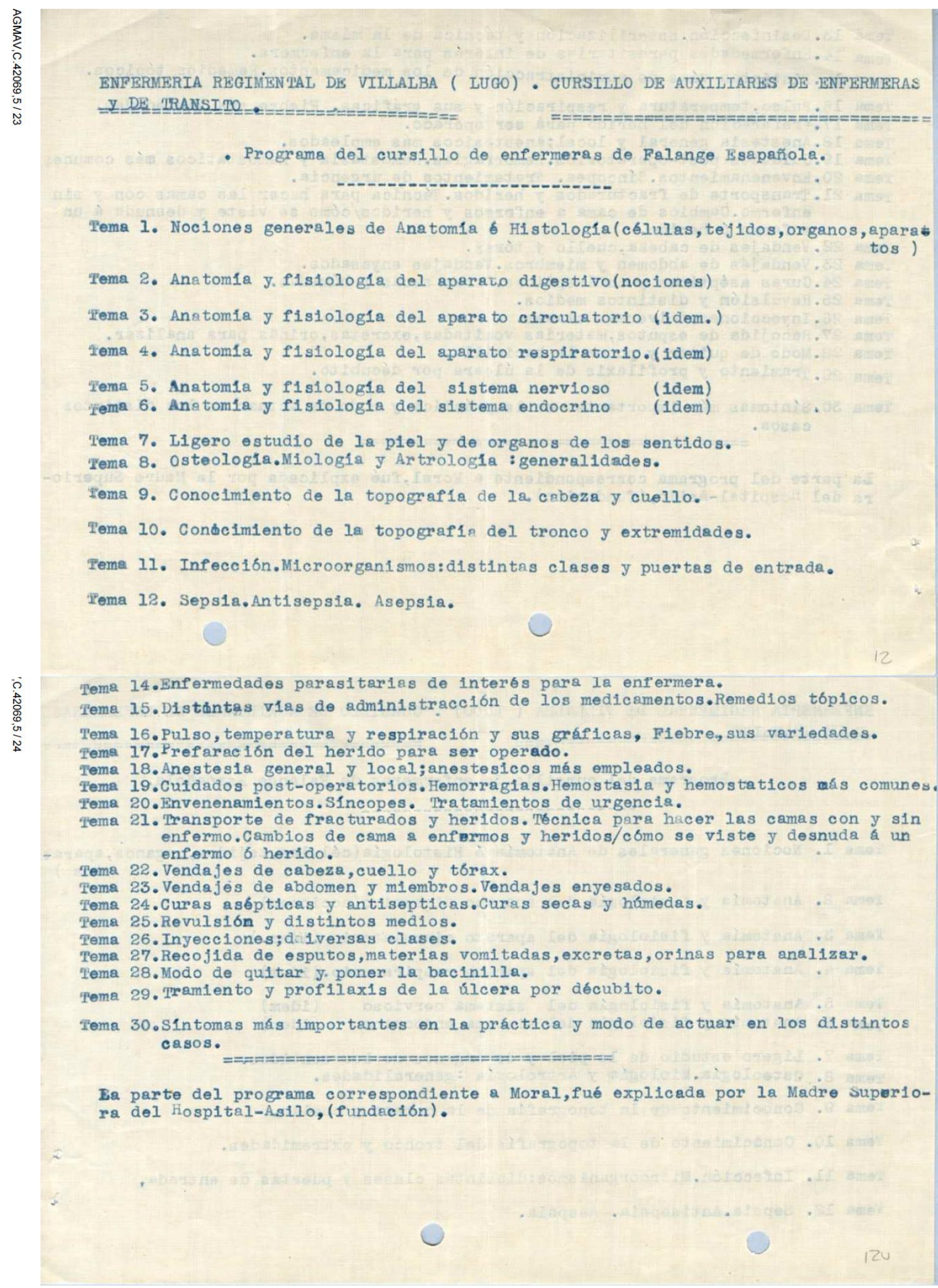

Fuente: Fuente: AGMAV, C. 42069,5/23-24. Correspondencia de Mercedes Milá. 


\section{Anexo XVII. Temario cursos impartidos por Sanidad Militar.}
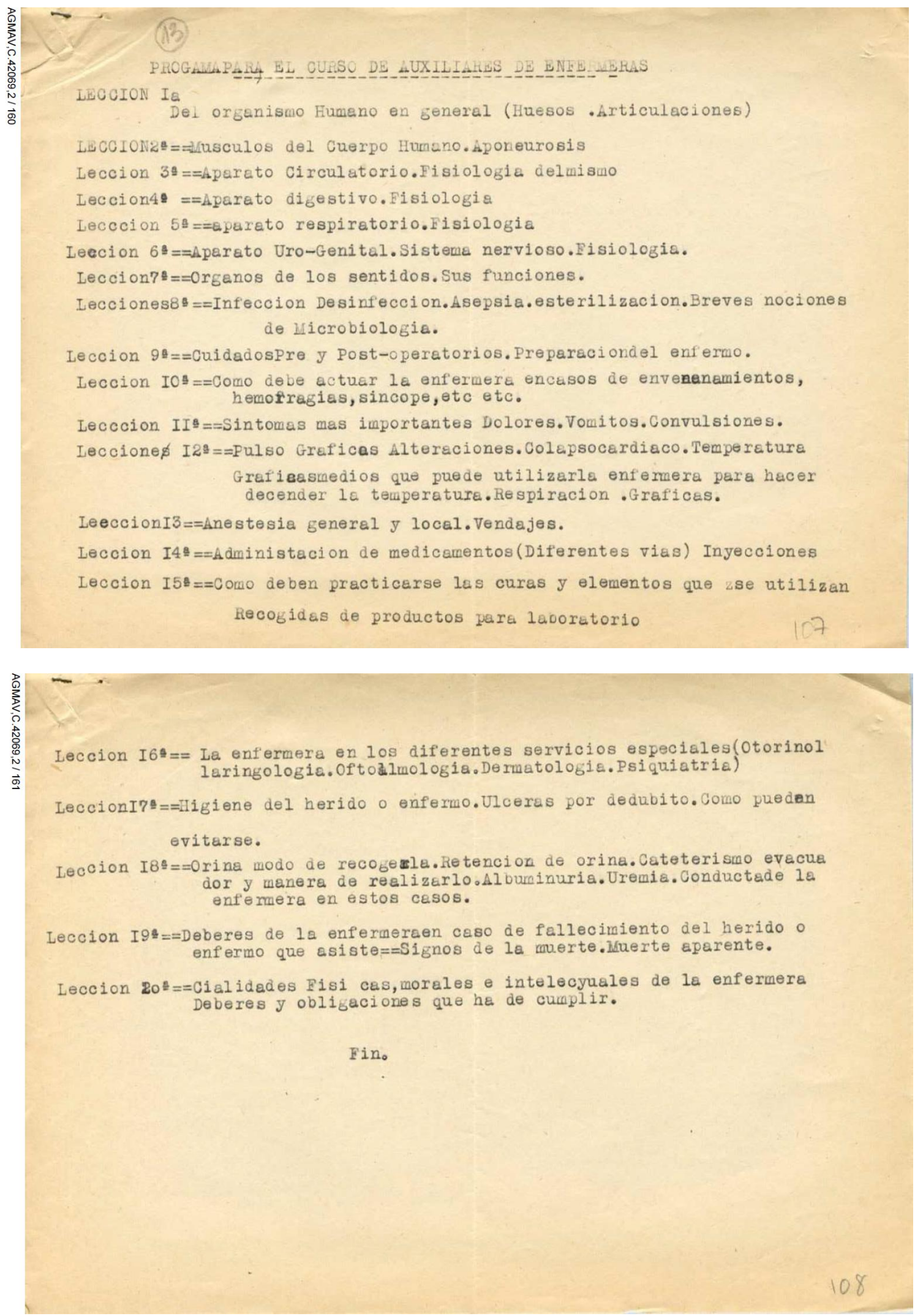

Fuente: AGMAV, C. 42069,2/160-161. Correspondencia de Mercedes Milá, 3 de julio 1937. 
Anexo XVIII. Número de alumnas admitidas por curso.

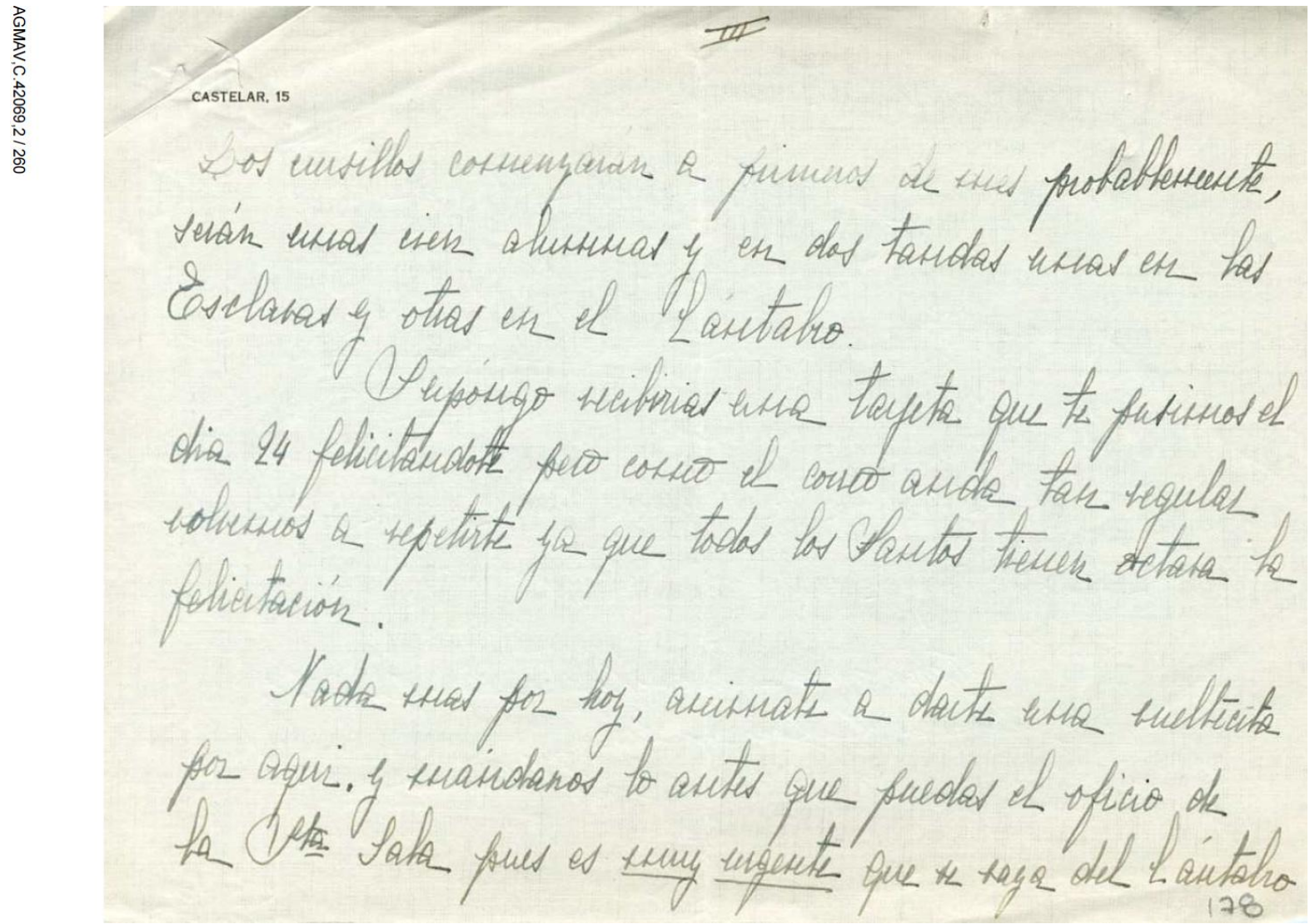

Fuente: AGMAV, C. 42069,5/260. Correspondencia de Mercedes Milá, 29 de septiembre de 1937.

\section{Anexo XIX. Resultados exámenes enfermeras auxiliares voluntarias}

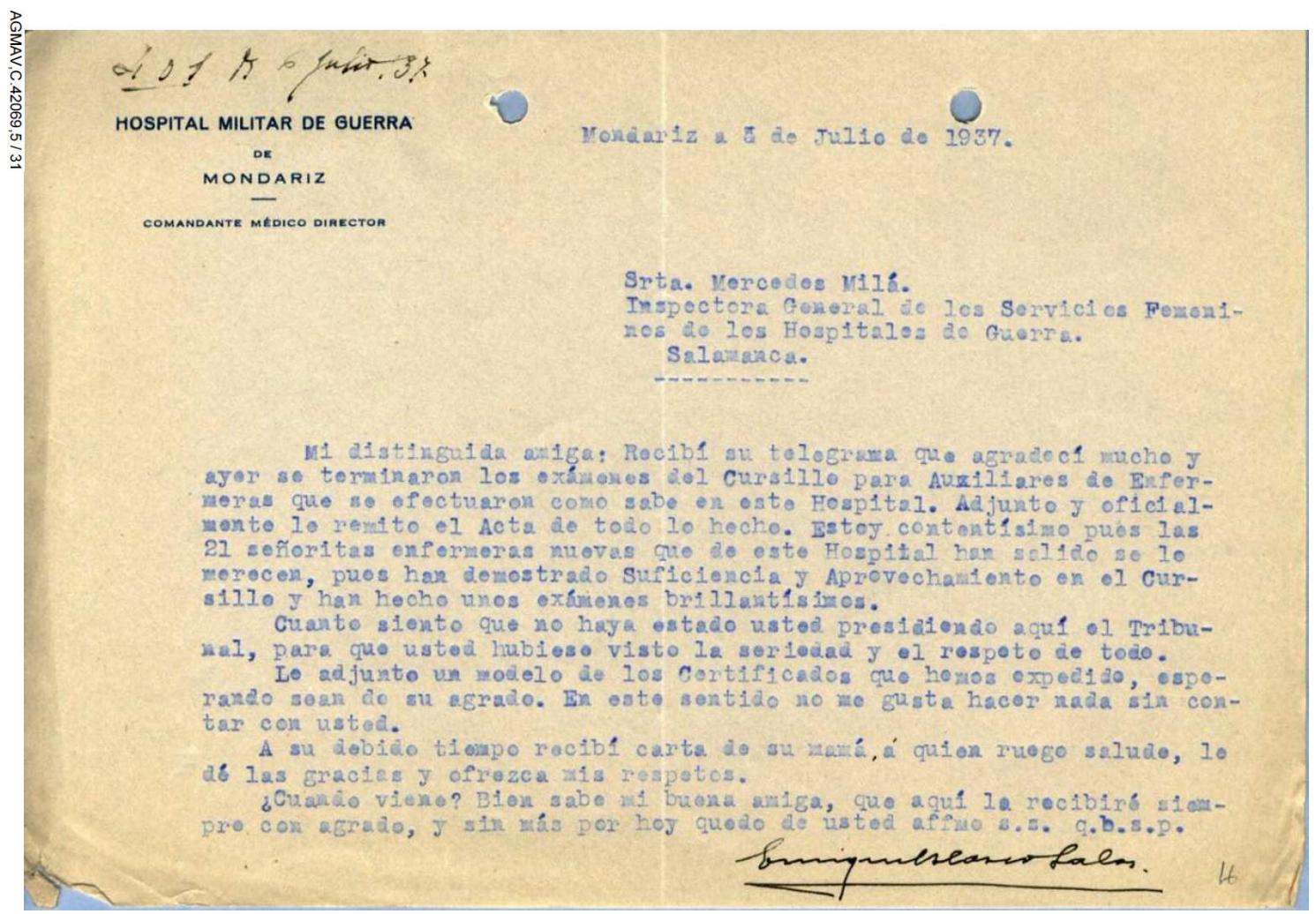

Fuente: AGMAV, C. 42069,5/31. Correspondencia de Mercedes Milá, 3 de julio 1937. 
Anexo XX. Solicitud autorización constitución tribunal examinador.

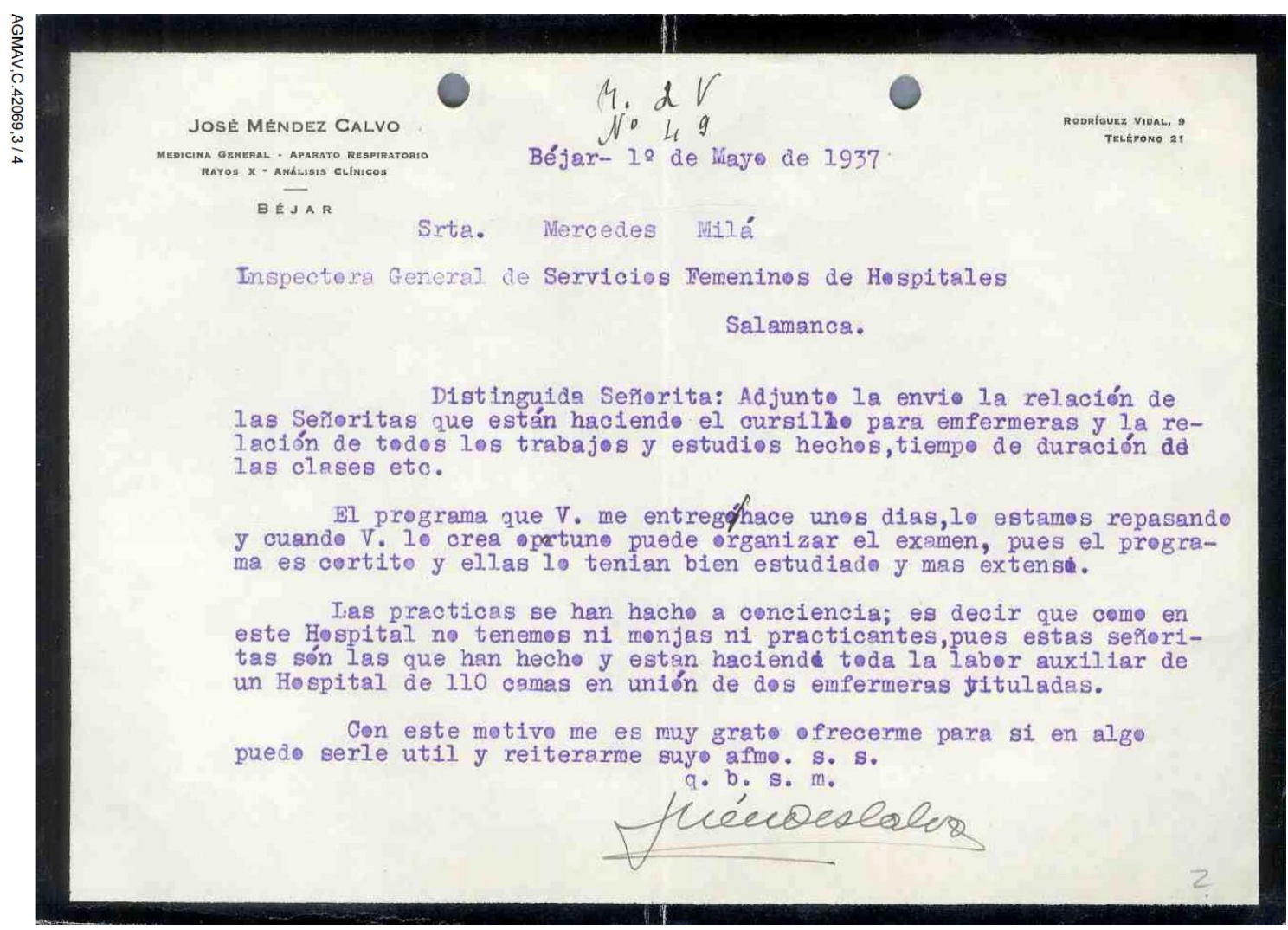

Fuente: AGMAV, C. 42069,3/4. Correspondencia de Mercedes Milá, 1 de mayo 1937.

Anexo XXI. Tipo de examen para las enfermeras voluntarias de Sanidad Militar.

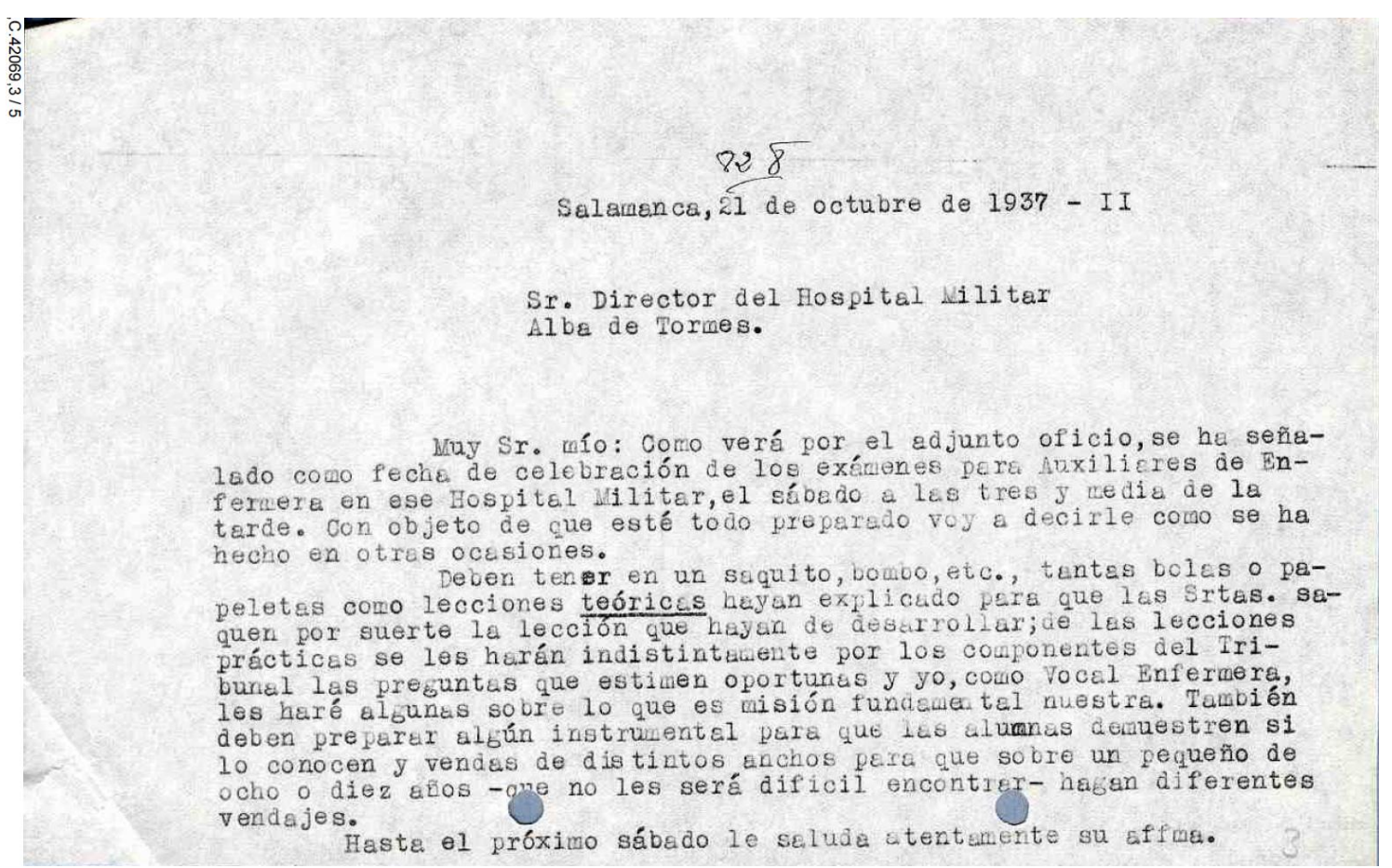

Fuente: AGMAV, C. 42069,3/5. Correspondencia de Mercedes Milá, 21 de octubre 1937. 
Anexo XXII. Título provisional de dama enfermera.

\section{UEl Gobemador Cíbil de la Alovincía de Cádís,}

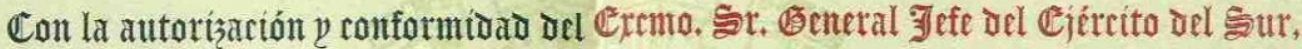
y bisto el fallo oe aptitud dado por el Cribunal nombrado que la examinó, senún consta en las actas que se contserban en este Gobiento Cínil, concede

\section{Citulo provisional de}

\section{Dama \\ Enfermera \\ spañala}

a la 引rta.

羿 para la debtóa constantia, se exptoe el presente Cítulo en Cádiz, a De of 1937.

el Gobernador Civil,

Citulo de Damta Enfernteta Española.

Fuente: AGMAV, C. 42068,2/8. Correspondencia de Mercedes Milá. 
Anexo XXIII. Ratificación títulos provisionales enfermeras voluntarias.

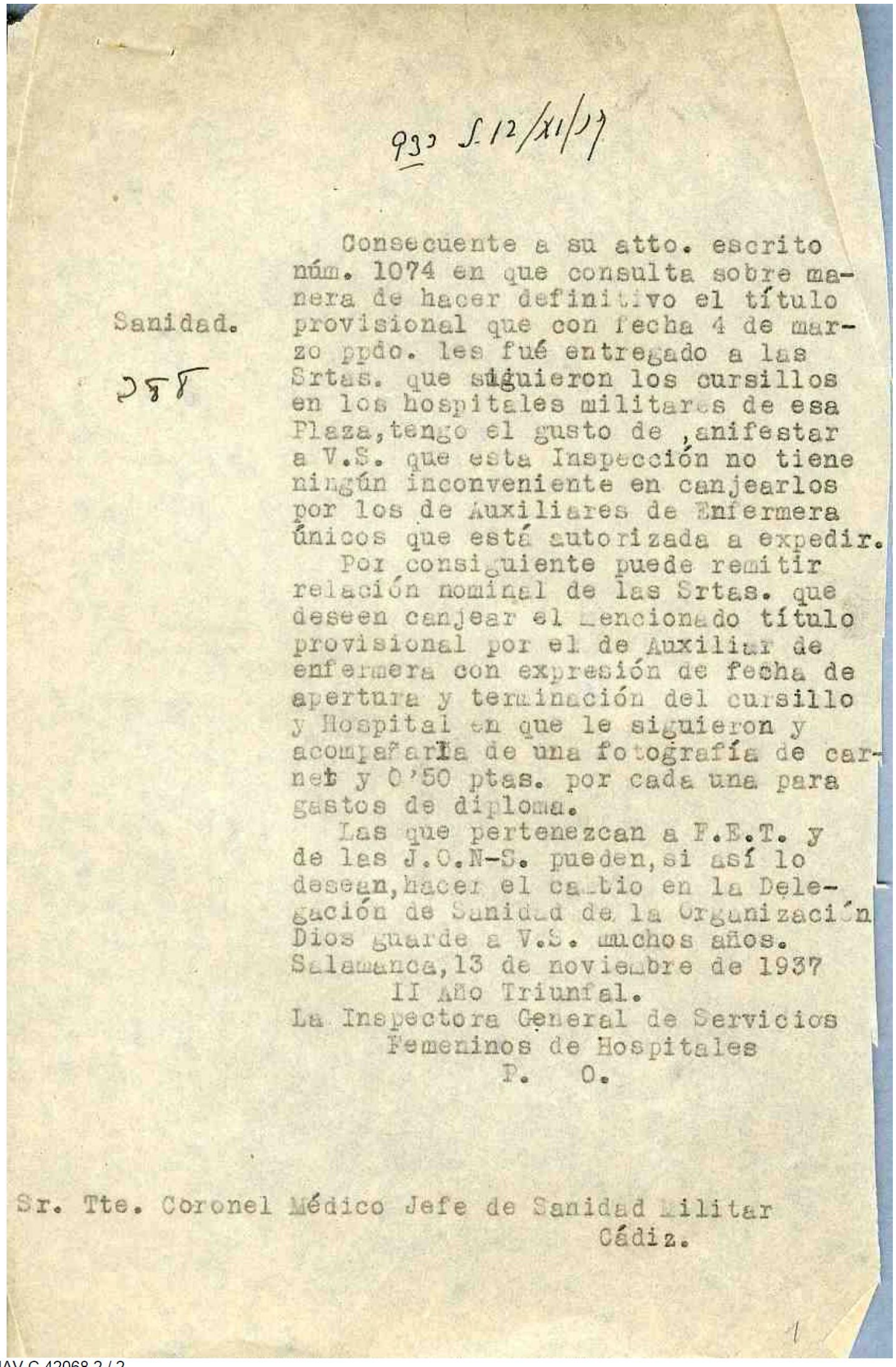

AGMAV,C.42068,2 / 2

Fuente: AGMAV, C. 42068,2/2. Correspondencia de Mercedes Milá, 13 de noviembre 1. 

Capítulo V. Las enfermeras en la zona nacional: conflictos, vivencias y trabajo desempeñado

1. PAPEL DE LAS ENFERMERAS NACIONALES DURANTE EL CONFLICTO: UN MODELO DE MUJER

Se ha visto la formación que recibieron las voluntarias interesadas en trabajar como enfermeras y cuál eran las características físicas y morales exigidas a las profesionales ${ }^{1}$. Es necesario establecer cuál fue la labor que desempeñaron durante el conflicto, saber qué requisitos las exigía Sanidad Militar para trabajar en los hospitales del frente y si estaban interesadas en ir o preferían quedarse en los de retaguardia. También es conveniente identificar qué deberes y compromisos adquirían con las instituciones sanitarias y las sanciones impuestas por el incumpliendo de los mismos, además de estudiar los peligros a los que se enfrentaron. Analizar el papel que jugó la religión y la propaganda en su vida permitirá relacionarlo con el prototipo de mujer ideal establecido durante el conflicto. También es indispensable estudiar las funciones de Mercedes Milá inherentes a su cargo, debido a la relación directa que tuvo con el personal sanitario femenino nacional. El interés de este capítulo radica en el estudio de la afianzamiento del modelo de enfermera nacional que será el que se establezca durante el franquismo.

\footnotetext{
${ }^{1}$ A lo largo de todos los textos analizados se utiliza indistintamente la palabra enfermera para referirse tanto a las auxiliares como a las profesionales. De esta forma se empleará el mismo término para englobar a todas las mujeres que participaron en la rama sanitaria durante la Guerra Civil. Únicamente se hará distinción entre unas y otras, cuando las diferencias en su trabajo o formación sean de interés para la investigación.
} 


\subsection{Requisitos exigidos para trabajar en los hospitales militares}

Para poder trabajar en los hospitales del frente las enfermeras tenían que cumplimentar un cuestionario ${ }^{2}$, en el que figuraban nombre y apellidos de la interesada, dirección, edad y estado civil, título sanitario que poseía, incluyendo el lugar y la fecha en que había sido expedido, y experiencia profesional. También quedaba reflejado que aceptaban el destino que les fuera dado y el reglamento de las damas de Sanidad Militar (ver Anexo XXIV). Los cuestionarios los enviaba Mercedes Milá a las delegadas para que los distribuyeran entre las enfermeras interesadas en ir al frente. La falta de papel y los problemas con la imprenta, unido a las dificultades en la comunicación, en ocasiones enlentecieron los trámites ${ }^{3}$. A veces, los paquetes quedaban retenidos y no se llegaban a entregar a sus destinatarios a pesar de reclamarlos y hacer nuevas peticiones de material ${ }^{4}$.

Las delegadas enviaban a Mercedes la relación de enfermeras que se ofrecían de forma voluntaria a trabajar en los hospitales militares, acompañada de una fotografía y de una reseña en la que se explicaba la actitud de las mismas. Para admitirlas se las exigía el título que acreditaba su formación ${ }^{5}$. Se valoraba de forma positiva que fueran buenas enfermeras, eficientes y abnegadas. Que tuvieran "la cabeza un poco a pájaros", ser algo "exagerada cuando va de calle", conocerlas poco, o no "acabar de convencer" a las delegadas, eran motivos para no seleccionarlas (ver anexo XXV.) Ser enfermera de oposición militar, mayor y formal eran suficientes credenciales para ser admitida en cualquier centro sanitario, también ser trabajadora y seria, tener conciencia y abnegación ${ }^{6}$. Cuando una enfermera no era eficiente en el desempeño de su trabajo o un "poco insustancial y no muy capaz", se la denegaba el permiso para ir a los hospitales del frente ${ }^{7}$. Además de todas estas características también era conveniente que tuvieran un elevado sentido

\footnotetext{
${ }^{2}$ AGMAV, C. 42069,6/5, Correspondencia Mercedes Milá, 19 de mayo de 1938.

${ }^{3}$ AGMAV, C. 42069,2/6, Correspondencia Mercedes Milá, 17 de diciembre de 1937.

${ }^{4}$ AGMAV, C. 42069,2/40. Correspondencia de Mercedes Milá, 15 de febrero de 1938.

${ }^{5}$ AGMAV, C. 42069,2/23, Correspondencia Mercedes Milá.

${ }^{6}$ AGMAV, C. 42067,2, C. 42068,3 Correspondencia de Mercedes Milá, 25 de junio y 11 de diciembre de 1938.

${ }^{7}$ AGMAV, C. 42069,2/85, Correspondencia Mercedes Milá, 28 de enero de 1938.
} 
moral y que fueran religiosas $^{8}$. Estas exigencias eran mayores para todas las interesadas en trabajar en vanguardia, siendo preferibles las que tuvieran un carácter serio y formal ${ }^{9}$ :

[...] Adjunto le envío estos dos cuestionarios de estas dos candidatas al frente de las cuales han hablado muy bien como moralidad, y la Chaves como una buenísima enfermera, mi médico el doctor Tello. La otra Ángeles Sánchez López muy recomendada por las Hermanas de la Doctrina Cristiana en cuyo colegio ha sido maestra. Es también enfermera de la Facultad de Medicina pero ni ha practicado ni parece espabilada aunque las monjas la encuentren mucha serenidad. $[\ldots]^{10}$

Mercedes Milá como responsable principal de los servicios femeninos de Sanidad Militar, después de leer la documentación que aportaban sus delegadas, seleccionaba ella misma a las voluntarias, decidía los destinos y los equipos quirúrgicos con los que tenían que trabajar ${ }^{11}$. Todos estos informes eran confidenciales, a pesar de todo, en algunas ocasiones las enfermeras se enteraron del contenido de los mismos ${ }^{12}$. En estos certificados se adjuntaba información sobre su vida laboral y experiencia, expediente académico y lugar de estudios ${ }^{13}$, además de su afiliación política y lugar de obtención del título ${ }^{14}$.

Hasta que no se organizaron de forma sólida los servicios femeninos de Sanidad Militar no se empezó a exigir un carnet como acreditación ${ }^{15}$, por lo que inicialmente las voluntarias fueron aceptadas sin estar en posesión del mismo, hasta 1938, año en que pasó a ser un requisito obligatorio para todas. Ello implicó un aumento de la demanda de carnets por parte de las voluntarias ${ }^{16}$. Todas las interesadas en trabajar para Sanidad Militar debían tener el suyo, tanto las que hubieran recibido un título después de los cursillos formativos, como las que

\footnotetext{
${ }^{8}$ AGMAV, C. 42069,2/270. Correspondencia de Mercedes Milá, 21 de enero de 1938.

${ }^{9}$ AGMAV, C. 42069,5/41. Correspondencia de Mercedes Milá, de diciembre de 1937.

${ }^{10}$ AGMAV, C. 42068,2/95. Correspondencia de Mercedes Milá, 9 de octubre de 1938.

${ }_{11}$ AGMAV, C. 42069,2/137, Correspondencia Mercedes Milá, 29 de julio de 1938.

${ }^{12}$ AGMAV, C. 42069,2/59. Correspondencia de Mercedes Milá, 29 de mayo de 1938.

${ }^{13}$ AGMAV, C. 42069,2/126. Correspondencia de Mercedes Milá, 20 de noviembre de 1938.

${ }_{14}^{14}$ AGMAV, C. 42069,2/135-136, Correspondencia Mercedes Milá, 22 de julio de 1938.

${ }^{15}$ Cada uno llevaba la foto, nombre, apellidos, el número de enfermera que le correspondía tras su solicitud y la fecha en la que habían empezado a prestar sus servicios.

${ }^{16}$ AGMAV, C. 42069,2/235, Correspondencia Mercedes Milá, 10 de diciembre de 1938.
} 
carecieran de él. Esto no las eximía de presentar el diploma de enfermera en caso de ser movilizadas ${ }^{17}$. El carnet del personal sanitario sin título era diferente al expedido para las enfermeras y auxiliares que lo tenían ${ }^{18}$. Las enfermeras de Cruz Roja para poder trabajar en los hospitales militares también solicitaron los carnets de Sanidad Militar en las mismas condiciones que el resto de las voluntarias ${ }^{19}$.

La solicitud del carnet ${ }^{20}$ se debía acompañar de dos fotografías, del título de enfermera, de un informe sobre el comportamiento de la interesada y las preferencias de destino. También debían indicar "a que persona o entidad ofrecieron en un principio sus servicios", el trabajo que habían prestado, puesto que ocupaban y nombre de la persona que las había nombrado en el cargo, además de mostrar un certificado en el que constaba la fecha en la que comenzaron el mismo ${ }^{21}$. Jesús Bescós especifica que también se exigía un certificado de buena conducta, disciplina y eficiencia técnica, emitido por el director y la superiora del hospital y un informe sobre los antecedentes políticos e ideológicos expedidos por las delegaciones de orden público. Si se consideraba que tenían una ideología afín a partidos de izquierdas o incluso haber pertenecido al Ateneo Cultural, se las denegaba la expedición del carnet ${ }^{22}$. Haber trabajado para los republicanos convertía a las enfermeras en peligrosas, y desde la inspección consiguieron que no llegaran a trabajar a pesar de tener suficientes avales ${ }^{23}$.

Los carnets únicamente se dieron a las enfermeras dispuestas a ofrecer más de seis meses de servicio o a aquellas que los hubieran prestado ya y no se hubieran dado de baja de forma voluntaria, "sino por causa de fuerza mayor debidamente justificada"24. A lo largo del conflicto fue común retirar de los equipos del frente a

\footnotetext{
${ }^{17}$ AGMAV, C. 42069,2/227, Correspondencia Mercedes Milá, 18 de agosto de 1939.

${ }^{18}$ AGMAV, C. 42069,2/293, Correspondencia Mercedes Milá, 28 de noviembre de 1938.

${ }^{19}$ AGMAV, C. 42069,6/134, Correspondencia Mercedes Milá, 7 de diciembre de 1938. AGMAV, C. 42069,6/140-141, Correspondencia Mercedes Milá, 18 de junio de 1938.

${ }^{20}$ La extensión del carnet tenía un coste de una peseta.

${ }^{21}$ AGMAV, C. 42069,2/81-82. Correspondencia de Mercedes Milá, 8 de junio de 1938.

${ }^{22}$ Bescos TORRES, Jesús: Las enfermeras en la guerra de España (1936-1939). Revista de Historia Militar no 53, 1982, pp. 99-100.

${ }^{23}$ AGMAV, C. 42069,2/304. Correspondencia de Mercedes Milá, 10 de noviembre de 1938.

${ }^{24}$ AGMAV, C. 42068,2/38, Correspondencia Mercedes Milá, 9 de enero de 1939.
} 
las enfermeras que carecían de carnet, a pesar de haber hecho bien su trabajo ${ }^{25}$ (ver anexo XXVI).

A la hora de entregar los carnets también se tuvo en cuenta la opinión de las delegadas y de Mercedes Milá sobre el comportamiento, actitud y aptitud de las voluntarias. Se comprobaba el listado recibido de las diferentes delegaciones con la relación de nombres y comportamiento de las enfermeras ${ }^{26}$. Mercedes Milá enviaba los carnets a las delegadas para que fueran ellas las que los repartieran entre sus enfermeras $^{27}$, tras la firma por duplicado del recibo que servía como comprobante de su entrega. A veces era difícil localizarlas, sobre todo durante los periodos de descanso ${ }^{28}$. Todas aquellas que dejaron de trabajar antes de finalizar el conflicto no recibieron carnet, a pesar de haberlo solicitado (ver anexo XXVII). Algunas pensaron que estar en posesión del mismo les serviría como salvoconducto ${ }^{29}$, ya que era un documento de identidad que las acreditaba para poder desplazarse con mayor libertad de sus domicilios a los hospitales ${ }^{30}$, aunque para el delegado de orden público no fue asi ${ }^{31}$. Por lo tanto, las enfermeras necesitaron los salvoconductos para poder trasladarse, debido a la demora en su emisión se expedían con validez para todo un año 32 .

La entrega de carnets sufrió retrasos y en algunas ocasiones hubo problemas con los envíos de los mismos, lo que propició que aumentara la solicitud de estos al finalizar la Guerra Civil ${ }^{33}$, incluidos también los de las voluntarias que no habían recibido el suyo ${ }^{34}$. El problema fue que una vez terminado el conflicto dejaron de expedirse, ya que únicamente servía como recuerdo del trabajo desempeñado. Las últimas solicitudes se admitieron el 15 de septiembre de $1939^{35}$.

\footnotetext{
${ }^{25}$ AGMAV, C. 42069,2/122. Correspondencia de Mercedes Milá, 17 de noviembre de 1938.

${ }^{26}$ AGMAV, C. 42068,3, C. 42069,2/48. Correspondencia de Mercedes Milá, 15 de febrero de junio y 25 de julio de 1938 .

${ }^{27}$ AGMAV, C. 42069,3/109-110, Correspondencia Mercedes Milá, 25 de junio de 1938.

${ }^{28}$ AGMAV, C. 42069,2/50-51. Correspondencia de Mercedes Milá, 19 de julio de 1938.

${ }^{29}$ AGMAV, C. 42069,2/194-195, Correspondencia Mercedes Milá, 18 de agosto de 1938.

${ }^{30}$ AGMAV, C. 42069,2/142. Correspondencia de Mercedes Milá, 9 de febrero de 1938.

${ }^{31}$ AGMAV, C. 42069,2/196. Correspondencia de Mercedes Milá, 21 de agosto de 1938.

${ }^{32}$ AGMAV, C. 46761,2/36. Correspondencia de Mercedes Milá, 27 de noviembre de 1938.

${ }^{33}$ AGMAV, C. 46761,2/232 Correspondencia Mercedes Milá, 1 de julio de 1939.

${ }^{34}$ AGMAV, C. 42069,3/85, Correspondencia Mercedes Milá, 25 de agosto de 1939.

${ }^{35}$ AGMAV, C. 42069,3/87, Correspondencia Mercedes Milá, 12 de diciembre de 1939.
} 


\subsection{Mercedes Milá y Nolla: su labor como Inspectora de Servicios Femeninos del Cuartel General de Sanidad Militar}

El cargo de inspectora general llevaba implícitos una serie de deberes entre los que se encontraba la obligación de "destinar, destituir y vigilar a todo el personal femenino" de los hospitales de guerra. Mercedes Mila fue la responsable principal de las enfermeras militarizadas y de las congregaciones religiosas que prestaron servicios para Sanidad Militar. En las poblaciones que tenían más de un hospital, contó con la ayuda de las delegadas que solían residir en la localidad ${ }^{36}$.

Los nombramientos, destinos ${ }^{37}$ y traslados dependían siempre de la autorización previa de la inspectora ${ }^{38}$, al igual que la adjudicación de vacantes y $\operatorname{ceses}^{39}$ (ver anexo XXVIII). Milá y Nolla tomaba las decisiones de una forma crítica sin dejarse llevar por los favoritismos, valoraba el trabajo bien hecho y elegía a las enfermeras más capacitadas para desempeñarlo ${ }^{40}$. En su cargo como inspectora contó con las "atribuciones para proponer traslados, admisiones y despidos", y con el apoyo de las autoridades militares y los jefes de Sanidad Militar siempre que los necesitó para cumplir su misión ${ }^{41}$.

También se encargó de la elección de las delegadas, que en ocasiones fue compleja porque tanto el director como la Madre Superiora del hospital tenían que aprobarlas, sobre todo en las localidades pequeñas. De esta forma, algunas necesitaron "unos toques patrióticos" para animarse a aceptar el puesto ${ }^{42}$. Mercedes Milá las recomendaba dejar constancia por escrito de todos los asuntos oficiales para evitar errores o malas interpretaciones ${ }^{43}$. Todos los nombramientos, destituciones y cambios de hospital debían pasar por la inspectora como máxima responsable y

\footnotetext{
${ }^{36}$ AGMAV, C. 42069,6/96, Correspondencia Mercedes Milá, 23 de agosto de 1938.

${ }^{37}$ AGMAV, C. 42069,2/122, Correspondencia Mercedes Milá, 17 de noviembre de 1938.

${ }^{38}$ AGMAV, C. 42069,5/41, Correspondencia Mercedes Milá, 2 de diciembre de 1937.

${ }^{39}$ AGMAV, C. 42067,2, Correspondencia de Mercedes Milá, 24 de junio de 1938.

${ }^{40}$ AGMAV, C. 42069,3/223. Correspondencia de Mercedes Milá, 9 de enero de 1937.

${ }^{41}$ BOE, $\mathrm{n}^{\mathrm{o}}$ 157, 26 de marzo de 1937, Orden.- Nombrando Inspector General de todo el personal femenino de Hospitales, a la señorita Mercedes Milá Moya, p. 811.

${ }^{42}$ AGMAV, C. 42069,2/232. Correspondencia de Mercedes Milá, 9 de enero de 1939.

${ }^{43}$ AGMAV, C. 42067,2, Correspondencia de Mercedes Milá, 22 de diciembre de 1937.
} 
coordinadora de toda la actividad laboral de las enfermeras, siendo las delegadas las que comunicaban sus decisiones a las interesadas:

Por cierto, me dice Cancela que recibió un oficio tuyo diciéndole que de orden de la Autoridad se diera de baja en Griñón a tres enfermeras y una en Cáceres y me extraña mucho no saber yo nada en absoluto. Qué ha pasado y quién es la Autoridad que ha dado esa orden? Te agradeceré que no se nombre ni se destituya a nadie sin darme a mí cuenta. Cual no es mi sorpresa después de que una de las que me dijo Cancela figuraban en la relación de las tres de Griñón me la encuentro con su hermana y dos más que también pertenecían a la plantilla de Griñón, en Alhama que habían ido con el equipo de otorrino. Las regañé como es natural y una de ellas me dijo que habían preguntado a la Superiora de Griñón que tenían que hacer para poder dejar el Hospital y marchar legalmente y que esta les dijo que nada, que se podían ir, de manera que agradeceré que le digas a Sor Eulogia que eso no puede ser y las cosas no se hacen así ${ }^{44}$.

Mercedes Milá destinaba a las enfermeras según las peticiones de personal hechas por los jefes sanitarios y nunca por iniciativa propia ${ }^{45}$. Por lo tanto, lo habitual fue que los capitanes médicos con cargos directivos en los hospitales militares solicitaran directamente a la inspectora, el número de enfermeras, auxiliares y Hermanas de la Caridad que precisaban para cubrir las necesidades sanitarias de sus respectivos centros, requiriendo, cuando fue posible, que estas tuvieran experiencia práctica ${ }^{46}$. Las madres superioras y las delegadas, también solicitaron enfermeras para sus hospitales ${ }^{47}$. En ocasiones no se tuvo en cuenta esta vía burocrática y administrativa, y los médicos pidieron directamente a las enfermeras que acudieran al hospital:

Hoy ha venido a verme desde Griñón donde dice está hace unos días ya porque la reclamó el jefe del equipo C5 aquella que estaba en Sevilla y que me dijiste no convenía y quedamos en que no fuera. Por lo visto el médico le escribió directamente que se fuera y allí estaba, ya la he dicho que no puede continuar y se

\footnotetext{
${ }^{44}$ AGMAV, C. 42067,2, Correspondencia de Mercedes Milá, 17 de diciembre de 1937.

${ }^{45}$ AGMAV, C. 42068,2, Correspondencia de Mercedes Milá, 8 de octubre de 1938.

${ }^{46}$ AGMAV, C. 42069,3/153. Correspondencia de Mercedes Milá, 23 de septiembre de 1937.

${ }^{47}$ AGMAV, C. 42067,2, Correspondencia de Mercedes Milá, 29 de octubre de 1938.
} 
marche de manera que está sobre aviso y dile al Director y Superiora una vez más que no pueden admitir a ninguna si no está nombrada por ti o por mí ${ }^{48}$.

Los médicos no tenían autoridad para hacer nombramientos y desde un principio se comunicó a los jefes de los equipos quirúrgicos que únicamente Mercedes Milá sería la encargada de ello en lo que respectaba al personal auxiliar femenino $^{49}$. Mercedes tenía que tener el control sobre todas las voluntarias y en caso de que los nombramientos se llevaran a cabo sin su consentimiento, en los distintos centros tenían la orden de no admitir a las enfermeras movilizadas ${ }^{50}$. A pesar de todo, hubo directores médicos que se extralimitaron en sus funciones y nombraron al personal femenino que a ellos les interesaba sin dar cuenta de ello a la inspectora ${ }^{51}$.

La delegada nacional de Frentes y Hospitales, María Rosa Urraca Pastor, tampoco podía destinar a su personal en los hospitales militares sin la autorización de la inspectora. Mercedes admitió la colaboración de esta organización, pero no los nombramientos ni traslados de enfermeras. Frentes y Hospitales tenía que remitir a las voluntarias a la Inspección General y no decidir por sí mismos los destinos de éstas ya que no era de su jurisdicción ${ }^{52}$. Aún así, tramitó traslados de monjas sin el permiso de la inspectora, basándose en la solicitud formulada por el comandante de la Plaza ${ }^{53}$.

Con algunas de sus delegadas también tuvo problemas porque se excedieron en sus funciones, como fue el caso de Rosario Q. de Quirós y Luque, responsable de las enfermeras en Cáceres:

Las instrucciones que te he dado últimamente te las había dado ya en otras ocasiones por escrito y de palabra y siempre que las he repetido ha sido a causa de lo mismo o sea que has hecho algún nombramiento que por una causa u otra he tenido que desautorizar resultando para mí muy desagradable el tener que hacerlo

\footnotetext{
${ }^{48}$ AGMAV, C. 42067,2, Correspondencia de Mercedes Milá, 21 de junio de 1938.

${ }^{49}$ AGMAV, C. 42069,3/47. Correspondencia de Mercedes Milá, 14 de octubre de 1937.

${ }^{50}$ AGMAV, C. 42068,2, Correspondencia de Mercedes Milá, 8 de octubre de 1938.

${ }^{51}$ AGMAV, C. 42069,3/229. Correspondencia de Mercedes Milá, 17 de agosto de 1937.

${ }^{52}$ AGMAV, C. 42069,6/102. Correspondencia de Mercedes Milá, 5 de julio de 1938.

${ }^{53}$ AGMAV, C. 42069,2/41. Correspondencia de Mercedes Milá, 15 de febrero de 1938.
} 
por lo molesto que es también para ti. Encuentro esto muy fácil de evitar si tú me haces las propuestas de destino antes de hacer los nombramientos y no después, cosa que me parece naturalísima puesto que soy yo la que oficial y ulteriormente tengo la responsabilidad de los Servicios femeninos ${ }^{54}$.

En algunas ocasiones las voluntarias pidieron recomendaciones o hicieron alusión a determinadas amistades o cargos aristocráticos para conseguir otros destinos $^{55}$, sobre todo para estar más cerca de sus familias. Las enfermeras no podían elegir dentro del hospital el servicio en el que querían trabajar, era el director del centro o la superiora los que decidían el puesto de acuerdo con las necesidades asistenciales $^{56}$.

Fue habitual que aparecieran problemas con las comunicaciones, tanto a nivel telefónico como con el transporte ${ }^{57}$. La inspectora solía estar ocupada con los viajes al frente y la organización sanitaria desde la retaguardia, así lo expresaba Rosario Gaminde, delegada en Bilbao: "He querido comunicar con Ud. 3 o 4 veces, pero la línea con Salamanca, siempre ocupada por otras conferencias oficiales, solo me la ofrecían para hora muy temprana o a altas horas de la noche, por lo que no hice uso de ella"58. Estas dificultades a la hora de localizar a Mercedes Milá, obligó a algunas de sus delegadas a dar destino a enfermeras sin el consentimiento de la inspectora:

Ves tú por lo que no se puede nombrar a ninguna enfermera sin decírmelo antes! Ahora tenemos un lío con la Srta. Ángeles García Álvarez que como dices se empeña en pedir explicaciones y si no se la nombra no pasa nada. Por muy buenos informes que te haya dado el Conde de la Florida yo los tengo de Valdecilla nada buenos y de acuerdo con los cuales no se la puede destinar y es muy molesto tenerle que dar explicaciones. El que se tenga que ganar la vida no tiene que ver nada con nosotros no será a nosotros a quien pidan informes ${ }^{59}$.

\footnotetext{
${ }^{54}$ AGMAV, C. 42067,2, Correspondencia de Mercedes Milá, 10 de junio de 1938.

${ }^{55}$ AGMAV, C. 42067,2, Correspondencia de Mercedes Milá, 8 de noviembre de 1938.

${ }^{56}$ AGMAV, C. 42069,3/183-184. Correspondencia de Mercedes Milá, 7 y 10 de octubre de 1938.

${ }^{57}$ AGMAV, C. 42069,2/3. Correspondencia de Mercedes Milá, 10 de agosto de 1937.

${ }^{58}$ AGMAV, C. 42069,2/4. Correspondencia de Mercedes Milá, 10 de agosto de 1937.

${ }^{59}$ AGMAV, C. 42067,2, Correspondencia de Mercedes Milá, mayo de 1938.
} 
En los hospitales italianos trabajaron conjuntamente enfermeras italianas y españolas, todas con la titulación reglamentaria, nombradas habitualmente por sus mandos y no por Mercedes, ya que la jefatura de Sanidad Militar no intervenía en los hospitales italianos por no ser "diplomático ni galante". De esta forma, se les daba libertad de acción a los extranjeros para nombrar y cesar a su personal según su criterio $^{60}$.

Respecto al personal femenino de Cruz Roja hay que señalar que no dependió directamente de Mercedes Milá, ya que era la Marquesa de Valdeiglesias la encargada de gestionar y organizar el trabajo de las enfermeras de la institución ${ }^{61}$.

\subsection{Deberes y sanciones}

\section{Responsabilidades y obligaciones}

Las enfermeras que prestaron sus servicios en los hospitales militares tuvieron que aceptar la autoridad de la Madre Superiora, a la que debían obedecer, cumpliendo con los horarios y el servicio que ella decidiera. Trabajaron bajo la dirección de la enfermera jefe, que las exigía seriedad de conducta, disciplina y puntualidad $^{62}$. Las damas auxiliares voluntarias de Cruz Roja que estaban en activo debían aceptar el puesto que les encomendara la presidenta de enfermeras, sin poder negarse ni abandonar el mismo sin previa autorización. La enfermera jefe no podía admitir bajo su tutela a ninguna dama que no fuera debidamente acreditada para trabajar y que no contara con la autorización de la presidenta. El compromiso mínimo que adquirieron con el centro donde prestaron asistencia fue de cuatro meses, que podían renovar por periodos de tres ${ }^{63}$.

\footnotetext{
${ }^{60}$ AGMAV, C. 42069,3/221-222. Correspondencia de Mercedes Milá, 12 de noviembre de 1937.

${ }^{61}$ AGMAV, C. 42069,2/306. Correspondencia de Mercedes Milá, 11 de marzo de 1938.

${ }^{62}$ AGMAV, C. 42068,3/189. Correspondencia de Mercedes Milá, Reglamento de los Servicios Femeninos de los hospitales de guerra.

${ }^{63}$ CRUZ Roja ESPAÑOla: Reglamento para las enfermeras auxiliares voluntarias ...op.cit., p. 6.
} 
El reglamento de las damas enfermeras de Cruz Roja especificaba que debían atender con dulzura y paciencia a los heridos, con el celo y el interés propios de la responsabilidad que implicaba su cuidado ${ }^{64}$. También se comprometieron a obedecer puntualmente las órdenes del médico, sin criticarlas con otras compañeras o con los pacientes $^{65}$. Debían mantener la discreción y la cortesía, por lo que tenían prohibido todo tipo de familiaridad que diera pie a comentarios mal intencionados. Tampoco podían pasear solas con los enfermos, médicos y oficiales, ni recibir visitas en sus habitaciones, ni aceptar ningún tipo de invitación sin permiso de la superiora del hospital o en su defecto de la enfermera jefe ${ }^{66}$. Debían llevar el uniforme reglamentario, compuesto por bata-vestido, delantal, capa y toca, siempre que estuvieran prestando servicio, sin ningún tipo de adornos, únicamente la insignia y el brazal de la Cruz Roja. También se las permitía llevar un reloj de bolsillo y la insignia de Sanidad Militar. Los zapatos debían ser blancos, lisos, escotados y con tacón a la inglesa, las medias y guantes blancos. El uniforme era exclusivamente de uso hospitalario y debían ponérselo allí, si salían de casa con él debían llevar encima un abrigo y quitarse la toca. Tenían prohibido llevar el uniforme a sitios públicos, salvo autorización de la asamblea en caso de presentarse a actos oficiales ${ }^{67}$.

El personal sanitario femenino perteneciente a los hospitales militares únicamente podía llevar como insignia en el uniforme la medalla de Sanidad Militar. El color de la cinta diferenciaba a las profesionales de las auxiliares, amarillo para las primeras y los colores nacionales para las segundas ${ }^{68}$. Además de medallas también se hicieron pasadores que pidieron de forma voluntaria las que quisieron, justificando en la solicitud los días que habían prestado servicio ${ }^{69}$. La medalla era "signo exterior del carnet" por lo que no podían entregarse sin estar en posesión del mismo, ya que era un requisito indispensable que exigía Sanidad Militar ${ }^{70}$.

\footnotetext{
${ }^{64}$ CRUZ ROJA ESPAÑOLA: Reglamento para las enfermeras auxiliares voluntarias...op.cit., p. 7.

${ }^{65}$ AGMAV, C. 42068,3/190. Correspondencia de Mercedes Milá, Reglamento de los Servicios Femeninos de los hospitales de guerra.

${ }^{66}$ CRUZ RoJA ESPAÑOLA: Reglamento para las enfermeras auxiliares voluntarias ... op.cit., p. 7.

${ }^{67}$ Ibid., pp. 7-8.

${ }^{68}$ AGMAV, C. 42069,2/71 y 72. Correspondencia de Mercedes Milá, 18 y 9 de noviembre de 1938.

${ }^{69}$ AGMAV, C. 42069,2/105. Correspondencia de Mercedes Milá, 25 de noviembre de 1938.

${ }^{70}$ AGMAV, C. 42069,2/155. Correspondencia de Mercedes Milá, 13 de mayo de 1939.
} 
La instauración de la medalla de sanidad fue idea de Mercedes Milá, como un distintivo para el personal sanitario femenino que tuviera titulación ${ }^{71}$.

El reglamento de las enfermeras de hospitales de guerra dejaba claro que en acto de servicio siempre tenían que vestir el uniforme compuesto de bata, delantal y gorro blanco, prescindiendo de todo tipo de joyas y alhajas. Debían llevar reloj con segundero, pluma estilográfica y bloc. Si era posible también se las recomendaba llevar un termómetro y unas tijeras ${ }^{72}$. El uniforme debían utilizarlo en su lugar de trabajo y no tenían derecho a llevarlo fuera del mismo ${ }^{73}$, su uso inadecuado, en cafés, bares y cines, hizo que Mercedes Milá emitiera una circular en la que prohibía su uso fuera de los hospitales ${ }^{74}$. Estaba permitido vestir de uniforme en los actos oficiales y aún así hubo problemas, porque durante las manifestaciones o concentraciones, las enfermeras en esos momentos "de gran regocijo, saltan, corren y hacen mil cosas impropias de la seriedad del uniforme"75. A pesar de todo se tuvo que advertir a las enfermeras movilizadas en campaña de las consecuencias de llevarlo fuera del lugar de trabajo:

Ha llegado a mis oídos que en Alcora estuvieron bailando en la Plaza del pueblo con los médicos vestidas de uniforme dando lugar a las consecuentes habladurías y escándalo en el pueblo y quiero rogar a $\mathrm{Vd}$. les diga de mi parte espero que nada parecido se vuelva a repetir, que al solicitar ir al frente es con el espíritu de sacrificio que ello requiere y que estando tan en contacto con el dolor no demuestra el sentimiento de que deben estar poseídas y demostrar esas manifestaciones y sobre todo el uniforme es para trabajar y no para bailar. Espero que debidamente advertidas ni eso ni nada parecido volverá a suceder porque si así fuera me vería precisa a devolverlas a retaguardia donde pueden divertirse lo que

\footnotetext{
${ }^{71}$ AGMAV, C. 42069,3/79. Correspondencia de Mercedes Milá, 31 de mayo de 1938.

${ }^{72}$ AGMAV, C. 42068,3/190. Correspondencia de Mercedes Milá, Reglamento de los Servicios Femeninos de los hospitales de guerra.

${ }^{73}$ AGMAV, C. 42067,2, Correspondencia de Mercedes Milá, 29 de octubre de 1938.

${ }^{74}$ AGMAV, C. 42069,2/173. Correspondencia de Mercedes Milá, 16 de diciembre de 1938.

${ }^{75}$ AGMAV, C. 42069,2/232. Correspondencia de Mercedes Milá, 19 de enero de 1939.
} 
quieran. También ruego les diga que el fumar es otra cosa que no considero deban hacer las enfermeras en los hospitales $[\ldots]^{76}$.

Se las exigía puntualidad y no se las permitía abandonar su trabajo hasta que no fueran relevadas o terminaran su turno ${ }^{77}$. Tampoco podían dejar su servicio sin que fueran autorizadas por sus superiores y menos sin causa justificada. Únicamente entraban en la sala de trabajo asignada, por lo que no podían circular libremente por el hospital. Si deseaban ir a otra necesitaban la autorización de la superiora o del director del centro. Si querían vacaciones debían solicitarlo a la Madre Superiora, que se las concedería si eran dentro de un periodo inferior a cuatro días, y únicamente si podía prescindir de su trabajo. En caso de cesar en su puesto, no podían abandonarlo hasta que fueran sustituidas por otra compañera ${ }^{78}$. Las casadas necesitaban la autorización del marido para poder ir a trabajar a los hospitales de guerra y las menores de los padres o tutores ${ }^{79}$.

A las enfermeras se las movilizó cuando no hubo posibilidad de "cubrir los servicios con las de la localidad" $" 80$. En estos casos, al tener que desplazase de su domicilio habitual, tenían derecho a alojamiento y manutención, estando siempre bajo la tutela de la Madre Superiora ${ }^{81}$. A la hora de destinarlas como internas, Mercedes Milá solía elegir a las que tenían mayor posibilidad de rendir más, teniendo en cuenta el trabajo desempeñado en otros centros ${ }^{82}$. Antes de movilizarlas debían saber si poseían una titulación oficial ${ }^{83}$ y si se las podía dar alojamiento y las condiciones del mismo ${ }^{84}$. En ocasiones se las hospedó en casas particulares de la plaza donde estaba el hospital, de forma que compartieron la vivienda con la familia

\footnotetext{
${ }^{76}$ AGMAV, C. 42068,3, Correspondencia de Mercedes Milá, 29 de septiembre de 1938.

${ }^{77}$ CRUZ ROJA ESPAÑOLA: Reglamento para las enfermeras auxiliares voluntarias .... op.cit., p. 7.

${ }^{78}$ AGMAV, C. 42068,3/190. Correspondencia de Mercedes Milá, Reglamento de los Servicios Femeninos de los hospitales de guerra.

${ }^{79}$ Ibid.

${ }^{80}$ AGMAV, C. 46761,2/27. Correspondencia de Mercedes Milá, 15 se junio de de 1939.

${ }^{81}$ AGMAV, C. 42068,3/190. Correspondencia de Mercedes Milá, Reglamento de los Servicios Femeninos de los hospitales de guerra.

${ }^{82}$ AGMAV, C. 46761,2/40. Correspondencia de Mercedes Milá, 27 de marzo de 1939.

${ }^{83}$ AGMAV, C. 42068,3, Correspondencia de Mercedes Milá, 12 de julio de 1938.

${ }^{84}$ AGMAV, C. 42067,2, Correspondencia de Mercedes Milá, 3 de diciembre de 1937.
} 
que residía allí ${ }^{85}$. Otras veces, se requisaron locales o pisos amueblados lo que permitió alojar a mayor número de personal, normalmente Hermanas de la Caridad $^{86}$. Cuando no hubo suficientes enfermeras profesionales en los hospitales para hacerse cargo del trabajo, se dio permiso a las alumnas de segundo y tercer curso para que cubrieran esas plazas, pero no las de primero, ya que se consideraba que su formación no equivalía ni a la de auxiliar ${ }^{87}$.

Hasta diciembre de 1938, todas las damas y auxiliares que fueron movilizadas durante la contienda no recibieron ningún tipo de compensación económica por su trabajo, fue gratuito, únicamente tenían derecho a alojamiento y manutención. Mercedes Milá solicitó que se equipararan las condiciones laborales de las damas enfermeras y auxiliares agregadas a los hospitales y equipos del frente, con las religiosas de los mismos, ya que solo tenían derecho a habitación y ración de hospital, "por el hecho de estar movilizadas y prestar servicio fuera de la residencia habitual”. La Inspectora de los Servicios Femeninos propuso que se les concediera "una gratificación, que podía ser, de 25 pesetas mensuales, para atender a su vestuario y gastos personales", al igual que se hacía con las Hermanas de la Caridad cuyas funciones suplían o complementaban ${ }^{88}$. Mercedes consiguió que se concediera dicha gratificación a todas aquellas que estuvieran "separadas de su habitual residencia" ${ }^{\prime 89}$. Cuando trabajaron en los hospitales de su ciudad lo hicieron en calidad de externas, sin recibir ningún tipo de remuneración ${ }^{90}$. Por lo tanto, el trabajo de las enfermeras en los hospitales militares era voluntario y gratuito por lo que aquella que buscaba en ello una solución a los problemas económicos acecidos por la guerra no lo encontró ${ }^{91}$.

\footnotetext{
${ }^{85}$ AGMAV, C. 42069,3/232. Correspondencia de Mercedes Milá, 1 de diciembre de 1937.

${ }^{86}$ AGMAV, C. 42069,3/234. Correspondencia de Mercedes Milá, Sin fecha.

${ }^{87}$ AGMAV, C. 42068,4, Correspondencia de Mercedes Milá, 5 de julio de 1938.

${ }^{88}$ AGMAV, C. 2333, L. 63, Cp. 93, 5 de marzo de 1938.

${ }^{89} \mathrm{BOE}, \mathrm{n}^{\circ} 148,25$ de noviembre de 1938, Orden asignando la gratificación que indica a las Damas Enfermeras que prestar, servicios en Hospitales y Equipos Móviles, p. 2569.

${ }^{90}$ AGMAV, C. 46761,2/27. Correspondencia de Mercedes Milá, 15 se junio de de 1939.

${ }^{91}$ AGMAV, C. 42069,3/267-268. Correspondencia de Mercedes Milá, 22 de junio de 1938.
} 


\section{Capítulo V}

\section{Ceses y destituciones de enfermeras}

En Cruz Roja, las faltas graves de disciplina o contra el servicio llevaban implícito la separación del cuerpo de damas auxiliares voluntarias ${ }^{92}$. En Sanidad Militar, las faltas de disciplina y el comportamiento poco adecuado $^{93}$ fueron duramente castigados, principalmente destituyendo y cesando en sus puestos a las enfermeras involucradas, tanto durante su periodo laboral como formativo en los cursillos:

Las cursillistas del Hospital Provincial afectas a la organización de Falange E. T. después de intentar durante unos días obstruccionar el desenvolvimiento normal de los cursillos, comportándose con poca corrección en las clases, dejando de asistir posteriormente a las mismas y negándose de una manera absoluta a efectuar las guardias dentro de la clínica donde prestan servicios, me he visto en la precisión de eliminarlas oficialmente para imponer la disciplina que tan necesaria considero en nuestros servicios hospitalarios ${ }^{94}$.

Que las enfermeras llegaran a altas horas de la noche y demostraran una conducta moral poco deseable podía desencadenar su cese o traslado, después de leerles "bien la cartilla" y avisar al director del hospital de lo sucedido 95 . Abandonar sus puestos de trabajo se consideraba una falta grave de disciplina, tal fue el caso de tres enfermeras del hospital de Griñón que se trasladaron a Aragón sin ningún tipo de permiso ${ }^{96}$. Los informes de las madres superioras y los directores médicos de los hospitales eran decisivos, quedando en el expediente de las enfermeras un registro de los mismos:

Respecto a la Señora Simeonne Peronat estoy extrañadísima que hayas recibido una Orden del Inspector General de Sanidad para que destines en algún hospital a dicha Enfermera, pues esta fue dada de baja en Griñón durante el mes de Junio por tener conducta sumamente sospechosa, moral y personal, dicho por el Comandante Guzmán y la Madre Superiora; luego la destiné aquí, al Hospital del

\footnotetext{
92 CRUZ ROJA ESPAÑOLA: Reglamento de las enfermeras auxiliares voluntarias...op.cit., p. 7

${ }_{93}$ AGMAV, C. 42069,2/155. Correspondencia de Mercedes Milá, 13 de mayo de 1939.

${ }_{94}$ AGMAV, C. 42067,2, Correspondencia de Mercedes Milá, 29 de julio de 1937.

${ }^{95}$ AGMAV, C. 42067,2, Correspondencia de Mercedes Milá, 24 de junio de 1938.

${ }^{96}$ AGMAV, C. 42067,2, Correspondencia de Mercedes Milá, 22 de diciembre de 1937.
} 
Generalísimo, más que por nada, por las recomendaciones que traía de destacadas personalidades. En el mes de Octubre fue dada de baja por ti junto con cuatro más y hasta se abrió un expediente sobre el comportamiento de dichas Enfermeras y la que peor parada quedó es esta. Tú tienes la palabra después de darte conocimiento hacer lo que creas conveniente $[\ldots]^{97}$.

En otras ocasiones el motivo de su cese no estaba relacionado con su comportamiento sino con su bajo rendimiento laboral:

Del asunto que le exponía en su carta al Comandante, me encargó le dijera, que la chica quiere continuar, pero que a él le es violento decirle a ella que debe renunciar a seguir en el Equipo por su escasa salud, que hace tenga que rebajarse con extraordinaria frecuencia del servicio y sobre todo en los días en que con más intensidad se trabaja en los quirófanos. Tampoco quiere el Comandante que la chica sepa nada de esto, por temor a herir su amor propio, ya que aparte de eso, demuestra un extraordinario celo y empeño en su cometido; por esto ha querido que sea yo quien se lo diga ${ }^{98}$.

La disciplina era la principal consigna que se exigía a las enfermeras movilizadas, en ocasiones "meterlas en cintura" no fue fácil, lo que generó que fueran las propias voluntarias las que presentaran sus bajas por no estar conformes con las medidas impuestas. En la zona de Zaragoza estaban acostumbradas a empezar la jornada a las 10:00h y por las tardes, sobre las 18:00-19:00h se iban al cine o a merendar, por lo que Mercedes Elósegui, como delegada, se vio obligada a tomar medidas restrictivas con el horario, además de no permitirlas salir a la calle una vez que hubieran empezado a prestar sus servicios. Estos cambios generaron sesenta bajas voluntarias de las enfermeras a su cargo ${ }^{99}$. Estaba mal visto que las internas pernoctaran fuera del hospital o del lugar habitual en el que se alojaban, aunque fuera con una amiga. No se aprobaba que bebieran o fumaran, motivos suficientes para castigarlas y retirar el nombramiento ${ }^{100}$. Tampoco admitieron

\footnotetext{
${ }^{97}$ AGMAV, C. 42067,2, Correspondencia de Mercedes Milá, 15 de octubre de 1937.

${ }^{98}$ AGMAV, C. 42067,2, Correspondencia de Mercedes Milá, 10 de diciembre de 1937.

${ }^{99}$ AGMAV, C. 42068,4, Correspondencia de Mercedes Milá, 26 de mayo de 1938.

100 AGMAV, C. 42069,2/264, Correspondencia de Mercedes Milá, 17 de diciembre de 1937.
} 
enfermeras que anteriormente hubieran "dejado de prestar sus servicios sin causa justificada" en los hospitales militares ${ }^{101}$.

En los hospitales no querían enfermeras “ineptas y holgazanas" que no madrugaran y prefirieran echarse la siesta. Eran un mal ejemplo para las de la localidad ya que veían como las internas eran poco aptas para el trabajo. Tampoco querían enfermeras desobedientes, que vieran el hospital como un "pasatiempo". Estos motivos fueron suficientes para darlas de baja en el servicio ${ }^{102}$ (ver anexo XXIX). Desobedecer las órdenes de la Madre Superiora, dar contestaciones irrespetuosas en presencia de los enfermos y tener una conducta privada de dudosa moralidad, favoreció la destitución de las enfermeras implicadas en los hechos. También se tuvieron en cuenta el tipo de compañías y amistades del personal sanitario femenino y los lugares que frecuentaban en sus "ratos de esparcimiento":

[...] tiene por norma establecer relación con cuantos elementos rebeldes o sospechosos políticamente han permanecido en el Hospital, y considera la Superiora, que por su pretendida cultura no alcanzará nunca la humildad que para la asistencia de enfermos es menester, y la perturbará siempre $[\ldots]^{103}$.

Las enfermeras tenían prohibido entablar amistad de tipo personal con los médicos del equipo quirúrgico. Estos romances generaban "disgustos y sinsabores", por lo que se cesaba a las enfermeras, enviándolas de vuelta a su casa ${ }^{104}$.

Las delegadas eran las encargadas de comunicar a Mercedes los conflictos que surgían con el personal auxiliar femenino para su cese, aunque en ocasiones las faltas eran tan graves que directamente tomaban ellas la decisión, para posteriormente comunicársela a la inspectora. Estos casos podían ser discusiones o peleas entre compañeras durante una noche de vela delante de los heridos, utilizando un lenguaje grosero e impropio ${ }^{105}$. Habitualmente Mercedes aprobaba y valoraba positivamente la vigilancia estrecha que llevaban a cabo sus delegadas "velando para que nada desagradable" ocurriera y las decisiones que tomaban ante las faltas de

\footnotetext{
${ }^{101}$ AGMAV, C. 42069,5/46, Correspondencia de Mercedes Milá, 12 de julio de 1938.

${ }^{102}$ AGMAV, C. 42067,2/98, Correspondencia de Mercedes Milá, 26 de agosto de 1938.

${ }^{103}$ AGMAV, C. 42068,4/3, Correspondencia de Mercedes Milá, 31 de agosto de 1937.

${ }^{104}$ AGMAV, C. 42068,4/31. Correspondencia de Mercedes Milá, 2 de julio de 1938.

105 AGMAV, C. 42069,3/179. Correspondencia de Mercedes Milá, 9 de agosto de 1937.
} 
disciplina ${ }^{106}$. También comunicó a las delegadas los nombres de todas aquellas que no debían aceptar en los hospitales militares ${ }^{107}$. Los directores y capitanes médicos debían solicitar a Mercedes Milá el cese de las enfermeras en caso de no estar conformes con su trabajo o actitud ${ }^{108}$. En otras ocasiones la inspectora desautorizó los nombramientos por carecer de información y antecedentes de las voluntarias o por no tener informes favorables de las mismas ${ }^{109}$.

Dentro de este apartado cabe tener en cuenta el caso de Priscilla Scott-Ellis ${ }^{110}$ y su amiga Consuelo Osorio de Moscoso, hija de los duques de Montemar, que trabajaron en hospitales de vanguardia como internas. Sus problemas con Mercedes Milá y con el jefe del equipo quirúrgico al que pertenecían figuran tanto en el diario de Prisicilla, Diario de la guerra de España, como en la correspondencia de Mercedes Milá ${ }^{111}$. A principios de febrero de 1938, Priscilla y Consuelo fueron admitidas en el equipo quirúrgico del capitán Roldán, falangista y antimonárquico, que no toleró la actitud de las enfermeras aristócratas, con las que tuvo diferentes enfrentamientos $^{112}$. La situación se resolvió cuando Priscilla enfermó gravemente y tuvo que volver temporalmente a Inglaterra para recuperarse. A su vuelta a España se incorporó con Consuelo en otro equipo quirúrgico (ver anexo XXX).

Priscilla no fue la única enfermera extranjera que tuvo problemas por su comportamiento y faltas de disciplina, Mirka Ben Haddux, de origen árabe estuvo destinada al inicio de la contienda en los hospitales cántabros a petición del General Martínez Anido. Mirka entabló amistad con otra compañera y su hermano, salía a merendar con ellos y en alguna ocasión durmió fuera del centro. Además sabían que fumaba y bebía a escondidas en uno de los cuartos del hospital. Mercedes Milá se

\footnotetext{
${ }^{106}$ AGMAV, C. 42069,3/179. Correspondencia de Mercedes Milá, 16 de agosto de 1937.

${ }^{107}$ AGMAV, C. 42069,3/214. Correspondencia de Mercedes Milá, 12 de marzo de 1938.

${ }^{108}$ AGMAV, C. 42069,3/216-217. Correspondencia de Mercedes Milá, 2 de febrero de 1939.

109 AGMAV, C. 42067,2/147 Correspondencia de Mercedes Milá, 18 de mayo de 1938.

${ }^{110}$ Priscilla Scott- Ellis, hija del octavo lord Howard de Walden. Amiga de la familia real española, especialmente del infante don Alfonso de Orleans. Estuvo en España como voluntaria desde octubre de 1937 hasta abril de 1939.

${ }^{111}$ AGMAV, C. 42068,3/63-64-65-68. Correspondencia de Mercedes Milá, febrero-junio 1938.

112 SCOTT- ElLis, Priscilla: Diario de la Guerra de España. Plaza y Janés editores, Barcelona, 1996, p. 68.
} 
vio obligada a buscarla otro destino con cierta reticencia, finalmente Mirka solicitó el traslado a un hospital de Andalucía por motivos de salud, ya que el clima del norte no le sentaba bien ${ }^{113}$.

\section{EI Servicio Social y las enfermeras}

Inicialmente más que desorganización, hubo desconocimiento y poca orientación a la hora de definir la forma de llevar a cabo el Servicio Social ${ }^{114}$. En un primer momento a las enfermeras no se las permitió cumplirlo en los hospitales militares $^{115}$ y no se computó el tiempo trabajado en los mismos como horas de desempeño del Servicio Social. Esta situación obligó a las enfermeras a abandonar sus puestos para acudir a los talleres femeninos y a las guarderías para prestar la nueva obligación. De esta forma los centros hospitalarios se vieron privados del personal femenino cualificado por lo que se solicitó que el desempeño del trabajo sanitario fuera convalidado como Servicio Social ${ }^{116}$ para evitar que las enfermeras que no lo hubieran realizado recibieran órdenes de dejar sus puestos en los hospitales para presentarse en otros destinos para cumplirlo ${ }^{117}$.

La nueva medida tampoco facilitó el trabajo asistencial, se podría decir que complicó el funcionamiento de los hospitales, ya que la obligatoriedad del mismo hizo que mujeres sin interés en la asistencia se decantaran por realizarlo en los centros sanitarios. La inspectora y sus delegadas se encargaron de controlar a este personal, entregando los carnets de Sanidad Militar únicamente a aquellas enfermeras que una vez terminado el Servicio Social continuaran con su trabajo $\operatorname{asistencial}^{118}$. Algunos hospitales se tuvieron que reorganizar con las mujeres del Servicio Social que únicamente prestaron colaboración durante los seis meses exigidos, completando el trabajo en esos centros con voluntarias. El caos inicial

\footnotetext{
113 AGMAV, C. 42069,2/266-274. Correspondencia de Mercedes Milá, septiembre 1937 a enero 1938.

${ }^{114}$ AGMAV, C. 42069,3/9. Correspondencia de Mercedes Milá, 13 de enero de 1938

${ }^{115}$ Boletín de Auxilio de Invierno. $\mathrm{n}^{\mathrm{o}}$ 10, septiembre de 1938, Circular $N^{o}$ 39: El Servicio social no puede cumplirse en los hospitales militares, p. 11.

${ }_{116}^{11}$ AGMAV, C. 42069,5/43-44. Correspondencia de Mercedes Milá, 12 de septiembre de 1938

${ }^{117}$ AGMAV, C. 46761,2/129. Correspondencia de Mercedes Milá, 10 de agosto de 1938.

${ }^{118}$ AGMAV, C. 42069,2/15. Correspondencia de Mercedes Milá, 17 de noviembre de 1938.
} 
impuesto por la obligatoriedad del Servicio Social propició que a los hospitales llegara una "avalancha de muchachas" sin interés en la profesión ${ }^{119}$.

La labor desempeñada por Mercedes Milá y sus delegadas se vio dificultada porque Auxilio Social no enviaba con antelación la lista de enfermeras destinadas a cumplir el Servicio Social en los hospitales militares, por lo que no podían acreditar su validez y capacitación para desempeñar el trabajo. Las enfermeras que estaban empleadas antes de que se impusiera la obligatoriedad del Servicio Social tuvieron que acreditarlo para que se les convalidara a través de un certificado de servicios prestados en el que se especificaba equipo y centro en el que habían prestado su labor de forma gratuita ${ }^{120}$ (ver anexo XXXI). Para Mercedes Milá, el Servicio Social duplicaba su trabajo ya que tenía que ocuparse "de arreglar todo el lío" que $\operatorname{armaban}^{121}$, ya que era la delegación de Auxilio Social la encargada de aprobar las solicitudes de las voluntarias con edades comprendidas entre los 17 y los 35 años interesadas en prestar el Servicio Social en los hospitales. Los directores de los mismos estaban obligados a admitirlas, a pesar de no haber sido elegidas por Mercedes Milá, por lo que la inspectora perdía autoridad ${ }^{122}$. De esta forma, el control sobre todo el personal auxiliar femenino de los hospitales generó conflictos entre ambas instituciones ${ }^{123}$.

Algunas enfermeras tuvieron problemas a la hora de recibir la convalidación de la prestación. Pilar Díaz, margarita navarra, después del trabajo desempeñado durante la guerra y de haber permanecido en el hospital de Oña hasta el final de la misma, recibió una carta en la que se le decía que debía hacer el Servicio Social ${ }^{124}$. María Luisa del Castillo expresaba que a pesar de ser voluntaria y de no haber recibido ningún tipo de remuneración durante la contienda, el trabajo realizado en la guerra no le permitió obtener el título del Servicio Social. No entendía que a sus

\footnotetext{
${ }^{119}$ AGMAV, C. 42068,2/95. Correspondencia de Mercedes Milá, 9 de octubre de 1938.

${ }^{120}$ AGMAV, C. 42069,2/52-53 y 77. Correspondencia de Mercedes Milá, 19 de julio y 18 de febrero de 1938.

${ }^{121}$ AGMAV, C. 42069,2/54. Correspondencia de Mercedes Milá, Sin fecha.

${ }^{122}$ AGMAV, C. 42069,5/50. Correspondencia de Mercedes Milá, 21 de mayo de 1938.

${ }^{123}$ AGMAV, C. 42069,5/49. Correspondencia de Mercedes Milá, 31 de mayo de 1938.

${ }^{124}$ LARRAZ ANDÍA, P; SIERRA-SESÚ MAGA, V: op.cit., p. 603.
} 
amigas de Falange "que salían una vez al mes con la hucha de la cuestación les sirvió de Servicio de Social", mientras que a las enfermeras no les convalidaron el mismo a pesar de haber prestado servicio en los hospitales durante el conflicto ${ }^{125}$.

Hubo enfermeras que trabajaron en los equipos quirúrgicos de vanguardia que se olvidaron de solicitar la exención del cumplimiento del Servicio Social ${ }^{126}$. Por eso, una vez finalizada la guerra, Mercedes Milá pidió que les fuera convalidado a las enfermeras de los hospitales militares que habían prestado servicio durante la Guerra Civil ${ }^{127}$. Este problema afectó principalmente al personal sanitario femenino de las provincias de reciente "liberación" nacional. Por ejemplo, desde Valencia se solicitó que se convalidara el Servicio Social a las 145 voluntarias que habían trabajado en los hospitales militares desde el 1 de abril de 1939 hasta el 10 de agosto del mismo año ${ }^{128}$.Una vez terminada la guerra, se dio por concluido el cumplimiento del Servicio Social en los hospitales, por lo que las interesadas tuvieron que ocupar otros puestos que no fueran los de enfermeras para poder llevarlo a cabo ${ }^{129}$.

\subsection{Trabajo desempeñado: nuevas inquietudes profesionales}

Entre los destinos preferidos por las enfermeras se encontraban los hospitales y los equipos quirúrgicos situados cerca del frente. Por eso, algunas optaron por ir como agregadas en lugar de titulares, aunque no figuraran en la plantilla ${ }^{130}$. Las delegadas en sus cartas oficiales recordaban a la inspectora que tenían "muy buenas enfermeras" dispuestas a ir al frente, por lo que solicitaban que Mercedes Milá las tuviera en cuenta ${ }^{131}$. Las que no eran convocadas para trabajar en vanguardia pasaban a formar parte de una lista para cubrir futuras plazas ${ }^{132}$. A pesar de todo, las enfermeras a través de sus delegadas provinciales, solicitaron de forma reiterada ser

\footnotetext{
${ }^{125}$ LARRAZ ANDÍA, P; SIERRA-SESÚ MAGA, V: op.cit., p.788.

${ }^{126}$ AGMAV, C. 46761,2/127. Correspondencia de Mercedes Milá, 21 de septiembre de 1939.

${ }^{127}$ AGMAV, C. 46761,2/131. Correspondencia de Mercedes Milá, 7 de agosto de 1940.

${ }_{128}$ AGMAV, C. 46761,2/133. Correspondencia de Mercedes Milá, 24 de julio de 1940.

${ }^{129}$ AGMAV, C. 42069,2/162. Correspondencia de Mercedes Milá, 28 de diciembre de 1939.

${ }^{130}$ AGMAV, C. 42069,2/7. Correspondencia de Mercedes Milá, 10 de noviembre de 1937.

${ }^{131}$ AGMAV, C. 42069,2/12. Correspondencia de Mercedes Milá, 20 de noviembre de 1937.

${ }^{132}$ AGMAV, C. 42069,2/1197. Correspondencia de Mercedes Milá, sin fecha.
} 
destinadas en los hospitales emplazados en el frente, prefiriendo desempeñar su labor en los quirófanos de los mismos, mejor que en las salas de enfermos ${ }^{133}$.

La reorganización de los hospitales y su personal femenino fue común a lo largo del conflicto, sobre todo en las poblaciones "liberadas". Inicialmente se necesitaron enfermeras internas que con el paso del tiempo se suplieron con monjas $\mathrm{y}$ auxiliares que terminaban los cursillos en la localidad ${ }^{134}$. Constantemente se solicitaban Hermanas de la Caridad $^{135}$, ya que su trabajo era apreciado por los directores de los centros, que fueron poco partidarios de la destitución de las mismas $^{136}$. De esta forma, las religiosas formaron parte del personal femenino sanitario de los hospitales nacionales, siendo las Madres Superioras las que ocuparon los puestos de responsabilidad encargadas del control de las enfermeras y del buen funcionamiento hospitalario. No obstante, la supervisión que ejercieron sobre su plantilla, en ocasiones, generó problemas ${ }^{137}$ :

La Hermana mira por debajo de las camas a ver si nos dejamos algo. [...]Rezamos un poco; hay respeto, porque la voz de la Hermana y las palabras de la oración lo imponen, aunque muchos no conozcan el rezo ${ }^{138}$.

Las hermanas debían encargarse de las guardias nocturnas, acompañadas en su labor por las enfermeras ${ }^{139}$. Cuando disminuyó el número de heridos en los diferentes hospitales se retiró a las enfermeras para ubicarlas en puestos donde fueran más útiles y se quedaron a cargo de los mismos las religiosas ${ }^{140}$. Cada vez que se inauguraba un nuevo centro se solicitaban hermanas para cubrir los puestos vacantes $^{141}$, ya que consideraban que "las enfermeras solas eran una pega para

\footnotetext{
133 BEeCham, MONOGRAFÍAS: op.cit., en MAZO BurÓn, Luis: Hospital de Sangre de Retaguardia. Actuación de un médico durante la guerra civil española, p. 252.

${ }^{134}$ AGMAV, C. 42069,2/274. Correspondencia de Mercedes Milá, 13 de enero de 1938.

${ }^{135}$ AGMAV, C. 42069,2/275 a 280. Correspondencia de Mercedes Milá.

${ }^{136}$ AGMAV, C. 42069,2/311 a 317. Correspondencia de Mercedes Milá, 1937.

${ }^{137}$ AGMAV, C. 42069,2/119. Correspondencia de Mercedes Milá, 26 de noviembre de 1937.

${ }^{138}$ Y: revista de la mujer nacional sindicalista, abril 1938, Sala de la enfermera provisional, p. 39.

${ }^{139}$ AGMAV, C. 42069,2/140. Correspondencia de Mercedes Milá, 17 de agosto de 1938.

${ }^{140}$ AGMAV, C. 42069,2/211. Correspondencia de Mercedes Milá, 28 de julio de 1937.

${ }^{141}$ AGMAV, C. 42069,2/220. Correspondencia de Mercedes Milá, 4 de junio de 1939.
} 
todo" ${ }^{142}$. Las monjas estaban en las salas y dirigían los pabellones militares ${ }^{143}$, por lo que fue necesario su reparto equitativo en los diferentes hospitales. A pesar de todo, en ocasiones no fue así y centros de 160 camas contaron con dos hermanas y otros de 240 tuvieron cinco ${ }^{144}$. Relatos como los de José Llordés dejan constancia de la labor organizativa que desempeñaron las religiosas:

Sor Micaela era la más adecuada para proveer la "intendencia" del hospital. Poco le costaba coger algún coche y darse un paseo por los pueblos cercanos pidiendo víveres para los soldados heridos que tenían en el hospital; [...]. Estaba hecha a propósito para estas cosas y siempre sacaba algo; nunca nos faltaba leche, arroz, judías, patatas, huevos, conejos, pollos, algún cabrito o lechones de tres o cuatro semanas, chocolate, pastas y otras cosas ${ }^{145}$.

En los hospitales de Cruz Roja, todo el personal de Enfermería, tanto religiosas como seglares, estaba bajo la supervisión de la Madre Superiora, siendo ésta la responsable ante el director del cumplimiento de sus órdenes y de que todos los servicios estuvieran debidamente atendidos. Solían hacer la solicitud de personal para cubrir las plazas vacantes, para después distribuirlo entre las diferentes salas. También designaron a las "jefas de servicios de acuerdo con las necesidades del mismo y las aptitudes de cada una, pudiendo recaer estos cargos en enfermeras tanto religiosas como seglares". Además de la gestión de personal, la Madre Superiora debía velar por "la salud y por el bienestar moral y físico de todas las enfermeras bajo sus órdenes". En caso de observar alguna infracción que fuera motivo de cese, debía comunicarlo al director del centro y a la inspectora ${ }^{146}$.

Las enfermeras profesionales desempeñaron su labor en las salas de hospitalización y quirófanos, siendo las que ocuparon los puestos de jefas de Enfermería. Además de organizar el trabajo, anotar las prescripciones y órdenes médicas, también se encargaron de las curas principales, de poner inyecciones intravenosas y de instrumentar en quirófano. María Teresa Arellano Dihinx, jefa de

\footnotetext{
${ }^{142}$ AGMAV, C. 42069,2/225. Correspondencia de Mercedes Milá, 23 de julio de 1939.

${ }^{143}$ AGMAV, C. 42069,2/239. Correspondencia de Mercedes Milá, 7 de diciembre de 1938.

${ }^{144}$ AGMAV, C. 42069,3/208. Correspondencia de Mercedes Milá, 15 de diciembre de 1938.

${ }^{145}$ LLORDÉS BADÍA, J: op.cit., p. 113.

${ }^{146}$ ACCRE. Caja 2532, Exp. 8. Sección de enfermeras 1937. Instrucciones para la organización de los servicios de enfermeras.
} 
enfermeras, explicaba que hacían "de todo: vendajes, inyecciones, colocar yesos, sacar esquirlas de metralla y unas curas que se me ponía la carne de gallina solo de recordarlas" ${ }^{\prime 147}$. La enfermera jefe o responsable de la sala, era la encargada de acompañar al médico durante la visita a los heridos. Después, según el trabajo de la sala, enseñaba a las auxiliares a poner inyecciones, hacer curas y vendajes ${ }^{148}$. Eran las "responsables ante el médico del más exacto cumplimiento de todas sus órdenes, debiendo darle cuenta de cuantos cambios observen en los enfermos". También debían exponer ante la superiora la "buena marcha de los servicios de orden, limpieza y economía". Distribuyeron el trabajo de las salas entre el personal adscrito al mismo, "exigiendo a éste la más absoluta puntualidad, formalidad, disciplina, economía y orden". La organización de turnos debían hacerla de forma conjunta con la superiora. También fueron las responsables de la "asistencia moral y espiritual de todos sus enfermos ${ }^{149}$, procurando tener siempre los nombres y direcciones de sus familiares más allegados para en caso de gravedad o defunción poderlos proporcionar al director". Cuando se evacuaba el centro hospitalario, debían procurar que toda la información sobre el proceso clínico del enfermo (historia, analíticas y radiografías), no se perdiera y se trasladara con el herido. Fueron las encargadas de la recepción de pacientes evacuados, durante la que debían reunir los datos clínicos "para dar cuenta de ello al médico en su primera visita"

María del Socorro, como jefa, tenía a su cargo cuatro salas de unas quince camas cada una, con seis enfermeras y dos enfermeros seminaristas a su cargo. Explicaba que la jornada comenzaba a las ocho y media y como responsable debía permanecer todo el día en la sala. La dedicación era plena, los domingos y festivos también acudían al hospital:

A primera hora iba repartiendo termómetros en un vaso de alcohol, anotaba las temperaturas, y a continuar. Luego las medicinas: aspirinas, optaloides, las

\footnotetext{
${ }^{147}$ LARRAZ ANDÍA, P; SIERRA-SESÚ MAGA, V: op.cit., p. 144.

148 AGMAV, C. 42067,2/46-47. Correspondencia de Mercedes Milá, 19 de septiembre de 1937.

149 Ante los heridos musulmanes se abstuvieron de toda acción de proselitismo religioso.

${ }^{150}$ ACCRE. Caja 2532, Exp. 8. Sección de enfermeras 1937. Instrucciones para la organización de los servicios de enfermeras.
} 


\section{Capítulo V}

pastillas contra el paludismo... Escribir las evoluciones, las incidencias... era toda labor mía y, mientras, mis compañeras sin parar con las camas, las limpiezas, los desayunos... para que estuviera todo listo para la visita. Luego iba con mi libreta siguiendo al médico y apuntando todas las órdenes y normas que me daban. Y vuelta a distribuir el trabajo entre las compañeras, según lo que supieran hacer, mientras yo me encargaba principalmente de las curas más gordas, aunque siempre estaba pendiente procurando llevar el control de todo ${ }^{151}$.

La jornada laboral de las enfermeras difería un poco de la de las jefas de sala:

Lo primero que hacíamos todos los días al llegar era dar los buenos días a los heridos, cama por cama. Luego a darles el desayuno, hacer las camas, tomar temperaturas, repartir las medicinas, asear a los que no se podían levantar, cambiar los vendajes... y luego preparar el material, porque en cada sala había un carro de curas, un botiquín y un hornillo que usábamos para la desinfección de las agujas y las jeringuillas ${ }^{152}$.

También se encargaron de "tomar la filiación a todos los soldados que entraban en el hospital, tanto heridos como enfermos" y de anotar las constantes en la ficha de cada paciente ${ }^{153}$.

Las voluntarias movilizadas se tuvieron que encargar de habilitar los hospitales del frente:

[...] Limpiamos la habitación que sería la sala de operaciones, fregamos el piso y los muebles y desembalamos las cosas. [...] Durante toda la tarde Consuelo y yo estuvimos de rodillas con baldes de agua, fregando el suelo, que estaba recubierto de una gruesa capa de lodo e inmundicia. [...] por último llegaron los camiones con unas cuarenta camas y algunas enfermeras muy cansadas. Trabajamos entonces cómo locos, distribuyendo las camas y acondicionándolas, hasta las dos de la mañana. $[\ldots]^{154}$

\footnotetext{
${ }^{151}$ LARRAZ ANDÍA, P; SIERRA-SESÚ MAGA, V: op.cit., p. 800

${ }^{152}$ Ibid., p.786.

${ }^{153}$ LLORDÉS BADÍA, J: op.cit., p. 253.

${ }^{154}$ SCOTT-ELLIS, P: op.cit., p.73.
} 
Los turnos de trabajo e incluso la organización del mismo dependieron del tipo de hospital. En los puestos de socorro, si era preciso, la enfermera debía acudir a la zona de fuego a atender a los heridos, si no, los recibía en el mismo puesto, realizaba las primeras curas y después ayudaba en el traslado al hospital de sangre:

Yo quedé con una ambulancia en el Puesto de Socorro en la carretera: más allá de Cerezo de Abajo, donde se inicia la subida del puerto. [...]Agazapada en la cuneta, con la cabeza entre las zarzas, sin comer en todo el día, bajo el efecto de la modorra de un sol de justicia y arrullada con el mosconeo de los motores de los aparatos rojos, me quedé dormida. Cuando, a media tarde, me despertaron, fue para decirme que tenía que curar al primer herido. El Capitán Médico y yo, atravesando rastrojos, fuimos hasta una caseta de ferrocarril: allí estaba un teniente con el brazo $\operatorname{roto}^{155}$

En los hospitales de sangre instalados en poblaciones cercanas al frente se recibía a los heridos del mismo campo de batalla, en ambulancias o en camiones con "un revoltijo de carne humana"156. Por lo que el trabajo dependía del resultado de las ofensivas y de las bajas ocasionadas tras las mismas. En los hospitales de vanguardia también hubo salas para soldados enfermos de sífilis y tuberculosis ${ }^{157}$.

Respecto a los horarios y turnos de trabajo, las noches en vela se contaban como un día de trabajo ${ }^{158}$. La sobrecarga laboral y las guardias nocturnas se prolongaron a lo largo del conflicto, perdiendo algunas voluntarias el entusiasmo por su tarea que se veía en "faltas de asiduidad" y de constancia sin que se pudieran tomar medidas coercitivas ${ }^{159}$. Es complejo establecer una jornada concreta ya que dependía del hospital y de la carga de trabajo. En ocasiones fue de nueve de la mañana a nueve de la noche, seguido de un descanso de veinticuatro horas, dentro de un turno rotatorio. En otros centros la jornada era de ocho de la mañana hasta que caía la noche y las enfermeras se iban a sus casas. En cambio, el trabajo realizado en

\footnotetext{
${ }^{155}$ URRACA PASTOR, M. R: op.cit., p.18.

${ }^{156}$ LARRAZ ANDÍA, P; SIERRA-SESÚ MAGA, V: op.cit., p.599.

${ }^{157}$ Idid., p. 603.

${ }^{158}$ AGMAV, C. 42069,2/15. Correspondencia de Mercedes Milá, 17 de noviembre de 1938.

${ }^{159}$ AGMAV, C. 42069,2/138-139-140. Correspondencia de Mercedes Milá, 13 y 17 de agosto de 1938.
} 


\section{Capítulo V}

vanguardia dependía completamente de las ofensivas y de sus consecuencias, por lo que el horario era flexible y las enfermeras se tenían que adaptar a las demandas del frente, llegando a trabajar día y noche:

[...] Hacia las cuatro lo teníamos todo arreglado y estábamos considerando la posibilidad de un merecido descanso cuando vino una ambulancia con cuatro pacientes graves. Antes de que pudiéramos atenderlos llegaron cinco más, y así continuó toda la noche. [...] Operando uno tras otro, las ambulancias llegando continuamente con camillas de gente que gemía y yo metida entre ellas detrás del nuevo teniente Mirat, agarrando un fajo de compresas en una mano y llevando tablillas y algodón hidrófilo en la otra, con los bolsillos llenos de vendas, esparadrapos, tijeras, etc. Consuelo daba frenéticamente las inyecciones antitétanos"160.

Las urgencias disminuían cuando no había ofensivas y únicamente se atendía a los pacientes hospitalizados ${ }^{161}$.

El número de camas y personal hizo que las cargas de trabajo también variaran. Por ejemplo, una de las salas el hospital San Carlos tenía unas sesenta camas y cinco enfermeras por turno ${ }^{162}$. El hospital de Alhama, en Aragón, cerca del frente, tenía ciento diez camas, e inicialmente contó con tres enfermeras ${ }^{163}$, por eso, solicitaron setenta enfermeras en $1937^{164}$. De esta forma, durante la contienda hubo ocasiones en las que fue insuficiente el número de auxiliares, damas y hermanas para cubrir las necesidades asistenciales, por eso, en la correspondencia de Mercedes Milá se suceden las solicitudes de personal femenino sanitario ${ }^{165}$. Hospitales de doscientas camas fueron gestionados por una única enfermera, sobre todo al inicio de la contienda cuando no había suficientes auxiliares y las hermanas no eran

\footnotetext{
${ }^{160}$ SCOTT-ELLIS, P: ob.cit., p.85.

${ }^{161}$ Ibid., p.55.

${ }^{162}$ LARRAZ ANDÍA, P; SIERRA-SESÚ MAGA, V: op.cit., p. 786.

163 SCOTT-ELLIS, P: op.cit., p. 48.

164 AGMAV, C. 42069,3/237. Correspondencia de Mercedes Milá, 12 de diciembre de 1937.

${ }^{165}$ AGMAV, C. 42067,2, Correspondencia de Mercedes Milá, 12 de enero de 1939.
} 
capaces de soportar solas toda la carga de trabajo ${ }^{166}$. El número máximo de enfermeras que debía tener todo equipo quirúrgico hospitalario era de tres ${ }^{167}$, se daba por hecho que dos hermanas y tres enfermeras eran suficiente personal para atender las necesidades del mismo ${ }^{168}$. La solicitud de enfermeras tituladas para cubrir los puestos de vanguardia fue común a lo largo del conflicto, prefiriendo a aquellas que ya tuvieran experiencia en el trabajo:

[...] Ante la necesidad de velar por el buen funcionamiento del hospital encomendado a mi dirección y en vista de la imposibilidad de solucionar con el personal femenino voluntario de este pueblo los problemas que diariamente se presentan, que requieren el concurso de personas expertas y conocedoras de nuestro medio y nuestros reglamentos, me atrevo a molestarla para suplicarle que vea el modo de enviarnos, por lo menos, seis señoritas enfermeras, que ya hayan estado en otros hospitales y sepan gobernar salas de enfermos y heridos, $[\ldots]^{169}$

La falta de material y medios fue una constante durante toda la guerra, que tuvo sus repercusiones en el trabajo de las enfermeras. Escasearon las toallas, sábanas y tela blanca necesaria para la confección de uniformes. Los envíos se extraviaban y no llegaban a sus destinos, por lo que tenían que emprender nuevas gestiones para recuperarlos ${ }^{170}$. Siempre era buena noticia la llegada de sábanas y orinales de cama (conejos y cuñas) ${ }^{171}$ que facilitaban la labor asistencial e higiénica de los heridos. Cruz Roja se enfrentó a la falta de material gracias a la colaboración de una asociada que desde París localizaba el material solicitado por la institución, especialmente por la Duquesa de la Victoria, para enviarlo a España ${ }^{172}$ (ver anexo XXXII).

\footnotetext{
${ }^{166}$ AGMAV, C. 42069,3/64. Correspondencia de Mercedes Milá, 16 de septiembre de 1937.

${ }^{167}$ AGMAV, C. 42069,3/135. Correspondencia de Mercedes Milá, 19 de marzo de 1939.

${ }^{168}$ AGMAV, C. 42069,3/138. Correspondencia de Mercedes Milá, 10 de noviembre de 1937.

169 AGMAV, C. 42067,2/46-47. Correspondencia de Mercedes Milá, 19 de septiembre de 1937.

${ }^{170}$ AGMAV, C. 42069,2/14. Correspondencia de Mercedes Milá, 12 de agosto de 1937.

${ }^{171}$ AGMAV, C. 42069,2/268. Correspondencia de Mercedes Milá, 13 de septiembre de 1937.

172 ACCRE, Caja 994, Exp. 4. Presidencia de enfermeras y hospitales, mandato de la Duquesa de la Victoria. 8 de abril de 1938 .
} 


\section{Capítulo V}

Respecto a los alojamientos, las enfermeras movilizadas, en ocasiones tuvieron que hospedarse en condiciones penosas, ya que no contaron con ningún tipo de privilegio. En la mayoría de los casos compartieron habitación y colchón, otras tuvieron que dormir en el mismo centro habilitado como hospital y las más afortunadas se alojaron en casas cercanas al hospital. Hubo habitaciones para cinco enfermeras, sin agua, ni cristales en las ventanas, con una vela como luz y un baño que debían compartir con los soldados, además de tener que dormir en el suelo ${ }^{173}$. No tuvieron comodidades, pasaron frio, hambre, en la mayoría de las ocasiones no tenían luz eléctrica y únicamente disponían de velas que dificultaban su trabajo nocturno:

Nuestro habitáculo es diminuto, una habitación para dos lechos, una lacena y un lavabo, sin calefacción ni agua caliente y muy poca luz, pero para un hospital es muy lujoso, lo esperábamos mucho peor. Esta mañana nos levantamos a las $8.30 \mathrm{y}$ casi nos morimos de frío. Tomamos una taza de café y fuimos al otro hospital a ver si la Madre Superiora tenía algún trabajo para nosotras $[\ldots]^{174}$

La falta de medios, principalmente de agua, impedía la higiene diaria, los uniformes estaban sucios y negros, los rostros polvorientos y el pelo enredado y sin lavar. Prisicilla llegó a pasarse quince días sin lavarse los pies y tuvo que esperar dos meses para poder darse un buen baño ${ }^{175}$.

Los puestos de socorro, carecieron de luz eléctrica, eran lugares de escasa ventilación y falta de limpieza, impregnados de un olor desagradable. En Somosierra, la putrefacción de los cadáveres contaminaba las aguas, los heridos estaban hacinados y la falta de agua y alcohol impedía que las enfermeras se lavaran las manos después de atenderlos ${ }^{176}$.

Los testimonios de las margaritas reflejan la carencia de material y medicinas que existió durante el conflicto. Para evitar la falta de vendas, las monjas cocían las

\footnotetext{
${ }^{173}$ SCOTT-ELLIS, P: op.cit., p. 51.

${ }^{174}$ Ibid., pp.47-48.

${ }^{175}$ Ibid., pp. 56 y 92.

${ }^{176}$ URRACA PASTOR, M.R: op.cit., p.40.
} 
que ya se habían utilizado y las enfermeras las enrollaban para volver a emplearlas en nuevas curas:

Había escasez, y lavábamos las vendas todos los días: las poníamos en unos barreños a remojar en lejía, luego las lavábamos, las tendíamos en la terraza, y a la mañana siguiente, a enrollarlas. Teníamos destreza en eso: cogíamos la punta de la venda y enrollábamos con la palma de la mano hasta hacer fajardillo, y a por otra. Así otra vez la venda limpia y desinfectada, para ponérsela a otro, porque una nueva era un lujo ${ }^{177}$.

A pesar de las dificultades impuestas por la situación bélica, las enfermeras desempeñaron una labor "encomiable y magnífica". Las condiciones climatológicas adversas, sobre todo el temporal de nieve, no impidieron que cumplieran con su trabajo "haciendo algunas el viaje a pie o en camioneta descubierta demostrando un alto espíritu patriótico" 178 . Los hospitales estaban llenos de enfermos y las cargas de trabajo aumentaban, pero las enfermeras respondieron "admirablemente" produciendo "plena satisfacción" en sus delegadas ${ }^{179}$. Su esfuerzo fue reconocido por Mercedes Milá que no dudó en felicitarlas por su "abnegado comportamiento" y mostrarles la satisfacción que le produjo esa "prueba de elevado espíritu" "

El trabajo duro y diario del hospital unió a las enfermeras, que compartieron momentos difíciles y muchas horas de trabajo. A pesar del cansancio o las desgracias, sabían apreciar los buenos momentos y disfrutar de ellos. Algunas amigas se presentaron juntas como voluntarias, llenas de ilusión ${ }^{181}$, otras forjaron su amistad durante el conflicto ${ }^{182}$. Algunos hospitales, como el de San Carlos, se convirtieron en centros de una "alegría femenina", ya que casi todo el personal eran mujeres que hacían su trabajo con cariño y confianza, dentro de la familiaridad y

\footnotetext{
${ }^{177}$ LARRAZ ANDÍA, P; SIERRA-SESÚ MAGA, V: ob.cit., p. 800.

${ }^{178}$ AGMAV, C. 42069,2/207. Correspondencia de Mercedes Milá, 29 de diciembre de 1938.

${ }^{179}$ AGMAV, C. 42069,2/42. Correspondencia de Mercedes Milá, 18 de enero de 1938.

${ }^{180}$ AGMAV, C. 42069,2/206. Correspondencia de Mercedes Milá, 10 de enero de 1939.

${ }^{181}$ LARRAZ ANDÍA, P; SIERRA-SESÚ MAGA, V: op.cit., p. 785.

${ }^{182}$ Priscilla Scott-Ellis no se separó hasta el final de su amiga y compañera Consuelo Osorio. Hicieron juntas el curso de capacitación de enfermeras en Jerez y desde ese momento fueron inseparables, compartiendo destino y trabajo en los distintos hospitales.
} 
disciplina. Entre las enfermeras "todo era alegría y voluntad, nos parecía que estábamos salvando a España y, cuando se ha vivido lo que nos toco vivir, una no puede olvidar aquel hospital ${ }^{183}$.

Respecto a los periodos de descanso, Mercedes estableció que en caso de que los permisos fueran de más de quince días, las enfermeras que los solicitaran serían sustituidas definitivamente en su puesto de trabajo ya que la organización del personal del hospital no podía estar a "merced del veraneo de las señoritas". Para la inspectora era "improcedente y antipatriótico abandonar el cuidado y la atención de los bravos" solados que defendían al pueblo "sin desmayarse ni irse a veranear". Únicamente podían darse permisos de descanso cuando no afectaran al funcionamiento del servicio y siempre que se pusieran de acuerdo entre ellas para no coincidir $^{184}$.

\subsection{Conflictos laborales y políticos}

Los hospitales y su personal se enfrentaron a diversos conflictos, muchas veces burocráticos $\mathrm{y}$ otras personales. El trabajo dentro de un equipo multidisciplinar, enfrentarse a la sobrecarga laboral y a situaciones de estrés, unido a al hecho de tener que pasar juntos muchas horas, generó diferentes ambientes laborales. Hubo casos en los que las enfermeras trabajaron bien y parecían “compenetradas con los médicos", mientras que en otros se las dejaba en un segundo plano, dando todas las competencias a las hermanas ${ }^{185}$. Catalogar como "inepto, inservible e ineducado" al personal femenino destinado, generó tensiones entre las delegadas de Sanidad Militar, que de forma precipitada, emitieron juicios de este tipo, desacreditando la decisión tomada por Mercedes Milá en esos nombramientos ${ }^{186}$. Respecto a las enfermeras movilizadas, estaba claro que únicamente podían residir como internas y recibir alojamiento y manutención aquellas que designara la inspectora, pero hubo ocasiones en las que los hospitales

\footnotetext{
${ }^{183}$ LARRAZ ANDÍA, P; SIERRA-SESÚ MAGA, V: op.cit., p. 150.

${ }^{184}$ AGMAV, C. 42069,3/266. Correspondencia de Mercedes Milá, 3 de julio de 1938.

185 AGMAV, C. 42069,2/20. Correspondencia de Mercedes Milá, 11 de mayo de 1938.

${ }^{186}$ AGMAV, C. 42068,4/13. Correspondencia de Mercedes Milá, 7 de agosto de 1938.
} 
se vieron obligados a acoger a mujeres que no cumplían dichos requisitos obedeciendo órdenes de los gobernadores o personas influyentes de la plaza donde estaban instalados ${ }^{187}$.

Las desavenencias entre compañeras o las inconformidades con el tipo de trabajo se solventaron con nuevos nombramientos y destinos. En estos casos las enfermeras dejaron sus puestos y solicitaron traslado a otras unidades ${ }^{188}$. Priscilla Scott-Ellis, en su diario deja clara la animadversión que sentía hacia algunas de las compañeras con las que tuvo problemas. Explicaba que en algunos equipos quirúrgicos existía mal ambiente, a veces a causa del jefe del mismo y otras, entre médicos y enfermeras ${ }^{189}$.

Los conflictos entre el personal sanitario de los hospitales también afectaron a las religiosas. Fue habitual evitar que congregaciones diferentes coincidieran en un mismo hospital para impedir "rozamientos que pudieran surgir entre ellas"190. En algunas ocasiones las relaciones entre la delegada nombrada por Mercedes y la dirección del centro fueron complejas, sobre todo con la Madre Superiora, en cuanto a líneas de autoridad se refiere ${ }^{191}$. En la escala jerárquica las inspectoras o delegadas tanto provinciales como regionales, estaban por encima de las madres superioras que eran las que ejercían la labor directa de supervisión en los hospitales sobre las enfermeras. Las superioras en ocasiones actuaron sin tener en cuenta a las delegadas nombradas por Mercedes, cesando o sancionando a las enfermeras que a sus ojos eran indisciplinadas a pesar de haber sido elegidas para el puesto por su buena "conducta personal, su piedad, rectitud y educación" $" 192$. A veces las superioras eran “difíciles de llevar" pero con diplomacia se terminaba por solucionar los $\operatorname{conflictos}^{193}$.

\footnotetext{
${ }^{187}$ AGMAV, C. 42069,3/66 a 68. Correspondencia de Mercedes Milá, 10 de marzo de 1938.

${ }^{188}$ AGMAV, C. 42069,2/99. Correspondencia de Mercedes Milá, 7 de septiembre de 1938.

${ }^{189}$ SCOTT-ELLIS, P: op.cit., pp. 115 a 123.

${ }^{190}$ AGMAV, C. 42069,3/239. Correspondencia de Mercedes Milá, 3 de junio de 1937.

${ }^{191}$ AGMAV, C. 42069,2/114. Correspondencia de Mercedes Milá, 12 de junio de 1938.

${ }^{192}$ AGMAV, C. 42069,2/183. Correspondencia de Mercedes Milá, 21 de febrero de 1938.

${ }^{193}$ AGMAV, C. 42069,2/288. Correspondencia de Mercedes Milá, 13 de marzo de 1940.
} 
En el Hospital Militar del Seminario de Vitoria, hubo bastantes problemas con las monjas y la dirección del centro. La delegada, Purificación Canosa, siguiendo la disciplina militar, se vio obligada a ceder para evitar mayores conflictos, ciñéndose al reglamento que especificaba que las superioras eran las jefas de enfermeras dentro del hospital ${ }^{194}$. Mercedes fue partidaria de "suavizar las cosas y no agriarlas" instándola a gestionar los otros hospitales de Vitoria para que se aplacaran los ánimos, mientras la madre se ocupaba de arreglar el conflicto interno con sus monjas ${ }^{195}$. A pesar de todo, las enfermeras también tuvieron desavenencias con las religiosas del Seminario durante su trabajo a las que las calificaban de "insoportables". El director del centro había emitido una orden en la que prohibía a las enfermeras hacer curas, especificando que únicamente debían hacer las camas, por lo que las desplazaba del puesto que realmente debían ocupar. Había sido siempre reacio a tener una plantilla de internas ya que prefería cubrir las vacantes con hermanas. Reconocía la valía de la mayoría de las enfermeras destinadas en su centro, aunque consideraba que a algunas había que "estimularlas en el servicio" mientras que otras eran "ligeras de cascos"196. También prohibió a la delegada la entrada en los hospitales de Vitoria y llevar el uniforme de enfermera, mientras que permitía que sus hijas le asistieran en el quirófano y pusieran inyecciones a pesar de vestir de calle ${ }^{197}$. Seguramente el conflicto estuvo ocasionado más por motivos personales que burocráticos. Purificación Canosa había trabajado anteriormente como enfermera en el centro y en el dispensario demostrado su valía y su cualificación, el director estaba contento con su trabajo y no quería que dejara su puesto en el hospital ${ }^{198}$.

Las enfermeras tampoco percibieron del mismo modo la asistencia a los heridos, sabían que todos eran iguales y tenían derecho a los mismos cuidados, por lo que no podían hacer ningún tipo de distinción entre ellos. Pero reconocían que no era lo mismo atender a falangistas, requetés o legionarios, que a marroquíes y

\footnotetext{
${ }^{194}$ AGMAV, C. 42069,2/188. Correspondencia de Mercedes Milá, 12 de marzo de 1938.

195 AGMAV, C. 42069,2/193. Correspondencia de Mercedes Milá, 9 de marzo de 1938.

${ }^{196}$ AGMAV, C. 42069,2/256. Correspondencia de Mercedes Milá, 7 de diciembre de 1937.

197 AGMAV, C. 42069,2/190-191. Correspondencia de Mercedes Milá, 19 de marzo de 1938.

198 AGMAV, C. 42069,2/199. Correspondencia de Mercedes Milá, 9 de febrero de 1938.
} 
republicanos ${ }^{199}$. Por eso no encontraron muchas enfermeras dispuestas a atender la sala del hospital dedicado a los prisioneros de guerra, porque no querían estar con "los heridos rojos". Pilar Díaz Iribarren, margarita navarra, se presentó como voluntaria para cuidar a los heridos republicanos, entre los que no se hacía ningún tipo de diferenciación en la prestación de cuidados:

Allí no se lucía el uniforme, ni había visitas... solo penas, tristezas y muchos piojos. Sin embargo, pude hacer mucho bien en cuerpos y almas. Dentro del hospital, los heridos no estaban separados ni por una cortina: misma comida para todos, mismo médico, mismo trato... todo igual, porque éramos cristianos. La única diferencia era que los heridos nacionales podían salir a pasear por el pueblo y los prisioneros no salían de la sala, donde había en la puerta dos soldados con mosquetón y bayoneta calada ${ }^{200}$.

Priscilla, en su diario refleja su animadversión hacia los heridos marroquíes. De hecho, explicaba que el amor a su trabajo fue lo que le permitió tolerar el comportamiento de algunos de ellos:

Empiezo a detestar a los moros. Son tan pesados, siempre peleando y gritándote. [...] Cada vez que terminaba de poner un vendaje se lo quitaban y querían otro de distinta medida. [...] sin embargo me encanta el trabajo; aun cuando llego a tener intensa antipatía hacia esa gente, me siguen interesando sus heridas ${ }^{201}$.

La condición sexual de las enfermeras en ocasiones generó problemas a la hora de atender a los heridos. Socorro Viscarret, explicaba que en el Hospital Alfonso Carlos de Pamplona, también trabajaban enfermeros seminaristas, que se encargaban de la movilización de los heridos y de acompañarlos al baño por delicadeza, para que no pasaran vergüenza. De hecho en el hospital existía una sala prohibida para las voluntarias, la de los pacientes con enfermedades venéreas, que era atendida por los enfermeros ${ }^{202}$.

\footnotetext{
${ }^{199}$ URRACA PASTOR, M.R: op.cit., p.39.

${ }^{200}$ LARRAZ ANDÍA, P; SIERRA-SESÚ MAGA, V: op.cit., p. 600.

${ }^{201}$ SCOTT-ELLIS, P: op.cit., pp. 29-30.

${ }^{202}$ LARRAZ ANDÍA, P; SIERRA-SESÚ MAGA, V: op.cit., p. 787.
} 
Los conflictos entre las organizaciones de diferente filiación política encargadas de la asistencia sanitaria también fueron comunes. Sección Femenina contribuyó a la formación temprana de enfermeras para cubrir las necesidades del frente y coordinó la ayuda voluntaria, pero no tuvo todo el control sobre la delegación de Frentes y Hospitales. A pesar de que las margaritas ocupaban puestos de responsabilidad y trabajaban duramente como enfermeras, Pilar Primo de Rivera se quejó de la falta de cooperación de las tradicionalistas. En un informe redactado por Pilar después de la unificación política bajo el mando de Franco encomiaba "la labor interrumpida de la Sección Femenina en los hospitales y en la sección de lavaderos de los frentes de batalla" sin hacer alusión ni a la sección de Frentes y Hospitales ni al trabajo desempeñado por las margaritas ${ }^{203}$. Ese enfrentamiento entre ambas organizaciones queda plasmado en los testimonios de las margaritas navarras:

Tuvimos nuestros roces con Falange. Pasó lo mismo que ocurrió en tantos sitios: el día 19 de julio no había más de un centenar de falangistas en Pamplona, y al mes había miles. Les llamábamos "los atunes", azules por afuera y rojos por dentro $^{204}$.

Inicialmente las voluntarias de Frentes y Hospitales eran carlistas, pero con el aumento del número de asociadas de Sección Femenina, la organización contó afiliadas de ambos tipos. A pesar de todo, hubo hospitales como el Alfonso Carlos de Navarra en el que únicamente trabajaron margaritas. La división que existió entre ambas organizaciones tuvo consecuencias negativas para las margaritas cuya animadversión hacia Falange hizo que la consideraran "refugio de pecadores" 205.

Finalizada la guerra, se disolvió Frentes y Hospitales, posteriormente se cerraron los Círculos Carlistas, llegando incluso a clausurar la Academia Alfonso Carlos fundada por las margaritas:

\footnotetext{
${ }^{203}$ RICHMOND. K: op.cit., p.135.

${ }^{204}$ LARRAZ ANDÍA, P; SIERRA-SEsÚ MAGA, V: op.cit., p. 150.

${ }^{205}$ Ibid., p. 600.
} 
El régimen no se portó bien, ni fue agradecido con los carlistas, que tanto habíamos luchado durante la República y en la guerra. Si citase la lista de ingratitudes e injusticias mi narración sería interminable ${ }^{206}$.

Dentro de la disputa por el monopolio del trabajo de las mujeres, Sección Femenina también tuvo conflictos entre sus delegadas y las de Sanidad Militar. La rama femenina de Falange quiso nombrar sus propias enfermeras jefes para que se hicieran cargo del personal femenino de la organización que trabajaba en los hospitales militares y obtener así un parte diario de la situación sanitaria. De esta forma la única autoridad para las afiliadas dentro del hospital sería la regidora provincial de Falange. También propusieron que sus enfermeras utilizaran un uniforme diferente que las diferenciara del resto, medida que finalmente no se llevó a cabo. Esta situación propiciaría una división de poderes, ya que por un lado estaría la delegada de la Inspección General de Sanidad elegida por Mercedes Milá, y por otro la de Falange ${ }^{207}$. Aún así, el cargo de delegada de Sanidad Militar fue compatible con el de regidora provincial de enfermeras de Falange. Rosario Gaminde ostentó los dos puestos en Bilbao con el permiso de Mercedes Milá que consideraba que era mejor que la inspección recayera en la misma persona, lo que facilitaría el trabajo entre ambas instituciones ${ }^{208}$. A pesar de todo, para Sección Femenina, las delegadas de Sanidad no tenían "autoridad para dar de baja a ninguna enfermera que perteneciera a Falange" ${ }^{, 209}$. Información completamente errónea, ya que "ningún otro organismo puede inmiscuirse en el funcionamiento interior de los hospitales militares". Tampoco tenían la obligación de comunicar a Falange los nombramientos, lo hacían por deferencia ${ }^{210}$. Aunque fue común que Sección Femenina solicitara a las delegadas provinciales la relación numérica de enfermeras y auxiliares movilizadas en los diferentes hospitales ${ }^{211}$.

\footnotetext{
${ }^{206}$ LARRAZ ANDÍA, P; SIERRA-SESÚ MAGA, V: op.cit., p. 588.

${ }^{207}$ AGMAV, C. 42068,4/257-260. Correspondencia de Mercedes Milá, 22 de abril de 1938.

${ }^{208}$ AGMAV, C. 42069,2/38. Correspondencia de Mercedes Milá, 4 de marzo de 1938.

${ }^{209}$ AGMAV, C. 42068,3/110. Correspondencia de Mercedes Milá, 2 de julio de 1939.

${ }^{210}$ AGMAV, C. 42068,3/112. Correspondencia de Mercedes Milá, 12 de julio de 1939.

${ }^{211}$ AGMAV, C. 42069,2/5. Correspondencia de Mercedes Milá, 10 de agosto de 1937.
} 
Mercedes Milá tuvo que trabajar conjuntamente con la rama de Frentes y Hospitales por la complementariedad de su labor en determinados campos, pero Sanidad Militar fue la que gestionó siempre el trabajo de las enfermeras y sus nombramientos:

Respecto a la lista de enfermeras apuntadas en Frentes y Hospitales para entrar en Madrid a V. exclusivamente toca seleccionar las que he de designar oficialmente y que serán las que únicamente irán. La delegada de Frentes y Hospitales no tiene la facultad de hacerlo y por consiguiente escoja V. aquellas que me dice merecen su entera confianza y reúnen las condiciones necesarias o propóngame otras que $\mathrm{V}$. conozca y lo deseen ${ }^{212}$.

\subsection{Las enfermeras y los peligros de la guerra}

Las enfermeras nacionales fueron capturadas y encarceladas por los republicanos durante el desempeño de su trabajo. Cruz Roja participó en las negociaciones por su liberación o canje por otros prisioneros. Tal fue el caso de las hermanas Larios, María Luz y María Isabel, capturadas en Brunete y encarceladas en Valencia ${ }^{213}$. Otras fueron heridas durante el desempeño de su labor, como Ofelia Diez Bádenas, enfermera del equipo quirúrgico de vanguardia del Cuerpo del Ejército de Aragón, a la que hirieron durante un bombardeo mientras atendía a los heridos en el frente ${ }^{214}$. Las enfermeras sufrieron bombardeos en los hospitales donde prestaron servicio y fueron hechas prisioneras durante el desempeño de su trabajo ${ }^{215}$, siendo también heridas en campaña ${ }^{216}$. Priscilla Scott-Ellis deja constancia de ello en su diario, no entendía cómo no fueron alcanzadas, "ya que los proyectiles estallaban en un radio de pocas yardas alrededor" ${ }^{217}$.

Hubo casos más dramáticos, como el de Olga Monteserin Núñez, Octavia Iglesias Blanco y Pilar Gullón Iturriaga, damas de la Cruz Roja de Astorga, que se

\footnotetext{
${ }^{212}$ AGMAV, C. 42069,2/19. Correspondencia de Mercedes Milá, 19 de mayo de 1938.

${ }^{213}$ Y: revista de la mujer nacional sindicalista, febrero de 1938, Dos muchachas de Brunete, p. 29.

${ }^{214}$ Y: revista de la mujer nacional sindicalista, febrero de 1939, Actualidades, p. 29.

${ }^{215}$ AGMAV, C. 42068,4/317. Correspondencia de Mercedes Milá.

${ }^{216}$ AGMAV, C. 42069,2/230. Correspondencia de Mercedes Milá, 18 de septiembre de 1939.

${ }^{217}$ SCOTT-ELLIS, P: op.cit., p. 77.
} 
ofrecieron de forma voluntaria para ir a Somiedo (Asturias) a cuidar a los soldados heridos. El 8 de octubre de 1936 comenzó su trabajo y aunque únicamente tenían permiso para permanecer ocho días en el puesto, solicitaron quedarse más tiempo en esa posición. Cuando las tropas republicanas llegaron a Somiedo, las enfermeras se negaron a abandonar a los heridos. De esta forma el 27 de octubre de 1936 fueron capturadas y hechas prisioneras, para asesinarlas y enterrarlas en un prado un día después de ser arrestadas. Sus restos no fueron exhumados hasta que los nacionales llegaron a Asturias, dándolas sepultura el 31 de enero de $1938^{218}$.

En la zona nacional se desconocía que las enfermeras estaban muertas. Por eso Cruz Roja comenzó con los trámites oportunos para conseguir su liberación, a través de un canje de prisioneros:

Mi querido amigo: he recibido una amable carta y quedo a V. muy reconocido por las gestiones que vienen haciendo a favor de mi sobrina $\mathrm{M}^{\mathrm{a}}$ del Pilar Gullón y sus dos compañeras de la Cruz Roja, quiera Dios que aquellas den pronto el resultado apetecido, pues, realmente, tanto su madre, como todos nosotros estamos llenos de inquietud hasta haberlas libres de las garras de los rojos y de los peligros de todo género que nuestra imaginación nos hace temer ${ }^{219}$.

Los republicanos no comunicaron el asesinato, por lo que hubo desconcierto sobre la situación real de las enfermeras a las que aseguraban haber visto vivas, ya que pensaron que una vez capturadas habían sido trasladadas a Pola de Somiedo ${ }^{220}$ :

Ayer mismo estuvo una Comisión de Astorga en la que figuraba su sobrino, hijo de mi antiguo y buen amigo Manolo Gullón y estando con ellos, me llamó por teléfono el Sr. Junod para decirme, que, como consecuencia de mi telegrama a Ginebra, había recibido instrucciones, que había estado en Asturias estos días y que las había visto y estaban bien y que, además, podría traerlas en el próximo viaje que iba a realizar y para donde partía el sábado próximo. Su mismo sobrino presenció la

\footnotetext{
${ }^{218}$ GoY, José María: Las tres ramitas de roble: romance histórico astorgano. Imprenta y litografía de Sierra, Astorga, 1939.

${ }^{219}$ ACCRE, C. 559, Exp. 72. Enfermeras Somiedo. San Sebastián, 12 de noviembre 1936.

${ }^{220}$ Ibid., 31 de octubre 1936.
} 
conversación y a él y a la Comisión, les di lectura de telegramas, cartas, oficios y comunicaciones por los medios más rápidos que había cursado ${ }^{221}$.

Las dificultades que había para comunicarse con la zona y los impedimentos que pusieron los republicanos que no aclararon los hechos, hicieron que se tardara en conocer el asesinato ${ }^{222}$. Hasta el 13 de febrero de 1937 no se supo que habían sido fusiladas en Pola de Somiedo. La familia recriminó a Cruz Roja nacional su falta de interés en localizar a las voluntarias y sus deficientes gestiones para intentar salvarlas. Una vez conocidos los hechos la familia sintió que Cruz Roja no dedicó suficientes homenajes y que se olvidó del trabajo que desempeñaron ${ }^{223}$ :

Mí querido amigo: Recibo tu escrito, en el que me expones las aspiraciones del Sr. Monteserín. Yo bien sé y es muy natural, que a los padres todo les parece poco para hacer resaltar el buen nombre de sus hijos cuando estos mueren y más cuando esto sucede en las circunstancias de estas señoritas enfermeras. Pero sucede, y esto se repite con frecuencia, que llegan a mí las reiteradas quejas de este Sr. que las expone a todo el mundo, manifestando que la Cruz Roja no ha hecho cuanto debía en honor de estas. Lo que sí puedo decirle, es como le dije al Sr. Gullón, al que hablé de este asunto, que más que se ha hecho no se puede hacer humanamente. La exposición del libro "Princesas del Martirio" se hizo con todos los honores, e idéntico homenaje se les rindió en Astorga al que asistió la Marquesa de Valdeiglesias y en la ceremonia del Pilar, también les dediqué un cálido recuerdo, como verás por la hojita que acompaño ${ }^{224}$.

Además de la concesión de la Cruz Roja al Mérito Militar, se celebraron diferentes misas con motivo del aniversario de la muerte de las enfermeras, como el acto religioso celebrado en la iglesia de San Bartolomé al que asistieron la Duquesa de la Victoria y la Marquesa de Valdeiglesias ${ }^{225}$.

\footnotetext{
${ }^{221}$ ACCRE, C. 559, Exp. 72. Enfermeras Somiedo. San Sebastián, 12 de noviembre 1936.

${ }^{222}$ Ibid., 23 de octubre 1939.

${ }^{223}$ Ibid., 17 de octubre 1939.

224 ACCRE, C. 559, Exp. 72. Enfermeras Somiedo. Burgos.

225 La Vanguardia, 29 de octubre de 1939, Sufragios por el alma de unas damas enfermeras asesinadas por los rojos, p. 19.
} 
La institución inició la construcción de un mausoleo en su memoria, en la catedral de Astorga donde fueron enterradas ${ }^{226}$. Entre los homenajes que recibieron, cabe destacar el libro de Concha Espina, Princesas del martirio, en el que con florituras literarias, presentaba a las enfermeras como grandes heroínas:

Estas eran, Dios mío, tres mujeres de tu Santa Fe. Estas fueron, señor, tres vírgenes tuyas. Habían florecido en el regazo austero de Maragatería, tierra matriarcal de acendradas raíces españolas, solar de insuperables reciedumbres femeninas ${ }^{227}$.

Tres cuerdas musicales que responden a un solo ritmo castellano y al más puro abolengo racial. Tres mujeres que se unen del brazo para ejercer con valentía indomable su profesión de enfermeras voluntarias donde sea más necesario y urgente aquel servicio piadoso ${ }^{228}$.

Octavia, Olga y Pilar no fueron las únicas enfermeras que perdieron la vida durante la Guerra Civil. Guadalupe Gaytan de Ayala y Londáiz, dama auxiliar voluntaria de la Cruz Roja de San Sebastián falleció por un disparo el 21 de julio de 1936 al volver en una ambulancia a su casa después de la jornada de trabajo en el hospital. María del Carmen Labourdette, dama auxiliar voluntaria de Irún murió a consecuencia de fiebres tifoideas, adquiridas por contagio, en el Hospital Militar de Castellón el día 12 de agosto de 1938. Ramona Usabiaga Michelena, dama auxiliar voluntaria de San Sebastián formó parte del equipo de Hermanas de la Caridad y enfermeras del hospital de la Cruz Roja de Oña. La carga de trabajo hizo que enfermara, muriendo en su casa el día 5 de diciembre de 1938. Ángela Moscoso del Prado y Martínez, dama auxiliar voluntaria de Logroño, destinada en el hospital de Oña, murió enferma por contagio, en febrero de 1939, mismo mes en el que comenzó su trabajo ${ }^{229}$. En Montjuich fueron fusiladas en 1938 otras dos enfermeras

\footnotetext{
${ }^{226}$ ACCRE, C. 559, Exp. 72. Enfermeras Somiedo, 14 de julio de 1942.

${ }^{227}$ ESPINA, C: op.cit., p. 25.

${ }^{228}$ Ibid., p. 27.

${ }^{229}$ ACCRE, C. 559, Exp. 72. Enfermeras de la Cruz Roja muertas en el cumplimento del deber durante la campaña de 1936 a 1939
} 
durante el desempeño de su trabajo, pasando a ser mártires a las que dedicaron palabras de "fervor religioso y patriótico",230.

La enfermedad fue otro de los peligros al que hicieron frente las enfermeras. Las condiciones inadecuadas de salubridad favorecieron que contrajeran distintas patologías. Por ejemplo, Priscilla y su amiga Consuelo sufrieron dolencias e infecciones, tuvieron fiebre, vómitos y cuadros de desorientación. Priscilla llegó a tener abscesos purulentos que necesitaban ser curados diariamente, disentería y se contagió de paratifoidea, por lo que tuvo que pasar el periodo de convalecencia en Londres $^{231}$. Algunas de las enfermeras que estuvieron en contacto con enfermos infecciosos se contagiaron durante el desempeño de su trabajo ${ }^{232}$, con secuelas para su salud ${ }^{233}$. Tuvieron que trabajar sin guantes y el contacto continuo con la sangre les hacía pasar malos momentos de angustia pensando en un posible contagio:

Consuelo y yo tuvimos que limpiar los instrumentos y temíamos contraer gangrena, dado que nuestras manos están doloridas y agrietadas por el frío y el trabajo manual. Sin embargo, después de lavarnos con alcohol deberíamos estar tranquilas $^{234}$.

En general, el trabajo del personal sanitario femenino fue agotador, muchas horas y días sin descanso y sometidas al estrés de la responsabilidad, todo lo cual favoreció que cayeran enfermas:

Un día como los demás: Trabajar como negros sin parar, sin dormir, tan cansadas que estamos semiinconscientes. Desde hace más de una semana llevamos trabajando cuarenta y dos horas seguidas con una pausa de seis. Suficiente para matarla a una ${ }^{235}$.

Este exceso de trabajo también afectó a las delegadas que enfermaron a lo largo del conflicto: ${ }^{236}$

\footnotetext{
${ }^{230}$ La Vanguardia, 12 de agosto de 1939, En sufragio de Carmen Vidal y Catalina Viader, p. 2.

${ }^{231}$ SCOTT-ELLIS, P: op.cit., p. 127.

${ }^{232}$ AGMAV, C. 42069,2/164. Correspondencia de Mercedes Milá, 23 de enero de 1940.

${ }^{233}$ AGMAV, C. 42069,2/226. Correspondencia de Mercedes Milá, 17 de noviembre de 1938.

${ }^{234}$ SCOTT-ELLIS, P: op.cit., p.65.

${ }^{235}$ Ibid., p. 87.

${ }^{236}$ AGMAV, C. 42069,2/43. Correspondencia de Mercedes Milá, 21 de noviembre de 1939.
} 
[...]Me encuentro mucho mejor, pero aún me duelen bastante las piernas y los riñones. El domingo pasado tuve que estar acostada casi todo el día, con mareo y vómitos biliosos. No sé si todavía no han dado en lo que tengo o es que está muy reciente la operación $[\ldots]^{237}$.

La propia Mercedes necesitó unos días de reposo y descanso para recuperarse ${ }^{238}$.

Otros peligros acechaban, la sospecha de la existencia de una "vasta red de espionaje" entre las enfermeras movilizadas obligó a controlar los antecedentes políticos de las voluntarias y a exigirlas un aval de "tres personas de reconocida solvencia" que se hicieran responsables de su actitud. Además de estas medidas tuvieron que comprobar que todas las enfermeras, incluidas las profesionales, que ya estaban prestando servicios, fueran "de una manera clara, terminante y evidente afectas a la causa". Este tipo de sospechas surgieron a raíz de los desplazamientos que llevaron a cabo algunas de las damas movilizadas en campaña que se trasladaban con "facilidad y frecuencia" desde la retaguardia a los puestos avanzados. De forma que solicitaron que "todas estas enfermeras una vez aceptados sus servicios y destinadas" en los hospitales se "ajustasen, dentro de él, en lo posible, a las mismas normas, régimen y disciplina establecidos para el restante personal de su plantilla del mismo establecimiento, no tolerando se ausenten más que en casos de verdadera necesidad y urgencia y siempre con la debida autorización en evitación de los hechos denunciados"239. Por eso se cesó a todas las enfermeras que habían prestado servicio en los hospitales republicanos con fechas posteriores al 18 de julio de 1936 hasta que se aclarara su "situación política y comportamiento durante el dominio rojo" ${ }^{240}$. A las voluntarias consideradas sospechosas se las denegaban los nombramientos y se las impedía trabajar en los hospitales del frente:

\footnotetext{
${ }^{237}$ AGMAV, C. 42069,2/113. Correspondencia de Mercedes Milá, 12 de junio de 1938.

${ }^{238}$ AGMAV, C. 42069,2/284. Correspondencia de Mercedes Milá, 14 de septiembre de 1940.

${ }^{239}$ AGMAV, C. 1299, Cp. 63 D. 1, 4 de abril de 1937.

${ }^{240}$ AGMAV, C. 42069,2/281. Correspondencia de Mercedes Milá, 31 de agosto de 1937.
} 
Me advierten que una enfermera considerada muy roja tiene amistad con un médico falangista que debe estar en Valladolid y parece ser que la quiere llevar al frente; su nombre es Mari Sol Rojo, y vive en Lamiaco cerca de las Arenas. Se lo advierto pues no me pediría a mí directamente porque sabe que no la autorizaría ${ }^{241}$.

\subsection{Religión, propaganda y adoctrinamiento}

La Sección Femenina se encargó de perfilar la figura de la mujer que la nueva España necesitaba. Además de utilizar distintos medios de difusión como la Revista " $Y$ " o la prensa escrita, las líderes se encargaron de ser un ejemplo a seguir y de propagar las virtudes y deberes que debían asumir las mujeres falangistas. Dentro de este adoctrinamiento jugó un papel muy importante la religión. Las mujeres carlistas y falangistas defendieron la figura de la buena cristiana, abnegada, piadosa y cercana a los postulados evangélicos. La Enfermería se vio implicada en los nuevos cambios y fue utilizada por la propaganda franquista, ya que las enfermeras fueron el mejor ejemplo de buenas samaritanas, sin alejarse de los trabajos tradicionalmente femeninos.

Algunas enfermeras fueron propagandistas o estuvieron implicadas en distintas acciones políticas. Tal fue el caso de María Rosa Urraca Pastor, líder carlista que aprovechó el trabajo que desempeñó como enfermera en el frente para dar a conocer a través de su obra Asi empezamos: Memorias de una enfermera, su opinión sobre la posición de las mujeres en la sociedad. Las margaritas habían participado en mítines y en labores de propaganda durante la Segunda República, por ejemplo, María Rosa nombró a Pilar Díaz Ibarra delegada del Socorro Blanco cuando ésta tenía diecisiete años ${ }^{242}$, y a Dolores Baleztena Ascárate, delegada de Frentes y Hospitales de Navarra ${ }^{243}$. Durante la Guerra Civil compaginaron la labor de enfermeras con sus obligaciones políticas, por eso fueron ellas las encargadas de acudir a los distintos frentes para repartir el Aguinaldo del soldado y la ropa de abrigo, además de organizar el trabajo en las poblaciones recién conquistadas.

\footnotetext{
${ }^{241}$ AGMAV, C. 42069,2/41. Correspondencia de Mercedes Milá, 15 de febrero de 1938.

${ }^{242}$ LARRAZ ANDÍA, P; SIERRA-SESÚ MAGA, V: op.cit., p. 597.

${ }^{243}$ Ibid., p. 568.
} 
Dolores, acompañó a los heridos a los funerales de los compañeros y, en algunas ocasiones, llevó a los pacientes a sus casas a visitar a los familiares ${ }^{244}$. Fueron ellas las que viajaron de forma habitual a los frentes:

A las brigadas navarras las vi en todos los frentes: entre las brumas del Norte, bajo el sol abrasador de Levante, soportando los hielos de Teruel, en las dilatadas llanuras de Castilla... Y en climas y paisajes tan distintos, en medio de todas las unidades, la boina roja de los Requetés ponía la nota animada. Su alegría llenaba el ambiente de optimismo; sus cantares acallaban el tronar del cañón ${ }^{245}$.

Pilar Díaz Ibarra, contribuyó a la organización de los cursos de enfermeras del Círculo Carlista, y del taller para aprender a cortar telas para camisas y uniformes. Durante el alzamiento organizó a los voluntarios que llegaban al Círculo de Estella, e incluso les enseñó a manejar un fusil, cargar y descerrajar ${ }^{246}$.

La religión tuvo mucha importancia para las margaritas, ya que todas eran mujeres católicas y tradicionalistas. En general las celebraciones religiosas formaron parte del día a día de los hospitales y en ellas participaron activamente las enfermeras.

Priscilla Scott-Ellis en su diario deja claro que todos los domingos acudía a misa y que el cura daba la extremaunción a los heridos graves. Explica que en la retaguardia eran comunes las misas en el hospital, donde el sacerdote iba cama por cama dando la comunión a los pacientes mientras las enfermeras permanecían arrodilladas en el suelo del pabellón durante la misa:

El sermón fue tan aburrido como todos los sermones, y como si estuviéramos en la escuela: todas las chicas sentadas, con uniforme, en los pupitres con los que han equipado la capilla ${ }^{247}$.

\footnotetext{
${ }^{244}$ LARRAZ ANDÍA, P; SIERRA-SESÚ MAGA, V: op.cit., p. 584.

${ }^{245}$ Ibid., p.586.

${ }^{246}$ Ibid., p. 599.

${ }^{247}$ SCOTT-ELLIS, P: op. cit., p.195.
} 
Urraca Pastor, en todo momento se definía como una mujer tradicionalista y católica gracias a la educación que recibió. Su madre desde pequeña le inculcó el amor a Dios ${ }^{248}$. Su padre, militar y monárquico, formó a María Rosa “en el amor y el respeto a las Instituciones Patrias, especialmente el ejército"249. En Memorias de una enfermera es común encontrar ejemplos que aluden a la religiosidad en el frente y al catolicismo tradicional de los requetés. Rezaban juntos el rosario por los compañeros caídos y el capellán, después de los actos de contrición, les daba la absolución colectiva ${ }^{250}$.

La piedad y la caridad católica se ensalzaban en la zona nacional, por eso el trabajo desempeñado por las enfermeras se relacionaba directamente con dichas cualidades femeninas. La organización de misas y la asistencia a ellas se integró en la práctica diaria del personal auxiliar femenino, tal fue el caso de las eucaristías dedicadas a la figura de Franco ${ }^{251}$. Mercedes Milá quería que "todas las enfermeras en España hicieran los ejercicios de cuaresma", para lo que contó con la ayuda de sus delegadas encargadas de organizar los mismos con la colaboración de algún Padre Jesuita para dirigirlos ${ }^{252}$. También se fijó una misa comunión general anual que coincidía con el santo del caudillo y que se celebraba en todas las poblaciones en las que había un hospital militar como "prueba de adhesión y cariño de todas las enfermeras que sirvieron a su Ejército" 253 . Las voluntarias se encargaron de adornar la iglesia con flores para el acto religioso y participaron activamente en el mismo con las autoridades de la zona, "demostrando su fervor a la hora de comulgar"254. En este tipo de actos se permitía vestir el uniforme de la institución, de hecho era una petición que hacía la inspectora ${ }^{255}$. Se pueden ver en prensa imágenes de las enfermeras y hermanas que asistían a las ceremonias religiosas, fomentando el vínculo entre los cuidados y la caridad cristiana ${ }^{256}$.

\footnotetext{
${ }^{248}$ URRACA PASTOR, M.R: op.cit., p 135.

${ }^{249}$ Ibid., p. 136.

${ }^{250}$ Ibid., p. 15.

${ }^{251}$ AGMAV, C. 42069,3/126. Correspondencia de Mercedes Milá, 8 de octubre de 1939.

${ }^{252}$ AGMAV, C. 42069,3/164. Correspondencia de Mercedes Milá, 3 de marzo de 1938.

${ }^{253}$ AGMAV, C. 42069,3/165 y 166. Correspondencia de Mercedes Milá, 18 de septiembre de 1939.

${ }^{254}$ AGMAV, C. 42069,3/170-171. Correspondencia de Mercedes Milá, 5 de octubre de 1939.

${ }^{255}$ AGMAV, C. 42069,3/174. Correspondencia de Mercedes Milá, 29 de septiembre de 1939.

${ }^{256}$ La Vanguardia, 1 de agosto de 1939, En el Hospital de San Pablo, p. 4.
} 
Las cualidades físicas y morales de las enfermeras debían encajar con el nuevo régimen político y religioso. Su trabajo fue valorado positivamente por los pacientes al "saberse sabia y mimosamente atendidos". El hecho de ser mujeres hizo que causaran "las menores molestias posibles" atendiendo a los heridos con "mano

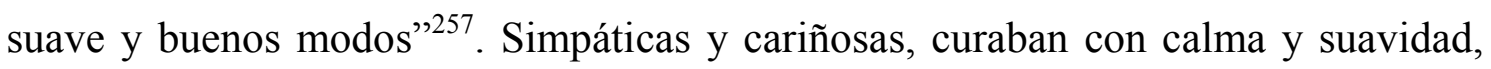
acompañando su trabajo de una sonrisa agradable ${ }^{258}$. Belleza, amabilidad y bondad, eran atributos suficientes para que los heridos se sintieran bien cuidados:

Sor Saturnina era natural de la provincia de Burgos o de la capital misma; era joven y con hábito negro y la toca de anchas alas blancas, estaba hermosa, y todos los heridos de la sala nos complacíamos con su presencia. Había un muchacho legionario herido, algo atolondrado, pero con sus chistes y desde la cama mismo, pues no se podía levantar, le decía siempre que estaba enamorado de ella, que era hermosa y por qué estaba allí siendo hermosa y de buen tipo. Ella se ruborizaba cuando le decían algo y se sonreía. Procuraba no estar sola nunca con un soldado. La otra hermana era pequeña de tipo y no muy bonita; por eso Sor Saturnina era como un hada y todos deseábamos que las camas, la ropa, el reparto de la comida en la mesa, yodo, nos lo hiciese ella. Era muy amable y bondadosa y siempre sonreía, lo que la hacía más hermosa... $[\ldots]^{259}$

La enfermera tenía que ser un "sol de guapa, un encanto de buena y como unas castañuelas de alegre" además de portarse bien, ser abnegada y valerosa ${ }^{260}$. Su espíritu patriótico quedaba probado, ya que trabajaron sin recibir compensación económica $^{261}$.

\footnotetext{
${ }^{257}$ BEECHAM, MONOGRAFÍAS: op.cit., en MAZO BURÓN, op.cit., p. 252.

${ }^{258}$ LLORDÉS BADÍA, J: op.cit., p. 107.

${ }^{259}$ Ibid., p. 112/113.

${ }^{260}$ URRACA PASTOR, M.R: op.cit., p. 16.

${ }^{261}$ AGMAV, C. 46761,2/65. Correspondencia de Mercedes Milá 19 de octubre de 1939.
} 


\section{Capítulo V}

La enfermera nacional era la mujer que llevaba el tabaco y el alimento al herido, además del consuelo a través de sus frases amables y entusiasta. Dulce, tierna, con manos "que prodigan los más esmerados cuidados y labios que hablan del Dios que ama", dedicada a su labor con altruismo y abnegación ${ }^{262}$ :

Nuestras enfermeras, las enfermeras españolas, han mantenido su actitud a la altura de su misión: abnegadas y diestras en el cumplimiento de su noble ocupación. Su gesto español ha sido constante y han sabido cumplir risueñas, sin dar muestras de cansancio, la tarea encomendada. [...] La enfermera es una gran auxiliar en la obra de la reconstrucción de España, en el anhelo de cordialidad, en el afán de Patria, Pan y Justicia ${ }^{263}$.

Tengo el gusto de poner en su conocimiento que durante el mes que al frente de mi Equipo Quirúrgico, he permanecido en el Hospital de Sangre de la Ciudad Universitaria y he podido apreciar la abnegada y eficaz actuación de las señoritas Enfermeras que en este puesto prestan sus servicios, siendo de notar el mejoramiento de este Hospital en relación con las veces anteriores en que el Equipo cumplió el turno correspondiente ${ }^{264}$.

Esta imagen ideal de enfermera como mujer nacional se puede apreciar en la obra de Concha Espina, Princesas del martirio, dedicada a las damas enfermeras de Cruz Roja asesinadas en Somiedo. Olga, tenía una voz cálida y luminosa, "como si la luz de sus ojos se le prendiera en los labios para alumbrarle las palabras". Octavia era bondadosa y dulce, "como un espíritu vigilante en el que se aposenta la gracia del señor. Con un halo de santidad en su noble expresión; en su rostro suave y tranquilo arde una lumbre de lámpara siempre encendida". Pilar tenía una cara perfecta, era bellísima: "Si es verdad que algunas mujeres atesoran la huella de los ángeles, Pilar reúne en sus facciones el privilegio angelical; y toda ella se mueve dentro de un soplo seráfico, con una beatitud indecible",265 (ver imagen XIX).

\footnotetext{
${ }^{262}$ Y: revista de la mujer nacional sindicalista, $\mathrm{n}^{\circ}$ febrero 1938, p. 30.

${ }^{263}$ Y: revista de la mujer nacional sindicalista, $\mathrm{n}^{\circ}$ septiembre 1938, p. 31.

${ }^{264}$ Y: revista de la mujer nacional sindicalista, $\mathrm{n}^{\circ}$ octubre 1938, p. 36.

${ }^{265}$ ESPINA, C: op.cit., p.38.
} 
Constantemente hace alusión a la belleza de las jóvenes, como una cualidad de la mujer abnegada y buena, de "ritmo elegante que escandaliza a sus perseguidores" ${ }^{266}$ :

Antes de verlas supieron con rencores y envidia que eran mozas, guapas y elegantes. Los tigres de la comuna habían dicho perversamente: -¡Vaya chicas! Son de primera... Se habló con cinismo de un reparto y hubo frases que trascendían al sacrilegio habitual en seres inferiores ${ }^{267}$.

El relato de Priscilla Scott-Ellis proporciona la nota discordante dentro de la visión que la España nacional tenía de la mujer. Ella misma no era un ejemplo de mujer abnegada y obediente. No era partidaria de quedarse en la retaguardia, quería ir al frente en busca de aventuras y experiencias. Demostrar al mundo que las mujeres eran capaces de salir solas adelante a pesar del trabajo duro. Era intrépida, con espíritu de aventuras: "todos estaban fascinados de ver a una mujer joven viajando sola y ocupándose ella misma del motor de su automóvil"268. A ojos de la guardia civil "una chica joven conduciendo sola a primeras horas de la mañana es inaudito en España. [...] Cuando le expliqué que había llevado a un aviador porque su chófer estaba enfermo, se horrorizó y me preguntó si estaba casada"269. Con su coche recorrió el camino de un hospital a otro, pasando por zonas bombardeadas y cerca de las trincheras. Priscilla fumaba, siempre que podía salía divertirse y no le importaba trasnochar ${ }^{270}$.

[...] entonces fuimos en busca de un nightclub que finalmente encontramos después de perdernos tres veces. Fue atrozmente cómico: un viejo teatro con mujeres semidesnudas en el escenario que no sabían ni bailar ni cantar ${ }^{271}$.

\footnotetext{
${ }^{266}$ ESPINA, C: op.cit., p.103.

${ }^{267}$ Ibid., p. 64.

268 SCOTT-ELLIS, P: op.cit., p. 37.

${ }^{269}$ Ibid., p. 45.

${ }^{270}$ Ibid., p. 25.

${ }^{271}$ Ibid., p. 103.
} 
Priscilla expone en su diario los problemas que le generaron su forma de ser y las exigencias que se le impusieron para poder continuar como enfermera. El día de su veintidós cumpleaños escribe: "parece que en un hospital una tiene que ser monja"272. Expone que "cada placer que puede inventarse para disminuir lo aburrido de la vida" era un crimen. No se le permitía fumar, beber alcohol o hablar con un hombre. Reconoce que no podía evitar haber sido educada en libertad, por eso, no toleraba que la espiaran y la siguieran o que la trataran como a una "maldita fulana que hay que reformar". Estaba dispuesta a comportarse "como una monja en el hospital, de ocho de la mañana a nueve de la noche", pero exigía poder tener libertad para disfrutar de su tiempo libre ${ }^{273}$.

Esta actitud aperturista fomentó los conflictos entre Priscilla y Mercedes Milá. En una de las visitas de la inspectora al hospital de Híjar, para organizar el trabajo de las voluntarias y la distribución de las camas, criticó los fallos que encontró y recriminó a Priscilla que fuera demasiado maquillada ${ }^{274}$. Los informes negativos que Mercedes recibió de Priscilla y Consuelo fomentaron que separara a las enfermeras y no las permitiera trabajar juntas ${ }^{275}$.

\footnotetext{
${ }^{272}$ SCOTT-ElLis, P: op.cit., p. 174.

${ }^{273}$ Ibid., p. 175.

${ }^{274}$ Ibid., p. 83.

${ }^{275}$ Ibid., p. 206 у 212.
} 


\section{SITUACIÓN DE LAS ENFERMERAS AL TERMINAR LA GUERRA CIVIL: HACIA EL MODELO IDEAL DE PROFESIONALES}

Como expone Teresa Gallego, las mujeres han interesado a los distintos gobiernos, "no por su condición de persona, sino por las funciones que desempeñan en la familia", sobre todo por el papel que han jugado en la reproducción. Este discurso fue acorde con el ideario de Sección Femenina fiel defensora de la maternidad y el sacrificio a través del dolor, la abnegación y la religiosidad ${ }^{276}$. El Fuero del Trabajo reconocía a la familia como el núcleo principal de la sociedad española, de forma que el papel de la mujer en la misma sería el de madre y esposa cuya función era "ennoblecer y enaltecer el hogar con sus virtudes". En el mismo, también se prohibía el trabajo nocturno de mujeres y niños, además de fomentar que la mujer casada dejara su puesto de trabajo para dedicarse a sus nuevas responsabilidades, principalmente la maternidad ${ }^{277}$. Desde Sección Femenina se dejaba claro a las mujeres que su papel era el de esposas y madres. Ellas serían las responsables de inculcar los preceptos de Falange a sus hijos, siendo ese su "único puesto", estar en el seno de la familia, alejadas siempre de las "exhibiciones públicas que no eran propias de mujeres" ${ }^{278}$. Este compromiso de la mujer con la nueva España dificultó su emancipación ${ }^{279}$.

El discurso pronunciado por Franco en la concentración de Sección Femenina en Medina del Campo en mayo de 1939 dejaba claro, después de alabar el trabajo realizado por las mujeres durante la guerra, que su tarea se debía centrar en la "reconquista del hogar". Pilar Primo de Rivera también subrayó durante la concentración, la idea de que la misión de la mujer se encontraba en el hogar, haciendo a los "hombres agradable la vida en familia" "280. La maternidad y el

\footnotetext{
${ }^{276}$ GALlEGo MÉnDEZ, Teresa: Mujer, falange y franquismo. Taurus, Madrid, 1983, p. 13.

277 Y: revista de la mujer nacional sindicalista, $\mathrm{n}^{\circ} 3$, abril de 1938, El fuero del Trabajo y la mujer.

${ }^{278}$ Y: revista de la mujer nacional sindicalista, $\mathrm{n}^{\mathrm{o}} 13$, febrero de 1939, Discurso de la Delegada Nacional camarada Pilar Primo de Rivera, p. 14.

${ }^{279}$ Domingo, Carmen: Con voz y voto...op.cit. p. 331.

${ }^{280}$ Y: revista de la mujer nacional sindicalista, $\mathrm{n}^{\circ} 17$, junio de 1939, La gran Concentración femenina de Medina del Campo, pp. 12-15.
} 
cuidado de los hijos pasaron a un primer plano dentro de Sección Femenina, con el objetivo de fomentar la natalidad y disminuir la mortalidad infantil. Por eso, las delegadas provinciales tuvieron como tarea "formar a las mujeres como madres", y educarlas en el cuidado de sus hijos ${ }^{281}$. Como expresaba Pilar Jaraiz Franco, "la misión de una mujer era parir, contentar a su marido, y no precisamente en el aspecto intelectual, administrar su hogar, y criar hijos", sin olvidarse de saber religión, para educar a su familia en el catecismo. Las mujeres únicamente debían saber "leer, escribir, las cuatro reglas de aritmética y algo de música", por lo que cursar estudios superiores y dedicarse a una profesión no estaba al alcance de $\operatorname{todas}^{282}$. Como señala Teresa Gallego, era la maternidad la que hacía que una mujer fuera "digna de consideración”, siendo esta durante la década de los años cuarenta, el destino ineludible que debían aceptar ${ }^{283}$.

La delegada nacional de Sección Femenina era el ejemplo que debían seguir afiliadas y simpatizantes del movimiento, su "personalidad dulce, sencilla, recia y abnegada" era capaz de inspirar "admiración, respeto y ternura" 284 . Como señala Shirley Mangini, Pilar Primo de Rivera, como portavoz de la organización consolidó el que sería durante toda la dictadura franquista el principal precepto para las mujeres, "la sumisión a la Iglesia, al Estado y, especialmente, a los hombres"285. Según Teresa Gallego, Pilar Primo de Rivera defendió el "silencio femenino", era mejor que permanecieran calladas ya que no "tenían nada que decir", sino "acatar lo previsto y exigido por el varón" ${ }^{286}$. Desde un primer momento defendió el papel de Sección Femenina en la formación de la mujer nacionalsindicalista, inculcando disciplina sin perder de vista la orientación religiosa en su capacitación laboral e intelectual $^{287}$. Carmen Domingo señala que este discurso antifeminista de Pilar

\footnotetext{
${ }^{281} Y$ : revista de la mujer nacional sindicalista , $\mathrm{n}^{\mathrm{o}}$ 24, enero de 1940, del discurso inaugural del IV consejo Nacional de la Sección Femenina, pronunciando por Pilar Primo de Rivera.

${ }^{282}$ JARAÍZ FRANCO, P: op.cit., p. 28.

${ }^{283}$ GALLEGO MÉNDEZ, T: op.cit., p. 167.

${ }^{284}$ Revista “Y”, no 21, octubre de 1939, El día de Pilar Primo de Rivera.

${ }^{285}$ MANGINI, S: op.cit., p. 114.

${ }^{286}$ GALLEGO MÉNDEZ, T: op.cit., p. 194.

${ }^{287}$ ABC Sevilla, 11 de noviembre de 1938, p. 17, Declaraciones de Pilar Primo Rivera.
} 
Primo de Rivera permitió que consolidara su poder en el régimen franquista ${ }^{288}$. El fin del conflicto permitió que asumiera todo el control sobre la movilización femenina, facilitado por la disolución de Frentes y Hospitales justificada en el Decreto del 24 de mayo de 1939 y por el apoyo que recibió de Franco que la ratificó como líder indiscutible de las mujeres españolas ${ }^{289}$.

En este contexto, la Enfermería continúo siendo una puerta abierta para las mujeres interesadas en estudiar y trabajar. Enfermera, puericultura y maestra fueron las profesiones aceptadas socialmente por el régimen franquista ${ }^{290}$.

\subsection{Recompensas y reconocimiento laboral}

Una vez finalizada la guerra, se reconoció el trabajo que llevaron a cabo las enfermeras durante la misma "con insuperable celo y actividad infatigable", de forma brillante, obteniendo felicitaciones por "la patriótica y abnegada labor" recibiendo medallas por los méritos prestados en campaña. Cabe señalar que fueron las mismas que obtuvieron los generales, jefes, oficiales y soldados. Se otorga la Cruz Roja al Mérito Militar, la Medalla de Campaña, Medalla de Sufrimientos ${ }^{292}$ y ocasionalmente la Cruz de Guerra, concedida por méritos excepcionales al personal que se distinguió por su labor. Esta última fue recibida por Octavia Iglesias, Pilar Gullón, Olga Monteserin, y Agustina Simón Sanz, fusilada en Belchite por negarse a seguir prestando servicio como enfermera ${ }^{293}$.

\footnotetext{
${ }^{288}$ Domingo, C: Coser y cantar...op.cit., p. 24.

289 Aguado, Ana María y Ortega María Teresa: Feminismos y antifeminismos. Culturas políticas e identidades de género en la España del siglo XX. En Cenarro, Ángela. Trabajo, Maternidad y feminidad en las mujeres del fascismo español. Universidad, Valencia-Granada, 2011, p. 233.

${ }^{290}$ DomingO, C: Con voz y voto...op.cit., p. 337.

${ }^{291}$ AGMAV, C. 42069,2/25 y 26. Correspondencia de Mercedes Milá, 15 de marzo de 1939.

${ }^{292}$ BOE n $^{\circ}$ 99, 27 de enero de 1937, Decreto núm. 192.- Determinando las recompensas que, por méritos de campaña, pueden ser otorgadas, pp. 226-227.

${ }^{293}$ BOE n $^{\circ} 119,28$ de abril de 1940, Orden del 24 de abril concediendo la Cruz roja del Mérito Militar a las enfermeras que se relacionan, p. 2893.
} 
Pilar Primo de Rivera va llamando a las condecoradas. Las filas de las enfermeras se van quedando vacías. Con paso mesurado se van acercando a la tribuna del Generalísimo.

Este, condecora con la Medalla de la Cruz Roja del Mérito Militar a las muchachas heroicas que han sabido ofrecerse como un combatiente más, ejemplo de sacrificio y de heroísmo, a las Santa Cruzada de España. [... $]^{294}$

En este sentido se hizo distinción entre las que habían permanecido en vanguardia, en retaguardia y aquellas que fueron heridas por "el fuego enemigo", siendo estas últimas las únicas que pudieron solicitar la medalla de sufrimientos por la patria $^{295}$. El requisito para otorgarla era haber sido heridas en campaña, por lo que no aceptaron la solicitud de aquellas que habían enfermado durante el conflicto, aunque tuvieran como secuela una incapacidad para trabajar ${ }^{296}$. Los jefes de Sanidad de las diferentes divisiones eran los que debían hacer las propuestas de las enfermeras que ellos considerasen que debían tener la Cruz Roja al Mérito Militar. Tenían que hacerlo de "forma individual relatando los méritos de cada una" porque aunque fueran los mismos, no los podían hacer en grupo ${ }^{297}$. Aún así, en algunas ocasiones la solicitud de recompensa fue general para todas las enfermeras, sin referirse a una en concreto. Por ejemplo, en San Sebastián, la dirección del Hospital Militar del General Mola, solicitó la concesión de la Cruz Roja al Mérito Militar para todo el personal femenino, por la labor desempeñada durante la guerra ${ }^{298}$. Posteriormente tuvo que especificar la relación del mismo ${ }^{299}$. Las enfermeras extranjeras, especialmente las italianas, que trabajaron en los hospitales nacionales también optaron a la concesión de medallas militares ${ }^{300}$. Principalmente recibieron la

\footnotetext{
294 La Vanguardia, 31 de mayo de 1939, En Medina del Campo el Caudillo habla a las mujeres españolas, portada.

${ }_{295}$ AGMAV, C. 42068,2, Correspondencia de Mercedes Milá, 21 de noviembre de 1939.

${ }^{296}$ AGMAV, C. 42069,2/227. Correspondencia de Mercedes Milá, 18 de agosto de 1939.

${ }^{297}$ AGMAV, C. 42068,2, Correspondencia de Mercedes Milá, 10 de febrero de 1939.

${ }^{298}$ AGMAV, C. 46761,2/150. Correspondencia de Mercedes Milá, 28 de enero de 1940.

${ }^{299}$ AGMAV, C. 46761,2/152. Correspondencia de Mercedes Milá, 6 de febrero de 1940.

${ }^{300}$ AGMAV, C. 46761,2/77-78. Correspondencia de Mercedes Milá, 28 de mayo de 1940/14 de junio de 1940.
} 
medalla de campaña ${ }^{301}$, otorgada al personal que había prestado más de seis meses de servicio ${ }^{302}$.

En la solicitud se debía especificar la fecha, lugar y condiciones de trabajo que hacía a las enfermeras acreedoras de "la mencionada recompensa"303. El teniente médico o el jefe del equipo quirúrgico, certificaba esta información además de hacer alusión al "espíritu altamente nacional y de sacrificio" de las voluntarias ${ }^{304} \mathrm{o}$ a "su brillante comportamiento" durante las situaciones difíciles ${ }^{305}$. Las enfermeras y Hermanas de la Caridad que prestaron más de seis meses de servicio y estuvieron expuestas al fuego enemigo, recibieron ambas recompensas ${ }^{306}$. Los pasadores de las medallas eran de diferente color, en función del trabajo desempeñado. Recibían el distintivo rojo las enfermeras movilizadas, las que habían trabajado en vanguardia o habían sido desplazadas de sus domicilios. Y el blanco aquellas que habían "servido en el lugar de su residencia sea este cual fuere, con excepción de las plazas sitiadas de Oviedo, Huesca y Teruel” ${ }^{, 307}$. Haber prestado servicios en los hospitales de prisioneros no se consideraba trabajo en vanguardia y no se concedió el distintivo rojo $^{308}$, pero haber sido prisionera y resistir al asedio si lo fueron ${ }^{309}$. También hubo damas que recibieron recompensas por el desempeño de su trabajo durante la contienda en los hospitales musulmanes ${ }^{310}$. Mercedes Milá recibió la Cruz Roja al Mérito Militar "por los meritorios servicios prestados al ejército"311 y como reconocimiento al trabajo desempeñado durante el conflicto ${ }^{312}$. Y las enfermeras y hermanas por los "laudatorios servicios prestados, demostrando en todo momento

\footnotetext{
${ }^{301}$ AGMAV, C. 46761,2/153. Correspondencia de Mercedes Milá, 8 de julio de 1940.

302 AGMAV, C. 46761,2/158. Correspondencia de Mercedes Milá, 17 de mayo de 1940.

${ }^{303}$ AGMAV, C. 42068,2, Correspondencia de Mercedes Milá, 27 de octubre de 1938.

${ }^{304}$ AGMAV, C. 46761,2/89. Correspondencia de Mercedes Milá, 5 de noviembre de 1939.

${ }^{305}$ AGMAV, C. 46761,2/92. Correspondencia de Mercedes Milá, 9 de octubre de 1939.

${ }^{306}$ AGMAV, C. 46761,2/172. Correspondencia de Mercedes Milá, 10 de septiembre de 1940.

${ }^{307}$ AGMAV, C. 46761,2/69. Correspondencia de Mercedes Milá, 24 de abril de 1940.

${ }^{308}$ AGMAV, C. 42069,2/156. Correspondencia de Mercedes Milá, 13 de mayo de 1939

${ }^{309}$ AGMAV, C. 46761,2/90. Correspondencia de Mercedes Milá, 10 de mayo de 1940.

${ }^{310}$ AGMAV, C. 42069,5/38-39. Correspondencia de Mercedes Milá, 3 de abril de 1939

${ }^{311}$ BOE $^{\circ}$ 253, 10 de septiembre de 1939, Orden concediendo la Cruz Roja del Mérito Militar a la señorita Mercedes Mila, p. 5051.

${ }^{312}$ AGMAV, C. 42069,2/230. Correspondencia de Mercedes Milá, 18 de septiembre de 1939
} 
gran celo, alto espíritu en el cumplimiento de su deber, habiendo sufrido los efectos del fuego enemigo"313.

La concesión de las condecoraciones generó problemas ya que era deseo de muchas ostentar la insignia como reconocimiento a su trabajo:

Las enfermeras de Córdoba, hace unos días fueron condecoradas con la Cruz Roja del Mérito Militar porque en el bombardeo del Hospital Militar de San Fernando del día 1 de Abril de 1937 continuaron en sus puestos. Lo saben las enfermeras de aquí y se encuentran dolidas ya que ellas han soportado en sus puestos no uno, sino muchos bombardeos de artillería y aviación con un espíritu formidable, así como los ataques de los rojos contra Peñarroya en distintas ocasiones, llegando en alguna (noche del 2 al 3 de septiembre de 1937) con sus tanques hasta el cementerio situado a un kilómetro del Hospital $n^{\circ} 1$. También en esta ocasión se mantuvieron todas en sus puestos hasta las del turno de noche! $!^{314}$

Las enfermeras que estuvieron "un mínimun de 6 meses movilizadas en hospitales o equipos quirúrgicos del frente o 900 días en la retaguardia" obtuvieron el certificado de excombatientes. Para su concesión, además de la solicitud debían entregar una declaración jurada ${ }^{315}$. Inicialmente no se tenía muy claro quién podía solicitarlo y los requisitos exigidos ${ }^{316}$. Los certificados los debía emitir el director del centro, pero no la delegada, y menos sin solicitar permiso a Mercedes Milá ${ }^{317}$. Las enfermeras de Cruz Roja que trabajaron en hospitales de infecciosos durante más de un año tuvieron derecho a ser declaradas excombatientes ${ }^{318}$. Este certificado facilitaba el acceso a la Universidad, ya que permitía la admisión sin necesidad de realizar el examen de ingreso:

En los B.B.O.O del Estado n ${ }^{\circ} 162$ y 238 correspondientes a los días 6 de Junio y 20 de Agosto del corriente año, se dictan normas para el ingreso en Universidades, de los escolares bachilleres excombatientes dispensándoles el

\footnotetext{
${ }^{313}$ BOE no $^{\text {o } 257,} 14$ de septiembre de 1939, Orden concediendo la Cruz Roja del Mérito Militar a las Enfermeras Hermanas de la Caridad y Telefonistas que figuran en la relación que empieza... p. 5126.

${ }^{314}$ AGMAV, C. 42068,2, Correspondencia de Mercedes Milá, 9 de diciembre de 1938.

${ }^{315}$ AGMAV, C. 42069,2/66. Correspondencia de Mercedes Milá, 29 de julio de 1940.

${ }^{316}$ AGMAV, C. 42069,2/163. Correspondencia de Mercedes Milá, 8 de enero de 1939.

317 AGMAV, C. 42069,2/166. Correspondencia de Mercedes Milá, 18 de mayo de 1940.

318 ACCRE. Caja 2310, Exp. 2. Personal enfermeras. Cádiz. 1939-1940. Correspondencia Marquesa de Valdeiglesias. 21 de febrero de 1940.
} 
examen correspondiente por haber prestado servicios en el Glorioso Ejército. En mi calidad de haber terminado mis estudios de bachiller en el año 1936 y haber prestado servicio como Enfermera voluntaria de guerra en Hospitales Militares de esta plaza durante los tres años de nuestra guerra y creyéndome incluida en las mismas condiciones que los excombatientes escolares varones, es por lo que recurro a V. E. para que interponiendo su valiosa influencia cerca del Ministerio de Educación Nacional, me sea aplicada dicha excepción de examen de ingreso en la Universidad y por el mismo motivo rogándole la mayor actividad posible por el poco tiempo que falta para la apertura del curso $^{319}$.

Cruz Roja contó con sus propias condecoraciones, como fue la medalla conmemorativa de los servicios realizados por el personal de Asistencia y Transporte perteneciente a Cruz Roja Española. Para que fuera válida, el ministro de defensa nacional tuvo que dar su aprobación ${ }^{320}$. Se concedió a los que habían trabajado en "hospitales, equipos quirúrgicos, puestos de socorro y demás servicios directos a los heridos o enfermos de la campaña, tanto en vanguardia como en retaguardia" ${ }^{321}$. Las Hermanas de la Caridad adjuntas a la Cruz Roja, las damas auxiliares voluntarias, enfermeras profesionales y ayudantes de enfermeras que habían prestado un servicio "no inferior a cien días a razón de seis horas diarias, como mínimum" optaron a la concesión de la medalla. Las que prestaron servicio trescientos días tuvieron derecho a un pasador. En caso de haber trabajado más días se las entregaba otro pasador a mayores. Eran de distintos colores, rojo para las que habían prestado servicio en los hospitales o equipos de vanguardia y blancos para las de retaguardia. En todas aparecería inscrita la palabra "constancia"322. Cruz Roja entregó diplomas de gratitud a las enfermeras que prestaron servicio en los

\footnotetext{
319 AGMAV, C. 42068,2, Correspondencia de Mercedes Milá, 29 de septiembre de 1939.

${ }^{320}$ Era de plata para los médicos, practicantes, capellanes, damas auxiliares voluntarias, tanto religiosas como seglares, enfermeras profesionales y oficiales de la Cruz Roja Española, y de bronce para ayudantes de enfermeras y camilleros.

${ }^{321}$ La Presidenta de Enfermeras fue la encargada de presentar a la Asamblea Suprema la relación de Damas Auxiliares Voluntarias, Enfermeras Profesionales y Ayudantes de Enfermeras que según los datos remitidos por las Presidentas de Asambleas merezcan esta recompensa. El Inspector General Médico presentará lo que se refiere a los Médicos y Practicantes y el Inspector de Ambulancias.

${ }^{322}$ ACCRE. Caja 2532, Exp. 10. Sección Asamblea Suprema de Burgos, 1936-1939.
} 


\section{Capítulo V}

hospitales de la institución menos de cien días, ya que no tenían derecho a la concesión de la medalla de campaña ${ }^{323}$.

La medalla de Cruz Roja únicamente se concedió a las hermanas, damas auxiliares voluntarias y enfermeras profesionales que habían trabajado en los hospitales de la institución en la zona nacional o en equipos y hospitales militares de la misma. Por lo tanto aquellas que permanecieron en la zona republicana y no atendieron a los heridos nacionales, no tuvieron derecho a ningún tipo de condecoración. De esta forma, no se concedieron medallas al personal sanitario que trabajó “en hospitales de Cruz Roja de la zona marxista, aun cuando sean completamente de los nuestros" ${ }^{324}$.

El trabajo que desempeñaron las enfermeras durante la contienda fue importante y se reconoció por las diferentes instituciones:

En la Gran Semana en que se celebren las fiestas de la Victoria, la Asamblea Suprema y esta Presidencia de Enfermeras tienen un especial recuerdo para todas aquellas que supieron, con alto espíritu de patriotismo, ofrendar su juventud y bienestar, en el cumplimiento de su caritativa y humanitaria labor, quedando a la vez sumamente agradecidos a la constancia, abnegación y sacrificio con que han trabajado en nuestros hospitales de vanguardia y retaguardia todas las Enfermeras de la Institución ${ }^{325}$.

\footnotetext{
${ }^{323}$ ACCRE. Caja 2310, Exp. 6. Córdoba 1939-1940. 8 de mayo de 1940.

${ }^{324}$ ACCRE. Caja 2310, Exp. 26. Personal enfermeras. Murcia 1939-1940. Correspondencia Marquesa de Valdeiglesias. 22 de mayo de 1940.

${ }^{325}$ ACCRE. Caja 2310, Exp. 6. Córdoba 1939-1940. 16 de mayo de 1939.
} 


\subsection{Situación laboral y económica: vencedoras y vencidas}

La entrada de las tropas nacionales en Madrid hizo que muchas enfermeras nacionales quisieran participar en la misma, guiadas principalmente por el deseo de ver a la familia que había permanecido allí durante todo el conflicto. La gran demanda hizo que se cubrieran las plazas vacantes rápidamente por lo que Mercedes Milá tuvo que rechazar muchos de los ofrecimientos ${ }^{326}$. Fue común que las enfermeras quisieran formar parte de los grupos sanitarios destinados a las poblaciones liberadas, sobre todo a Barcelona, Madrid y Valencia ${ }^{327}$. Por eso Mercedes Milá no tuvo ningún problema a la hora de constituir los equipos de personal sanitario femenino para la ocupación de las ciudades. Diferente fue el caso de los hospitales de prisioneros que necesitaron personal para asistirlos. En Barcelona Mercedes propuso a la delegada que solicitara ayuda a Falange, Cruz Roja o Acción Católica, organizaciones con capacidad para reclutar voluntarias ${ }^{328}$.

Muchas enfermeras dejaron sus puestos de trabajo para acudir a Madrid a ver a sus familiares o presenciar el desfile de Franco, lo que ocasionó problemas a la hora de suplir las bajas ${ }^{329}$. Estaban "agotadas y sin fuerzas" por los meses de trabajo, animadas por sus familias, deseaban ser licenciadas y dejar sus puestos ${ }^{330}$. En algunas ocasiones, las damas fueron reacias a continuar con su trabajo cuando finalizó el conflicto porque estaban "cansadas de tanto hospital"331. Para evitar el abandono del servicio se hizo una restructuración de los horarios laborales adaptados a las nuevas cargas ocasionadas con los cierres de hospitales, lo que permitió reducir la jornada, de forma que trabajaban por semanas o quincenas, obteniendo mayores periodos de descanso ${ }^{332}$. Aún así, los ceses por falta de disciplina continuaron ${ }^{333}$. Una vez finalizado el conflicto, en los hospitales de

\footnotetext{
${ }^{326}$ AGMAV, C. 42069,2/27. Correspondencia de Mercedes Milá, 18 de febrero de 1939.

${ }^{327}$ AGMAV, C. 46761,2/43. Correspondencia de Mercedes Milá, 14 de marzo de 1939.

${ }^{328}$ AGMAV, C. 46761,2/45-46.Correspondencia de Mercedes Milá, 15 de marzo de 1939.

${ }^{329}$ AGMAV, C. 42069,2/157. Correspondencia de Mercedes Milá, 8 de mayo de 1939.

${ }^{330}$ AGMAV, C. 42069,2/168. Correspondencia de Mercedes Milá, 18 de diciembre de 1939.

${ }^{331}$ ACCRE. Caja 2310, Exp. 6. Córdoba 1939-1940. 11 de noviembre de 1939.

${ }^{332}$ AGMAV, C. 42069,2/167. Correspondencia de Mercedes Milá, 29 de diciembre de 1939.

${ }^{333}$ AGMAV, C. 46761,2/95. Correspondencia de Mercedes Milá, 13 de mayo de 1939.
} 
Sanidad Militar cambiaron las cargas de trabajo, según las enfermeras fue "la temporada más desagradable”. Tuvieron pocos heridos, ya que principalmente atendieron a enfermos de sarna, piodermitis, viruela y "otras cosas repugnantes" 334 .

La situación económica impuesta en la postguerra obligó a muchas enfermeras a "trabajar para vivir", pero el problema fue que cada vez se necesitaban menos profesionales por lo que fue complicado conservarlas en los hospitales. Para paliar esta situación se propuso que se les concedieran ciertos privilegios como excombatientes que les facilitaran el acceso a nuevos puestos laborales ${ }^{335}$. Ser viudas y con hijos que alimentar impulsó a las enfermeras a solicitar trabajo en los hospitales de Sanidad con la esperanza de obtener alguna remuneración económica. Únicamente se las podía conceder alojamiento, manutención y las 25 pesetas de gratificación, sueldo insuficiente para asumir las cargas familiares ${ }^{336}$. Algunas no llegaron a cobrarla por estar movilizadas sin causa justificada, ya que había personal femenino suficiente en la localidad para desempeñar el trabajo en la zona $^{337}$. Tampoco se permitió que trabajaran las enfermeras que no pasaron la "depuración", debido a su pasado profesional "dudoso" 338 , mientras que aquellas que la superaron y quedó demostrada su adhesión al "Glorioso Movimiento Nacional” sí pudieron ejercer $^{339}$.

Al terminar la guerra los hospitales militares volvieron a su régimen normal, contando únicamente con Hermanas de la Caridad como personal femenino auxiliar. Las plazas de voluntarias retribuidas desparecieron, por lo que las enfermeras interesadas en trabajar a cambio de un salario en los centros de Sanidad Militar no vieron cubiertas sus expectativas ${ }^{340}$. La retirada de las internas de los hospitales se hizo progresivamente según fue disminuyendo la carga asistencial que dejaron en

\footnotetext{
${ }^{334}$ ACCRE. Caja 2310, Exp. 2. Personal enfermeras. Cádiz. 1939-1940. Correspondencia Marquesa de Valdeiglesias. 3 de junio de 1940.

${ }^{335}$ AGMAV, C. 42069,2/151-152. Correspondencia de Mercedes Milá, 4 de octubre de 1939.

${ }^{336}$ AGMAV, C. 46761,2/25-26. Correspondencia de Mercedes Milá, febrero de 1939.

${ }^{337}$ AGMAV, C. 46761,2/27. Correspondencia de Mercedes Milá, 15 de junio de 1939.

${ }^{338}$ ACCRE. Caja 2310, Exp. 1. Personal enfermeras. Cáceres 1939-1940. Correspondencia Marquesa de Valdeiglesias. 8 de mayo de 1940.

${ }^{339}$ ACCRE. Caja 2310, Exp. 2. Hospital y dispensario 1939, Madrid. Correspondencia Marquesa de Valdeiglesias. 27 de julio de 1939.

${ }^{340}$ AGMAV, C. 46761,2/28. Correspondencia de Mercedes Milá, 20 de febrero de 1940.
} 
manos de las Hermanas ${ }^{341}$, por lo que fue necesario aumentar su contratación para cubrir las vacantes hospitalarias $^{342}$. El reglamento de hospitales militares fijaba una Hermana de la Caridad por cada veinticinco camas, siendo esta distribución en ocasiones insuficiente para asumir las cargas de trabajo, ya que además de dedicarse a la tarea asistencial, se tuvieron que encargar de la "cocina y despensa, lavadero y ropería"343. La máxima autoridad en el hospital continuó siendo la Madre Superiora $^{344}$, siendo, en algunas ocasiones, reacias a que las seglares ocuparan el cargo de jefe de enfermeras ${ }^{345}$.

Esta situación de desempleo, hizo que las enfermeras contratadas en sanatorios y clínicas durante el conflicto, temieran perder sus cargos al finalizar el mismo ${ }^{346}$. Ante la ausencia de plazas retribuidas, Mercedes Milá aconsejó a las interesadas en trabajar que se presentaran a las oposiciones de instructoras de sanidad $^{347}$. La asociación de viudas y huérfanas de militares solicitó a Mercedes Milá un trato preferente para sus enfermeras a la hora de las contrataciones ${ }^{348}$. El problema fue que en Sanidad Militar no existieron plazas retribuidas, por lo que la inspectora se comprometió a tenerlas en cuenta en el caso de que en un futuro existieran vacantes de ese tipo ${ }^{349}$. En los hospitales de Cruz Roja las enfermeras profesionales tuvieron derecho a alojamiento, manutención y a recibir un sueldo de ciento veinticinco pesetas, el problema fue que las plazas retribuidas vacantes, entre una y dos, dependiendo del centro, no fueron suficientes ${ }^{350}$.

\footnotetext{
${ }^{341}$ AGMAV, C. 42069,2/209. Correspondencia de Mercedes Milá, 7 de enero de 1939.

342 AGMAV, C. 46761,2/145-146. Correspondencia de Mercedes Milá, 26 de febrero y 8 de mayo de 1940 .

343 AGMAV, C. 46761,2/147-148. Correspondencia de Mercedes Milá, 17 de abril de 1940.

${ }^{344}$ ACCRE. Caja 2310, Exp. 27. Personal enfermeras. Navarra. 1939-1940. Correspondencia Marquesa de Valdeiglesias. 27 de septiembre de 1940.

345 ACCRE. Caja 2310, Exp. 27. Personal enfermeras. Navarra. 1939-1940. Correspondencia Marquesa de Valdeiglesias. 16 de octubre de 1940.

${ }^{346}$ AGMAV, C. 46761,2/31. Correspondencia de Mercedes Milá, 29 de febrero de 1940.

${ }^{347}$ AGMAV, C. 46761,2/75. Correspondencia de Mercedes Milá, 23 de abril de 1940.

${ }^{348}$ AGMAV, C. 46761,2/179-180. Correspondencia de Mercedes Milá, 15 de octubre de 1940.

349 AGMAV, C. 46761,2/181. Correspondencia de Mercedes Milá, 11 de noviembre de 1940.

${ }^{350}$ ACCRE. Caja 2310, Exp. 10. Enfermeras. San Sebastián, 1939-1940. 19 de diciembre de 1939.
} 
La necesidad de que las enfermeras percibieran un salario, hizo que Mercedes Milá solicitara las plazas de enfermeras del Sanatorio de Sierra Espuñea y las del Patronato Nacional de Antituberculosos, para las Excombatientes de Sanidad Militar y Sección Femenina ${ }^{351}$. También intercedió por las que se presentaron a las plazas del Dispensario Musulmán de Tánger, enviando al responsable político de la zona una relación de los servicios prestados durante la contienda por las enfermeras ${ }^{352}$.

Algunas de las enfermeras que trabajaron para la República y permanecieron fieles a ella se vieron obligadas a salir de España para evitar posibles represalias, ya que temían ser acusadas y encarceladas. Ejemplo ello fueron las enfermeras catalanas que atravesaron los pirineos con la esperanza de encontrar apoyo en el país vecino. Francia les dio alojamiento, inicialmente en campos de concentración, y trabajo, hasta 1940, año en el que todas las que no tenían familia en la zona o eran menores de edad, tuvieron que volver a España, donde pasaron diversos controles policiales hasta confirmar que no eran peligrosas para el nuevo régimen ${ }^{353}$.

Los títulos de las enfermeras de guerra obtenidos por las republicanas no tuvieron ningún tipo de validez al desaparecer la República, de forma que las interesadas en el campo sanitario tuvieron que volver a cursar los estudios para obtener el diploma oficial expedido durante el Franquismo ${ }^{354}$. Sección Femenina les dio la oportunidad de convalidar el título a través del Servicio Social, si acudían "durante meses a las puertas de los cines o de las iglesias a poner pegatinas para pedir dinero a la gente" ${ }^{, 355}$.

\footnotetext{
${ }^{351}$ AGMAV, C. 46761,2/184. Correspondencia de Mercedes Milá, 23 de abril de 1940. ${ }^{352}$ AGMAV, C. 46761,2/185. Correspondencia de Mercedes Milá, 13 de julio de 1940.

${ }^{353}$ RAMIÓ, A; TORRES, C: op.cit., pp. 77-78.

${ }^{354}$ Ibid., p. 79.

${ }^{355}$ Ibid., p. 85.
} 


\subsection{Formación de enfermeras para la paz}

El cuerpo de damas enfermeras voluntarias de Sanidad Militar no se disolvió una vez terminada la guerra, se continuó con su formación por si volvían a ser necesarios sus servicios ${ }^{356}$. Se organizó un servicio de Damas Auxiliares de Sanidad Militar en tiempos de paz para contar con un "cuerpo de reserva en caso de que fuera necesario" $" 357$. Carmen Polo de Franco fue la invitada principal en los actos de inauguración de los cursos ${ }^{358}$ e imposición de medallas y recompensas, a los que acudió siempre que pudo ${ }^{359}$. Una vez finalizado el conflicto, Sanidad Militar continuó impartiendo cursillos y conferencias para auxiliares voluntarias ${ }^{360}$. En 1941 se estableció el Reglamento de Damas Auxiliares de Sanidad Militar y se ratificó a Mercedes Milá como Inspectora General. La reorganización establecida en el reglamentó obligó a Mercedes a desplazarse fuera de Madrid, por lo que le fue difícil compaginar su trabajo con el cargo de Jefe de Sección de las Oficinas de la Asamblea Suprema que tenía en Cruz Roja:

Como por mi cariño a la Institución, a que pertenezco y vengo sirviendo en cargos voluntarios y remunerados desde el año 1919, me dolería en extremo tener que dejarla definitivamente, ruego a V. E. tenga a bien concederme un permiso ilimitado, sin sueldo, por si una vez pasadas estas circunstancias, pudiese volver a reanudar mis actividades dentro de la Institución, que por otra parte no quiero tampoco hacer cesar en absoluto mientras el poco tiempo de que puedo disponer, me permita serle útil en cualquier clase de trabajo ${ }^{361}$.

Como se ha visto, las enfermeras que prestaron servicios durante la Guerra Civil en los hospitales de vanguardia, quedaron equiparadas "al elemento masculino", y estuvieron exentas de hacer el examen de ingreso exigido para cursar

\footnotetext{
${ }^{356}$ AGMAV, C. 42761,2/139. Correspondencia de Mercedes Milá, 23 de agosto de 1939.

${ }^{357}$ AGMAV, C. 42068,2, Correspondencia de Mercedes Milá, 21 de noviembre de 1939

358 AGMAV, C. 46761,2/106. Correspondencia de Mercedes Milá, 2 de marzo de 1940.

${ }^{359}$ AGMAV, C. 46761,2/162. Correspondencia de Mercedes Milá, 22 de mayo de 1940.

${ }^{360}$ AGMAV, C. 46761,2/47. Correspondencia de Mercedes Milá, 1 de marzo de 1940.

${ }^{361}$ ACCRE. Caja 2532, Exp. 18. Sección de enfermeras 1939.
} 
cualquier carrera en la universidad ${ }^{362}$, lo que facilitó su acceso a la misma. En esta línea Cruz Roja permitió obtener el diploma de enfermera profesional a las damas auxiliares voluntarias que hubieran "prestado servicios como tales en los establecimientos de Cruz Roja, Hospitales Militares o Equipos Quirúrgicos, durante un periodo de tiempo superior a dos años". Se las permitió asistir a los cursos especiales convocados por la institución con el objetivo de cubrir en un cincuenta por ciento más, las plazas de alumnas enfermeras profesionales correspondientes al segundo y tercer curso de sus estudios, en el caso de que hubiera vacantes. Debían presentar una solicitud a la presidenta de enfermeras, un certificado del hospital o equipo en el que hubieran prestado sus servicios, y partida de bautismo y de nacimiento demostrando que tenían menos de treinta y cinco años. Debían pasar un reconocimiento médico y aprobar un examen de geografía, historia universal y de España, aritmética, gramática y escritura. Las maestras, o las que tuvieran el título de bachiller o carrera de comercio estaban exentas de realizar dicha prueba, pero tenían que presentarse, al igual que el resto de aspirantes, al examen técnico con arreglo al programa de enfermeras auxiliares voluntarias de segundo curso. Si eran aceptadas, tenían que permanecer como internas en la escuela en las mismas condiciones que las alumnas profesionales. La cifra máxima de solicitantes por curso fue de treinta. Las damas auxiliares voluntarias que ingresaron en la escuela contaron con manutención y estancia gratuita ${ }^{363}$. A pesar de las facilidades que Cruz Roja dio a las damas para entrar en la Escuela de Enfermeras Profesionales, muchas rechazaron la oferta, ya que tenían que desplazarse de su domicilio habitual para cursar los estudios ${ }^{364}$. Otro inconveniente fueron las calificaciones que obtuvieron en los exámenes:

Han estado flojísimas, tanto, que excepto dos que pasarán a tercer curso, las demás tienen que empezar por el primero si quieren obtener el título. Puedes figurarte lo que siento que tu recomendada la Srta. Isabel Martínez Carvajal se vea también en este caso; es una muchacha muy mona y de la que esperaba algo más pues no solo flojea en el conocimiento del programa sino que no está a la altura de

\footnotetext{
${ }^{362}$ AGMAV, C. 46761,2/201. Correspondencia de Mercedes Milá, 21 de septiembre de 1939.

${ }^{363}$ ACCRE. Caja 2351, Exp. 8. Personal 1944. 2 de octubre de 1941.

${ }^{364}$ ACCRE. Caja 2310, Exp. 2. Personal enfermeras. Cádiz. 1939-1940. Correspondencia Marquesa de Valdeiglesias. 19 de octubre de 1939.
} 
lo yo creí en cultura general. Comprendo la contrariedad que supone este retraso para la interesada, más yo espero que ella se convenza y comprenda es necesario estos tres años para su perfecta formación. Estoy decidida a que nuestras enfermeras obtengan la consideración y el prestigio profesional máximo por su preparación y cultura y para ello es necesario su permanencia en la Escuela ${ }^{365}$.

Respecto a la formación de damas auxiliares, Cruz Roja, continuó con la misma al finalizar la Guerra Civil. En algunas localidades, inicialmente hubo problemas por falta de profesorado, por lo que se retrasó el inicio de los cursos hasta que contaron con el personal necesario para impartirlos ${ }^{366}$. La Marquesa de Valdeiglesias, presidenta de enfermeras de Cruz Roja, fue partidaria de ofrecer una formación sólida y de calidad. Por eso hizo hincapié en que las delegadas de la institución cuidaran "con especial esmero" que las alumnas fueran "asiduas a las clases y prácticas", que estudiaran de verdad y se esforzaran. Debían tener claro que "aunque la misión que han de realizar sea de una manera voluntaria y gratuita no excluye el hacerla de un modo inteligente y de probada competencia para lo cual es necesario aprovechar en las clases y trabajar con entusiasmo" ${ }^{\text {367 }}$. La institución también continuó con la formación de enfermas visitadoras o sociales, especializadas en higiene y Salud Pública, que se convertirían en el "mejor intermediario entre el individuo y las organizaciones susceptibles de procurarle el bienestar físico y moral de que carece, contribuyendo de paso a su educación social" ${ }^{\prime 368}$.

\footnotetext{
${ }^{365}$ ACCRE. Caja 2310, Exp. 1. Personal enfermeras. Cáceres 1939-1940. Correspondencia Marquesa de Valdeiglesias. 13 de septiembre de 1939.

${ }^{366}$ ACCRE. Caja 2310, Exp. 7. Personal enfermeras. Coruña 1939-1940. Correspondencia Marquesa de Valdeiglesias. 18 de octubre de 1939.

${ }^{367}$ ACCRE. Caja 2310, Exp. 7. Personal enfermeras. Coruña 1939-1940. Correspondencia Marquesa de Valdeiglesias. 1 de diciembre de 1939.

${ }^{368}$ Liga de Sociedades de la CRUZ RoJa: La Cruz Roja y las enfermeras de higiene social, Ginebra, 1942 , p. 5.
} 
Falange Española Tradicionalista y de las J. O. N. S. siguió impartiendo cursos para damas enfermeras. Durante los dos meses de formación, las alumnas asistían por las mañanas a las clases prácticas y por las tardes a las teóricas ${ }^{369}$.

Los estudios de Enfermería, de dos años de duración, buscaban a través de la formación teórico-práctica, habilitar a las enfermeras para asistir a los enfermos, cuidar su aseo y alimentación, recoger los datos clínicos y administrar medicación. Las prácticas podían realizarlas en instituciones de "tipo religioso o patriótico". La edad mínima para acceder a los estudios era de dieciocho años, y cuarenta y cinco la máxima. Par obtener el título de enfermera debían demostrar ante el tribunal examinador constituido por dos profesores de la Facultad de Medicina y otro facultativo de la institución donde hubieran realizado sus estudios, que habían adquirido los conocimientos necesarios para el desempeño de la profesión ${ }^{370}$.

El programa de estudios quedó dividido en un total de treinta y tres lecciones y un programa práctico que incluía ocho apartados: habitación del enfermo, manera de hacer una cama, limpieza del enfermo, alimentación del enfermo, exploraciones generales, intervenciones, asepsia y vendajes ${ }^{371}$. La parte teórica se podría dividir a groso modo en dos bloques principales: Anatomía y Fisiología ${ }^{372}$, sin olvidarse de todo el temario centrado en los cuidados y las técnicas para llevar a cabo los mismos.

La vocación continuó formando parte de la profesión, necesaria para "dedicarse con entusiasmo" a cuidar a los enfermos, al igual que la disciplina necesaria para ejecutar las órdenes de los superiores y la normativa del hospital:

El amor al que sufre, la caridad bien sentida, la abnegación más profunda y hasta si llega el caso, el espíritu de sacrificio, son virtudes precisas, para quien se

\footnotetext{
${ }^{369}$ La Vanguardia, 21 de septiembre de 1939, Entrega de diplomas a las damas enfermeras, p. 9.

${ }^{370} \mathrm{BOE} \mathrm{n}^{\circ} 148,28$ de mayo de 1941, Orden sobre condiciones y estudios necesarios para la obtención del título de Enfermera, p. 3811.

${ }^{371}$ MURGA Y SERRET, Jorge: La enfermera española, sucesores de Rivadeneyra, S. A. Madrid, 1942, pp. $5-10$.

372 PonjoAn, Alberto: Manual de la enfermera de Santa Madrona. vol. I -fasc. I, Instituto de la mujer que trabaja, organismo de Acción Social Femenina, Caja de Pensiones para la Vejez y Ahorros, Barcelona, 1940.
} 
dispone a vivir, una buena parte de su vida, en medio del dolor ajeno y en contacto con el ambiente más humilde ${ }^{373}$.

Las características morales que exigían a la "enfermera española" se resumían principalmente en religiosidad "grabada en lo más profundo de su espíritu" y la cordialidad y buen trato como características sociales, necesarias "para el cumplimiento de los deberes" profesionales ${ }^{374}$. Las enfermeras debían ser mujeres cultas e instruidas, activas, diligentes, resolutivas, enérgicas, simpáticas y agradables $^{375}$. Tenían que reunir unas cualidades físicas que las permitiera ejercer la profesión, por lo que no se admitirían a aquellas que tuvieran "alteración de la función de los órganos de los sentidos, especialmente vista y oído"376.

El uniforme continuó siendo un distintivo y no perdió la importancia que había adquirido durante el conflicto. Por eso la imagen de la enfermera debía cuidarse y alejarse de toda frivolidad:

Creo que vistiendo nuestro uniforme se debe ir tocada modestamente; sin rizos ni alardes de atavío banal, pero... como nuestra Presidenta no quiere entender, o preocuparse de ello, tolera que las chicas vayan cada cual como quiera, y me dice: -“Hay que dar a la edad lo suyo"- Que es lo mismo que decirme -"Está usted vieja y no le concede la juventud que vaya disfrazada de Enfermera! Sigo creyendo cada día con más seguridades, que los enamorados de nuestra institución, y de cuanto de ella se deriva, no podemos compartir con los que no pueden sentir honradamente el realce de los detalles que coronan el éxito del Reglamento que se hizo para cumplirlo fielmente ${ }^{377}$.

Cruz Roja contó con un uniforme de calle, diferente al que utilizaban en el hospital, con toca azul en lugar de blanca. A nivel económico supuso un desembolso

\footnotetext{
373 ALMANSA DE CARA, Salvador: Lecciones para enfermeras de lucha antituberculosa, Editorial Dardo, Málaga, 1940, p. 22.

${ }^{374}$ La Vanguardia, 30 de marzo de 1939, Jefatura Provincial de Falange Española y Tradicionalista y de las J.O.N.S., p. 5.

${ }_{375}$ Almansa De CARA, S: op. cit., p. 23.

${ }^{376}$ Herrero, Dionisio; UnZaga, José; Cornago, alejo: Manual de la enfermera. Casa Central, Madrid, 1940 , p. 137.

377 ACCRE. Caja 2310, Exp. 3. Personal enfermeras. Canarias. Santa Cruz de Tenerife. 1939-1940. Correspondencia Marquesa de Valdeiglesias. 28 de marzo de 1940.
} 
importante para aquellas enfermeras que decidieron hacerse $u^{378}$, ya que la tela costaba trece pesetas el metro. Este traje no fue obligatorio, pero sí estaba prohibido que salieran a la calle con el uniforme de servicio. Únicamente podían utilizar el uniforme reglamentario blanco en actos oficiales, cuyo velo no podía ser redondo ya que no se correspondía con el de Cruz Roja ${ }^{379}$.

En Barcelona, se prohibió usar el uniforme en la calle y lugares públicos a todas aquellas profesionales que no pertenecieran a Sanidad, Cruz Roja, o a F. E. T. y J. O. N. S. ${ }^{380}$. Las enfermeras tenían que honrar el uniforme, ya que era el signo exterior de disciplina y no podía ser manchado por "una conducta irregular"

El modelo de enfermera que se consolidó durante la Guerra Civil y prevaleció durante el franquismo se ajustaba al icono de mujer nacional. Durante el conflicto fue el personal sanitario femenino el que llevó "a la cabecera de los heridos todos los consuelos de su cariño, de su bondad y de su angelical alma". De forma que una vez finalizado, la enfermera pasó a representar la bondad, la discreción y el talento, además de la sencillez y la modestia, siendo modelo de esposa y madre ${ }^{382}$. La enfermera pasó a ser una heroína y un ejemplo a seguir para otras mujeres, llegando a escribirse novelas en la que la protagonista había ejercido como voluntaria en los hospitales nacionales, encontrando el amor ${ }^{383}$.

A todas vosotras no hay más que veros el rostro: os encanta leer versos; tenéis un alma de poesía, como que la poesía no es más que una de las exhalaciones instintivas del corazón y del sentimiento, y todas vosotras, estoy seguro, que habréis leído El Alma, de Gabriel y Galán. ¡Cómo arrebatan y cómo embelesan aquellas descripciones suyas de la mujer castellana, el tipo de hogar, el ángel tutelar que a la

\footnotetext{
${ }^{378}$ ACCRE. Caja 2310, Exp. 2. Personal enfermeras. Cádiz. 1939-1940. Correspondencia Marquesa de Valdeiglesias. 26 de julio de 1939.

379 Ibid., 8 de agosto de 1939.

${ }^{380}$ La Vanguardia, 14 de febrero de 1939, El uso de uniformes de las enfermeras, p. 5.

${ }^{381}$ La Vanguardia, 30 de marzo de 1939, Jefatura Provincial de Falange Española y Tradicionalista y de las J.O.N.S., p. 5.

${ }^{882}$ VIZCONDE DE EZA: El alma femenina española. Conferencia dada el 7 de marzo de 1940, inaugural de las organizadas por la Inspección de Damas Auxiliares de Sanidad Militar de Madrid. Madrid, 1940, p. 3.

${ }^{383}$ BONEL, Maite: Episodios de una enfermera, El Noticiero, Zaragoza, 1940.
} 
familia sostiene y al campo convierte en la fuente perenne de toda la tonalidad y fuerza nacionales! ¿No recordáis? $[\ldots]^{384}$.

Estas características morales han acompañado a las enfermeras durante un largo periodo de tiempo, influyendo en su imagen social y limitando su desarrollo profesional.

${ }^{384}$ VIZCONDE DE EZA: op.cit., 10. 
ANEXOS V 

Anexo XXIV. Cuestionario para enfermeras interesadas en trabajar en el frente.

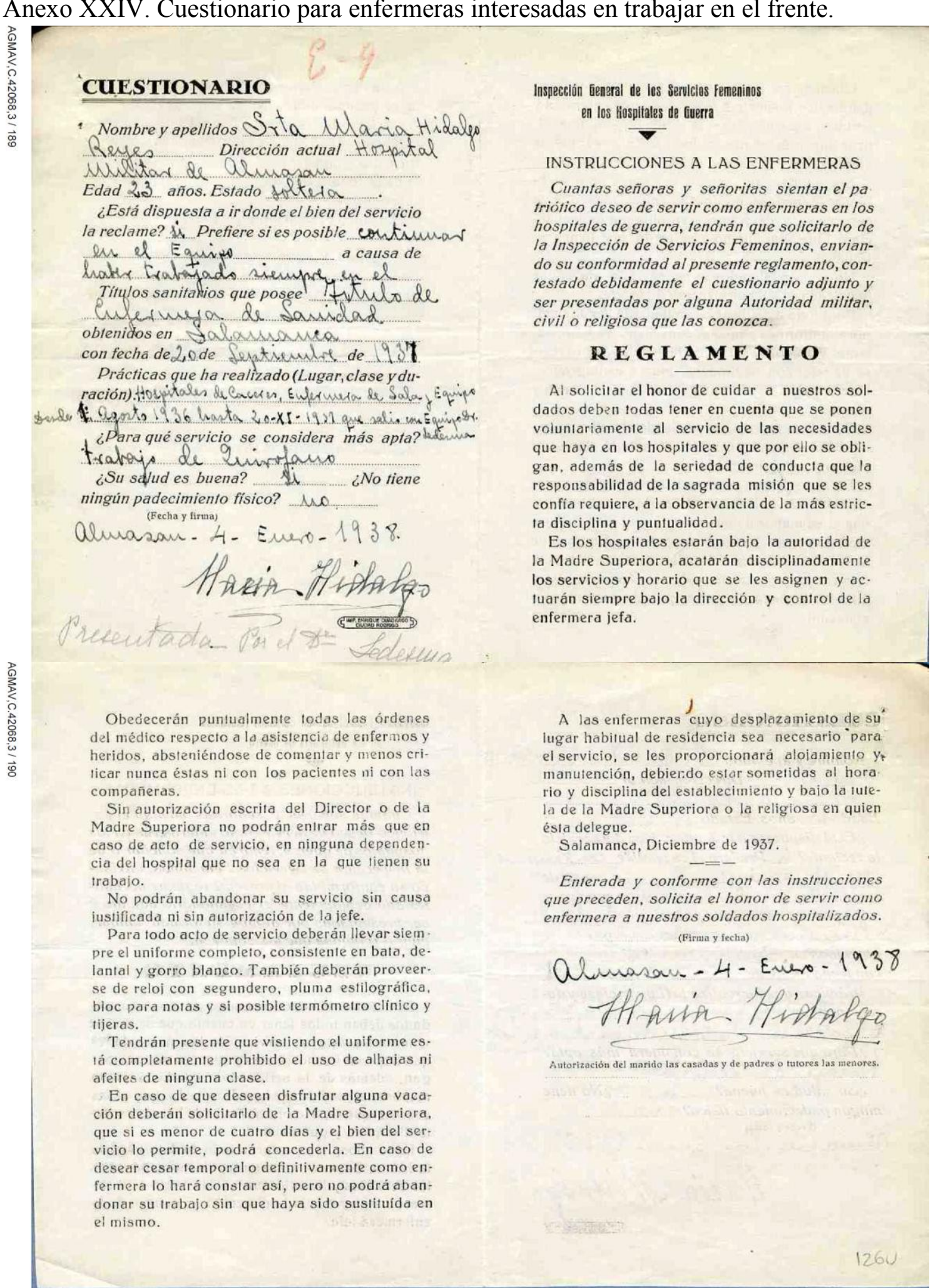

Fuente: AGMAV, C. 42068,3/189-190, Correspondencia Mercedes Milá. 
Anexo XXV. Listado de enfermeras interesadas en trabajar en hospitales militares y relación de su conducta.

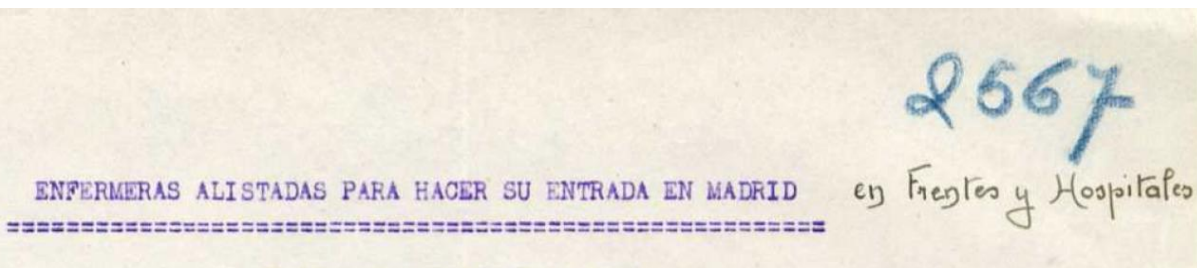

Enfermeras de la Cruz Roja

Isabel Solaun Ygartua Muy buepa enfermera. Tiese vendadero interes en in a Madrid. de toda confiánza Mar angeles Isasi Cobreros Formal y eficiente

Catalina Cadenas Cobreros Enf. de Unuguay.muy eficiente. Venida de su Patria deseosa de colabonar en lo que concepeión Zufía Baranguan tótá en ya en ef Frepte. pueda por juestra (ausa ivacioba Tersa Castiella Naiz Muy formal y Guena enfermera

Coneepeión Echague Mesteyer Buera enfermera contoda su familia en Madnid. muy formal. Vietoria Saenz de Nagarola No es de Pas más eficiegtes

Asunción Rodriguez Paseual Enf. de Madrid muy formal.

\section{Enfermeras Auxiliares de Sanidad Militar}

Juanita Echoverría Egusquiza Muy formal y bueva enfermera

Pilar Albert Rodriguez es de Madild.

Nievea Gonzalez Urttaga Fonmal y buena eyfermera

Pilar Alcántara Formal y buena enfermera

Aapare Ouenca Cervero May abyegada eficiente y formal. Detoda confianza - Tiene interes ep in. Frimilio

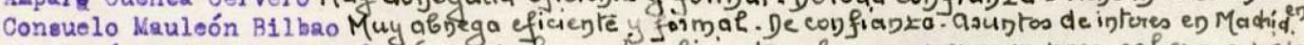
Ana Laría Rodriguez Bullón No es de las más efieiegtes. buega pero un poca cabeza a pajaros Margarita Simpson Muybuepa enfermera $y$ formal

Na Vietoria Dolagaray Uhagón de Madrid. Mnuy buena y muy eficiegte de toda confianza

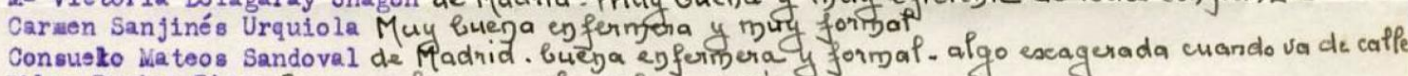
llar Pariza Diego Bueja eyfermera- algo cabesa a pojaros

Rolindez Gomez Cornejo, Enfermera Oficial fa conozjo poco y jo me acaba de copveycer

MP Puta Robadon Jbaies S. M. Buega y formal Lola Gawinde Sovilla de Madnid. Muy formal y funciona casi como enfermera. pasará exeames

Ma Angélica Humaran Varela de Madhid. toda su familia aplí. Fornjal y de muy buepa voluptad Carmen Albert Rodriguez de Madrid yo es de las más efieiegteo

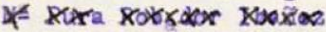

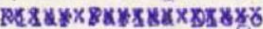

Virginia Oarnica y Pombo. Muy formal y funciona como una ejfermera de toda confiagza Awparo Susanna y Herrera Bueta efica pero uj poco cabeza a pájaros

Concepeión Corral de Pagoaga-Detoda confiagza-pinigía la pante de jervicio en H.M. de Trivitarias Algorta Carmen Garcia Vicente No la conozeo

Nagdalena Garcia Vicente NoPa eonozco

Sra. Dria. Felisa Valdés de Sara súa finve para enfermera, para dinigir imponer respeto. de toela

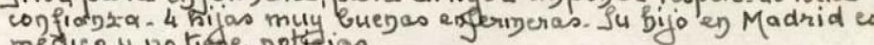
medico y jotiese jotheios.

Fuente: AGMAV, C. 42069,2/6, Correspondencia Mercedes Milá. 
Anexo XXVI. Carta de Isabel López Dóriga delegada de los servicios femeninos de Santander.

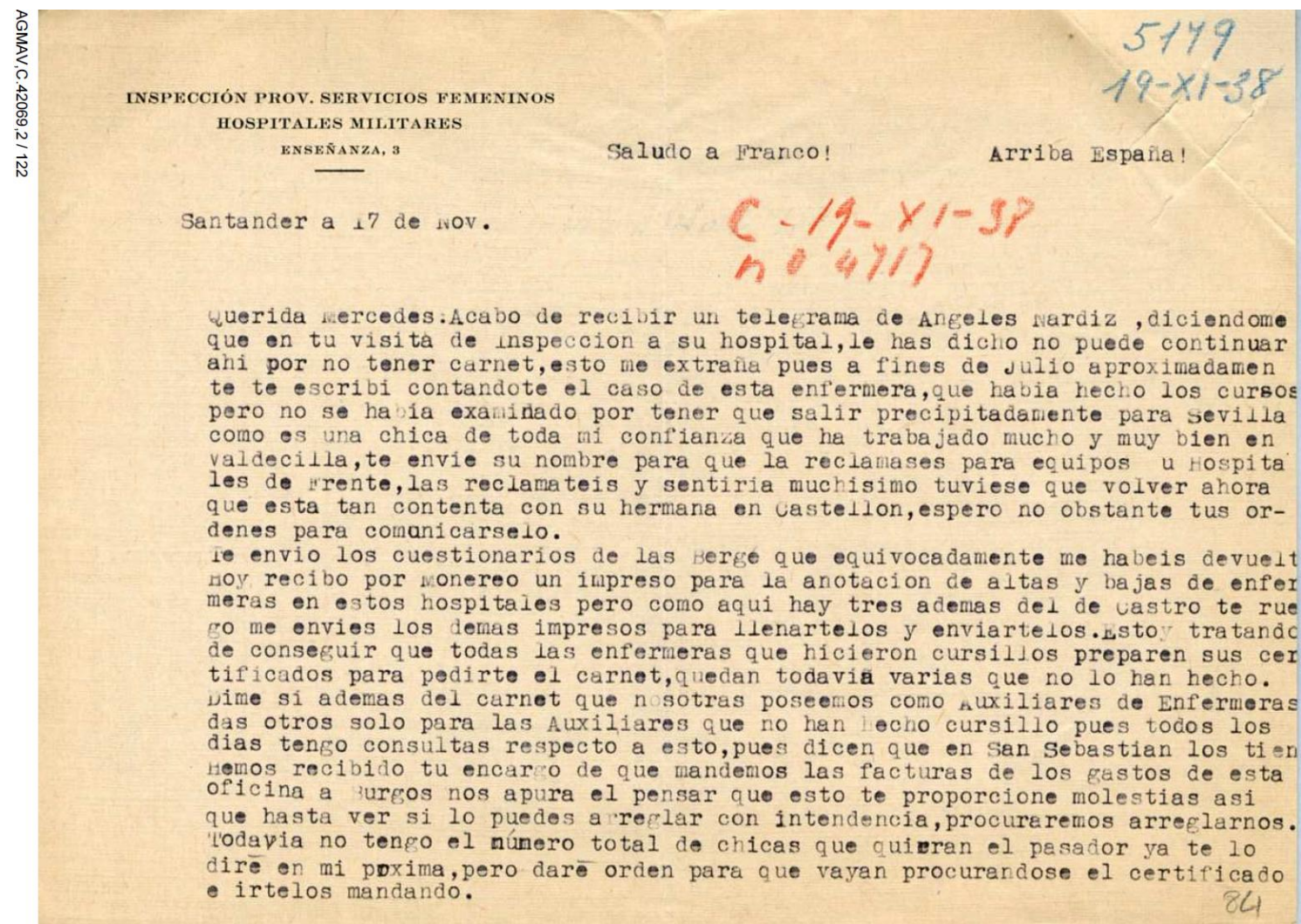

Fuente: AGMAV, C. 42069,2/122, Correspondencia Mercedes Milá, 17 de noviembre de 1938. 
Anexo XXVII. Carta de acuso de recibo de carnets.

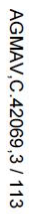

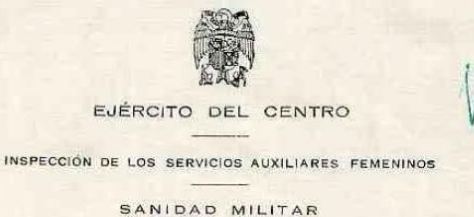

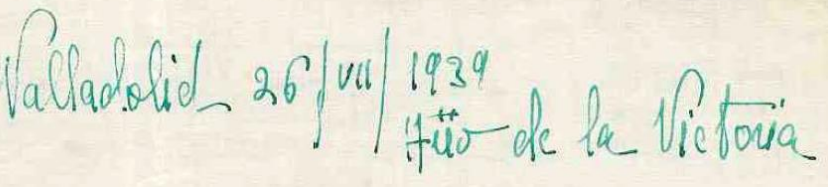

SANIDAD MILITAR

DELEGADA

carta cou los caruets anorida thilagnitos: Recibo tú.

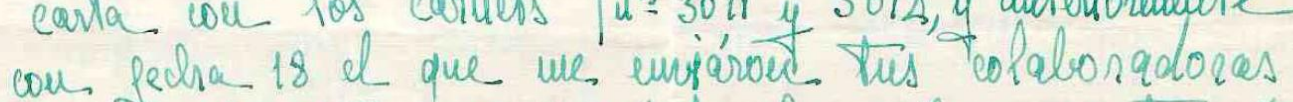
de equriqueta toca $4 \div-5641$, todo lo ncibo penpectameute

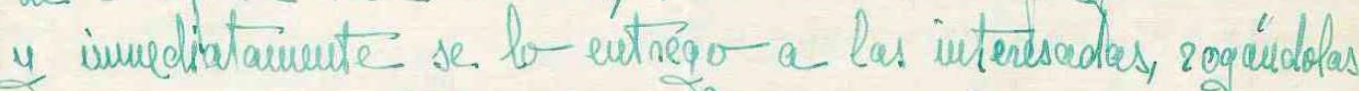
acusen. reubo, y te mino alqueros, y el aval, que la

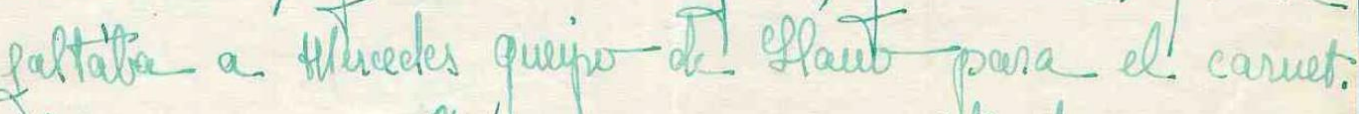

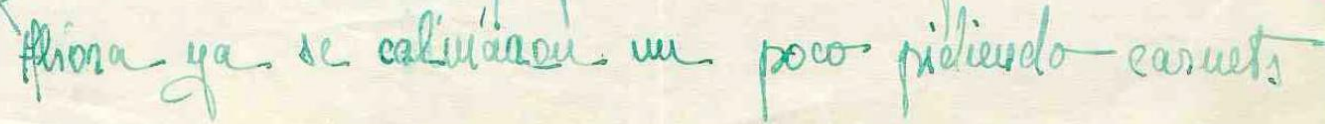

sar las he dicho-lu ondur de Hereedes de no- darkos a las que dejórou de prestar sus serus.

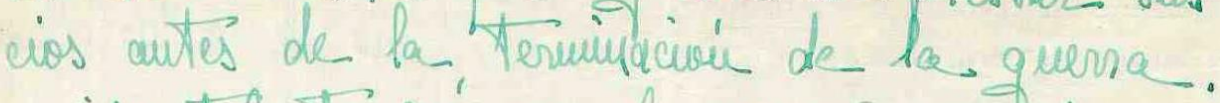
¿que tal Ve fué por el coupo? ue figuro-que.

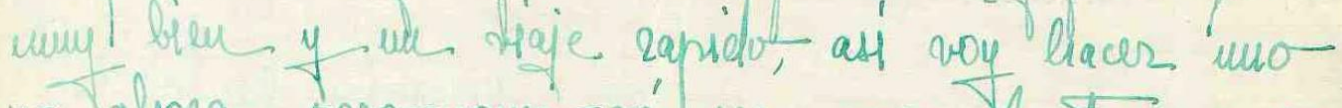
yo ahoras pero- como vál ser. cono Il Xeyo, ya ura finer sique duniaudo- todo lo misuo- que ensemida A. dasa curso, $\mathrm{H}_{2} \mathrm{sez}$ cuestiver de dias. Ya. we nutero que bucarma ya no está coutigo.

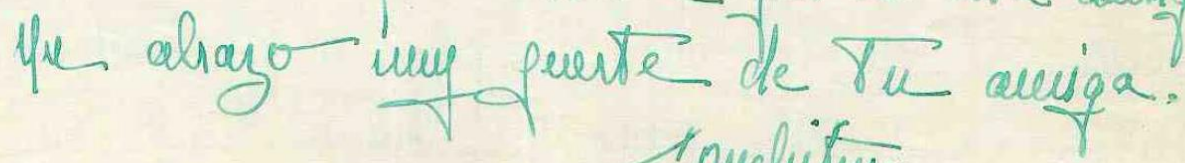

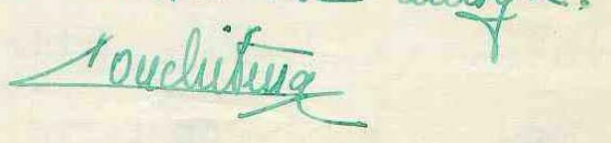

$92 v$

Fuente: AGMAV, C. 42069,3/113-114, Correspondencia Mercedes Milá, 26 de julio de 1939. 
Anexo XXVIII. Circular en la que se explica que Mercedes Milá es la única con autoridad para mover de puesto al personal femenino auxiliar.

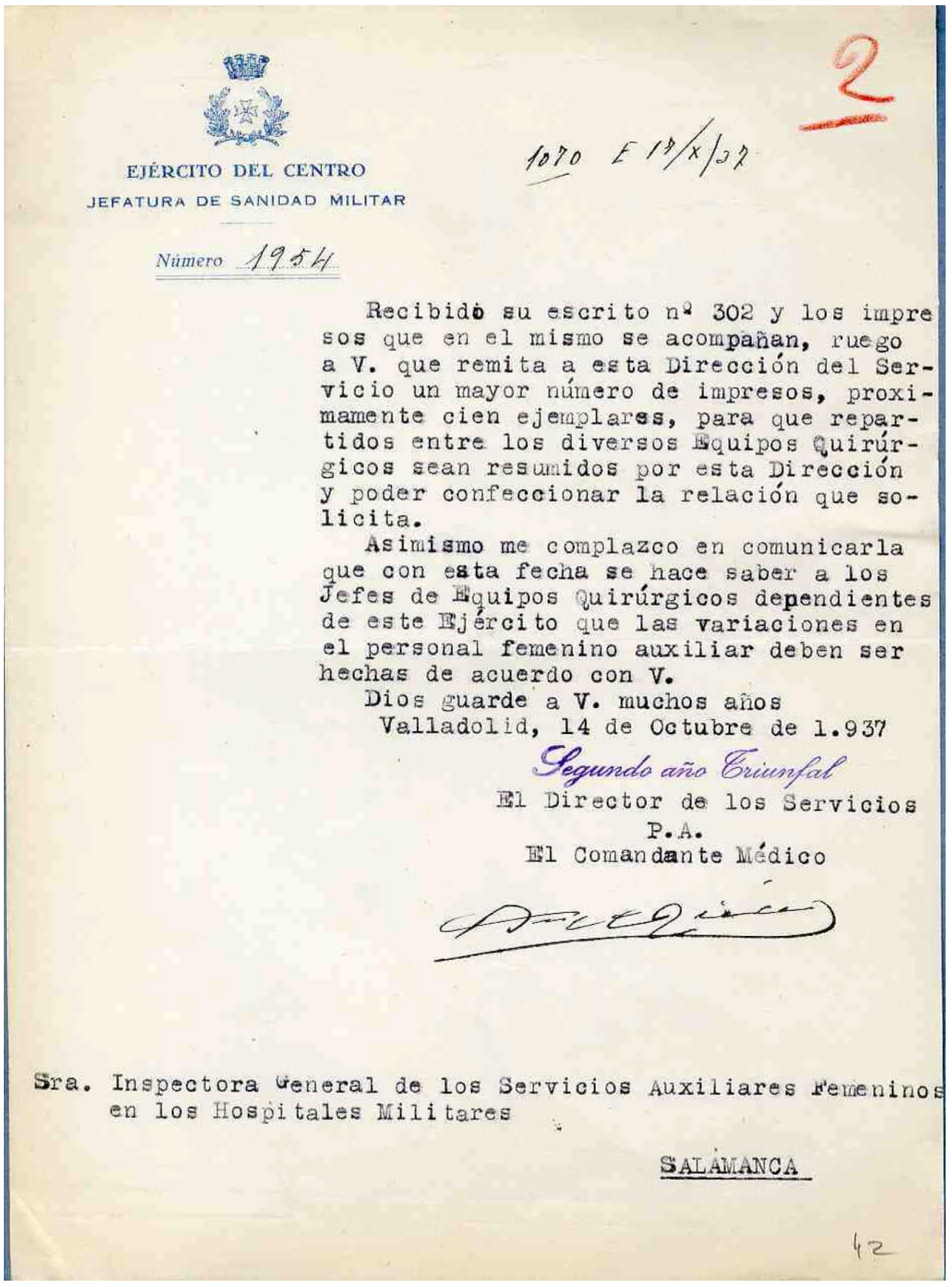

AGMAV,C. $42069,3 / 47$

Fuente: AGMAV, C. 42069,3/47, Correspondencia Mercedes Milá, 17 de octubre del 1937. 
Anexo XXIX. Ceses de enfermeras.

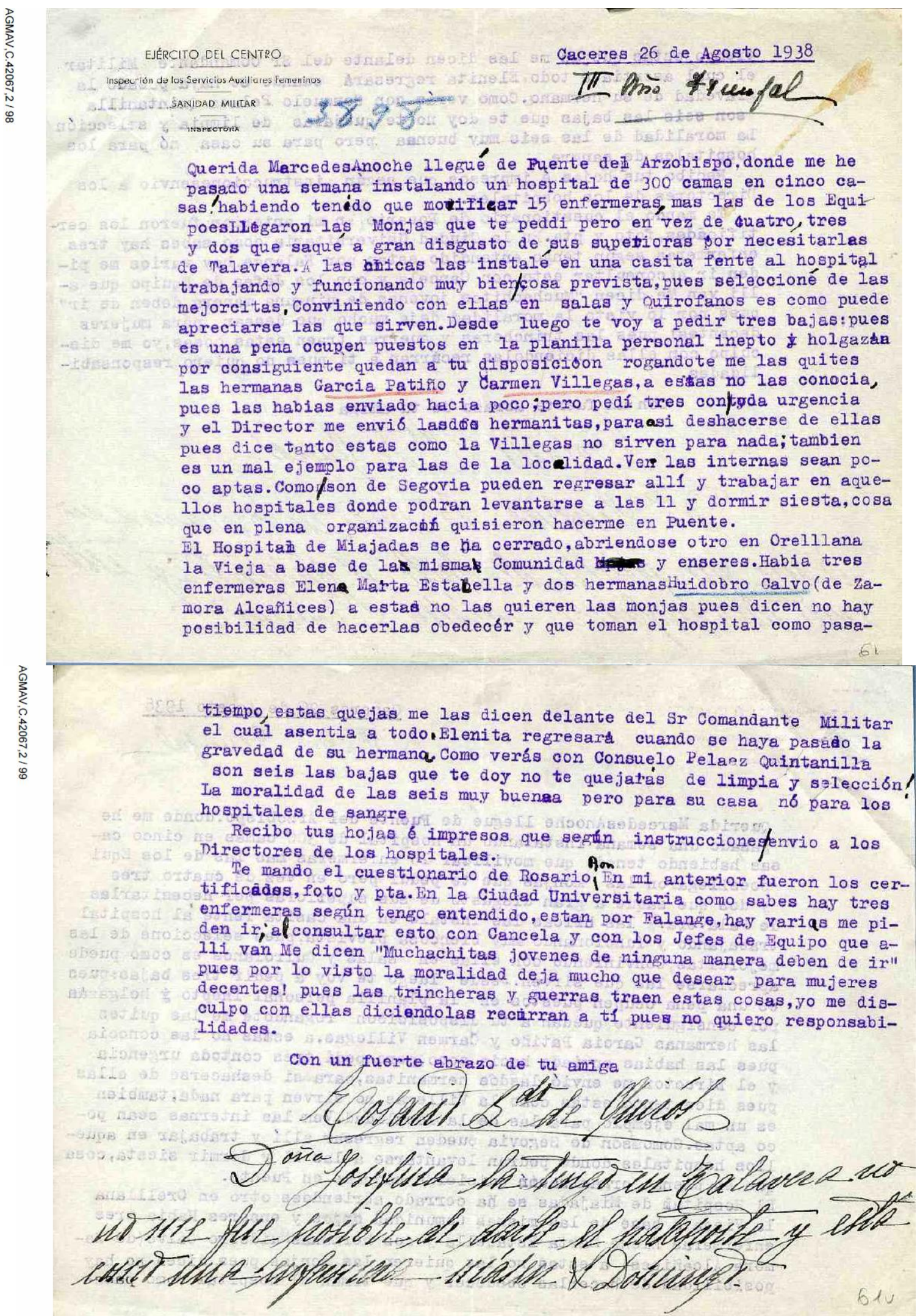

Fuente: AGMAV, C. 42067,2/98-99, Correspondencia de Mercedes Milá, 26 de agosto de 1938. 
Anexo XXX. Carta del Capitán Roldán a Mercedes Milá.

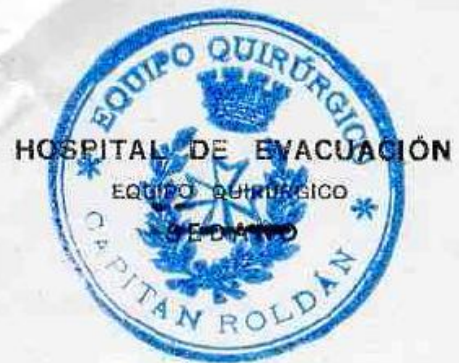

$$
E-25-41=38
$$
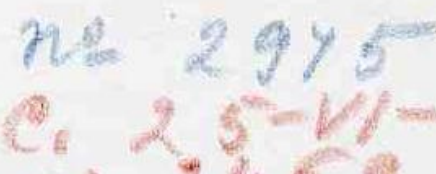

31 VI TABLLLA (OASLIHLLON) 20 a Junio de 1938

Srta. HAHCWDSS HIA

Distinguida señorita : Supongo saora $T_{0}$ por ellas nisinas que las enterineras priscila scot y Donsuelo Dsorte no pertenecen a este dquipo, una enfecinedad de la Sota. Prisctia ha dado esta solucion deseada por llit ( por Ios metitos que le explioare cuando tenga el gusto de rar a. V. ) pere que no Ine atreria a reselver.' he torndo a DF́a. PILAR HALLY espesa del Comariante de Ariweion SL. LLOP afecto al cuartel general del General GRrula VALIivo y aunque lleva pocos dias parece de excelenteg candiciones y rinie mucho trabajobes posible que tenga que teinar otra per que este lquipe sigue siende de les te nas inorilidal y trabajo pero cuando esto ocurra quiero que sean conocidas de $V$. o mias para no quedar defradiados.

$$
\text { come stempre es de } T \text {. aff. so so q. o. 3. p. }
$$
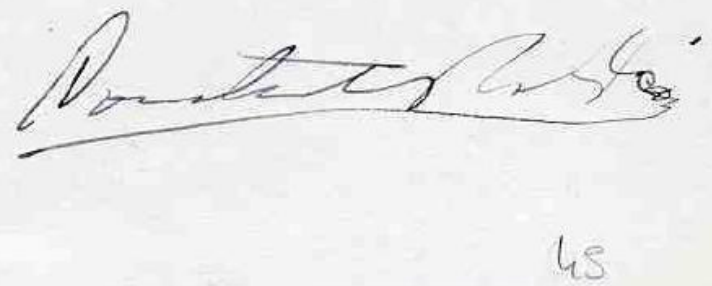

AGMAV,C.42068,3/65

Fuente: AGMAV, C. 42068,3/65. Correspondencia de Mercedes Milá, 20 de junio de 1938. 
Anexo XXXI. Servicio Social.

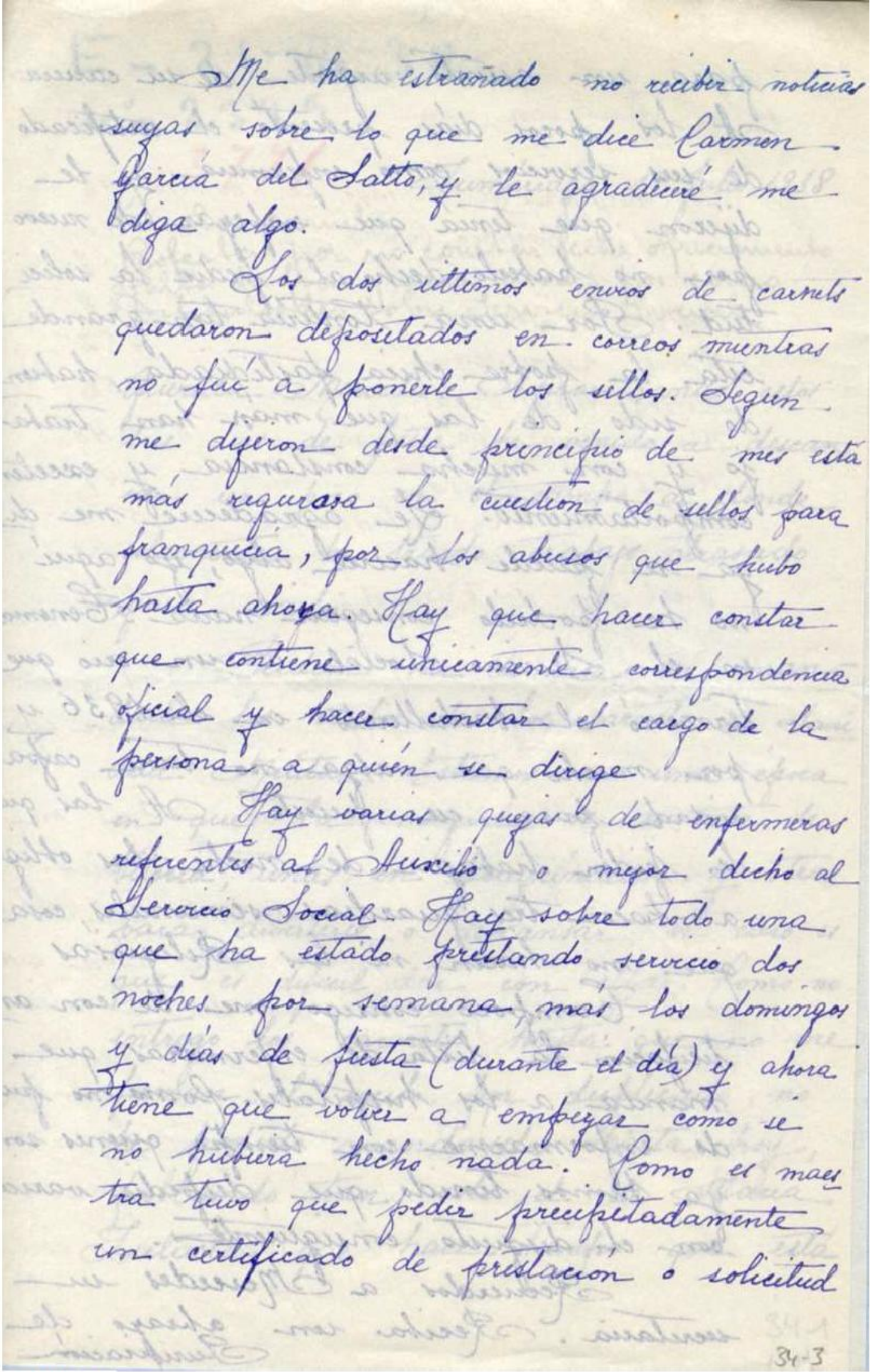


Índice

para un aumto irgente de su carrua. st los pocos días puesento el corteficado de sus servicios como enfermua y be dijeron que tenía que empreyar de nuevo for no habeilo dicho al fredic la solvi tud. Sor una tonieria ton grande uta la pobre chica factidiada hatien do sido de las que más han trabafo $y$ con mucha constancia y excelent comfortamiento. De agradeuc me di ga si juede hacure algo, yo aqué no he godido consequir nada. Tenemas en el Servicio Soctal a un cio que termino' el pachullirato en el $1936 \mu$ por mucho que valga no tine caforacidad frara en fruecto. If las que Les fiden trabajar de noche las ofliga a hacer tres quardeas semanales, cosa que no hacen ni las Ateliqusias

Camprec consigo me de con an ticifacion la lita de enfermeras que manda a los hospitales. forno no fue do informarme con tienfo quenes son, ya hemos tenids que despedir varear con ef disqueto consiguiunte.

stecucidos a sineucedes un 34-4 sectavia. Pecita un abrays de AGMAV,C.42069,2/ 53

Fuente: AGMAV, C. 42069,2/52-53. Correspondencia de Mercedes Milá, 19 de julio de 1938.

$-425-$ 
Anexo XXXII. Correspondencia Duquesa de la Victoria.

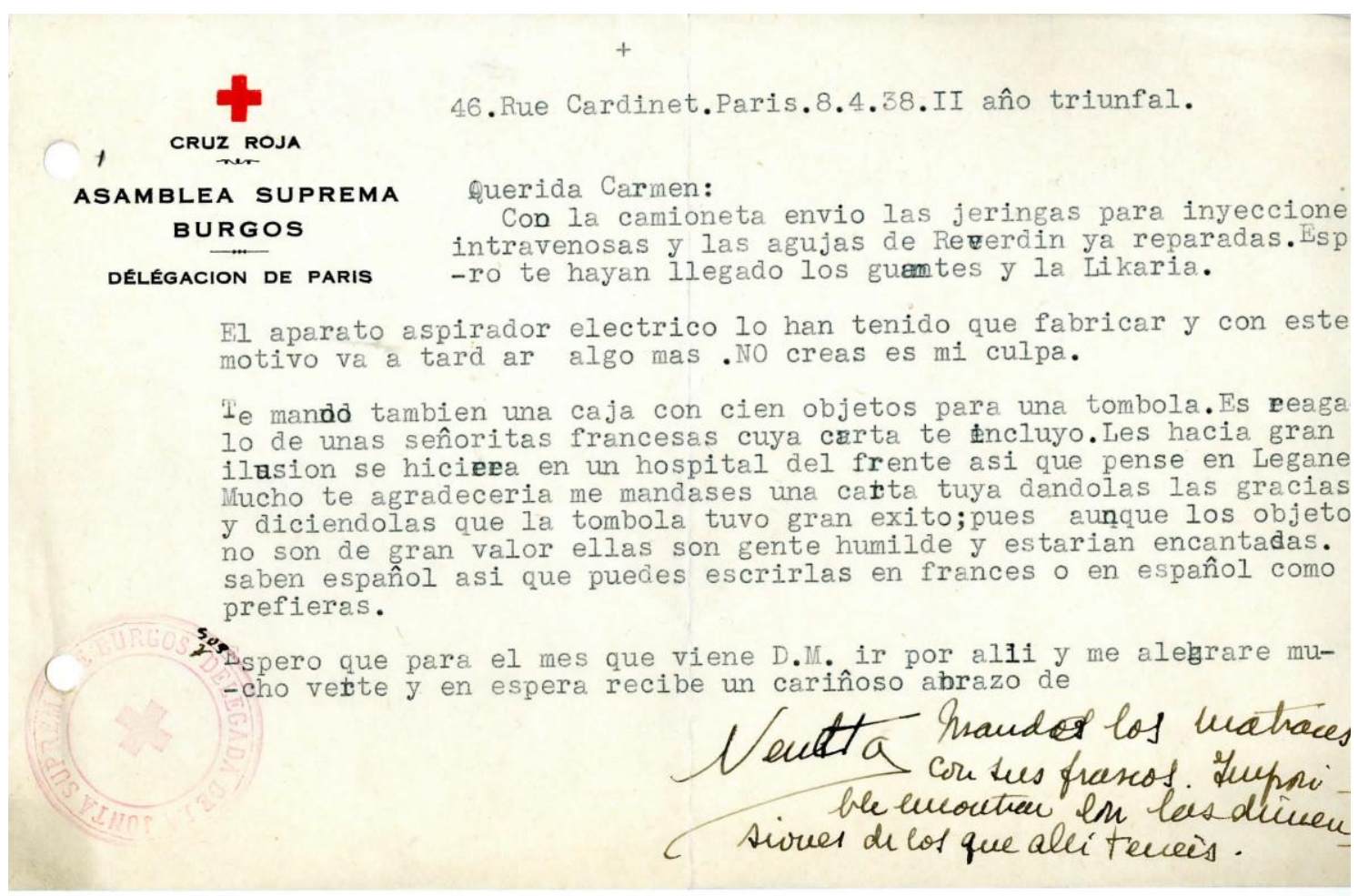

Fuente: ACCRE, Caja 994, Exp. 4. Presidencia de enfermeras y hospitales, mandato de la Duquesa de la Victoria. 8 de abril de 1938.

Imagen XIX. Olga, Octavia y Pilar, Damas de Cruz Roja asesinadas en Somiedo.

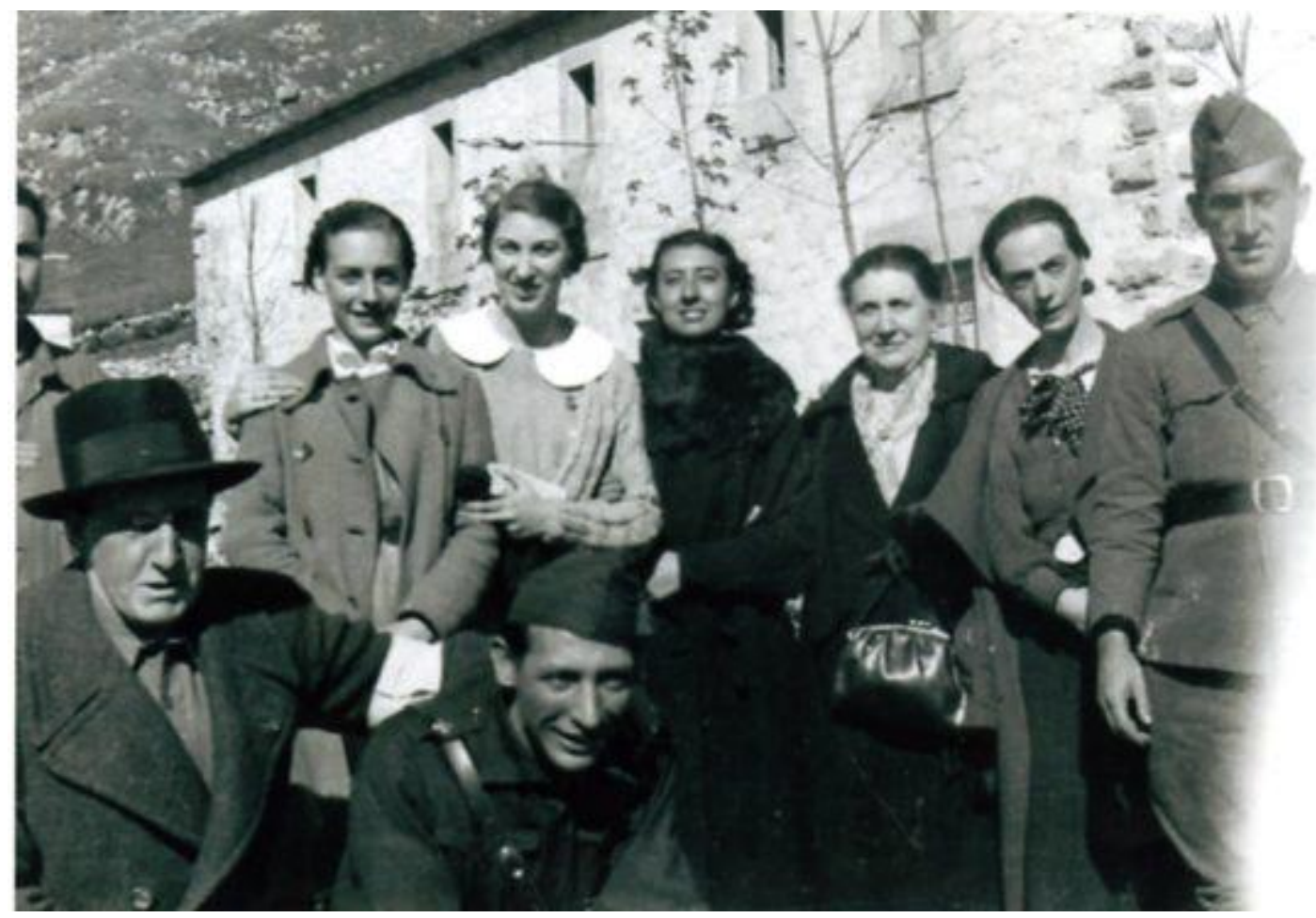

Fuente: ACCRE, Caja 559, Exp. 72. Enfermeras Somiedo. 
CONCLUSIONES 

A lo largo de los diferentes capítulos se ha descrito la evolución formativa y laboral de las enfermeras españolas, relacionándola con el contexto socio-político y con la situación de las mujeres en el mismo. El hilo conductor se ha centrado en identificar el papel que jugaron en los distintos acontecimientos históricos, principalmente en los conflictos bélicos, y cómo han repercutido los mismos en la profesión. También se han descrito las características físicas y morales exigidas a las enfermeras, plasmadas tanto en los manuales formativos como en la prensa, con el objetivo de definir la imagen social que se ha ido fraguando de las profesionales.

Cronológicamente, el análisis comienza en 1915 y llega hasta principios de 1940, por lo que puede decirse que es un periodo histórico bastante amplio y complejo con diferentes cambios políticos y sociales.

Respecto a las fuentes primarias hay que destacar la dificultad inicial para localizar información relevante relacionada con las enfermeras. Se puede constatar que el hecho de ser mujeres ha favorecido la dispersión de la documentación, sobre todo en los conflictos bélicos en los que participaron y realizaron una amplia labor. El Centro de Documentación de la Cruz Roja ha sido de vital importancia para el desarrollo de la tesis, porque sin su información no habría sido posible identificar los requisitos de acceso a los estudios de Enfermería, los contenidos formativos y el trabajo que desarrollaron las enfermeras. Ha sido imprescindible analizar en profundidad la documentación de Cruz Roja por la relación directa que tiene con la profesión, tanto a nivel nacional como internacional, por el apoyo que ha prestado a Sanidad Militar en los conflictos bélicos y porque instauró en España una de las primeras escuelas de Enfermería laicas.

Una de las limitaciones de la investigación ha sido la carencia de fuentes documentales sobre las enfermeras republicanas y el trabajo que desempeñaron. Para reconstruir esta parcela de la historia de las mujeres ha sido necesario apoyarse en las memorias de las enfermeras extranjeras que participaron en el conflicto. Por el 
contrario, sí se ha tenido acceso a la documentación de archivo de la correspondencia de Mercedes Milá como responsable de todo el personal sanitario femenino de Sanidad Militar en la zona nacional, información de inestimable valor que ha permitido describir cuales eran los requisitos exigidos a las enfermeras interesadas en prestar servicio en el frente, los motivos por los que se las trasladaba o destituía y las relaciones personales que se establecieron entre ellas.

En líneas generales puede decirse que la historia de la Enfermería ha estado ligada a la de las mujeres, por eso la profesión nace a principios del siglo $\mathrm{XX}$, cuando en España empieza a fraguarse el feminismo, se potencia el trabajo femenino en la industria y se consigue oficialmente el acceso y derecho de la mujer a la educación superior. En ese contexto, las juntas de señoras de Cruz Roja, apoyadas por la reina Victoria Eugenia, constituyen su cuerpo de damas enfermeras y enfermeras profesionales, de forma que la profesión quedará vinculada, principalmente a través de las damas, con la aristocracia y la burguesía. Cabe destacar que durante la monarquía de Alfonso XIII las juntas de señoras se establecen como una entidad independiente de la de caballeros, encargándose de recaudar fondos para la institución y de ayudar en los hospitales y dispensarios a través de su cuerpo de enfermeras, desarrollando una importante labor durante la Campaña de Marruecos. Habrá que esperar a la etapa republicana para que se otorgue a las señoras asociadas de Cruz Roja los mismos derechos que a los socios varones, además de unificar ambas secciones en una.

El título de dama enfermera de Cruz Roja era exclusivo de la institución, por eso, únicamente tuvo validez para trabajar en los centros sanitarios de la misma. Al finalizar los estudios se celebraban los actos de imposición de insignias y brazales, presididos habitualmente por la reina Victoria Eugenia, de forma que se consolidaba más la unión entre el cuerpo de damas y la aristocracia, confiriéndole un halo de privilegio a los estudios. La medalla o insignia que se las concedía fue la forma de diferenciarlas de las asociadas de la institución, distinguiéndose de las enfermeras profesionales en que las damas únicamente llevaban la cruz roja símbolo de la institución en el brazal y las enfermeras en la toca o cofia. 


\section{Conclusiones}

Hay que destacar que el trabajo de las damas enfermeras fue voluntario y no recibieron por el mismo ninguna compensación económica, ni siquiera durante la Campaña de Marruecos, a pesar de ser movilizadas lejos de sus domicilios. Este tipo de altruismo sanitario, centrado principalmente en la prestación de los cuidados básicos a los enfermos, idealizó la figura de la dama enfermera, convirtiéndola en un ejemplo para el resto de las mujeres. La Segunda República no consiguió romper con esta unión, aunque si hubo un cambio importante de denominación, ya que el cuerpo de damas enfermeras pasó a conocerse como damas enfermeras auxiliares voluntarias, suprimiéndose con el tiempo el término enfermera y prevaleciendo el de dama auxiliar voluntaria. Cabe resaltar que durante la etapa republicana se estableció que los gastos de manutención y desplazamiento en caso de movilización de las damas serían subvencionados por el hospital o centro en el que prestaran servicio.

Respecto al cuerpo de enfermeras profesionales, el programa teórico, establecido de forma oficial en 1915, constaba de un total de setenta lecciones, entre las que se encontraban temas específicos como: cualidades físicas, morales e intelectuales de la enfermera, deberes y obligaciones que debían cumplir. Esto contribuyó a configurar una imagen concreta de la mujer enfermera, relacionada principalmente con su rol femenino. En la Segunda República, el marco legal de 1932 unificaba el contenido de los estudios de Enfermería en todo el país, de forma que se estableció un nuevo programa en el que adquirieron mayor importancia las asignaturas técnicas del cuidado de los enfermos. En este periodo dejó de ser obligatoria la verificación de exámenes en la Facultad Central de Madrid y se permitió que el resto de Facultades de Medicina españolas otorgaran el título, medida que favoreció el aumento del número de profesionales.

Respecto a las enfermeras de Cruz Roja, durante la Segunda República no se produjo ningún cambio en la denominación ni en las funciones de las mismas. Cabe señalar que en esta etapa la institución amplió el periodo formativo de los estudios, fijó en veinticinco años la edad máxima de admisión y excluyó a las casadas del acceso a los mismos. Las alumnas, una vez admitidas, debían pasar un periodo de prueba de tres meses, tras el cual tenían que aprobar un examen para ser aceptadas o 
rechazadas definitivamente. También hay que tener en cuenta que en esta época la institución se comprometió a velar de una forma directa por sus profesionales, por eso fundó la residencia pensionado y una bolsa de empleo propia. Además estableció que las enfermeras seglares pasaran un reconocimiento médico antes de entrar a trabajar, principalmente por motivos legales, de cara a solicitar una incapacidad por enfermedad.

Durante la República Cruz Roja dividió su cuerpo de profesionales en enfermeras hospitalarias y enfermeras instructoras, estas últimas eran las encargadas de la formación práctica de las alumnas. Es importante tener en cuenta que durante este periodo, Cruz Roja aumentó el número de enfermeras diplomadas destinadas en cada servicio del hospital, además de fomentar su especialización y la asistencia a cursos internacionales, lo que promovió un mayor reconocimiento social.

Durante la Guerra Civil proliferaron en ambos bandos los cursillos formativos y de capacitación de voluntarias, ligados tanto a Cruz Roja como a otras instituciones políticas y sanitarias: CNT, FAI, Sección Femenina, Frentes y Hospitales y Sanidad Militar. El objetivo fue formar personal auxiliar femenino capaz de asistir a los heridos en los diferentes hospitales, ya que se necesitaban mujeres con unos conocimientos básicos sanitarios capaces de cuidar principalmente el aseo y alimentación de los soldados hospitalizados. Hay que señalar que esta figura de auxiliar enfermera potenciada por el conflicto bélico y las necesidades de campaña se aleja de la formación sólida y extensa que recibieron las damas enfermeras de Cruz Roja. A lo largo del conflicto se dio la oportunidad, en ambos bandos, de presentarse a los exámenes oficiales a todas las voluntarias interesadas en obtener el título de enfermera.

El tipo de formación que recibieron las enfermeras y las cualidades físicas y morales exigidas a través de los manuales analizados, se mantiene a lo largo del periodo estudiado. Eso sí, según avanza la Segunda República se consolida una nueva visión de la enfermera ya que su aprendizaje debía centrarse en el dominio de la técnica y del conocimiento científico, siendo durante la Guerra Civil cuando se 


\section{Conclusiones}

potencia de una forma más llamativa. Las características físicas exigidas a las enfermeras se centraban en estar sanas para poder realizar el trabajo, por eso no se admitía a las que tenían algún tipo de minusvalía. Se las recomendaba llevar una vida saludable, tanto en la alimentación, como en horas de sueño y actividades de ocio. La higiene personal era un requisito exigido para poder desempeñar el trabajo, haciendo hincapié en la importancia del lavado de manos como medida de prevención de las enfermedades.

Las cualidades morales tienen unas connotaciones claramente femeninas que se asocian con la vocación, más que con las competencias técnicas y profesionales. Se las pedía de fueran dulces, cariñosas, abnegadas, alegres, bondadosas, maternales, delicadas y discretas. Tenían que ser cultas y estar instruidas, saber observar al enfermo y su evolución, registrar el estado del mismo y las constantes en la gráfica correspondiente, y ser buenas subordinadas del médico, al que debían obedecer sin cuestionar sus órdenes.

Cabe resaltar que las enfermeras, a diferencias de las damas, recibían un salario por su trabajo, facilitándoles así la emancipación económica. Esto hizo que la imagen de la enfermera profesional tuviera una serie de connotaciones sociales diferentes, alejada del modelo femenino dedicado voluntariamente al cuidado de enfermos dentro de la misión caritativa, parcela del cuidado que había estado ligada a las obras benéficas. A principios del siglo XX las mujeres que recibían un sueldo por su trabajo en los hospitales y sanatorios eran las encargadas de la limpieza, por eso, socialmente, sobre todo en los círculos de mayor poder adquisitivo, no se vio con buenos ojos a las profesionales y no se configuró en torno a ellas ningún halo de privilegio. Por eso puede decirse que los inicios de la Enfermería fueron duros para aquellas que optaron por hacer de la profesión un medio de vida.

Durante el periodo republicano se produjo una revalorización de la Enfermería gracias a la mayor incorporación femenina al mundo laboral, por lo que recibir un sueldo por trabajar en un hospital comenzó a verse bien en la sociedad española que dejaba atrás los prejuicios relacionados con el cuidado. Además, la desvinculación de la monarquía y la aristocracia con la obra benéfica asistencial contribuyó a romper con ese círculo de inaccesibilidad a los estudios. 
Si la profesión se inició a principios del siglo XX y se consolidó durante el periodo republicano, fue la Guerra Civil la que impulsó la misma debido a las necesidades impuestas por la contienda. El número de hospitales y heridos aumentaba por lo que también fue imprescindible ampliar el de enfermeras.

Además de las dificultades sociales que se encontraron las enfermeras con la aceptación inicial de la profesionalización, tuvieron que hacer frente a la oposición y críticas de los practicantes, que en 1915 solicitaron una derogación de la Real Orden y llegaron a interponer un recurso ante el Tribunal Supremo para conseguir anularla. La disconformidad aumentó en la Segunda República cuando pensaron que obtendrían mayores beneficios profesionales, siendo las enfermeras las que consolidaron su misión y función durante la misma. Los conflictos de lucha por la supremacía de los practicantes sobre las enfermeras continuaron hasta 1935, basados en las funciones diferentes ligadas principalmente a los roles femenino y masculino. Los practicantes pedían que la Segunda República legislara y reglamentara el trabajo y las competencias de las enfermeras para poderse amparar en la ley a la hora de denunciar el "intrusismo" laboral cuando estas realizaban técnicas que ellos consideraban exclusivas de su profesión. Según los practicantes, las enfermeras debían encargarse de la alimentación, el aseo y la administración de medicación al enfermo, es decir, todas las labores manuales y mecánicas relacionadas con su rol de mujeres en la sociedad, prohibiéndolas llevar a cabo todo tipo técnicas: curas, vendajes, inyecciones, etc. Las matronas, sobre todo durante la República, apoyaron a los practicantes en la defensa por la legitimidad de sus profesiones frente a la incipiente Enfermería. Los enfrentamientos con las enfermeras son menores que los que tuvieron los practicantes ya que las matronas no veían un peligro directo en la Enfermería, a la que consideraban un sector profesional inferior a ellas, pero sí tuvieron en cuenta su consolidación y auge en la etapa republicana.

Por su relación directa con la profesión y su participaron en la Campaña de Marruecos y en la Guerra Civil, tanto en labores asistenciales como de mantenimiento de los hospitales: limpieza, cocina.... es indispensable hablar de las religiosas, principalmente de las Hermanas de la Caridad. Además de cursar los 


\section{Conclusiones}

estudios de Enfermería, desempeñaron su labor en los hospitales a lo largo de todo el periodo analizado, y estuvieron implicadas en la formación y gestión del personal sanitario femenino.

La figura de las religiosas en la escuela de Enfermería de Cruz Roja facilitó que las familias permitieran a sus hijas salir de casa para cursar los estudios, esto unido al régimen de internado garantizaba la correcta conducta moral de las futuras enfermeras. Por eso se encargaron principalmente de guiar y vigilar las faltas de disciplina, convirtiéndose en una pieza indispensable a la hora de salvaguardar la honradez de las jóvenes.

A pesar del anticlericalismo republicano, las Hermanas de la Caridad continuaron cursando los estudios de enfermeras en Cruz Roja y desempeñando los mismos puestos laborales y de supervisión. El único cambio fue que se las exigió estar en posesión del título oficial para poder ejercer la profesión y no superar en número a las alumnas enfermeras laicas de la institución a la hora matricularse en los estudios. La Ley de Confesiones y Congregaciones religiosas no afectó especialmente a las monjas dedicadas al cuidado de los enfermos, ya que no se especificaba la prohibición de trabajar en hospitales ni de ejercer como enfermeras, a diferencia de lo que sucedió con la enseñanza. Las religiosas eran mano de obra barata y su sustitución por enfermeras laicas implicaba un aumento importante en los salarios, esto unido a una modificación en los turnos de trabajo que obligaría a contratar más personal e implicaría un aumento de los gastos económicos, fomentó que en la etapa republicana no se produjeran los cambios esperados en este campo.

Hay que resaltar que las religiosas contribuyeron a aumentar el personal sanitario femenino de los hospitales, sobre todo durante los conflictos bélicos de principios del siglo XX. En la Guerra Civil, en los hospitales militares y de Cruz Roja de la zona nacional tuvieron como principal responsable de enfermeras a la Madre Superiora, autoridad a la que debían obedecer las voluntarias destinadas en los mismos. Además de la gestión de personal, la superiora debía velar por el bienestar moral y físico las enfermeras que estaban bajo sus órdenes, y en caso de observar alguna infracción que fuera motivo de cese, debía comunicarlo al director del centro y a la Inspectora de los Servicios Femeninos de Sanidad Militar. Respecto 
al trabajo desempeñado por las Hermanas de la Caridad hay que señalar que se encargaron de las velas o guardias nocturnas, de trabajar en las salas, de dirigir los pabellones militares y de las labores de limpieza e intendencia. Progresivamente fueron sustituyendo a las enfermeras en sus puestos, de forma que al terminar el conflicto, los hospitales militares volvieron a su régimen normal, contando únicamente con Hermanas de la Caridad.

Durante los conflictos bélicos las enfermeras han jugado un papel importante, de gran relevancia y poco estudiado. Su participación activa en Campaña de Marruecos y en la Guerra Civil las convirtió en personal sanitario indispensable en los hospitales. El trabajo que realizaron fue tanto asistencial como de gestión, implicándose también en la formación de las compañeras con menos experiencia. En líneas generales, las enfermeras fueron las encargadas del cuidado de los soldados heridos y enfermos en los hospitales, tanto los ubicados en el frente como en la retaguardia, así como en los trenes y barcos hospitales y en las ambulancias. Instalaron hospitales en casinos, escuelas, cuevas, habilitándolos para poder dar cobertura sanitaria a los soldados, además de implicarse en la evacuación de los heridos cuando fue necesario. Ocuparon puestos de responsabilidad como jefas en las salas de hospitalización y en los quirófanos. Además de pasar visita con los médicos, realizar las curas de mayor envergadura, poner inyecciones intravenosas y formar parte de los equipos quirúrgicos, en algunas ocasiones se encargaron de la clasificación de heridos (triaje) en función de su gravedad, decidiendo a quién se debía atender primero o evacuar con mayor rapidez. También organizaron y supervisaron el trabajo de las auxiliares voluntarias, encargadas principalmente del aseo y alimentación de los heridos, enseñándolas conocimientos sanitarios básicos.

La Guerra Civil y la reorganización de la asistencia, la falta de material y de hospitales fue un hecho que afectó a las enfermeras de ambos bandos. La diferencia fue, que mientras en la zona nacional se consolidaba la red sanitaria de una forma estructurada y organizada, en la republicana se desmantelaban los hospitales para replegarse en la retaguardia y constituir otros nuevos. Para ello debían trasladar el material, tanto sanitario como inmobiliario y a los heridos y enfermos que asistían. 
Otra diferencia a tener en cuenta fue la proliferación de hospitales fundados por sindicatos y partidos políticos republicanos, mientras que en la zona nacional, sobre todo tras el decreto de unificación, se consolidó una única red asistencial. La República contó con la ayuda sanitaria internacional necesaria para sacar adelante una sanidad desestructurada y con carestía de medios. De esta forma el Socorro Rojo Internacional y las Brigadas Internacionales a través de Ayuda Médica Extranjera, participaron activamente en el establecimiento de hospitales y en la dotación de material y personal.

En los conflictos bélicos las enfermeras se han adaptado a las dificultades asistenciales impuestas por la guerra sin que esto haya supuesto un impedimento para el desempeño de su trabajo. Se enfrentaron a condiciones climáticas adversas, a la falta de agua y luz, de material, de salubridad y de alimentos, sin exigir comodidades, sufrieron bombardeos y las consecuencias directas de los mismos, sin abandonar sus puestos. De esta forma enfermaron, se las acusó de espías, de auxilio a la rebelión, terminaron encarceladas, murieron o fueron asesinadas. A pesar de todo, permanecieron en los hospitales de campaña y quisieron estar cerca del frente, en primera línea, donde las jornadas de trabajo eran largas, con una dependencia directa de los resultados del conflicto, por lo que fue complicado establecer un turno concreto de trabajo, que habitualmente se alargaba, disponiendo de poco tiempo para descansar, ya que las cargas laborales se adaptaban al volumen de heridos que recibían y a las operaciones de urgencia.

Principalmente se ofrecieron de forma voluntaria a prestar sus servicios guiadas por las ganas de ayudar. Respecto al personal sanitario auxiliar femenino, sobre todo las damas enfermeras de Cruz Roja, hay que resaltar que no recibieron ninguna compensación económica por el mismo. Durante la Campaña de Marruecos las damas enfermeras tuvieron que costearse todos los gastos ya que no percibieron ningún tipo de ayuda, ni siquiera para su hospedaje, siendo las enfermeras profesionales y las Hermanas de la Caridad las únicas que pudieron alojarse en los hospitales, en alas específicas habilitadas para ellas. En la Guerra Civil, se facilitó alojamiento y manutención a las voluntarias que fueron movilizadas fuera de sus domicilios, sin hacer distinciones entre las tituladas. Por eso, puede decirse, que en 
general, el personal sanitario femenino fue mano de obra barata que contribuyó de una forma importante al sostenimiento sanitario.

Hay dos figuras femeninas claves de las guerras españolas del siglo XX por el papel de gestión sanitaria que llevaron a cabo, convirtiéndose en un referente para la profesión. Por un lado Carmen Angoloti y Mesa, Duquesa de la Victoria, cuyo trabajo en la Campaña de Marruecos se centró en la instalación de hospitales de Cruz Roja en la zona, demostrando que una mujer era capaz de establecer una amplia red asistencial. Dotó de material y personal los diferentes centros y compaginó esta labor con la asistencial, ya que como dama enfermera también cuidó a los soldados heridos y enfermos. Carmen Angoloti se convirtió en un referente para la Enfermería de principios del siglo XX, como imagen de dama de Cruz Roja capaz de dejar las comodidades de su vida en Madrid para acudir a Marruecos a prestar ayuda. Mercedes Milá y Nolla, Inspectora de Servicios Femeninos de Sanidad Militar en la zona nacional, durante la Guerra Civil estableció de forma sólida el control sobre todo el personal sanitario femenino de los hospitales militares, encargándose directamente de sus nombramientos, traslados y ceses. Fue la máxima responsable del mismo, reflejando cómo una mujer estaba cualificada para acreditar la preparación del voluntariado femenino, su moralidad y distribuirlo de forma equitativa y racional entre los diferentes hospitales militares.

Durante la Guerra Civil la República contó con la ayuda de enfermeras extranjeras, principalmente brigadistas, que fomentó el intercambio cultural de cuidados. Gracias a las memorias y diarios que dejaron como legado se puede construir cómo fue el trabajo que desempeñó todo el colectivo en la República, ya que es difícil encontrar relatos de las españolas, que una vez terminado el conflicto tuvieron que borrar su pasado o comenzar el camino hacia el exilio. En cambio, las enfermeras nacionales fueron las que se llevaron todo el reconocimiento por la labor que prestaron durante la guerra, son las que escribieron sus memorias y pudieron contar sus experiencias sin miedo a represalias. 


\section{Conclusiones}

Las diferencias entre las enfermeras republicanas y las nacionales no se encuentran en el tipo de trabajo que llevaron a cabo, sino en las condiciones que lo rodearon y en su visión de la mujer y su rol social.

En la zona nacional la religión convivía diaria y directamente con la asistencia, de forma que en los hospitales se decía misa y se rezaba, implicando a las enfermeras en los ritos cristianos y esperando de ellas un comportamiento de religiosas. Por eso fueron muy importantes las cualidades morales de las enfermeras nacionales, sobre las que se llevó una estrecha vigilancia dentro de una escala jerarquía bien delimitada. No se toleraron faltas de comportamiento, se las prohibía fumar, entablar amistad con el personal sanitario masculino y con los enfermos, ya que en ellos únicamente debían ver al padre, al hermano o al hijo. Visto así, eran mujeres rodeadas de hombres, de soldados, por eso se las exigía una conducta intachable, y que mejor ejemplo que las Hermanas de la Caridad. Por eso fueron destituidas y sancionadas las enfermeras que incurrieron en faltas de disciplina, que desobedecieron órdenes y que mantuvieron una actitud poco acorde con su rol de mujeres.

El papel de la religión y el adoctrinamiento no se aprecia en los relatos analizados de las enfermeras republicanas. Si se puede observar en las narraciones de las enfermeras brigadistas otra visión sociocultural de la relación entre hombres y mujeres, alejada del pudor y tendente a la igualdad. El enfoque tradicional del rol femenino y las restricciones sociales llamaron la atención de las brigadistas que mantuvieron sus costumbres, lo que las generó problemas y prohibiciones. En esta línea hay que abordar el relato de Priscilla Scott-Ellis, enfermera británica que apoyó a los nacionales, cuya actitud desenfada y aperturista le causó conflictos con sus compañeras y con sus superiores.

Respecto al control sobre el personal sanitario femenino hay que destacar que fue más estrecho y mejor organizado en la zona nacional que exigía a las enfermeras estar en posesión de un carnet que acreditara su aptitud para el puesto de trabajo. Para trabajar en los equipos quirúrgicos del frente tenían que presentar una solicitud en la que reflejaban su titulación y el lugar de su obtención, su experiencia profesional y sus preferencias de destino. También se las exigía una conducta moral 
intachable y se comprobaba su ideología política. Esta labor de gestión de personal la llevó a cabo Mercedes Milá con la colaboración de sus delegadas. En la zona republicana hubo un control menos estricto y riguroso, se exigía que el personal sanitario tuviera una acreditación para poder trabajar, se les tomaban las huellas digitales y se les hacía una foto, luego se les entregaba como identificación un brazalete blanco con una cruz roja cosida a máquina. La expedición de la documentación en Madrid la llevó a cabo la policía que tenía la obligación de controlar a las personas que prestaban servicios voluntarios.

En la zona nacional las enfermeras tuvieron que cumplir el Servicio Social, lo que generó problema en la organización del trabajo, siendo poco reconocida la labor asistencial que desempeñaron durante la guerra.

Respecto a los conflictos laborales y personales, en la zona republicana apenas hay testimonios de ellos, los que aparecen se refieren a casos puntuales entre algunas compañeras, ocasionados por la carga de trabajo y las duras condiciones impuestas por el conflicto. En cambio, en la zona nacional fueron comunes las desavenencias entre las religiosas y las enfermeras, entre las margaritas y el personal sanitario de falange, y a nivel institucional, entre la inspectora de Sanidad Militar y Sección Femenina.

Otra de las diferencias entre las enfermeras durante la Guerra Civil es que las nacionales se erigieron como mártires y las republicanas se perdieron en un olvido intencionado. La represión fue más fuerte sobre los vencidos, por eso las enfermeras republicanas fueron juzgadas por auxilio a la rebelión, o se vieron obligadas a salir de España o a ocultar su verdadera identidad. Mientras que las nacionales se convirtieron en heroínas a las que se las condecoró con la Cruz Roja al Mérito Militar, la Medalla de Campaña o la Medalla de Sufrimientos. Eso sí, no se reconoció igual la participación activa cerca del frente, el haber sufrido bombardeos o el haber sido heridas, que el haber permanecido en los puestos de retaguardia. En este punto hay que destacar que este tipo de recompensas fue igual al que se concedió a los soldados que participaron en la campaña, siendo una forma de 


\section{Conclusiones}

equiparar a las mujeres con los hombres. En esta línea, también se concedió a las enfermeras movilizadas más de seis meses en el frente o más de novecientos días en la retaguardia, el certificado de excombatientes, en las mismas condiciones que a los varones.

Una vez terminado el conflicto el modelo de enfermera que prevaleció y se consolidó fue el acorde con el icono de mujer nacional del régimen franquista. La Enfermería se convirtió en una salida profesional afín a la nueva ideología que veía bien que las mujeres se encargaran del cuidado de los enfermos, dentro de su rol como madres, hijas o esposas abnegadas, piadosas, dulces y caritativas.

La prensa ha jugado un papel importante en la configuración de la imagen social de las enfermeras. Difundió el trabajo que realizaron tanto en la Campaña de Marruecos como en la Guerra Civil, convirtiéndolas en un icono femenino. Hay que destacar que las enfermeras han sido noticia a lo largo del periodo analizado, primero para divulgar la aparición de una nueva profesión con las consecuentes desavenencias sociales que se plasmaron en la prensa, con posiciones a favor y otras en contra. Los conflictos con los practicantes se aprecian principalmente en los boletines de sus colegios oficiales. La imposición de brazales y la entrega de diplomas a damas y enfermeras de Cruz Roja quedó plasmada en los periódicos, que informaban de los acontecimientos, exponían la relación de tituladas y describían los hechos. Hasta la llegada de la República, la Reina Victoria Eugenia presidió este tipo de actos, por lo que la prensa confirió a la profesión una aureola privilegiada, relacionada con la dama aristócrata que prodigaba cuidados caritativos en los hospitales. Hay que destacar que la prensa de la época utilizó indistintamente el término dama y enfermera lo que podía dar lugar a equívocos, prevaleciendo de forma habitual la terminología de enfermera aunque la noticia se refiriera a las damas de Cruz Roja.

En la Campaña de Marruecos, el trabajo desempeñado por las damas, enfermeras y hermanas de Cruz Roja quedó plasmado en la prensa que divulgó de forma positiva el papel que jugaron en el conflicto. Las colectas benéficas llevadas a cabo por las asociadas de la institución, la relación de donativos y rifas también fueron noticia. Convirtieron a las enfermeras en heroínas, sobre todo a través de la 
figura de la Duquesa de la Victoria, líder indiscutible de la profesión en este contexto bélico. La enfermera se convirtió en imagen de mujer valiente, decidida, capaz de dejar la vida acomodada en la Península para acudir al Protectorado a prestar ayuda. Las recompensas y medallas que se entregaron una vez terminado el conflicto también se difundieron ampliamente a través de los periódicos.

Durante la Guerra Civil, en ambos bandos las enfermeras ocuparon portadas, fueron noticia, fotografiadas en el frente, a la cabecera de los heridos, en los hospitales... representaban un modelo de mujer que se implicaba con la lucha desde una perspectiva acorde con su rol femenino. Se publicaron artículos sobre su trabajo, los bombardeos que sufrieron y las consecuencias trágicas de la guerra que las afectaron directamente. En la zona republicana se divulgó la llegada de ayuda sanitaria internacional, ambulancias, personal, material... interesaban los relatos de las enfermeras brigadistas y su participación en la guerra. En la zona nacional las enfermeras se erigían como modelo de mujer ideal, mártires que habían entregado su vida por la causa, mujeres maternales capaces prodigar los mejores cuidados.

La prensa convirtió a las enfermeras en un icono femenino en los distintos contextos históricos, manteniendo las mismas características físicas y morales. Guapas, elegantes, saludables, piadosas, caritativas, dulces, abnegadas, risueñas, puras y cariñosas con los enfermos. Los periódicos contribuyeron a consolidar la Enfermería como una salida laboral eminentemente femenina, centrada en las connotaciones vocacionales de la profesión más que en las técnicas.

Puede decirse que la imagen de la enfermera plasmada a través de los manuales formativos y la descrita por la prensa es la misma, mujeres que debían reunir unas características físicas y unas cualidades morales concretas para poder desempeñar la profesión.

El contexto sociopolítico y la situación de la mujer en cada etapa histórica, ha afectado de una forma directa a la Enfermería, principalmente porque ha sido una profesión eminentemente femenina. Las enfermeras se han visto inmersas, directa o indirectamente en los acontecimientos históricos, unas veces por su papel como 


\section{Conclusiones}

profesionales del cuidado necesarias en los conflictos bélicos y otras por su carrera formativa. Se puede decir que la Enfermería nacía en 1915 para cubrir las necesidades socio-sanitarias de la población y como una salida profesional remunerada para aquellas mujeres interesadas en estudiar y trabajar. Las enfermeras se han adaptado, a lo largo del periodo analizado, a la situación política de cada etapa, consolidando su profesión y por extensión, la emancipación femenina. El hecho de convertirse en un icono de mujer ideal, ha afectado a las enfermeras y su imagen social, prevaleciendo el modelo nacional que una vez terminada la guerra continuó durante la etapa franquista. Esto condicionó lo que esperaba la sociedad de la mujer enfermera, centrándose en el carácter vocacional de la profesión y en unas cualidades morales concretas, principalmente de subordinación a la figura masculina, en este caso el médico, de obediencia, con una clara predisposición a la caridad, el amor, la piedad y la dulzura.

Conocer estos antecedentes y el estereotipo social que se configuró en torno a las enfermeras, ayuda a identificar la imagen de las mismas y a entender cómo las han afectado los distintos acontecimientos socio-políticos. El análisis de este periodo de la historia de la Enfermería contribuye a comprender mejor su desarrollo profesional, condicionado por el rol mayoritariamente femenino y el papel de la prensa que han establecido un modelo de enfermera adaptado a lo que sociedad espera de ella. 

FUENTES Y BIBLIOGRAFÍA 



\section{FUENTES}

\subsection{Fuentes de archivísticas}

\section{Centro de Documentación de Cruz Roja Española. Archivo Central de Cruz Roja Española}

Se han consultando todas las carpetas sobre enfermeras desde 1918 hasta 1940, encontrando información relevante en las siguientes cajas:

Caja 2022 expedientes 1al 17, año 1918 a 1939; caja 2531 expediente 17, 18, 20, 25, 28, 30, 31, 36, 38 y 41, años 1922 a 1940; caja 253 expedientes 3, 14, 15, años 1936 a 1939; caja 2061 expedientes 3 y 4, año 1922 y 1937 respectivamente; caja 2532 expedientes 5, 8, 10, 11 y 18, años 1937 a 1939; caja 2291 expedientes 2, 8 , 9 y 10, años 1921, 1932, 1933, 1934 y 1935 respectivamente; caja 995 expediente 5, año 1926; caja 994 expedientes 1, 2 y 4, años 1923 a 1953; caja 559 expedientes 72 y 75, años 1936 a 1939; caja 2310 expedientes 1 , 2, 3, 4, 6, 7, 10, 12, 13, 14, 20, 22, 25, 26 y 27, años 1939 a 1940 y caja 2248 expediente 29, año 1939.

\section{Archivo de Palacio Real}

Caja 1330 expediente 41, del nombramiento de la duquesa como dama de la reina en 1911.

\section{Archivo General de la Administración}

Se consultaron todas las cajas relacionadas con el tema de estudio, encontrando información sobre la Campaña de Marruecos y la situación sanitaria en las cajas:

Caja (15)81/09676, año 1922; cajas (15)3 81/09677, (15)3 81/09675, (15)3 81/09674, (15)3 81/09673, años 1911 a 1926; cajas (15)13 81/12550, (15) 13 81/10875, año 1938; cajas (15)003 81/9678, (15)003 81/9679, (15)003 81/9680, (15)003 81/9681, (15)003 81/9682, (15)003 81/9683, (15)003 81/9684, (15)003 81/9685, años 1911 a 1934. Se encontró documentación sobre la prensa gráfica nacional durante la Guerra Civil, caja (03)084.001. F/00768 sobre nº 1, 107 fotografías Sanidad Militar. 


\section{Archivo General Militar de Madrid}

Se ha encontrado documentación sobre la situación sanitaria durante la Campaña de Marruecos en los siguientes microfilms:

R. 455. 128, 496, 481, 482 y 536, carpeta 2 legajo 302; años 1922 a 1924.

Las cajas revisadas en las que se ha encontrado información relevante sobre la guerra de África han sido:

Caja $n^{\circ} 43$, Estante1, $n^{\circ} 4$, Fila 2, Carpeta 44; Caja n ${ }^{\circ}$ 53, Armario 44, Estante1, no 9, Fila 1, Carpeta 4; Caja nº 58, Armario 45, Estante 1, nº 4, Fila 1, Sala 1, Carpeta 16; años 1921 a 1926.

Respecto a la documentación sobre la Guerra Civil, desde el Archivo General Militar de Madrid se han podido consultar la información digitalizada sobre las siguientes cajas localizadas físicamente en el Archivo General Militar de Ávila:

C. 3675,3 ; C.2344, 86,1; C. 2344, 86; C. 1395,39; C.1209, 12; C. 1979, 6; C. 1983, 1; C. 1299,63, años de 1937 a 1940.

\section{Archivo Histórico de Defensa Judicial}

Fondo Madrid, signatura 3251, sumario 583, legajo 2696, año 1936.

\section{Archivo General Militar de Ávila}

Se han consultado diferentes carpetas, principalmente aquellas que contienen la correspondencia de Mercedes Milá, inspectora de los Servicios Femeninos de Sanidad Militar:

Cajas: 42062,2; 42069,3; 42069,5; 42069,6; 46761,2; 42067,2; 42068,2; 42068,3; 42068,4, de 1937 a 1940.

\section{Archivo del Instituto Nacional de Estadística}

Anuario Estadístico de España, fondo documental 1931-1940. Centros profesionales y especialidades de enseñanza: Enseñanza de enfermeras curso académico 1931, 1931-1932, 1932, $1932-$ 1933, 1940-1941; 1942-1943.

\section{Centro Documental de la Memoria Histórica}

Colección digitalizada de carteles de la guerra civil española. 


\section{Filmoteca Nacional Española}

AX. España en Alhucemas. 1925. 38'4".

AX. 408. 1.2 Guerra de África. 1925-1926.

AX. 283. 1926. Personalidades españolas (De la "Malcasada").

558. A-7724 La mujer en la guerra. Productora PCE, 1938 España, 2'8”.

559. A- 7724 La mujer y la guerra. 1938, España, productora Film popular. Documental republicanos, 9'30" dirección A. M. Sol.

AX. 435. Revista Hispano-Americana. 1927. Casa Real. 19'29”.

AX. 287 Mitin de Izquierda Republicana. 6'48”.

AX. 344. 1934, Sucesos revolucionarios en Asturias, 19'54".

8. A-7610. Actualidades de la guerra. Noticiario español. 35mm standard, ByN, sonoro. Tendencia republicana. 5’. Otoño invierno 1936.

16 A- 7616 Alas negras (Bombardeos sobre la retaguardia de Aragón y Cataluña) 1937. España. Productora SIE FILMS para el comisariado de Guerra de la 28 División. 12'24”.

61. A-7619 Ayuda a Madrid. 7'17” CNT. FAI, Sindicato de industria del espectáculo. 1936, Productora: SIE films para CNT/FAI. Fotografía: Félix Marquet.

79. La batalla de Farlete (Reportaje $n^{\circ}$ 4). 1936 España, productora SUEP (Sindicato único de Espectáculos Públicos) para la CNT/FAI. Documental republicano, 15'50”. A-7622.

A-7622 Bajo el Signo Libertario. 15'.

39. A-7622 Aragón 1937. 15'39”. Fotografía: Manuel Berenguer, Productora: Laya films.

23. A-7619 Alma y nervio de España. 1937. España, Departamento de Prensa y Propaganda de FET y de las JONS. Documental tendencia nacionalista. 11'25”.

99. A-7628 Bilbao para España. 1937, España, Productora Cifesa, documental nacionalista. $25^{\prime} 12^{\prime \prime}$.

587. A-7748 Noticiario español. $N^{\circ}$ 5, 6, 7, 8, 9, 10, 11, 12, 13, 14.

587. A-7748 Noticiario español. No 1, 2, 3 y 4 Noticiario Español. Productora: Departamento Nacional de Cinematografía. Dirección Política: Dionisio Ridruejo. Dirección: Manuel Augusto García Viñolas y otros.

379. A-10088. El gran desfile de la victoria en Madrid. 1939, España, Productora: Departamento Nacional de cinematografía.

A-7830 Tercer reportaje. Segundo Consejo Nacional de Sección Femenina en Segovia. 7’. 1938. España. Productora: Delegación de Prensa y Propaganda de Falange Española Tradicionalista y de J.O.N.S. documental Nacionalista.

847. vascongadas. A. 7715. 1928-1938.

480. A. 7718. Liberación de Barcelona. 1939. España. 5'04”. (Auxilio Social) Documental Nacionalista. Productora: Departamento Nacional de Cinematografía. Comentario y locución de Antonio de Obregón. En edición extraordinaria del Noticiario Español.

A-7718. Madrid: cerco y bombardeo de la capital de España. 14'35”.

192. A. 7637. Los Conquistadores del Norte. (Homenaje a las Brigadas Navarras) productora: Sección cinematográfica de F.E.T y J.O.N.S. realización M.A.P 43'25”. 


\subsection{Fuentes hemerográficas}

\section{Revistas Sanitarias}

El Auxiliar Médico. Revista profesional y científica. Órgano del Colegio Oficial de Practicantes de Medicina y cirugía de Córdoba

no 107 al 118, año 1935.

El auxiliar médico Aragonés

n 1 al 24, años 1932 a 1933.

\section{Gaceta del Practicante}

$n^{\circ} 1$, año 1936.

Boletín del Colegio Oficial de Practicantes en Medicina y Cirugía de Madrid y su Provincia n 263 de 1930, nº 269 a 279 de 1931, nº 280 a 287 de 1932.

\section{Boletín del Colegio Oficial de Matronas de Madrid y sus provincias}

Colección completa de enero 1931 a febrero 1935.

\section{La Visitadora Sanitaria}

$n^{\circ} 1$ (4. Trimestre 1934), $n^{\circ} 2$ (1. Trimestre 1935), $n^{\circ} 3$ (2. Trimestre 1935), $n^{\circ} 4$ (3. Trimestre 1935), $n^{\circ} 5$ (4. Trimestre año 1935).

\section{Boletín del colegio médico de Cádiz}

Colección completa de febrero 1937 a enero 1939.

\section{Boletín del instituto Provincial de Higiene de Asturias}

Colección completa de enero 1929 a enero de 1937.

\section{La Voz de Sanidad}

$n^{\circ} 4$ (junio 1937); nº 7((julio 1937); nº (agosto 1937); nº 3 (marzo 1938); nº12 (febrero-marzo 1938).

\section{Sanidad Popular}

n 2(mayo 1937); nº (junio 1937); nº 9 (septiembre 1937); nº 10 (noviembre 1937).

Ayuda

$n^{\circ} 3$ (febrero 1936); no 8 (mayo 1936); no 11 (julio 1936); no 13 (agosto 1936); $n^{\circ} 21$ (octubre 1936); $n^{\circ} 38$ (enero 1937); nº 45 (marzo 1937); no 49 (abril 1937); no 50 (abril 1937; no 86 (marzo 1938).

\section{AMI}

$\mathrm{n}^{\circ} 5$ (1 diciembre 1937); nº (15 diciembre 1937); nº (enero 1938); $n^{\circ} 9$ (febrero 1938); $\mathrm{n}^{\circ} 10$ (marzo 1938); $\mathrm{n}^{\circ} 11$ (10 marzo 1938).

\section{La voz de sanidad de la XV división}

Números del 1 al 22, falta 3, de 1937 a 1938.

Revista de la brigada sanitaria

Números 1, 2 y 3, 1937.

\section{Revista de sanidad en guerra}

Números del 1 al 13, 1937-1938. 


\section{Nuestra Sanidad}

$\mathrm{n}^{\circ} 1$ (febrero 1937); $\mathrm{n}^{\circ} 2$ у 3 (marzo 1937); $\mathrm{n}^{\circ} 4$ (abril 1937).

\section{Hospitales}

Número noviembre-diciembre, 1938.

\section{Revista Cruz Roja Española}

Colección completa 1915 a 1936.

Revista Española de Medicina y Cirugía de Guerra

Catálogo completo de septiembre 1938 a diciembre 1940.

\section{Medicina y cirugía}

$\mathrm{n}^{\circ} 1$ (octubre 1938) a n 5 (febrero 1939).

\section{Medicina española}

$\mathrm{n}^{\circ} 1$ (noviembre 1938); nº 4 (febrero 1939).

\section{Publicaciones oficiales}

Gaceta de Madrid/ Boletín Oficial del Estado

Del año 1915 a 1940.

Boletín de la Junta de Defensa Nacional de España

Año 1936.

\section{Otras publicaciones consultadas}

Ellas

$\mathrm{n}^{\circ} 2$ (junio 1932) a no 88 (febrero 1934).

Mujer

$\mathrm{n}^{\circ} 1$ (junio 1937); $\mathrm{n}^{\circ} 5$ (Octubre 1937).

\section{Hogar Español}

$\mathrm{n}^{\circ} 5$ (septiembre-octubre 1937); $\mathrm{n}^{\circ} 6$ (noviembre-diciembre 1937); $\mathrm{n}^{\circ} 7$ (enero-febrero 1937).

\section{La mujer en su casa}

$\mathrm{n}^{\circ} 350$ (febrero 1931) a $\mathrm{n}^{\circ} 413$ (mayo 1936).

\section{Mujer de Acción Católica}

$\mathrm{n}^{\circ} 2$ (mayo 1937); $\mathrm{n}^{\circ} 8$ (diciembre 1937); $\mathrm{n}^{\circ} 13$ (julio 1938).

\section{Mujeres católicas de España}

$\mathrm{n}^{\circ} 1$ (mayo 1937) a no 24 (diciembre 1939).

\section{Juventud de Acción Católica.}

Colección completa de junio 1937 a diciembre 1942.

Y: revista de la mujer nacional sindicalista

Colección completa de febrero 1938 a diciembre 1940.

Sembrad

$\mathrm{n}^{\circ} 2$ (mayo 1938); $\mathrm{n}^{\circ} 4$ (junio 1937). 


\section{CMCE}

$n^{\circ} 5$ (julio 1937); no 8 (septiembre 1937); no 9 (octubre-noviembre 1937).

Boletín Auxilio de Invierno

Colección completa de abril 1937 a septiembre 1938.

\section{Misión}

No 59 (noviembre 1939); nº3 (enero 1940).

\section{Mujeres Libres}

Sin número, diciembre 1936.

\section{Muchachas}

$\mathrm{n}^{\circ} 2$ mayo 1937 a no 10 (noviembre 1937).

\section{Juventud}

$\mathrm{n}^{0} 25$ (septiembre 1936).

\section{El miliciano rojo}

Octubre 1936.

\section{Mutilado}

no 2 agosto 1938.

\section{Potencia}

nº 1 diciembre 1937.

\section{¡Ofensiva!}

$n^{\circ} 17$ (agosto 1937); n 27 (octubre 1937).

\section{Periódicos de información general}

El ABC.

Ediciones de 1915 a 1940.

\section{La Vanguardia.}

Ediciones de 1915 a 1940. 


\subsection{Fuentes impresas}

\section{Memorias de hospitales y escuelas}

Asamblea Suprema de la Cruz Roja Española: Hospital-Escuela de Damas de la Cruz Roja de Madrid, San José y Santa Adela. Memoria del año 1923. Blass, Madrid, 1924.

CASA de SAlud de SAnTA CRIstina: Estatutos de la junta de patronato de la Casa de Salud de Santa Cristina. Imprenta Helénica, Madrid, 1936.

Cruz Roja Española: Anales de la policlínica de la Cruz Roja de Valencia. Tipografía moderna, Valencia, 1922.

CRUZ Roja EsPañola: Memoria descriptiva de la instalación y funcionamiento del hospital de evacuación de enfermos y heridos de África, establecido por Cruz Roja en Valencia en "El Progreso Pescador" durante la Campaña de 1921-1922. Talleres tipográficos "La Gutemberg”, Valencia, 1923.

Cruz Roja Española: Memoria del Hospital-Escuela de Damas de la Cruz Roja de Madrid San José y Santa Adela. 1920-1922.

CRUZ RoJA EsPaÑola: Memoria Hospital María Cristina. Escuela de damas enfermeras en San Sebastián, 1924.

Cruz Roja Española: Memoria del Hospital de la Cruz Roja en Tetuán, años 19241925. Balss, sin año de edición, Madrid.

Cruz Roja Española: Memoria del Hospital de la Cruz Roja en Cala Bonita, (VillaSanjurjo), 1926-1929. Balss, sin año de edición, Madrid.

Cruz Roja Española: Asamblea Suprema de la Cruz Roja Española. Real Dispensario Victoria Eugenia. Madrid, Helios, 1929.

Cruz Roja Española: Reglamento del Hospital Central de la Cruz Roja Española y su anejo de la Escuela de Enfermeras. Ernesto Catalá, Madrid, 1932

CRUz Roja EsPañola: Reglamento de las escuelas de enfermeras de la Cruz Roja española. Madrid, 1934.

VAlero Carreras, Luis: Memoria del Hospital de Oña, Cruz Roja Española, Gráficas Uguina, Madrid, 1940. 


\section{Memorias de juntas de señoras}

Asamblea Central de SeÑoras de la Cruz Roja Española: Información sobre el hospital-Escuela de Madrid de San José y Santa Adela, calle del Doctor Santero. Imprenta Blass y CIA, Madrid, 1920.

Cruz Roja La Coruña: Memoria del año 1921, Junta de Señoras de La Coruña, Cruz Roja Española. Imprenta del Ideal Gallego, La Coruña, 1922.

Cruz Roja Málaga: Memoria leída por la secretaria Doña Matilde Casanova, viuda de Cánovas en la Junta celebrada el 13 de septiembre de 1922. Tipografía de Enrique Montes, Málaga, 1922.

Cruz Roja Badajoz: Actuación de la Junta de Señoras de la Cruz Roja de Badajoz durante la campaña de África 1921-1922. La Libertad, Badajoz, 1923.

Cruz Roja Cartagena: Comisión departamental de la Cruz Roja de Cartagena, campaña de Marruecos 1921-1922. Imprenta de Emilio Garrido, Cartagena, 1923.

Cruz Roja Larache: Memoria del año 1923 al 30 de junio de 1924, Cruz Roja Española, Junta de damas de Larache. Tip. Giménez y Vacas, Sevilla, 1924.

\section{Manuales y reglamentos de enfermeras}

AlmANSA DE CARA, Salvador: Lecciones para enfermeras de lucha antituberculosa, Editorial Dardo, Málaga, 1940.

Asamblea Central de Señoras de la CRuz Roja Española: La EnfermeraVisitadora Pro-Higiene Pública. Lo que es, lo que consigue. Liga de las Asociaciones de la Cruz Roja Ginebra (Suiza). Tipográfica Fernando, Madrid, 1923.

Auxilio Social, FAlAnge EsPañola Tradicionalista Y DE LAS J.O.N.S. Puericultura en el hogar (Complementada con nociones de medicina casera e higiene). Madrid, 1939.

САBOT, Richard: Ensayos de Medicina Social (La función de la inspectora a domicilio). Calpe, Madrid, 1920.

Calatraveño, Fernando: Programa razonado para la enseñanza de las Damas Enfermeras de la Cruz Roja Española. Imprenta de la Rev. de Arch. Bibl. y Museos, Madrid, 1917.

COMISIÓn MÉdicA dE ENSEÑANZA: Manual de la enfermera hospitalaria. Segunda edición. Cruz Roja francesa. Unión de mujeres de Francia. Espasa-Calpe Madrid, 1937. 
CORTEJOSO, Leopoldo: La enfermera en la lucha antituberculosa. Librería Santarén, Valladolid, 1939.

CRIADO Y DOMÍNGUEZ, Juan, P: La enseñanza y la profesión enfermera en España. Liga de Sociedades de la Cruz Roja. Madrid, 1921.

Cruz Roja Española: Creación de un Cuerpo de Enfermeras Profesionales. Blass, S.A. Madrid, 1924.

CRUZ RoJA EsPañola: Reglamento del Cuerpo de Damas Enfermeras y programa para su enseñanza. Ernesto Catalá, Madrid, 1928.

Cruz Roja Española: Enfermeras visitadoras, Comité de Madrid, Memoria del año 1929. Ernesto Catalá, Madrid, 1930.

CRUZ Roja ESPAÑOla: Reglamento para las Enfermeras Auxiliares Voluntarias de la Cruz Roja Española. Gráfica Universal, Madrid, 1933.

CRUZ RoJa EsPañola: Reglamento para las enfermeras auxiliares voluntarias de la Cruz Roja española. Imprenta Aldecoa, Burgos, 1938.

Cruz Roja Francesa, Unión de Mujeres de Francia: Manual de la enfermera hospitalaria. Espasa-Calpe, Madrid, 1931.

Cruz Roja Francesa. Unión de Mujeres de Francia: Manual de la enfermera Hospitalaria. Segunda edición. Espasa-Calpe, Madrid, 1937.

DAFONT: Primeros cuidados a los heridos (modo de transportarlos y de hacerles la cura de urgencia). Librería Gali, Biblioteca Cultural, Santiago de Compostela, 1938.

Delegación Provincial de SANidAd de Segovia: Formación de enfermeras sociales. Falange española tradicionalista y de las Jons. Imprenta Provincial, Segovia, 1938.

Enciso Viana, Emilio: La enfermera de Acción Católica. Editorial social Católica, Vitoria, 1937.

Fernández-CoRredor y CHICOTE, Mariano: Manual de la enfermera de la Cruz Roja. Talleres tipográficos Cuesta, Valladolid, 1917.

FALANGe Española TRAdicionalista y DE LAS J.O.N.S.: Formación de enfermeras sociales. Ajustado al programa oficial de la Delegación Nacional de Sanidad. Editado por la Delegación Provincial de Sanidad de Segovia. Imprenta Provincial, 1938.

Fontán CAlvo; DAPORTA GonZÁLEZ: Contestaciones al programa de la carrera de la enfermera. Librería Gali, Santiago, 1936.

García TORnel, Lorenzo: Manual del practicante y de la enfermera. Tercera edición, tomo II. Bosch, Barcelona, 1935. 
GARCía TORNEL, Lorenzo: Manual del practicante y de la enfermera. Quinta edición, tomo I. Bosch, Barcelona, 1938.

GARCÍA TORNEL, Lorenzo: Manual del practicante y de la enfermera. Quinta edición, tomo II. Bosch, Barcelona, 1938.

GARCÍA TORnEL, Lorenzo: Manual del practicante y la enfermera. Sexta edición. Bosch, Barcelona, 1939.

Herrero, Dionisio; Unzaga, José; Cornago, Alejo: Manual de la enfermera. Casa Central, Madrid, 1940.

Liga de Sociedades de la CRUZ Roja: Sección de Enfermeras, París. Curso Internacional para Enfermeras Visitadoras dado en el Bedford College for Women. Universidad de Londres. 1923-1924.

Luque Beltrán, Francisco: El Alma de la Enfermera. Imprenta y encuadernación de Julián Espinosa, Madrid, 1928.

Martínez Vargas, Andrés: Manual de las Damas Enfermeras de Cruz Roja. Jaime Vives, Barcelona, 1917.

MORgenthaler, Walter; Forel, Luis: Manual del enfermero para pacientes nerviosos y mentales. Salvat editores, Barcelona, 1936.

Murga y SerRet, Jorge de: El auxiliar del Médico. Sucesores de Rivadeneyra, S.A, Madrid, 1938.

MuRGa y SERRET, Jorge de: La enfermera española, sucesores de Rivadeneyra, S. A. Madrid, 1942.

Naya Casademont, Pascual: Apuntes de la enfermera. Huesca, Abril 1936.

PÉREZ, Idelio, Padre Camilo: Jornada de la enfermera. Hijos de F. Núñez Ramos del Manzano, Salamanca, 1939.

PIgA, Antonio: Terapéutica de los gaseados de guerra. Rivadeneyra, Madrid, 1936.

PIJOAN, Baltasar: La enfermera moderna, conocimientos necesarios para el cuidado de enfermos. Segunda edición, Barcelona, sin año de edición.

PitTaluga, Gustavo: Técnica y vocación de la enfermera. Madrid, 1933.

PonjoAn, Alberto: Manual de la enfermera de Santa Madrona. vol. I -fasc. I, Instituto de la mujer que trabaja, organismo de Acción Social Femenina, Caja de Pensiones para la Vejez y Ahorros, Barcelona, 1940.

Romo Aldana, Emilio; Berzosa Recio, Emiliano: Manual de la enfermera adaptado al cuestionario oficial. Talleres Tipográficos Cuesta, Valladolid, 1937. 
SAfONT, Mercedes: Manual de la Enfermera. Editorial Cervantes, Barcelona, 1923.

SALAS, J: Manual de la enfermera general y psiquiátrica. Hermanas Hospitalarias del Sagrado Corazón de Jesús, Madrid, 1935.

SÁNCHEZ DE ARRoJo, Elena: El consultor de la Dama Enfermera. Sucesores de Antero Concha, Guadalajara, 1918.

SimÓN PIMUlier, Felipe: Temas prácticos de vendajes: adaptados a los temas de vendajes y análisis de orina de los programas prácticos de primer curso de practicantes y enfermeras. Litografía.-E, Nieto, Madrid, 1934.

SolAnO, Javier: Manual de la enfermera: cómo se asiste a los enfermos y cómo se ayuda al médico. Pequeña enciclopedia práctica. Ávila, 1936.

UsANDiZAGA, Manuel: Manual de la enfermera. Librería internacional, San Sebastián, 1934.

UsANDIZAGA, Manuel: Asistencia a los heridos de guerra. Normas elementales para el personal auxiliar. Aldus, Santander, 1936.

ZBIKOWSKI: Elementos de oftalmología indispensables a enfermeras, maestros, visitadoras, puericultores, practicantes. Imprenta y Librería Eulogio de las Heras, Sevilla, 1938.

\section{Memorias y testimonios}

\section{De enfermeras}

Bingham de URquidi, Mary. Misericordia en Madrid. B. Costa-Amic Editor, México, 1975.

Hodson, Agnes: A una milla de Huesca. Diario de una enfermera australiana en la Guerra Civil española. Rodle, Zaragoza, 2005.

Hurtado Albir, Amparo: Un testimonio de la Guerra Civil Española. Ana Pibernat: mis memorias. Arenal: Revista de historia de mujeres, Vol. 7, nº 2, 2000, pp. 439-459.

JACKSON, Angela: Las mujeres británicas y la guerra civil española, Valencia, Universitat, 2010.

JACKSON, Angela: Para nosotros era el cielo. Ediciones San Juna de Dios, Campus Docent, Barcelona, 2012.

OsSORIO DE GIL, Fernanda: Memorias de una Dama Enfermera. Recuerdos $e$ impresiones del Servicio en el Hospital de Cruz Roja de Melilla. Monte Carmelo, Burgos, 1923. 
RAMIÓ, Anna; TORRES, Carme; coordinadoras: Enfermeras de guerra, Ediciones San Juna de Dios, Barcelona, 2015.

ScotT- Ellis, Priscilla: Diario de la Guerra de España. Plaza y Janés editores, Barcelona, 1996

URraca PAstor, María Rosa: Así empezamos: memorias de una enfermera. La editorial Vizcaína, Bilbao, 1939.

\section{De otros actores implicados en el conflicto}

Bastos AnsART, Manuel: De las Guerras Coloniales a la Guerra Civil, memorias de un cirujano. Ariel, Barcelona, 1969.

EtCHebÉHÈRe, Mika: Mi guerra de España. Testimonio de una miliciana al mando de una columna del POUM. Alikornio ediciones, Barcelona, 2003.

JARNÉS MILLÁN, Benjamín: Su línea de fuego. Guardia Editorial, Zaragoza, 1980.

KEMP, Peter: Legionario en España. Luis de Caralt editor, Barcelona, 1975.

LARIOS, José: Combate sobre España. Memorias de un piloto de caza. Editorial San Martín, Madrid, 1982.

LARRAZ ANDÍA, Pablo: Entre el frente y la retaguardia. La sanidad en la Guerra Civil: El hospital "Alfonso Carlos" Pamplona 1936-1939. Editorial Actas, Madrid, 2004.

Larraz Andía, Pablo; Sierra-Sesú Maga, Víctor: Requetés: de las trincheras al olvido. La esfera de libros, Madrid, 2010.

LlORDÉS BADÍA, José: Al dejar el fusil. Memorias de un soldado raso en la guerra de España. Ariel, Barcelona, 1969.

O’ NeILL, Carlota: Una mujer en la guerra de España. Anaya, Madrid, 2003.

PARSHINA, Elizaveta: La brigadista, diario de una dinamitera de la Guerra civil. La Esfera de los Libros, Madrid, 2002.

Rodrigo, Antonia: Rosario Sánchez Mora, La Dinamitera. Cuadernos Hispanoamericanos $n^{\circ}$ 503, mayo 1992, pp.13-26.

STROBL, Ingrid: Partisanas: la mujer en la resistencia armada contra el fascismo y la ocupación alemana (1936-1945). Virus, Barcelona, 1996. 


\section{Otras fuentes impresas}

BASTARRECHE, María Rosa: Impresiones sobre la formación de Enfermeras en los Estados Unidos. Conferencia pronunciada en el Hospital Central de la Cruza Roja el día 21 de marzo de 1935.Madrid, 1935.

BASTOS ANSART, Manuel: Algunos aspectos de las heridas por arma de fuego. Labor, Barcelona, 1936.

Bonel, Maite: Episodios de una enfermera, El Noticiero, Zaragoza, 1940.

Criado Domínguez, Juan P: El comité Central de la Cruz Roja Española y su labor desde el advenimiento de la República hasta el 30 de septiembre de 1933. Imprentalitográfica Ernesto Catalá, Madrid, 1933.

Cruz Roja Española: Homenaje a la Duquesa de la Victoria. Talleres Depósito de Guerra, Madrid, 1926.

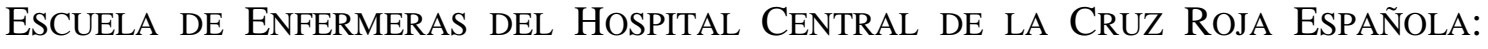
Florencia Nightingale: conferencia pronunciada el día 23 de enero de 1933 por Mercedes Milá. Madrid, 1933.

EsPINA, Concha: Princesas del martirio. Ediciones Afrodisio Aguado S.A. Madrid, 1941.

FALANGE ESPAÑOLA TRADICIONALISTA Y DE LAS J.O.N.S.: Misión y organización de la S. F. (Sección Femenina, Gráfica Imperium, Madrid, 1941.

Francos Rodríguez, José: La mujer y la política españolas. Librería Sucesores de Hernando, Madrid, 1920.

Gimenez Enrich, S: Anales de la Cruz Roja. Espasa Hermanos, Barcelona, sin año de edición.

GIRAL, José: Año y medio de gestiones de canje. Monografías de Cruz Roja Española, subsecretaria de propaganda, 1938.

GoY, José María: Las tres ramitas de roble: romance histórico astorgano. Imprenta y litografía de Sierra, Astorga, 1939.

Instituto NAcional De PREvisión: Seguro de maternidad: tercer convenio con la federación española de colegios oficiales de matronas. Oficina tipográfica del instituto nacional de previsión Madrid, 1934.

JUNQUERA, María Teresa: Lo que puede y debe ser la enfermera. Conferencia pronunciada el día 6 de abril de 1933, Madrid, 1933.

Los católicos y la República. Cultura Española, Madrid, 1934. 
Maeztu Whitney, María: El trabajo de la mujer, nuevas perspectivas. Conferencia pronunciada el día 8 de abril de 1933, Madrid, 1933.

MARTEL, Carmen: La guerra a través de las tocas. Establecimientos Lerón, Cádiz, 1938.

MARQUeSA DE VALDEIGLESIAS: Memoria sobre el Congreso Internacional de Enfermeras celebrado en Ginebra en julio de 1927. Imprenta Gracigoy, Madrid, 1928.

Mejías CorreA, María de la Luz: Así fue pasando el tiempo. Memorias de una miliciana extremeña. Renacimiento, Sevilla, 2006.

MonTSEnY Mañé, Federica: Mis primeros cuarenta años. Barcelona, Plaza y Janes, 1987.

NÁJERA Angulo, Luis: Libro de actas del Primer Congreso Nacional de Sanidad (6-12 mayo de 1934). Tomo I, Gráfica Literaria, Madrid, 1935.

NÁJeRa Angulo, Luis: Libro de actas del Primer Congreso Nacional de Sanidad (6-12 mayo de 1934). Tomo IV, Gráfica Literaria, Madrid, 1935.

Pla i Casadevall, Josep: El advenimiento de la República. Destino, Barcelona, 1933.

Primo de Rivera, Pilar: Escritos. Discursos, circulares, escritos Sección Femenina de F. E. T. y de las J. O. N. S. Gráficas Afrodisio Aguado, Madrid, 1942.

VIZCONDE DE EZA: El alma femenina española. Conferencia dada el 7 de marzo de 1940, inaugural de las organizadas por la Inspección de Damas Auxiliares de Sanidad Militar de Madrid. Madrid, 1940. 


\section{BIBLIOGRAFIA}

Acosta RAmíRez, Francisco, Coord: Conflicto y sociedad civil: la mujer en la guerra: actas de las "Cuartas Jornadas sobre la Batalla de Bailén y la España Contemporánea. Organizadas por el Ayuntamiento de Bailén. Jaén, Universidad de Jaén, 2003.

Aguado, Ana María y Ortega, María Teresa: Feminismos y antifeminismos. Culturas políticas e identidades de género en la España del siglo XX. En Cenarro, Ángela. Trabajo, Maternidad y feminidad en las mujeres del fascismo español. Universidad, Valencia-Granada, 2011.

AlCALDE, Carmen: La mujer en la Guerra Civil Española. Cambio 16, Madrid, 1976.

Álvarez NeBredA, Carlos: Catálogo bibliográfico de publicaciones enfermeras (15411978). Colegio Oficial de Enfermería de Madrid, Madrid, 2008.

Álvarez NeBredA, Carlos: Semblanzas de la profesión enfermera (1862-1953). Colegio Oficial de Enfermería de Madrid, Madrid, 2011.

ÁlvareZ, Santiago: Historia política y militar de las Brigadas Internacionales. Compañía literaria, Madrid, 1996.

Álvarez TARdío, Manuel; Villa GarcíA, Roberto: El precio de la exclusión. La política durante la Segunda República. Encuentro, Madrid, 2010.

Angoloti de CÁRdenAs, Ignacio: La Duquesa de la Victoria. Cruz Roja, Madrid, 1958.

APARICIO GOÑI, Idoia: Historia del sistema formativo de las enfermeras visitadoras de la Cruz Roja Española. Diego Marín, Librero-Editor, Murcio, 2011.

ANTÓN SOLANAS, Isabel: Enfermeras, practicantes y voluntarios: La disolución de divisiones prácticas y profesionales durante la Guerra Civil Española (1936-1939). Tesis doctoral, Universidad de Manchester, Reino Unido, 2009.

Beecham, Monografías: Los médicos y la medicina en la Guerra Civil Española. Saned, Madrid, 1986.

BENEITO LlORIS, Ángel: El Hospital Sueco-Noruego de Alcoi durante la Guerra Civil española. Producciones Visual, 2004. 
Bernabeu Mestre, Josep; Gascón Pérez, Encarna: Historia de la Enfermería de Salud Pública en España (1860-1977). Publicaciones de la Universidad de Alicante, Alicante, 1999.

Bescós TORRES, Jesús: Las Enfermeras en la Guerra de España 1936-1939. Revista de Historia Militar. 1982; n $^{\circ}$ 53, pp. 97-142.

Bescós Torres, Jesús. La Sanidad Militar en la Guerra de España (1936-1939). Primera Parte. La Sanidad en el ejército republicano. Revista de Medicina Militar, 1987, Vol. 43, n 1, pp. 88-99.

Bescós Torres, Jesús: La Sanidad Militar en la Guerra de España (1936-1939). Segunda Parte. La Sanidad en el ejército nacional. Revista de Medicina Militar 1987, Vol. 43, n 4 pp. 434-447.

BRANCIFORTE, Laura: Legitimando la solidaridad femenina internacional: el Socorro Rojo. Arenal, nº16:1, enero-junio, 2009, pp. 27-52.

Bullón de Mendoza, Alfonso; Diego, Álvaro de: Historias orales de la Guerra Civil. Ariel, Barcelona, 2000.

Caballé Masforroll, Anna: El feminismo en España. La lenta conquista de un derecho. Cátedra, Madrid, 2013.

CABEZA SÁNCHEZ-AlbORNOZ, Sonsoles: Legislación protectora de la maternidad en la época de la Restauración española, Departamento Historia Contemporánea, Cuadernos de Historia Moderna y Contemporánea, Universidad complutense, Madrid, 1985.

Cabrera Bosch, María Isabel; Folguera, Pilar: El feminismo en España: dos siglos de historia. Editorial Pablo Iglesias, Madrid, 1988.

Calvo Calvo, Manuel Ángel: La reacción de los practicantes en Medicina y Cirugía frente a la creación del título de Enfermera en 1915. Dynamis, 2013. Disponible en: [0211-9536] 201; 34 (2): http://dx.doi.org/10.4321/S0211-95362014000200008, pp. 425 a 446.

Calvo Calvo, Miguel Ángel: La reacción de los colegios oficiales de practicantes a la creación de la enfermera titulada en 1927. En: Un siglo cuidando a la sociedad. Centenario del reconocimiento oficial de la Enfermería en España. Colegio Oficial de Enfermería de Cantabria, Santander, 2015.

CAMPOAMOR RODRíGUEZ, Clara: El voto femenino y yo. Mi pecado mortal. Horas y horas, Madrid, 2006.

CANTERO GonzÁLEz, María Lourdes: Formación e identidad enfermera en el franquismo. Diego Marín Librero-Editor, Murcia, 2010. 
CaO TORIJA, María José: Estudio de alimentación, nutrición y actividad física en población femenina adulta urbana de Valladolid (AMUVA). Tesis doctoral, Facultad de Medicina, Universidad de Valladolid, Valladolid, 2013.

Capel Martínez, Rosa María: El sufragio femenino en la $2^{a}$ República Española. Granada, Universidad de Granada, 1975.

CAPEL MARTínez, Rosa María: El trabajo y la educación de la mujer en España (19001930), Ministerio de Cultura, Dirección General de Juventud y Promoción Sociocultural, 1982.

CAPel Martínez, Rosa María: Mujer y trabajo en el siglo XX. Madrid, Arco/libros, 1999.

Capel Martínez, María Rosa: Presencia y visibilidad de las mujeres: recuperando historia. Abada editores, Madrid, 2013.

CAsanova, Julián; GIL AndrÉs, Carlos: Historia de España en el siglo XX. Ariel, Barcelona, 2009

Celada, Antonio R; GonzÁlez de la Aleja, Manuel; Pastor García, Daniel: La prensa británica y la Guerra Civil española. Amarú, Salamanca, 2013.

CerverA, Javier: Madrid en Guerra, la ciudad clandestina, 1936-1939. Alianza, Madrid, 2006.

Clemente, Josep Carles: Historia de la Cruz Roja Española. Cruz Roja Española. Gráfica Universal, Madrid, 1990.

Clemente, Josep Carles: La Escuela Universitaria de enfermeras de Madrid: historia de una iniciativa humanitaria de la Cruz Roja Española (1918-1997), Madrid, Fundamentos, 1999.

Cohen, Helen A: La enfermera y su identidad profesional. Ediciones Grijalbo, Barcelona, 1988.

Choperena ARMEndÁRIz, Ana: Memorias de enfermeras en la Guerra Civil Americana: de la dimensión doméstica a la profesional. Tesis doctoral, Universidad de Navarra, Facultad de Filosofía y Letras, Pamplona, 2014.

DERBY, Mark: Compañeros "kiwis" Nueva Zelanda y la guerra civil española. Ediciones de la Universidad de Castilla la Mancha, Cuenca, 2001.

DÍAZ FUENTES, José Manuel: República y Primer Franquismo: la mujer española entre el esplendor y la miseria, 1930-1950, en Alternativas cuadernos de Trabajo Social, $\mathrm{n}^{\circ} 3$, 1995, pp. 23-40. 
Domingo Álvaro, Alfonso: Retaguardia. La Guerra Civil tras los frentes. Oberon, Madrid, 2004.

Domingo, Carmen: Nosotras también hicimos la guerra. Defensoras y sublevadas. Flor del Viento, Barcelona, 2006.

Domingo, Carmen: Coser y Cantar. Las mujeres bajo la dictadura franquista. Lumen, Barcelona, 2007.

DomíngueZ-AlCón, Carmen: Los cuidados y la profesión enfermera en España. Ediciones Pirámide, Madrid, 1986.

Dronda Martínez, Francisco Javier: Catolicismo político y movimiento católico en Navarra. 1931-1936, en V.V.A.A., Ayeres en discusión. Temas clave de Historia Contemporánea, Murcia, 2008.

DueÑAs CEPEDA, María Jesús: Avances y retrocesos en la educación de las mujeres en Castilla y León, 1900-1970, en V.V.A.A., Oficios y saberes de mujeres, Valladolid, Universidad de Valladolid. Secretariado de Publicaciones e Intercambio Editorial, 2002.

DunANT, Henry: Un recuerdo de Solferino. Ediciones Botas-México, México, 1937.

EBY, Cecil: Voluntarios norteamericanos en la Guerra Civil española. Ediciones Acervo, Barcelona, 1974.

EgIDO, Ángeles; Fernández Asperilla, Ana: Ciudadanas, militantes y feministas. Mujer y compromiso político en el siglo XX. Eneida, Madrid, 2001.

Enciclopedia general ilustrada del País Vasco: Cuerpo A. Diccionario enciclopédico vasco. Auñamendi, San Sebastián, 1979-2008.

FAgOAgA BARTOLOMÉ, Concha: La voz y el voto de las mujeres. El sufragismo en España 1877-1931. Barcelona, Icaria, 1985.

FAURÉ, Christine (dir.) Enciclopedia histórica y política de las mujeres, Europa y América. Diccionarios Akal, Madrid, 2010.

Faus Sevilla, Pilar: Emilia Pardo Bazán: su época, su vida, su obra. Fundación Pedro Barrié de la Maza. Coruña, 2003.

Fernández Jiménez, María Antonia: Pilar Primo de Rivera. El falangismo femenino. Editorial Síntesis, Madrid, 2008.

FERNÁNDEZ Rodríguez, Carlos: La lucha es tu vida. Retrato de nueve mujeres combatientes republicanas. Fundación Domingo Malagón, Madrid, 2008. 
FrANCO FERnÁndeZ, Francisco José: Mujeres de la España republicana. Editorial Áglaya, Cartagena, 2007.

Frutos Herranz, Martín de: La Cruz Roja en Burgos. Los primeros 66 años (18731939). Imprenta Santos, Burgos, 2008.

FUENTE, Inmaculada de: La roja y la falangista: dos hermanas en la España del 36. Barcelona, Planeta, 2006.

Galiana SÁnchez, María Elena; Bertomeu Mestre, J; García Paramio, M. P: Enfermeras para una nueva patria. Género e ideología en la enfermería de Falange. En

GonzÁlez CANAlejo, Carmen; Martínez LÓPez, F. (EDS): La transformación de la enfermería. Nuevas miradas para la historia. Comares, Granada 2010.

GALINDO CASERO, Antonio: Formación, profesionalización e ideologías en enfermería (1953-2000). Tesis doctoral, Universidad de Extremadura, departamento de Historia. Cáceres 2003.

Gallego MÉndez, Teresa: Mujer, falange y franquismo. Taurus, Madrid, 1983.

García Colmenares, Pablo: Historia de la Guerra Civil y Primer Franquismo en Castilla y León. Universidad de Valladolid, Secretario de Publicaciones e Intercambio Editorial, 2007.

García Hourcade, Juan Luis; Moreno Yuste, Juan M; Ruiz Hernández, Gloria: Estudios de historia de las técnicas. La arqueología industrial y las ciencias. Volumen II. Junta de Castilla y León, Consejería de Educación y Cultura. Europa artes gráficas, Salamanca, 1998.

García Martínez, Antonio Claret; García Martínez, Manuel Jesús: Fechas Clave para la historia de las matronas en España. Híades, revista de Historia de la Enfermería, nº 5-6, 1998-1999, pp. 243-260.

GARCÍA RodRÍGUEZ, Fernando: Margarita Nelken: el arte y la palabra. Fragua Editorial. Madrid, 2010.

GINARD I FÉRON, David: Matilde Landa, de la institución libre de enseñanza a las prisiones franquistas. Flor del Viento, Barcelona, 2005.

GONZÁLEZ AlLENDE, Iker: Líneas de fuego. Género y nación en la narrativa española durante la Guerra Civil (1936-1939). Biblioteca Nueva, Madrid, 2011.

GonzÁlez AndRAdAs, Rogelio: Campaña del Rif, Marruecos 1859-1927: final de un soldado español en Monte Arruit. CSED, Astorga, 2013. 
GONZÁLEZ IGLESIAS, María Elena: El asociacionismo de las enfermeras: Los inicios de la Enfermería como profesión. En VV.AA: El asociacionismo en la Enfermería y su influencia en el desarrollo de la profesión: 150 años de historia del colegio de enfermeras de Madrid (1862-2012). Colegio Oficial de Enfermería de Madrid, Madrid, 2012.

GonzÁlez Canalejo, Carmen: Asistencia Sanitaria, género y cuestión social en Almería, (1857-1930). Tomo II, tesis doctoral. Departamento de Historia, Geografía, Historia del Arte y Sociología. Facultad de Humanidades y Ciencias de la Educación Universidad de Almería, 2005.

GonZÁlez CANAlejo, Carmen: Las cuidadoras. Historia de las practicantes, matronas $y$ enfermeras (1857-1936). Premio de ensayo "Carmen Burgos" 2005. Instituto de Estudios Almeriense, Almería, 2006.

GonzÁlez CANAlejo, Carmen; MARTínez LÓPEZ, Fernando (EDS.): La transformación de la enfermería. Nuevas miradas para la historia. Comares, Granada 2010.

GONZÁLEZ GARCÍA, Alberto: La epidemia de gripe de 1918-1919 en la provincia de Cuenca. Tesis doctoral, Programa de Doctorado en Investigación Sociosanitaria, Universidad de Castilla la Mancha, Cuenca, 2012.

GonZÁlez YANeS, Jerónimo: Historia de la Enfermería Militar Española. Diagonal Gráfica S. C. P. La Laguna, Tenerife, 2003.

GUTIÉRREZ VEGA, Zenaida: Victoria Kent: una vida al servicio del humanismo liberal. Servicio de Publicaciones Universidad de Málaga, Málaga, 2001.

HeIERle VAlero, Cristina: Imagen social de las enfermeras a través de los medios. Tesis doctoral del Departamento de Didáctica de la expresión musical, plástica y corporal. Universidad de Granada, 2011.

HENDERSON, Virginia: La naturaleza de la Enfermería: reflexiones de 25 años después. Interamericana- McGraw-Hill, Madrid, 1994.

HERnÁNDEZ CONESA, Juana María: Un estudio de los paradigmas educativos enfermeros durante el siglo XIX. Diego Marín Librero-Editor, Murcia 2012.

HERnÁNDEZ Holgado, Fernando: Mujeres encarceladas. La prisión de las Ventas: de la República al franquismo, 1931-1941. Marcial Pons, Ediciones de Historia, Madrid, 2003.

Hurtado Albir, Amparo: Memorias del pueblo. La Guerra Civil Española contada por testigos de ambos bandos: Anna Pibernat, Frascesca Sallés, Josep Torras. La Esfera de libros, Madrid, 2004. 
IzQUIERdo RoJo, José María: 70 años de Valdecilla. Salud y prestigio para Cantabria. Algo más que un hospital. Caja Cantabria, Santander, 2000.

JARAÍZ Franco, Pilar: Historia de una disidencia. Planeta, Barcelona, 1981.

Las mujeres en la Guerra Civil. Madrid, Ministerio de Cultura, Dirección General de Bellas Artes y Archivos, 1989.

Madariaga DE, María Rosa: Marruecos ese gran desconocido. Breve historia del protectorado español. Alianza Editorial, Madrid, 2013.

MaILlaRd GARCÍA, María Luisa: Asociación Española de Mujeres Universitarias 19201990. Asociación Española de Mujeres Universitarias, Instituto de la Mujer, Madrid, 1990.

MANGINI, Shirley: Recuerdos de la Resistencia, la voz de las mujeres de la Guerra Civil Española. Península, Barcelona, 1997.

Marcos Del Olmo, Concepción: Las mujeres en los procesos electorales de la Segunda República. 1931-1936 en SANTO TOMÁs, Magdalena. ET AL (COORDS). Vivir siendo mujer a través de la historia / Valladolid: Universidad de Valladolid, Secretariado de Publicaciones e Intercambio Editorial, 2005.

MARTín, Elvira: Concepción Arenal. Confederación Española de Gremios y Asociaciones de libreros. Madrid, 1994.

MARTÍN DE LA GUARDIA, Ricardo: Información y propaganda en la prensa del Movimiento: "Libertad"' de Valladolid: 1931-1979. Universidad de Valladolid, Valladolid, 1994.

MARTínez BANDE, José Manuel: La ofensiva sobre Segovia y la batalla de Brunete. Editorial San Martín, Madrid, 1972.

MARTínez SIERRA, María: Una mujer por caminos de España. Editorial Castalia, Madrid, 1989.

Maza Zorrilla, Elena: Miradas desde la historia, Isabel la Católica en la España Contemporánea. Ámbito, Instituto Universitario de Historia Simancas, Valladolid, 2006.

Miqueo Miqueo, Consuelo: ¿Feminismo en el mundo científico médico? Isegoría, $\mathrm{n}^{\circ}$ 38, 2008, pp. 155-167.

Montero, José Ramón: La CEDA. El catolicismo social y político en la II República, Vol. I. Ediciones de la Revista de Trabajo, Madrid, 1977.

MontSEny MaÑÉ, Federica: La indomable, Madrid, Castalia [etc.], 1991. 
Moral Roncal, Antonio Manuel: La cuestión religiosa en la Segunda República española: Iglesia y Carlismo. Biblioteca Nueva, Madrid, 2009.

Morant, IsABel, en VV.AA: Historia de las mujeres en España y América latina del siglo XX a los umbrales del XXI. Cátedra, Madrid, 2006.

NASH, Mary: Mujer, familia y trabajo en España (1875-1936). Barcelona, Anthropos, 1983.

NASH, Mary; TAVERA, Susana: Las mujeres y las guerras. El papel de las mujeres en las guerras de la Edad Antigua a la contemporánea. Icaria, Barcelona, 2003.

NASH, Mary: Rojas, las mujeres republicanas en la Guerra Civil. Taurus, Madrid, 1999.

Navarro Carballo, José Ramón: Creación y desarrollo del Cuerpo de Damas Auxiliares de Sanidad Militar. Revista de Medicina Militar. 1987, Vol. 43, nº 3, pp. 320-323.

NAVARRo CARBALlo, José Ramón: La sanidad en las Brigas Internacionales. Estado Mayor del Ejército, Madrid, 1989.

NELKEN, Margarita: La condición social de la mujer en España. CVS ediciones, Madrid, 1975.

Nicolas Mass, C. M: Notas para la historia de las Hijas de la Caridad en España. Tomo II: 1800 a 1850. Editorial CEME, Salamanca, 1988.

NogAles EsPert, Amparo: El asociacionismo en el arte de la enfermería. Hacia una estética del optimismo: la ilusión. En VV.AA: El asociacionismo en la Enfermería y su influencia en el desarrollo de la profesión: 150 años de historia del colegio de enfermeras de Madrid (1862-2012). Colegio Oficial de Enfermería de Madrid, Madrid, 2012.

NÚÑEZ DÍAZ-BALART, Mirta: La prensa de guerra en la zona republicana durante la guerra civil española 1936-1939, Tomo I, II, III. Ediciones de la Torre, Madrid, 1992.

NúÑEZ DÍAZ-BALART, Mirta: La disciplina de la conciencia: las Brigadas Internacionales y su artillería de papel. Flor del viento ediciones, Barcelona, 2006.

NúÑEZ PÉREZ, María Gloria: El Trabajo extradoméstico de las mujeres en España (1931-1936). Tesis doctoral. Departamento de Historia Contemporánea. Facultad de Geografía e Historia, Universidad Complutense de Madrid, 1987.

NúÑEz PÉREZ, María Gloria: Trabajadoras en la Segunda República, un estudio sobre la actividad extradoméstica (1931-1936), Madrid, Centro de publicaciones Ministerio de Trabajo y Seguridad social, 1989. 
NúÑEZ PUENTE, Sonia: Una historia propia. Historia de las mujeres en la España del siglo XX. Pliegos, Madrid, 2009.

Orduña Prada, Mónica: El Auxilio Social (1936-1940). La etapa fundacional y los primeros años. Escuela Libre Editorial, Madrid 1996.

Orduña Prada, Mónica: Asistencia y Beneficencia Públicas. Ciudad Argentina, Buenos Aires, 1999.

PANOS INSTITUTE: Armas para luchar, brazos para proteger. Las mujeres hablan de la guerra. Círculo de Lectores, Barcelona, 1996.

PAYNE, Stanley George: El colapso de la República. Los orígenes de la Guerra Civil (1933- 1936). La Esfera de Libros, Madrid, 2005.

PEINADO RodRÍGUEZ, Matilde: Enseñando a señoritas y sirvientas. Formación femenina y clasismo en el franquismo. Catarata, Madrid, 2012.

Pelaz LóPez, José Vidal; Tomasoni, Mateo: Cine y Guerra Civil. El conflicto que no termina. Diacronie. Studi di Storia Contemporanea: Spagna Anno Zero: la guerra come soluzione, 29/07/2011, pp. 1-29.

http://www.studistorici.com/2011/07/29/tomasoni2_numero_7

PÉRez LÓPez, Pablo: Católicos, política e información. Diario Regional de Valladolid (1931-1980). Tesis doctoral, Departamento de Historia Moderna, Contemporánea y de América. Facultad de Filosofía y Letras, Universidad de Valladolid, 1992.

Pérez Villanueva Tovar, Isabel: María de Maetzu: Una mujer en el reformismo educativo español. Universidad Nacional de Educación a Distancia. Madrid, 1989.

PERNAS, Juan Carlos: La CEDA. La derecha accidentalista católica durante la Segunda República. Casa Eolo, Huesca, 2001.

PoniATOWSKA, Elena: Tinísma. Ediciones Era, México, 2000.

PReston, Paul: Palomas de guerra. Plaza y Janes, Barcelona, 2001.

PRESTON, Paul: La Guerra Civil española: reacción, revolución y venganza. Debolsillo, Barcelona, 2011.

PRESTON, Paul: Las tres Españas del 36. Debolsillo. Barcelona 2011.

Pulido Mendoza, Rosa: La formación de las enfermeras de la Cruz Roja Española, Tomo I y II. Diego Marín Librero-Editor, Murcia, 2011.

RAMón CARrión, Manuel de; Ortiz SÁnChez, Carmen. Madrina de guerra. Cartas desde el frente. La Esfera de Libros, Madrid, 2003. 
RICHMOND, Kathleen: Las mujeres en el fascismo español: la sección femenina de la Falange, 1934-1959. Madrid, Alianza editorial, 2004.

RodríGuez Álvarez, Mikel: Mujeres en las trincheras. Historia, n 349, mayo 2005, pp. 13-29.

RodríGuez JiméneZ, José Luis: ¡A mí la Legión! De Millán Astray a las misiones de paz. Planeta, Barcelona, 2005.

RODRÍGUEz LóPEZ, Sofía: El patio de la cárcel. La Sección Femenina de FET-JONS en Almería (1937-1977). Fundación Pública Andaluza, Sevilla, 2010.

Rodríguez Ocaña, Esteban; Bernabeu Mestre, J; Barona J. L: La fundación Rockefeller y España, 1914-1939. Un acuerdo para la modernización científica y sanitaria. En Roig Castellanos, Mercedes. A través de la prensa la mujer en la historia. Servicios Gráficos Colomina, Madrid, 1982.

Ruiz-Berdún, Dolores; Gomis, Alberto: La matrona y el Seguro de Maternidad durante la Segunda República (1931-1936). Matronas Profesión, 15(3), pp.76-84.

Salas Franco, María Pilar: Salvad España, Salvad la paz. Memorias de la Guerra Civil Española en el Reino Unido e Irlanda. Siníndice, Logroño, 2011.

SÁnchez Aranda, José Javier; BARReda del BARRio, Carlos: Historia del periodismo español desde sus orígenes hasta 1975. EUNSA, Pamplona 1992.

SAnTO TOMÁs PÉREZ, Magdalena: Historia de la enfermería, en V.V.A.A: Enfermería Fundamental, Barcelona, Masson, 2003.

SANTO TOMÁs PÉREZ, Magdalena: Líneas de investigación para avanzar en la historia de la Enfermería, p. 395, en GonzÁlez CANALEJO, Carmen, MARTínez LóPEZ, Fernando: La transformación de la Enfermería. Nuevas miradas para la historia. Editorial Comares, Granda, 2010.

SANTO TOMÁs PÉREz, Magdalena: Antecedentes de la Enfermería que contribuirán al reconocimiento legal de la profesión. En: Un siglo cuidando a la sociedad. Centenario del reconocimiento oficial de la Enfermería en España. Colegio Oficial de Enfermería de Cantabria, Santander, 2015.

SCHAEFER, Lola, M: Florence Nightingale. Capstone, Minesota, 2005.

Segura López, Gabriel; Hernández ConesA, Juan María; Beneit Montesinos, Juan Vicente: Los sistemas formativos enfermeros durante la Guerra Civil Española 19361939. Diego Marín Librero Editor, Murcia, 2012.

SELlÁN Soto, Carmen: La profesión va por dentro. FUDEN, Madrid, 2009. 
Serrallonga Urquidi, Joan; SANTIRSO, Manuel; CASAS SORIANO, Just: Vivir en guerra. La zona leal a la república (1936-1939). Ediciones UAB, Barcelona, 2013.

THÉBAud, Françoise: Historia de las mujeres en occidente. 5, el siglo XX. Taurus, Madrid, 2000.

UsAndizagA, Aránzazu: Ve y cuenta lo que pasó en España, Mujeres extranjeras en la guerra civil. Editorial Planeta, 2000.

UsAndizAgA, Aránzazu: Escritoras al frente. Intelectuales extranjeras en la Guerra Civil. Nerea, San Sebastián, 2007.

VAl VAldivieso, María Isabel del: El trabajo de las mujeres en España (desde la Antigüedad al siglo XX). Casa de Velázquez, Madrid, 2010.

Val VAldiVIESO, María Isabel del: Protagonista del pasado. Las mujeres desde la prehistoria al siglo XX. Castilla D. L. Valladolid, 2009.

VArela DíAz, Santiago: Partidos y parlamento en la II República española. Madrid, Fundación Juan March y Editorial Ariel, 1978.

VARIAS AUTORAS: Mujer y Sociedad en España (1700-1975). Ministerio de Cultura, Estudios sobre la Mujer. Dirección General de Juventud y Promoción Socio-Cultural, Madrid, 1982.

VARIOS AUTORES: Mujeres en la historia de España. Enciclopedia biográfica. Plantea, Barcelona, 2000.

VARIOS AUTORES: Historia de las mujeres en España y América latina. Del siglo XX a los umbrales del XXI. Cátedra, Madrid, 2006.

ZAMORANO PABÓN, Ingrid Carolina: Identidad profesional en Enfermería: un reto personal y profesional. Invest Educ Enferm. 2008; 26(suppl):168-171. 




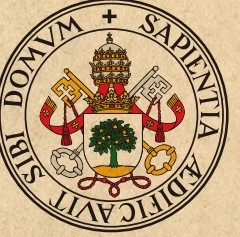

\section{Universidad deValladolid}

Instituto Universitario de Historia Simancas 